UNIVERSIDADE DE SÃO PAULO

FACULDADE DE FILOSOFIA, LETRAS E CIÊNCIAS HUMANAS

DEPARTAMENTO DE LETRAS ORIENTAIS

PROGRAMA DE PÓS-GRADUAÇÃO EM LITERATURA E CULTURA RUSSA

\title{
SERGUEI DOVLÁTOV: TEXTO DE CULTURA \\ NA LITERATURA RUSSA CONTEMPORÂNEA
}

\author{
Yulia Mikaelyan
}




\author{
UNIVERSIDADE DE SÃO PAULO \\ FACULDADE DE FILOSOFIA, LETRAS E CIÊNCIAS HUMANAS \\ DEPARTAMENTO DE LETRAS ORIENTAIS \\ PROGRAMA DE PÓS-GRADUAÇÃO EM LITERATURA E CULTURA RUSSA
}

\title{
SERGUEI DOVLÁTOV: TEXTO DE CULTURA NA LITERATURA RUSSA CONTEMPORÂNEA
}

Yulia Mikaelyan

Tese apresentada ao Programa de PósGraduação em Literatura e Cultura Russa, do Departamento de Letras Orientais, da Faculdade de Filosofia, Letras e Ciências Humanas da Universidade de São Paulo, para a obtenção do título de Doutor em Letras.

Orientadora: Profa Dra Arlete Orlando Cavaliere Ruesch

Pesquisa financiada pela CAPES

São Paulo

2016 
Autorizo a reprodução e divulgação total ou parcial deste trabalho, por qualquer meio convencional ou eletrônico, para fins de estudo e pesquisa, desde que citada a fonte.

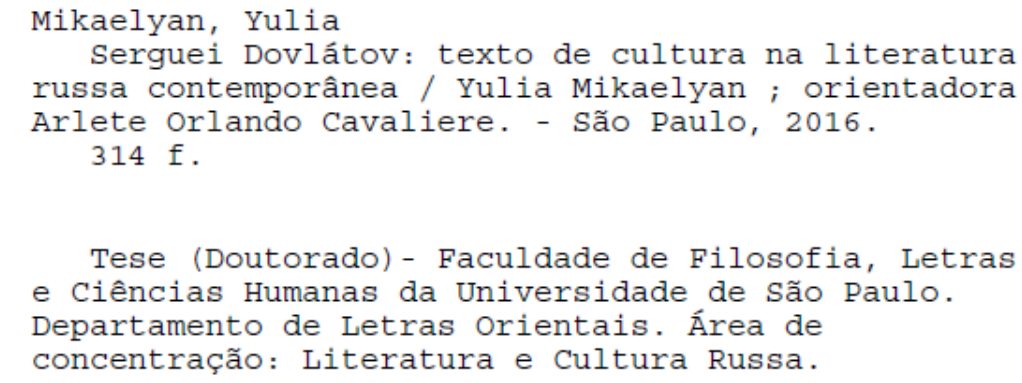

1. literatura russa. 2. crítica literária. 3. semiótica das culturas. I. Cavaliere, Arlete orlando, orient. II. Título. 


\section{FOLHA DE APROVAÇÃO}

Yulia Mikaelyan

Serguei Dovlátov: texto de cultura na literatura russa contemporânea

Tese apresentada à Faculdade de Filosofia, Letras e Ciências Humanas da Universidade de São Paulo para a obtenção do título de Doutor. Área de concentração: Literatura e Cultura Russa.

Aprovado em:

\section{Banca Examinadora}

Prof. Dr

Institução: Assinatura:

Prof. Dr.

Institução: Assinatura:

Prof. Dr.

Institução: Assinatura:

Prof. Dr.

Institução: Assinatura:

Prof. Dr.

Institução: Assinatura:

São Paulo, de de 2016 


\section{Agradecimentos}

À minha orientadora, Professora Arlete Orlando Cavaliere, pela orientação, paciência, sugestões e valiosas dicas, além da orientação não apenas no processo de pesquisa, mas também na vida. Agradeço pelo apoio nos momentos difíceis e pela amizade.

Aos Professores Aurora Fornoni Bernardini e Bruno Barreto Gomide, que participaram da minha banca de qualificação, pelo incentivo e pelas sugestões que enriqueceram tanto este trabalho. Um agradecimento especial à Professora Aurora, pela revisão estilística da primeira versão da tradução e pelas valiosas sugestões tradutórias.

Ao Professor Mário Ramos, pelas revisões, sugestões e pela ajuda na tradução da novela.

À minha amiga Daniela Mountian, da Editora Kalinka, pela ajuda com as revisões e pela minuciosa revisão da tradução da novela e sugestões, assim como pelo interesse na publicação e na divulgação da obra de Dovlátov no Brasil.

Ao meu amigo Rodrigo Alves do Nascimento, pela revisão do trabalho e pelas críticas e sugestões oportunas.

À minha família: aos meus pais, Igor e Galina Mikaelyan, e à minha avó, Rimma Karpéieva, por sempre estarem ao meu lado, apesar das distâncias geográficas.

A todos os meus queridos amigos russos e brasileiros, pela paciência, inspiração e pelo apoio nos dois hemisférios.

À CAPES, pela concessão da bolsa de doutorado e pelo apoio financeiro para a realização desta pesquisa. 


\section{Resumo}

O presente trabalho tem como objetivo traduzir para português brasileiro e fazer uma análise semiótica da novela Parque cultural (1983), do escritor russo Serguei Dovlátov. Além disso, pretendemos apresentar aos leitores e pesquisadores brasileiros os traços fundamentais da obra deste, que é um dos principais prosadores russos da segunda metade do séc. XX e um dos maiores representantes da Terceira Onda de emigração russa.

Uma das especificidades do método artístico de Dovlátov consiste em uma forte vinculação de sua obra com fatos da cultura, literatura e história da Rússia e da União Soviética. Essa característica permite-nos analisar seus textos como textos de cultura, segundo a concepção semiótica de Iú. Lótman. Na novela Parque cultural, espelham-se tais fenômenos da cultura soviética, como o mito "soviético" do poeta Aleksándr Púchkin, considerado símbolo da cultura, a existência na União Soviética de duas culturas paralelas (a oficial e a não oficial), o fenômeno da massiva emigração dos anos 1970, entre outros.

A tradução da novela Parque cultural (título em russo, Zapoviédnik) para o português do Brasil, com notas e comentários, constitui parte integrante deste trabalho. Praticamente toda a obra de Dovlátov é humorística, e a transmissão dos elementos de humor e marcas culturais, presentes no texto, foi um dos desafios dessa tradução.

Palavras-chave: Serguei Dovlátov, literatura russa, cultura russa, literatura russa de emigração, semiótica da cultura, Iúri Lótman. 


\section{Abstract}

This work is aimed at translating the novel Pushkin Hills by Sergei Dovlatov into Brazilian Portuguese (the title in Russian is Zapoviednik, and the title in Portuguese is Parque Cultural, 1983) and analyze this text from a semiotic point of view. We furthermore intend to present the basic features of Dovlatov's work, who is considered to be one of the leading Russian prose writers of the second half of the XX century and one of the greatest representatives of the Third Wave of Russian Emigration, to readers and Brazilian researchers.

One of the features of Dovlatov's artistic methods lies in the close connection of his work with the culture, literature and history of Russia and the Soviet Union. This feature allows us to analyze his texts as cultural texts, according to Yuri Lotman's semiotic concept. The themes of the novel Pushkin Hills reflect such phenomena of Soviet culture as, among others, the "Soviet" myth of the poet Aleksandr Pushkin, who is considered to be a symbol of culture, the existence in the Soviet Union of two parallel cultures (official and unofficial), the massive emigration of the 1970s.

The translation of the novel into Brazilian Portuguese, with notes and comments, is an integral part of this work. Almost all of Dovlatov's work is humorous, and conveying elements of humor and cultural references in the text was one of the challenges of this translation.

Keywords: Sergei Dovlatov, Russian literature, Russian culture, Russian Émigré literature, semiotics of culture, Yuri Lotman 


\section{Sumário}

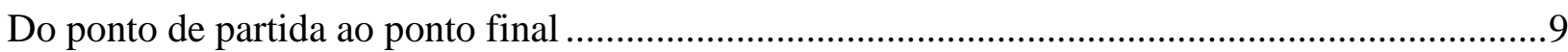

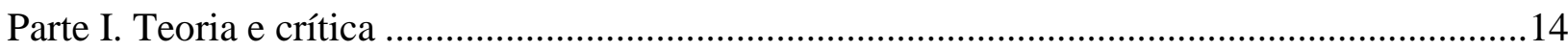

Capítulo I. Serguei Dovlátov, um escritor russo na América................................................... 15

Serguei Dovlátov no contexto da literatura não oficial soviética e da literatura de emigração.44

Capítulo II. Poética, tradição e procedimentos artísticos ..............................................................67

O contador de histórias: anekdot e a "oralidade" da obra de Dovlátov ....................................85

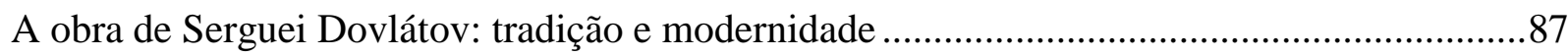

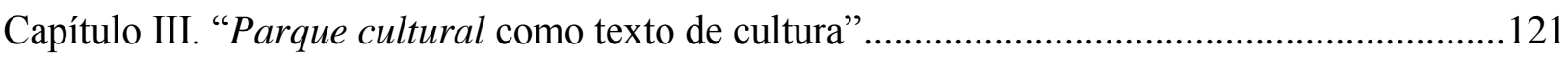

Parte II - Tradução e criação......................................................................................... 175

Capítulo IV. De Zapoviédnik a Parque cultural ...................................................................176

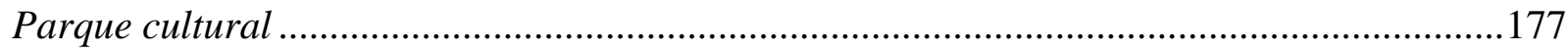

Estratégias da tradução e da transferência cultural ................................................................270

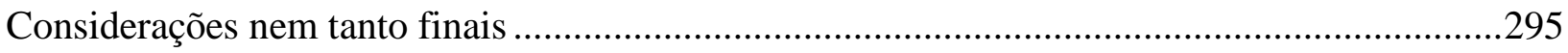

Regras de tradução e transliteração de nomes próprios........................................................298

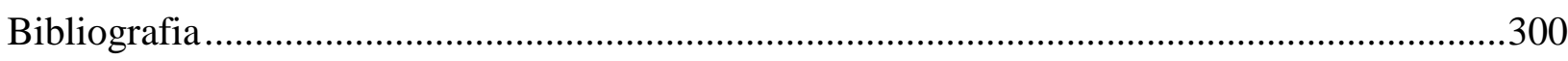




\section{Do ponto de partida ao ponto final}

A escrita de Serguei Dovlátov me acompanha desde os meus quinze ou dezesseis anos. $\mathrm{Na}$ época, quando comecei a conhecer seus livros, sabia muito pouco do contexto histórico e cultural no qual viveu e trabalhou, da literatura não oficial e da emigração dos anos 1970 - 1980 . E o que me atraía em seus textos, em primeiro lugar, era o humor cintilante e certo carisma da personagem principal, o "Serguei Dovlátov ficcional” que, na época, para dizer verdade, eu siquer separava do seu autor.

Desde a adolescência, seus textos A mala, Parque cultural, Os nossos e A troca formavam parte da série de livros de cabeceira, bons para reler tanto nos momentos de cansaço ou tristeza, para levantar o ânimo, como nos momentos de alegria, para compartilhar esse sentimento com o bem humorado e irônico protagonista das narrativas. Com o passar do tempo, conforme a minha própria evolução intelectual, abriam-se para mim novos significados de seus textos.

Assim, se aos meus quinze - dezoito anos o que mais me atraía era a comicidade, a ironia com a qual o protagonista sabia encarar as peripécias da vida, assim como a capacidade de rir dos próprios vícios, defeitos e fracassos, com o avançar da idade começaram a chamar atenção outras facetas mais sérias e até trágicas da sua criação, como a tragédia de não se poder realizar profissionalmente em seu país, a vida no contexto semi-clandestino da literatura não oficial na União Soviética, e a emigração como uma solução paradoxal para seguir a carreira de um escritor russo.

O estudo da obra do escritor e do seu papel no contexto da Terceira Onda de emigração (e da literatura russa de emigração em geral) começou durante a minha estada no Brasil, estando eu, portanto, também em uma "emigração". Tal pesquisa foi para mim uma experiência não apenas acadêmica, mas também uma exploração íntima e pessoal. A minha própria experiência de vida fora do país natal e do contexto cultural familiar também contribuiu para o desenvolvimento desse trabalho, já que me permitiu enxergar sob outro ângulo, "do outro lado da barreira" os temas levantados pelo escritor na sua criação durante a emigração, assim como os detalhes de sua vida. Desse modo, a evolução durante esses quatro anos de pesquisa foi "mútua": descobrindo novas facetas sobre Dovlátov, a literatura e cultura de emigração, descobria também a mim mesma. 
Serguei Dovlátov: texto de cultura na literatura russa contemporânea

O desdobramento desta pesquisa ainda é incerto, mas é certo que o escritor seguirá presente na minha vida, e os seus livros continuarão a ser durante muito tempo um bálsamo nos momentos difíceis e um modo de se deleitar ainda mais nos momentos bons, já que, afinal, servindo-me da metáfora de Ray Bradbury, posso afirmar que não há melhor remédio para a melancolia que um bom livro.

O presente trabalho busca analisar a novela Parque cultural (1983, título em russo, Zapoviédnik), do escritor russo Serguei Dovlátov (1941 - 1990), como texto de cultura, segundo a teoria da semiótica da cultura de Iúri Lótman. A partir de tal aporte, extrairemos alguns conceitos da cultura russa e soviética que se desdobram no texto dovlatoviano (em primeiro lugar, o conceito do mito puchkiniano e a sua transformação na cultura soviética). Apresentar a leitores e pesquisadores brasileiros a obra de Serguei Dovlátov, um dos principais prosadores da segunda metade do séc. XX, já considerado clássico da contística russa, constitui, certamente, um dos objetivos dessa pesquisa.

Emigrado em 1978, Serguei Dovlátov, junto com Joseph Brodsky e Aleksándr Soljenítsyn, é considerado um dos maiores representantes da Terceira Onda de emigração russa, que aconteceu nos anos 1970 - 1980. A literatura de emigração russa é estudada como um gênero à parte por críticos e teóricos russos e ocidentais, a partir de suas características bastante específicas de uma literatura produzida em língua russa, mas fora de seu contexto social e cultural. A especificidade da emigração russa consiste na existência de várias ondas massivas de emigração que aconteceram em diferentes momentos históricos, o que levou à formação de vários centros de cultura russa no exterior e contribuiu para a heterogeneidade da cultura e inclusive da própria língua no âmbito da emigração. Para compreender melhor o contexto da Terceira Onda de emigração e o papel de Serguei Dovlátov nesse contexto, apontamos um breve panorama comparativo das ondas de emigração que aconteceram ao longo do século XX.

Na emigração, o caso de Dovlátov não foi típico, pois nos EUA ele teve um êxito dificilmente imaginável para um escritor emigrado: a sua obra obteve grande sucesso e uma recepção vibrante não apenas entre o público da colônia de falantes de russo, mas também entre leitores e críticos norte-americanos, sendo que na União Soviética, antes de emigrar, Dovlátov fora proibido de publicar em revistas e editoras soviéticas. Ele pertencia ao âmbito da cultura não oficial, ou seja, a um fenômeno cultural "paralelo" à cultura oficial do país. Na URSS, seus 
Serguei Dovlátov: texto de cultura na literatura russa contemporânea contos eram distribuídos através dos meios semi-clandestinos de samizdat e tamizdat, ${ }^{1}$ e o número de leitores em seu país era muito pequeno. Portanto, apesar de o autor escrever apenas em russo (e seus textos serem traduzidos para o inglês nos EUA por tradutores nativos), a carreira literária de Dovlátov de fato desenvolveu-se na emigração.

Uma das peculiaridades da criação do escritor é, por um lado, um forte autobiografismo presente em sua ficção, e, por outro, um estreito vínculo com a cultura, história e atualidade da União Soviética. Embora a maior parte da obra de Dovlátov fosse escrita já na emigração, a maioria de suas narrativas se desenvolve na Rússia, na cidade de Leningrado, ou em outros lugares onde o autor havia vivido e trabalhado. Assim, em sua obra se entrelaçam os fatos e fenômenos da cultura russa com as peculiaridades da biografia e da vida do autor, dados pelo prisma da personagem autobiográfica. Todos os principais textos do escritor correspondem a períodos de sua vida, e neles o leitor pode adivinhar o contexto cultural, social e histórico vivido pelo autor na URSS nos anos 1960 - 1970, antes de sua emigração. Tal estreita relação da obra de Dovlátov com a cultura russa nos permite analisar a novela Parque cultural do ponto de vista da teoria da semiótica da cultura, segundo a conceituação de Iúri Lótman.

Além do seu estilo característico, a novela possui uma complexa estrutura com várias camadas de significados, que empreende um diálogo não apenas com a tradição da literatura clássica russa, mas, em particuular, com um dos seus maiores representantes, Aleksándr Púchkin. Além disso, há um diálogo com a literatura soviética contemporânea, por meio da ótica do protagonista, também pertencente à literatura não oficial, além de referências claras ao ambiente social e político da União Soviética no período de estagnação, nos anos de 1970, marcado por um fenômeno de emigração massiva. Neste trabalho, por meio da análise textual da novela, tentamos identificar alguns dos principais conceitos próprios da cultura e literatura russas aos quais apela o escritor, e propusemos na Parte II a nossa variante da tradução da novela para o português brasileiro, explicitando as estratégias tradutórias usadas.

A obra de Dovlátov chegou à Rússia logo após a sua morte, no começo dos anos 1990, com a queda do regime soviético e da Cortina de Ferro. Desde então, o interesse dos leitores russos pela personalidade e pelos textos do escritor não disminuiu. Desde os anos 1990 desenvolveu-se também uma série de estudos referentes à sua vida e obra. Além dos estudos acadêmicos na Rússia, surgiu também o interesse científico pela obra de Dovlátov no Ocidente: há várias pesquisas, desenvolvidas principalmente no Estados Unidos e no Canadá, tanto devido à difusão da obra do autor em inglês como à grande colônia de falantes de russo nessa região.

\footnotetext{
${ }^{1}$ Samizdat e tamizdat, meios de distribuição da literatura não censurada na URSS na época de estagnação. Denominavam-se de samizdat manuscritos copiados à máquina, e de tamizdat, livros publicados em russo no exterior.
} 
Serguei Dovlátov: texto de cultura na literatura russa contemporânea

Portanto, o objetivo central deste trabalho consiste em apresentar ao público brasileiro a obra de Serguei Dovlátov, um dos clássicos da contística russa, reconhecido e estudado não só em sua terra natal, mas também em outros países. Apesar de sua relevância, ele ainda é desconhecido no Brasil. Não há estudos de sua obra e até agora foi publicado em português apenas um de seus contos, Na rua e em casa, na Nova Antologia do Conto Russo, de 2011 (título em russo Na úlitse i doma, tradução de Mário Ramos e Yulia Mikaelyan), e também um fragmento de seu romance $A$ mala (em russo, Tchemodán; tradução de Marina Darmaros) no caderno Ilustríssima da Folha de São Paulo. Além disso, na área dos estudos da literatura e cultura russa no Brasil, ainda não há trabalhos que desenvolvam pesquisas referentes a escritores da Terceira Onda da emigração russa. Portanto, a apresentação da biografia do escritor e a análise do seu papel no contexto literário da Terceira Onda de emigração, juntamente com a tradução e análise da novela Parque cultural, considerada por muitos críticos um dos melhores textos de Dovlátov, não apenas vem apresentar ao leitor brasileiro um escritor russo praticamente desconhecido, mas também contribuir do ponto de vista acadêmico para os estudos da literatura russa no Brasil. A análise do texto da novela como texto de cultura, na terminologia de Iúri Lótman, também nos permite recorrer á análise de séries da cultura, tais como a histórica e a social, estabelecendo, assim, relações com os processos históricos e sociais que tiveram lugar na União Soviética na década 1970, chamada de "época de estagnação".

O resultado final dessa pesquisa estrutura-se em duas partes. A Parte I, intitulada "Teoria e crítica", é composta de três capítulos e é dedicada ao estudo da biografia do escritor e ao contexto social e histórico no qual se insere, assim como à análise de sua poética por meio do estudo da novela Parque cultural como texto de cultura.

No Capítulo I, intitulado "Serguei Dovlátov, um escritor russo na América”, apresenta-se a biografia do escritor em relação aos seus principais textos artísticos (o acentuado "pseudobiografismo" da ficção de Dovlátov é uma das marcas de sua obra) e o surgimento do mito referente à figura de Dovlátov; analisa-se também o contexto da literatura não oficial soviética nos anos 1960 - 1970, ao qual pertencia o escritor; oferece-se ainda um panorama das quatro ondas da emigração russa que tiveram lugar ao longo do século $\mathrm{XX}$, com atenção especial à Terceira Onda de emigração e o papel de Serguei Dovlátov nesse contexto histórico e cultural.

No Capítulo II, intitulado "Poética, tradição, procedimentos artísticos", analisam-se as principais marcas da poética do escritor, os traços de diferentes correntes artísticas em sua obra, o dialogismo com outros escritores ocidentais e russos e a relação e o diálogo que estabelece o escritor com a tradição literária russa do século XIX. 
Serguei Dovlátov: texto de cultura na literatura russa contemporânea

No Capítulo III, intitulado "Parque cultural como texto de cultura", expõem-se os pressupostos teóricos e os principais conceitos da teoria da semiótica da cultura, de Iúri Lótman; sob o viés da semiótica da cultura de Lótman analisa-se a novela Parque cultural como texto da cultura; analisa-se um dos principais fenômenos da cultura russa presentes na novela, que é o mito referente ao poeta Aleksándr Púchkin, o seu surgimento e desenvolvimento ao longo dos séculos XIX e XX, e como o mito foi abordado na literatura não oficial soviética. Outros fenômenos da cultura soviética que o texto evoca, como o problema do alcoolismo como forma de protesto e harmonização com a realidade, a época de estagnação brejneviana, o problema do antissemitismo na URSS e a massiva emigração dos judeus nos anos 1970 são também analisados no capítulo.

A Parte II, intitulada "Tradução e criação", é composta de um capítulo e é dedicada ao processo da tradução da novela Parque cultural para o português brasileiro.

No Capítulo IV, intitulado "De Zapoviédnik a Parque cultural”, apresentamos a nossa versão da tradução da novela com notas e comentários; a seguir, pontuamos os pressupostos teóricos da abordagem funcionalista dos Estudos da Tradução e as estratégias utlilizadas na tradução; também apresenta-se uma análise comparativa das respectivas traduções da novela para o inglês, francês e italiano, e são extraídas algumas das dificultades que enfrentam os tradutores no processo da tradução, bem como as suas possíveis soluções. Além do mais, nos comentários finais à novela, explicam-se alguns fenômenos da vida e da cultura russa que o texto evoca, não contemplados na análise da Parte I do trabalho. 


\section{Parte I. Teoria e crítica}




\section{Capítulo I. Serguei Dovlátov, um escritor russo na América}

Uma das marcas do estilo do escritor Serguei Dovlátov (1941 - 1990) é o aparente caráter documental de sua prosa. Praticamente toda a sua obra, escrita em forma de "pseudomemórias", possui fortes elementos autobiográficos e espelha a trajetória da vida de Dovlátov. Assim, a maioria de seus textos é escrita em primeira pessoa, o herói autobiográfico possui traços físicos e de caráter semelhantes ao de seu autor e, inclusive, em alguns de seus textos, como nos romances Os nossos, A mala e A troca, o narrador leva o nome do escritor.

Se em diferentes narrativas a personagem principal apresenta o nome de Boris Alikhánov, Serguei Dovlátov e Serguei Dalmátov, trata-se, no entanto, do mesmo herói lírico e autobiográfico. E o seu desenvolvimento se dá ao longo de narrativas, que correspondem a períodos muito próximos aos da vida do escritor, o que permite a Igor Sukhikh, um dos principais pesquisadores da obra de Dovlátov na Rússia, declarar que "cada livro, é uma etapa, uma época na história da personagem central da prosa dovlatoviana". ${ }^{2}$ Para a mistura do documentário com a ficção contrubui o fato de que em todos os seus principais textos o autor usa como pontos de referência os acontecimentos reais de sua vida e lugares, nos quais morou e trabalhou. Assim, a maioria das personagens de seus livros tem protótipos reais e facilmente reconhecíveis. Entre eles, figuram parentes, colegas e amigos do escritor.

No entanto, como sempre sublinhou o próprio Dovlátov, que afirmava, com ironia, que "os erros factuais eram parte de sua poética", ${ }^{3}$ tal aparente aspecto documental é ilusório, e o gênero ao qual o escritor se dedicou era o gênero de ficção, não o das memórias. Em sua obra, o escritor não seguia fielmente a crônica dos acontecimentos, que de fato aconteceram, como é próprio a gêneros documentais, mas recriava uma história ficcional, embora o núcleo da narrativa tivesse como base um fato que realmente tivera lugar. Portanto, todas as narrativas de Dovlátov são textos de ficção, nos quais o autor usa como base os acontecimentos e referências de sua própria vida, construindo sobre essa base efetiva o mundo da ficção literária.

A mistura da vida real e da ficção na obra de Dovlátov desconcerta os leitores, os quais, em muitos casos, compreendem as histórias narradas por Dovlátov como acontecimentos reais, confundindo as suas personagens com pessoas reais. Essa construção de "outra realidade" em sua prosa contribui para a criação do mito em torno de sua personalidade e de sua vida. Como

\footnotetext{
${ }^{2}$ SUHKIKH, Igor. Serguei Dovlátov. Vriémia, miesto, sudbá. São Petersburgo: Néstor - Istória, 2006, p. 51

3 VAIL, Piotr. "Bez Dovlátova". IN: Maloizvéstnyi Dovlátov: Sbórnik. São Petersburgo: AOZT "Jurnal Zviezdá", 1996, p. 463.
} 
Serguei Dovlátov: texto de cultura na literatura russa contemporânea lembra um amigo de Dovlátov na emigração, o escritor Lev Lóssev, Dovlátov costumava dizer: “Sinto um orgulho especial quando me perguntam: 'E isso aconteceu de verdade?', ou quando os meus parentes adicionam seus esclarecimentos aos meus contos, especificam os fatos pelas suas lembranças. Isso significa que tomam as minhas invencionices pela realidade". 4

Sabe-se que os acontecimentos da vida pessoal de qualquer escritor, de uma forma ou de outra, têm impacto em sua obra; no entanto, normalmente não podemos analisar uma obra literária partindo dos fatos biográficos de seu autor. O caso de Dovlátov é diferente: o escritor cria a sua obra com base na própria vida. Os principais textos de Dovlátov, colocados na seguinte ordem ${ }^{5}$ - A zona, A troca, O livro invisível, Parque cultural, Os nossos, A mala, $O$ ofício, A filial - representam a trajetória pessoal e profissional da personagem autobiográfica, que em muito coincide com a trajetória do seu autor. Nessa anulação das fronteiras entre o real e o ficcional, podemos ver uma das marcas da modernidade e da pós-modernidade. Assim, criando uma realidade paralela no mundo literário com base em fatos reais, o escritor, ainda em vida, conseguiu construir uma espécie de mito em torno de sua personalidade e do círculo de sua família e amigos, transformados em personagens de suas narrativas. Nas palavras do filósofo e semiólogo Roland Barthes, o mito, que "transforma a história na ideologia", forma parte importante da cultura moderna e se realiza hoje em vários aspectos da sociedade e da cultura modernas, como política, cinema, publicidade etc. Assim, por um lado, o mito é orientado a mudar a realidade e, por outro, tem como objetivo criar determinada imagem da realidade, que coincida com as aspirações dos portadores da consciência mitológica. ${ }^{6}$

A biografia mitologizada do escritor aparece em seus livros principais: A zona (1982, em russo, Zona) é um romance dedicado ao tempo de serviço de Dovlátov no exército, já que ele trabalhou como carcereiro numa colônia penal na República de Kómi, e ao começo de sua carreira literária. A troca (1981, em russo, Kompromiss) é um livro dedicado à sua vida em Tallin e ao trabalho de jornalista num jornal estoniano; Parque cultural (1983, título em russo, Zapoviédnik), trata-se de uma novela que recria a experiência de trabalho como guia no parquemuseu Púchkinskie Góry (“Colinas de Púchkin”), já na véspera da emigração; Os nossos (1983, em russo, Náchi), é a história de todos os membros da família de Dovlátov ao longo de quase um século; A mala (1986, em russo, Tchemodán), romance mais conhecido de Dovlátov, é um verdadeiro resumo simbólico de sua vida russa, pois se refere à bagagem que está levando à emigração; $O$ ofício (1985, em russo, Remesló), é uma novela que retrata o desenvolvimento

\footnotetext{
${ }^{4}$ LÓSSEV, Lev. "Rússki pissátel Serguei Dovlátov". IN: Dovlátov, S. Posliédniaia kniga. São Petersburgo: Ázbuka, 2012, p. 383.

${ }^{5}$ Tal ordem não segue a ordem da publicação dos romances, no entanto corresponde à sequência cronolôgica dos acontecimentos na vida do escritor.

${ }^{6}$ BARTHES, R. Ízbrannye. rabóty: Semiótika. Poétika Moscou: Progress, 1989, p. 111.
} 
Serguei Dovlátov: texto de cultura na literatura russa contemporânea profissional de Dovlátov e a sua carreira literária desde os anos 1960, como a literatura não oficial soviética, até os anos 1980, e a sua realização profissional como escritor já na emigração; A filial (1989, em russo, Filial), novela dedicada a uma vida na colônia russa na emigração, nos Estados Unidos.

Embora o escritor mude o nome do protagonista e do narrador em seus textos (o nome da personagem principal é Boris Alikhánov, em A zona e Parque cultural; Serguei Dovlátov em $A$ troca, Os nossos e A mala; Serguei Dalmátov, em A filial), como indica Sukhikh, o conjunto dos principais textos do escritor pode ser visto como partes integradas ou capítulos de uma epopeia, na qual há um único protagonista. Segundo Sukhikh, este seria o "o herói lírico dovlatoviano", o qual emerge em uma linha de enredo que se desenvolve ao longo de todas estas narrativas. ${ }^{7}$

Tendo em vista tal especificidade do método artístico de Dovlátov, parece produtivo apresentar a seguir uma breve biografia do escritor captada pelo prisma de sua obra. É possível focalizar a realidade ficcional gerada em seus textos em estreita simbiose à vida real do escritor. Assim, pretende-se compreender melhor a trajetória do escritor, e, ao mesmpo tempo, o mito referente à sua personalidade, criado por ele próprio.

Serguei Donátovitch Dovlátov ${ }^{8}$ nasceu no dia 3 de setembro de 1941 na cidade de Ufá, para onde sua família havia sido evacuada de Leningrado durante a Segunda Guerra Mundial. Fragmentos dedicados à infância aparecem nos livros Os nossos, $O$ ofício e A mala. Em seus textos, o mito literário que o escritor criara em torno do "Dovlátov ficcional" começa a funcionar já desde os primeiros meses de vida do protagonista. Na época da guerra, por um curto período também esteve em Ufá o escritor russo Andrei Platónov ${ }^{9}$, uma das figuras da literatura russa que Dovlátov sempre admirou. Nas primeiras páginas do livro $O$ ofício Dovlátov criou um episódio curioso, no qual a mãe do protagonista Serguei Dovlátov, passeando com o pequeno Serioja, cruza na rua com um homem estranho e misterioso que aponta para a criança, pedindo à mãe a autorização para beliscá-la. Naquele homem, posteriormente, o protagonista reconhece Andrei Platónov: "Resulta que Platónov morou em Ufá. Ainda que por muito pouco tempo. Todo o mês de outubro do ano de 1941. (...) O homem que queria beliscar-me era Andrei Platónov". ${ }^{10}$ Assim, em sua ficção, o escritor marca o seu destino de escritor desde os primeiros meses de vida: segundo o autor, o grande escritor soviético o abençoou e determinou a sua futura carreira.

\footnotetext{
${ }^{7}$ SUKHIKH. Op. cit., p. 51.

${ }^{8}$ Serguei Dovlátov era nome artístico; nos documentos, o escritor levava o sobrenome duplo, Dovlátov-Miétchik.

9 Andrei Platónov (1899 - 1951), escritor e dramaturgo soviético; as suas obras mais famosas são as distopias Tchevengur e Kotlovan (título em português, "A escavação").

${ }^{10}$ DOVLÁTOV, S. Remesló. São Petersburgo: Ázbuka, 2014, p. 9.
} 
Serguei Dovlátov: texto de cultura na literatura russa contemporânea

A família voltou a Leningrado em 1944, e foi esta a cidade onde Dovlátov viveu a maior parte de sua vida, e que sempre esteve muito presente em sua obra, mesmo durante os anos de emigração. Em muitos de seus textos, Dovlátov, com detalhes e minúcia histórica, descreve ruas, edifícios, restaurantes, pátios e esquinas com quiosques onde se vendia cerveja. Todos eles são lugares que o escritor realmente frequentava com amigos. A cidade de Leningrado tem um lugar especial na obra de Dovlátov, figurando quase como uma personagem a mais em alguns de seus textos como, por exemplo, Os nossos ou A mala. Assim, numa das suas colunas como redator no jornal novaiorquino Nóvyi amerikánets ("O novo americano”), ele dedica a Leningrado o seguinte fragmento:

Nem precisa falar que não esqueci e penso o tempo todo em Leningrado. Querem que enumere as placas desde "Barricada" até "Titan"? Querem que os leve pelos pátios desde a rua Raz'iézjaia até a Marat? (...)

$\mathrm{O}$ meu nome continua o mesmo. Nacionalidade: leningradense. Patronímico: do Nevá. ${ }^{11}$

O livro Os nossos representa uma verdadeira enciclopédia de história e de vida da família de Dovlátov, na qual o escritor, como sempre, em forma ficcional com base nos fatos reais, descreve os membros de sua família que tiveram maior influência em sua vida, desde os avós e até os filhos; um capítulo do livro é inclusive dedicado à cachorra Glacha, que o escritor levou consigo à emigração, outra personagem que aparece em muitas de suas narrativas.

Podemos dizer que a família do escritor pertencia ao círculo de intelligentsia russa: sua mãe, Nora Stepánovna Dovlátova, de origem armênia, fora atriz teatral na juventude, mas trabalhou a maior parte da vida como revisora literária, e o pai, Donat Moisséievitch Miétchik, judeu, era diretor teatral. Os pais separaram-se ainda na infância do escritor; no entanto, Dovlátov sempre manteve contato e uma boa relação com o pai e com sua nova família, tanto que a meia irmã do escritor, Ksana Mechik-Blank, é pesquisadora do patrimônio literário de seu pai e do meio irmão e também uma das mantenedoras do patrimônio de Dovlátov.

A tia de Serguei Dovlátov por parte de mãe, Margarita Dovlátova, era uma importante redatora literária leningradense, que trabalhou com vários grandes escritores soviéticos, como Iúri Guérman e Aleksei Tolstói, entre outros. Portanto, através dela, Serguei Dovlátov desde pequeno conhecera os maiores literatos de Leningrado que frequentavam a casa da tia, o que, de certa forma, influenciou-o no interesse pelo fazer literário. Nos livros, o escritor atribui à tia inclusive a amizade com Mikhaíl Zóschenko, outro grande escritor que influenciara o estilo de

\footnotetext{
${ }^{11}$ DOVLÁTOV, S. Rietch bez póvoda... ili Kolónki redáktora. Moscou: Izdátelstvo Makhaon i Mejdunaródnyi fond Serguéia Dovlátova, 2006, p. 376.
} 
Serguei Dovlátov: texto de cultura na literatura russa contemporânea

Dovlátov e de quem, de certa maneira, considerava-se herdeiro: "Segundo os seus autógrafos, Zóschenko gostava de minha tia. Sempre agradecia a ela pelo trabalho conjunto". ${ }^{12}$

Em 1959, Dovlátov ingressou na Faculdade de Letras da Universidade Estatal de Leningrado, no departamento de língua finlandesa, de onde foi expulso dois anos mais tarde. Em forma humorística, no romance $A$ mala, o escritor caracteriza os anos de seus estudos na faculdade da seguinte maneira: "Os prédios da universidade encontravam-se na parte antiga da cidade. A combinação de água e de pedra gerava ali uma atmosfera especial, majestosa. Num ambiente assim, era difícil ser mandrião, mas eu conseguia."13

Os anos na universidade foram um período bastante fecundo para o desenvolvimento da carreira literária de Dovlátov. Andrei Áriev, escritor e amigo de Dovlátov ainda da época da faculdade, lembra assim o ambiente universitário leningradense da época:

Quando estudávamos na Faculdade de Letras, de repente fizemos uma descoberta assombrosa para nós mesmos. Resultou que em nossa literatura censurada, maltratada, ainda existiam bons escritores. (...) Vimos que na cidade continuava a existir a poesia. Em diferentes cafés, casas da cultura, na Universidade aconteciam sem parar competições poéticas. Surgiram Gleb Gorbóvski, Aleksandr Kúchner, Viktor Sosnora, depois alcançou-os todos Joseph Brodsky. Todos muito diferentes e muito talentosos. Começava algum novo período da nossa literatura, e nós podíamos participar diretamente disso. ${ }^{14}$

Justamente na época da faculdade, Dovlátov conheceu e fez amizade com muitos dos jovens representantes do círculo artístico e literário de Leningrado, como os poetas Ievguéni Rein, Anatóli Náiman, Joseph Brodsky, o artista plástico Aleksandr Nejdánov, entre outros. Com muitos deles, o escritor se encontraria de novo na emigração, nos Estados Unidos.

Depois de ser expulso da universidade por mau aproveitamento escolar em 1962, Dovlátov foi convocado ao exército soviético e passou três anos na República de Kómi, servindo como carcereiro numa das colônias penais da região. O fato de ser expulso da universidade e convocado ao exército e, ainda mais, como carcereiro em colônia penal (tal tipo de serviço era considerado um dos mais duros e difíceis de suportar, tanto física como psicologicamente), provocou um choque entre seus familiares e amigos. Valéri Popóv, escritor e amigo de Dovlátov, autor de sua biografia, intitulada Dovlátov, caracterizou esse fato como mais um "do conjunto premeditado de acontecimentos tragicômicos" da vida do escritor: "Todos ao redor (...) com pavor e admiração, acompanhavámos os ziguezagues dovlatovianos. Como? Ser expulso da

\footnotetext{
12 DOVLÁTOV, S. Náchi. IN: Zapoviédnik. São Petersburgo: Ázbuka, 2003, p. 309.

${ }^{13}$ DOVLÁTOV, S. Tchemodán. IN: Vstriétilis, pogovorili. São Petersburgo: Ázbuka, 2003, p. 277.

${ }^{14}$ KOVÁlovA, Anna, Lurié, Lev. Dovlátov. São Petersburgo: Amfora, 2009, p. 92.
} 
Serguei Dovlátov: texto de cultura na literatura russa contemporânea universidade?! E direto para o exército?! E direto para a tropa da prisão?! Bom, isso, só ele podia!..". 15

O período de serviço de Dovlátov no exército ficou documentado nas cartas que o escritor trocava com a família, as quais foram publicadas na coletânea Serguei Dovlátov. A vida e as opiniões. Correspondência seleta (em russo, Serguei Dovlátov. Jizn i mniénia. Ízbrannaia perepiska), organizada por Andrei Áriev, em 2011. As cartas enviadas ao pai demonstram que a experiência de trabalho como carcereiro na prisão fora bastante chocante para ele. ${ }^{16}$ Como o próprio Dovlátov afirmou depois em várias fontes, foi ali, na prisão, que ele "vira o inferno na terra". 17

Durante o serviço no exército o escritor fez os primeiros experimentos no campo da literatura. Lá, além de vários poemas que o escritor enviava aos familiares e amigos, foram escritos os esboços dos fragmentos e contos que, quase vinte anos mais tarde, integrariam o romance A zona, baseado nessa experiência de carcereiro. Como dizia o poeta Joseph Brodsky, amigo do escritor desde a época da universidade, Dovlátov voltara do exercito "como Tolstói da Crimeia, com um rolo de contos e um certo aturdimento no olhar". ${ }^{18}$

O próprio Dovlátov, seguindo as regras da construção do mito, afirmava em suas narrativas que o livro inteiro fora escrito durante seu serviço. No entanto, como mostram os dados e a análise do texto de $A$ zona, embora alguns de seus fragmentos realmente pertencessem ao período do começo da carreira literária de Dovlátov, ou seja, aos anos 1960, a maior parte do livro foi escrita já nos anos 1980, na emigração.

Desde o seu retorno do exército, em 1965, tem início a atuação de Dovlátov no campo literário. Ao longo de sua vida, o escritor realizou vários ofícios, trabalhando como jornalista, redator, secretário literário, vigilante, guia e inclusive pedreiro na construção de uma das estações de metrô de Leningrado, ofício ao qual é dedicada uma das novelas de $A$ mala, intitulada Sapatos de nomenclatura (em russo, Nomenklatúrnye botínki). Como afirmam os entes próximos do escritor, Dovlátov sempre procurou escolher um trabalho que lhe permitisse dedicar bastante tempo ao fazer literário.

Logo após voltar do exército, o escritor começa a trabalhar como jornalista no jornal de grande tiragem Za kádry viérfiam ("Por quadros aos estaleiros"), e ao mesmo tempo escreve

\footnotetext{
${ }^{15}$ POPÓV, Valéri. "Krov - edínstvennye tchernila”. IN: Maloizvéstnyi Dovlátov: Sbornik. São Petersburgo: AOZT "Jurnal Zvezdâ", 1996, pp. $78-79$.

16 Áriev, Andrei. Serguei Dovlátov. Jizn i mniénia. Ízbrannaia perepiska. São Petersburgo: OOO Jurnal Zviezdá, 2011, p. 39.

${ }^{17}$ Por exemplo, o escritor usa essa expressão no seu livro $O$ ofício (DOVLÁTOV. Op. cit., p. 16). Também encontramos essa expressão no seu romance A zona (DOVLÁTOV. Op. cit., p. 22), e também em vários textos e entrevistas.

${ }^{18}$ BRODSKY, Joseph. “O Serioje Dovlátove”. IN: Dovlátov, S. Posliédniaia kniga. São Petersburgo: Ázbuka, 2012, p. 297.
} 
Serguei Dovlátov: texto de cultura na literatura russa contemporânea ativamente e leva seus textos a revistas literárias, com intenção de publicá-los. Como lembrava o amigo de Dovlátov da época, o escritor Iákov Górdin, "Serioja queria ser escritor muito mais do que qualquer um de nós, para ele, era forçosamente sério. (...) Serioja queria ser publicado". ${ }^{19}$

Tal aspiração de ser publicado tinha a ver com a situação social e profissional dos escritores na União Soviética: para ser oficialmente reconhecido como escritor, era necessário ser membro da União dos Escritores Soviéticos (em russo, Soiuz Pissátelei), e ter publicações em revistas soviéticas ajudava a conseguir a filiação. Como Dovlátov queria trabalhar como escritor profissional e viver de literatura, para ele o caminho mais evidente era começar com publicações em periódicos soviéticos. ${ }^{20}$

Ainda na adolescência, Dovlátov conseguiu publicar alguns textos e poesias em revistas de Moscou e também na revista infantil leningradense Kostior ("A fogueira”). ${ }^{21}$ Para poder dedicar mais tempo à literatura, o escritor pede demissão no jornal e começa a trabalhar como secretário literário de Vera Panova (1905 - 1973), famosa escritora soviética, considerada clássica já na época. O trabalho conjunto com Panova enriqueceu a experiência literária de Dovlátov, de quem o próprio escritor gostava de se lembrar, sempre se referindo a Panova com respeito e gratidão. ${ }^{22}$

Para Dovlátov, era muito importante tornar-se escritor profissional, e, a princípio, o escritor tentou todos os caminhos "legais" para entrar na literatura oficial soviética, levando seus textos às maiores revistas leningradenses. Sukhikh caracteriza a vontade de Dovlátov de conseguir publicações em revistas soviéticas como "as tentativas de entrar na literatura oficial pela entrada principal". ${ }^{23}$ É importante mencionar que, a princípio, embora Dovlátov fizesse amizade com representantes do círculo boêmio de Leningrado e compartilhasse opiniões céticas em relação à ideologia oficial, como afirmam seus contemporâneos, a maior parte de sua obra poderia passar pela censura. Como lembra Elena Dovlátova, a viúva do escritor, “frequentemente, seus contos provocavam aprovação nas pessoas que ocupavam cargos oficiais

\footnotetext{
${ }^{19}$ KOVÁLOVA. Op. cit., p. 145.

${ }^{20} \mathrm{Na}$ União Soviética, o status de escritor profissional, reconhecido pelas autoridades soviéticas, além de emprego estável e prestígio, possibilitava ao seu portador vários privilégios. Tal sistema de apoio dos homens da cultura por parte do governo do país consolidara-se já nos primeiros anos da existência soviética. Para compreender melhor o que era ser "escritor profissional" na URSS, cabe lembrar aqui o ensaio Introductory Remarks on Series for L'Humanité, da coletânea Moscow, de Walter Benjamin, onde o filósofo reflete sobre a sua experiência de viagem à União Soviética em 1927, e lembra dos tratos e privilégios que recebia, pelo simples fato de ser escritor: "For the first time in my life I found myself in a city where I enjoyed privileges of a material and administrative nature simply because I am a writer. (I know of no city apart Moscou where a writer can obtain a reduced price for a hotel room at the behest of the state - for the hotels are all run by the Soviets)" (BENJAMIN, Walter. "Moscow". IN: Selected Writings. Vol. 2, part 1, 1927 - 1930. Cambridge, Massachusetts, London, England: The Belknap Press of Harward University Press, 2005, p. 21).

${ }^{21}$ Ibid., p. 125.

22 Dovlátov, S. Zapisnye Kníjki. São Petersburgo: Ázbuka, 2001, p. 178.

${ }^{23}$ SUKHIKH. Op. cit., p. 23.
} 
Serguei Dovlátov: texto de cultura na literatura russa contemporânea em redações soviéticas. No entanto, acontecia sempre de algo inesperadamente impedir a publicação". ${ }^{24}$

Os contemporâneos e amigos de Dolvátov relacionavam esse malogro do escritor no campo de literatura oficial com a sua participação no famoso Sarau da Juventude Criativa de Leningrado (em russo, Viétcher tvórtcheskoi molodióji Leningrada), que teve lugar na Casa dos Escritores (Dom pissátelei), em janeiro de 1968. Participaram do Sarau poetas e escritores leningradenses, já famosos entre o público, como Joseph Brodsky, Vladímir Maramzín, Vladímir Úfliand, Valéri Popóv, Iákov Górdin, entre outros. Para Dovlátov, essa foi a sua primeira intervenção pública. Como lembram seus participantes, o Sarau chamou a atenção da intelligentsia leningradense e reuniu grande público. ${ }^{25}$ E embora fosse um evento oficial, o Sarau produziu um grande escândalo e, posteriormente, foi considerado pelas autoridades da cidade uma sabotagem. Em algumas fontes, o sarau chegou até a ser chamado de "meeting sionista antissoviético", ${ }^{26}$ devido ao fato de que muitos de seus participantes eram judeus, o que inclusive levou à demissão do diretor da Casa dos Escritores. Iákov Górdin, um dos participantes, explica assim as razões do escândalo:

Simplesmente superestimamos o grau da nossa liberdade e proteção, e o sarau realmente acabou por ser muito provocativo. A situação agravava-se com o fato de que na sala feita para duzentas e cinquenta pessoas, na verdade, havia umas trezentas, e eram pessoas simpatizantes, que compreendiam do que estávamos falando. ${ }^{27}$

Como consequência disso, voltou a reforçar-se o controle e o receio por parte das autoridades em relação à contracultura, ou seja, em relação à cultura que não tinha relação com a aquela oficial. Assim como para Joseph Brodsky, para Dovlátov a participação nesse evento "teve um papel fatídico" para sua futura carreira literária na União Soviética, na expressão de Iákov Górdin. ${ }^{28}$

Como o nome de Dovlátov também figurava na lista dos participantes, embora, como atestavam as testemunhas do Sarau, o conto que o escritor relatara fosse ideologicamente “inofensivo", ${ }^{29}$ seu nome chamou a atenção das autoridades e da KGB. Portanto, a participação

\footnotetext{
${ }^{24}$ KOVÁLOVA. Op. cit., p. 144.

${ }^{25}$ Ibid., p. 148.

${ }^{26}$ Ibid., p. 150.

${ }^{27}$ Ibid., p. 149.

${ }^{28}$ Ibid., p. 145.

${ }^{29}$ Ibid., p. 149.
} 
Serguei Dovlátov: texto de cultura na literatura russa contemporânea do evento de certo modo fechou para ele o caminho para publicação nas revistas literárias de Leningrado.

Como dizia o próprio escritor, em cartas aos amigos, e também a sua viúva, embora muitas vezes Dolvátov recebesse pareceres elogiosos, seus textos nunca eram aceitos. ${ }^{30}$ Elena Dovlátova, na entrevista aos autores do livro Dovlátov, expressou a opinião de que, na época, já existiam listas negras em redações soviéticas, nas quais figurava o nome de Dovlátov. ${ }^{31}$

Apesar de normalmente elogiar o estilo e talento do escritor, nos pareceres enviados das revistas aos escritores oficiais também, em muitos casos, parecia impróprio que os contos de Dovlátov demonstrassem defeitos e vícios das personagens (por exemplo, o alcoolismo, do qual o próprio escritor padecia). As personagens dovlatovianas, muitas vezes pertencentes aos círculos marginalizados, não se submetiam a nenhum tipo de julgamento moral por parte do seu autor. O próprio escritor descrevia assim a sua posição na União Soviética: "Na União Soviética eu não era dissidente. (A bebedeira não conta.) Eu apenas escrevia contos alheios à ideologia". ${ }^{32}$

O desejo de Dovlátov de ser escritor oficialmente reconhecido era tão grande, que o autor chegou a escrever e enviar às editoras alguns contos "ideologicamente alinhados". ${ }^{33}$ No entanto, aparentemente devido à atenção especial dada ao escritor por causa da sua participação do Sarau, tampouco foram aceitos. No livro Dovlátov, Valéri Popóv lembra a seguinte conversa com Dovlátov, na qual este, com ironia, relatou sua experiência de "ajustar a obra ao regime" da seguinte maneira: "Que estranho. Quero ser como todos, escrevi um romance sobre a classe operária. E não querem publicá-lo. Publicam todos, menos eu. As pessoas vendem a alma ao diabo, e eu dei de graça". ${ }^{34}$

Nos anos 1970, morando em Tallin, com a ajuda dos amigos, Dovlátov consegue publicar dois contos seus em revistas leningradenses: em 1973, na revista Nevá (№ 5), sai o seu conto Pela vontade própria (em russo, Po sóbstvennomu jelániu), e em 1974, na revista Iúnost (“A juventude”) (№ 6), é publicado o conto A entrevista (em russo, Interviú). São as primeiras publicações do Dovlátov prosador em revistas literárias soviéticas. No entanto, embora na época as duas revistas fossem consideradas bastante liberais, o texto aceito para publicação devia seguir a política e a ideologia oficial, o que exigia sérias concessões por parte do autor. Os dois contos, principalmente A entrevista, foram modificados pela censura, sem que o autor fosse avisado previamente, algo que, pelo visto, deixou Dovlátov muito descontente, já que a princípio ele estava iludido com a perspectiva de ser publicado pela primeira vez em revistas literárias de

\footnotetext{
${ }^{30}$ CHTERN, Liudmila. Dovlátov - dóbryi moi priátel. São Petersburgo: Ázbuka-Klássika, 2005, p. 171.

${ }^{31}$ KOVÁLOVA. Op. cit., p. 144.

${ }^{32}$ DOVLÁTOV, S. March odinókikh. Holyoke, Massachusetts: New England Publishing Co, 1983.

33 Infelizmente, devido ao rigor do próprio autor com o seu legado artístico, não se conservaram os contos “ideologicamente verificados", escritos por Dovlátov durante a vida na URSS.

${ }^{34}$ POPÓV, V. Dovlátov. Moscou: Molodáia Gvárdia, 2010, p. 165.
} 

referência na União Soviética. Na revista Iúnost, o conto foi publicado junto com uma foto de Dovlátov, o que lhe permitiu escrever a seguinte auto-crítica sarcástica:

\begin{tabular}{|l|l|}
\hline $\begin{array}{l}\text { Портрет хорош, годится для кино. } \\
\text { Но текст - беспрецедентное говно! }\end{array}$ & $\begin{array}{l}\text { O retrato é bom pra quem gosta. } \\
\text { Mas o texto é uma bela bosta! }\end{array}$ \\
\hline
\end{tabular}
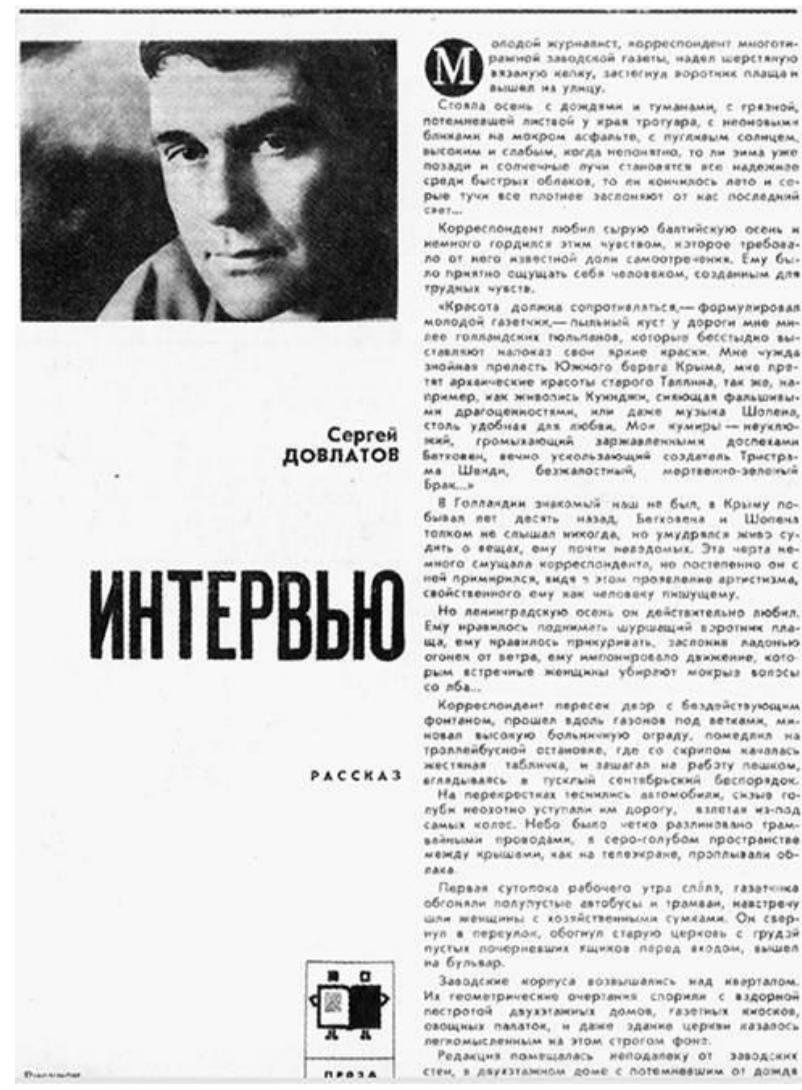

Primeira página do conto Interviú, publicado na revista "Iúnost"

Cabe mencionar que, posteriormente, o próprio escritor sempre se referiu com bastante desprezo aos textos publicados na União Soviética e não gostava de mencioná-los em sua bibliografia. Inclusive no seu testamento, Dovlátov proibiu a republicação após a sua morte da obra publicada na União Soviética antes de sua emigração. Portanto, esses dois contos nunca passaram a formar parte de nenhuma coletânea da obra do escritor.

Apesar de não ser reconhecido oficialmente, no começo dos anos 1970 o nome de Dovlátov já era bastante conhecido nos círculos da intelligentsia leningadense. Sua prosa era distribuída entre os amigos através de samizdat. ${ }^{37}$ Portanto, pode-se falar de uma certa fama literária de Dovlátov na União Soviética, embora isso tenha ocorrido num círculo de leitores muito estreito e semi clandestino.

\footnotetext{
${ }^{35}$ KOVÁLOVA. Op. cit., p. 178.

36 Tradução de Mário Ramos.

${ }^{37} \mathrm{O}$ fenômeno de samizdat será analisado no capítulo dedicado à literatura não oficial soviética.
} 
Serguei Dovlátov: texto de cultura na literatura russa contemporânea

Uma das provas do reconhecimento do escritor em meios literários foi o convite para formar parte do grupo literário Gorojane ("Habitantes de cidade"), criado pelos escritores leningradenses Vladímir Maramzín, Ígor Iefímov (o futuro editor de Dovlátov na emigração), Boris Vakhtin e Vladímir Gúbin. O grupo surgiu em 1964, quando os jovens escritores prepararam uma coletânea conjunta de prosa, intitulada Gorojane (o título que posteriormente deu o nome ao grupo). Os quatro integrantes do grupo, no momento de sua criação, já tinham publicações em revistas soviéticas e participavam de um modo ou de outro da vida literária oficial; portanto, consideravam-se escritores profissionais. Embora a coletânea de sua prosa nunca fosse aceita para publicação e o grupo não fosse reconhecido pelos órgãos oficiais, Gorojane era conhecido e exercia muita influência em círculos literários leningradenses. Para Dovlátov, o convite foi um evidente sinal de reconhecimento de seu talento literário. Infelizmente, o grupo não perdurou muito tempo, e o livro coletivo preparado nunca veio à luz.

É importante mencionar que, como afirmam os amigos e familiares de Dovlátov, o seu desejo de entrar na literatura oficial não era relacionado com fama ou dinheiro: a sua maior aspiração era tornar-se escritor profissional, conseguindo, assim, viver de literatura e dedicar todo o seu tempo ao fazer literário. Como provam várias fontes, a impossibilidade de seguir a carreira que tanto desejava deprimia-o bastante. Por exemplo, sua amiga Elena Klépikova, escritora e co-autora do livro de memórias Dovlátov de cabeça para baixo: a tragédia do homem alegre (em russo, Dovlátov vverkh nogámi: traguédia vessiólovo tchelovieka), cita as seguintes palavras de Dovlátov, referentes à impossibilidade de ser publicado:

Sou um escritor mediano que frisa a maestria. Uma terceira categoria decente. Um animador. Um beletrista deselegante. Não tenho atração pelo futuro. Sou como uma mosca efêmera, carregada de energia e talento, mas só por este dia. Mas fazem-na esperar o amanhã e o depois de amanhã. Você me propõe escrever para mim mesmo, para a gaveta. É a mesma coisa que deitar vivo no caixão. ${ }^{38}$

Separou-se da segunda mulher e ficou decepcionado com a falta de perspectivas de carreira em Leningrado, pois o conservadorismo e a extrema burocratização eram características da cidade à época, como afirmam os contemporâneos de Dovlátov. Em Moscou o ambiente era um pouco mais liberal para os jovens escritores, já que havia mais chance de ser publicado ali. Desse modo, à procura de um ambiente mais próspero, o escritor decidiu partir para Tallin, capital da República Socialista Soviética da Estônia.

\footnotetext{
${ }^{38}$ SOLOVIÓV, Vladímir, Klépikova, Elena. Dovlátov vverkh nogámi: traguédia stchastlívovo tcheloviéka. Moscou: Kolliéktsia "Soverchenno sekrietno", 2001, pp. 80 - 81.
} 
Serguei Dovlátov: texto de cultura na literatura russa contemporânea

Na época, Tallin era considerada a cidade mais europeia do país, e a Estônia, em geral, tinha fama de um dos lugares mais liberais da União Soviética, que guardava tradições de certo liberalismo ocidental. Alguns historiadores veem nesse fenômeno o vestígio dos vinte anos da independência da Estônia (desde 1918, depois da queda do Império Russo, e até 1940). A Estônia, junto com a Letônia e a Lituânia, fora anexada à União Soviética apenas no ano de 1940, sendo o último entre os países bálticos a ser anexado. Os autores do livro Dovlátov caraterizam o ambiente na Estônia soviética da seguinte maneira:

Na Estônia, havia mais liberdade do que em qualquer outro lugar do país. Aqui, permitiam com mais facilidade e proibiam com menos prazer. Aqui, com mais vontade fechavam os olhos para a apatia política, com mais frequência deixavam passar manifestações mal vistas, mais raramente castigavam pelos erros ideológicos". 39

Assim, não foi por acaso que justamente na cidade estoniana de Tartu encontrou abrigo o famoso grupo de Iúri Lótman.

Nos anos 1970, os autores mal vistos pela ideologia oficial tinham maiores chances de publicar um livro justamente na República da Estônia. Na época, além de ser famosa por seu ambiente mais distendido e liberal, também não havia muitos escritores contemporâneos falantes de russo, o que facilitava a publicação de textos literários em russo. Por isso, Dovlátov considerou a mudança para Tallin como uma chance de finalmente entrar na literatura soviética: parecia-lhe mais real a possibilidade de publicar um livro ali e assim entrar na União de Escritores local. Mesmo a filiação em uma União de Escritores periférica já aumentava consideravelmente as futuras chances de publicar em outras regiões. Valéri Popóv, em seu livro Dovlátov, denomina a mudança para Tallin como "a primeira emigração" de Dovlátov. ${ }^{40} \mathrm{O}$ escritor morou em Tallin entre os anos de 1972 e 1975, onde trabalhou como jornalista no jornal do partido Soviétskaia Estônia (“A Estônia soviética”), um dos maiores jornais da região.

De certo modo, as aspirações de Dovlátov referentes às possibilidades de carreira na Estônia confirmaram-se: em Tallin, o escritor começou a trabalhar num dos maiores jornais da república e se tornou um periodista de referência no ambiente profissional. Ao seu trabalho como jornalista na imprensa estoniana posteriormente seria dedicado seu livro A troca, em que, de uma forma humorística, descrevia-se o dia a dia da redação de um jornal ideológico soviético, onde trabalhava o herói, e se mostrava o laboratório de criação de reportagens "ideologicamente verificadas" (que resultavam não ter nada a ver com a situação inicial a ser narrada).

\footnotetext{
${ }^{39}$ KOVÁLOVA. Op. cit., p. 176.

${ }^{40}$ POPÓV. Dovlátov. Op. cit., p. 205.
} 
Serguei Dovlátov: texto de cultura na literatura russa contemporânea

Mas a realização mais importante para Dovlátov no solo estoniano foi a preparação para publicação do seu primeiro livro, intitulado Cinco esquinas (em russo, Piat uglóv; mais tarde o título seria mudado para Contos da cidade (Gorodskie rasskázy), na editora estoniana Eesti Raamat. Era um acontecimento em que o escritor depositava muitas esperanças, vendo nele a possibilidade de finalmente entrar na literatura oficial soviética e ganhar o status de escritor profissional.

Com a publicação do livro, que nunca aconteceu, está relacionado um episódio bastante dramático na vida de Dovlátov, que, recriado, passou a formar parte do livro O ofício. O livro, aprovado pela censura, já estava pronto para a publicação, mas de repente a composição editorial já feita foi destruída sob ordem da KGB estoniana.

Valéri Popóv vê essa situação como mais um grande azar nos ziguezagues da vida do escritor, e que levou à destruição do livro: um conhecido de Dovlátov, Vladímir Kotiélnikov, por acaso estava com o manuscrito de seu livro em casa quando sofreu uma busca por parte da polícia. Na casa de Kotiélnikov, a polícia achou vários livros proibidos, como os de Soljenítsyn, Mandelstam e Gumilióv, e, por má sorte, o manuscrito de Dovlátov fora levado junto. Assim, o nome do escritor e seu manuscrito foram envolvidos num escândalo relacionado com a literatura proibida. Após esse acontecimento, como lembra a terceira mulher do escritor, Tamara Zibunova, com a qual ele morou em Tallin, Dovlátov foi a KGB da Estônia, onde conseguiu provar que o seu manuscrito não tinha a ver com a literatura dissidente (como afirma Zibunova, os órgãos concordaram que o manuscrito fora levado por engano e não tinha nada a ver com o caso de Kotiélnikov). ${ }^{41}$ No entanto, esse episódio e o fato de Dovlátov ter amizade com "pessoas precárias" de novo chamou atenção para seu nome, o que determinou o destino do livro. Após o escândalo com o manuscrito, a censura vetou a sua publicação, e, além do mais, Dovlátov foi demitido do Soviétskaia Estônia, tendo que voltar a Leningrado.

Como mencionam os biógrafos e familiares de Dovlátov, foi um golpe muito traumático para ele, que o levou a uma forte depressão. Liudmila Chtern, escritora e amiga de Dovlátov, cita o seguinte trecho de uma de suas cartas, enviadas a Chtern naquele período: "Não tenho medo de afirmar a você que estou absolutamente desamparado, como nunca estive, e vivi a derrocada de todas as minhas esperanças, de todas as minhas miseráveis ilusões". ${ }^{42}$

Esse fracasso foi visto por Dovlátov como um dos primeiros sinais da impossibilidade de sua atuação como escritor em seu país, a União Soviética. O próprio autor, num tom bastante trágico, relata esse acontecimento em seu livro $O$ ofício. De forma tragicômica, no livro é descrito o momento da discussão da situação em reunião convocada pela redação, quando se

\footnotetext{
${ }^{41}$ KOVÁLOVA. Op. cit., p. 224.

${ }^{42}$ CHTERN. Op. cit., p. 163.
} 
Serguei Dovlátov: texto de cultura na literatura russa contemporânea anuncia a demissão do protagonista. Ali, ${ }^{43}$ os discursos pronunciados pelos colegas do herói autobiográfico tomam formas do absurdo kafkiano:

- Camaradas, começou o redator, reunimo-nos aqui para discutir... Para comprender as raízes da queda moral... O camarada Dovlátov irresponsavelmente passou o seu manuscrito $A$ zona à pessoa, cuja personalidade ideológica... À pessoa, de que se ocupam os órgãos correspondentes... Não há certeza, meus amigos, de que... E se os nossos inimigos estão brandindo com este livro? Está acontecendo a luta de dois mundos, de dois sistemas... Conhecíamos Dovlátov como um jornalista talentoso... Mas era uma pessoa dupla, como se diz... Duas caras, camaradas. E, além disso, duas caras totalmente diferentes... (...)

Meu Deus, o quê começou aqui! Primeiramente, eu até sorria. O viceredator K. Málychev:

- Dovlátov caiu num pântano... Joga água no moinho da burguesia... Difamou tudo o que é mais caro... ${ }^{4}$

Evidentemente, na ficção, Dovlátov exagera o grau de absurdo em prol do efeito artístico. No entanto, como afirmam em entrevistas os colegas do escritor de Soviétskaia Estônia, a reunião e a discussão realmente aconteceram. Assim como lembra o jornalista Mikhail Roguínski, "uma das exclamações mais ridículas daquela noite soava como 'É pior do que Soljenítsyn!'”. ${ }^{45}$ De toda forma, o escândalo provocado pela confiscação do manuscrito realmente levou à sua demissão do jornal, e Dovlátov não tinha outro remédio senão voltar a Leningrado.

Dovlátov regressou em 1975. Depois do escândalo na Estônia, para ele se tornou quase impossível receber um cargo fixo em jornais leningradenses. Seus amigos ajudaram-no com um trabalho provisório na revista infantil Kostior, onde Dovlátov trabalhou por alguns meses como redator, substituindo uma das funcionárias da revista durante a sua licença maternidade.

Em 1976 - 1977, sob a recomendação dos amigos Andrei Áriev e Vladímir Guerássimov, ${ }^{46}$ de maio a outubro, Dovlátov trabalhou como guia no complexo histórico Mikháilovskoe-Trigórskoe, nas Colinas de Púchkin, região de Pskóv, na antiga propriedade do poeta russo Aleksándr Púchkin.

\footnotetext{
${ }^{43}$ No livro, em prol da invenção artística, narrava-se que o livro preparado para a publicação em Tallin e cujo manuscrito fora posteriormente confiscado era $A$ zona; era o romance que, no momento da publicação da novela $(O$ ofício foi publicado em 1985), já era famoso entre os leitores.

${ }^{44}$ DOVLÁTOV. Remesló. Op. cit., p. 71.

${ }^{45}$ KOVÁLOVA. Op. cit., p. 226.

46 O historiador Vladímir Guerássimov foi protótipo da personagem do erudito extremamente preguiçoso Volódia Mitrofánov, em Parque cultural.
} 
Serguei Dovlátov: texto de cultura na literatura russa contemporânea

O parque museu foi criado em 1922, sob a resolução do Sovnarkom ${ }^{47}$ no território da antiga propriedade do poeta, que, no momento, estava em ruínas (as duas aldeias, Mikháilovskoe e Trigórskoe, foram praticamente destruidas durante a Guerra Civil, entre 1917 e 1922). A casa que pertencia ao poeta fora demolida ainda em 1860 pelo seu filho Grigóri, e no lugar dela fora construída outra, com arquitetura totalmente distinta. ${ }^{48}$ Portanto, o parque museu não pode ser considerado um patrimônio histórico no sentido estrito da palavra, pois no local não se havia conservado quase nada da época, quando o poeta morava ali (Púchkin frequentou Mikháilovskoe na adolescência, e passou ali o seu segundo exílio, nos anos entre 1824 e 1826). No parque museu, foi recriado o ambiente da época de Púchkin, da qual, de fato, sobrara apenas a paisagem. Esse elemento decorativo e até teatral do museu, e o pathos ideológico soviético que transmitia a administração nos anos de 1960 a 1970, quando já estava consolidado o mito soviético de Púchkin, era objeto de constante piada entre os intelectuais. Na novela Parque cultural, o escritor faz constantes referências à natureza meramente decorativa, teatral, do complexo histórico, e o tema da falsidade, da substituição é, como salienta Sukhikh, um dos leitmotifs do texto. $^{49}$

O "exílio" na antiga propriedade de Púchkin era bastante popular entre os representantes do circulo literário não oficial leningradense: ali, trabalhando como guias, os escritores e intelectuais sentiam-se muito mais livres do que, por exemplo, trabalhando no campo jornalístico. O trabalho no parque museu era bastante bem pago, e, para uma pessoa culta, não representava muita dificuldade: bastava ler apenas alguns livros para tornar-se guia. ${ }^{50}$

Liudmila Tíkhonova, funcionária do museu e ex-colega de Dovlátov, explica assim a atração da intelligentsia criativa de Leningrado por Mikháilovskoe:

Os petersburgueses como Serioja, Andrei Áriev e Volódia Guerássimov salvavam-se no parque museu. Para eles, era um escape. Aqui, podiam descansar de tudo aquilo que não lhes convinha na vida soviética. Era quase o único lugar de toda a União Soviética onde pessoas como eles podiam trabalhar de um modo criativo, recebendo, ao mesmo tempo, bastante dinheiro. Dovlátov veio aqui também como escritor. Veio não para guiar excursões, mas para acumular impressões. ${ }^{51}$

\footnotetext{
${ }^{47}$ Sovnarkom, abreviação de Soviet Naródnykh Kommissárov (em português, "Conselho de Comissários do Povo"), nome do Governo da República Socialista Federativa Soviética da Rússia, no período entre 1917 e 1946.

${ }^{48}$ NÓVIKOV, Vladímir. Púchkin. Moscou: Molodáia Gvárdia, 2014, p. 21.

${ }^{49}$ SUKHIKH. Op. cit., p. 134.

${ }^{50}$ KOVÁLOVA. Op. cit., p. 262.

${ }^{51}$ Ibid., p. 265.
} 


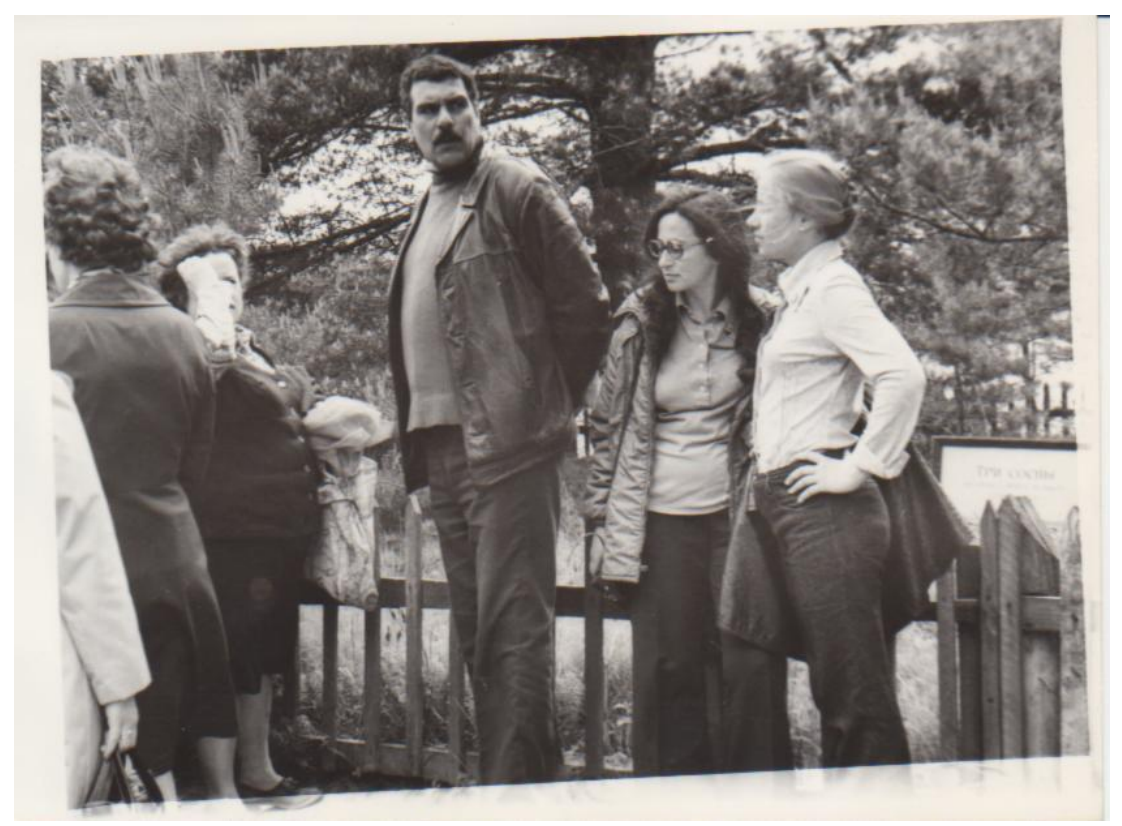

Na foto, Serguei Dovlátov guiando uma excursão, em Púchkinskie Góry

Dovlátov recria a experiência de seu trabalho no parque museu em sua novela Parque cultural, uma de suas novelas mais notáveis, considerada por muitos críticos uma de suas melhores obras. ${ }^{52} \mathrm{Na}$ novela, o autor descreve com muita ironia e sarcasmo a falsidade do mito soviético de Aleksándr Púchkin, e o museu como seu panteão principal.

Cabe mencionar que o sarcasmo com o qual Dovlátov retratou no livro o museu e seus funcionários, provocou uma forte reação entre eles após a publicação da novela. Muitos dos funcionários do museu (e alguns trabalham nas Colinas de Púchkin até hoje), entre eles, o diretor do museu da época, Semión Guéitchenko (o seu nome nem sequer foi mudado no texto da novela), ficaram ofendidos com a caricatura feita por Dovlátov. Assim também ficou indignado com o seu "retrato" Valéri Kárpov, protótipo da personagem do fotógrafo Valera Márkov, acusando Dovlátov de descrevê-lo no livro como "um alcoólatra sem solução". 53 Já Vladímir Guerássimov comenta o seu "aparecimento" no livro, na personagem do erudito extremamente preguiçoso Mitrofánov, da seguinte maneira: “As pessoas inteligentes compreendem que as suas imagens são muito distantes da realidade. As personagens têm protótipos, mas Dovlátov, fiel à sua maneira grotesca de ver o mundo como absurdo, distancia-se muito dos traços verdadeiros do protótipo". 54

Outro leitmotif do livro é o tema de emigração e da possibilidade de um escritor realizarse profissionalmente fora de seu contexto linguístico e cultural: uma das perguntas que se faz o narrador é se é possível para um escritor sobreviver e continuar escrevendo longe de sua língua,

\footnotetext{
52 GUÉNIS, Aleksándr. "Púchkin”. IN: Dovlátov, S. Posliédniaia kniga. São Petersburgo: Ázbuka, 2012, p. 328.

${ }^{53}$ KOVÁLOVA. Op. cit., p. 290.

${ }^{54}$ Ibid., p. 286.
} 
Serguei Dovlátov: texto de cultura na literatura russa contemporânea de seu leitor e de seu contexto cultural. Em Parque cultural, Dovlátov descreve as hesitações da personagem principal na escolha de sua futura vida: ou emigrar, abandonando a própria cultura e o seu leitor, ou continuar na terra natal, mas vivendo na miséria e sem possibilidades de ser um escritor profissional.

As hesitações do protagonista correspondem ao estado do seu autor na época: em 1977, emigram do país a mulher (a segunda esposa de Dovlátov, Elena Dovlátova, com a qual o escritor estava oficialmente divorciado, mas o casal mantinha relações de família) e a filha mais velha do escritor. Como lembram os seus amigos, no momento da partida da mulher e da filha, Dovlátov manifestava a certeza de que iria ficar na União Soviética. A colega do escritor do parque museu, Liudmila Kravéts, lembra as seguintes palavras do escritor: "Dizia que nunca tinha tanta certeza de que ia ficar aqui para sempre, como no momento quando foram embora a mulher e a filha. Como não foi com elas, então fechou o caminho para si mesmo", 55

Em 1977, nos Estados Unidos, a editora Ardis, que se especializava na publicação de literatura russa proibida na União Soviética, publicou $O$ livro invisível (em russo, Nevídimaia kniga $^{56}$ de Dovlátov, escrito por ele entre 1975 - 1976. Logo após a publicação de O livro invisivel, nas maiores revistas em russo no exterior saíram três contos seus: na revista Kontinent (№ 11), foi publicado o conto Diretamente (em russo, Po priamói), e em Vriémia i my (№ 14), foram publicados os contos A voz (Golos) e De quê se queixa, sargento? (Na chto jáluietes, serjant?).

Por causa das publicações no exterior, o escritor foi excluído da União de Jornalistas da URSS. Assim, no final dos anos 1970 a situação profissional de Dovlátov piorou ainda mais, tornando-se ele de fato persona non grata não apenas no campo de literatura, mas também no campo de jornalismo soviético.

Como demostram as entrevistas de Dovlátov e as memórias dos familiares e amigos, os últimos anos em seu país já eram momentos de uma hesitação torturante do escritor entre a emigração e a vida na miséria, sem possibilidade de ser publicado, porém em sua pátria: tal sensação deprimente, de beco sem saída no próprio país e de incerteza, é expressa plenamente em Parque cultural, considerado pela crítica o seu livro mais sombrio e pessimista, ${ }^{57}$ apesar de possuir vários elementos de humor, característicos da prosa de Dovlátov.

Tendo origem judia por parte do pai, o escritor tinha direito de pedir permissão para a repatriação, um direito do qual na época aproveitaram muitos de seus amigos do círculo literário

\footnotetext{
55 Ibid., p. 297.

56 Posteriormente, o livro foi modificado pelo escritor e passou a integrar a primeira parte da novela Remesló, publicada em 1985 (a segunda parte da novela, intitulada O jornal invisível (Nevídimaia gazeta), fora escrita já nos EUA, em 1984 - 1985).

${ }^{57}$ SUKHIKH. Op. cit., p. 140.
} 
Serguei Dovlátov: texto de cultura na literatura russa contemporânea e inclusive a sua mulher e a filha. Mas, como mencionam os amigos e colegas de Dovlátov, a princípio ele não queria emigrar. A jornalista Natália Antónova cita as palavras do escritor, pronunciadas na época de seu trabalho nas Colinas de Púchkin: "Esta é a minha terra natal, aconteça o que acontecer aqui, esta é a minha língua, a minha cultura, a minha literatura. Quero morar aqui". 58

Outro acontecimento que agravou a posição do escritor, já nada fácil naquele momento, foram os preparativos para a Olimpíada de 1980. Como explica Popóv, "Uns dois anos antes [da Olimpíada], começaram uma nova limpeza: foi decidido enviar todos os mal vistos ou à prisão, ou ao hospício, ou ao exterior. Foi nesse momento que a polícia começou a caçar seriamente Serioja, o que em grande medida determinou sua decisão [de emigrar]". ${ }^{59} \mathrm{Na}$ época, Dovlátov foi detido pela polícia mais de uma vez, e em uma delas até passou quinze dias na prisão, sob o pretexto de haver brigado com um policial.

Como o nome do escritor já era conhecido no Ocidente, devido às publicações em tamizdat, a sua prisão teve uma repercussão na imprensa ocidental, com ajuda de seus amigos que já estavam na emigração. Provavelmente essa pressão por parte da mídia estrangeira ajudou na libertação do escritor. O próprio Dovlátov descreveu assim a sua repentina prisão e libertação em $O$ ofício: "Prenderam-me sem motivo e me soltaram sem explicações. Talvez tenham funcionado os comunicados em periódicos ocidentais, no rádio também foi mencionado o meu sobrenome. Não sei...". 60

É curioso que, um mês antes da prisão, na rádio Liberty fora transmitida a novela de Dovlátov O livro invisível, mais uma confirmação da crescente popularidade do escritor nos círculos de emigrados russos, e ao mesmo tempo, de sua "precariedade" e de seu status de dissidente para as autoridades soviéticas.

Após as perseguições, o escritor toma a decisão de abandonar o país, e, junto com a mãe e a sua cachorrinha, embarca para Viena no dia 24 de agosto de 1978. Como Dovlátov relatou posteriormente em seu artigo Apoderou-se de mim uma preocupação (em russo, Mnoi ovládiélo bespokóistvo), as perseguições tinham evidente intenção de forçá-lo a emigrar (prática muito comum na época, que permitia às autoridades soviéticas livrar-se de personagens indesejáveis no país sem recorrer à prisão), seguindo o programa dos preparativos para a Olimpíada. O escritor citou a seguinte conversação com um coronel da KGB:

\footnotetext{
${ }^{58}$ KOVÁLOVA. Op. cit., p. 328.

${ }^{59}$ POPÓV. Dovlátov. Op. cit., p. 193.

${ }^{60}$ DOVLÁTOV. Remesló. Op. cit., p. 102. O escritor repete a mesma visão da situação em outros textos, como em entrevistas, ou no artigo Apoderou-se de mim uma preocupação (DOVLÁTOV, 2005).
} 
Serguei Dovlátov: texto de cultura na literatura russa contemporânea

Um homem não alto, vestido de civil. $\mathrm{O}$ rosto padronizado, ordinário. $\mathrm{O}$ tom é paternal:

- Aconselho-o sinceramente... Ali estão seus amigos... Ali está sua filha... Ali há perspectivas...

- Não tenho convite.

- Escreva um requerimento: "Quero unir-me de novo a minha esposa".

- Divorciamo-nos em 1971.

- Mas continuaram a morar juntos. O seu divórcio foi uma formalidade, e nós não somos formalistas. ${ }^{61}$

Seu romance A mala, talvez a obra mais conhecida do escritor, apresenta um certo resumo de sua vida na União Soviética, desde a infância e até o momento da emigração: mala na qual o escritor leva para uma nova vida no exterior alguns objetos mais emblemáticos e as lembranças mais vivas da terra natal e da vida russa. Assim como Parque cultural, podemos considerar A mala, de certa forma, um livro-despedida da Rússia. Mas se Parque cultural é colorido de hesitação, medos e de dúvidas referentes à emigração e a possibilidade de realizar-se profissionalmente fora de sua língua e de seu contexto cultural e literário, em A mala, a decisão já está tomada, e o herói dá o último adeus da janelinha do avião ao país que deixa.

De Viena Dovlátov chega a Nova Iorque, onde lhe esperam a mulher e a filha. Como menciona Popóv, devido às prévias publicações e à história da perseguição e da prisão no último ano na União Soviética, Dovlátov chega nos EUA “como um herói”. ${ }^{62} \mathrm{Na}$ época, nos Estados Unidos já estavam muitos dos amigos do círculo leningradense, como Joseph Brodsky, Liudmila Chtern, Igor Iefímov, entre outros.

Tendo já um certo reconhecimento entre os leitores da colônia russa devido às publicações em revistas ocidentais, Dovlátov logo acha o seu lugar na Nova Iorque literária russa: praticamente desde a chegada começa a colaborar ativamente com editoras e revistas russas no exterior, tanto como jornalista quanto como escritor; trabalha na rádio Liberty; nos anos de 1981 e 1982 é redator-chefe do jornal Nóvyi amerikánets (“O novo americano”). Seus contos logo serão traduzidos ao inglês. Elena Dovlátova, a viúva do escritor e a principal mantenedora de seu patrimônio, em entrevista ao jornal russo Kommersant (edição do dia 06.09.1998), descreve assim o primeiro momento da emigração de Dovlátov:

Talvez, realmente de Leningrado tenha saído o Serioga, ${ }^{63}$ mas quem chegou em Nova Iorque já foi o escritor Dovlátov. Em algumas semanas de trânsito em Viena, ele havia escrito alguns contos excelentes que depois formaram parte de A troca, e imediatamente ficou famoso entre os emigrados que haviam lido suas publicações em Kontinent e em Vriémia i my. O editor Carl Proffer, uma

\footnotetext{
${ }^{61}$ DOVLÁTOV, S. "Mnoi ovladiélo bespokóistvo". IN: CHTERN. Op. cit., p. 227.

${ }^{62}$ POPÓV. Dovlátov. Op. cit., p. 203.

${ }^{63}$ Serioga, diminutivo do nome Serguei.
} 
Serguei Dovlátov: texto de cultura na literatura russa contemporânea autoridade indubitável no mundo eslavista, se interessou por ele. Em sua editora Ardis logo saiu o livro de Serguei. ${ }^{64}$

Assim, na emigração, finalmente começa a verdadeira carreira literária de Dovlátov: durante os doze anos de vida na emigração, foram publicados doze livros seus, e já em vida o escritor começou o processo da tradução de sua obra para o inglês e para outros idiomas europeus. Portanto, à diferença da maioria dos escritores russos na emigração, Dovlátov conseguiu conquistar não apenas o público falante de russo da colônia, mas também os leitores americanos. Como prova disso serve o fato de que as traduções de seus contos foram publicadas em revistas americanas de referência como New Yorker, Partizan Review e Grand Street, entre outros, e o clássico reconhecido estadounidense Kurt Vonnegut mantinha amizade com Dovlátov e valorizava bastante seu talento.

Como o fazer literário não trazia o lucro necessário para manter a família, desde os primeiros anos na emigração Dovlátov trabalhou também como jornalista na imprensa e no rádio. O seu programa do rádio Liberty, Escritor ao microfone (em russo, Pissátel u mikrofona), era muito popular e, apesar das interrupções do sinal da rádio Liberty por parte do governo, ouvia-se também na União Soviética.

Outro emprego que não se pode deixar de mencionar foi o trabalho no jornal Nóvyi amerikánets, que Dovlátov fundou e onde foi redator chefe nos anos de 1981 e 1982. O jornal teve um grande sucesso entre o público da colônia russa. Elena Dovlátova, que também participou do jornal, descreve essa época na vida do escritor da seguinte maneira:

Foi o período mais alegre e agitado da nossa vida. Muito rápido as pessoas que faziam o jornal tornaram-se heróis e favoritos do povo emigrado. Reconheciam os emigrados na rua, o nosso telefone tocava sem parar, e na redação formou-se um tipo de clube no qual todo mundo queria entrar. O jornal era tão diferente do jornalismo soviético e também do [jornalismo] dos emigrados, tão cheio de ideias frescas, de elegância estilística, que com ele vinculavam-se as melhores esperanças. Infelizmente, o nosso jornal existiu apenas por dois anos e meio. As pessoas que o faziam eram escritores brilhantes, mas péssimos financistas... ${ }^{65}$

O jornal deixou de existir em 1982 por causa dos problemas de financiamento e após um conflito com o seu patrocinador. Já após a morte do escritor, o material publicado por Dovlátov em Nóvyi amerikanets e, principalmente, suas colunas como redator, que tinham um sucesso

\footnotetext{
${ }^{64} \mathrm{O}$ texto inteiro na entrevista está disponível na página do jornal: http://www.kommersant.ru/doc/2286025

${ }^{65}$ DOVLÁTOVA, Elena. “Nóvyi amerikánets v Novom Sviete”. IN: Dovlátov, S. Rietch bez Póvoda... ili Kolónki

Redáktora. Moscou: Makhaon, 2006, pp. $31-32$.
} 
Serguei Dovlátov: texto de cultura na literatura russa contemporânea enorme entre os leitores devido a seu tom sempre bem humorado, informal e ao humor brilhante, foram publicadas na Rússia, em 2006, numa coletânea intitulada Discurso sem pretexto... ou as colunas do redator (em russo, Rietch bez póvoda... ili kolónki redáktora). ${ }^{66}$

À vida na emigração e ao dia a dia no jornal estão dedicados o segundo volume da coletânea Cadernos de anotações (em russo, Zapisnye kníjki), Um solo no IBM (Solo na IBM); a segunda parte de $O$ ofício, A filial, e a novela A estrangeira (em russo, Inostranka), assim como os contos dos últimos anos de vida do escritor. A novela A estrangeira é uma das poucas obras de Dovlátov, em que a personagem principal não é o herói autobiográfico, que, no entanto, está presente no texto na qualidade de narrador da história, mas uma mulher russa emigrada, Mússia Tataróvitch, que foi parar na colônia novaiorquina.

Apesar do sucesso profissional que o escritor teve na emigração e da vida bastante estável, Dovlátov continuava a ter problemas com o alcoolismo (aliás, o alcoolismo e o álcool são temas inseparáveis de sua criação). Foi a doença que o levou à morte, aos 48 anos, no dia 24 de agosto de 1990. Dovlátov faleceu no carro de ambulância, por causa da insuficiência cardíaca provocada por uma dipsomania. Sua morte repentina, uma semana antes de seu $49^{\circ}$ aniversário, provocou um choque e uma grande ressonância na colônia russa no exterior e também na União Soviética, onde o escritor já era famoso pelo programa de rádio e, devido à liberalização da sociedade e o período de Perestroika, que tinham possibilitado a publicação em jornais de alguns de seus contos. ${ }^{67}$

Tanto nos EUA quanto na União Soviética, amigos e colegas de Dovlátov organizaram vários eventos e coletâneas de artigos em homenagem ao escritor. Na revista Zviezdá ("Estrela") saíram edições em homenagem a Dovlátov, e, em 1995, a redação da revista fundou um prêmio literário que leva o nome de escritor, o Prêmio Dovlátov (em russo, Dovlátovskaia priémia); em 1998 e em 2011 celebraram-se conferências internacionais dedicadas à vida e obra do escritor, Dovlátovskie tchtiénia ("Leituras dovlatovianas"). Além do mais, nas cidades de São Petersburgo, Tallin e Pskóv (a cidade mais próxima das Colinas de Púchkin), organizam-se festivais em homenagem ao escritor.

No momento da morte do escritor, na União Soviética, já estava em preparação a primeira coletânea de seus contos. Portanto, a obra de Dovlátov chegou à Rússia logo após a sua

\footnotetext{
${ }^{66}$ DOVLÁTOV, S. Rietch bez Póvoda... ili Kolónki Redáktora. Moscou: Makhaon, 2006.

${ }^{67}$ As primeiras publicações dos contos de Dovlátov na URSS saíram no no jornal Nediélia (“Semana”) em 1989 1990. Entre eles está o conto Na rua e em casa (em russo, Na úlitse i doma) cuja tradução foi publicada no Brasil, na Nova antologia do conto russo (São Paulo: Editora 34, 2011, pp. 603 - 610, tradução de Mário Ramos e Yulia Mikaelyan).
} 
Serguei Dovlátov: texto de cultura na literatura russa contemporânea morte, no começo dos anos 1990, e desde então Serguei Dovlátov continua a ser um dos escritores da segunda metade do século XX mais lidos e mais queridos pelos leitores russos. ${ }^{68}$

Essa breve biografia demonstra a estreita relação entra a vida do escritor, sua obra e sua intenção consciente de criar a realidade literária de sua obra a partir dos fatos de sua biografia e com base em acontecimentos da vida real. Embora a obra de Dovlátov seja ficcional, praticamente todos os fatos e pessoas relevantes da sua biografia tiveram reflexos em suas narrativas.

Pode-se dizer que a interação entre a realidade e a ficção no caso de Dovlátov é mútua, ou seja, a literatura também teve repercussões e influenciou a vida do escritor. Como opinam alguns dos amigos e familiares de Dovlátov, desde a juventude o escritor procurava atribuir um certo ar de "literariedade" à sua vida. Assim, na opinião de Valéri Popóv, que conhecia Dovlátov desde jovem, muitas vezes o escritor intencionalmente caía em situações difíceis, gerando assim estórias para a sua futura obra: "Toda a sua vida parece um conjunto intencional, premeditado de acontecimentos tragicômicos. (...) Dovlátov compreendeu de vez e por completo que a única tinta do escritor é o seu próprio sangue". ${ }^{69}$

Devido a esse entrelaçamento da realidade e da ficção, o mito em torno da personalidade de Dovlátov começou a se criar ainda na juventude do escritor nos anos 1960, ou melhor, com os primeiros textos do escritor criados com base em sua própria vida, e que posteriormente formariam parte do seu romance A zona.

Dovlátov propositalmente tornara visíveis as "raízes documentais" de sua ficção, atribuindo às suas personagens nomes e traços (de aparência ou de caráter) de pessoas reais, ou às vezes apenas modificando um pouco o nome da personagem, para que o seu protótipo fosse facilmente reconhecível (assim, por exemplo, o nome Valéri Kárpov convertia-se, na novela Parque cultural, em Valéri Márkov, e Vladímir Guerássimov, em Vladímir Mitrofánov ${ }^{70}$ ). A forte relação com a realidade extraliterária em torno do escritor às vezes dá ao leitor a impressão de puro documentarismo, de ter nas mãos uma autobiografia, o que muitas vezes confunde os leitores ingênuos. No entanto, como não cansam de sublinhar tanto os pesquisadores e biógrafos

\footnotetext{
${ }^{68}$ LÓSSEV. Op. cit., p. 386.

${ }^{69}$ POPÓV. "Krov - edínstvennye tchernila". Op. cit., pp. 438 - 439.

70 O sobrenome "Guerássimov" deriva do nome "Guerássim", já antiquado, e que era bastante popular entre os camponeses russos. Além disso, esse nome é familiar aos leitores russos, pois assim se chama o protagonista do conto Мumu, de Iván Turguêniev (1818 - 1883), o camponês surdo-mudo Guerássim. Para fazer visível a relação da personagem com o seu protótipo real, o escritor escolhe para ela o sobrenome "Mitrofánov", derivado de "Mitrofán", outro nome que soa antiquado atualmente, próprio de âmbito rural, e que também tem um background literário: é nome de um das personagens da famosa comédia de Denis Fonvísin (1745 - 1792), Niédorosl (poderíamos traduzir o título para o português como "O ignorante").
} 
Serguei Dovlátov: texto de cultura na literatura russa contemporânea como os amigos e familiares do escritor, a obra dovlatoviana pertence ao gênero de ficção, e os fatos relatados e as personagens descritas nela formam parte da convenção artística. ${ }^{71}$

O próprio autor espalha ao longo de seus textos os sinais de sua natureza ficcional para desmentir um pouco esse presumido documentarismo. Assim, Dovlátov às vezes com propósito "confundia" o leitor, mudando as datas ou voltando atrás o percurso do tempo em sua obra, criando cidades inexistentes e representando em diferentes narrativas diferentes variantes de como ocorrera o mesmo acontecimento. Assim, por exemplo, na novela Parque cultural, o tempo corre no parque museu no sentido contrário, e o mês de junho vem depois de julho.

Da mesma forma é mistificado o encontro do escritor com a sua segunda mulher, Elena Dovlátova, uma das personagens principais da maioria de suas obras. A história do namoro é narrada de três modos diferentes em Parque cultural, Os nossos e A mala. Tais detalhes insinuam para o leitor a natureza ficcional, e não documental, da obra do escritor.

Como era de se esperar, a divisão tão tênue entre realidade e ficção levou a vários conflitos entre Dovlátov e seus contemporâneos após a publicação de seus textos, além de ressentimentos por parte das pessoas descritas ou mencionadas em sua obra, pois, como é característico ao gênero humorístico, muitas vezes em seus textos as personagens carregavam traços hiperbolizados e caricaturais (de caráter ou de aspecto visual).

Popóv denomina tal peculiaridade do método artístico de Dovlátov, a de inserir em suas narrativas nomes de pessoas reais e acontecimentos que de fato aconteceram, como "talhar em carne viva". ${ }^{72}$ Evidentemente, nem todos os conhecidos do escritor suportavam comparecer em sua obra como personagens cômicas. Posteriormente, muitos reclamavam das calúnias feitas por Dovlátov em seus textos, acusando o escritor de ter transmitido em seus contos imagens e traços atribuídos a pessoas reais (pois em muitos casos, o escritor dava às personagens nomes de seus conhecidos sem modificação nenhuma) que não tinham nada a ver com o caráter ou aspecto visual de seus donos. Assim ocorre, por exemplo, no caso dos livros A troca e Parque cultural, nos quais Dovlátov descreve praticamente todos os colegas com os quais trabalhou. Muitos dos "protótipos" das personagens desses livros afirmaram posteriormente que Dovlátov atribuíra-lhes frases ou ações que nunca fizeram, ou exagerara algum traço de seu caráter ou de aspecto visual, tornando-os ridículos. Assim, o jornalista Dmítri Kliónski, colega de Dovlátov do jornal Soviétskaia Estônia, referindo-se à personagem que levava seu nome em $A$ troca, dizia que no livro "não havia nem uma palavra de verdade sobre ele". ${ }^{73}$ Da mesma forma, reclamou Valéri Kárpov, após ver em Parque cultural o seu protótipo na personagem de Valera Márkov. ${ }^{74}$

\footnotetext{
${ }^{71}$ SUKHIKH. Op. cit., p. 57.

72 POPÓV. Dovlátov. Op. cit., p. 151.

${ }^{73}$ KOVÁLOVA. Op. cit., p. 199.

${ }^{74}$ Ibid., p. 291.
} 
Serguei Dovlátov: texto de cultura na literatura russa contemporânea

Muitas vezes o escritor, na descrição de suas personagens, usava apenas uma característica da pessoa real, exagerando-a até dimensões caricaturais em função de sua participação do enredo. A personalidade do protótipo, como a vida real, não lhe interessava, o que era importante e chamava a atenção era tudo o que poderia servir de material para a futura prosa. Tamara Zibunova descreve assim tal peculiaridade da poética do escritor e de suas relações com os protótipos de suas personagens: "Serguei estava na constante procura de um enredo. Quase não havia vida ordinária, imediatamente tentava transferir tudo ao plano de literatura". ${ }^{75}$ Com essa procura por um enredo e a modificação do caráter e dos acontecimentos reais em prol da literatura, está relacionada certa inclemência por parte do escritor em relação a pessoas que aparecem como personagens de ficção em sua prosa.

Porém, como concordam pesquisadores e biógrafos, quem sempre foi o objeto principal de piadas e zombaria em sua obra foi o próprio escritor, ou, melhor, seu herói autobiográfico. Em suas narrativas, Dovlátov atribui-lhe, muitas vezes de forma exagerada, todos os vícios de que padecia na vida real, zombando de sua aparência e fraquezas de caráter. O herói autobiográfico dovlatoviano sempre é tão pouco heroico que talvez nesta "anti-heroicidade" resida também a razão da simpatia dos leitores.

O escritor Igor Iefímov, amigo e editor de Dovlátov, descreve tal característica de sua prosa (ou seja, a inclemência do autor com suas personagens) da seguinte maneira:

... Também era inclemente em relação a si mesmo. Tanto o herói lírico de seus contos e novelas publicados, quanto ele mesmo, o herói de suas histórias orais, sempre foram o objeto de constantes zombarias, às vezes bastante cruéis. Da mesma maneira, era inclemente e exigente com o seu estilo literário". ${ }^{76}$

Muitos viam no protagonista de sua obra, alcoólatra e mulherengo que levava uma vida semi-marginal na União Soviética, a personalidade do escritor Serguei Dovlátov. No entanto, como testemunham os amigos e familiares de Dovlátov, assim como as personagens inspiradas nos amigos e colegas, a sua personagem autobiográfica também era um produto de ficção, embora, certamente, possuísse certos traços comuns com o seu autor.

Ksana Mechik-Blank, meia-irmã do escritor por parte do pai, lembra:

Serguei era, em primeiro lugar, escritor, e somente depois, todo o resto. E como um escritor verdadeiramente bom, transfigurava os acontecimentos de sua vida em excelente prosa que, no entanto, tinha muito pouco a ver com a realidade. Dovlátov, de fato, construiu com as próprias mãos um mito ao seu redor, no qual

\footnotetext{
${ }^{75}$ Ibid., p. 206.

${ }^{76}$ IEFÍMOV, Igor. "Nepovtorímost liubói tsenói”. IN: Maloizviéstnyi Dovlátov. São Petersburgo: AOZT Jurnal "Zvezdá", 1995, p. 448.
} 
Serguei Dovlátov: texto de cultura na literatura russa contemporânea

todos acreditaram. (...) Em sua prosa ele construía a imagem de um outsider que olhava para tudo ironicamente, com o olhar de fora. $\mathrm{Na}$ vida real, claro, era praticamente antípoda dessa imagem. Mas mais perto do momento de sua morte, pelo visto, Dovlátov conseguira converter-se em seu alter ego literário. O que, no final das contas, arruinou-o". ${ }^{77}$

Aqui, falando da "transformação de Dovlátov em seu alter ego literário", outsider e alcólatra, que aparece em todas suas narrativas, Mechik-Blank faz referência às crises de alcoolismo que Dovlátov sofria, mais frequentes no final de sua vida, e que acabaram levando à sua morte. Segundo ela, havia ali a trágica junção da pessoa real de Serguei Dovlátov e de sua personagem literária.

Embora o mito referente à personalidade de Dovlátov fosse construído por ele mesmo ainda em vida, após a sua morte o desenvolvimento do mito continuou e foram produzidas mais algumas de suas versões. Em 1994, a obra do escritor foi publicada na Rússia em três volumes. Além do mais, foram publicadas na Rússia as primeiras pesquisas sobre a vida e a obra do escritor, bem como memórias de seus amigos e textos em sua homenagem, o que contribuiu para a consolidação de seu status de escritor cultuado, ou seja, de um escritor cuja personalidade, biografia e detalhes de vida geravam o mesmo interesse que a sua obra. Atualmente, os lugares nos quais o escritor morou, em Leningrado, Tallin, as Colinas de Púchkin e Nova Iorque, são objetos de interesse por parte de seus leitores. Assim, as ruas das três cidades, descritas por Dovlátov em sua obra (e o escritor apresenta em sua obra descrições detalhadas das ruas, esquinas, restaurantes e cervejarias, introduzindo na ficção este elemento documental), atualmente são de interesse turístico. Existem inclusive excursões que percorrem os caminhos empreendidos pelas personagens dovlatovianas. São bastante famosas "as rotas dovlatovianas" na São Petersburgo moderna, como, por exemplo, a região perto do prédio onde o escritor morou, na rua Rubinchtein, 23.

\footnotetext{
${ }^{77}$ Apud KOVÁLOVA. Op. cit., p. 421.
} 


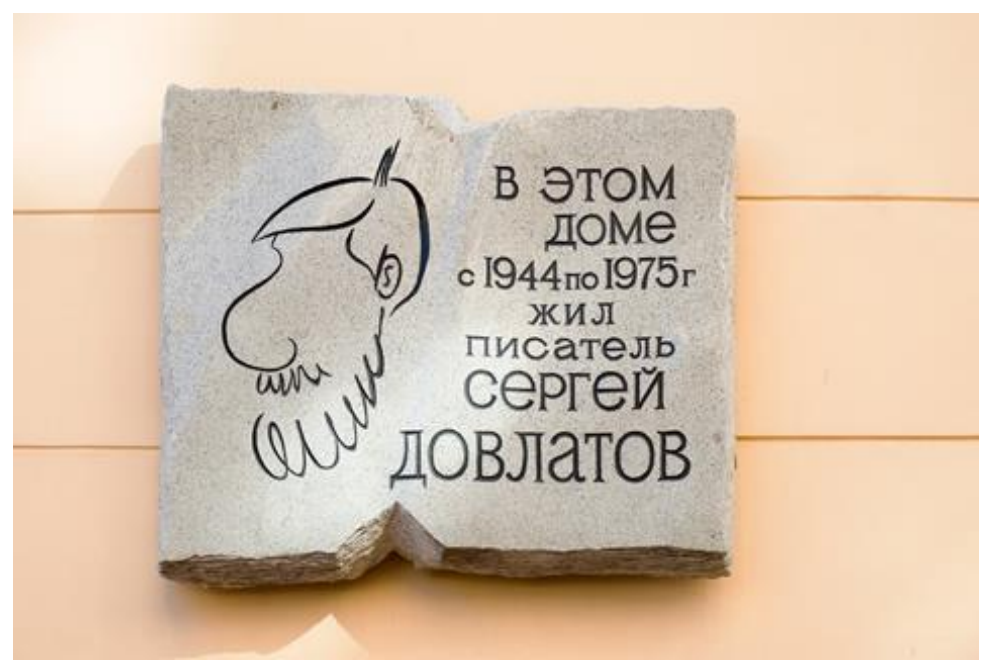

Placa em homenagem a Dovlátov em São Petersburgo, no prédio na Rua Rubinchtein, 23. A inscrição indica: "Nesta casa de 1944 a 1975 morou o escritor Serguei Dovlátov".

O mesmo destino teve a casa alugada pelo escritor na aldeia de Beriózino, nas Colinas de Púchkin (em Parque cultural, a aldeia aparece sob o nome Sosnovo ${ }^{78}$ ): hoje em dia, há muitos turistas que vêm à região para visitar não os lugares puchkinianos, mas os lugares onde morou e trabalhou Dovlátov.

Cabe mencionar que em julho de 2014 finalmente foi inaugurada a casa-museu de Serguei Dovlátov, em Beriózino. O museu encontra-se na casa privada que o escritor alugou durante a sua estada nas Colinas de Púchkin, em 1977, e que foi comprada com a intenção de convertê-la em museu em sua memória. Por sorte, a morada não sofreu quase nenhuma modificação desde os anos 1970, e os donos do museu (é um museu privado, seus donos são homens de negócios petersburgueses) conseguiram recriar o ambiente no qual morava o escritor há quase 40 anos. ${ }^{79}$

\footnotetext{
${ }^{78} \mathrm{O}$ nome da aldeia, Beriózino, provém da palavra berioza, "bétula". No livro, o escritor cria o nome da aldeia onde mora o protagonista, Sosnovo, a partir do nome de outra árvore típica da região, que é sosná, "pinheiro".

${ }^{79}$ As reportagens referentes à inauguração da casa-museu de Dovlátov saíram em vários jornais russos, entre eles, em Rossíiskaia Gazeta (edição do dia 31.07.2014). A versão on-line está disponível no site do jornal: http://www.rg.ru/2014/07/31/dovlatov.html
} 


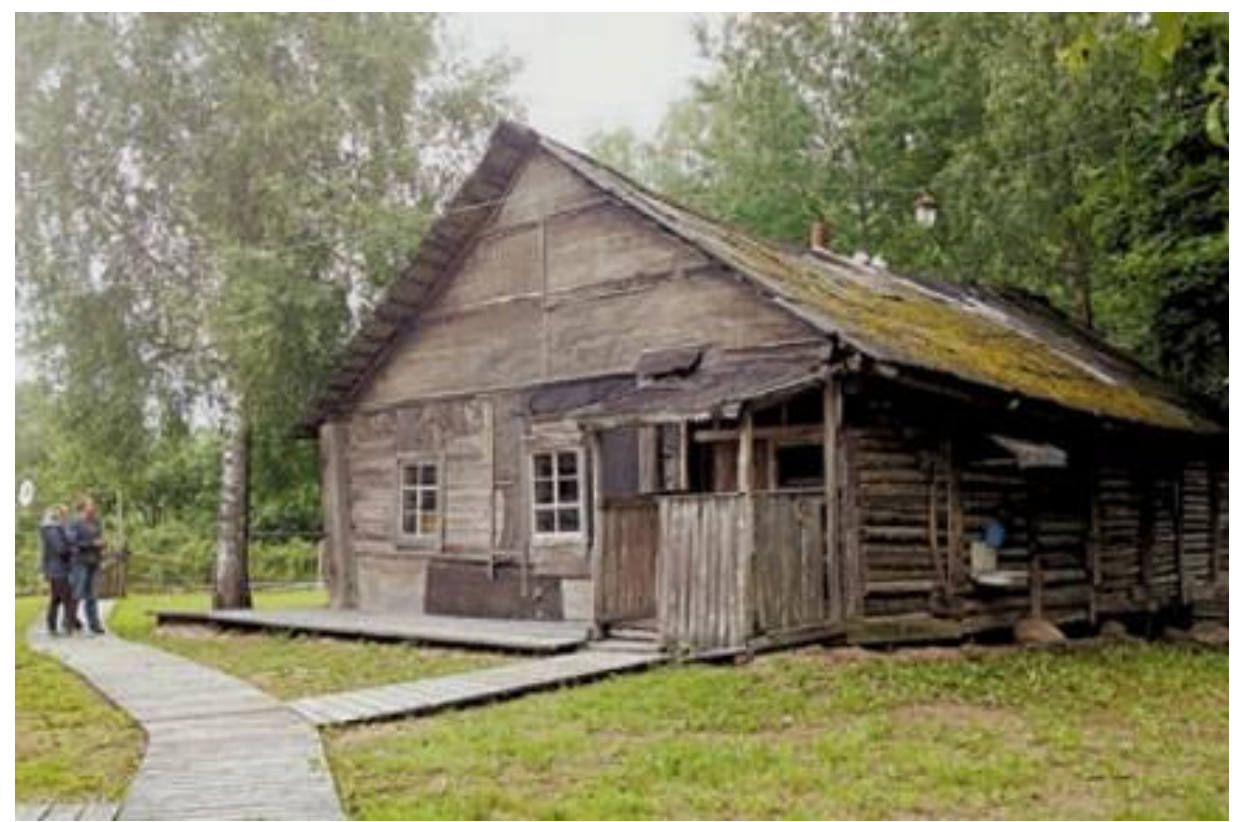

Casa alugada por Dovlátov em Beriózino (fotografia feita em 2012)

Além do mais, desde os anos 1990, várias biografias do escritor, livros de memórias e publicações de cartas a familiares, amigos e colegas foram publicadas pelos seus amigos e conhecidos. Assim, a primeira esposa de Dovlátov, Ássia Pekuróvskaia, publicou um livro de memórias intitulado Quando S. D. e eu tivemos a ocasião de cantar juntos. Serguei Dovlátov pelos olhos da primeira mulher (em russo, Kogdá slutchílos piet S. D. i mne. Serguei Dovlátov glazámi piérvoi jeny); uma biografia, Dovlátov, foi escrita por seu amigo leningradense, o escritor Valéri Popóv; outro livro de memórias, Dovlátov, meu bom amigo (em russo, Dovlátov, dobryi moi priátel), foi escrito pela escritora Liudmila Chtern, com a qual Dovlátov mantinha amizade e trocava cartas ao longo de toda a vida; os amigos de Dovlátov na emigração, o casal de escritores Vladímir Solovióv e Elena Klépikova, escreveram o livro de memórias Dovlátov de cabeça para baixo: a tragédia de um homem alegre (em russo, Dovlátov vverkh nogámi: traguédia vessiólovo tchelovieka). Uma biografia bastante interessante, intitulada Dovlátov, foi publicada pelos jornalistas Anna Koválova e Lev Luriê. Além do mais, muitos amigos, colegas e também conhecidos do escritor escreveram artigos e ensaios sobre ele.

Além de livros de memórias, na onda do interesse pela personalidade de Dovlátov, foram publicadas algumas de suas correspondências: assim, Igor Iefímov, escritor, filósofo e dono da editora russo - americana Hermitage (ali saíram em russo vários livros de Dovlátov, publicados na emigração), publicou a correspondência que ocorreu entre ele e Dovlátov sob o título Romance epistolar (em russo, Epistoliárnyi roman). A publicação do livro, em 2001, gerou um conflito entre Iefímov e a família do escritor, que considerou ilegal a publicação de cartas privadas sem autorização prévia. A viúva de Dovlátov e a dona de seus direitos autorais, Elena 
Serguei Dovlátov: texto de cultura na literatura russa contemporânea

Dovlátova, por meio da justiça conseguiu suspender a venda do livro; no entanto, no momento da decisão do tribunal, a maior parte da tiragem já fora vendida, e o livro está disponível na Biblioteca Estatal da Rússia, em Moscou.

Embora praticamente todos os livros mencionados possuam informações e dados interessantes que contribuíram na elaboração desse trabalho, apresentam visões muito diferentes e às vezes até opostas sobre como era Serguei Dovlátov na vida real. Parece-nos que, em tais discrepâncias, de novo se reflete a complexa relação na vida de Dovlátov entre a realidade que vivia o autor e a sua ficção literária, assim como a intenção consciente do escritor de mitificar e mistificar a sua vida.

Não podemos deixar de mencionar que as biografias e memórias escritas pelos amigos do escritor dão uma visão muito subjetiva referente à personalidade de Dovlátov. Às vezes, no texto, como no caso de livros de Popóv e Chtern, percebe-se a evidente parcialidade de seus autores em relação a alguns fatos da biografia e às situações na vida do escritor. Já no caso do livro escrito pela primeira mulher de Dovlátov pareceu-nos evidente a intenção de sua autora de chamar mais atenção à própria biografia e méritos literários do que à vida do ex-marido.

É compreensível a dificuldade de relatar de um modo imparcial e objetivo a vida e a personalidade de uma pessoa próxima, e as biografias escritas pelos amigos de Dovlátov, bem como o tom com o qual seus autores referem-se à sua personalidade, lembram-nos um fragmento da novela Parque cultural, no qual o protagonista Boris Alikhánov descreve a sensação produzida pela leitura das memórias dos amigos de Púchkin:

Eu estava folheando Os diários, de Aleksei Vulf. ${ }^{80}$ Ali se falava de Púchkin de um modo amigável, às vezes até condescendente. Trata-se de uma proximidade nociva para o ponto de vista. É óbvio que os gênios têm amigos. Mas quem irá acreditar que seu amigo é um gênio?! ${ }^{81}$

Considerando essa especificidade na apresentação das biografias escritas sobre Dovlátov, parece-nos o mais objetivo e imparcial o livro Dovlátov, de Koválova e Luriê, que está estruturado em forma de compilação de memórias, entrevistas, histórias e opiniões não apenas de amigos, colegas e familiares de Dovlátov, mas também de amigos de infância, vizinhos, colegas de escola e faculdade e até professores do escritor, alternando-se com trechos de textos e cartas do próprio escritor. Tal complexo de histórias, opiniões e pontos de vista permitiu aos autores do livro traçar uma visão mais panorâmica, mais volumétrica da personalidade de Dovlátov.

\footnotetext{
${ }^{80}$ Aleksei Vulf (1805 - 1881), autor de memórias e amigo íntimo de Púchkin.

${ }^{81}$ DOVLÁTOV, S. Zapoviédnik. São Petersburgo: Ázbuka, 2003, p. 178.
} 
Serguei Dovlátov: texto de cultura na literatura russa contemporânea

Além de textos biográficos, também foram produzidos vários filmes documentais e artísticos dedicados à personalidade de Dovlátov, entre os quais podemos destacar: $\mathrm{O}$ anjo de carga. As cartas do exército de Serguei Dovlátov (2000, em russo, Lomovói arkhánguel. Armiéiskie pisma Sergueia Dovlátova); Serguei Dovlátov. Ecologia da literatura (2000, em russo, Serguei Dovlátov. Ekológuia literatúry); Meu vizinho Serguei Dovlátov (2001, em russo, Moi sossied, Serioja Dovlátov); A cidade íntima (2007, em russo, Intímnyi górod); Uma história viva. Dovlátov (2007, em russo, Jiváia istória. Dovlátov); A vida não é fácil. Seu Serguei Dovlátov (2007, em russo, Jizn nelegká... Vach Serguei Dovlátov); Fim da bela época. Brodskye Dovlátov (2007, em russo, Koniéts prekrásnoi epókhi. Brodsky i Dovlátov); Dovlátov: a troca (2010, em russo, Dovlátov: kompromiss); Dovlátov: a mala (2010, em russo, Dovlátov: tchemodan); Foi embora para ficar. Serguei Dovlátov (2011, em russo, Uchol, tchtóby ostatsa. Serguei Dovlátov); Escrito por Serguei Dovlátov (2011, em russo, Napíssano Serguéiem Dovlátovym), Cinco esquinas de Dovlátov (2015, em russo, Piat uglóv Dovlátova).

Além de vários materiais de caráter documental, foram escritos inclusive dois romances dedicados à personalidade de Dovlátov: A faquinha de Serioja Dovlátov (em russo, Nójik Serióji Dovlátova), de Mikhail Véller, e Dovlátov e os arredores. Romance filológico (em russo, Dovlátov i okrésntosti. Filologuítcheskii roman), de Aleksándr Guénis. No caso do segundo livro, a obra do escritor, jornalista e crítico literário Aleksándr Guénis, embora chamada de "romance" por seu autor, não pode ser considerada puramente ficcional. Nela, Guénis, colega e amigo de Dovlátov (trabalharam juntos no jornal Nóvyi amerikánets), descreve o ambiente literário e cultural da colônia russa nos EUA entre os anos 1970 e 1990, o papel e o impacto que a obra jornalística e literária de Dovlátov tiveram nela.

Também em 2015 saiu filme artístico de Stanisláv Govorúkhin inspirado na obra de Dovlátov, intitulado Fim da bela época (em russo, Koniéts prekrásnoi epókhi). Sabe-se também que, agora, no estúdio Lenfilm, está no processo de rodagem outro filme artístico dedicado ao escritor, intitulado Dovlátov, do diretor Aleksei Guérman Jr. A estreia está prevista para 2017. 
Serguei Dovlátov: texto de cultura na literatura russa contemporânea

\section{Serguei Dovlátov no contexto da literatura não oficial soviética e da literatura de emigração}

Para compreender o papel de Dovlátov na literatura contemporânea e as razões de sua emigração, é importante fazer uma breve revisão do panorama da literatura soviética nos anos 1960 e 1970 e o fenômeno da literatura não oficial do período.

O processo de formação da literatura não oficial soviética começou desde a segunda metade da década de 1950, com o período histórico de Degelo (em russo, Óttepiel), relacionado com uma certa liberalização da sociedade soviética, durante o governo de Nikita Khruschóv, entre os anos 1953 e 1964. Nesse período, a esfera cultural da sociedade soviética fora liberada por um tempo do controle tão rigoroso por parte de órgãos governamentais, como o Comité Central do Partido, o Ministério da Cultura e das assim chamadas uniões criativas (em russo, tvórtcheskie soiúzy), como a União dos Escritores Soviéticos ou a União dos Artistas Soviéticos, que estavam sob o seu controle.

A atenuação do controle por parte do governo, junto com o discurso de Nikita Khruschóv, pronunciado no XX Congresso do Partido Comunista da União Soviética, em fevereiro de 1956, denunciando os crimes do regime de Ióssif Stálin, deu início a novas buscas criativas no âmbito da literatura e das artes. O período de Degelo deu origem à geração de chestidessiátniki (em português, poderíamos traduzir o nome como "os sessentistas", vinculado com o período dos anos 1960, quando foi o auge da atuação de chestidessiátniki), escritores, artistas e intelectuais, nascidos entre os anos de 1925 e 1945, pertencentes principalmente ao círculo da intelligentsia soviética, cujo caráter e identidade influenciaram a Segunda Guerra Mundial, as atrocidades do regime stalinista e a sua queda. A morte de Stálin, em 1953, e o discurso de Khruschóv no XX Congresso foram os acontecimentos que determinaram, em grande medida, o pathos da geração. A atuação dos representantes de chestidessiátniki revelouse principalmente no campo de literatura, relacionada com nomes de escritores e poetas como Vassíli Aksiónov, Anatóli Gladílin, Andrei Voznessiénski, Ievguéni Evtuchenko, Bella Akhmadúlina, Bulát Okudjava, entre outros.

$\mathrm{Na}$ época, a atenuação da censura possibilitou a publicação e o reconhecimento oficial de escritores de opiniões mais liberais, que não seguiam a linha ideológica do partido. Assim, em 1962, na revista Nóvyi mir, foi publicado o conto de Soljenítsyn Um dia na vida de Ivan Deníssovitch.

Cabe mencionar que, embora Dovlátov fosse coetâneo de alguns dos representantes da geração de chestidessiátniki, os pesquisadores não o consideram pertencente a esse movimento artístico. Isso tem a ver com o fato de que a carreira literária de Dovlátov começa a desenvolver- 
Serguei Dovlátov: texto de cultura na literatura russa contemporânea se já após o fim do período de Degelo, no final dos anos 1960, e, embora muitos dos ídolos da geração de chestidessiátniki tivessem influenciado também a sua criação, como, por exemplo, a personalidade e a obra de Ernest Hemingway, seus textos carecem das características próprias aos representantes desse movimento, como, por exemplo, o tema da guerra como um dos leitmotifs na criação, a fé na possibilidade do "socialismo com uma face humana" 82 e o otimismo em relação às mudanças ideológicas na sociedade soviética. ${ }^{83}$

Mas, apesar de certa liberalização da sociedade, as autoridades compreendiam o perigo que podia levar a falta de controle no âmbito da cultura e da ideologia. Por isso, já no começo dos anos 1960 foram retomados os assim chamados "trabalhos educacionais" com representantes da cultura que expressavam opiniões alheias ao regime; também voltou a praticar-se a perseguição aberta, inclusive judicial, dos artistas que discordavam da linha ideológica do partido. Assim foi o caso de Joseph Brodsky, que fora perseguido e posteriormente condenado a exílio em 1964, acusado de parasitismo. No entanto, uma das características da política do governo de Khruschóv e da época de Degelo em geral foi a possibilidade de diálogo e de discussão entre as autoridades e os representantes da intelligentsia soviética, embora o objetivo principal desse diálogo fosse convencê-los da razão da postura do governo.

O último acontecimento que quebrara o consenso instável entre as autoridades e a intelligentsia de opiniões liberais e pusera fim ao período de Degelo foi o notório processo judicial dos escritores Iúli Daniel ${ }^{84}$ e Andrei Siniávski, ${ }^{85}$ que teve lugar entre setembro de 1965 e fevereiro de 1966. Daniel e Siniávski foram condenados a cinco e sete anos de prisão, acusados de "propaganda antissoviética", por terem publicado no exterior as suas obras, que não foram aceitas para publicação na União Soviética (e que, em si, a princípio, não continham nenhuma opinião aberta contra a ideologia do Estado soviético). O processo gerou uma grande ressonância na sociedade soviética e no exterior: muitos artistas e intelectuais soviéticos assinaram petições em apoio aos réus, que, no entanto, não tiveram efeito, e os dois escritores foram presos.

O endurecimento de perseguições e da censura levou à decepção de uma grande parte dos representantes dos círculos intelectuais e artísticos em relação à possibilidade de mudanças na sociedade soviética e, ao mesmo tempo, fomentou o surgimento do movimento dissidente e impulsionou o processo de formação da cultura não oficial, paralela à ideologia soviética. Como indicam historiadores, o processo da formação da cultura não oficial soviética, que começara na

\footnotetext{
${ }^{82}$ Foi expressão de Aleksandr Dubcek, presidente da Tchecoslováquia, pronunciada por ele no dia de 18 de julho de 1968, em relação às reformas da Primavera de Praga, e que resumia a tentativa de combinar a doutrina socialista com os elementos da sociedade democrática.

${ }^{83}$ FEDÚLOV, A. Neofitsiálnaia kultura v SSSR vo vtoroi polovine 1960-kh-1980-e gódy. Dissertátsia na soiskánie utchiónoi stiépeni kandidata istorítcheskikh naúk. Elistá: Kalmytski institut gumanitárnykh issliédovani RAN, 2010, p. 33 .

${ }^{84}$ Iúli Daniel (1925 - 1988), poeta, prosador e tradutor.

${ }^{85}$ Andrei Siniávski (1925 - 1997), escritor e teórico e crítico literário.
} 
Serguei Dovlátov: texto de cultura na literatura russa contemporânea

época de Degelo, finalizou-se em agosto 1968, com os acontecimentos na Tchecoslováquia, quando a União Sovética, junto com outros países do Pacto de Varsóvia, invadiram o país para interromper as reformas da Primavera de Praga. ${ }^{86}$

Para o final dos anos 1960, na União Soviética consolidou-se o movimento dissidente: formaram-se algumas organizações dissidentes, como Gruppa revoliutsiónnovo kommunisma (“Grupo de comunismo revolucionário"), Initsiatívnaia gruppa po zaschite prav tchelovieka $v$ SSSR (“Grupo iniciativo da defesa de direitos humanos na URSS”), Komitiet prav tcheloviéka v SSSR (“Comité de direitos humanos na URSS”) e outras organizações políticas, nacionais e religiosas. $^{87}$

Ao mesmo tempo, começou o processo da massiva "emigração interior" (em russo, vnútrenniaia emigrátsia) por parte de muitos intelectuais e artistas soviéticos. A resistência passiva à ideologia oficial fazia muitas pessoas renunciarem a possibilidades de carreira e escolherem profissões semi-marginais que, em compensação, permitiam-lhes não ter quase nenhum contato com o governo e a ideologia soviéticos. As profissões como a de zelador ou foguista permitiam não participar de eventos ideológicos (na época, obrigatórios na maioria dos estabelecimentos) e davam uma certa liberdade em relação à postura ideológica e política de cada um. Como aponta Aleksandr Fedúlov, o fenômeno da "emigração interior" contribuiu ao nascimento da cultura do underground soviético e, junto com o movimento dissidente, esses foram dois polos que determinaram a personalidade da cultura não oficial soviética até o começo de Perestroika. ${ }^{88}$

No campo literário, a atuação dos representantes da cultura não oficial manifestava-se, principalmente, por meio dos samizdat e tamizdat, e também em encontros e reuniões não oficiais. Samizdat (abreviação que poderia ser traduzida do russo como "publicado por conta própria”) foi a forma fundamental para a cultura não oficial da época. O fenômeno surgiu no período de "degelo", sendo o meio mais comum de distribuição da literatura não censurada. ${ }^{89}$ Assim denominavam-se cópias de manuscritos feitos à máquina que circulavam entre os leitores, principalmente em grandes cidades, como Moscou e Leningrado. Evidentemente, quem tinha acesso a samizdat era um círculo bastante reduzido da intelligentsia soviética e, portanto, não podia influenciar significativamente as opiniões da maioria da sociedade soviética.

\footnotetext{
${ }^{86}$ Ibid., p. 79.

87 Liudmila Alekséieva (nasc. em 1927), historiadora, ativista de direitos humanos e veterana do movimento dissidente soviético, em seu livro A história do inconformismo na URSS: novíssimo período, dá o panorama do movimento dissidente soviético, denominando os seus principais ramos e organizações. Cf.: Alekséieva, L. Istória inakomyslia v SSSR: novéichii períod. Moscou: Moskóvskaia Khélsinkaia Gruppa, 2012.

${ }^{88}$ Ibid., p. 97.

89 Cabe mencionar, que por meio de samizdat circulavam não apenas textos proibidos por ser considerados antissoviéticos, mas também literatura erótica e, em muitos casos, obras que a princípio não tinham nenhum inconveniente para o regime, mas por alguma razão ficaram fora da literatura oficial, como a obra de J. R. R. Tolkien ou as histórias infantis sobre a família de mumins, de Tove Jansson.
} 
Serguei Dovlátov: texto de cultura na literatura russa contemporânea

Outro meio de distribuição de textos não censurados era tamizdat (abreviação que poderíamos traduzir como "publicado lá"), ou seja, publicações em russo nas editoras e revistas no exterior. Na época de Degelo, restabelecem-se parcialmente os contatos com os representantes da colônia russa no exterior, emigrados da Primeira e Segunda Onda. Assim, em 1958, na revista novaiorquina Nóvyi Jurnal (“A nova revista”), uma das maiores revistas russas no exterior, foram publicados fragmentos do romance de Boris Pasternák Doutor Jivago. Como lembra Roman Gul, um dos maiores representantes literários e políticos da Primeira Onda de emigração, que durante vinte anos foi redator-chefe de Nóvyi Jurnal (entre 1966 e 1986), no seu livro Levei a Rússia embora. Apologia da emigração russa (em russo, Iá unióis Rossíu. Apológuia rússkoi emigrátsii), depois daquela publicação até a redação de Nóvyi Jurnal começam a chegar "vários ecos, pareceres e até saudações de alguns escritores soviéticos". 90 Assim, nos anos 1960 tinham acesso à revista novaiorquina escritores e cientistas que pertenciam à elite soviética, e na imprensa da União Soviética, de vez em quando, surgiam citações e referências à Nóvyi jurnal. Embora as relações entre a União Soviética e a emigração russa esfriassem com o começo da época brejneviana, e referências a Nóvyi jurnal sumissem da imprensa soviética, a interação entre a emigração e a União Soviética continuou, pois os escritores soviéticos começaram a enviar ativamente manuscritos ao exterior. Além de Nóvyi jurnal, os representantes da literatura não oficial enviavam seus textos a revistas, como as parisienses Kontinient (“O continente”) e Ekho (“O eco”), ou Gráni (“As bordas”, Francforte do Meno), entre outras. Com a Terceira Onda de emigração, nos anos 1970 e 1980, o número de edições russas no exterior aumentava consideravelmente, e a sua colaboração com os escritores não oficiais tornava-se ainda mais intensa. A publicação da obra em tamizdat elevava o prestígio de seu autor na sociedade cultural não oficial, pois chamava atenção para seu nome nos círculos literários ocidentais. Além do mais, a vida cultural não oficial acontecia em reuniões, encontros, saraus que, normalmente, tinham lugar em cafés e apartamentos privados.

Evidentemente, tais manifestações da cultura não oficial eram mal vistas pelas autoridades, e os autores que se publicavam em samizdat e tamizdat sofriam perseguições. O que representava o maior perigo para os escritores não reconhecidos eram suas publicações no exterior, em tamizdat. $\mathrm{O}$ autor de tamizdat automaticamente denominava-se cúmplice dos "inimigos da pátria" (ou seja, dos cidadãos que emigraram) e, além de perder o trabalho oficial, podia ser preso, como foi o caso de Siniávski e Daniel e muitos outros. Mas, é importante mencionar que nos anos 1970, após os notórios processos políticos dos anos 1960, as autoridades soviéticas procuravam evitar medidas penais em relação a artistas e outras personalidades da

\footnotetext{
${ }^{90}$ GUL, Román. Iá uniós Rossíu. Apológuia rússkoi emigrátsii. V. 3. Rossia v Amiérike. Nova Iorque, 1989.
} 
Serguei Dovlátov: texto de cultura na literatura russa contemporânea cultura que trabalhavam no campo de cultura não oficial, principalmente já conhecidos no exterior, preferindo forçá-las a emigrar e evitando, assim, uma ressonância pública. Por isso, a publicação no exterior frequentemente servia como um degrau intermediário para a futura emigração do escritor. Assim foram os casos de Joseph Brodsky, Vassíli Aksiónov, Serguei Dovlátov, Ígor Iefímov e muitos outros escritores, cujo caminho em direção à emigração começara com publicações em tamizdat.

No princípio de sua carreira literária, Dovlátov, tendo como exemplo o sucesso dos escritores de linha liberal reconhecidos oficialmente nos anos do Degelo, também empreende várias tentativas de entrar na literatura soviética, levando seus textos a revistas e editoras soviéticas. Mas a mudança do rumo ideológico no país a partir de meados de 1960, junto com outros fatores descritos no capítulo dedicado à biografia do escritor, torna impossível o seu reconhecimento na literatura oficial.

Como apontam os autores da biografia Dovlátov, Koválova e Luriê, o escritor e muitos outros nascidos nos anos 1940 (entre eles também Joseph Brodsky), poderiam ser considerados "geração do intervalo", pois eles não tiveram tempo de se realizarem durante o período de Degelo, por serem ainda muito jovens nos anos 1950, e ainda não estarem preparados para a existência clandestina na "segunda realidade cultural soviética", no começo da época de estagnação. Assim, diferentemente dos demais, os escritores e artistas um pouco mais novos, que começaram o seu caminho criativo já nos anos 1970 (por isso às vezes essa geração denomina-se semidiessiátniki, ou seja, "os setentistas”, em analogia com chestidiessiátniki), desde o início de sua carreira não tinham pretensões de entrar na cultura oficial. Entre representantes de semidessiátniki, podemos destacar Víktor Krivúlin, Sacha Sokolóv, Serguei Stratanóvski, entre outros. Os autores da biografia caracterizam a geração de Dovlátov da seguinte maneira:

... eles não tiveram tempo de adquirir habilidades, mas tiveram tempo de ganhar ilusões, e sentiram as mudanças bruscas de pressão da inconstante ideologia estatal na idade mais imprópria para este tipo de provação: não suficientemente jovem, para não perceber; não suficientemente madura, para conseguir superar. ${ }^{91}$

Para Dovlátov, a impossibilidade de reconhecimento oficial de certo modo torna-se uma tragédia, embora o escritor tenha sucesso no âmbito da cultura não oficial. O seu encontro com a cultura não oficial, após a volta do exército, é descrito em seu livro $O$ ofício: "Na época, eu já

${ }^{91}$ KOVÁLOVA. Op. cit., p. 62. 
Serguei Dovlátov: texto de cultura na literatura russa contemporânea sabia da existência da literatura não oficial. Da existência da assim chamada "segunda vida cultural". Aquela vida que, em alguns anos, se tornara a única realidade...". 92

Embora a obra de Dovlátov também fosse distribuída através de samizdat, o maior sucesso o esperava em tamizdat: a editora americana Ardis publicou seu livro O livro invisível, e seus contos saíram em revistas Kontinent e Vriémia i my, o que chamou a atenção de críticos e de leitores no Ocidente. Justamente após essas publicações começaram as perseguições ao escritor, que determinaram a sua decisão de emigrar em 1978. Após a partida da União Soviética, a carreira de Dovlátov desenvolve-se no âmbito de literatura russa de emigração, o fenômeno de cultura russa que será analisado a seguir.

Embora a formação e a consolidação de Serguei Dovlátov como escritor tivesse acontecido na União Soviética, onde o escritor morou até seus 37 anos, o reconhecimento no âmbito literário aconteceu na emigração. Certamente, podemos considerá-lo um dos maiores representantes da literatura russa na emigração, no contexto da Terceira Onda de emigração.

A literatura de emigração russa é estudada como um gênero à parte por críticos e teóricos russos e ocidentais, a partir de suas características bastante específicas, como uma literatura produzida em língua russa, mas fora de seu contexto social. A seguir, faremos uma breve resenha das ondas de emigração que formaram o fenômeno da "literatura russa na emigração" ao longo do século XX, e o lugar de Serguei Dovlátov na literatura da Terceira Onda.

Durante o século XX, os acontecimentos históricos e políticos levaram a várias ondas de emigração da população da Rússia (e depois, da União Soviética) para o exterior. Os historiadores distinguem quatro ondas de emigração ao longo do século passado: a Primeira Onda, nos anos 1920, a Segunda Onda, nos anos 1940, a Terceira Onda, nos anos 1970 - 1980, e a Quarta Onda, nos anos 1990.

A Primeira Onda de emigração, também conhecida como "a emigração branca" (pois a maioria dos emigrados simpatizava com o antigo regime e com o exército branco que o representava na Guerra Civil, chamado assim em oposição ao exército "vermelho", prórevolução), está relacionada com a Revolução de Outubro de 1917 e a Guerra Civil que a seguiu. Nessa época, saíram do país muitos descendentes da nobreza russa e intelectuais que não haviam aceitado o regime comunista. Vários artistas e pensadores foram obrigados a abandonar o país, entre eles escritores como Vladímir Nabókov, Ivan Búnin, Aleksándr Kuprin, Dmítri Merejkóvski, Zinaída Guíppius, entre outros. Foi durante esse período que se formaram os

${ }^{92}$ DOVLÁTOV. Remesló. Op. cit., p. 15. 
Serguei Dovlátov: texto de cultura na literatura russa contemporânea principais núcleos culturais e literários da colônia russa no exterior, na Europa Ocidental, nas cidades de Paris, Berlim e Praga, e também no Extremo Oriente, na cidade chinesa de Harbin.

Como observa o professor da Universidade de Toronto e pesquisador da obra dos escritores da Primeira Onda de emigração Leonid Livak, a comunidade dos emigrados russos que saíram do país na época dos anos 1920 gerou uma série de mitos que posteriormente obtiveram uma ampla difusão nos estudos dedicados a esse período. Assim, é popular a concepção de que "os emigrados eram as pessoas que abandonaram o país devido a não aceitação do Bolchevismo". ${ }^{93}$ Tal visão simplifica demais o fenômeno da emigração russa do começo do século XX, pois, segundo Livak, entre os emigrados nem todos não concordavam com o novo regime soviético. Também havia aqueles que fugiam de privações; que saíam do país a fim de juntar-se com a família; que, após a queda do Império Russo, terminaram por encontrar-se e ser cidadãos de outros países recém-formados (como no caso dos países Bálticos, Polônia e Finlândia) ou, ao contrário, de províncias anexadas (como Moldávia ou Ucrânia Ocidental); ou pessoas ainda muito jovens no momento de partida para fazer uma escolha consciente. Além disso, nos anos 1920 ainda não havia uma linha divisória clara entre os emigrados e os cidadãos soviéticos que viajavam ou residiam no exterior. Assim, muitos exilados políticos, como Víktor Chklóvski, Maxim Górki, Iliá Erenburg ou Alexei Tolstói, entre outros, que na época residiam na Europa, posteriormente voltaram à União Soviética. A divisão entre o "emigrado" e o "soviético" tornou-se mais drástica já no período posterior, nos anos 1930, quando a cultura soviética e a cultura russa na emigração realmente ficaram polarizadas. ${ }^{94}$

Se nas décadas de 1920 e 1930 os centros principais da emigração russa eram as capitais europeias (em primeiro lugar, Paris), depois do começo da Segunda Guerra Mundial, nos anos 1940, muitos emigrados russos mudam-se para os EUA, onde se consolida uma colônia bastante grande, com uma vida cultural e literária ativa. Desde os primeiros anos da emigração, tanto na Europa como nos EUA surge uma série de periódicos em língua russa. Neles são publicadas não apenas obras literárias criadas na emigração, mas também artigos de caráter variado, dedicados tanto a questões de literatura e cultura como às de política e filosofia. Vários representantes da Primeira Onda deram uma grande contribuição tanto à cultura russa, com a qual iriam se reunir após a queda do regime soviético, como à cultura dos países que os acolheram.

A Segunda Onda, conhecida também como "a emigração pós-guerra", foi constituída principalmente por pessoas que foram deslocadas à força durante a Segunda Guerra Mundial e acabaram não voltando para as terras natais (displaced persons, ou abreviado como DP, em

\footnotetext{
93 LIVAK, L. How It Was Done in Paris. Russian Émigré Literature and French Modernism. Madison: The University of Wisconsin Press, 2003, p. 9.

${ }^{94}$ Ibid., pp. 9 - 10.
} 
Serguei Dovlátov: texto de cultura na literatura russa contemporânea inglês) e habitantes das repúblicas do mar Báltico que se recusavam a reconhecer o poder da União Soviética. Foi durante a Segunda Onda de emigração que se estabeleceram colônias russas nos Estados Unidos, principalmente em Nova Iorque e São Francisco, às quais se juntaram também alguns dos representantes da Primeira Onda, como foi o caso dos escritores Vladímir Nabókov, Roman Gul e Gleb Struve, entre outros. Entre os escritores-representantes desta onda de emigração podemos destacar Iúri Ivásk, Dmítri Klenóvski, Ivan Eláguin. Mas, em geral, a Segunda Onda, em comparação com a Primeira, gerou poucos nomes de referência no âmbito da literatura e das artes.

A Terceira Onda, conhecida como a emigração dos dissidentes e às vezes também chamada de "emigração judia", começou numa época de estagnação na União Soviética, quando no começo dos anos 1970 foram liberados para sair e morar permanentemente no exterior os judeus soviéticos e também os que não concordavam com o regime e eram perseguidos por suas opiniões políticas - os dissidentes. Durante aproximadamente 20 anos (a Terceira Onda de emigração durou até o final dos anos 1980), saíram ou foram expulsos do país muitos intelectuais e artistas (a "intelligentsia criativa", tvórtcheskaia intelliguêntsia, em russo), entre eles, a grande maioria dos escritores contemporâneos mais significativos que não aceitavam o regime estabelecido no país. O eslavista Arnold McMillin chamou esta onda de emigração de um dos acontecimentos mais dramáticos da cultura europeia contemporânea: "trágico e ao mesmo tempo promissor". ${ }^{95}$ Nesse período, emigraram Vassíli Aksiónov, Joseph Brodsky, Aleksándr Soljenítsyn, Iúz Alechkóvski, Serguei Dovlátov, Andrei Siniávski, Eduard Limónov, entre outros. Os destinos dos emigrados da União Soviética foram diferentes: assim, muitos judeus soviéticos foram a Israel; uma parte se instalou em países europeus (como Alemanha e França), e um grande número foi para os Estados Unidos. O contexto e os representantes da Terceira Onda de emigração serão analisados mais detalhadamente a seguir.

A Quarta Onda (dos anos 1990) começou com a queda da Cortina de Ferro, levando para o exterior as minorias étnicas russas (principalmente judeus e alemães). Essa onda de emigração às vezes também denomina-se "econômica", tendo em vista os motivos que estimulavam pessoas para emigrarem. ${ }^{96}$ A emigração da Rússia após a queda da Cortina de Ferro acontecia já num contexto histórico e social totalmente diferente. Além do mais, não se tratava mais de isolamento cultural e informativo das pessoas emigradas, como no caso das três ondas anteriores. Assim, não pode ser desconsiderado um fato como a abertura das fronteiras da Rússia pós-soviética, o

\footnotetext{
${ }^{95}$ MCMILLIN, A. "Exiled Russian Writers of the Third Wave and the Émigré Press". In: The Modern Language Review. MHRA, Vol. 84, № 2, April, 1989, p. 406.

${ }^{96}$ Uma análise das ondas de emigração que aconteceram na Rússia desde o começo do século XX está apresentada no artigo da edição em russo de BBC (edição do dia 26.12.2012), disponível na página da corporação: http://www.bbc.co.uk/russian/russia/2012/12/121128_russia_emigration_waves
} 
Serguei Dovlátov: texto de cultura na literatura russa contemporânea que, para muitos emigrados, deu a possibilidade de fazer constantes visitas à terra natal e não perder contatos com amigos e familiares que ficaram. No campo da cultura e das artes, devido ao pouco tempo que se passou depois dessa última onda de emigração, ainda não há estudos relevantes sobre seus representantes culturais e literários. Mas, entre os escritores representantes da Quarta Onda, podemos citar os nomes de Dina Rúbina, Aleksandr Goldchtein, Vladímir Bátchev, entre outros.

Embora todas as ondas formassem uma continuidade, devido ao pertencimento a uma mesma cultura em termos gerais e à auto-definição por meio da língua russa, pensando-se no contexto histórico-cultural, cada uma das ondas de emigração possuía características próprias que a diferenciava das outras ondas.

Neste trabalho, para a compreensão do processo cultural, apoiamo-nos nos pressupostos teóricos de Iúri Lótman e sua concepção da cultura como sistema dinâmico que está em constante evolução. ${ }^{97}$ No seu artigo O problema do signo e do sistema de signos e a tipologia da cultura russa dos séculos XI - XIX (em russo, Probliema znaka i znákovoi sistiémy i tipológuia rússkoi kultúry XI - XIX vekov), Lótman define cultura como "um conjunto de informação não hereditária, como uma memória coletiva da humanidade e de seus coletivos mais estreitos, nacionais, de classe, etc." 98 A percepção da cultura como um reservatório da memória comum de um determinado coletivo, e a sua compreensão como um sistema dinâmico, permitem-nos destacar as suas especificidades em diferentes gerações de escritores emigrados russos.

O desenvolvimento constante da cultura leva a diferenças e à incompreensão inclusive entre diferentes gerações de portadores da mesma cultura, pertencentes à mesma comunidade social e nacional. Portanto, é natural que, quando se trata de comunidades de pessoas que têm a língua e história comuns, mas estão isoladas ao longo de algumas décadas, a diferença de mentalidades e da percepção cultural não apenas da realidade contemporânea, mas também do passado comum, pode ser enorme. Assim foi o caso dos representantes das três ondas de emigração. A diferença ressaltava-se entre a Primeira e a Segunda (juntamente com a Terceira) ondas de emigração, cujos representantes, do ponto de vista formal, eram portadores de culturas de diferentes países - do Império Russo (no caso dos representantes da "emigração branca") e da União Soviética.

Assim, os emigrados soviéticos que chegaram ao Ocidente nos anos 1940 e 1950, e, depois, nos anos 1960, eram portadores de uma cultura diferente, da cultura de outro país, em comparação com os que saíram da Rússia pré-revolucionária. As diferenças de idade e também de caráter cultural em certa medida contribuíram para uma certa falta de compreensão entre os

\footnotetext{
${ }^{97}$ Lótman, Iúri. Semiosfera. São Petersburgo: Iskusstvo-SPB, 2010, p. 116.

${ }^{98}$ Lótman. Op. cit., p. 400.
} 
Serguei Dovlátov: texto de cultura na literatura russa contemporânea representantes de diferentes ondas de emigração. Assim, além de carecer de um desenvolvimento intelectual tão grande como a nobreza e os intelectuais do Século de Prata que emigraram nos anos 1920, a Segunda Onda de emigração, em comparação com a Primeira, já não possuía laços tão fortes nem com a cultura ocidental (pois a maioria dos emigrados nobres era bilíngue e possuía formação europeia), nem com a cultura do Século de Prata. Embora a princípio os emigrados mantivessem contatos constantes com a União Soviética e ambas partes tivessem notícias da vida cultural e literária de cada uma delas, já para o ano 1923, devido à polarização das ideologias e a crescente pressão por parte do governo soviético, começaram a proibir livros dos emigrados russos na União Soviética. ${ }^{99}$ Portanto, a partir dos anos 1930, a obra dos representantes da emigração de fato fora excluída da vida cultural e literária da União Soviética, considerada ideologicamente precária e antissoviética. Assim, tendo em vista o antagonismo ideológico das duas culturas, a partir dos anos $1930^{100}$ os contatos entre a colônia russa no exterior e a União Soviética diminuíram drasticamente, e a maioria dos representantes da Primeira Onda ficou isolada da cultura da metrópole e desconhecia os novos hábitos, a cultura e inclusive a língua russa soviética, que sofreu certas modificações.

Além do mais, a maioria dos intelectuais representantes da Terceira Onda de emigração tinha uma postura diferente da postura das primeiras gerações de emigrados quanto ao seu futuro. Para a maioria dos emigrados dos anos 1920, a emigração era uma condição temporária, pois poucos acreditavam que o novo regime soviético durasse muito tempo. Portanto, os primeiros emigrados guardavam os costumes e a própria língua com um cuidado especial, pensando que voltariam à terra natal após a queda do poder soviético. Além disso, como a emigração consistia principalmente em russos de origem nobre, muitos deles intelectuais, eles sentiam-se portadores e protetores "daquela Rússia” que os bolcheviques ousaram arruinar. Tal postura expressou-se, por exemplo, no famoso discurso, intitulado A missão da emigração russa (em russo, Míssia rússkoi emigrátssii), pronunciado por Ivan Búnin em Paris, em 1924. Nela, o escritor, referindo-se à missão dos emigrados russos de conservar a cultura russa até a queda do regime soviético, anunciou que essa emigração "agia em nome da Rússia cativa, sofrida, mas não conquistada até o fim". ${ }^{101}$ Tais opiniões permitiram ao eslavista americano David Bethea

\footnotetext{
${ }^{99}$ LIVAK. Op. cit., p. 33.

${ }^{100}$ É importante mencionar que, durante os primeiros anos após a Revolução, os emigrados mantinham contato com a Rússia (e depois, com a União Soviética) e se interessavam ativamente pela vida literária e cultural da metrópole. Na Rússia, também demonstravam interesse pelos escritores russos na emigração, o que até contribuía para um intercâmbio literário e cultural. Mas depois dos anos 1920, os contatos com a Rússia soviética interrompem-se, na expressão de G. Struve "são arruinadas as ilusões da unidade da literatura soviética e [russa] estrangeira" (STRUVE, Gleb. Rússkaia literatura v izgnánii. Paris - Moscou: YMCA-Press - Rússki Put, 1996, p. 41). Desde os anos 1930 estabelece-se o período de vácuo informativo (e também literário e cultural) que seria superado apenas nos anos 1960.

${ }^{101}$ BÚNIN, Iván. Míssia rússkoi emigrátsii. Discurso pronunciado em Paris em 16 de fevereiro de 1924.
} 
Serguei Dovlátov: texto de cultura na literatura russa contemporânea expressar a ideia de que as duas primeiras ondas de emigração caracterizavam-se por manter "um olhar nostálgico para o passado", sem muita capacidade de olhar para o futuro da emigração. $^{102}$

Já a postura dos dissidentes recém-chegados ao Ocidente nos anos 1970 foi bastante diferente, devido ao contexto histórico e social no qual eles deixavam o país natal. Na época, devido à pressão por parte dos países do Ocidente, o governo soviético liberou a emigração do país para judeus e alemães étnicos. Cabe mencionar que na União Soviética o antissemitismo era apoiado pelo próprio Estado: assim, para um judeu era muito mais difícil entrar numa universidade de alto prestígio e praticamente impossível obter um alto cargo de funcionário público.

Então, as pessoas que abandonavam o país eram em sua maioria judeus ou tinham parentes judeus (fato que deu o nome à esta onda de emigração como a "emigração judia"). Também eram comuns as situações de falsificação da origem judia para poder emigrar: por exemplo, eram bastante frequentes matrimônios fictícios com judeus, o que se refletiu numa piada, popular na época, que fazia alusão a uma famosa expressão, na qual a palavra "carro" trocava-se pela palavra "judeu”: "O judeu não é luxo, mas é meio de transporte” (em russo, Ievriei - eto ne róskoch, a sriedstvo peredvijénia). ${ }^{103}$

Falando da emigração dos anos 1970 - 1980, não podemos deixar de mencionar o fenômeno dos assim chamados otkázniki (refuseniks, em inglês; em português, o nome poderia ser traduzido como "os recusados"). Com esse termo, na linguagem não oficial, denominavam-se pessoas cuja petição para sair do país fora recusada pelo governo. O processo de conseguir a permissão para emigrar pressupunha uma série de formalidades burocráticas e vários obstáculos, pois, apesar de abrir uma oportunidade de emigrar para algumas camadas dos cidadãos soviéticos, as autoridades tinham como objetivo criar o maior número possível de dificuldades para os futuros emigrados, para evitar a emigração massiva. O número de otkázniki cresceu consideravelmente a partir dos anos 1980, após o começo da guerra com o Afeganistão e o exílio de Andrei Sákharov. ${ }^{104}$ Com o começo de Perestroika, em meados de 1980, as restrições

\footnotetext{
102 BETHEA, David. "Emigration and Heritage". IN: The Slavic and East European Journal, Vol. 31, Thirtieth Anniversary Issue, 1987, p. 155.

Aqui cabe mencionar de novo o trabalho de Leonid Livak, How it was done in Paris, no qual o pesquisador afirma que "a ideia da missão de conservar "a verdadeira Rússia" também formava parte da mitologia da emigração, e é preciso separar as suas interpretações mais tardias do seu papel na vida literária na emigração" (LIVAK. Op. cit., p. 10). Pois, ao contrário da ideia exposta nesse mito, os intelectuais russos não haviam abandonado a Rússia "com uma missão", e esse conceito surgiu já mais tarde, em oposição à cultura soviética (Ibid.).

${ }^{103}$ KOVÁLOVA. Op. cit., p. 301.

${ }^{104}$ Andrei Sákharov (1921 - 1989), físico nuclear soviético, dissidente e defensor das liberdades civis, ganhador do Prémio Nobel da Paz (1975). Em 1980, devido a sua atuação na URSS e às manifestações contra a entrada das tropas soviéticas em Afeganistão, foi privado de todos os prêmios e títulos e deportado de Moscou à cidade de Górki.
} 
Serguei Dovlátov: texto de cultura na literatura russa contemporânea para a saída foram diminuídas, e muitas pessoas dos otkázniki conseguiram obter a permissão para a emigração. O escritor russo-americano Maxim D. Shrayer, procedente de uma família de otkazniki, em seu livro À espera da América (em russo, V ojidánii Amiériki; título em inglês: Waiting for America), relata a história da emigração de sua família, que durante nove anos, até 1987, recebia respostas negativas do governo nas tentativas de sair da União Soviética. Nele, o escritor se refere ironicamente ao termo em inglês, refuseniks: “...em inglês, o termo ganhou uma ambivalência que duvido ser proposital; era o poder soviético que 'recusava' (em inglês, refuse), e a única coisa que os próprios judeus recusavam era a passagem ao paraíso soviético". ${ }^{05}$

Ao mesmo tempo, apesar dessa obstacularização do processo para os cidadãos soviéticos que queriam emigrar, a liberação deu possibilidade para as autoridades de se livrarem de figuras dissidentes sem a necessidade de prendê-las (os casos de processos judiciais de escritores e artistas como Brodsky, Siniávski e Daniel geraram uma grande repercussão não apenas na sociedade soviética, mas também chamaram a atenção da imprensa e de organizações de direitos humanos ocidentais). Por isso, no caso dos representantes da cultura não oficial, o governo soviético não apenas incentivava a sua emigração, mas, muitas vezes, até forçava a pessoa a emigrar. Nesse caso, para a pessoa "culpada", o governo não deixava alternativa alguma, propondo escolher entre a prisão (ou, em alguns casos, o tratamento forçado no hospício) e a emigração. Assim foi forçado a emigrar Joseph Brodsky; semelhante foi o caso de Serguei Dovlátov, que sofreu perseguições abertas uns meses antes de emigrar. O escritor descreve assim os seus últimos momentos na Rússia: “A alternativa "ir - não ir” transforma-se na alternativa "ir - ser preso". O que há que escolher aqui? Não se escolhe entre a prisão e Paris". ${ }^{106}$

Pensando no drama da partida e da separação da terra natal, é importante sublinhar que a maioria dos emigrados da Terceira Onda nunca havia saído do país antes (ou havia visitado apenas os países socialistas, devido à Cortina de Ferro) e compreendia que partia para o Ocidente "para sempre", perdendo a cidadania soviética, junto com a possibilidade de encontrar-se de novo com os parentes e amigos. Nesse sentido, a ruptura com a terra natal, para eles, era ainda mais extrema do que para os representantes da Primeira Onda, pois estes pelo menos tinham a esperança de que o regime dos bolcheviques acabasse logo e pudessem voltar para casa. A consciência da irreversibilidade da emigração diferenciava-os dos emigrados pósrevolucionários, fazendo-os tentarem adaptar-se quanto antes ao novo país, à sua cultura e às novas condições de vida.

\footnotetext{
105 SHRAYER, M. V ojidánii Amiériki (Na espera da América). Moscou: Alpina non-fiction, 2013, p. 12.

${ }^{106}$ DOVLÁTOV. "Mnoi ovladielo bespokoistvo". Op. cit., p. 227.
} 
Serguei Dovlátov: texto de cultura na literatura russa contemporânea

Nina Aloviert, fotógrafa, crítica de ballet e uma das representantes da emigração dissidente, autora das fotografias mais famosas dos representantes da colônia russa nos EUA, caracteriza assim a onda de emigração à qual ela mesma pertencia:

A Terceira Onda realmente diferenciava-se muito de todas as outras (...) A questão não está nos detalhes, mas no essencial: nós íamos embora do poder soviético e para poder realizar livremente os nossos intentos. Íamos embora, deixando para sempre os que eram nossos próximos, os amigos e parentes. Sabíamos que nunca mais na vida íamos vê-los de novo. ${ }^{107}$

O nome de Aleksandr Soljenítsyn, no contexto da Terceira Onda, merece uma atenção especial, pois o próprio escritor e filósofo sempre se manteve muito próximo à tradição e à cultura russa e nunca saiu desse contexto e tampouco se considerou emigrado, mas um exilado político, afirmando ter sido forçado a sair do país e voltando à Rússia assim que se modificou o regime político. Como menciona David Bethea, Soljenítsyn "poderia pertencer à Terceira Onda fisicamente, mas não espiritualmente, suas origens remontam a outra Rússia, à Rússia de Matriona (a personagem principal do conto do escritor A casa de Matriona (em russo, Matriónin Dvor) e à de Tolstói e Dostoiévski". ${ }^{108}$

Devido a diferenças de idade, de mentalidade e de cultura, o encontro dos dissidentes soviéticos com os representantes da "emigração branca", muitos dos quais ainda eram vivos entre os anos de 1970 e 1980, levou a uma certa incompreensão e até provocou polêmicas e discussões. Embora os emigrados dissidentes partissem justamente da ideologia totalitária, odiando e amaldiçoando-a, a Terceira Onda inevitavelmente levava em si os traços de mentalidade soviética, reproduzindo o seu código cultural.

Assim, se no campo de literatura a Primeira Onda de emigração procurava continuar no Ocidente o desenvolvimento da tradição de literatura russa pré-revolucionária, seguindo os exemplos e padrões do Século de Ouro e Século de Prata russos, ou se inspirava na obra do modernismo europeu, como o prova o mencionado estudo de Leonid Livak How it was done in Paris (2003), com a Terceira Onda chegou à emigração a literatura soviética, no sentido amplo da palavra ${ }^{109}$ (embora, na maioria dos casos, fosse antissoviética pelo seu pathos).

\footnotetext{
${ }^{107}$ ALOVIERT, Nina. "V liubói igrié suschéstvennen itog”. IN: Dovlátov, S. Rietch bez Póvoda... ili Kolónki Redáktora. Moscou: Makhaon, 2006, p. 20.

108 BETHEA. Op. cit., p. 159.

109 Alguns pesquisadores preferem evitar o adjetivo "soviético", referindo-se à cultura e literatura não oficial da União Soviética. Por exemplo, M. Tchudakova propõe usar o termo "literatura russa do período soviético" (apud: SKARLÝGUINA, Elena. Jurnalístika rússkoi emigrátsii: 1960 - 1980-e gódy. Moscou: Fakultiet jurnalístiki Moskovskovo gossudárstvennovo universitieta ímeni M. V. Lomonóssova, 2010, p. 23), para sublinhar o status não oficial dos seus representantes e a sua estética e ideologia totalmente diferentes da estética da literatura oficial.
} 
Serguei Dovlátov: texto de cultura na literatura russa contemporânea

As discrepâncias entre os representantes da Primeira e da Terceira ondas de emigração eram não apenas ideológicas e culturais, mas também estilísticas. Além de trazer uma mentalidade totalmente distinta (formada pelo regime soviético), a Terceira Onda trouxe um vocabulário novo, que, para os representantes da "emigração branca", em muitos casos, soava grosseiro e vulgar. Ao mesmo tempo, o estilo da "velha geração" parecia aos emigrados soviéticos artificial e grandiloquente, o que gerava piadas no âmbito de novos emigrados. Serguei Dovlátov descreve assim a linguagem da imprensa russa nos EUA: "Nóvoe rússkoe slovo empregava a língua com a qual falavam lacaios na obra de Értel e Zlatovrátski”. 110

Tudo isso levou a vários conflitos entre os representantes das duas ondas, da Primeira e da Terceira, no âmbito da literatura e do jornalismo. Assim, o público da colônia russa assistia ao conflito entre o redator-chefe do jornal novaiorquino Nóvoe rússkoe slovo ("A nova palavra russa"), Andrei Sedykh, e Serguei Dovlátov, na época de seu trabalho no jornal Nóvyi amerikánets, já que eles discutiam nas páginas de seus jornais. ${ }^{111}$ Outro conflito que se tornou público foi o conflito entre Sedykh e Eduard Limónov. ${ }^{112}$ A publicação do livro Passeios com Púchkin (em russo, Progúlki s Púchkinym), de Andrei Siniávski (o livro foi publicado sob o nome artístico de Abram Terts), gerou uma polêmica com Roman Gul que, indignado com a leitura de Siniávski da figura de Púchkin, escreveu-lhe uma resposta, intitulada Passeios de um grosseirão com Púchkin (em russo, Progúlki khama s Púchkinym). ${ }^{113}$

No entanto, apesar de relações nem sempre desanuviadas entre os representantes de várias ondas e de suas diferenças e discrepâncias, certamente podemos ver a literatura russa de emigração (ou a literatura russa estrangeira, russkaia zarubiéjnaia literatura, o termo que propõe Gleb Struve, em seu livro A literatura russa no exílio (em russo, Rússkaia literatura $v$ izgnánii $^{114}$ ) como um todo, um único gênero que se desenvolve ao longo do século XX. Apesar de serem separadas durante décadas e possuírem características próprias, as literaturas russa soviética e russa emigrada mostram uma unidade e formam um único continuum literário e cultural. Uma das provas disso é a facilidade e a rapidez com a qual a literatura russa estrangeira

Nesse trabalho, empregamos o adjetivo "soviético" no sentido mais amplo, caracterizando com ele o período histórico.

${ }^{110}$ DOVLÁTOV, March odinókikh. Op. cit.

Aleksandr Értel (1855 - 1908) e Nikolai Zlatovrátski (1845 - 1911), escritores secundários russos do século XIX.

111 Todos os materiais jornalísticos escritos por Dovlátov na emigração para o jornal Nóvyi Amerikánets estão reunidos na coletânea intitulada Discurso sem pretexto... ou colunas do redator (DOVLÁTOV. Op. cit.). Ali está publicada a carta aberta ao redator-chefe de Nóvoe rússkoe slovo, em resposta ao seu artigo Quem precisa disso? (em russo, Komu eto nujno?; Nóvoe russkoe slovo, de 28 de abril de 1981), publicada no № 65 do jornal, de 10 - 16 de maio de 1981 (Ibid., p. 200 - 208).

${ }^{112}$ As relações e conflitos entre os representantes de diferentes ondas de emigração estudam-se nos trabalhos de Elena Skarlyguina, por exemplo, no seu artigo No espelho de três emigrações (em russo, $V$ ziérkale triokh emigrátsii) (SKARLYGUINA, E. "V ziérkale triokh emigrátsii”. IN: NLO. Nezavíssimyi filologuítcheskii jurnal, № 93, 2008.).

113 GUL, R. “Progúlki khama s Púchkinym”. IN: Nóvyi jurnal. Nova Iorque, 1976, № 24.

114 STRUVE. Op. cit., p. 56. 
Serguei Dovlátov: texto de cultura na literatura russa contemporânea "voltou" à terra natal após a queda da Cortina de Ferro, quando começaram a ser publicados os textos de escritores emigrados na época da Perestroika e na Rússia pós-soviética.

Nina Aloviert, que também colaborou ativamente como fotógrafa com o jornal Nóvyi Amerikánets, lembra assim o momento de encontro das duas literaturas russas:

Quando se abriram as fronteiras soviéticas, quando na Rússia começaram a publicar tanto seus antigos não conformistas como os emigrados, resultou que essa realidade da cultura russa formava-se na mesma medida na Rússia e no Ocidente. E que um dos criadores mais notáveis da cultura russa era o escritor emigrado Serguei Dovlátov. ${ }^{115}$

Como durante a Terceira Onda de emigração muitos escritores emigram para os Estados Unidos, ali se forma uma forte colônia literária russa, constituída por vários grandes nomes, entre eles, Joseph Brodsky, Vassíli Aksiónov, Iúz Alechkóvski, Serguei Dovlátov. O centro dessa colônia foi a cidade de Nova Iorque, que já recebera russos de outras ondas de emigração e, em meados dos anos 1970, tinha vida literária própria no círculo dos emigrados russos. Essa vida literária foi enriquecida com a chegada de uma nova onda de escritores, jornalistas e críticos literários que, finalmente livres para exercer seu trabalho sem censura e perseguição por parte do poder, começaram a contribuir com seus escritos.

Assim, nos anos 1970 e 1980 nos EUA, surgiram vários novos jornais e revistas em língua russa para a comunidade novaiorquina (como, por exemplo, Vriémia i my ("O tempo e nós”), Streléts (“Sagitário”), Nóvyi amerikánets, entre outras) e outros já existentes receberam nova vida e novos temas com os autores recém-chegados. Após as publicações em tamizdat, logo antes de emigrar, Dovlátov chegou a Nova Iorque já tendo uma certa fama nos círculos dos emigrados, e logo incorporou-se à vida literária e jornalística novaiorquina. Como lembra Elena Dovlátova, no seu artigo O Novo americano no Novo Mundo (em russo, Nóvyi amerikánets v Nóvom Sviéte), já durante os primeiros meses em Nova Iorque Dovlátov conseguiu realizar vários projetos literários e jornalísticos:

Nos primeiros seis meses ele conseguiu publicar no Vriémia i my (...) na [revista] parisiense Kontinent (...) Fez alguns programas no rádio Liberty. E até uma vez colocou um artigo sobre Vladímir Úfliand em Nóvoe rússkoe slovo (...) Durante esse período, foi publicado na New Yorker o seu primeiro conto, traduzido para o inglês. ${ }^{116}$

\footnotetext{
115 ALOVIERT. Op. cit., p. 20.

${ }^{116}$ DOVLÁTOVA. Op. cit., p. 28.
} 
Serguei Dovlátov: texto de cultura na literatura russa contemporânea

Já na emigração, Dovlátov falava em palestras e entrevistas sobre as razões de sua emigração da União Soviética, marcando como a razão principal para emigrar, além das perseguições, a impossibilidade de exercer a profissão de escritor e de ter acesso ao público. $\mathrm{Na}$ entrevista à revista novaiorquina da comunidade russa Slovo - Word ele explica assim seus motivos para a emigração: "Eu fui embora para ser escritor, e me tornei escritor ao fazer uma escolha não muito difícil entre a prisão e Nova Iorque". ${ }^{117}$

Ao chegar aos Estados Unidos, Dovlátov começou a participar ativamente da vida literária de Nova Iorque. Além do trabalho como escritor (no total, durante os 12 anos de vida do escritor na emigração nos Estados Unidos e na Europa foram publicados 12 livros), ele trabalhou ativamente como jornalista, usando a sua profissão "oficial” na União Soviética. Assim, durante a vida na emigração, colaborou com a notória rádio Liberty (o público soviético o conhecia por seu programa $O$ escritor ao microfone) e durante dois anos e meio, de 1980 a 1982, foi redatorchefe do jornal semanal Nóvyi amerikánets, um dos jornais de maior referência na época na colônia russa nos Estados Unidos.

É preciso dedicar algumas palavras a Nóvyi amerikántes, pois foi o maior empreendimento e sucesso de Dovlátov no campo jornalístico na emigração. O escritor foi um dos fundadores do jornal e seu redator-chefe e principal ideólogo. Como lembra Elena Dovlátova, o próprio Dovlátov chamava o jornal de sua "cria", ${ }^{118}$ e logo após o surgimento de Nóvyi amerikánets, seus leitores começaram a chamá-lo de "jornal dovlatoviano" (em russo, dovlátovskaia gazieta). ${ }^{119}$

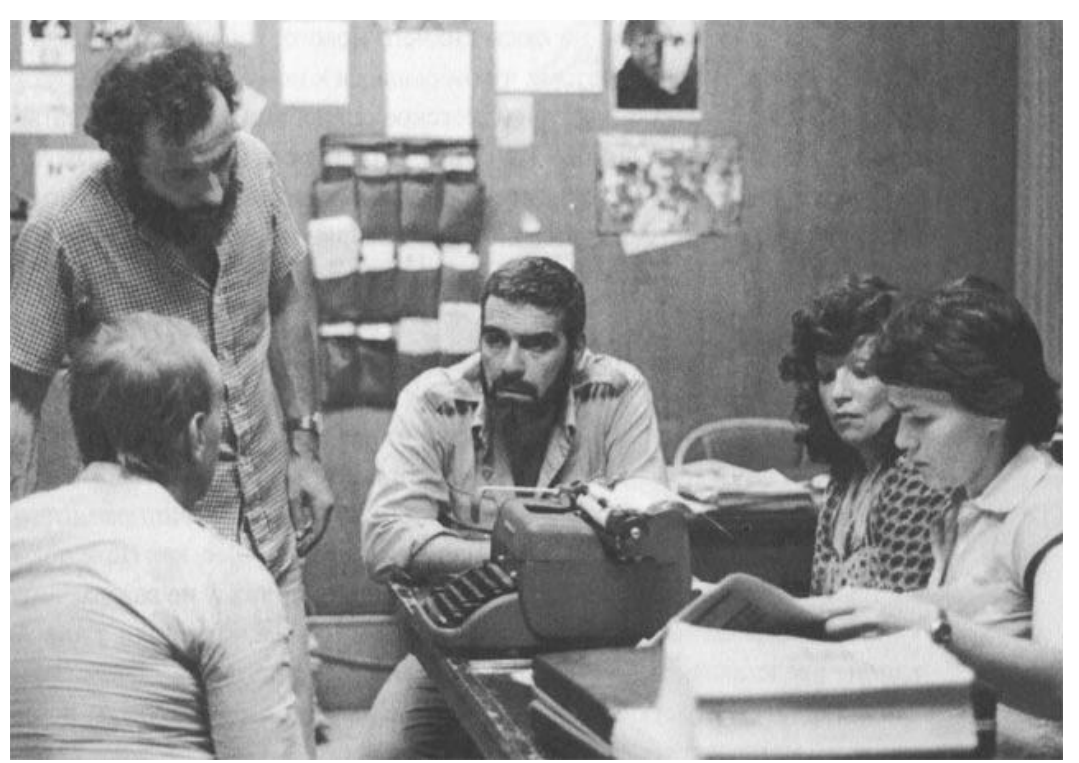

Dovlátov com colegas na redação de Nóvyi amerikánets

\footnotetext{
${ }^{117}$ DOVLÁTOV, S. "Pissátel v Emigrátsii””. IN: Revista "Slovo-Word”. Nova York, № 9, 1991.

${ }^{118}$ DOVLÁTOVA. Op. cit., 36.

119 Ibid., 31.
} 
Nóvyi amerikántes foi pensado como alternativa a Nóvoe rússkoe slovo (“A nova palavra russa"), o principal jornal novaiorquino em russo, que na época monopolizara o mercado jornalístico da colônia nos EUA. Nóvoe rússkoe slovo conservava o mesmo estilo desde os anos 1940 e era famoso pela postura autoritária de seu redator-chefe, Andrei Sedykh, que não permitia publicações de opiniões diferentes da sua. Por isso, Aleksándr Guénis, criticando o jornal por seu conservadorismo, estilo antiquado e visão muito estreita, dá a seguinte característica a Nóvoe rússkoe slovo, comparando-o com a imprensa soviética: "Quando Serguei [Dovlátov] compareceu em Nova Iorque, a imprensa emigrada resumia-se a Nóvoe rússkoe slovo, órgão que se diferenciava dos jornais soviéticos apenas pelo fato de ser seu suplemento antissoviético". ${ }^{20}$

A incompreensão entre os representantes de diferentes gerações de emigrados acontecia inclusive no nível linguístico. A primeira geração da emigração russa criara "um refúgio mágico da língua russa", na expressão de M. Rózanova. ${ }^{121}$ Assim, os emigrados da Primeira Onda conservaram e empregavam a língua russa do começo do século XX, livre das mudanças e desenvolvimentos pelo qual havia passado a língua falada na metrópole ao longo de 50 anos. Por isso, aos representantes mais velhos da emigração parecia-lhes rude, tosca e iletrada a linguagem de muitos autores soviéticos. Assim, por exemplo, não encontrou compreensão e foi muito criticada a poesia de Vladímir Vyssótski (1938 - 1980), poeta, cantor e compositor soviético, cultuado na URSS e considerado uma das principais vozes da sua época. ${ }^{122}$

Já em Nóvyi amerikánets, a própria redação posicionava o novo jornal como uma edição principalmente para a Terceira Onda de emigração, que falava a sua língua, bem diferente da língua de gerações anteriores de emigrados, e correspondia a suas necessidades. Como afirmam muitos dos colegas e contemporâneos do escritor, Nóvyi amerikánets teve tanto sucesso e repercussão entre os leitores justamente por haver trazido "uma corrente de ar fresco" ao âmbito de periódicos para falantes de russo nos Estados Unidos. Citaremos as palavras de Guénis, que trabalhou no jornal junto com Dovlátov:

Nóvyi amerikánets, sem falar nada novo, falava de um modo diferente. Ele conquistou o amor do leitor só por dirigir-se a ele de uma maneira amigável, em boa língua russa. (...) Serguei, com o seu gosto literário perfeito, levava o jornal pelo caminho do "estilo médio", legado por Lomonóssov. ${ }^{123}$ Evitando a

${ }^{120}$ GUÉNIS, A. “Tchessutchá i Rogoja”. IN: Dovlátov, S. Rietch bez Póvoda... ili Kolónki Redáktora. Op. cit., p. 14.

${ }^{121}$ Apud AGUENÓSSOV, Vladímir. Literatura rússkovo zarubiéjia. Moscou: Terra-Sport, 1998, p. 477.

122 Ibid.

123 Aqui, o autor faz alusão ao famoso sistema de três estilos de Mikhaíl Lomonóssov, que correspondiam a diferentes gêneros literários: o estilo elevado, que se empregava em odes, poemas heroicos e tragédias e outros gêneros solenes e elevados; o estilo médio, que se usava em elegias, dramas, éclogas, etc.; e o estilo baixo, usado em comédias, fábulas e outros gêneros de diversão. Neste sistema, o estilo médio corresponde justamente ao emprego 
Serguei Dovlátov: texto de cultura na literatura russa contemporânea

oficialidade inexpressiva e a familiaridade vulgar, sob a pressão direta de Dovlátov, todos aqui escrevíamos numa língua humana, de conversação amistosa. $^{124}$

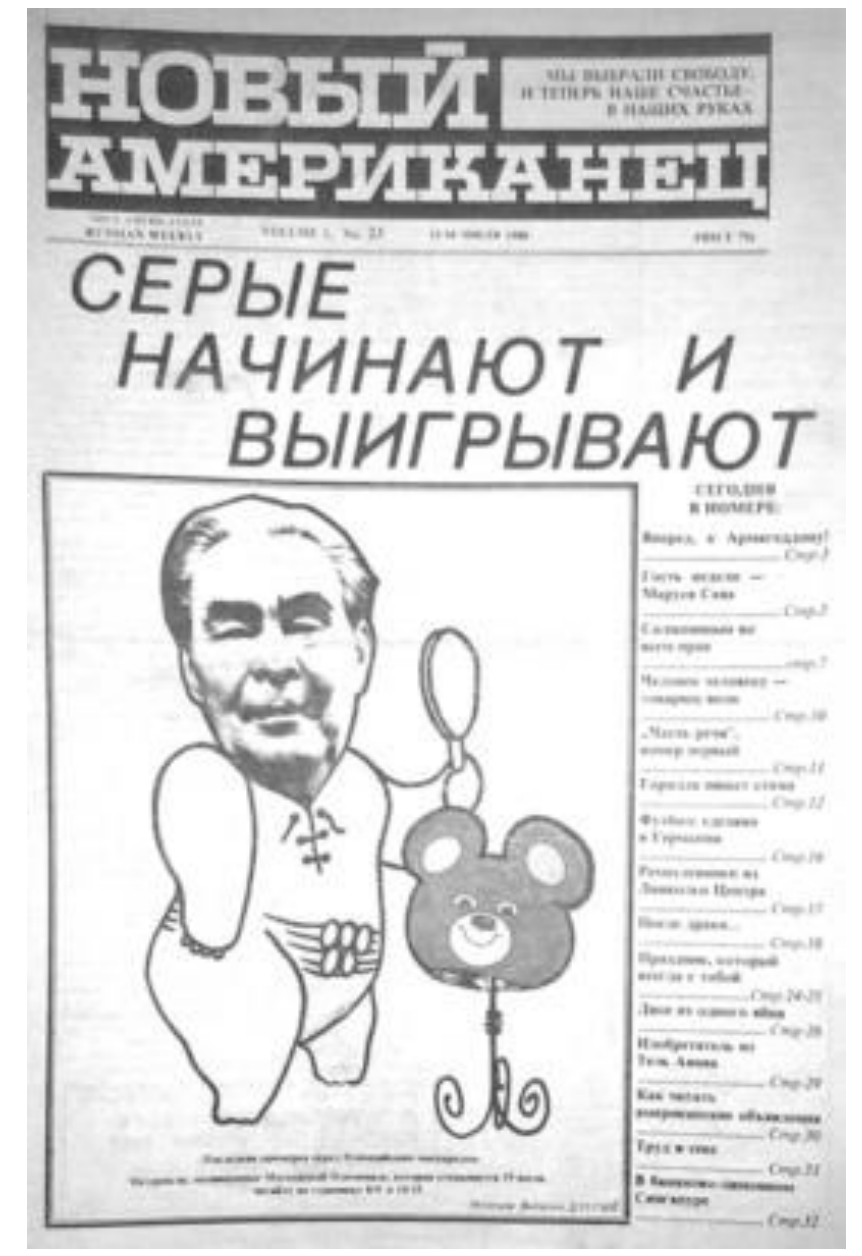

Capa de Nóvyi amerikánets, №23, 1980

Portanto, o estilo leve e espirituoso, a linguagem mais moderna e atual e a postura muito mais liberal e informal em relação a seus leitores, conquistaram aqueles leitores. Certamente, em grande medida esse sucesso devia-se à personalidade e ao talento de seu redator-chefe, Serguei Dovlátov. Como afirmam seus colegas do jornal, as colunas do editor eram muito esperadas pelos leitores e sempre recebiam muita atenção. Posteriormente, os materiais publicados no jornal de autoria de Dovlátov foram publicados na Rússia numa coletânea intitulada Discurso sem pretexto... ou as colunas do redator.

de língua russa de conversação, porém, de registro neutro, sem palavras coloquiais ou vulgares. Víktor Vinográdov, em seu trabalho As principais etapas da língua russa, além de dar o panorama de desenvolvimento de língua literária russa ao longo dos séculos, analisa a teoria de três estilos de Lomonóssov (VINOGRÁDOV, Víktor. “Osnovnye etápy istórii rússkovo iazyká”. IN: Ízbrannye trudy. Istória rússkovo literatúrnovo iazyká. Moscou: Naúka, 1978, pp. 10 - 64).

${ }^{124}$ GUÉNIS. “Tchessutchá i rogoja”. Op. cit., p. 16. 
Serguei Dovlátov: texto de cultura na literatura russa contemporânea

O próprio escritor em seus textos e entrevistas lembrava depois a época de Nóvyi amerikánets como um dos períodos mais animados e felizes de sua vida. ${ }^{125}$ Mas é importante sublinhar que para Dovlátov, apesar de seu sucesso também como jornalista, o único trabalho sério sempre fora a literatura, e na profissão de jornalista ele via apenas um modo de sustentar a família, chamando-a de "quebra-galhos". ${ }^{126}$

O sucesso da obra do escritor pelo mundo provou, posteriormente, o quanto seu talento era maior do que a esfera apenas jornalística. A esse respeito, Aleksandr Guenis ironiza, caracterizando a relação de Serguei Dovlátov com o jornal Nóvyi Amerikánets e com a profissão de jornalista, em geral, da seguinte maneira: "Poderíamos esgotar o tema "Dovlátov e o jornal" em uma frase, dizendo que ele não cabia ali". ${ }^{127} \mathrm{O}$ crítico faz referência não apenas ao tamanho do talento do escritor, mas também sarcasticamente a seu tamanho físico, pois Dovlátov tinha quase dois metros de altura.

Apesar de criar uma imagem boêmia de seu alter ego nos textos literários, todos os familiares e amigos de Dovlátov salientavam sua disciplina e eficiência no que se referia ao trabalho e ao fazer literário. Como lembra a viúva do escritor em entrevista aos autores da biografia Dovlátov, o escritor acordava todo dia de madrugada e escrevia durante algumas horas antes de sair para o trabalho na redação ou no rádio. ${ }^{128}$ Essa eficácia, junto com o talento e a vontade de ser publicado, serviram-lhe na emigração: o nome de Dovlátov ficou famoso não apenas entre o público da colônia, mas também entre os leitores americanos logo depois de o escritor ter chegado a Nova Iorque, e rapidamente a sua fama superou a fama de outros escritores emigrados que tinham chegado anos antes.

Assim, já na vida do escritor em emigração, sua obra foi reconhecida também por leitores americanos: além de Brodsky e Soljenítsyn, Dovlátov foi o terceiro escritor russo no exterior, representante da Terceira Onda de emigração, que mereceu o maior número de artigos críticos na imprensa estrangeira, quase todos elogiosos. Além do mais, o escritor ganhou o prêmio do PEN Clube americano (1986), e as traduções de contos de Serguei Dovlátov foram publicadas nas revistas Partisan Review, New Yorker e Grand Street. Na New Yorker, foram publicados nove contos de Dovlátov, o que o tornou o segundo autor russo, depois de Vladímir Nabókov, cuja obra fora publicada nessa revista americana de grande referência.

Outro sinal de reconhecimento é o fato de que também sua obra foi valorizada pelo clássico americano Kurt Vonnegut, com quem Dovlátov mantinha amizade nos anos 1980.

\footnotetext{
${ }^{125}$ DOVLÁTOVA. Op. cit., p. 34.

${ }^{126}$ SUKHIKH, I. "Serguei Dovlátov. Proza po kraiám”. IN: Dovlátov, S. Uróki Tchtiénia. São Petersburgo: Ázbuka, 2012, p. 31.

${ }^{127}$ GUÉNIS. “Tchessutchá i rogoja”. Op. cit., p. 13.

${ }^{128}$ KOVÁLOVA. Op. cit., p. 355.
} 
Serguei Dovlátov: texto de cultura na literatura russa contemporânea

Como mencionava o próprio Dovlátov em seus textos, e também atestavam os amigos do escritor, para Vonnegut, o fato de Dovlátov ter publicado no New Yorker, e o próprio escritor americano nunca tê-lo sido, sempre foi objeto de anedotas. Ievguéni Rein, poeta e amigo de Dovlátov, conta o seguinte episódio: "Serioja dirigiu-se a ele [a Vonnegut] com o pedido de algum favor bastante simples, do qual Vonnegut esquivou-se com a seguinte argumentação: Com o quê posso ajudar uma pessoa que publica constantemente no New Yorker? Pois eu mesmo não publico ali". ${ }^{129}$

O nome de Joseph Brodsky merece uma atenção especial na vida e na criação de Dovlátov. Brodsky e Dovlátov eram amigos ainda na época de Leningrado, e Dovlátov sempre admirou o talento do poeta, referindo-se a ele como o "único gênio de sua geração". ${ }^{130}$ Para ele, a aprovação de Brodsky de sua obra sempre foi um dos maiores elogios possíveis, e o escritor valorizava muito a amizade que mantinham.

Na emigração, o próprio Dovlátov sempre foi muito grato a Brodsky, que, já sendo famoso nos Estados Unidos, de certo modo abriu o caminho para o escritor recém-chegado, apresentando-o a editores e tradutores americanos. Foi ele que apresentou Dovlátov a Ann Frydman, tradutora com quem Dovlátov colaborou ativamente (Dovlátov inclusive chamava Frydman de "sua co-autora"131 e que traduziu para o inglês alguns de seus textos mais famosos, como A zona, A troca, Os nossos. ${ }^{132}$ Justamente as traduções de Ann Frydman foram publicadas em New Yorker.

Portanto, podemos dizer que, nos Estados Unidos, ainda em vida Dovlátov conseguiu um sucesso quase inimaginável para um escritor emigrado, e que até agora nenhum escritor russo pôde repetir. Para o próprio escritor, como atestam os amigos, esse sucesso tinha uma enorme importância. Assim, nas palavras de Guénis, "as publicações na imprensa americana foram para Dovlátov a recompensa por todas as suas humilhações anteriores. Ele via isso exatamente assim. Para ele, era um acontecimento de extrema importância". ${ }^{133}$

Como mais uma prova da fama do escritor na América do Norte, serve o fato de que em 2014, em Nova Iorque, no bairro de Forest Hills (região do Queens), onde o escritor morou e onde continua morando a sua família, a prefeitura deu nome a uma das ruas em sua honra. Agora, na intersecção da Travessa 63 e da Rua 108, em Forest Hills, está a Sergei Dovlatov

\footnotetext{
${ }^{129}$ REIN, Ievguéni. "Niéskolko slov vdogónku”. IN: Maloizviéstnyi Dovlátov: Sbórnik. São Petersburgo: AOZT "Jurnal Zviezdá", 1996, pp. 401 - 402.

${ }^{130}$ DOVLÁTOV. Zapisnýe kníjki. Op. cit., p. 206.

${ }^{131}$ DOVLÁTOV, S. "Perevodnye kartínki”. IN: Maloizvéstnyi Dovlátov: Sbornik. São Petersburgo: AOZT “Jurnal Zvezdâ", 1996, p. 248.

132 Como indicam as cartas de Dovlátov a Iefímov, enviadas em 1987, a novela Parque cultural também foi traduzida por Ann Frydman (DOVLÁTOV. Epistoliárnyi roman. Op. cit., p. 407), mas por alguma razão que desconhecemos não chegou a ser publicada na época. A tradução de Parque cultural para o inglês foi publicada apenas em 2013, sob o nome Pushkin Hills, feita pela filha do escritor, Katherine Dovlatov.

133 Apud KOVÁLOVA. Op. cit., 388.
} 
Way. Foi escolhido esse lugar, perto da casa do escritor, pois as suas descrições aparecem em vários de seus textos dedicados à vida na emigração, entre eles sua novela $A$ estrangeira. A cerimônia de inauguração aconteceu no dia 7 de setembro de 2014.

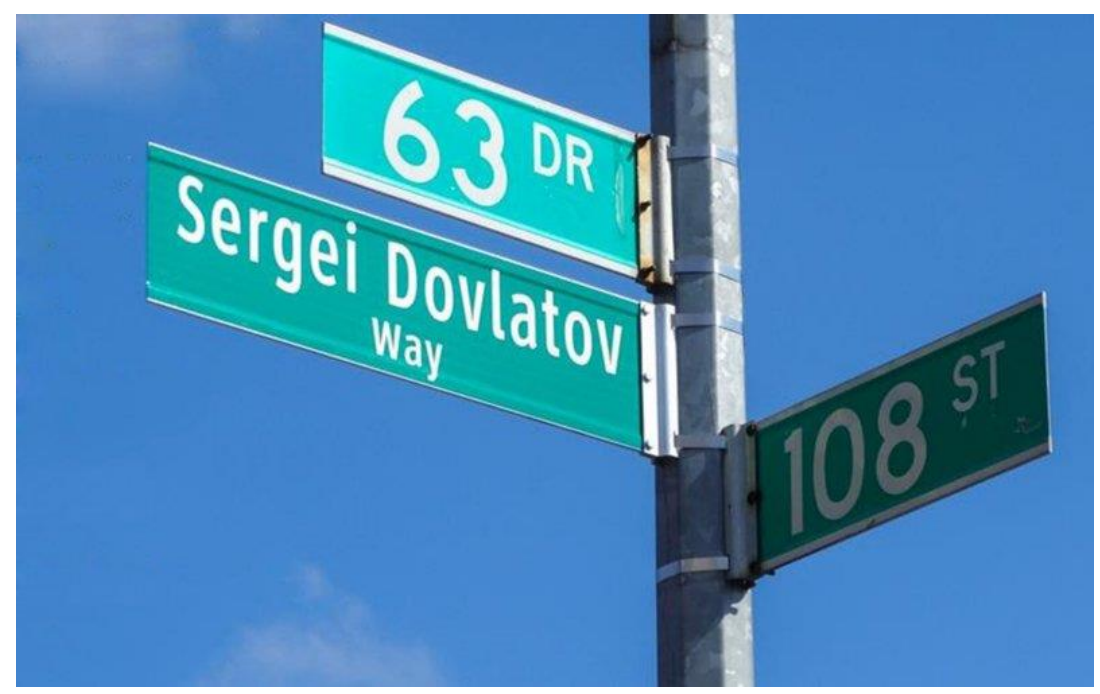

Placa 'Sergei Dovlatov Way', em Forest Hills, Nova Iorque

Apesar de tamanho sucesso na emigração, Dovlátov nunca abandonou a esperança de apresentar a sua obra na terra natal, a União Soviética. Como lembra Guénis, "Dovlátov, evidentemente tinha consciência de que o seu público principal estava na Rússia". ${ }^{134}$ Desde 1988, devido ao início de Perestroika e a certa abertura do regime, o escritor começa a estabelecer contatos com editoras e periódicos russos, a fim de publicar a sua obra. Primeiro, seus contos começam a ser publicados em periódicos russos, junto com a obra de outros escritores não oficiais. Um dos primeiros jornais soviéticos que publicou os contos de Dovlátov foi o jornal Nediélia (“A semana”). O redator da seção de literatura e arte do jornal na época, jornalista Andrei Malguin, mantinha correspondência com Dovlátov entre os anos de 1988 e 1990, e publicou algumas das cartas do escritor em seu blog na Internet. Numa das cartas, datada de 22 de maio de 1989, Dovlátov, agradecendo por haver publicado o conto, menciona a importância que tem para ele a publicação em casa: "Por mais que nós, emigrantes, façamo-nos de valentes a esse respeito, todos queremos ser publicados na terra natal, e apenas a ideia disso provoca em qualquer pessoa sã uma profunda emoção na alma. Obrigado". ${ }^{135}$

\footnotetext{
134 Ibid., 399.

${ }^{135}$ Esta e outras cópias digitalizadas das cartas de Dovlátov estão no blog do jornalista:

http://avmalgin.livejournal.com/3889928.html
} 
Serguei Dovlátov: texto de cultura na literatura russa contemporânea

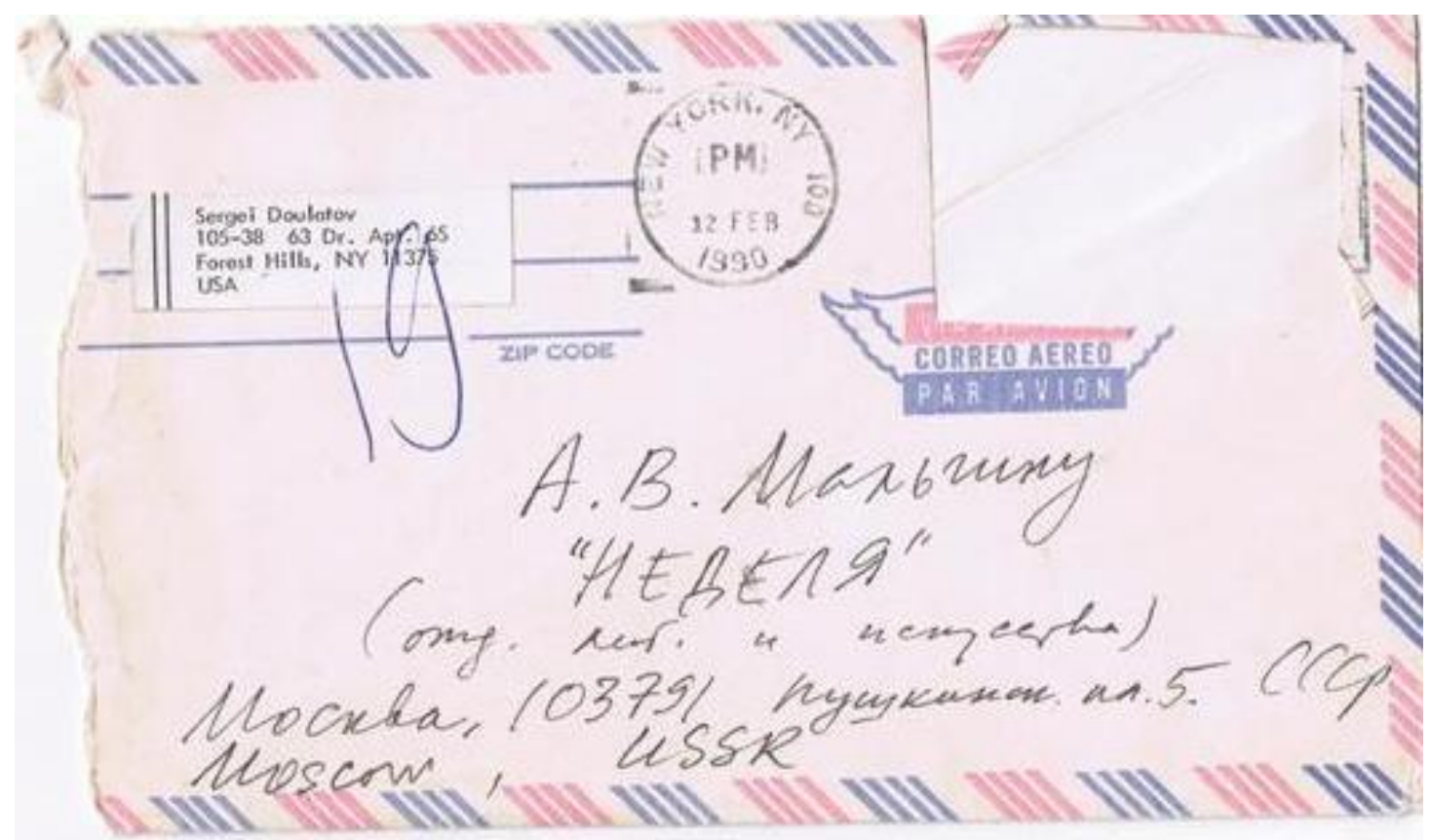

Envelope de uma das cartas de Dovlátov a Malguin (arquivo de A. Malguin)

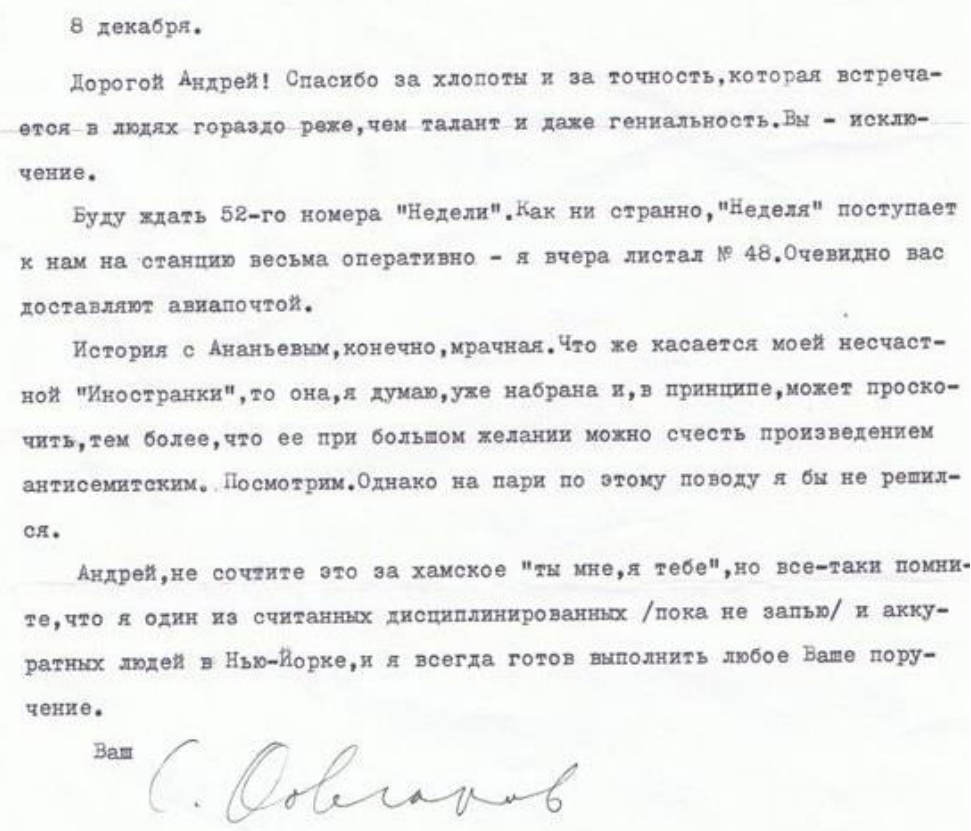

Uma das cartas de Dovlátov a Malguin (arquivo de A. Malguin)

Infelizmente, o reconhecimento massivo do escritor na Rússia aconteceu somente logo após a sua morte. Como lembram Vladímir Solovióv e Elena Klépikova, no seu livro Dovlátov de cabeça para baixo: a tragédia do homem alegre, nos últimos anos de vida Dovlátov dedicava muito tempo aos preparativos para a publicação dos livros na União Soviética. Uma das publicações estava planejada para o ano de 1991: 
Serguei Dovlátov: texto de cultura na literatura russa contemporânea

A glásnost apenas começava, jornalistas e redatores tinham muito cuidado, e, lembro, uma editora (...) colocou o seu livro no plano para o ano de 1991, o que na época, parecia-me muito distante, mas o Serioja não concordou comigo:

- Mas o ano de 1991 também vai chegar. Cedo ou tarde.

Para ele, não chegou. ${ }^{136}$

${ }^{136}$ SOLOVIÓV. Op. cit., p. 40. 


\section{Capítulo II. Poética, tradição e procedimentos artísticos}

Uma das principais características de Dovlátov escritor, que destacam todos os pesquisadores e críticos literários, é o “estilo impecável e único de sua prosa”. Na expressão de Brodsky, ele foi "um ótimo estilista", ${ }^{137}$ de modo que, em sua prosa, o escritor conseguiu, ao mesmo tempo, juntar as tradições estilísticas dos melhores representantes da literatura russa dos séculos XIX e XX, bem como as tendências da literatura soviética dos anos 1960 e 1970 que se inspiravam na linguagem viva e na fala popular. O teórico de literatura e pesquisador da obra de Dovlátov, Igor Kargáchin, carateriza essa peculiaridade do estilo de Dovlátov e a sua contribuição para a literatura contemporâneas da seguinte forma:

A prosa de S. Dovlátov (...) nesse contexto foi realmente "nova", pois herdava outra - a clássica mesmo! - tradição. (...) A singeleza e a clareza, a brevidade e a exatidão do estilo dovlatoviano ("as primeiras qualidades da prosa" - lembremos da famosa sentência de Púchkin!) colocam a sua prosa no contexto da literatura russa do século XIX. Por outro lado, (...) também é tão produtiva e perceptível na prosa de Dovlátov a outra tendência: a tendência da "liberação" da palavra dos cânones e regras literários, a reprodução das "múltiplas linguagens" da atualidade. ${ }^{138}$

Assim, por um lado, o escritor está marcado por um certo "conservadorismo" no que se refere ao estilo e à forma, mesclado pela tradição clássica; e, por outro lado, pela capacidade e habilidade de parodiar e inserir em seus textos a linguagem ágil e colorida das várias nações e camadas sociais da União Soviética. A este último aspecto, soma-se o humor cintilante, que faz da obra de Dovlátov uma leitura cativante e prazerosa para o leitor russo de qualquer idade, nível intelectual e condição social.

De modo geral, destacam-se em seus textos qualidades que lhe eram caras, como concisão, clareza, preferência pelo uso de palavras estilisticamente neutras e maior atenção à organização rítmica da frase.

O estilo conciso de sua prosa se deve ao fato de que o escritor parece preferir usar frases curtas e sintaxe simples. Evita construções prolixas e considera a simplicidade uma das principais qualidades do bom escritor. $\mathrm{O}$ seu credo se expressa no seguinte aforismo: “ $\mathrm{O}$

\footnotetext{
${ }^{137}$ BRODSKY. Op. cit., p. 298.

${ }^{138}$ KARGÁCHIN, Igor. “Osvobojdiónnoie slovo”. IN: O Dovlátove. Statiú, retsénzii, vospominánia. Tvier: Druguie beregá, 2001, p. 118.
} 
Serguei Dovlátov: texto de cultura na literatura russa contemporânea complexo na literatura é mais acessível do que o simples", ${ }^{139}$ no qual Dovlátov sublinha o trabalho literário que se esconde atrás da aparente simplicidade de um texto. Portanto, a dominante estilística na prosa do escritor era criar frases lacônicas, isentas de "adornos" desnecessários, mas expressivas. Serve como exemplo do laconismo de seu estilo o seguinte fragmento de Parque cultural, onde é descrita uma manhã de verão na base turística das Colinas de Púchkin:

Manhã. Passos abafados pela passadeira vermelha. Um balbucio repentino e entrecortado no alto-falante. Ruído de água atrás da parede. Caminhões do lado de fora. O grito súbito e distante de um galo...

Na infância, o verão era marcado por sons de apitos de locomotivas a vapor. Casas de campo suburbanas... Cheiro de queimado da estação e da areia quente. Pingue-pongue embaixo das árvores... O ruído tenso e sonoro da bolinha. ${ }^{140}$

Aqui, as frases curtas, com sintaxe simples, e a ausência de predicado na oração, organizam ritmicamente os parágrafos e dão uma expressividade especial ao fragmento. O leitor como que mergulha nas imagens descritas, que parecem "tridimensionais" e "palpáveis". Nessa brevidade expressiva de Dovlátov o poeta Brodsky via uma tendência do escritor "ao laconismo, ao lapidarismo próprio da linguagem poética e à capacidade máxima da expressão". ${ }^{141}$

Nesse fragmento podemos ver também outra característica própria do estilo dovlatoviano, no que se refere à procura da concisão: a clareza do texto e da palavra. Dovlátov tendia a evitar metáforas e comparações complexas, achando-as desnecessárias e até poluidoras. Referindo-se a tal aparente simplicidade do seu estilo, Sukhikh sustenta que "a palavra na prosa de Dovlátov não é tecido, não é matéria, não é superfície ou ornamento, não é música, não é plástica pura, é mais um vidro transparente, através do qual podemos, seguindo o narrador, perscrutar o mundo". ${ }^{142}$

Frequentemente a palavra na prosa de Dovlátov apenas nomeia, constata as características e os detalhes mais típicos do objeto ou da ação descrita. Portanto, as descrições prolixas ou demasiado detalhadas não eram características da poética do escritor. Ao contrário, como mostra a análise de seus textos, nas descrições Dovlátov preferia marcar apenas um detalhe, um gesto ou uma definição precisa. Como exemplo, observa-se um fragmento de Parque cultural, no qual é descrita a paisagem da aldeia de Sosnovo, na região das Colinas de Púchkin. Nele, de maneira lacônica, o escritor cria uma imagem viva dos animais que o protagonista vê na rua, criando comparações insólitas. Assim, as vacas que vê ao redor, são

\footnotetext{
${ }^{139}$ DOVLÁTOV. Zapisnýe kníjki. Op. cit., p. 240.

${ }^{140}$ DOVLÁTOV. Zapoviédnik. Op. cit., p. 187.

${ }^{141}$ BRODSKY. Op. cit., p. 298.

${ }^{142}$ SUKHIKH. Serguei Dovlátov. Vriémia, miesto, sudbá. Op. cit., p. 33.
} 
Serguei Dovlátov: texto de cultura na literatura russa contemporânea "monocromáticas e achatadas como num cenário teatral"143 e as ovelhas têm "caras decadentistas". ${ }^{144}$ Tal imagem passa ao leitor a sensação da decadência e tristeza da paisagem que reinam à sua volta.

Igor Kargáchin também aponta para tal especificidade da poética do escritor, sustentando que o objeto de descrição, isento de detalhes desnecessários ou características casuais, "torna-se vivo e tridimensional no mundo artístico do escritor, mais expressivo e significativo do que na realidade do dia a dia". ${ }^{145}$

Tal orientação artística pronuncia-se no romance $A$ zona, numa das “cartas ao editor” que precedem cada capítulo do livro. Nela, a personagem do escritor, falando do ambiente do campo de prisão soviético, reflete sobre a criação artística dos presos (no caso, as artes plásticas), seus postulados e regras, mencionando a descrição concreta, quase fotográfica, como um dos principais valores a ser seguido pelo artista: "E sem nenhum modernismo. Quanto mais perto da fotografia, melhor. Duvido que Modigliani e Gauguin tivessem sucesso ali”. ${ }^{146}$ Na referência à imagem fotográfica, reflete-se a orientação do próprio Dovlátov para uma descrição extremamente nítida e precisa. Analisando tal característica da poética de Dovlátov, Kargáchin acrescenta que "na prosa de Dovlátov não há palavras acidentais". ${ }^{147}$

Kargáchin insere Dovlátov na vertente dos escritores da literatura russa do período clássico, vendo em seu estilo e linguagem a tradição do Século de Ouro, como é chamado o século XIX na história literária nacional.

Em geral, em sua prosa, o escritor tende a usar um registro estilisticamente neutro, uma linguagem clara e singela e ao mesmo tempo elegante, livre de regionalismos e jargões. É essa a linguagem que, na Rússia, tanto os pesquisadores como os leitores comuns chamam de "linguagem de Púchkin", por ser este o primeiro escritor a introduzir tal estilo na literatura russa e a estabelecer a norma estilística vigente, em certo sentido, até os nossos dias. ${ }^{148}$ Assim, em seus textos, com exceção do discurso direto das personagens, Dovlátov evitava empregar palavras estilisticamente marcadas ou pertencentes à linguagem coloquial. Muitos pesquisadores, entre eles, Janna Motýguina, veem em tal característica do estilo dovlatoviano a marca doseu

\footnotetext{
143 Vemos aqui uma metáfora importante para a narrativa, pois a teatralidade, a falsidade do ambiente do parque cultural, é sublinhada constantemente no livro, sendo um de seus leitmotifs.

${ }^{144}$ DOVLÁTOV. Zapoviédnik. Op. cit., p. 194.

145 KARGÁCHIN. Op. cit., p. 104.

${ }^{146}$ DOVLÁTOV, S. Zona. IN: Zapoviédnik. São Petersburgo: Ázbuka, 2003, p. 117.

${ }^{147}$ KARGÁCHIN. Op. cit., p. 107.

${ }^{148} \mathrm{O}$ panorama do desenvolvimento da língua literária russa e as principais características da linguagem de Púchkin, seu fundador, analisam-se no artigo de Víkor Vinográdov As principais etapas da história da língua russa (VINOGRÁDOV, 1978).
} 
Serguei Dovlátov: texto de cultura na literatura russa contemporânea trabalho jornalístico, ao qual o escritor se dedicou durante toda a vida, já que os bons textos jornalísticos não devem apresentar uma expressividade estilística acentuada. ${ }^{149}$

No entanto, o escritor dominava perfeitamente todos os registros estilísticos da língua russa, usando-os tanto nos discursos de suas personagens pertencentes a diferentes camadas da sociedade como nos daqueles pertencentes a diferentes regiões e etnias da União Soviética. Assim, as personagens do romance $A$ zona, prisioneiros da colônia penal, conversam numa linguagem própria aos campos de prisão russos, muito diferente, por exemplo, da linguagem dos guias do parque museu em Colinas de Púchkin, na novela Parque cultural, assim como da dos emigrados judeus soviéticos nos bairros de Brighton Beach e Forest Hills, em Nova Iorque, nos textos A filial e A estrangeira.

$\mathrm{Na}$ caracterização das personagens por meio de sua fala (que, em muitos casos, permite ao leitor adivinhar de imediato a origem e a ocupação da personagem), Dovlátov segue a tradição do estilo do skaz, já expressado pelo escritor russo do séc. XIX Nikolai Gógol, seguido, nessa tradição, por Nikolai Leskóv. Víktor Vinográdov, linguista e teórico de literatura, explica e analisa o fenômeno de skaz em seu artigo O problema do 'skaz' na estilística (em russo, Problema skaza v stilístike). Como anota Vinográdov, "o escritor nem sempre escreve, mas as vezes como que transcreve uma conversação oral, criando a ilusão de uma improvisação viva". ${ }^{150}$ Portanto, o estilo do skaz é estreitamente vinculando à figura do narrador, por meio do qual o leitor enxerga a narrativa. O skaz sempre imita a linguagem falada, e como a narrativa tem como foco narrativo a personagem, o skaz salienta suas peculiaridades linguísticas regionais e sociais. Portanto, o escritor, nas palavras de Vinográdov, "arrasta atrás de si uma cadeia de consciências linguísticas alheias, uma série de narradores" (ibid.: 53), caracterizando a personagem por meio de sua linguagem.

Como Gógol e Leskóv, Dovlátov usa o recurso do skaz para gerar um efeito humorístico, a conferir uma expressividade verbal a suas personagens, muitas vezes em contraste com o estilo neutro do narrador. Como assinala a pesquisadora francesa Catherine Géry, em seu artigo Sergej Dovlatov, le conteur, Dovlátov "faz da tradição da anedota uma forma contemporânea de skaz". ${ }^{151}$ A pesquisadora refere-se aqui ao fato de que o autor atualiza o procedimento tradicional de skaz em seus textos, tornando-o adequado à época na qual vive: as personagens de Dovlátov transmitem por meio de sua fala, além das próprias características de sua personalidade

\footnotetext{
149 MOTYGUINA, Janna. Tvórtcheskaia individuálnost Sergueia Dovlátova. Ástrakhan: Izdátelski Dom “Astrakhánski Universitiet”, 2006, p. 17.

${ }^{150}$ VINOGRÁDOV, Víktor. "Probliema skaza v stilístike”. IN: O iazyké khudójestvennoi prózy. Moscou: Naúka, 1980, p. 42.

${ }^{151}$ GÉRY, Catherine. “Sergej Dovlatov, le conteur”. IN: Modernités russes 2. Vitesse et modernité. Lyon: Centre d'Études Slaves André Lirondelle, Université Jean Moulin, 2000, p. 105.
} 
Serguei Dovlátov: texto de cultura na literatura russa contemporânea e nível social, as peculiaridades e contradições do contexto histórico-cultural e ideológico no qual vivem, o que adensa o efeito cômico procurado.

Na novela Parque cultural, por meio da técnica do skaz são caracterizadas as personagens do literato Stássik Potótski, Mikhal Iványtch e do fotógrafo Valera. O escritor consegue transmitir a origem, o grau de educação e outros aspectos de caráter socio-cultural da personagem, por meio de sua maneira de falar, das palavras e expressões que esta emprega.

Assim, embora a personagem de Stássik Potótski represente na narrativa a profissão nobre do literato, a sua maneira de falar, o vocabulário pobre, o uso de várias frases feitas e bordões, gírias e expressões vulgares, de imediato revelam para o leitor não apenas a falta de "capacidades literárias evidentes", ${ }^{152}$ mas também a sua ignorância e a incapacidade de expressar-se num estilo mais elegante. Isso se percebe no seguinte monólogo de Potótski, no qual a personagem usa vários palavrões e vulgarismos:

- Cara, quase fiquei rico. Inventei um truque fora de série. Escuta, a ideia é esta. Conheço um trouxa qualquer. Ele tem carro, dinheiro, porra, e por aí vai. Pegamos uma safada (note-se: só uma) e vamos ao ar livre mesmo. Ali, nós dois marcamos o território...

- Não entendi.

- Cada um vai com ela... De manhã corro até ele. "Cara, o meu tá pingando." Ele entra em pânico. Então digo: "Dá pra quebrar o galho, porra. Vai custar apenas vinte e cinco rublos". ${ }^{153}$

A pobreza da linguagem de Pótotski ressalta-se ainda mais em situações mais formais, como durante a conversação com a mulher de Alikhánov, quando o beletrista não consegue desfazer-se de vulgarismos ("O Vovka, me perdoem, soltou um escarro"154) e, na tentativa de ser mais elegante, usa apenas clichês estilísticos e frases feitas:

— U-a fa-i-a — acrescentou Mitrofánov.

- Volódia quer dizer "uma vadia". E, mesmo falando grosseiramente, ele tem razão. Anna Petrovna tinha dezenas de amantes. ${ }^{155}$

A expressão "mesmo falando grosseiramente" aqui não acrescenta absolutamente nada à frase, sendo apenas um clichê estilístico, frase feita que se emprega para fazer com que o discurso soe mais culto e intelectual. Tais características "linguísticas" da fala de Potótski definem a personagem, sem que o narrador interfira para a sua caraterização.

${ }^{152}$ DOVLÁTOV. Zapoviédnik. Op. cit., p. 212.

${ }^{153}$ Ibid., 213.

${ }^{154}$ Ibid., 243.

${ }^{155}$ Ibid. 
Serguei Dovlátov: texto de cultura na literatura russa contemporânea

A personagem de Mikhal Iványtch, senhorio de Alikhánov, vive na aldeia e trabalha na indústria madeireira (ele mesmo se apresenta como "drujbista", ou seja, serrador que trabalha com a serra de marca Drujba ("Amizade", em russo)), é homem de poucos estudos, provavelmente só tem o diploma de ensino escolar, ou nem isso. Tudo isso se reflete em sua fala: a personagem se utiliza de várias construções erradas ou vulgares em russo, com muitos palavrões - expressões que na época de imediato permitiam distinguir uma pessoa de classe operária ou aldeã, pois entre os habitantes da cidade e representantes de intelligentsia o emprego de tal tipo de palavra era considerado tabu:

Deram quinze dias de cadeia, sem cigarrinho, sem nada... Tava cagando e andando... E cadeia não é trabalho... Lizka escreveu um papel ao procurador, algo assim, prendam o homem, se não, vai me matar... E pra que matar?... ${ }^{156}$

— Vizinho, dê uma força, me dê cinco rublinhos... Bom, três... Imploro, por Deus Jesus Cristo... Seu cuzão... ${ }^{157}$

No segundo exemplo, quando Mikhal Iványtch chama o vizinho "seu cuzão", em russo, a personagem usa a expressão sutchara batsílnaia (a tradução literal seria "cadela infecciosa"), gíria própria aos campos de prisão, um insulto comum entre os presos, o que imediatamente insinua ao leitor que provavelmente Mikhal Iványtch tenha passado algum tempo preso. ${ }^{158}$ Ao mesmo tempo, mencionar Jesus Cristo ou usar outras expressões de caráter religioso era mais comum na província, característica que também distingue Mikhal Iványtch como um habitante da aldeia. Em grandes cidades, devido à perseguição da igreja por parte das autoridades soviéticas e a proibição de praticar cultos religiosos, tais expressões já haviam caído em desuso, porém seguiam vigentes na província, onde o "controle ideológico" das práticas da religião era mais fraco. Aqui, também podemos ver um procedimento frequentemente usado por Dovlátov para gerar o efeito cômico: o contraste entre o elevado (no caso, a menção religiosa) e o baixo (o palavrão), que se alternam ao longo do discurso da personagem.

As referências a Jesus Cristo, nos discursos de Mikhal Iványtch são acompanhadas também de várias expressões relacionadas com a ideologia soviética. Assim, ameaçando o vizinho que se nega a emprestar-lhe dinheiro para comprar bebida, Mikhal Iványtch menciona tais fatos da realidade soviética como as Revoluções de Fevereiro e de Outubro de 1917, o

\footnotetext{
156 Ibid., p. 198.

157 Ibid., p. 204.

${ }^{158}$ Em português, não achamos um paralelo que possuísse o mesmo grau de expressividade e ao mesmo tempo insinuasse ao leitor o seu uso nas prisões, por isso optamos por uma variante de palavrão que permite conservar ao menos a expressividade da frase original.
} 
Serguei Dovlátov: texto de cultura na literatura russa contemporânea

Tcheká, as perseguições dos kulaki (camponeses abastados), entre outras coisas. Isso demonstra que a sua personalidade foi formada e influenciada pela ideologia oficial do partido, que emoldura a sua visão de mundo. Assim, para Mikhal Iványtch, o maior insulto é dizer que alguém é ou trabalha para capitalistas, e como castigo para os seus inemigos, ele ameaça com o processo de deskulakização e investigação no Tcheká:

— Faremos você lembrar tudo. Vai lembrar o ano de 1917! Vamos fazer... Vamos deskulakizar ${ }^{159}$ você, seu peste! Vamos deskulakizar todos os membros do partido! Vamos mandar você a Theká ${ }^{160}$ como aquele... Como o Makhnó... ${ }^{161}$ Lá, rapidinho... ${ }^{162}$

No caso da personagem de Valera Márkov a variedade de palavras e registros empregados no discurso é ainda mais ampla: Valera possui um grau de ensino maior e pretende pertencer à boêmia do local. Isso se reflete também em sua profissão - Valera é fotógrafo - mais "nobre" e muito mais rentável também. A fala da personagem também representa uma mistura de palavras e expressões de vários registros (no caso de Valera, mistura de elevado, médio e baixo, léxico obsceno, regionalismos e jargão), mesclados com os clichês e expressões oficiais próprias de ideologia soviética e também outras antissoviéticas. O protagonista de Alikhánov denomina os discursos de Márkov como "confusão nauseante de cabeçalhos de jornais, slogans, citações desconhecidas". ${ }^{163}$ Tal mistura de ideias, interesses e ideologias reflete a sua personalidade caótica e extravagante, pois Valera é considerado o abobalhado e o palhaço do local. Como no caso de Mikhal Iványtch, a convivência desses contrastes na visão de mundo da personagem, as viradas bruscas do elevado para o baixo, ou do soviético para o antissoviético, geram um efeito cômico peculiar. Cabe mencionar que os fragmentos que continham falas destas duas personagens foram os que geraram mais dúvidas no processo da tradução da novela. Analisemos com um exemplo de skaz, um discurso da personagem de Valera:

- Antes pensava em ir à Turquia de canoa. Até comprei um atlas. Mas é que vão me afogar, bastardos... Então, isso ficou no passado. Como se diz, passado e pensamentos... ${ }^{164}$ Agora, conto mais com os judeus... Uma vez viramos uma, Natella e eu, perto do rio. Eu digo: vamos casar, eu e você. Ela diz: você é selvagem, feio. Terra preta se arrebata dentro de você, diz... E em nossas paragens, a propósito, nem sequer ouviram falar de terra preta... Mas eu fiquei

\footnotetext{
159 "Deskulakização" (em russo, raskulátchivanie) foi uma política oficial de repressão aos kulaki, camponeses abastados, que começo em 1918 e perdurou até os anos 1930.

${ }^{160}$ Tcheká (abreviação de Tchrezvytcháinaia Komíssia, “Comissão Extraordinária”), primeira polícia secreta da União Soviética.

${ }^{161}$ Néstor Makhnó (1888 -1934), líder anarco-comunista ucraniano.

162 Ibid., p. 204.

163 Ibid., p. 258.

${ }^{164}$ Alusão ao livro Passado e pensamentos (em russo, Bylóe i dúmy) (1868), de Aleksandr Herzen.
} 
quieto. E até a encoxei um pouco. Ela grita: me deixe! Aqui podem ver... E eu digo: assim viviam os nossos antepassados eslavos... Enfim, não deu certo... Talvez devesse ter falado numa boa? Tipo, você é uma pessoa de nacionalidade judia. Então auxilie um dissidente russo por conta de Israel... ${ }^{165}$

Nesse fragmento, o humor se constrói na peculiaridade do discurso da personagem, que reflete o seu caráter e a visão de mundo, e no qual convivem expressões coloquiais e até vulgares (“bastardos", "viramos uma”, “a encoxei um pouco”), construções próprias de linguagem escrita, culta ("assim viveram os nossos antepassados eslavos", "terra preta se arrebata dentro de você") e oficialismos soviéticos ("uma pessoa de nacionalidade judia", "auxilie um dissidente"). Ao mesmo tempo, a personagem de Valera evoca em suas falas várias alusões a fatos e fenômenos de diferentes esferas da cultura russa e soviética: assim, nesse fragmento, é mencionado o título do livro de Hertzen, Passado e pensamentos (em russo, Bylóe $i$ dúmy); ${ }^{166}$ outra referência “cultural” é a "terra preta" (em russo, tchernozióm), um tipo de solo fértil que caracteriza as terras ao sul da Rússia. Assim, dizendo que "terra preta se arrebata dentro de você", a personagem de Natella, insinua a descendência "selvagem" e camponesa de Valera (as regiões da terra preta eram principalmente agrárias).

Como foi mencionado antes, o discurso da personagem se constrói sempre no contraste tanto estilístico quanto ideológico: além de passar bruscamente de estilo elevado a gírias e palavrões, e vice versa, normalmente o conteúdo e o pathos das frases da personagem também são polares. No texto da novela, a personagem de Alikhánov, descrevendo Valera, menciona essa peculiaridade de seu caráter: "A empáfia e a auto-humilhação alternavam-se nele constantemente". ${ }^{167}$ Assim, no seu discurso convivem tanto as expressões próprias da ideologia soviética, como as antissoviéticas. Tais reviravoltas geram um efeito cômico imediato. O fragmento seguinte demonstra a brusca virada tanto no humor como também no registro estilístico usado por Valera:

Voltamos à janela. A quantidade de pessoas aumentou sensivelmente. Alguém até deu de tocar sanfona.

— Reconheço-te, Rus! - exclamou Márkov e acrescentou baixinho: Detesto... Detesto esses trastes de Pskóv!... Pardon, primeiro bebamos. ${ }^{168}$

\footnotetext{
165 Ibid., p. $261-262$.

166 Cabe mencionar que uma das características do discurso da personagem de Valera é a abundância de alusões a livros, filmes, canções populares na época, cujos títulos, linhas ou referências aparecem em seus monólogos. Por isso o próprio Dovlátov confessava em cartas aos amigos que considerava intraduzível a novela para outros idiomas, em primeiro lugar devido às falas da personagem de Valera, com o complexo de todas as associações que elas traiam para o leitor russo (GUÉNIS. "Púchkin". Op. cit., p. 334).

167 Ibid., p. 264.

168 Ibid., p. 260.
} 
Esses são alguns exemplos de como o escritor consegue misturar vários registros estilísticos de diferentes personagens para caracterizar as suas personagens apenas por meio de sua fala, sem fazer uso de outros procedimentos. Mas, como foi dito antes, nas bordas do discurso direto das personagens, em geral Dovlátov procurava usar em seus textos uma linguagem simples, lacônica e concisa. Essa simplicidade parece ser um objetivo consciente do escritor. Seu colega e amigo Aleksándr Guénis caracteriza o seu estilo como quase imperceptível, chamando-o de "ausência de língua": "O sucesso de Dovlátov na América devese à sua língua, ou melhor, à ausência dela". ${ }^{169} \mathrm{O}$ crítico chama de "ausência de língua" a aparente transparência e singeleza dos textos do escritor. No entanto, como sempre testemunhou o próprio Dovlátov e todas as pessoas que tiveram a ocasião de trabalhar com ele, atrás desta transparência residia a sua maestria. Assim, Lev Lóssiev, escritor e amigo de Dolvátov, em seu artigo O escritor russo Serguei Dovlátov (em russo, Rússki pissátiel Serguei Dovlátov), ao se referir ao afinco e escrúpulo de Dovlátov na hora de escrever, assinalava, que o escritor "sabia com quanto esforço conseguiam-se as melhores palavras e o quanto era trabalhoso achar a melhor ordem para elas". 170

Vejamos algumas características da "ausência de língua" de Dovlátov. Apesar dessa aparente simplicidade, os textos do escritor possuem um estilo próprio e individual, difícil de ser imitado.

Em seu ensaio Sobre Serioja Dovlátov (em russo, O Serioje Dovlátove), Joseph Brodsky aporta a seguinte característica do estilo do escritor: "antes de tudo, Serioja era um ótimo estilista. Seus contos baseiam-se principalmente no ritmo da frase, na cadência da linguagem do autor. Eles são escritos como poemas: o enredo tem neles um significado secundário, é apenas um pretexto para falar. É mais um canto do que uma narrativa...”. 171

Realmente, o escritor dedicava muita atenção à forma de seus textos no sentido estrito da palavra: à organização formal e rítmica da frase, assim como à sua sonoridade. Como lembravam os amigos de Dovlátov, às vezes ele ficava semanas trabalhando com apenas uma frase, na procura do tom e concisão necessários. A questão da forma, do som e do ritmo preocupavam-no tanto que, muitas vezes, o escritor mudava o nome da personagem apenas por considerar que a sua forma não se encaixava perfeitamente na frase. Essa preocupação com a forma é ressaltada por Aleksándr Guénis, que dedicou vários artigos à obra de seu amigo: "Dovlátov gostava das

\footnotetext{
${ }^{169}$ GUÉNIS, A. Dovlátov i okriéstnosti. Filologuítcheski roman. Moscou: Astriel, CORPUS, 2011, p. 49.

${ }^{170}$ LÓSSEV. Op. cit., p. 381.

${ }^{171}$ BRODSKY. Op. cit., p. 298.
} 
palavras. Não somente das ideias que elas transmitem, mas também [gostava] das palavras em si, simplesmente porque são partes do discurso". ${ }^{172}$

O método de trabalho de Dovlátov e os seus princípios de elaboração do material verbal, tinham muito em comum com o método de trabalho do poeta, e vários pesquisadores apontam que a sensação "poética" sensu stricto, é uma das forças organizadoras de sua prosa. Assim, como aponta Brodsky no mesmo ensaio, Dovlátov "guiava-se pela sensação de que a prosa deve ser medida por meio do verso". ${ }^{173}$

Em seus textos, à procura de equilíbrio entre o conteúdo e forma, e à busca da organização rítmica, o escritor conscientemente evitava repetições acidentais ou coincidências de elementos da língua (tanto no nível léxico, quanto no fonético). Ao mesmo tempo, Dovlátov usava repetições de unidades de fala como princípio poético. Assim, por exemplo, o escritor usa construções anafóricas, que geram uma sensação de periodicidade do discurso da narrativa e lhe atribuem um certo ritmo. Há vários exemplos de tal ritmização da narrativa. Vejamos um exemplo de Parque cultural:

\begin{tabular}{|c|c|}
\hline 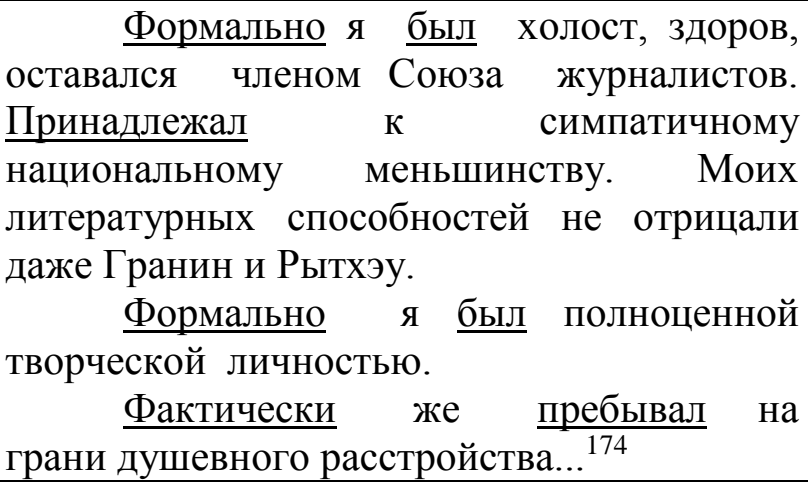 & $\begin{array}{l}\text { Formalmente estava solteiro, saudável, } \\
\text { continuava sendo membro da União dos } \\
\text { Jornalistas. Pertencia a uma simpática minoria } \\
\text { étnica. Meu talento literário era reconhecido } \\
\text { até por Gránin e Rytkheu. } \\
\quad \frac{\text { Formalmente, era um artista completo. }}{\text { Efetivamente, }}, \underline{\text { estava à beira de uma }} \\
\text { crise nervosa. }\end{array}$ \\
\hline
\end{tabular}

Como se vê, o fragmento organiza-se pela construção anafórica feita de advérbios (formalno, formalno, faktítcheski) e a repetição de verbos que expressam o estado e as qualidades da personagem, que estão no mesmo tempo verbal (em russo, o escritor usa o passado imperfectivo dos verbos byt ("ser" / "estar") e prebyvát (“estar”)). Além do mais, a organização rítmica da narrativa também se sustenta ao nível composicional e gráfico: a divisão do texto em parágrafos dá um efeito adicional de discurso fluido, que pulsa de uma maneira regular, e a sequência do monólogo, dividida de tal maneira, gera estrofes em prosa. Tentamos manter esse efeito na tradução, conservando a mesma construção de advérbios (formalmente, formalmente, efetivamente) e verbos no pretérito imperfeito (estava, era, estava).

\footnotetext{
172 GUÉNIS. "Púchkin". Op. cit., p. 326.

${ }^{173}$ BRODSKY. Op. cit., p. 298.

${ }^{174}$ DOVLÁTOV. Zapoviédnik. Op. cit., p. 234.
} 
Serguei Dovlátov: texto de cultura na literatura russa contemporânea

O "elemento poético" da prosa de Dovlátov, assim como o interesse do escritor pelo princípio rítmico do texto em prosa, reflete-se também no fato de que ele usava amplamente o recurso de prosa ritmizada. Assim, o conto inteiro Um blues para Natella (em russo, Bliuz dliá Natélly, 1985), é escrito em prosa ritmizada. Nele, a fluidez e o ritmo do texto remetem o leitor tanto ao gênero de poemas épicos georgianos (cuja obra mais famosa é o poema épico do séc. XII de autoria Chota Rustavéli, O cavaleiro na pele de pantera (em russo, Vítiaz v tigróvoi chkúre), como ao gênero musical de blues, cujo nome aparece no título do conto. O ritmo do texto é organizado em torno do melodioso e sonoro nome da protagonista, a georgiana Natella Bokutchava.

Também podemos encontrar fragmentos de prosa organizada metricamente em Parque cultural. Na novela, assim são organizados os fragmentos relacionados com a descrição da propriedade do poeta Aleksándr Púchkin, nas Colinas de Púchkin:

\begin{tabular}{|l|l|}
\hline $\begin{array}{l}\text { Дорога тянулась к вершине холма, огибая } \\
\text { унылое поле. }\end{array}$ & $\begin{array}{l}\text { O caminho ia ao topo do morro, volteando о } \\
\text { triste campo. }\end{array}$ \\
\hline $\begin{array}{l}\text { До этого были холмы, река, просторный } \\
\text { горизонт с неровной кромкой леса. }{ }^{176}\end{array}$ & $\begin{array}{l}\text { Até ali tínhamos visto colinas, um riozinho, um } \\
\text { amplo horizonte e um bosque margeando. }\end{array}$ \\
\hline
\end{tabular}

As descrições da paisagem nos lugares ligados ao nome de Púchkin, feitas em prosa rítmica, são uma forma de tributo ao poeta e ao seu legado literário.

Outro exemplo da preocupação de Dovlátov com a forma de sua prosa é o fato de que ele, que sempre afirmava que para o escritor é muito importante ter um princípio organizacional no trabalho, inventou para si mesmo uma restrição formal na literatura: em russo, todas as palavras usadas por Dovlátov numa frase deviam começar com letras diferentes. O próprio autor chamava esta autorrestrição de “cadeias criativas" (em russo, tvórtcheskie verígui), alegando que, como na poesia existem o ritmo e a rima como procedimentos de organização, na prosa é preciso ter algo semelhante. ${ }^{177}$ Dovlátov explica o seu método numa carta a seu amigo, o poeta Naúm Sagalóvski:

Acho que todo prosador deve inventar cadeias criativas, introduzir em sua escrita algum elemento disciplinador. Em poesia, o papel de tais cadeias interpreta a rima e o metro. Este princípio disciplinador protege os poetas de prolixidade e do

\footnotetext{
175 Ibid., 193.

176 Ibid., 180. Marcamos em negrito as tônicas em russo, para que seja mais fácil sentir o ritmo da frase.

177 Cabe mencionar que Dovlátov não foi pioneiro na ideia de criar restrições literárias formais: nisso o escritor segue o exemplo do grupo francês OuLiPo (abreviação de Ouvroir de littérature potentielle, "Oficina de literatura potencial"), que surgiu na França em 1960, formado por escritores e matemáticos, e que estudava as possibilidades potenciais da língua e da literatura através de constrangimentos literários. Os representantes literários mais famosos do OuLiPo são os escritores Raymond Queneau, Italo Calvino, Georges Perec, entre outros.
} 
Serguei Dovlátov: texto de cultura na literatura russa contemporânea

vazio. A prosa não tem estes limites e, parece-me, é preciso introduzi-los artificialmente. ${ }^{178}$

Em prol de tal restrição, Dovlátov chegava a mudar citações que apareciam em seus textos, caso nelas houvesse duas palavras que começavam com a mesma letra. ${ }^{179}$ Assim, na novela Parque cultural, foi deturpada a citação do famoso poema de Púchkin, Iá pámiatnik sebié vozdvig nerukotvórnyi (em português, na tradução de José Casado, "Um monumento ergui a mim, obra extra-humana" ${ }^{180}$ ): no verso "ne zarastiót $k$ nemú naródnaia tropá", o escritor troca a palavra naródnaia ("popular") por sviaschiénnaia ("sagrada"), para evitar o emprego de dois $n$ iniciais. ${ }^{181}$ A tradução literal da estrofe seria a seguinte: ${ }^{182}$

\begin{tabular}{|l|l|}
\hline $\begin{array}{l}\text {...не зарастёт к нему народная тропа (versão } \\
\text { original de Púchkin). }\end{array}$ & $\begin{array}{l}\text { Não se cobrirá a vereda popular até ele [o } \\
\text { monumento]. }\end{array}$ \\
\hline $\begin{array}{l}\text {...не зарастёт к нему священная тропа } \\
\text { (versão de Dovlátov). }\end{array}$ & $\begin{array}{l}\text { Não se cobrirá a vereda sagrada até ele [o } \\
\text { monumento]. }\end{array}$ \\
\hline
\end{tabular}

No texto do livro, Dovlátov deixou uma nota de rodapé, apontando que a citação está errada, o que foi conservado na tradução.

Por outro lado, as palavras que pareciam sonoras ao escritor e podiam servir como ponto de referência para a organização rítmica da frase eram usadas por Dovlátov em vários textos. Assim, por exemplo, várias personagens levam o mesmo nome ou sobrenome: aparece em vários textos o nome feminino de Natella (como no conto Um blues para Natella, ou em Parque cultural), assim como o sobrenome georgiano de Tchikvaídze: o protagonista do conto Emigrados (Emigránty) e o juiz em Parque cultural, que formaliza o divórcio de Alikhánov e a sua mulher. Evidentemente, os dois nomes pareciam a Dovlátov expressivos e ritmicamente adequados. Da mesma forma, não à toa parece ter escolhido o nome do protagonista de $A$ zona $\mathrm{e}$ Parque cultural, Boris Alikhánov, nome que encaixa no pé de verso antigo de anfíbraco.

Refletindo sobre o interesse do escritor pelos aspectos formais na organização de sua prosa, alguns críticos acusavam Dovlátov de formalisme, de falta de profundidade em seus textos, chamando-os de "palavreado sobre bagatelas", ${ }^{183}$ onde a forma é mais valorizada do que

\footnotetext{
178 ÁRIEV, A. Serguei Dovlátov. Jizn i mniénia. Ízbrannaia perepiska. São Petersburgo: OOO Jurnal Zviezdá, 2011, p. 241.

${ }^{179} \mathrm{Na}$ tradução, devido às diferenças na estrutura morfológica e sintática do russo e do português, não seguimos esse princípio organizacional de Dovlátov.

${ }^{180}$ PÚCHKIN, A.S. Poesias escolhidas. Rio de Janeiro: Nova Fronteira, 1992, p. 67.

${ }^{181}$ DOVLÁTOV. Zapoviédnik. Op. cit., p. 190.

${ }^{182} \mathrm{Na}$ tradução da novela, usamos a estrofe da tradução do poema, feita por José Casado, "Sua vereda o mato não há de ocultar", e trocamos a palavra "vereda" por "atalho": "Seu atalho o mato não há de ocultar". Assim, na tradução, foi conservado o "erro" do texto original.

183 BONDARIENKO, Vladímir. "Plebiéiskaia proza Serguéia Dovlátova”. IN: Rússki perepliot, 1999.
} 
Serguei Dovlátov: texto de cultura na literatura russa contemporânea o conteúdo. Tais acusações parecem-nos inconsistentes já que, como veremos a seguir, em seus contos aparentemente humorísticos, o autor tratava nas entrelinhas de temas profundos e filosóficos, referentes à existência e natureza humanas, à criação artística, etc. Mas é certo que a forma de seus textos realmente preocupava muito o escritor. Tal paixão pela forma, pela palavra em si, é caracterizada por Guénis da seguinte maneira:

A palavra é a personagem principal de Dovlátov. Às aventuras das palavras, reduz-se todo o enredo de seus contos. Em geral, não lhe importa sobre o quê contar. Segundo Dovlátov, a arte do contador [de histórias] é afim a outras artes que não dominam uma linguagem clara, como música ou pintura. ${ }^{184}$

Dovlátov sempre trabalhou principalmente com formas curtas, como contos curtos e crônicas. Como escreve Andrei Áriev, referindo-se à prosa de Dovlátov, "seu gênero canônico é o livro que se lê em uma noite". ${ }^{185}$ Alguns pesquisadores veem nessa tendência, assim como nas especificidades de seu estilo, a influência de seu trabalho de muitos anos como jornalista e, em especial, de repórter. ${ }^{186}$

Já em vida, Dovlátov recebeu o título de mestre de gênero curto: suas histórias, concisas e lacônicas, que seguiam a tradição tchekhoviana, foram muito bem acolhidas pelos críticos no Ocidente, e, posteriormente, nos anos 1990 na Rússia. Como aponta Popóv, Dovlátov tinha uma intuição exata para a composição de um texto curto, com o seu início, desenvolvimento e final. $^{187}$

Podemos dizer que a prosa de Dovlátov corresponde plenamente à definição de "bom conto", dada por Júlio Cortázar em seu artigo Alguns aspectos do conto. Na opinião de Cortázar, um bom conto deve ser "incisivo, mordente, sem trégua desde as primeiras frases", ${ }^{188}$ o que pressupõe que o escritor-contista sempre trabalha com material significativo, ou seja, no conto não há elementos gratuitos, meramente decorativos. Cortázar destaca como principais características da estrutura do conto sua significação, intensidade e tensão. Estas características são vistas em textos de Dovlátov, sempre lacônicos, isentos de prolixidade e que contêm apenas o material significativo.

O gênero de conto constitui o núcleo mesmo de obras mais longas do escritor. Assim, seus romances, como A zona, A troca, A mala ou Os nossos, do ponto de vista estrutural representam coletâneas de contos que não têm um enredo único. O que une as narrativas desses

\footnotetext{
${ }^{184}$ Apud SUKHIKH. Serguei Dovlátov. Vriémia, miesto, sudbá. Op. cit., p. 32.

185 ÁRIEV, A. "Istória rasskáztchika”. IN: Sukhikh. Serguei Dovlátov. Vriémia, miesto, sudbá. Op. cit., p. 6.

${ }^{186}$ VLÁSSOVA, Iúlia. Issliédovanie tvórtchestva Sergueia Dovlátova. Moscou: Kompánia Sputnik +, $2001 .$, p. 13.

${ }^{187}$ POPÓV. Dovlátov. Op. cit., p. 315.

${ }^{188}$ CORTÁZAR, Júlio. “Alguns aspectos do conto”. IN: Valise de cronópio. São Paulo: Perspectiva, 2011, p. 152.
} 
Serguei Dovlátov: texto de cultura na literatura russa contemporânea contos, organizados como capítulos, é a personagem principal do narrador, o herói autobiográfico de Dovlátov (em A troca, A mala e Os nossos, a personagem do narrador leva o nome do escritor, Serguei Dovlátov). No caso de A zona, no qual a personagem de Boris Alikhánov (o nome que o escritor atribui a seu herói autobiográfico também em Parque cultural) aparece apenas em alguns episódios: o meio de junção dos fragmentos numa linha narrativa são as "cartas ao editor", escritas em primeira pessoa, que precedem cada capítulo do romance.

Contudo, os capítulos dos livros mencionados representam, cada um, um conto isolado e independente, com a fábula e o enredo próprios, que podem ser lidos (ou publicados, como aconteceu já com os fragmentos desses romances, publicados em revistas) de forma isolada. $\mathrm{O}$ próprio Dovlátov reconhecia nas cartas aos amigos que, para ganhar status de escritor sério e consolidar a fama, era necessário publicar um romance, que era aquilo que as editoras americanas esperavam de seus autores, o que lhe motivou a criar seus romances usando como base os contos. ${ }^{189}$

Mas se os livros mencionados acima apresentam a forma de coletânea de contos, no entanto, como aponta Sukhikh, mesmo os textos com fábula única, como as novelas Parque cultural ou A estrangeira, podem ser divididos em várias micronovelas, com o enredo e a composição próprios, “encaixados" no enredo ${ }^{190}$ principal da narrativa. Vejamos como esse sistema de micronovelas funciona na estrutura da novela Parque cultural.

A fábula da narrativa é a história da personagem de Boris Alikhánov, alcoólatra e escritor fracassado que, passando por uma crise familiar e criativa, vem trabalhar como guia no parque museu nas Colinas de Púchkin, na tentativa de repensar sua própria vida e sua criação. Ao longo do trabalho no museu, Boris conhece os funcionários, faz amizades com os habitantes da região, tem um encontro com a mulher, que lhe anuncia a sua decisão de emigrar junto com a filha. Ao saber da notícia, Alikhánov, após sofrer uma crise de alcoolismo, volta a Leningrado para despedir-se da mulher e da filha. O final da narrativa é aberto: o texto termina com a conversa telefônica do herói, que está em Leningrado, com a mulher, que lhe telefona de Nova Iorque. Mas os indícios indiretos, como a dedicatória no começo do livro ("A minha mulher, que tinha razão"), o lugar e a data no final (junho de 1983, Nova Iorque), insinuam para o leitor qual foi a decisão tomada pelo protagonista.

Mas dentro dessa narrativa maior cabem várias narrativas menores que se apresentam deslocadas da fábula e do enredo, e que o escritor introduz como lembranças, eventos que

\footnotetext{
${ }^{189}$ DOVLÁTOV, S., Iefímov, I. Epistoliárnyi roman. Moscou: Zakhárov, 2001, p. 402.

${ }^{190}$ Nesse trabalho, usamos os conceitos de fábula e enredo, desenvolvidos pela escola formalista. Assim, o crítico e teórico literário Boris Tomachévski define a fábula como a relação causo-temporal entre os elementos temáticos introduzidos na narrativa (TOMACHÉVSKI. Op. cit., p. 179), e o enredo como a distribuição artística dos acontecimentos na obra (Ibid.: 181).
} 
Serguei Dovlátov: texto de cultura na literatura russa contemporânea ocorrem ocasionalmente, relacionados com o protagonista e as personagens que o rodeiam. Assim, no eixo da narrativa encaixam-se histórias curtas sobre momentos de vida de outros funcionários do museu e conhecidos de Alikhánov, como as histórias do erudito extremamente preguiçoso Volódia Mitrofánov, do literato Stássik Potótski e do dedo-duro universitário Liónia Guriánov; as histórias contadas por Mikhal Iványtch e Valera Márkov; a história do conhecimento e namoro de Alikhánov e a sua mulher; o encontro com o primo de Tânia, Édik Malínin.

Normalmente, essas micronovelas introduzidas na narrativa, com um final inesperado e cômico, provocam riso no leitor e conferem um tom humorístico à obra. Tal uso de breves histórias cômicas permite a Sukhikh afirmar que a criação de Dovlátov baseia-se no gênero oral de anekdot (em português, "anedota", "caso" ou "causo"): "A estrutura do texto dovlatoviano pode ser representada da seguinte maneira: gira-se lentamente a roda do enredo "maior", central, e nela tilintam alegremente e sem parar os chocalhos de anedotas". ${ }^{191}$

É necessário esclarecer o significado do termo de anekdot, tal como usado na língua russa moderna, como história curta e engraçada, normalmente transmitida oralmente. O Dicionário monolíngue de língua russa, sob redação de S. Ójegov, dá a seguinte definição ao termo: "uma história muito curta com o conteúdo engraçado, cômico, e um final inesperadamente gracioso". ${ }^{192}$ Como aponta Iefim Kurgánov, em seu livro A anedota como gênero na literatura russa (em russo, Anekdot kak janr v rússkoi sloviéstnosti), "o efeito de surpresa, que rompe a inércia da narrativa" é uma das características essenciais da anekdot. ${ }^{193}$

Dessa definição pode-se ver a evolução do significado da palavra desde o século XIX, quando anekdot compreendia "uma história curta sobre algum acontecimento curioso ou cômico" (a definição que nos propõe o Dicionário de Vladímir Dal). ${ }^{194}$ Assim, no sentido empregado no século XIX, anekdot não necessariamente devia ser cômica, portanto, o acréscimo importante na língua moderna foi a obrigatória comicidade do conteúdo da anekdot, o que determinou o gênero e o seu uso. Aqui, referindo-se à obra de Dovlátov, usaremos o termo no seu sentido moderno.

Anekdot, gênero oral de entretenimento, até hoje continua sendo um gênero semimarginal no âmbito da literatura, considerado mais pertinente à literatura de massa. No sentido histórico de anekdot, qual seja, o de uma história curiosa (e não necessariamente engraçada), trabalharam os escritores do período clássico como Púchkin, Gógol, Dostoiévski. No entanto, quem introduziu a anekdot no seu sentido moderno na alta literatura na Rússia no final do séc.

\footnotetext{
${ }^{191}$ SUKHIKH. Serguei Dovlátov. Vriémia, miesto, sudbá. Op. cit., p. 54.

192 ÓJEGOV, S., Chvédova, N. Tolkóvyi slovar rússkovo iazyká. Moscou: Azbukóvnik, 2001, p. 25.

${ }^{193}$ KURGÁNOV, Iefim. Anekdot kak janr v rússkoi sloviésnosti. Moscou: Arsis Books, 2014, p. 8.

${ }^{194}$ DAL, Vladímir. Slovar jivóvo velikorússkovo iazyká. Moscou: Rússki iazyk, 1989, p. 17.
} 
Serguei Dovlátov: texto de cultura na literatura russa contemporânea

XIX foram escritores como Nikolai Leskóv e, principalmente, Anton Tchékhov. A construção da narrativa com base numa piada foi muito criticada na época, e, a princípio, os críticos resistiam em ver em Leskóv e Tchékhov representantes da alta literatura. Nikolai Leskóv foi reconhecido como escritor sério apenas após a morte. Em vida, ele foi chamado pelos críticos, com tom pejorativo, de "contador de anedotas" (em russo, rasskáztchik anekdótov). ${ }^{195}$ Quem conseguiu dar respeito a este gênero e introduzi-lo na literatura séria, foi Anton Tchékhov. Assim, o enredo, o núcleo de muitos contos de Tchékhov, nem sempre humorísticos, nasce justamente da "anedota". O nome de Tchékhov tinha uma importância especial para Dovlátov, que sempre afirmou que na literatura russa, apesar de admirar e respeitar muito o talento dos clássicos do século XIX, como escritor ele sempre quisera se parecer com Tchékhov: "Pode-se venerar a inteligência de Tosltói. Admirar a elegância de Púchkin. Apreciar as buscas morais de Dostoiévski. O humor de Gógol. Et cetera. No entanto, tem-se vontade de parecer somente com Tchékhov". 196

O gênero de anekdot era muito popular na União Soviética, sendo parte inalienável da vida soviética: oralmente, transmitiam-se casos políticos, históricos, eróticos, casos sobre líderes do partido etc. ${ }^{197}$ A popularidade desse gênero humorístico estava relacionada com a sua função de harmonização com a realidade cotidiana, própria do humor, e que fora estudada por Mikhaíl Bakhtin em sua obra Cultura popular na Idade Média e no Renascimento no contexto de François Rabelais (título em russo, Tvórtchestvo Fransuá Rablé i naródnaia kultura srednevekóvia i renessansa ). Como aponta Sukhikh, “[Anekdot] era um antídoto: as piadas grotescas destruíam o absurdo grotesco do dia a dia. Não é à toa que mandavam à prisão em razão do riso. Além do mais, a anekdot era a antilinguagem, uma vacina contra a fiênia 198 ideológica do partido". 199

Portanto, a anekdot era um meio de expressão da cultura não oficial, “o ar da segunda realidade literária". ${ }^{200} \mathrm{Na}$ época, vários literatos contemporâneos recorriam a esse gênero em sua obra, entre eles, além de Dovlátov, podemos destacar Víktor Goliávkin e Andrei Siniávski.

No caso de Dovlátov, usar anekdot como base composicional da narrativa foi um procedimento que o escritor escolheu conscientemente. Isso demonstram seus cadernos de anotações, publicados em dois volumes: Solo na Undervude ("Solo na Underwood”, o título faz

\footnotetext{
195 SUKHIKH, I. Probliémy poétiki A.P. Tchékhova. Leningrado: Izdátelstvo LGU, 1987, p. 40.

${ }^{196}$ DOVLÁTOV. Zapisnýe kníjki. Op. cit., p. 81.

${ }^{197}$ Posteriormente, no final dos anos 1980, devido à liberalização da imprensa, começaram a publicar antologias de anedotas soviéticas, como A história da URSS em anedotas (em russo, Istória SSSR v anekdótakh), Staliniada etc. O desenvolvimento do gênero de anekdot soviético e a sua repercussão na literatura são analisados no livro de I. Sukhikh, Serguei Dovlátov: Tempo, lugar, destino.

${ }^{198}$ Fiênia é a palavra própria de argot russo, que denomina a linguagem usada na prisão.

${ }^{199}$ SUKHIKH. Serguei Dovlátov. Vriémia, miesto, sudbá. Op. cit., p. 49.

${ }^{200}$ Ibid., p. 42.
} 
Serguei Dovlátov: texto de cultura na literatura russa contemporânea referência à marca da máquina de escrever), dedicado à vida na União Soviética, e Solo na IBM (“Solo no IBM”), dedicado à vida na emigração, nos Estados Unidos. Os cadernos demonstram ao leitor o laboratório criativo do escritor que, seguindo o exemplo de Tchékhov, anotava casos, piadas ou frases que lhe pareciam graciosas ou interessantes e, posteriormente, inseria-os em sua obra. Às vezes um pouco modificado, o mesmo fragmento surgia em mais de um texto.

Podemos dar como exemplo o seguinte fragmento que, um pouco modificado, passou de Um solo na Underwood à novela Parque cultural:

\begin{tabular}{|c|c|}
\hline Solo na Undervude & Zapoviédnik \\
\hline $\begin{array}{l}\text { Isso aconteceu nas Colinas de Púchkin. } \\
\text { Eu passava ao lado do correio. Ouvi uma voz } \\
\text { feminina: uma moça estava conversando numa } \\
\text { ligação interurbana: } \\
\text { - Clara! Você está me ouvindo?! Não } \\
\text { aconselho a vir! Aqui não tem homem } \\
\text { nenhum! Tem muitas meninas indo embora } \\
\text { sem nem ter aproveitado! }\end{array}$ & $\begin{array}{l}\text { As portas do departamento de correio } \\
\text { estavam escancaradas. Ali também ficavam } \\
\text { duas cabines de telefones interurbanos. Uma } \\
\text { delas estava ocupada. Uma loira com as pernas } \\
\text { gordas gritava gesticulando: } \\
\text { - Tatússia, está me ouvindo?! Não } \\
\text { aconselho a vir... O tempo não está lá aquelas } \\
\text { coisas... E o mais importante: não tem homem } \\
\text { nenhum... Alô! Está me ouvindo?! Tem muitas } \\
\text { meninas indo embora sem nem ter } \\
\text { aproveitado... }{ }^{202}\end{array}$ \\
\hline
\end{tabular}

Tal exemplo demonstra como os momentos da vida ao seu redor, fragmentos de conversas captados num momento, passavam a formar parte da realidade literária dovlatoviana, o que permitiu a Áriev dizer que "na prosa de Dovlátov, sempre se sentia o seu equivalente oral". 203

Anekdot forma a base composicional de praticamente toda a obra de Serguei Dovlátov. Nas palavras de Sukhikh, Dovlátov aposta no gênero de anekdot e não o utiliza como "pano de fundo", um adorno, mas o coloca no centro de atenção em sua prosa. Por exemplo, seu romance A mala consiste em oito narrativas cômicas, cada uma relacionada a um dos objetos pessoais que o escritor leva na mala à emigração, e cada uma delas pode ser contada separadamente como uma anedota. Do mesmo modo é feita a composição de Os nossos. Inclusive, como no caso de Parque cultural, algumas das piadas anotadas em Um solo na Underwood transformam-se em um livro em capítulos dedicados a membros da família de Dovlátov. Assim foi o caso da história de seu avô armênio. Em Um solo na Underwood, um fragmento é dedicado ao avô do autor que, conhecido por seu caráter severo e explosivo nos momentos de raiva, pronunciava uma misteriosa fórmula, "abanamat", que inspirava pavor em todos os membros da família e que

\footnotetext{
${ }^{201}$ DOVLÁTOV. Zapisnýe kníjki. Op. cit., p. 121.

${ }^{202}$ DOVLÁTOV. Zapoviédnik. Op. cit., p. 268.

${ }^{203}$ Apud VLÁSSOVA. Op. cit., p. 7.
} 
Serguei Dovlátov: texto de cultura na literatura russa contemporânea ninguém conseguia decifrar. ${ }^{204}$ Já adulto, o autor adivinhou que se tratava de uma expressão indecorosa em russo, pronunciada com um forte sotaque caucasiano. ${ }^{205}$ Esse fragmento formou base do capítulo de Os nossos sobre o avô armênio Stepán.

A anekdot como gênero, em sua composição, normalmente é baseada em sua parte final numa reviravolta inesperada do tema ou num jogo cômico de palavras. Dovlátov usa frequentemente esse procedimento de anekdot para gerar o efeito cômico. Vejamos dois exemplos de inserção de anekdot na narrativa de Parque cultural. No primeiro episódio, a personagem de Alikhánov está conversando com uma das funcionárias do museu, Gália, que lhe mostra o parque:

- Aqui tudo vive e respira Púchkin — disse Gália —, literalmente cada raminho, cada talo de grama. Você até espera que neste instante ele apareça virando a esquina... A cartola, o sobretudo, o perfil tão familiar...

No entanto, quem surgiu virando a esquina foi Liónia Guriánov, o exdedo-duro da universidade. mesmo?! ${ }^{206}$

- Borka, seu filho da mãe — gritou como um possesso —, é você

Aqui, o escritor usa o procedimento de "demetaforização" (em russo, demetaforizátsia), na expressão de Iefim Kurgánov, ${ }^{207}$ própria do gênero de "causo": cria-se uma metáfora que é destruída no final, ao deslocar os planos metafórico e literal. Devido a esse deslocamento, a metáfora desintegra-se, o que provoca o efeito necessário. No fragmento, a metáfora de Púchkin que aparece no local, é destruída pela imagem da personagem de Liónia-Dedo-duro virando a esquina.

Além do mais, a comicidade do fragmento é baseada no contraste entre o elevado e o baixo, pois as personagens estão tendo uma conversa importante, espirituosa, que se rebaixa bruscamente tanto pela linguagem usada (em russo, a personagem de Liónia usa a expressão khrien morjóvyi,equivalente em português a "seu filho da mãe", algo que, embora não seja palavrão, é uma expressão vulgar, e literalmente poderíamos traduzi-la como "pau de morsa"), quanto pela "profissão" - dedo duro - da personagem de Liónia Guriánov.

No segundo fragmento, que aparece na novela alguns parágrafos depois, a reviravolta da conversa entre as personagens de Liónia e Gália, ao contrário, vai do baixo para o elevado:

\footnotetext{
${ }^{204}$ DOVLÁTOV. Zapisnýe kníjki. Op. cit., p. 94.

${ }^{205} \mathrm{Na}$ tradução do romance para o espanhol, Los nuestros, o tradutor Ricardo San Vicente criou a expressão "Tu utamá", que transmite a mesma ideia que a expressão original (DOVLÁTOV, S. Los nuestros. La vida de una familia de la Unión Soviética contada con sarcasmo. Barcelona: Áltera, 2008, p. 19).

${ }^{206}$ DOVLÁTOV. Zapoviédnik. Op. cit., p. 183.

${ }^{207}$ KURGÁNOV. Op. cit., pp. $40-41$.
} 
Ele olhou para Gália.

— Você está mais bonita. Pelo jeito, colocou uma dentadura?

Seus bolsos alargavam-se, pesados.

- Que escroto! — disse de súbito Galina. E, um minuto depois: - Que bom que Púchkin não está vendo isso.

— Sim — disse eu —, é bom mesmo. ${ }^{208}$

Aqui, Galina começa a fala com um palavrão (em russo, zasrániets; a tradução literal seria "cagão", mas em russo a expressão tem um significado distinto, determinando uma pessoa má, desonesta) e acaba mencionando o poeta Aleksándr Púchkin, figura totalmente sagrada no âmbito do museu.

Nos dois exemplos, podemos ver como Dovlátov explora o procedimento próprio de formas carnavalescas, construindo o efeito cômico com base na ambivalência e na tensão entre os polos elevado e baixo. Nos dois fragmentos, o autor faz conviver numa situação o "sagrado" (a figura de Púchkin e tudo o que é relacionado com ela, no parque museu) e "o baixo carnal", na terminologia de Bakhtin, ${ }^{209}$ pois tanto em russo, como na tradução para o português, as expressões empregadas pelas personagens, khren morjóvyi ("fillho da mãe", na tradução), ou zasrániets ("escroto", na tradução), remetem-nos a elementos "baixos" do ser humano. Por meio de tal contraste, acontece uma anulação ou "rebaixamento" do sagrado. ${ }^{210}$

\section{O contador de histórias: anekdot e a "oralidade" da obra de Dovlátov}

O próprio Dovlátov gostava de se referir a si mesmo não como a um escritor, mas como a um contador de histórias, confessando o seu amor por contar histórias e dizendo que primeiro começara a contar suas histórias, casos e chistes para, depois, anotá-los no papel. ${ }^{211}$ Em vários textos seus, Dovlátov repetia a seguinte divisão entre as funções do contador de histórias (em russo, rasskáztchik), prosador (prozaik) e escritor (pissátel): "O contador de histórias fala sobre como as pessoas vivem. O prosador, sobre como as pessoas devem viver. $\mathrm{O}$ escritor, para que as pessoas vivem". 212

A facilidade de relatar os textos de Dovlátov, de citar suas piadas, está relacionada com a aparente "oralidade" de sua prosa, pois parece que todas as histórias escritas por ele poderiam ser

\footnotetext{
${ }^{208}$ DOVLÁTOV. Zapoviédnik. Op. cit., p. 184.

${ }^{209}$ BAKHTIN, Mikhaíl. Tvórtchestvo Fransuá Rablé i naródnaia kultura Srednevekóvia i Renessansa. Moscou: EKSMO, 2014, p. 34

${ }^{210}$ Ibid., 29.

${ }^{211}$ DOVLÁTOV, S. Uróki tchtiénia. São Petersburgo: Ázbuka, 2012, p. 35.

${ }^{212}$ DOVLÁTOV. Zapisnýe kníjki. Op. cit., p. 130.
} 
Serguei Dovlátov: texto de cultura na literatura russa contemporânea contadas de forma oral. De certa forma, isso corresponde à natureza do conto, forma narrativa milenar, que inicialmente provém justamente da tradição oral de se contar histórias (o que sugere o próprio termo tanto em português quanto em outras línguas de origem latina, ou como em russo: a palavra é rasskaz, e tem a mesma raíz que o verbo rasskázyvat, “contar, relatar”).

Cabe mencionar que todas as pessoas que conheciam Dovlátov pessoalmente também destacavam tal sua habilidade, afirmando que, quando Dovlátov começava a contar algo, ninguém podia não prestar atenção, o público permanecia fascinado até o escritor terminar a história. ${ }^{213}$

O gênero oral de anekdot e o estilo lacônico contribuíam para a aparente oralidade dos textos do escritor e para a facilidade para relatar oralmente as histórias escritas por Dovlátov. Tal oralidade levou à folclorização de seus textos, que de certa maneira perderam seu autor. A penetração da sua obra no folclore urbano russo constitui outra faceta do "mito dovlatoviano". Assim, muitas de suas expressões, piadas e jogos verbais saíram dos livros e passaram a ser contadas oralmente. Empregando as expressões e piadas do escritor, muitas vezes as pessoas nem sabem que a história ou a expressão é de sua autoria.

Podemos citar como exemplo uma frase de Parque cultural, famosa já "por conta própria”, sem ter vínculo com o nome de seu autor: Kak khorochó chto Púchkin étovo ne vídit (“Que bom que Púchkin não está vendo isso”). ${ }^{214}$ A citação já perdeu a autoria para muitas pessoas que a empregam, e faz parte do folclore moderno. A frase até ganhou uma ilustração (vendem-se camisetas com a imagem), na qual o slogan vem acompanhado de imagem do poeta Púchkin tapando os próprios olhos.

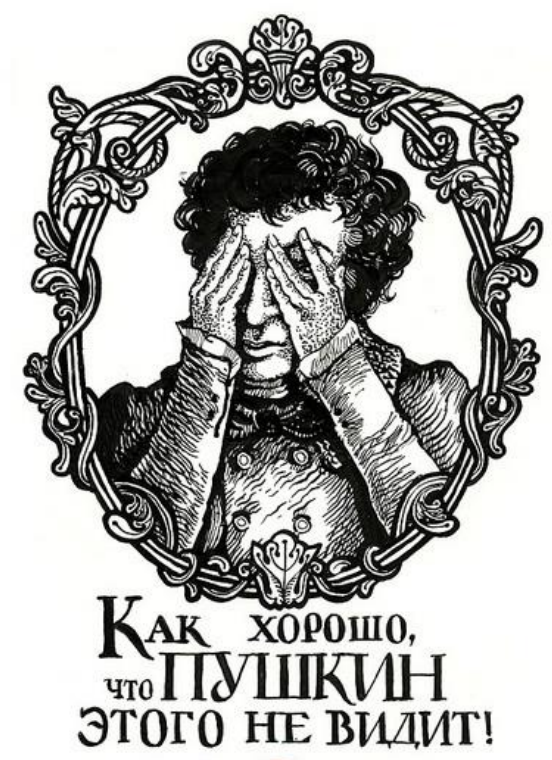

"Que bom que Púchkin não está vendo isso!"

\footnotetext{
${ }^{213}$ KOVÁLOVA. Op. cit., p. 112.

${ }^{214}$ DOVLÁTOV. Zapoviédnik. Op. cit., p. 184.
} 
Como exemplo de outras frases curtas e graciosas do escritor que entraram no folclore moderno, podemos citar as seguintes:

Toská, $i$ vypit niétchevo. - "Uma tristeza, e não tem nada para beber". É a frase da personagem Chlippenbákh (como sempre, construída com base no protótipo real: o jornalista leningradense Nikolai Chlippenbákh era amigo do escritor), do romance A mala. O tema do álcool é muito presente em toda obra de Dovlátov, e revela a postura de muitos (para não dizer da maioria) de suas personagens, para quem a harmonização com o mundo real pode acontecer apenas com ajuda de bebida alcoólica.

Mnie stalo protivno, i iá uchol. Verniée, ostálsia. - "Senti nojo e fui embora. Ou melhor, fiquei." A frase do protagonista do livro A troca serve como exemplo de um dos procedimentos poéticos próprios de Dovlátov: uso de construções alógicas, absurdas, para obter efeito cômico. O papel do absurdo é um tema de especial importância na obra do escritor.

Otmorózil páltsy nog i úchi golovy. - "Gelei os dedos dos pés e as orelhas da cabeça”. A frase do conto Tchirkóv e Berendiéev (em russo, Tchirkóv i Berendiéev) serve como exemplo irônico do quanto algumas pessoas não dominam o estilo da língua russa. O próprio escritor, conhecido por seu purismo literário, sempre foi implacável em relação a pessoas que pretendiam trabalhar com literatura, mas não dominavam a língua russa e cometiam erros estilísticos desse tipo no processo de escrita.

Iá pissátel, bliá, tipa Tchékhova. - "Sou escritor, porra, tipo Tchékhov”. A frase da personagem do literato Stássik Potótski, da novela Parque cultural, como a própria personagem em geral, descreve a postura do escritor em relação a muitos representantes da literatura oficial soviética, autores de livros ideológicos e propagandistas. Aqui, o efeito cômico é conseguido no contraste entre o nome do clássico de literatura russa, Anton Tchékhov, e o léxico obsceno, assim como a própria construção da frase, que emprega a personagem.

\section{A obra de Serguei Dovlátov: tradição e modernidade}

Dovlátov foi contemporâneo de escritores pós-modernistas, e em sua obra críticos e pesquisadores veem elementos do pós-modernismo. Como sustenta o teórico literário Mark Lipoviétski, em sua obra Dovlátov leva traços de duas correntes literárias: do neorrealismo filosófico e do pós-modernismo. Segundo o pesquisador, a prosa do escritor "evidentemente se radica na tradição realista, mas com a mesma evidência leva em conta a experiência da arte pós- 
Serguei Dovlátov: texto de cultura na literatura russa contemporânea modernista". 215 Assim, podemos distinguir os seguintes traços pós-modernistas na poética de Dovlátov: o deslocamento, fusão das categorias de autor e personagem como resultado das raízes autobiográficas de sua prosa (já que o protagonista da obra de Dovlátov leva fortes traços autobiográficos, porém é personagem de ficção); o caráter intertextual de sua obra (nela abundam tanto alusões e referências à obra de outros autores como autocitações e referências a seus próprios textos); o absurdo, o caos da existência humana como um dos temas recorrentes e focos de atenção no pensamento do autor.

A natureza autobiográfica e ao mesmo tempo ficcional da criação de Dovlátov, o conceito do "eu" autobiográfico e a problematização da identidade do autor e seu herói, remetem-nos à concepção pós-modernista da crise da categoria do "autor", estudada sobretudo por Roland Barthes. No seu artigo A morte do autor, Barthes analisa a evolução do conceito de autor e sua relação com as personagens e a eliminação dessa categoria na textologia pósmodernista, que passa a ser substituída pela categoria de scriptor, "que nasce no momento da criação do texto e não tem nenhuma existência antes ou fora da escrita". ${ }^{216}$

Na maioria dos textos de Dovlátov, chega a ser impossível separar a figura do autor e a figura do protagonista, já que, além de ser escrita em primeira pessoa (ou seja, no texto não há a figura do "autor-narrador", toda a história é dada pelo prisma de sua personagem principal), a narrativa nasce da própria vida do seu autor, transformada em ficção, e, como foi demonstrado no primeiro capítulo, as raízes documentais de sua prosa põem-se no centro de sua criação, sendo a sua base efetiva. Isso às vezes até confunde os leitores e os faz acreditarem no documentalismo da prosa de Dovlátov. Tal condição torna impossível a interpretação do texto em categorias tradicionais de "autor" / "personagem".

Por outro lado, a história do herói autobiográfico dovlatoviano narrada nos livros do escritor vem apresentada em uma sequência lógica e cronológica, de modo a formar um texto íntegro, ao mesmo tempo em que seu caráter "intertextual" corresponde a outra característica importante da poética pós-modernista, abarcada pelo conceito de intertextualidade, introduzido por Julia Kristeva, filósofa e teórica literária búlgaro-francesa. Analisando o conceito, a pesquisadora sustenta a ideia de que "qualquer texto se constrói como um mosaico de citações, qualquer texto é uma absorção, transformação de outro texto". ${ }^{217}$

Além de poderem ser vistos como partes integrantes ou "representações" de um texto íntegro da obra de Dovlátov, seus textos em muitos casos também remetem o leitor a textos de

\footnotetext{
215 LIPOVIÉTSKI, Mark. Rússki postmodernism (Ótcherki istorítcheskoi poétiki). Ekaterinburgo: Ural. Gos. Ped. Un-t., 1997, p. 312.

216 BARTHES, Roland. "Smiert ávtora”. IN: Ízbrannye. rabóty: Semiótika. Poétika. Moscou: Progress, 1989.

217 KRISTEVA, Julia. "Bakhtin, slovo, dialog i roman”. IN: Frantsúzskaia semiótica: Ot strukturalizma $k$ poststrukturalízmu. Moscou: IG Progress, 2000, p. 429.
} 
Serguei Dovlátov: texto de cultura na literatura russa contemporânea outros escritores. Assim, podemos dizer que Parque cultural representa uma interpretação do texto puchkiniano. ${ }^{218} \mathrm{Na}$ novela, há alusões e referências à obra, à figura e à biografia de Púchkin em diferentes níveis, tanto no nível da narrativa (no texto há várias alusões a textos e personagens da obra de Púchkin, citações de sua obra, etc.), como no nível da poética e da linguagem: como visto acima, Dovlátov introduz fragmentos de prosa ritmizada como tributo ao legado poético de Púchkin.

Além do mais, como dito, o escritor frequentemente citava os próprios textos. Assim como palavras isoladas, as frases, expressões, comparações e metáforas que o escritor considerava acertadas, e que, na opinião de Dovlátov, possuíam um ritmo interessante, apareciam em vários textos, tanto em obra artística como em textos críticos e jornalísticos. Por exemplo, caracterizando o estilo do jornal Nóvoe russkoe slovo no conto A marcha dos solitários (em russo, March odinókikh), o escritor usa a mesma expressão que está no livro $O$ ofício. No fragmento, mudam-se apenas os nomes dos escritores:

\begin{tabular}{|c|c|}
\hline A marchados solitários & O ofício \\
\hline $\begin{array}{c}\text { Nóvoe rússkoe slovo empregava a } \\
\text { língua na qual falavam lacaios na obra de Értel } \\
\text { e Zlatovrátski. }\end{array}$ & $\begin{array}{c}\text { Numa língua assim falavam lacaios na } \\
\text { obra de Gógol e Dostoiévski. }\end{array}$ \\
\hline
\end{tabular}

Da mesma forma, mas um pouco modificada, a expressão "o seu aspecto perturba a harmonia (atmosfera) deste lugar" é empregada no texto de Parque cultural e também no texto do romance $A$ mala.

\begin{tabular}{|c|c|}
\hline A mala & Parque cultural \\
\hline Lembro como o diretor do parque & O capitão de polícia Chatkó, ao \\
museu Púchkin me dizia: & encontrá-lo, dizia em tom de reprovação: \\
- A sua calça, camarada Dovlátov, & "Potótski, seu aspecto perturba a \\
perturba a atmosfera festiva deste lugar... & harmonia deste lugar..."222 \\
\hline
\end{tabular}

\footnotetext{
${ }^{218}$ Aqui compreendemos o termo texto sob o viés da semiótica da cultura, ou seja, como um sistema sígnico estruturado "que guarda diferentes códigos e é capaz de transformar as mensagens recebidas e gerar novas mensagens, um gerador de informação que possui traços de uma personalidade intelectual" (LÓTMAN. Op. cit., p. 162). Usando o termo "texto puchkiniano" (em russo, púchkinski tiekst, o termo foi empregado por primeira vez por B. Gaspárov), referimo-nos não apenas à biografia e obra de Púchkin, mas também ao como seu legado gravou-se na memória cultural, às interpretações de seu mito como símbolo da cultura russa.

${ }^{219}$ DOVLÁTOV. March odinókikh. Op. cit.

${ }^{220}$ DOVLÁTOV. Remesló. Op. cit., p. 111.

${ }^{221}$ DOVLÁTOV. Tchemodán. Op. cit., p. 303.

${ }^{222}$ DOVLÁTOV. Zapoviédnik. Op. cit., p. 213.
} 
Serguei Dovlátov: texto de cultura na literatura russa contemporânea

Da mesma forma, a expressão “isso é mais forte do que Fausto de Goethe” é encontrada no texto de A zona, pronunciada por um dos presos, no campo de prisão, e de Parque cultural, no monólogo do major da KGB Beliáiev:

\begin{tabular}{|l|l|}
\hline \multicolumn{1}{|c|}{ A zona } & \multicolumn{1}{c|}{ Parque cultural } \\
\hline $\begin{array}{l}\text { voltar? Em um ano, cinco meses e dezesseis } \\
\text { dias? }\end{array}$ & $\begin{array}{l}\text { Os órgãos educam, educam, mas } \\
\text { também, por uma besteira, podem castigar. E o } \\
\text { seu dossiê é mais forte do que Fausto de } \\
\text { ser mais forte do que Fausto de Goethe. }\end{array}$ \\
\hline
\end{tabular}

É importante comentar essa frase, usada por Dovlátov: a expressão não foi inventada pelo escritor, e inicialmente foi pronunciada por Ióssif Stálin, em reação ao conto de Maksim Górki $A$ moça e a morte (em russo, Diévuchka i smiert, de 1892). Como assinala o Dicionário on-line de locuções proverbiais (Slovar krylátykh slov i vyrajénii), em 1931 Górki leu o conto para o líder do partido em sua casa, e após a leitura Stálin pediu o livro do qual fora lido o texto, e na última página escreveu: "Essa coisa é mais forte do que Fausto de Goethe". ${ }^{225}$ É curioso e irônico que, se no primeiro texto a frase é atribuída a um preso, em Parque cultural quem usa a expressão é o major da KGB.

O caos e alogismo do mundo como objeto de ironia e piada representam outro traço pósmodernista da poética de Dovlátov. Assim, o absurdo em sua obra, abordado de uma forma lúdica, aparece como a lei do funcionamento do universo.

Um dos problemas centrais da obra de Dovlátov é a antinomia "norma - absurdo", que "forma o eixo de seus textos", nas palavras dos pesquisadores da obra de Dovlátov Nina Orlova e Aleksándr Petrienko. ${ }^{226}$ A oposição entre o normal e o absurdo, porém, não possui polos definidos, já que a "norma" e a "antinorma” podem ser percebidas e avaliadas pelas personagens de maneiras opostas. Assim, aquilo que é visto como norma pela maioria das personagens (e que até pode ser sustentado em nível oficial pela ideologia oficial), frequentemente representa uma ausência total de lógica e o protagonista que em muitas ocasiões tenta abordar a vida desde os princípios de bom senso é visto por outras personagens como um outsider tolo, por não apoiar o absurdo ao seu redor.

\footnotetext{
${ }^{223}$ DOVLÁTOV. Zona. Op. cit., p. 25.

${ }^{224}$ DOVLÁTOV. Zapoviédnik. Op. cit., p. 273.

$225 \mathrm{O}$ artigo dedicado a essa expressão é disponível na página web do Dicionário: http://dic.academic.ru/dic.nsf/dic_wingwords/3501/\%D0\%AD\%D1\%82\%D0\%B0

226 ORLOVA, Nina, Petrienko, Aleksándr. Semiotítcheskie e folklórnye modéli smekhovovo mira Serguiéia Dovlátova. Piatigorsk: PGLU, 2011, p. 22.
} 
Serguei Dovlátov: texto de cultura na literatura russa contemporânea

Em Parque cultural, "a norma oficial”, que é o âmbito do parque museu, constantemente choca o leitor com o absurdo e a falta de bom senso reinantes ali, o que se reflete tanto em pequenos detalhes (como o retrato de Púchkin embaixo da placa "Inflamável”, ou a brochura $A$ pérola da Crimeia na agência turística de Mikháilovskoe), como nas conversas entre as personagens. Assim, aos funcionários parece-lhes normal e natural que o retrato representado no museu como o retrato do bisavô de Púchkin seja retrato de outra pessoa. No entanto, quando o protagonista tenta explicar as razões do seu amor por Púchkin, ligando-o à inovação e importância de Púchkin no contexto da literatura russa, a personagem da metodologista não vê nenhuma lógica em suas frases, já que, para ela, a única resposta aceitável é que Púchkin "não é apenas um grande poeta, mas também um grande cidadão". 227 Tal fusão dos conceitos de norma e antinorma destróem o sistema sígnico estabelecido e gera caos, o que é expresso nas seguintes palavras da personagem principal de Parque cultural: "Caminhava e pensava: o mundo está dominado pela loucura. A loucura tornou-se norma. E a norma provoca a sensação de milagre".228

$\mathrm{Na}$ postura de comprender o mundo como caos e dialogar com esse caos vemos um dos principais postulados da filosofia pós-modernista, "o mundo como caos", desenvolvido nos trabalhos de Gilles Deleuze, Felix Guattari e Jaques Derrida, entre outros. Nesse sentido, um dos livros de Dovlátov que melhor reflete a ideia do absurdo da existência e a filosofia pósmodernista de relatividade dos critérios axiológicos é o romance $A$ zona, no qual o fenômeno da corrente literária da prosa de prisão é abordado sob o ângulo pós-modernista, com uma total fusão de fronteiras e critérios entre o bom e o mau, e entre a liberdade (no sentido mais amplo, filosófico da palavra) e a prisão (no sentido existencial também). Assim, uma das características importantes das personagens dessa novela é a sua ambivalência.

Ao longo da narrativa, mostra-se em várias ocasiões que entre o mundo dos presos e dos carcereiros (ou, no sentido mais amplo, das pessoas livres) há muito pouca diferença: em várias situações ao longo do romance os prisioneiros e os soldados trocam de lugar. Às vezes, isso acontece no sentido metafórico: no romance há uma cena na qual os soldados cometem um estupro coletivo; outro capítulo é dedicado à história de um preso que se apaixona e escreve cartas românticas ao objeto de seu amor. E num dos capítulos acontece uma troca "literal" das personagens: nela, um guarda de escolta tem uma crise nervosa, e o prisioneiro leva-o até o hospital. Nessa relatividade dos critérios axiológicos, na problematização da questão da

\footnotetext{
${ }^{227}$ DOVLÁTOV. Zapoviédnik. Op. cit., p. 192.
}

228 Ibid., p. 273. 
Serguei Dovlátov: texto de cultura na literatura russa contemporânea

liberdade interior, os pesquisadores também veem os traços de filosofia pós-modernista de Dovlátov. ${ }^{229}$

Se pensarmos em suas raízes literárias, o próprio Dovlátov reconhecia a marca de vários escritores em sua obra. Assim, por exemplo, o escritor dizia que, no começo da carreira literária, as suas referências estéticas e éticas foram escritores norte-americanos como Ernest Hemingway, Sherwood Anderson e William Faulkner. Esses escritores, muito populares na União Soviética na época, foram ídolos da juventude soviética dos anos 1960. O amor por sua literatura era declarado por muitos representantes de chestidessiátniki e também pelas gerações de escritores posteriores.

Dovlátov confessava que, para ele, a estética lacônica dos escritores americanos do séc. $\mathrm{XX}$ e o os seus pressupostos éticos eram-lhe mais próximos do que a estética dos clássicos russos do século XIX:

Quando éramos jovens e estudávamos na Universidade de Leningrado, éramos viciados na literatura norte-americana, cujas qualidades eram, em primeiro lugar, a precisão, o laconismo, o humor e a expressividade na descrição da vida cotidiana. Quando líamos Turguêniev, sempre era difícil para nós imaginar se o seu protagonista podia ou não atravessar nadando um lago. Quando você lê a prosa norte-americana, sempre está mais ou menos claro o que uma ou outra pessoa é capaz de fazer. Esta literatura era terrena, isso quer dizer que era breve, engraçada, inteligente e prática. E quando digo "breve", não me refiro ao tamanho do livro, mas à concordância entre a quantidade de dramaticidade e a de palavras escritas. ${ }^{230}$

Nesse fragmento da entrevista de Dovlátov, podemos observar os postulados e objetivos literários que o próprio escritor sempre manteve em sua prosa, como a brevidade, a concisão, e mesmo a comicidade.

Na emigração, o sucesso da obra de Dovlátov provocou os primeiros estudos e discussões sobre suas origens literárias. No artigo Sobre Serioja Dovlátov, Joseph Brodsky levanta a questão do lugar de Dovlátov no contexto da tradição da literatura russa. Para Brodsky, Serguei Dovlátov não seguia os clássicos da literatura russa em sua obra: "a imagem da pessoa que surge de seus contos é uma imagem que não coincide com a tradição literária russa", afirmava o poeta. ${ }^{231}$ Brodsky sustenta que Dovlátov tendia muito mais à literatura ocidental, principalmente

\footnotetext{
${ }^{229}$ LIPOVÉTSKI. Op. cit., p. 315.

${ }^{230}$ Fragmento de vídeo-entrevista com S. Dovlátov, feita em Nova Iorque, em janeiro de 1989.

A entrevista está disponível em: https://vk.com/video-68171501_170525328

${ }^{231}$ BRODSKY. Op. cit., p. 299.
} 
Serguei Dovlátov: texto de cultura na literatura russa contemporânea norte-americana, o que, em sua opinião, também ajudara no sucesso de Dovlátov entre os leitores dos Estados Unidos. ${ }^{232}$

Esse ponto de vista é apoiado também pelos críticos literários, colegas de Dovlátov no jornal Nóvyi amerikánets, Piotr Vail e Aleksándr Guénis. Assim, analisando a poética e o estilo de Dovlátov, os dois observam o estilo ocidentalista de sua prosa e sua técnica de construção de personagens como mais próximos à literatura norte-americana. ${ }^{233}$ Como outro argumento a favor dessa teoria também deve-se mencionar o fato de que Serguei Dovlátov sempre admirou e mesmo se considerou influenciado pela obra dos prosadores americanos Sh. Anderson, W. Faulkner e E. Hemingway, entre outros.

De fato, Dovlátov frequentemente faz referências a esses escritores americanos tanto em seus textos jornalísticos e críticos como em sua obra artística. Nas páginas de seus Cadernos de anotações (tanto em Um solo na Underwood como em Um solo no IBM), há aforismos que elogiam a prosa de Faulkner ("Um mistério de Faulkner. Uma mistura de eloquência e reticência”), ${ }^{234}$ reflexões sobre a prosa de Salinger, ${ }^{235}$ entre outros.

Ernest Hemingway, ídolo dos jovens soviéticos dos anos 1960, merece uma atenção especial, pois referências, alusões à personalidade e à obra do escritor aparecem em vários textos dovlatovianos. Em Parque cultural, o nome do escritor é mencionado várias vezes. Assim, o protagonista tem no seu quarto além do violão e a máquina de escrever, o retrato de Hemingway, que serve como um sinal de que o protagonista pertence ao âmbito boêmio e artístico:

Tinha um apartamento com janelas que davam para um lixão. Uma escrivaninha, um sofá, uns halteres, uma radiola Tonus. (Tonus é um bom sobrenome para um gerente de mercearia.) Uma máquina de escrever, um violão, um retrato de Hemingway, alguns cachimbos num copo de cerâmica. ${ }^{236}$

Ao mesmo tempo, a personagem de Tânia, mulher de Alikhánov, compara ironicamente o talento do marido com o de Hemingway: "E você leva uma vida de escritor famoso sem a menor condição para isso. Com seus vícios, deveria ser, no mínimo, um Hemingway”. 237

Como aponta Sukhikh, a influência de Hemingway na obra de Dovlátov é sentida principalmente em seus primeiros textos: “Com Hemingway, como se diz, aprendiam a escrever.

\footnotetext{
232 Ibid., p. 300.

${ }^{233}$ VAIL, Piotr. "Bez Dovlátova”. IN: Maloizvéstnyi Dovlátov: Sbórnik. São Petersburgo: AOZT “Jurnal Zviezdá”, 1996, p. 453.

${ }^{234}$ DOVLÁTOV. Zapisnýe kníjki. Op. cit., p. 127.

235 Ibid., p. 136.

${ }^{236}$ DOVLÁTOV. Zapoviédnik. Op. cit., p. 222.

${ }^{237}$ Ibid., p. 178.
} 
Serguei Dovlátov: texto de cultura na literatura russa contemporânea Os traços evidentes dessa aprendizagem tem também Dovlátov". ${ }^{238}$ Assim, falando do texto do romance $A$ zona, Sukhikh vê semelhanças com Hemingway nas alternâncias de cenas cruéis com fragmentos líricos, assim como no próprio estilo e ritmo "sincópico" da narração. ${ }^{239}$ Contudo, o pesquisador aponta para uma peculiaridade dessa "aprendizagem com Hemingway": nos anos 1960 Dovlátov, como outros escritores soviéticos contemporâneos influenciados pelo autor norte-americano, conhecia a obra de Hemingway apenas em russo, na tradução dos tradutores russos dos anos 1930, em cujo trabalho se sentia fortemente a influência da tradição clássica russa. Na opinião de Sukhikh, os tradutores deixaram marcas dessa tradição também em suas traduções. Isso se refere à obra de todos os escritores ocidentais que eram disponíveis na época apenas em tradução, e que com certeza continham marcas estilísticas "adicionadas" pelos tradutores.

Outro escritor ocidental, cujo nome é impossível deixar de mencionar se analisa a prosa dovlatoviana, é Franz Kafka. O absurdo kafkiano, os procedimentos que usa o escritor tcheco na criação do mundo artístico repleto de absurdo em seus textos, são próximos do método artístico de Dovlátov. Como foi visto acima, o tema do absurdo, em contraposição à norma, é um dos leitmotifs de muitos textos dovlatovianos. Neles, seguindo o modelo da obra de Kafka, o protagonista enfrenta o tempo todo situações de absurdo na vida, no sistema político e social, vistas por pessoas ao seu redor como algo normal, o que faz o protagonista chegar a duvidar de sua própria saúde mental.

O nome de Kafka também aparece nos textos e aforismos de Dovlátov, como num deles, dificilmente traduzível para o português, que justamente faz alusão a situações absurdas das narrativas kafkianas, tão presentes na vida soviética: My rojdieny, tchtob Káfku sdiélat byliu (literalmente, "Nascemos para tornar Kafka realidade"). ${ }^{240}$ Aqui, o escritor brinca com a sonoridade parecida em russo das palavras "Kafka" e skazka, "conto maravilhoso". É curioso que a frase com a qual se faz o trocadilho, My rojdeny chtob skázku sdiélat byliu, é linha da canção March aviátorov (“A marcha dos aviadores”), escrita nos anos 1920 e que, glorificando o novo mundo soviético, tornou-se popular nos anos 1930, em plena época stalinista. ${ }^{241}$

No entanto, apesar de Kafka marcar a obra de Dovlátov, é importante salientar uma profunda diferença na criação do escritor tcheco e na de Dovlátov: se o mundo de Kafka é um pesadelo que provoca no leitor uma sensação de horror e angústia, na obra de Dovlátov as

\footnotetext{
${ }^{238}$ SUKHIKH. Serguei Dovlátov. Vriémia, miesto, sudbá. Op. cit., p. 96.

${ }^{239}$ Ibid.

${ }^{240}$ DOVLÁTOV, S. Zapíski tchinóvnika. IN: Siem dniei. Nova York, 1984, № 47, p. 14.

241 Svetlana Boym, em seu livro Common places: mythologies of everyday in Russia, relata outro fato curioso relacionado com essa marcha: em 1933 a canção foi traduzida para o alemão, cantada pelos comunistas alemães, e mais tarde, com a sua melodia cativante, também foi adaptada pelos nazistas, sob o nome Herbei zum Kampf (BOYM, Svetlana. Common Places. Mythologies of Everyday Life in Russia. Cambridge: Harvard University Press, 1994, p. 111).
} 
Serguei Dovlátov: texto de cultura na literatura russa contemporânea situações de absurdo provocam riso em seus leitores. Isso tem a ver com o caráter universal do humor dovlatoviano: na prosa de Dovlátov, o mundo ao redor é dado sob o ângulo lúdico, cômico, e com tal visão está relacionada a comicidade das colisões no enredo, das situações nas quais se veem as personagens, e o caráter ridículo dos diálogos.

Vejamos como exemplo de "absurdo cômico" da prosa dovlatoviana a cena de Parque cultural, na qual o protagonista Boris Alikhánov tem uma conversa com o major da KGB local, que, no decorrer da conversa e depois de tomar algumas doses, passa a desenvolver opiniões dissidentes. Poderíamos comparar essa cena e o grau de seu absurdo com as cenas de Processo de Kafka; no entanto, a comicidade do texto de Dovlátov confere à narrativa um tom totalmente diferente:

Vi um cofre, o retrato de Dzerjínski, ${ }^{242}$ cortinas marrons. (...)

Sentei-me na poltrona, tirei um cigarro. (...) Saiu um homem de uns trinta e seis anos e deu-me uma baita reprimenda:

- Por acaso sugeri que sentasse?

Levantei-me.

- Sente-se.

Sentei-me.

O homem declarou ainda mais contrariado:

- Por acaso sugeri que fumasse?

Movi-me na direção do cesto de lixo, mas logo ouvi:

- Fume...

Em seguida, ele sentou-se e fixou em mim um olhar longo, triste, quase trágico. Seu sorriso expressava a imperfeição do mundo e o pesado fardo da responsabilidade pelos pecados alheios. No entanto, o rosto permanecia medíocre, como o botão de uma cueca.

$\mathrm{O}$ retrato sobre sua cabeça parecia mais animado. (Apenas no meio da conversa compreendi que não era Dzerjínski, mas Makárenko. $\left.{ }^{243}\right)^{244}$

Ao longo da conversa com fins supostamente educativos, o pathos ideológico do major Beliáiev muda para o oposto, e o kgbista começa a refletir sobre a situação política no país e as possibilidades de emigração.

O humor, nesse caso, elimina a sensação de horror, harmonizando assim a personagem, o leitor e a realidade na qual estes vivem. Os procedimentos que envolviam riso, por meio da carnavalização da vida ao redor, como um meio de harmonização com a realidade, foram estudados por Mikhaíl Bakhtin, no seu trabalho Cultura popular na Idade Média e no Renascimento no contexto de François Rabelais. ${ }^{245}$ Nele, o filósofo analisa o papel do riso e do lúdico na Idade Média (e as suas transformações na época do Renascimento), apontando a

${ }^{242}$ Félix Dzerjínski (1877 - 1926), fundador da Tcheká.

${ }^{243}$ Anton Makárenko (1888 - 1939), pedagogo e escritor soviético.

${ }^{244}$ DOVLÁTOV. Zapoviédnik. Op. cit., p. 270 - 271.

${ }^{245}$ BAKHTIN. Op. cit., p. 23. 
Serguei Dovlátov: texto de cultura na literatura russa contemporânea harmonização com a realidade como uma de suas principais funções. Bakhtin sublinha o caráter ambivalente do riso que, "alegre, jubiloso e, ao mesmo tempo zombeteiro, jocoso, tanto nega como afirma; tanto enterra como ressuscita". ${ }^{246}$ Podemos observar tal função "positiva" do humor na percepção do mundo na obra de Dovlátov.

A partir do ponto de vista da prosa de Dovlátov como produto de seu diálogo com a literatura ocidental, nos estudos sobre sua vida e sua obra, principalmente no âmbito de crítica literária na emigração, surgiu uma opinião que sustentava a ideia de que, em sua obra, o autor rompera com a tradição literária russa. ${ }^{247}$ Porém, como prova a pesquisa da pesquisadora da obra de Dovlátov, Galina Dobrozrákova, a posição de Dovlátov como escritor da tradição ocidental tinha mais relação com a postura política e as opiniões da geração dos dissidentes em geral do que, de fato, com o estilo do escritor. ${ }^{248}$

Como prova disso ressalta-se o fato de que o próprio Dovlátov sempre se autodefiniu como um escritor russo, e os estudos de vários pesquisadores, tanto na Rússia quanto no exterior, entre eles, Igor Sukhikh, Galina Dobrozrákova, Janna Motýguina, Jekaterina Young, Natália Pakhómova, Igor Kargáchin demonstraram uma estreita relação entre a obra do escritor e a tradição literária realista russa, com a qual ele dialoga, relendo textos de seus maiores clássicos ao longo da toda sua trajetória literária, o que torna impossível excluí-lo do contexto dessa tradição. Os objetos de reflexão e de criação de Dovlátov são, principalmente, clássicos russos como Púchkin, Dostoiévski, Tchékhov, Zóschenko, entre outros, aos quais apela em muitos de seus textos, para não dizer na maioria.

A zona, que Dovlátov começara a escrever ainda nos anos 1960 e no qual relata e recria sua própria experiência de trabalho como guarda de segurança em uma prisão soviética durante seu serviço no exército, os pesquisadores veem alusões à obra de Fiódor Dostoiévski (1821 1881), mais especificamente a Recordações da casa dos mortos ${ }^{249}$ (em russo, Zapíski iz miórtvovo doma). ${ }^{250} \mathrm{Em}$ A zona, Dovlátov faz várias referências a Recordações da casa dos mortos, que se revelam tanto na composição da narrativa quanto na construção de personagens.

\footnotetext{
246 Ibid., p. 21.

247 DOBROZRÁKOVA, Galina. "Tvórtchestvo S. Dovlátova v kontiekste tradítsii rússkoi literatúry (obzor issliédovanii)”. IN: Izviéstia Samárskovo naútchnovo tsentra Rossíiskoi akadiémii naúk. Samara, v. 11, № 4 (6), 2009, p. 1533.

248 Ibid., p. 1534.

${ }^{249}$ Nesse trabalho usamos o título como tem sido publicado tradicionalmente no Brasil, no entanto é importante mencionar que a tradução do russo mais adequada seria "Recordações (ou cadernos) da casa morta". A metáfora da casa morta é muito importante para o romance, justamente porque, como demonstra o escritor, os que habitam esta casa morta são pessoas vivas, entre as quais há todo tipo de caracteres, de santos a pecadores, e é a casa que pode destruir personalidades mais frágeis, mortificando-os.

${ }^{250}$ SUKHIKH. Serguei Dovlátov. Vriémia, miesto, sudbá. Op. cit., p. 107.
} 
Serguei Dovlátov: texto de cultura na literatura russa contemporânea

Como no romance de Dostoiévski, na composição de A zona há capítulos dedicados aos hábitos dos prisioneiros, ao hospital da prisão, à fuga e até a uma cena de apresentação teatral.

O capítulo que retrata a apresentação teatral é um dos mais expressivos do romance. Esse fragmento encerra o livro (depois dele, há um epílogo) e faz uma alusão clara ao capítulo homônimo de Recordações da casa dos mortos. No entanto, à diferença de Dostoiévski, Dovlátov atribui à cena um tom totalmente diferente: se no livro de Dostoiévski se trata de uma experiência séria, catártica e até purificadora para os presos, tanto para os que estão no palco como para o público, em seu livro Dovlátov constrói uma imagem irônica e grotesca: os presos de $A$ zona montam uma apresentação teatral sobre a vida de Lênin que acaba sendo sabotada, pois durante o discurso final de Lênin, ideológico e otimista, os presos não conseguem conter o riso:

Finalmente Vladímir Ilitch ${ }^{251}$ deu um passo ao microfone. Permaneceu calado alguns segundos. Depois seu rosto encheu-se da luz da previsão histórica.

— Quem são estes?! exclamou Gúrin. Quem são?!

Da escuridão olhavam para o líder caras magras e pálidas.

- Quem são? De quem são estes rostos jovens e felizes? De quem são estes olhos brilhantes e alegres? Será que esses são os jovens dos anos setenta? (...) Será que são aqueles em nome de quem nós erguíamos barricadas? Será que são os belos netos da revolução?

Primeiro começaram a dar risadas inseguras na primeira fila. Em um segundo momento, todo mundo já estava dando gargalhadas. No coro comum ouvia-se a voz grave do major Amóssov. (...)

- Invejo-os, mensageiros do futuro! Foi para vocês que acendemos as primeiras luzes dos novos edifícios! Foi para vocês que... Escutem até o fim, seus cães! Só falta uma titica de nada!..

A sala respondeu a Gúrin com um uivo terrível que não diminuía. ${ }^{252}$

Assim, a imagem do líder soviético e o pathos de seu discurso acabam sendo carnavalizados tanto pelo fato de que o ator que interpretava o papel de Lênin, Gúrin, era um ladrão reincidente, quanto pelas últimas palavras, de registro totalmente coloquial, usadas por ele para chamar a atenção do público.

Cabe mencionar também que nesse texto o escritor estabelece um diálogo não apenas com o conhecido romance de Dostoiévski, mas com a tradição de prosa de prisão russa em geral, e com os seus principais representantes no século XX, Aleksandr Soljenítsyn (e seu famoso livro Um dia na vida de Ivan Deníssovitch (1962)) e Varlám Chalámov (e seus Contos de Kolymá (1967)). Como A zona saiu à luz quando os dois escritores já estavam mundialmente famosos (Soljenítsyn recebera o Prêmio Nobel em 1970), e o gênero da prosa de prisão soviética estava

\footnotetext{
${ }^{251}$ Patronímico de Vladimir Lênin.

${ }^{252}$ DOVLÁTOV. Zona. Op. cit., p. 150.
} 
Serguei Dovlátov: texto de cultura na literatura russa contemporânea no auge de popularidade, Dovlátov tentou se afastar da tradição gerada por Soljenítsyn e Chalámov e apresentar um olhar diferente para a prisão soviética. $\mathrm{O}$ escritor menciona isso em várias entrevistas e até no texto de A zona. Das diferenças de seu romance da prosa de Soljenítsyn fala-se numa das "cartas ao editor": "Nossos livros são totalmente diferentes. Soljenítsyn descreve os campos políticos. Eu, os criminosos comuns. Soljenítsyn era prisioneiro. Eu, carcereiro. Segundo Soljenítsyn, a prisão é um inferno. E eu acho que o inferno somos nós mesmos...". 253 A ideia de que o inferno está dentro de uma pessoa e não nas condições externas pelas que ela passa é um dos leitmotifs da narrativa, e em tal postura podemos ver uma interpretação pós-modernista de Dovlátov do gênero da prosa de prisão.

Outra diferença substancial do romance de Dovlátov do gênero dos livros de Soljenítsyn e Chalámov consiste na comicidade e nos elementos de humor que são próprios de toda obra do escritor. Embora $A$ zona não seja um texto humorístico (ao contrário, nele abundam cenas "pesadas" da vida na prisão), praticamente cada capítulo possui algum elemento de humor, o que atribui certa leveza à narrativa e, certamente, nisso também se diferencia a obra de Dovlátov da de seus contemporâneos que trabalhavam no gênero "prosa de prisão".

A zona é o romance no qual a presença de Dostoiévski e as referências e alusões a Recordações da casa dos mortos são as mais evidentes. No entanto, o nome de Dostoiévski e alusões a sua obra aparecem também em outros textos de Dovlátov, tanto artísticos como jornalísticos e críticos. Uma boa parte do seu artigo Esplendores e misérias da literatura russa (em russo, Bliesk i nischetá rússkoi literatúry) é dedicada a Dostoiévski, onde o escritor é chamado "um dos gigantes da literatura russa". 254

Parece-nos que a admiração e o respeito pelo escritor por Dostoiévski se expressam plenamente no seguinte fragmento de Um solo no IBM:

Cena num hospital. Estão me levando para tratamento. Sobre o meu peito está um tomo da obra de Dostoiévski. Nina Aloviert acaba de trazê-lo para mim. O médico norte-americano me pergunta:

Que livro é este?

- Dostoiévski.

- O idiota?

- Não, $O$ adolescente.

— É alguma tradição? Interessa-se o médico.

- Sim, digo, é uma tradição. Escritores russos morrem com um livro de Dostoiévski sobre peito.

$\mathrm{O}$ americano pergunta:

- No Bible?

${ }^{253}$ Ibid., p. 12.

${ }^{254}$ DOVLÁTOV, S. "Bliesk i nischetá rússkoi literatúry”. IN: Uróki tchtiénia. São Petersburgo: Ázbuka, 2012, p. 232. 
Serguei Dovlátov: texto de cultura na literatura russa contemporânea — Não, digo, precisamente com um livro de Dostoiévski. $\mathrm{O}$ americano olhou para mim com interesse. ${ }^{255}$

Pode-se venerar a inteligência de Tolstói. Admirar a elegância de Púchkin. Estimar as buscas morais de Dostoiévski. O humor de Gógol. Et cetera. No entanto, tem-se vontade de parecer apenas com Tchékhov. ${ }^{256}$

Nesse fragmento, publicado em Um solo no IBM, expressam-se as principais referências de Dovlátov e as suas orientações no campo de literatura, que o escritor chegou a manifestar em vários textos. A obra e a figura de Anton Tchékhov (1860 - 1904), junto com Aleksandr Púchkin, outro escritor que Dovlátov costumava destacar, sempre teve um papel especial na criação de Dovlátov. Referindo-se a Púchkin, o escritor afirma que o poeta, para ele, era um ideal ético e estético, já Tchékhov era a sua principal referência no fazer literário. Nele, Dovlátov valoriza não apenas o talento do escritor, mas também a sua postura ética em relação ao fazer literário e aos objetivos do escritor.

Nesse sentido, Dovlátov compartilha a postura de Boris Eikhenbaum, que, ao se referir a Tchékhov, aponta que o escritor pertencia "a outra literatura russa, que se desenvolvia fora do círculo estreito das tradições da intelligentsia (...) que não pregava nem ensinava nada, mas apenas contava sobre a vida russa de uma maneira viva e detalhada". 257

A orientação "educadora" de muitos escritores russos do século XIX era vista por Dovlátov como um ponto fraco da tradição literária russa, já que "de um fenômeno meramente estético, puramente artístico, a literatura transformava-se num manual de vida" (DOVLÁTOV, 2012: 229). ${ }^{258}$ Portanto, o escritor admirava a decisão de Tchékhov de se dedicar apenas à literatura, sem expressar suas opiniões políticas ou sociais, sua recusa das tentativas de "educar" o leitor: "Anton Pávlovitch Tchékhov foi o primeiro europeu de verdade na literatura russa, que se dedicava unicamente à criação artística e não se manchou com nenhuma extravagância ou truque político-social". ${ }^{259}$ Em sua palestra na Universidade da Carolina do Norte, transformada posteriormente no artigo, intitulado Esplendores e misérias da literatura russa, Dovlátov, ao fazer a comparação com Tchékhov, faz referência a Tolstói, Dostoiévski, Turguêniev e Gógol, escritores que, além de textos puramente artísticos, produziram textos de caráter político-social

\footnotetext{
${ }^{255}$ DOVLÁTOV. Zapisnýe kníjki. Op. cit., p. 154.

${ }^{256}$ Ibid., p. 81.

${ }^{257}$ EIKHENBAUM, Boris. “O Tchékhove”. IN: O proze. Leningrado: Khudójestvennaia literatura. Leningrádskoe otdelenie, 1969 , p. 358.

${ }^{258}$ DOVLÁTOV. "Bliesk i nischetá rússkoi literatúry”. Op. cit., p. 229.

${ }^{259}$ Ibid., p. 233.
} 
Serguei Dovlátov: texto de cultura na literatura russa contemporânea ou filosófico e religioso, que refletiam suas buscas. Segundo Dovlátov, esses escritores "em certa medida tornaram-se vítimas das tentativas desenfreadas de expressar-se na esfera política, social e religiosa de vida". ${ }^{260}$ Dovlátov sublinhava a diferença de Tchékhov nesse aspecto, o seu silêncio quanto a certos temas e a ausência do julgamento moral em sua obra em geral, assinalando, inclusive, que tal postura provocara a incompreensão de muitos contemporâneos, e vários críticos "que provinham da escola de Belínski, Tchernychévski e Dobroliúbov (...) acusavam-no de cinismo, crueldade e indiferença aos sofrimentos do povo". ${ }^{261}$

No caso de Tchékhov, a "ausência da opinião", de simpatia ou antipatia do autor em relação às personagens, foi um procedimento consciente. $\mathrm{O}$ próprio escritor, numa das cartas a seu editor Aleksei Suvórin, explicava tal postura da seguinte maneira: "Quando escrevo, eu confio inteiramente no leitor, supondo que ele mesmo acrescentará os elementos subjetivos que faltam ao conto". ${ }^{262}$ Tal princípio foi denominado pelos pesquisadores da obra de Tchékhov como "o princípio da forma objetiva da narrativa" (em russo, príntsip ob'ektívnoi fórmy povestvovánia), ${ }^{263}$ que consistia em evitar uma opinião explícita ou julgamento por parte do autor em relação a personagens, objetos ou situação descritos. Com esse princípio está relacionado o laconismo do escritor e a brevidade de seus textos, já que neles muitos significados permanecem implícitos, "entre linhas", e a opinião do leitor forma-se com base nos reflexos de vários pontos de vista dados pelo prisma das personagens. A interpretação se forma, em suma, "através de sentido oculto (em russo, podtiékst) e de várias ligações intertextuais". ${ }^{264}$

Além das semelhanças na postura ética dos dois escritores, os traços da poética tchekhoviana são reconhecíveis na obra de Dovlátov, tanto na composição de seus textos, como nos procedimentos artísticos e humorísticos. A marca de Tchékhov é sentida já na forma com que trabalhou Dovlátov: como Tchékhov, o escritor sempre trabalhou principalmente com formas curtas, dando uma atenção especial ao gênero anekdot, analisado acima. Cabe mencionar, a propósito, que até o começo do século XX Tchékhov era visto como um escritor secundário, submetido a várias críticas. Sua “origem literária" (o escritor viera à literatura séria a partir de revistas de entretenimento), a própria forma breve à qual se dedicava, assim como o tipo de temas e de heróis de sua obra, e a aparente falta de ação e de trama, a princípio não permitiam aos críticos verem em Tchékhov um grande escritor. Todas essas características dos contos tchekhovianos, criticados a princípio por seus contemporâneos, acabaram mudando o curso da literatura mundial e a tradição do gênero em si. Muitas delas estão presentes na obra de Serguei

\footnotetext{
260 Ibid., p. 232.

261 Ibid., p. 234.

262 TCHÉKHOV, Anton. Sem trama e sem final (99 conselhos de escrita). São Paulo: Martins, 2007, p. 84.

${ }^{263}$ DOBROZRÁKOVA, G. "Tchékhov v proze Serguéia Dovlátova”. IN: Izviéstia Samárskovo naútchnovo tsentra Rossíiskoi akadiémii naúk. Samara, v. 13, № 2 (2), 2011, p. 407.

264 Ibid., p. 411.
} 
Serguei Dovlátov: texto de cultura na literatura russa contemporânea

Dovlátov, que conscientemente seguia a linha ética e estética introduzida na literatura por Anton Tchékhov. Vejamos as principais semelhanças e interseções nas opiniões e na poética de dois escritores.

Dovlátov segue o seu precursor no princípio da forma objetiva da narrativa. Como aponta Igor Sukhikh, estudioso da obra dos dois escritores, Dovlátov e Tchékhov eram próximos na compreensão de seu papel na literatura como indivíduos que apenas contavam como as pessoas vivem, e não como elas devem viver. ${ }^{265}$ Assim como Tchékhov, Dovlátov normalmente abstinha-se de julgar suas personagens e de dar opinião direta em relação à situação descrita. Em vez disso, para insinuar a sua postura, o escritor se utiliza de procedimentos como a ironia por meio da qual a mensagem subliminar aparece sugerida. Um exemplo de tal procedimento é uma das expressões mais famosas da personagem de Stássik Potótski, de Parque cultural, escritor medíocre, no entanto "ideologicamente alinhado", alcoólatra e malandro que se apresenta dizendo: "Sou escritor, porra, tipo Tchékhov". ${ }^{266}$ O contraste entre a maneira de falar vulgar, com o uso de palavrões, a própria imagem e biografia de Potótski, e a comparação com um dos principais escritores russos, deixa o leitor logo adivinhar a opinião do autor em relação à personagem e o seu grau de inteligência e talento.

Já o respeito do próprio Dovlátov pelo legado literário russo evidencia ainda mais a ironia oculta nessa frase. Amigo de Dovlátov, o escritor Lev Lóssev lembrava que "Dovlátov sempre foi demasiado profissional para gabar-se de genialidade. Mesmo quando lhe pediram que nomeasse os escritores que lhe serviam de ponto de referência, nomeou Kuprin. ${ }^{267}$ Nomear Tolstói ou Tchékhov, segundo seu ponto de vista, seria desajeitado, inconveniente". ${ }^{268}$ Portanto, o descaramento com o qual Potótski, que "não tinha capacidades literárias evidentes", 269 compara-se com Tchékhov, e ainda mais por meio de um discurso totalmente indecoroso, de imediato caracteriza tanto o talento quanto a inteligência e a erudição da personagem.

Ao princípio da forma objetiva da narrativa corresponde o "minimalismo narrativo" 270 e o laconismo dos dois escritores, pois tanto Dovlátov como Tchékhov expressam conotações em seus textos de forma implícita, por meio de ironia oculta, sentidos ocultos, alusões e ligações intertextuais.

Um exemplo de tal minimalismo narrativo de Dovlátov em Parque cultural é o retrato de Anton Makárenko, famoso pedagogo soviético, no escritório do major da KGB. A princípio o protagonista toma o homem retratado por Félix Dzerjínski, fundador da Tcheká, primeira

\footnotetext{
${ }^{265}$ SUKHIKH. Serguei Dovlátov. Vriémia, miesto, sudbá. Op. cit., p. 32.

${ }^{266}$ DOVLÁTOV. Zapoviédnik. Op. cit., p. 211.

${ }^{267}$ Aleksándr Kuprin (1870 - 1938), escritor e tradutor russo.

268 Apud SUKHIKH. Serguei Dovlátov. Vriémia, miesto, sudbá. Op. cit., p. 74.

${ }^{269}$ DOVLÁTOV. Zapoviédnik. Op. cit., p. 212.

${ }^{270}$ DOBROZRÁKOVA. “Tchékhov v proze Serguéia Dovlátova”. Op. cit., p. 407.
} 
Serguei Dovlátov: texto de cultura na literatura russa contemporânea organização de polícia secreta da União Soviética. A imagem do pedagogo, conhecido por suas ideias inovadoras quanto à educação infantil (Makárenko tornou-se famoso também por seus métodos de trabalho e inserção na sociedade de crianças e adolescentes problemáticos) como que faz eco ao discurso da personagem do major Beliáiev sobre os fins educativos que tem atualmente a KGB, o que atribui um tom especialmente irônico e expressivo à cena.

A brevidade tchekhoviana deve-se também à própria composição de seus textos, inovadora para a época, cuja principal inovação consistia na nova abordagem dos conceitos de fábula e enredo. O crítico e teórico literário Boris Tomachévski, representante da escola formalista, define a fábula como a relação causo-temporal entre os elementos temáticos introduzidos na narrativa, ${ }^{271}$ e o enredo como a distribuição artística dos acontecimentos na obra. Os pesquisadores da criação de Tchékhov apontam para tal característica na obra do escritor como na falta de fábula na narrativa (besfábulnost, em russo). O próprio escritor, numa das cartas a seu irmão, dizia: "O enredo tem que ser novo e a fábula pode faltar". 272

Assim, Tchékhov usa uma forma lacônica, concisa em seus contos, o que leva à construção dos começos de narrativa curtos, de poucas palavras, que diretamente remetem já ao desenvolvimento da ação principal. O próprio escritor era ciente de sua postura inovadora quanto à composição, dizendo que o conto ideal era aquele, no qual o autor cortava o começo e o final e deixava apenas o meio, e até dava tal conselho em cartas para seu irmão, Aleksándr, reforçando que "a brevidade é irmã do talento". ${ }^{273}$ Analisando os procedimentos que contribuem para a brevidade dos contos tchekhovianos, Regina Pontieri denomina as lacunas, a ausência de alguns dos elementos significativos, deixados em elipse na estrutura da narrativa, os "silêncios constitutivos". 274

Dovlátov também usava amplamente esse procedimento, o que podemos ver tanto em seus contos curtos (por exemplo, no conto Na rua e em casa, publicado na Nova antologia do conto russo (2011), no qual o autor remete o leitor à ação sem dar nenhuma explicação quanto às personagens ou contexto no qual elas vivem), como nos textos maiores, como é o caso da novela Parque cultural. Nela, a história de relações do protagonista e Tânia, sua mulher, assim como a questão da emigração, são relatados por meio de fragmentos; e alguns temas importantes, como o tema da crise matrimonial e as razões da separação, são apenas insinuados, mencionados de leve, sem entrar em explicações ou criar relações causo-temporais.

\footnotetext{
271 TOMACHÉVSKI, Boris. Teória literatúry. Poétika. Moscou: Aspekt Press, 2003, p. 179.

272 Apud LINKOV, Vladímir. Khudójestvennyi mir prózy Tchékhova. Moscou: Izdátelstvo Moskóvskovo universitieta, 1982, p.107.

273 TCHÉKHOV. Op. cit., p. 43.

${ }^{274}$ PONTIERI, Regina. "Formas históricas do conto: Poe e Tchekhov". IN: Ficções: leitores e leituras. São Paulo: Ateliê, 2001, p. 110.
} 
Serguei Dovlátov: texto de cultura na literatura russa contemporânea

Outra característica da obra tchekhoviana herdada por Dovlátov, na qual se refere à composição do conto e aos conceitos de fábula e enredo, é a descontinuidade do tempo na narrativa: assim, nos contos de Tchékhov não há tempo contínuo, isento de lacunas. ${ }^{275}$ Às vezes o escritor omite décadas na narrativa ou provoca deslocamentos ao passado. Essas lacunas, "a subversão temporal", ${ }^{276}$ fazem com que cada momento da narrativa seja mais independente e valioso e, portanto, seja percebido pelo leitor com mais intensidade do que num desenvolvimento de acontecimentos linear e lógico. Como menciona Vladímir Linkóv, "enfraquecendo a continuidade do desenvolvimento da ação, Tchékhov reforça a percepção de cada momento isolado da vida das personagens". ${ }^{277}$

Podemos ver exemplos de tal subversão temporal na novela Parque cultural, onde as cenas do presente do protagonista no parque cultural alternam-se com as cenas do passado, relacionados com a história de seu amor, casamento e separação (que tampouco aparecem em ordem cronológica, mas estão espalhadas ao longo da narrativa). Em determinado momento, a subversão temporal em Parque cultural torna-se literal: o mês de junho no parque cultural vem depois do mês de julho. Igor Sukhikh sustenta que nessa mudança do curso do tempo revela-se mais uma vez a falsidade, a teatralidade do espaço do parque cultural, que representa um lugar totalmente deslocado no tempo e espaço. ${ }^{278}$ Em geral, o pesquisador destaca o motivo do "tempo parado" com um dos leitmotifs da novela, que recebe a sua principal representação no final, quando diante dos olhos do protagonista junta-se o passado, o presente e o futuro: "De repente, vi o mundo como um todo. Tudo acontecia ao mesmo tempo. Tudo se realizava diante dos meus olhos..."279

\footnotetext{
${ }^{275}$ A esse respeito cabe lembrar de novo a concepção de Tomachévski de fábula e enredo, para a compreenção da inovação de Tchékhov. Segundo Tomachévski, a fábula e o enredo podem ser decompostos em motivos. Em sua terminologia, os motivos são os elementos íntegros que constroem a continuidade temática da obra. Do ponto de vista formalista, a fábula é o conjunto de motivos em sua relação causo-temporal e o enredo é o conjunto de motivos na sequência e relação em que eles aparecem na narrativa. Os motivos podem ser divididos em interligados, aqueles que não podem ser eliminados sem alterar a relação de causa e consequência entre os acontecimentos (normalmente se referem a ações e acontecimentos na narrativa), e livres, ou seja, que podem ser eliminados sem romper a integridade do desenvolvimento causo-temporal dos acontecimentos (por exemplo, pensamentos da personagem, descrições, conversas entre personagens etc.). Apenas os "motivos interligados" têm importância para a fábula, já que no enredo os "motivos livres" podem dominar e determinar a composição da obra (TOMACHÉVSKI. Op. cit., p. 182 - 183). Seguindo a terminologia de Tomachévski, podemos comprovar que em muitas obras de Tchékhov a composição e o enredo estão construídos com base em "motivos livres" - elementos que não são necessários para a fábula - o que transmite a impressão de inacabamento, falta de desfecho e de ação na narrativa.

A eliminação da fábula, como foi mencionado antes, foi um princípio consciente na poética do escritor e revela a concentração especial de Tchékhov não nos acontecimentos, mas na vida interna, nos pensamentos e emoções da personagem. A vida interna da personagem, passiva quanto à realidade ao redor, era muito mais importante para o escritor. Podemos ilustrar esta afirmação citando as palavras do próprio Tchékhov sobre o pathos de sua criação: "As pessoas almoçam, apenas almoçam e neste momento forma-se sua felicidade e arruínam-se suas vidas" (apud LINKÓV. Op. cit., p. 118).

${ }^{276}$ PONTIERI. Op. cit., p. 104.

${ }^{277}$ LINKÓV. Op. cit., p. 123.

${ }^{278}$ SUKHIKH. Serguei Dovlátov. Vriémia, miesto, sudbá. Op. cit., p. 135.

${ }^{279}$ DOVLÁTOV. Zapoviédnik. Op. cit., p.280.
} 
Serguei Dovlátov: texto de cultura na literatura russa contemporânea

Galina Dobrozrákova, falando das semelhanças na composição da obra de Tchékhov e de Dovlátov, denomina tal maneira dos escritores de alternar as cenas e deixar lacunas temporais de "ligação de montagem" (em russo, montájnaia sviáz), fazendo referência à montagem do cinema. $^{280}$

No princípio de sua carreira, Tchékhov tornou-se conhecido na Rússia como escritorhumorista, e não podemos deixar de ver a proximidade dos dois escritores nesse campo, pois o humor de Dovlátov, delicado e frequentemente "oculto" (já que o humor explícito não era comum na poética de Dovlátov), tem muitos paralelos com o humor tchekhoviano. Assim como Tchékhov, Dovlátov sabia muito bem encontrar o equilíbrio entre o triste e o cômico, dentro de uma obra de tamanho reduzido.

Na obra de Dovlátov, como nos textos humorísticos de Tchékhov, as situações cômicas estão espalhadas ao longo de toda a narrativa, alternando-se com trechos mais sérios e até dramáticos. $\mathrm{O}$ equilíbrio de fragmentos cômicos e dramáticos confere às narrativas de Dovlátov, ao lado de seu estilo suave e claro, uma leveza que cativa o leitor. Referindo-se a essa leveza dos textos dovlatovianos, Brodsky apontava que a leitura de seus textos era tão prazerosa e fascinante que era difícil interrompê-la pela metade, antes de chegar ao fim. O poeta lembra que "devorava seus livros em média em três, quatro horas de leitura ininterrupta". ${ }^{281}$

De certo modo, a leveza e o fascínio de seus contos estão relacionados com a capacidade do escritor de ponderar o humorístico e o dramático. A habilidade de Dovlátov em combinar o senso de humor e o senso de drama em sua obra foi altamente valorizada pelos críticos. Como aponta Sukhikh, a melhor prosa de Dovlátov se baseia na tensão entre esses dois polos opostos. ${ }^{282}$ E o gênero de anekdot usado pelo autor auxilia na manutenção dessa tensão, pois ao mesmo tempo em que a anekdot provoca o riso por trabalhar com fatos inusitados, pode provocar também a tensão dramática pela rapidez e pelo efeito que provoca no leitor. Nesse procedimento, Dovlátov segue os grandes escritores da tradição russa, como Gógol, Dostoiévski, e, claro, Tchékhov, em cujo mundo artístico a farsa e a tragédia, o sério e o cômico frequentemente estão em síntese, sendo uma característica fundamental de sua criação. Combinando o cômico e o trágico, Tchékhov, em sua obra, em muitos casos consegue rebaixar e ironizar o pathos da situação sem recorrer a meios puramente humorísticos, nem expressar abertamente sua opinião. Arlete Cavaliere em seu ensaio Tchékhov: da farsa ao drama,

\footnotetext{
${ }^{280}$ DOBROZRÁKOVA. "Tchékhov v proze Serguéia Dovlátova”. Op. cit., p. 412.

${ }^{281}$ BRODSKY. Op. cit., p. 299.

${ }^{282}$ SUKHIKH. Serguei Dovlátov. Vriémia, miesto, sudbá. Op. cit., p. 51.
} 
Serguei Dovlátov: texto de cultura na literatura russa contemporânea referindo-se a tal capacidade de Tchékhov, introduz o termo "comicidade subterrânea", definindo-o como "uma espécie de contracanto burlesco, sempre presente e incisivo". 283

Podemos observar tal interpenetração do cômico e do dramático em vários contos de Tchékhov, como A corista (em russo, Khoristka), entre muitos outros. Em A corista, a fábula é própria de um vaudeville ou de um "caso": a esposa chega à casa da amante de seu marido, corista, e o esposo, que está ali escondido, ouve toda a conversa a partir do quarto. No entanto, a narrativa recebe tons trágicos quando a dama humilha a corista Pacha, acusa-a de ter gastado o dinheiro da família e acaba levando embora todas as jóias da moça (que Pacha recebera de outros clientes). O cômico e o trágico alternam-se ao longo do desenvolvimento da estória, pois, por um lado, as personagens femininas vivem uma situação de confronto com um grau de tensão dostoievskiana, ${ }^{284}$ mas o pathos trágico acaba sendo rebaixado pela ironia do autor, quando a dama exclama "Matar esta mulher infame ou ajoelhar-me diante dela?"285 e, adiante, começa a chantagear Pacha, ameaçando com o ajoelhar-se.

Referindo-se a esse conto, cabe destacar outra característica de muitas obras de Tchékhov herdada por Dovlátov: os elementos de dramaturgia introduzidos em seus textos em prosa. Assim, muitos dos contos de Dovlátov, assim como fragmentos de seus textos, compostos por diálogos, poderiam facilmente ser montados em cena, ${ }^{286}$ devido à tensão dramática ali presente, a rapidez das reações das personagens, assim como a significação das conversas que, à primeira vista, podem parecer superficiais. No entanto, elas contêm um sentido oculto, que o escritor expressa por meio de ironia ou da intertextualidade. Um exemplo de tal diálogo "teatral" é a conversa entre as personagens Alikhánov e Marianna, durante a "sua entrevista de emprego":

\footnotetext{
- O que Goethe tem com isto? - perguntou Marianna. — E o que tem a ver a Renascença?

- Não tem nada a ver! - finalmente, explodi. - Goethe não tem absolutamente nada a ver! E Renascença era o nome do cavalo de Dom Quixote! Que também não tem nada a ver! E, pelo visto, eu também não tenho nada a ver!...

- Acalme-se — sussurrou Marianna. - Que nervoso... Eu apenas perguntei por que o senhor ama Púchkin?

- Amar em público é uma obscenidade! — gritei. — Há um termo especial na sexologia para isso.

Com a mão trêmula, ela estendeu-me um copo de água. Afastei-o.
}

\footnotetext{
${ }^{283}$ CAVALIERE, Arlete. Teatro Russo: percurso para um estudo da Paródia e do Grotesco. São Paulo: Humanitas, 2009 , p. 182.

${ }^{284}$ Boris Scnhaiderman aponta para as alusões e as imagens femininas da obra de Dostoiévski neste conto em seus comentários à tradução do conto em português (TCHÉKHOV, A. “A dama do cachorrinho” e outros contos. São Paulo: Editora 34, 2011, p. 350).

285 Ibid., p. 85.

${ }^{286}$ Cabe mencionar que, na Rússia, as obras de Dovlátov, como A zona, Parque cultural, A filial, entre outras, várias vezes foram transformadas em peças teatrais.
} 
Serguei Dovlátov: texto de cultura na literatura russa contemporânea

— E a senhora mesma amou alguém? Alguma vez na vida?

Não devia ter falado aquilo: irá se desfazer em pranto e gritar:

"Tenho trinta e quatro anos e sou uma donzela solitária!....". ${ }^{287}$

Nessa cena, a tensão dramática é diluída com a comicidade, devido ao absurdo da conversa e à falta de compreensão entre as personagens, que parecem falar em diferentes idiomas. A convivência dos elementos dramáticos e cômicos na cena, por um lado, dá-nos a possibilidade de interpretá-la de diferentes maneiras e, por outro, ressalta a ironia do autor.

A capacidade de combinar o triste, o trágico e o cômico na obra de Tchékhov foi denominada pelos críticos através da metáfora "as lágrimas invisíveis para o mundo" (em russo, nevídimye miru sliózy), como é intitulado um dos contos tchekhovianos. ${ }^{288}$ O próprio Dovlátov dava muita atenção ao "senso de drama", achando-o uma característica imprescindível para um bom escritor:

Existe o termo "senso de humor". No entanto, existe algo oposto ao senso de humor. Digamos, o "senso de drama". A falta de senso de humor é uma tragédia para o escritor. Melhor, uma catástrofe. Mas a falta de senso de drama é uma desgraça igual. ${ }^{289}$

Dovlátov referia-se à capacidade do escritor de sentir e transmitir a emoção e a vivência do triste e do trágico, provocando ressonância no leitor. Como foi dito, Dovlátov, que possuía tanto senso de humor quanto senso de drama, sabia muito bem combiná-los, gerando em sua prosa uma tensão entre o cômico e o trágico. Por isso, em seus textos, muitas vezes as situações cômicas recebem um tom trágico ou, ao contrário, momentos dramáticos rebaixam-se, seguidos de um momento humorístico.

Como exemplo disso, salienta-se o fragmento de Parque cultural, quando no restaurante Alikhánov e a sua mulher estão tendo uma conversa extremamente tensa, discutindo a futura emigração de Tânia e Macha e questões tão profundas e sérias como a questão da liberdade, o destino do escritor e a possibilidade para um escritor de realizar-se na emigração. Neste momento chegam os amigos de Alikhánov, Mitrofánov e Potótski, personagens cômicas, e a cena seguinte muda totalmente de tom. Da mesma forma "alivia-se" com humor uma das cenas finais da novela, quando o protagonista, numa crise de dipsomania, está encerrado no seu

\footnotetext{
${ }^{287}$ DOVLÁTOV. Zapoviédnik. Op. cit., pp. 191 - 192.

${ }^{288}$ SUKHIKH, I. Probliémy poétiki A.P. Tchékhova. Leningrado: Izdátelstvo LGU, 1987, p. 50.

${ }^{289}$ DOVLÁTOV. Zapisnýe kníjki. Op. cit., pp. 168 - 169.
} 
Serguei Dovlátov: texto de cultura na literatura russa contemporânea apartamento após a partida da mulher e da filha, e o vizinho alcóolatra avisa-o da chegada da patrulha de polícia pronunciando por telefone apenas uma frase: “As putas estão chegando!". 290

Já na cena bufa da bebedeira de Alikhánov e Márkov, pelo contrário, quando as personagens bêbadas perambulam pela região do parque cultural, o encontro com o curador do mosteiro Lóguinov e o comentário de Valera de repente diminui o grau da bufonaria, atribuindo um matiz sombrio à conversa:

O curador do mosteiro refletiu e nos benzeu. Então, Márkov disse:

- Não devia ter feito isso... Agora, em vez de Deus, temos o Comitê Central de Lênin. Mas estas putas também terão seu grande expurgo... ${ }^{291}$

Outra característica na qual Dovlátov segue a tradição tchekhoviana são as próprias personagens retratadas na obra do escritor. Júlio Cortázar, no seu artigo Alguns aspectos do conto, referindo-se à obra de Tchékhov, perguntava-se: “o que há ali que não seja tristemente cotidiano, medíocre, muitas vezes conformista ou inutilmente rebelde?". ${ }^{292}$ Tal característica aplica-se perfeitamente ao perfil da personagem tchekhoviana: em sua obra, Tchékhov continua a desenvolver a personagem do "homem pequeno" (em russo, málenki tcheloviék), introduzida na literatura russa com o surgimento do realismo, nos anos $1820-1830$. O primeiro escritor russo que introduziu esse tipo de personagem foi Aleksándr Púchkin, na sua novela $O$ chefe da estação (1831). Posteriormente a personagem do homem pequeno, uma pessoa simples, sem nenhuma capacidade ou talento extraordinário, que leva uma vida humilde e que normalmente é transtornada na narrativa por algum acontecimento fora do comum, desenvolveu-se ao longo do século XIX na tradição realista. Encontramos "o homem pequeno" na obra de Gógol (o representante gogoliano mais expressivo dessa personagem é Akáki Akákievitch, de $O$ capote), dos escritores da "escola natural”, Dostoiévski (a personagem de Makar Diévuchkin, em Gente pobre, ou a família Marmeládov, em Crime e castigo, entre outros), Tolstói (Platón Karatáiev, em Guerra e paz), etc.

Na obra de Tchékhov, a imagem do homem pequeno recebe uma abordagem até então inusitada. Muitos pesquisadores e teóricos de literatura, entre eles Igor Sukhikh, Anton Aníkin e Vladímir Katáiev, coincidem na opinião de que Tchékhov pusera o ponto final no desenvolvimento do homem pequeno na corrente do realismo russo. Assim, segundo Aníkin, “Tchékhov elimina o pequeno homem, (...) na aspiração de regenerar (transformar) tal tipo de

\footnotetext{
${ }^{290}$ DOVLÁTOV. Zapoviédnik. Op. cit., p. 279.

${ }^{291}$ Ibid., p. 266.

292 CORTÁZAR. Op. cit., p. 153.
} 
Serguei Dovlátov: texto de cultura na literatura russa contemporânea personagem", ${ }^{293}$ Como apontam Mikhaíl Esptein ${ }^{294}$ e Igor Sukhikh, “A morte do funcionário, de Tchékhov, frequentemente é analisada em comparação com $O$ capote, de Gógol, principalmente no seu aspecto temático, como o encerramento do tema do homem pequeno". ${ }^{295}$ Como se transforma o homem pequeno na obra tchekhoviana?

Como sustenta Sukhikh, na tradição realista do século XIX do período "antes de Tchékhov", o mundo artístico dos escritores clássicos russos era construído de uma maneira hierárquica, tendo seus próprios "níveis de humanismo". 296 Portanto, as características de cada personagem costumavam se determinar pelo seu lugar na escala hierárquica, e ao longo do desenvolvimento da corrente realista russa, muitas das características das personagens tornaramse clichês, definindo a priori o valor da personagem e o conflito da obra. Assim, o homem pequeno sempre merecia compaixão do leitor justamente por ser pequeno, pobre e ofendido. ${ }^{297}$

Tchékhov, em sua criação, problematiza e dá novos significados ao tema do homem pequeno, rompendo, "arrancando as características ideológicas e morais, que haviam calcificado na imagem dessa personagem". ${ }^{298}$ Em sua obra, o tema costumeiro das personagens que são "humilhadas e ofendidas", e merecem exclusivamente compaixão e simpatia por parte do leitor, é profundamente repensado. Assim, algumas das personagens, como a personagem de Tcherviakóv, em A morte do funcionário, ou a personagem de Biélikov, em O homem no estojo, já não inspiram compaixão, mais desprezo e, no caso de Biélikov, até um certo medo (pois, como aponta Mikhaíl Epstein, apesar de sua “pequenice”, Biélikov consegue oprimir quase toda a sociedade do lugar ${ }^{299}$ ). Ao mesmo tempo, em outros textos, como nos contos A corista ou Toská, as personagens desse tipo ("homem pequeno"), a corista Pacha e o cocheiro Iona são retratados em tons profundamente trágicos. Merece uma atenção especial a personagem de $A$ corista, que recebe uma ambivalência, antes inusitada: no conto, a corista Pacha aparece ao mesmo tempo como agressora ("mulher indecente", que ameaça o bem-estar de uma família) e como vítima (humilhada e até roubada pela esposa do seu cliente).

Em tal abordagem do tema do homem pequeno está o princípio inovador tchekhoviano de tentar se desprender de qualquer rótulo ou estereótipo (seja ideológico, social ou psicológico) no retrato de suas personagens, mas explorar o arquétipo de qualquer vida humana, de qualquer pessoa (seja "mulher indecente", funcionário, mujique etc.) no aspecto de sua ordinariedade e de

${ }^{293}$ ANÍKIN, Anton. "Tiema málienkovo tchelovieka v rússkoi klássike”. IN: PETRIENKO, L., Aníkin, A., Gálkin, A. Tiémy rússkoi klássiki. Utchébnoe possóbie. Moscou: Prometei, 2000, pp. 96 - 120.

${ }^{294}$ EPSTEIN, Mikhaíl. "Málenkii tcheloviek v futliáre: sindróm Bachmátchkina-Biélikova". IN: Vopróssy literatúry. Moscou, 2005, № 6 .

${ }^{295}$ SUKHIKH. Probliémy poétiki A.P. Tchékhova. Op. cit., p. 53.

${ }^{296}$ Ibid.

${ }^{297}$ Segundo Sukhikh, da mesma forma funcionava a imagem do "homem novo" no realismo russo, que merecia simpatia do leitor por lutar por seus ideais e apontar para os defeitos da sociedade atual (ibid.).

${ }^{298}$ Ibid., 48.

${ }^{299}$ EPSTEIN. Op. cit. 
Serguei Dovlátov: texto de cultura na literatura russa contemporânea sua semelhança com outros. Assim, como se pode ver, a inovação de Tchékhov não residia no tema abordado (pois o tema de uma pessoa comum, de retratar o cotidiano, "a prosa da vida" entraram na alta literatura com o surgimento da tradição realista), mas em uma visão nova da realidade, em uma nova postura quanto às personagens. "Sejamos pessoas comuns, tratemos todos de uma maneira igual". ${ }^{300}$ Nessa frase, escrita por Tchékhov numa carta a seu amigo, escritor e dramaturgo Iván Leóntiev (nome artístico, Ivan Scheglóv), manifesta-se a orientação do mundo artístico do escritor.

Dovlátov herda de Tchékhov a complexidade e a ambivalência das personagens, além da ausência de julgamento por parte do autor. Suas personagens (e principalmente o protagonista da maioria dos textos de Dovlátov, seu herói autobiográfico), sempre muito pouco heróicas, seguem a linha "volumétrica" das personagens tchekhovianas: Dovlátov não oculta seus vícios e pontos fracos, e ao mesmo tempo não as submete a nenhum tipo de julgamento moral, tentando mostrar tanto as virtudes como os vícios de cada um. Como apontava Valéri Popóv, em sua biografia Dovlátov, "na condescendência moral está a principal sedução da prosa dovlatoviana". ${ }^{301}$ Em muitos casos, suas personagens boêmias, semi-marginais, tristes e engraçadas ao mesmo tempo, provocam a simpatia do leitor. Como exemplo, podem lembrar-se as personagens de Mikhal Iványtch ou de Valera Márkov, com as suas personalidades contraditórias, nas quais convivem qualidades incompatíveis - o que se reflete em suas atitudes, às vezes inexplicáveis de uma forma racional. Assim é descrita a personalidade de Mikhal Iványtch:

Nunca consegui compreender sua personalidade. Aparentemente, era desajeitado, bondoso, atrapalhado. Uma vez, enforcou dois gatos numa sorveira. Fez a forca com linha de pesca. debulhando pra todo lado.

— Estão pululando- disse -, nas cuspideiras,

Uma vez, sem querer, tranquei a porta por dentro com o ferrolho. E ele ficou até de manhã sentado no terraço, com receio de me acordar... rancor. $^{302}$

Era desajeitado tanto em sua bondade quanto em seu

Quanto ao herói autobiográfico da obra de Dovlátov, nele o escritor desenvolve ainda mais a linha da personagem do homem pequeno e da falta do heroísmo: o autor de propósito chama a atenção do leitor para os fracassos, fraquezas e vícios do protagonista. Sublinha-se

300 TCHÉKHOV, A. Pólnoie sobránie sotchiniénii i píssem: v 30 t. Písma: v 12 t. V. 2. Písma, $1887-$ sentiabr 1888. Moscou: Naúka, 1975, p. 262.

${ }^{301}$ POPÓV. Dovlátov. Op. cit., p. 53.

${ }^{302}$ DOVLÁTOV. Zapoviédnik. Op. cit., pp. $218-219$. 
Serguei Dovlátov: texto de cultura na literatura russa contemporânea constantemente que o seu herói é um fracassado, e, como sustentam os pesquisadores Nina Orlova e Aleksándr Petrienko, tal procedimento coloca o herói autobiográfico "ao nível de outros personagens e, o que é muito importante, não acima do leitor. Isso dá a possibilidade de não julgar a outros, mas sim a si mesmo, sem ter medo de parecer fraco ou ridículo". 303

Além do mais, na sua abordagem da imagem do homem pequeno, Dovlátov consegue enlaçá-la com outro fenômeno da literatura do século XIX: na construção de suas personagens, o autor repensa também a personagem do homem supérfluo, desenvolvida nos anos 1820 - 1850 por Púchkin, Griboiédov, Lérmontov, Turguêniev (título de cuja obra, Diário de um homem supérfluo, (Dnevnik líchnevo tchelovieka, 1850), deu o nome ao tipo da personagem), entre outros. Iúri Mann, na Breve Encilopédia Literária (em russo, Krátkaia literatúrnaia entsiklopédia), apresenta as seguintes características à personagem do homem supérfluo: seu isolamento da vida oficial da Rússia, do ambiente social próximo à personagem (normalmente nobre), em relação ao qual a personagem é consciente de sua superioridade intelectual e moral; ao mesmo tempo, as características do homem supérfluo são cansaço espiritual, profundo ceticismo, desacordo entre a palavra e a atitude e, normalmente, passividade social. ${ }^{304}$

Dovlátov consegue juntar no protagonista de sua obra ao mesmo tempo os traços do homem pequeno e do homem supérfluo: o herói dovlatoviano sempre é um outsider, representante do círculo da intelligentsia russa que não consegue adaptar-se na sociedade soviética e não compartilha o sistema de valores dessa sociedade; ao mesmo tempo, a sua personagem é "pequena" (em todos os textos sublinha-se que o protagonista é um escritor mediano, sem pretensões à genialidade, ou seja, não se trata de uma personalidade extraordinária), fraca, pouco ou nada heroica, perdida nas peripécias do cotidiano. Assim, na personagem dovlatoviana sintetizam-se as duas tradições literárias: o seu herói ao mesmo tempo é "supérfluo" e "pequeno". Em tal combinação paradoxal Sukhikh vê uma inovação de Dovlátov: "'Pequeno e supérfluo', eis a fórmula desse caráter dovlatoviano, de novo paradoxal, pois reúne (...) dois tipos da literatura clássica russa que estão bem longe um do outro". 305

Esses exemplos demonstram como a criação de Tchékhov influenciou o gênero do conto não apenas na tradição da literatura russa, mas, de modo geral, na literatura mundial. A análise da obra de Dovlátov demonsta o quanto o legado de Tchékhov está presente em sua obra, e que, para Dovlátov, sua orientação tanto nas questões éticas como nas questões estéticas era um princípio consciente.

\footnotetext{
${ }^{303}$ ORLOVA. Op. cit., p. 108.

${ }^{304}$ MANN, Iúri. "Líchnii tcheloviek". IN: Krátkaia literatúrnaia entsiklopédia. V. 4. Moscou: Soviétskaia entsiklopédia, 1967, p. 400.

${ }^{305}$ SUKHIKH. Dovlátov. Vriémia, miesto, sudbá. Op. cit., p. 121.
} 
Aleksándr Púchkin (1799 - 1837) é outro escritor que de certa forma determinou o fazer literário de Dovlátov. Para essa pesquisa, discutir a figura do poeta é de extrema importância: o livro Parque cultural é uma espécie de tributo a Aleksándr Púchkin e à tradição literária russa em geral, sendo Púchkin o seu maior símbolo. Na novela, a figura do poeta se torna uma das personagens, através da qual Dovlátov estabelece um profundo diálogo com o legado puchkiniano, assim como com a figura e a personalidade do poeta. O significado da figura de Púchkin para a cultura russa e o mito do poeta existente na Rússia até os nossos dias será analisado no Capítulo III, dedicado à semiótica da cultura. Veremos aqui os procedimentos artísticos e os aspectos literários com os quais dialoga Dovlátov.

Como lembrava Aleksándr Guénis, Dovlátov dera o nome de Aleksandra à sua segunda filha, nascida em Tallin, em homenagem ao poeta. ${ }^{306}$ Púchkin sempre foi objeto de admiração por parte do escritor, tanto por seus méritos literários e estilísticos, quanto por suas opiniões estéticas e éticas, afins à postura tchekhoviana.

Dovlátov valorizava muito a maestria estilística e literária de Púchkin, e o seu zelo quanto ao estilo e a forma provém da tradição puchkiniana. Não podemos deixar de mencionar o fato de que o poeta é considerado fundador da língua literária russa moderna. Víktor Vinográdov, linguista, teórico e crítico literário, explica em seu artigo As principais etapas na história da língua russa o percurso de desenvolvimento da língua literária moderna, no qual Púchkin foi o primeiro escritor a introduzir em seus textos uma linguagem viva, antes não empregada pela "alta literatura":

$\mathrm{Na}$ língua de Púchkin toda a cultura antecedente da linguagem literária russa encontrou uma transformação drástica. A língua de Púchkin, ao realizar uma síntese profunda da cultura linguística nacional, tornou-se a suprema encarnação da norma linguística nacional no âmbito da literatura. ${ }^{307}$

Como explica o pesquisador, após as reformas iniciadas por Pedro, o Grande, no século XVIII, orientadas para a europeização da sociedade russa, os nobres russos passaram a se comunicar entre si basicamente em francês, enquanto usavam o idioma russo em situações do dia a dia e nas conversas com os servos, considerando-a "língua do povo", demasiado rude e incapaz de verbalizar ideias elevadas e sentimentos delicados. Portanto, até o começo do século XIX, os literatos russos costumavam evitar o uso de certas palavras, próprias das camadas sociais inferiores, substituindo-as por termos análogos da língua francesa. ${ }^{308}$ A postura de Púchkin a

\footnotetext{
${ }^{306}$ GUÉNIS. Púchkin. Op. cit., p. 327.

307 VINOGRÁDOV. “Osnovnye etápy istórii rússkovo iazyká”. Op. cit., p. 45.

${ }^{308}$ Ibid., p. 37.
} 
Serguei Dovlátov: texto de cultura na literatura russa contemporânea esse respeito era bem diferente: o escritor tinha certeza de que a língua russa era capaz de expressar qualquer sentimento, qualquer ideia, mesmo a mais elevada. ${ }^{309} \mathrm{O}$ escritor introduziu em suas obras muitos folclorismos, dialetismos etc., antes impensáveis nos gêneros literários "sérios". Muitas dessas palavras e expressões usadas em textos de Púchkin, reconhecidos e populares já durante a vida do escritor, posteriormente foram "oficializadas" na linguagem escrita. Isso permite considerar o poeta também um criador do idioma literário russo, que, como assinalou Nikolai Gógol, "ampliou as fronteiras da língua russa, revelando toda a sua dimensão".310

A maestria literária e a elegância estilística de Púchkin sempre foram objeto de admiração por parte de Dovlátov, pois, segundo ele, a estética da literatura e o valor artístico da obra são as principais garantias de sua permanência na história. $\mathrm{O}$ escritor expressou essa ideia numa entrevista coletiva em Los Angeles, feita em 1981, posteriormente transformada em artigo, intitulado $O$ escritor no papel de Cassandra (em russo, Pissátiel v róli Kassándry):

Os netos vão apreciar nossos alcances apenas na escala estética. Restará o único critério, a qualidade. Seja a qualidade plástica, a qualidade de espírito, de humor, de inteligência... (...) De um estudo metodológico que diz respeito a como viver e "que fazer", a literatura se converterá num fenômeno cativante da própria vida. ${ }^{311}$

O próprio Dovlátov considerava-se herdeiro dessa linha "estética" na literatura russa, e também via em Tchékhov um dos principais seguidores de Púchkin, no qual "renascera da forma mais clara e talentosa a independência espiritual puchkiniana, a sua plenitude de percepção da vida". 312

A postura ética do poeta foi próxima a Dovlátov, que admirava em Púchkin sua “indiferença olímpica e a disposição de aceitar qualquer ponto de vista". ${ }^{13} \mathrm{O}$ escritor considerava um grande mérito a capacidade de Púchkin de estar em sua obra acima dos preceitos morais e ideológicos, e ter uma visão mais complexa do ser humano. Dovlátov identificava, por exemplo, a capacidade de Púchkin em ver traços humanos em personagens tradicionalmente vistas como negativas, como acontecera com a personagem de Emelián Pugatchóv, conhecido por suas atrocidades, em A filha do capitão. Na novela de Púchkin, a personagem de Pugatchóv é

\footnotetext{
${ }^{309}$ LÓTMAN, Iú. Púchkin. Biográfia Pissátielia. Roman "Ievguéni Oniéguin”. São Petesburgo: Ázbuka, 2015, p. 188.

${ }^{310}$ GÓGOL, Nikolai. "Niéskolko slov o Púchkine”. IN: Pólnoe sobránie sotchiniénii , V. 8. Moscou, Leningrado: Izdátelstvo AN SSSR, 1952, p. 50.

${ }^{311}$ DOVLÁTOV. Rietch bez póvoda... ili Kolónki redáktora. Op. cit., p. 261 - 262.

${ }^{312}$ DOBROZRÁKOVA. "Tchékhov v proze Serguéia Dovlátova”. Op. cit., p. 409.

${ }^{313}$ DOVLÁTOV. Zapoviédnik. Op. cit., p. 216.
} 
Serguei Dovlátov: texto de cultura na literatura russa contemporânea retratada como uma personalidade ambivalente e em certos momentos provoca simpatia por parte do leitor. O escritor via na postura de Púchkin um sinal de clemência: "Em A filha do capitão, Pugatchov é retratado com uma certa simpatia. É como se hoje alguém pintasse Biéria $^{314}$ num tom positivo. Isso é 'a piedade para com os depravados"’.315

Em vários textos, Dovlátov afirmava a sua consciente orientação pelo legado de Púchkin. Dobrozrákova, em seu artigo A criação de Serguei Dovlátov no contexto da tradição da literatura russa (retrospectiva de estudos) (em russo, Tvórtchestvo Serguéia Dovlátova v kontiékste tradítsii rússkoi literatúry (obzor isslédovanii)), aponta que para escritor estranhavalhe o fato de que Púchkin, à diferença de outros grandes escritores russos, não possuísse muitos seguidores entre escritores modernos. Segundo Dovlátov, para a maioria dos escritores Púchkin existia como um ícone (a visão de Púchkin como ícone e o símbolo da literatura e a cultura nacional será analisada no próximo capítulo), e não como "manual de instrução", 316 embora a precisão do pensamento da prosa puchkiniana e a singeleza e elegância de seu estilo devessem ser um ponto de referência para outros literatos: "Lendo Púchkin, você vê que a prosa pode passar-se sem erudição, sem filosofia e religião e até sem uma espiritualidade evidente e sublinhada. Ou seja, basta apenas contar uma história, um caso da vida e a profundidade da vida, o seu conteúdo espiritual, revelar-se-ão por conta própria".317

O texto Parque cultural torna-se um tributo ao poeta: nele, a figura de Púchkin aparece em diferentes tons, e ao longo de toda a narrativa há alusões à biografia, à vida e obra puchkiniana, em diferentes níveis. Nas cartas ao seu editor Igor Iefímov, Dovlátov explicava que, em Parque cultural, queria situar a personagem principal nas mesmas condições, idade e lugar, onde nessa idade encontrava-se Púchkin - colocá-la ante as mesmas questões e problemas.

Além de representações e referências explícitas à figura do poeta, alusões a Púchkin e a sua obra aparecem em várias cenas ao longo da narrativa. No texto da novela estão espalhadas alusões ao poeta e à sua obra que podem ser identificadas inclusive nos nomes das personagens: a filha de Alikhánov se chama Macha, como a protagonista da novela de Púchkin A filha do capitão; sua esposa é Tatiana (Tânia), nome que nos remete à principal personagem feminina do romance em versos Ievguéni Oniéguin.

\footnotetext{
${ }^{314}$ Lavriénti Biéria (1899 - 1953), político soviético, conhecido como um dos principais organizadores e executores do Grande Expurgo de Stálin, na década dos anos 1930.

${ }^{315}$ DOVLÁTOV. Zapisnýe kníjki. Op. cit., p. 198.

Cabe mencionar aqui que a comparação de Pugatchóv com Lavriénti Biéria, feita por Dovlátov, refere-se meramente às crueldades feitas por ambos, e não ao tamanho da personalidade de cada um. Seria incoerente comparar essas duas figuras históricas, pois se Emelián Pugatchóv (1742 - 1775), inspirador e líder da Guerra camponesa de 1773 1775, realmente foi uma personalidade marcante na história russa, Lavriénti Biéria no primeiro lugar era funcionário do aparelho stalinista e entrou na história devido as atrocidades cometidas durante o Grande Expurgo.

${ }^{316}$ DOBROZRÁKOVA. "Tvórtchestvo Serguéia Dovlátova v kontiékste tradítsii rússkoi literatúry (obzor isslédovanii)". Op. cit., p. 1535.

${ }^{317}$ Apud DOBROZRÁKOVA, ibid.
} 
Serguei Dovlátov: texto de cultura na literatura russa contemporânea

O leitor encontra no texto várias citações de Púchkin, às vezes corrompidas, como o mencionado acima verso do poema "Um monumento ergui a mim, obra extra-humana". Além das citações diretas, estabelecem-se ligações intertextuais com vários textos puchkinianos: no texto da novela, além dos nomes das personagens emblemáticas puchkinianas, estão introduzidas frases e imagens derivadas da obra do poeta.

Assim, a pesquisadora da obra de Dovlátov, Galina Dobrozrákova, ressalta na cena da conversa entre Alikhánov e Natella uma alusão à peça de Púchkin $O$ convidado de pedra (em russo, Kámennyi gost, 1830). Natella repete as palavras da personagem de dona Anna, "o senhor é um homem perigoso", ${ }^{318}$ que, na versão de Dovlátov, recebe, uma conotação humorística:

- O senhor é um homem perigoso.

- Isso significa?

- Senti isso na hora. O senhor é um homem terrivelmente perigoso.

- Em estado de embriaguez?

- Não estou falando disso.

- Não compreendo.

- Amar alguém como o senhor é perigoso. ${ }^{319}$

Aleksándr Guénis vê na cena do encontro de Alikhánov com a personagem do cunhado, uma paródia do encontro de Dom Juan com a estátua do Comodoro, da mesma peça de Púchkin:

O primão produziu uma impressão forte.

Sobre os penhascos dos ombros erguia-se um rosto pardo de tijolo. Seu cocuruto coroava-se com um canteiro de grama áspera e poeirenta do ano passado. As abóbadas moldadas das orelhas perdiam-se na penumbra. Ao posto avançado da testa larga e sólida faltavam seteiras. Os lábios descerrados pareciam um barranco. Os charcos brilhantes dos olhos, cobertos de uma crosta de gelo, lançavam uma indagação. A boca insondável, como uma fenda no rochedo, guardava uma ameaça. ${ }^{320}$

Aqui Guénis refere-se aos traços hiperbolizados e comparações "poéticas” que remetem à obra de Púchkin.

Já Igor Sukhikh aponta para as semelhanças da personagem de Mikhal Iványtch com a do ferreiro Arkhip, de Dubróvski (1841), ${ }^{321}$ tanto no seu aspecto físico como na convivência paradoxal de crueldade com a bondade em seu caráter. Na novela de Púchkin, Arkhip cruelmente tranca na casa incendiada os funcionários que agem em nome de Troekúrov, inimigo de

\footnotetext{
318 PÚCHKIN, A. "Kámennyi gost”. IN: Sotchiniénia v triokh tomakh. V. 2. Poémy. Ievguéni Oniéguin. Dramatítcheskie proizvediénia . Moscou: Khudójestvennaia literatura, 1986, 467.

319 DOVLÁTOV. Zapoviédnik. Op. cit., p. 193.

${ }^{320}$ Ibid., p. 231.

${ }^{321} \mathrm{O}$ romance foi escrito em 1832 - 1833, porém publicado pela primeira vez já após a morte de Púchkin. O próprio autor deixou a obra sem título, e o nome Dubróvski foi dado ao romance pelos editores.
} 
Serguei Dovlátov: texto de cultura na literatura russa contemporânea Dubróvski, deixando-os morrer no incêndio, mas põe em risco a sua vida para salvar o gato que está no telhado da casa em chamas. Dovlátov guarda essa ambivalência no caráter da personagem de Mikhal Iványtch: assim, Mikhal Iványtch enforca dois gatos com uma linha para pescar, por "pulular demais", e também aprova os fascistas que matavam judeus e ciganos durante a Segunda Guerra Mundial; no entanto, em outra situação, quando Alikhánov sem querer tranca por dentro a porta da casa, pernoita na rua porque não quer acordar o seu hóspede. ${ }^{322}$

Como foi visto acima, Dovlátov também faz referência a Púchkin no nível da linguagem poética: nos fragmentos das descrições das paisagens ao redor da propriedade do poeta, o autor chega a utilizar uma espécie de prosa ritmada.

A orientação de Dovlátov nos planos da ética e estética de Púchkin é sublinhada por vários pesquisadores da obra do escritor, como Igor Sukhikh, Aleksándr Guénis, Igor Kargáchin, Galina Dobrozrákova, entre outros. Vale comentar aqui a opinião de Sukhikh e a sua explicação a propósito do interesse de Dovlátov por Púchkin, e de certa negação por parte do escritor dos pressupostos (éticos, em primeiro lugar) dos representantes da literatura realista da segunda metade do século XIX. Segundo Sukhikh, a postura de Dovlátov era oposta não tanto às tradições da literatura clássica russa, mas ao realismo socialista, que em grande medida derivara "o paradigma literário" dos escritores da segunda metade do séc. XIX, com os seus slogans sobre o serviço do escritor perante o povo e suas convicção ideológicas. ${ }^{323}$

Além dos exemplos mencionados, no texto da novela estão presentes muitas outras referências a Púchkin e a seu legado, que serão comentadas no capítulo seguinte, dedicado ao mito soviético de Púchkin e também nos comentários à tradução da novela.

Se Púchkin, Tchékhov e Dostoiévski são os escritores russos do período clássico que mais interessavam e marcara a obra e os pressupostos éticos e estéticos de Dovlátov, em sua obra o escritor estabelece um diálogo constante com vários representantes da literatura russa, tanto do século XIX como do século XX. Sukhikh vê na criação do escritor "as vozes dos poetas russos" Aleksándr Blok, Óssip Mandelstam, Boris Pasternak, Joseph Brodsky, assim como elementos isolados, citações e alusões à prosa dos escritores como Lev Tolstói, Maxim Górki, Mikhaíl Bulgákov, Mikhaíl Zóschenko, Andrei Platónov, entre outros. Referindo-se a constantes alusões e diálogo de Dovlátov com outros escritores, o pesquisador nota que "o comentário literário nos textos de Dovlátov poderia constituir um livro".324

Em Parque cultural, tal relação com a tradição literária russa torna-se mais evidente, já que esse texto é considerado "a obra mais literária” de Dovlátov, nas palavras de Guénis. ${ }^{325}$

\footnotetext{
${ }^{322}$ SUKHIKH. Serguei Dovlátov. Vriémia, miesto, sudbá. Op. cit., p. 140.

323 Ibid., 38.

${ }^{324}$ Ibid., 83.

${ }^{325}$ GUÉNIS. "Púchkin”. Op. cit., p. 331.
} 
Serguei Dovlátov: texto de cultura na literatura russa contemporânea

Além de Púchkin, ao longo da narrativa aparecem várias referências e alusões a outros escritores, os quais Dovlátov vê como herdeiros da tradição de Púchkin. Assim, no texto há menções, citações e alusões a textos de Lérmontov, Gógol, Dostoiévski, Iessiênin, Mandelstam, entre outros.

Raciocinando sobre o seu fazer literário e a impossibilidade de publicar o escrito, o protagonista lembra as palavras do poeta Óssip Mandelstam: "Vá trabalhar de carregador e escreva de madrugada. Mandelstam dizia que as pessoas sempre conservam o que lhes é sagrado. Então escreva.....326

Essas palavras de Mandelstam são mencionadas no livro de memórias, intitulado Memórias (em russo, Vospominánia), de sua esposa, Nadiéjda Mandelstam. É importante o contexto no qual o poeta pronuncia a frase, nos anos 1930, auge do período stalinista, em resposta a uma advertência de possíveis repressões:

Na Niévski, no escritório do Izviéstia, o representante desse jornal, pessoa à primeira vista amigável, leu Voltei à minha cidade ${ }^{327}$ e disse a O.M.: "Sabe o que acontece depois de tais poesias? Vêm três... de farda"... Sabíamos disso, mas as autoridades soviéticas, pacientes, ainda não tinham pressa... Os poemas divulgavam-se com uma velocidade incrível, porém num círculo bastante reduzido. O.M. considerava que esse era o meio de conservá-los: "As pessoas conservarão". 328

Em outro fragmento da novela, de novo refletindo sobre a sua criação, o protagonista cita Dostoiévski e sua frase do romance Demónios: “Em julho, comecei a escrever. Eram esboços estranhos, diálogos, buscas por um tom. Algo como um esquema, com figuras e enredos vagamente delineados. Amor infeliz, dívidas, casamento, criação, conflito com o Estado. Além disso, como dizia Dostoiévski, um matiz de significado supremo". ${ }^{329}$ Evidentemente, aqui a expressão empregada por Dostoiévski recebe uma interpretação irônica, já que a personagem de Alikhánov frequentemente sublinha o fato de ser um escritor mediano.

Os nomes de Iessiênin, Dostoiévski e Pasternak são mencionados no livro, quando o protagonista conversa com uma das funcionárias do parque sobre a falta de peças autênticas no museu, já que o museu fora fundado dezenas de anos após a morte do poeta, quando muitos de seus pertences foram perdidos e a propriedade fora modificada e saqueada várias vezes:

\footnotetext{
${ }^{326}$ DOVLÁTOV. Zapoviédnik. Op. cit., p. 186.

${ }^{327}$ Em russo, Iá vernúlsia v moi górod, primeira linha do poema Leningrado (em algumas edições intitulado Petersburgo, 1930), um dos poemas emblemáticos de Mandelstam, escrito já perto de ser preso.

${ }^{328}$ MANDELSTAM, Natália. Vospominánia. Moscou: Soglássie, 1999.

${ }^{329}$ DOVLÁTOV. Zapoviédnik. Op. cit., p. 220.
} 
Serguei Dovlátov: texto de cultura na literatura russa contemporânea sua morte...

— Pertences de Púchkin?... O museu foi criado dezenas de anos depois de

- E é assim — disse - é como sempre acontece. Primeiro, matam uma pessoa e depois começam a procurar seus pertences. Assim foi com Dostoiévski, com Iessiênin... Assim será com Pasternak. Reconsiderarão e começarão a procurar os pertences de Soljenítsyn... ${ }^{330}$

Nesses fragmentos se revela um dos temas dolorosos da novela: o "caminho de sofrimento" de um verdadeiro talento na Rússia e a sua recepção pelos contemporâneos. Segundo Dovlátov, nisso reside a tragédia do escritor que adianta o seu tempo, e cujo legado será compreendido plenamente e passará a ser valorizado apenas após a morte.

Além das menções diretas aos nomes dos escritores e poetas, vários pesquisadores veem alusões a obras emblemáticas da literatura do período clássico em citações ocultas, na composição de cenas e na construção de personagens.

Galina Dobozrákova vê na cena de encontro de Alikhánov e Liónia Guriánov uma alusão à cena de encontro da personagem de Petchórin com Gruchnítski, de O herói do nosso tempo, de Lérmontov. ${ }^{331}$ Como aponta a pesquisadora, nos dois casos, embora a cena parecesse alegre e cordial, não se trata de um reencontro de amigos, mas, pelo contrário, de antagonistas. A alusão ao texto de Lérmontov reforça essa sensação de antagonismo oculto no livro de Dovlátov.

\begin{tabular}{|c|c|}
\hline O herói do nosso tempo & \\
\hline $\begin{array}{l}\text { Parei-me, ao perder o fôlego, à beira da } \\
\text { montanha e, encostando-me no canto da } \\
\text { casinha, pus-me a observar os arredores, } \\
\text { quando de repente ouvi uma voz familiar: } \\
\text { — Petchórin! Há muito que está aqui? } \\
\text { Dei uma volta: Gruchnítski! Abraçamo- } \\
\text { nos. }\end{array}$ & $\begin{array}{l}\text { No entanto, quem surgiu virando a } \\
\text { esquina foi Liónia Guriánov, o ex-dedo-duro } \\
\text { da universidade. } \\
\text { - Borka, seu filho da mãe — gritou } \\
\text { como um possesso - é você mesmo?! } \\
\text { Respondi com uma cordialidade } \\
\text { inesperada. }{ }^{333}\end{array}$ \\
\hline
\end{tabular}

E nas descrições hiperbolizadas da aldeia e da morada de Mikhál Iványtch, na "galeria de retratos satíricos" (de Mikhal Iványtch, Valera Márkov, Stássik Potótski e outros), G. Dobrozrákova encontra referências à criação gogoliana e, em primeiro lugar, ao poema em prosa de Nikolai Gógol, Almas mortas. ${ }^{334}$

A pesquisadora destaca as seguintes semelhanças composicionais entre Parque cultural e Almas mortas:

\footnotetext{
${ }^{330}$ Ibid., p. $199-200$.

${ }^{331}$ DOBROZRÁKOVA. “Tchékhov v proze Serguéia Dovlátova”. Op. cit., p. 411.

${ }^{332}$ LÉRMONTOV, Mikhaíl. “Gerói náchevo vriémeni”. IN: Sobránie sotchiniénii v tchetyriókh tomakh. V. 4. Proza. Pisma. Moscou - Leningrado: Izdátelstvo Akadiémii Naúk SSSR, 1959, p. 358.

${ }^{333}$ DOVLÁTOV. Zapoviédnik. Op. cit., p. 183.

${ }^{334}$ DOBROZRÁKOVA. "Tvórtchestvo S. Dovlátova v kontiekste tradítsii rússkoi literatúry (obzor issliédovanii)". Op. cit., p. 1541.
} 
- o motivo de viagem (como a personagem de Tchítchikov, Alikhánov está de visita e, de certa forma, "de passagem” nas Colinas de Púchkin);

- as descrições da aldeia de Sosnovo, das propriedades locais;

- a descrição da morada de Mikhal Iványtch (que lembra as descrições das casas das personagens de Koróbotcha e de Pliúchkin);

- sobrenomes significativos;

- características das personagens por meio de sua fala (skaz);

- a cena de regateio. Na cena de conversa entre as personagens de Alikhánov e Mikhal Iványtch sobre o aluguel, Dobrozrákova vê alusão às cenas em Almas mortas, quando Tchítchikov negocia com os proprietários as almas dos camponeses falecidos:

— Quanto devo pagar?

- Ah, nada.

— Como assim? - perguntei.

- Assim mesmo. Por seis garrafas do veneno o espaço é seu. conviriam?

- Podemos combinar algo mais concreto? Digamos, vinte rublos lhe

O senhorio refletiu:

— Isso será quanto?

- Estou lhe dizendo, vinte rublos.

- E se traduzir isso em bebida? Por um rublo e quatro copeques?

- Dezenove garrafas de Rosé capitoso. ${ }^{335}$ Um maço de Bielomor. Duas caixas de fósforos - escandiu Tólik.

— E dois rublos para esquentar — precisou Mikhal Iványtch. ${ }^{336}$

Em primeiro lugar, a semelhança está relacionada com o motivo da incompreensão entre as partes, pois tanto no poema de Gógol, como na novela de Dovlátov, as personagens a princípio não conseguem compreender de que se trata e o que quer o seu interlocutor, porém, continuam o negócio.

Quanto aos sobrenomes com significado, que falam por si mesmos (em russo, govoriáschaia família, "sobrenome falante”), Dobrozrákova aponta para o sobrenome de Mikhal Iványtch, Sorókin, que provém do nome do pássaro, soroka ("gralha"). No texto, o protagonista compara a maneira de falar de Mikhal Iványtch com o canto de um pássaro, devido à sua negligência em relação às normas de coesão e concordância:

Pronunciava, de modo bem articulado e cuidadoso, apenas substantivos e verbos. Principalmente em combinações obscenas. Quanto aos complementos, Mikhal Iványtch os usava de modo totalmente arbitrário. Do jeito que

\footnotetext{
335 Vermute produzido na URSS.

${ }^{336}$ DOVLÁTOV. Zapoviédnik. Op. cit., p. 197.
} 
Serguei Dovlátov: texto de cultura na literatura russa contemporânea

aparecessem. Já nem falo das preposições, partículas e conjunções. Criava-as na hora. Sua fala era como a música clássica, a pintura abstrata ou o canto do pintassilgo. As emoções evidentemente predominavam sobre o sentido. ${ }^{337}$

Ao mesmo tempo, em russo, pode-se chamar de soroka uma pessoa leviana, despreocupada, traços de caráter que sem dúvida correspondem à personagem de Mikhal Iványtch. Em tais características da personagem Dobrozrákova vê uma alusão à criação literária de Gógol.

Um dos temas de Parque cultural também é a literatura contemporânea soviética, em primeiro lugar, a literatura oficial, "aceita" e apoiada pelas autoridades. Em geral, se as alusões aos escritores clássicos comparecem no texto da novela quando se abordam temas sérios, relacionados com a criação e o destino do escritor e de seus textos, a literatura oficial soviética (o principal representante de tal literatura "ideologicamente alinhada" é a personagem de Stássik Potótski) torna-se o objeto de ironia e até zombaria por parte do autor.

Além de Soljenítsyn, que na época já estava na emigração, o único escritor contemporâneo soviético mencionado no texto da novela, do qual o autor não fala em tom pejorativo, é Víktor Likhonóssov (nascido em 1936), representante da "prosa rural" (em russo, dereviénskaia proza). Um dos exemplos mais famosos da prosa rural soviética e o texto que deu início a essa corrente literária é o conto de A. Soljenítsyn, A casa de Matriona, de 1965. Em geral, o que unia os representantes da prosa rural era a tendência de analisar e chamar atenção aos valores tradicionais da aldeia russa na sociedade moderna.

Falando de Likhonóssov, a personagem de Alikhánov reconhece o seu talento e méritos literários, no entanto não pode aceitar tal abordagem das tradições russas, sua nostálgica tristeza pelo passado e pelas tradições, que praticamente deixaram de existir após a coletivização e formação de kolkhoz:

Enquanto isso, li Likhonóssov. Sem sombra de dúvida, um bom escritor. Talentoso, brilhante, plástico. Reproduz com maestria a fala viva. (...) E, mesmo assim, lá no fundo, persistia uma sensação desagradável, triste, impertinente. Um motivo caquético e enfadonho: "Cadê você, Rus?! Para onde tudo se foi?! Cadê as modinhas, os rúchniks, ${ }^{338}$ os kokóchniks?! ${ }^{339}$ Cadê a hospitalidade, a audácia e o ímpeto?! Cadê os samovares, os ícones, os devotos, os iuródvis?! ${ }^{340}$ Cadê os estrujões, as carpas, o mel, o caviar?! Cadê os cavalos habituais, caramba?! Cadê o pudor casto?"

Os miolos queimando:

"Cadê você, Rus?! Onde se meteu?! Quem a desfigurou?!"

Quem, quem... Sabe-se quem foi...

\footnotetext{
${ }^{337}$ Ibid., p. 218.

${ }^{338}$ Um tipo de toalha de pano de linho, objeto de cultura popular dos eslavos orientais.

339 Adereço de cabeça tradicional para mulheres.

${ }^{340}$ Pessoa religiosa louca que tinha dom de vidente.
} 
Serguei Dovlátov: texto de cultura na literatura russa contemporânea Nem é preciso queimar os miolos nesse ponto... ${ }^{341}$

Em tais lamentações o protagonista de Parque cultural vê uma certa hipocrisia, já que, apesar de sentir nostalgia pela "velha Rússia", os representantes da prosa rural não desmascaravam o regime e a ideologia soviéticos, que puseram fim às tradições que tanto faziam falta aos dereviénchiki (literalmente, "ruralistas", como se chamavam os representantes dessa corrente literária).

Essa breve retrospectiva dos procedimentos poéticos do escritor, suas referências éticas e estéticas e as relações com os escritores russos do período clássico, assim como com os escritores contemporâneos, ressaltam as raízes profundas da criação de Dovlátov no seio da tradição literária russa.

${ }^{341}$ Ibid., p. 217. 


\section{Capítulo III. "Parque cultural como texto de cultura"}

Uma das peculiaridades da obra de Dovlátov, que por um lado gera parte de seu fascínio e, por outra, representa verdadeiro desafio para a tradução e compreensão de seus textos em outra cultura, é o seu vínculo muito estreito com a cultura russa e soviética. Aqui, trata-se do termo cultura num sentido mais amplo, ou antropológico, definido pela filósofa, escritora e antropóloga Svetlana Boym como "a maneira de compreender o mundo e o sistema de matizes do comportamento e dos sinais". ${ }^{342}$ Assim, o escritor faz referência a fenômenos da vida russa, fatos e costumes do cotidiano, alude a símbolos, códigos culturais e mitos existentes na visão do mundo russa e soviética.

Como já analisado, um dos principais modelos seguidos por Dovlátov é o escritor Anton Tchékhov e a sua "poética do ordinário". Como aponta o teórico de literatura e um dos grandes representantes da escola formalista russa, Boris Eikhenbáum, Tchékhov "havia descoberto uma enorme esfera da vida russa, não usada pela literatura: a esfera das miudezas e casos cotidianos, pouco importantes à primeira vista e apenas engraçados ou esquisitos, mas que em realidade eram característicos e mereciam atenção". ${ }^{343}$ Como a Tchékhov, a Dovlátov lhe interessavam, em primeiro lugar, pessoas comuns e o seu entorno, transformados em personagens de seus textos, histórias de vida banais que não continham em si nada de heroico ou extraordinário. No entanto, através dessas pequenas coisas ordinárias descritas pelo escritor, e as banalidades da vida do dia a dia, ${ }^{344}$ abre-se ao leitor um panorama da vida e da história russas na segunda metade século XX, e, de forma mais geral, as peculiaridades da cultura, da mentalidade e da visão de mundo russas.

O texto de Dovlátov que transmite da melhor maneira uma espécie de metáfora da vida russa, por meio de um elemento insignificante, é o seu romance A mala: as personagens do romance literalmente são coisas, "trastes", como os determina o próprio protagonista-narrador 345 - são levados à emigração numa mala. Ao longo da narrativa o protagonista de Serguéi Dovlátov "desfaz" a mala, relatando como cada objeto chegou a parar em sua casa e em sua vida. Os detalhes que são relatados em cada capítulo (histórias relacionadas com meias finlandesas que se vendiam no mercado negro soviético, sapatos roubados de um funcionário soviético de alto

\footnotetext{
${ }^{342}$ BOYM. Op. cit., p. 5.

${ }^{343}$ EIKHENBAUM. Op. cit., p. 358.

${ }^{344}$ Em inglês, commonplaces, a palavra que deu título ao livro de Svetlana Boym, que trata justamente das manifestações da cultura, história e da mentalidade russa nos objetos do cotidiano (BOYM. Op. cit.).

${ }^{345}$ DOVLÁTOV. Tchemodán. Op. cit., p. 276.
} 
Serguei Dovlátov: texto de cultura na literatura russa contemporânea nível, cinto militar que o protagonista usara no exército, na colônia penal, etc.) fazem alusão para o leitor ao contexto cultural, social e histórico, no qual vivia o protagonista e o seu entorno, e detrás de cada objeto abre-se um amplo panorama da vida soviética da época.

O romance A mala é representativo justamente pela "materialidade" do objeto da análise, ou seja, cada coisa da "mala imaginária" pode ser analisada e posta no contexto correspondente. No entanto, da mesma forma, a partir de certos pontos de referência pode-se analisar a novela Parque cultural que, entre outras coisas, revela ante o leitor o panorama da literatura (desde os clássicos de literatura russa do século XIX até a literatura oficial e não oficial soviética) e da cultura russa e soviética, celebrando Aleksándr Púchkin como um dos seus principais símbolos e mitos no século XX.

O filósofo, teórico e crítico literário Iúri Lótman (1922 - 1993), fundador e líder da Escola Semiótica de Tártu - Moscou, é considerado um dos fundadores da semiótica da cultura do século XX e um dos representantes mais notáveis da semiótica russa. A semiótica como campo do saber que estuda os signos e os sistemas sígnicos ${ }^{346}$ surgiu no final do século XIX e consolidou-se nos anos 1930, em primeiro lugar com os nomes do filósofo e lógico americano Charles Peirce, do linguista suiço Ferdinand de Saussure e do filósofo americano Charles Morris. Uma das peculiaridades da semiótica como ciência é o fato de ela não possuir um objeto de estudo específico, já que vários fenômenos e manifestações tanto da vida humana, como as manifestações da natureza ou biológicas, podem ser interpretados como signos, dependendo da situação de comunicação. ${ }^{347}$ Tal amplidão de interpretações sobre o que é signo, ou seja, o objeto de estudo (de fato, cada campo de saber elabora e opera a própria definição desse termo), determina o caráter interdisciplinar da semiótica, no qual podem confluir estudos literários, linguísticos, históricos, filosóficos, matemáticos etc.

A obra de Iúri Lótman representa da melhor maneira tal caráter interdisciplinar do próprio campo do saber, que se refletiu na amplitude dos interesses acadêmicos do pesquisador (Lótman trabalhou no campo da literatura (em primeiro lugar, da literatura russa), da arte e da cultura em geral), e também de seus métodos. ${ }^{348}$ Como aponta Ekaterina Vólkova, "a mistura de métodos culturológico, semiótico, flilológico e, antes de tudo, histórico é um dos traços mais

\footnotetext{
${ }^{346}$ Iúri Lótman, no seu artigo Pessoas e signos (em russo, Liúdi i znaki), define a semiótica como "ciência sobre os sistemas comunicativos e signos que usam as pessoas no processo de comuniação (e não somente pessoas, mas também animais ou máquinas)" (LÓTMAN, "Liúdi i znaki". IN: Semiosfera. Op. cit., p. 6).

${ }^{347}$ KRÉIDLIN, Grigóri, Krongauz, Maksim. Semiótika ili Ázbuka obschénia. Utchébnoe possóbie. Moscou: Flinta Naúka, 2015, p. 51.

$348 \mathrm{O}$ panorama da vida acadêmica e a trajetória do desevolvimento das ideias do pesquisador, assim como a explicação dos principais conceitos científicos, estão discutidas na tese de doutorado de Ekaterina Vólkova Américo Alguns aspectos da semiótica da cultura de Iúri Lótman (São Paulo, 2012).
} 
Serguei Dovlátov: texto de cultura na literatura russa contemporânea marcantes da análise de Lótman". ${ }^{349}$ Herdeiro das ideias de Saussure, Peirce, formalistas russos, esturturalistas, ao longo de sua carreira acadêmica o teórico elaborou a sua própria concepção da cultura sob viés semiótico. Vejamos alguns dos principais conceitos da teoria de Lótman, que adequado à nossa análise.

Os principais conceitos que formam a teoria de Lótman são os conceitos de cultura, de texto de cultura, e de como ele se insere no conceito maior de semiosfera. O próprio autor não deixou definições acabadas destes termos, já que as suas descrições evoluiam ao decorrer de sua carreira científica. Dessa forma, em diferentes textos do autor é possível flagrar diferentes facetas de suas postulações.

Assim Lótman, em sua obra, postula várias definições do termo cultura, mostrando, assim, as caraterísticas e funções que esta tem. Uma das principais carácteristicas da cultura, para a qual o autor aponta em vários textos, é que a cultura funciona como "um mecanismo que integra a personalidade coletiva, com a memória coletiva e a consciência coletiva" 350

Um dos traços específicos da Escola Semiótica de Tártu-Moscou é a sua centralização no texto: este é o centro de seu sistema conceitual. Nele, o texto é concebido de uma maneira diferente da abordagem linguística e literária. Em sua teoria, Lótman repensou o conceito de texto, mudando a perspectiva para um enfoque cultural, abordando assim o texto como fenômeno da cultura. O texto é compreendido como um todo imanente, que possui uma organização complexa, estruturada por uma hierarquia de níveis que gera o sentido. A interpretação lotmaniana permite chamar de textos formações de vários tipos, desde a personalidade humana ou obra artística até o texto da vida ou texto da cultura em geral. Ou seja, uma determinada cultura também pode ser interpretada como texto. Assim, como aponta Oksana Leuta, na teoria de Lótman vemos "a específicidade da compreensão cultorológica do texto sob o viés do método estrutural-semiótico".351

Uma das definições propostas por Lótman interpreta a cultura como um conjunto de textos ou como um texto íntegro, o qual possui uma complexa estrutura hierárquica, composta por "textos dentro de outros textos". ${ }^{352}$ Por textos de cultura, segundo o pesquisador, são compreendidos somente aqueles enunciados que demonstram, além da expressividade linguística, sinais de uma expressividade (em russo, vyrajennost) adicional, importante para este

\footnotetext{
${ }^{349}$ VOLKOVA Américo, Ekaterina. Alguns aspectos da semiótica da cultura de Iúri Lótman. São Paulo, 2012., p. 95.

${ }^{350}$ LÓTMAN. Semiosfera. Op. cit., 176.

${ }^{351}$ LEUTA, Oksana. "Iú. M. Lótman o triokh fúnktsiakh tiéksta". IN: Kántor, V (org.). Iúri Mikháilovitch Lótman. Moscou: ROSSPEN, 2009, p. 296.

${ }^{352}$ LOTMAN, Iú. Ízbrannye statii v triokh tomakh. V. 1. Statií po semiótike i topológuii kultúry.Tallin: Aleskandra, 1992, p. 160.
} 
Serguei Dovlátov: texto de cultura na literatura russa contemporânea sistema de cultura. Estes textos contrapõem-se aos não-textos, que carecem dessa expressividade. $^{353}$

Uma das importantes funções do texto, segundo o pesquisador, é a função da memória. O texto não é apenas gerador de novos sentidos, mas também o condensador da memória cultural: o texto é capaz de guardar a memória de seus contextos anteriores. ${ }^{354}$ Em outras palavras, o texto de cultura é aquele que traz em si conotações de diferentes tipos (históricas, sociais, políticas, pragmáticas, etc.), evidentes e importantes para os nativos da língua e cultura na qual ele foi gerado. O texto é o resultado e o produto da atividade semiótica, é obra da língua, da arte e da cultura, é elemento do diálogo semântico, do discurso entre sociedades e culturas.

No entanto, como aponta Lótman, o texto de cultura em princípio é heterogêneo, pois "as rodas de diferentes mecanismos da cultura movem-se com diferente velocidade". ${ }^{355}$ Dessa forma, como esclarece o pesquisador, em diferentes esferas da cultura o processo de evolução tem o seu próprio ritmo: assim, por exemplo, o ritmo de desenvolvimento de uma língua natural é diferente do ritmo de desenvolvimeno da moda, e a esfera do sagrado sempre é mais conservadora do que a esfera do profano. Tal heterogeneidade interna constitui uma das condições e leis da existência da cultura, que determina a diversidade interna do espaço semiótico.

Para que o espaço heterogêneo da cultura não se desintegre em diferentes fragmentos cronológicos, existem os símbolos, elementos importantes no funcionamento da cultura. O pesquisador postula a sua interpretação do termo: segundo Lótman, "o símbolo sempre representa um texto tanto no plano do conteúdo como no plano da expressão, ou seja, possui um certo sentido definido e uma fronteira nítida, o que permite destacá-lo facilmente no contexto semiótico que o rodeia". 356

Sendo um dos elementos mais estáveis do continuum cultural, os símbolos têm a capacidade de guardar em si de forma condensada os textos extremamente densos e importantes. Além do mais, o símbolo, sendo um texto fechado, sempre conserva a sua independência semântica e estrutural. Ele evade facilmente do entorno semiótico, e com a mesma facilidade entra em um novo entorno textual. Portanto, como sublinha Lótman, "o símbolo nunca pertence a um corte sincrônico da cultura, ele sempre transpassa esse corte pela vertical, vindo do passado e indo para o futuro. A memória do símbolo sempre é mais antiga do que a memória do seu entorno textual não simbólico". 357

\footnotetext{
${ }^{353}$ Ibid., 165.

${ }^{354}$ LÓTMAN. Semiosfera. Op. cit., p. 162.

355 Ibid., p. 241.

356 Ibid., p. 240 - 241.

357 Ibid.
} 
Serguei Dovlátov: texto de cultura na literatura russa contemporânea

Em outras palavras, sendo um mecanismo importante da memória da cultura, os símbolos carregam os textos, os esquemas de enredo e outras formações semióticas de uma camada a outra. Os conjuntos constantes de símbolos que permeiam a diacronia da cultura, em grande medida assumem a função da integridade: realizando a memória da cultura sobre si, não se desintegram em camadas cronológicas isoladas.

Ao mesmo tempo, é muito importante a natureza ambivalente do símbolo: como explica Lótman, por um lado, atravessando a massa das culturas, o símbolo realiza-se em sua essência invariante, e nesse aspecto pode-se observar como se repete em diferentes contextos. Mas por outro lado, o símbolo sempre dialoga ativamente com o seu entorno cultural, transforma-se sob a ifluência desse entorno e também o transforma. Assim, a sua essência invariante realiza-se em variantes. ${ }^{358}$

Vejamos na novela Parque cultural como se transforma o significado "eterno" do símbolo em suas variantes, nas diferentes etapas do desenvolvimento da cultura. Quando o protagonista Boris Alikhánov chega à casa da personagem de Mikhal Iványtch, onde acaba de combinar de alugar um quarto, uma das primeiras coisas que vê na parede são os retratos de Mao, líder comunista chinês, e de Gagárin, cosmonauta soviético e primeiro homem que viajou pelo espaço: "No quarto do senhorio, sentia-se cheiro de comida azeda. Em cima da mesa vi um retrato colorido de Mao, da revista Ogoniok. ${ }^{359}$ Ao lado, Gagárin exibia-se num sorriso largo". 360

Como se sabe, na União Soviética, antes do começo do debate ideológico contra a religião, surgido logo depois da Revolução de Outubro de 1917, tradicionalmente as casas das pessoas, que pertenciam à igreja ortodoxa russa (ou seja, a maioria da população do país), não necessariamente praticantes, costumavam ter ícones, que eram objeto de adoração. Tal hábito era especialmente comum em moradas camponesas. O lugar de imagens religiosas na casa chamavase o "canto vermelho", ou "canto sagrado" (em russo, krásnyi úgol). Quando o governo começou a lutar contra a religiosidade e a prática de cultos religiosos, ter qualquer atributo religioso em casa passou a ser proibido, e os ícones pouco a pouco começaram a sumir dos lares russos; no entanto, o "canto vermelho" não permanecia vazio, passaram a ocupá-lo os retratos de líderes e heróis comunistas. As pessoas, acostumadas a ter ícones em casa, trocaram-nos por retratos de Lênin, Stalin e outras personalidades importantes da cena soviética, ou simplesmente heróis populares, como é o caso de Gagárin. O paralelo com esse processo é reforçado na novela em outro fragmento, no qual se diz que a personagem de Mikhal Iványtch sempre tirava o chapel quando via a imagem de Friedrich Engels, ${ }^{361}$ já que tradicionalmente era necessário tirar o chapel

\footnotetext{
${ }^{358}$ Ibid., p. $241-242$.

${ }^{359}$ Ogoniok ("Luzinha"), uma das revistas ilustradas russas mais antigas.

${ }^{360}$ DOVLÁTOV. Zapoviédnik. Op. cit., p. 196.

${ }^{361}$ Ibid., p. 219.
} 
Serguei Dovlátov: texto de cultura na literatura russa contemporânea na igreja ou diante das imagens sagradas, durante a oração. Ou seja, aqui presenciamos a "variante soviética" ou "comunista" da essência invariante do símbolo da imagem sagrada: as imagens dos novos líderes passaram a ocupar, na consciência popular, o lugar de ícones. ${ }^{362}$ Como assinala Svetlana Boym a respeito dessa troca "do sagrado", "em espaços públicos soviéticos o 'canto vermelho' tornou-se 'canto de Lênin', ainda conservando muita cor vermelha, cor de sangue, cor dos ícones russos, cor da Revolução". 363

Cabe esclarecer também o conceito de semiosfera, introduzido e elaborado por Lótman. No seu livro Universe of the Mind (título do livro em russo, Vnutri mysliaschikh mirov), ele define o seu conceito de semiosfera: "a semiosfera é um espaço semiótico sincrônico que preenche os limites da cultura e que é a condição do funcionamento de estruturas semióticas isoladas e, ao mesmo tempo, o seu produto". 364

Em outras palavras, sendo o resultado e a condição do desenvolvimento da cultura, a semiosfera é todo o espaço semiótico próprio de uma dada cultura. Nele existem todos os sistemas sígnicos, assim como as linguagens e textos; é o espaço da semiose, do processo de geração, funcionamento e interpretação dos textos de cultura. Uma das leis da existência da semiosfera é o seu dinamismo e sua mutabilidade. ${ }^{365}$ Resumindo as características da semiosfera, o Lótman propõe a seguinte metáfora para explicar o termo:

Imaginemos um certo mundo íntegro, tomado num corte sincrônico, como uma sala de museu, onde, em diferentes vitrinas, estão expostas as peças de diferentes épocas, inscrições em línguas conhecidas e desconhecidas, instruções de como decifrá-las, textos explicativos à exposição, feitos por metodistas, esquemas de itinerários das excurções e regras de comportamento dos visitantes. Coloquemos nessa sala também guias e visitantes e imaginemos isso tudo como um mecanismo único (o que, em determinado sentido, tudo isso é). Teremos a imagem da semiosfera. Além do mais, é preciso levar em consideração que todos os elementos da semiosfera não são estáticos, mas dinâmicos, mudando o tempo todo as fórmulas de relações entre si. ${ }^{366}$

Determinando o corte temporal que nos interessa no nosso estudo, podemos identificar a semiosfera soviética, que pertence ao conceito maior da semiosfera russa.

\footnotetext{
362 Cabe lembrar aqui as reflexões de Eleazar Meletínski sobre o modelo mitológico na ideologia soviética. O pesquisador via os traços do modelo mitológico na ritualização das festas revolucionárias, no fato de que os líderes comunistas não eram percebidos na consciência massiva como personalidades históricas, mas como "novas transformações do mesmo héroe cultural de Lênin", assim como no próprio ateísmo comunista, que "se convertira numa religião 'ao avesso', o partidos comunistas, na igreja, e a oposição, em seitas heréticas” (MELETÍNSKI, Eleazar. Ot mifa k literature. Moscou: Rossíiski gossudárstvennyi gumanitárnyi universitet, 2001, p. 6 - 7).

${ }^{363}$ BOYM. Op. cit., p. 151.

${ }^{364}$ LÓTMAN. Semiosfera. Op. cit., p. 152.

365 Ibid., 276.

366 Ibid., 253.
} 
Serguei Dovlátov: texto de cultura na literatura russa contemporânea

Um dos métodos de análise derivados da Escola Semiótica de Tártu-Moscou, do formalismo russo e do estruturalismo é o modelo binário, ${ }^{367}$ que Lótman aplica tambén na interpretação do conceito da semiosfera. Assim, como aponta o pesquisador, um dos principais mecanismos da individualidade semiótica é a fronteira, já que cada cultura começa com uma divisão binária do mundo no espaço interno (“o meu”) e externo (“o deles”). Se o "nosso" espaço é concebido como "cultural", "seguro", "bem organizado" etc., o espaço "deles", que se contrapõe, é visto como "alheio", "hostil”, "caótico", "perigoso". 368

Nas reflexões das personagens da novela Parque cultural sobre a emigração, a União Soviética e o Ocidente não estão divididos apenas pela fronteira geográfica e pela distância, mas também pela fronteira semiótica, que separa a semiosfera das personagens da "outra", sentida por elas como alheia. Para o protagonista Alikhánov, a América é vista como o além-mundo, fantástico, assustador e, ao mesmo tempo, atrativo; e a emigração é concebida metafóricamente como morte (claro, em primeiro lugar, o protagonista refere-se à sua morte como escritor no exterior, mas são evidentes outras alusões à morte, como, por exemplo, o luto de vários dias do protagonista, encerrado no seu apartamento, pela mulher e filha, quando estas vão embora para os Estados Unidos). Como aponta Lótman no mesmo estudo, a divisão em dois mundos tem caráter universal e está presente em cada cultura, e muitas vezes pode significar justamente a divisão entre o mundo dos vivos e dos mortos. ${ }^{369}$ Aqui, cabe um paralelo com a percepção mitológica da morte, ou seja, como processo de entrada no além-mundo, na outra vida.

Como já referido, uma das características do texto de cultura é, ao desempenhar a função de memória cultural, ser capaz de trazer conotações de diferentes tipos. Como aponta Iúri Lótman, no seu artigo A memória numa interpretação cultorológica (em russo, Pámiat v kultorologuitcheskom osveschénii), que integra a coletânea Semiosfera, do ponto de vista da semiótica, "o espaço da cultura pode ser definido como um espaço de certa memória coletiva, ou seja, um espaço, dentro do qual alguns textos comuns podem se conservar e ser atualizados". 370 No que se refere à atualização dos textos, o pesquisador pontua o fato de que, ao longo da evolução da cultura, transformam-se não apenas a composição dos textos, mas também a sua qualidade. Assim, sob a influência de novos códicos culturais, que se usam para decifrar os textos que haviam ficado na memória da cultura já desde os tempos antigos, acontece o deslocamento dos elementos relevantes e não relevantes da sua estrutura. Dessa maneira, os

\footnotetext{
${ }^{367}$ VÓLKOVA. Op. cit., p. 64.

${ }^{368}$ LÓTMAN. Semiosfera. Op. cit., p. 257.

${ }^{369}$ Ibid.

${ }^{370}$ Ibid., p. 673.
} 
Serguei Dovlátov: texto de cultura na literatura russa contemporânea textos que formam "a memória comum" de um coletivo cultural, não apenas servem para decifrar aqueles que circulam no corte sincrônico - contemporâneo da cultura -, mas também para gerar novos textos. ${ }^{371}$

A novela Parque cultural, de Dovlátov, pode ser analisada como um exemplo de texto de cultura, que contribui para a transformação do texto de cultura "Púchkin", 372 o qual se consolidara ainda no século XIX e recebera várias transformações e novos significados ao longo do século XX. Ao mesmo tempo, esse texto de Dovlátov evoca vários outros fenômenos importantes da cultura russa e soviética, como o fenômeno da "segunda realidade cultural" dos anos 1960 - 1970, oposta à realidade oficial; o álcool como um dos elementos importantes da visão de mundo russo e da cultura em geral, inclusive no período de estagnação; a emigração massiva dos anos 1970 - 1980, entre outros.

Certamente, um dos temas mais complexos da novela é o tema da figura e da obra de Aleksándr Púchkin e o seu papel na cultura russa e, mais precisamente, as suas interpretações no período soviético. Na cultura russa, a imagem de Púchkin tem valor muito além da literatura, sendo um dos principais símbolos da cultura, da identidade nacional (Púchkin é considerado o principal poeta nacional) para os próprios russos. Vejamos como surgiu e se desenvolveu o mito de Aleksándr Púchkin, e como o aborda Serguei Dovlátov, nesta novela.

É preciso, antes de mais nada, esclarecer o conceito de mito. O pesquisador russo Eleazar Meletínski, que trabalhou nos campos da história da literatura, do folclore e da cultura, e que dedicou vários textos ao estudo da mitologia universal (com a qual estão relacionados os principais motivos do folclore e os enredos e motivos literários mais arcáicos), no seu texto $D o$ mito à literatura (em russo, Ot mifa $k$ literature), propõe o mito como um dos fenômenos centrais na história da cultura e "um dos meios mais antigos para a concepção da realidade e da essência humana". ${ }^{373}$ Uma das principais funções do mito, segundo Meletínski, é "manter a harmonia do subjetivo, do coletivo, do natural, como uma espécie de apoio e controle da ordem cósmica e social". ${ }^{374}$ Assim, o mito propõe soluções simples aos problemas insolúveis de caráter metafísico, como o sentido da vida, o mistério da morte, etc. (questões que a ciência não foi capaz de resolver até hoje), dando explicações por meio de ideias simples. Assim, como aponta o teórico, no mito não há desordem ou caos: "no mito prevalece o pathos da superação do caos e a sua transformação no cosmos, da defesa do cosmos das forças do caos, que ainda se

\footnotetext{
${ }^{371}$ Ibid., p. 675.

372 O filósofo e historiador da cultura Igor Kondakóv oferece uma retrospectiva da formação do texto de cultura "Púchkin" no seu artigo "Púchkin" como texto de cultura do século XX (em russo, "Púchkin" kak tiekst kultúry XX vieka) (KONDAKÓV, 2011).

${ }^{373}$ MELETÍNSKI. Op. cit., p. 5.

374 Ibid., p. $6-7$.
} 
Serguei Dovlátov: texto de cultura na literatura russa contemporânea conservam". 375 Tudo isso determina o caráter eterno da mentalidade mitológica, que conserva os seus traços, inclusive na modernidade, nas sociedades desenvolvidas.

Meletínski, definindo o mito como "meio de conceitualização do mundo", assinala que este é caraterístico tanto para a mentalidade arcaica, como também para a consciência de massa, ao longo de todas as épocas, o que permite chamar o mito do "primeiro modelo da grande ideologia". 376

Como já referido anteriormente, o poeta e escritor Aleksándr Púchkin (1799-1837) ocupa uns dos papéis centrais tanto na literatura, como na cultura russa de modo geral. Até os dias de hoje é considerado uma das figuras mais relevantes do imaginário nacional. Autor de textos como A Filha do Capitão, Contos de Biélkin, Ievguiéni Oniéguin, O Cavaleiro de Bronze, entre outros, e inúmeras poesias, que são familiares a qualquer um que tenha estudado numa escola russa (ou soviética), Púchkin representa o exemplo de um autor reconhecido mundialmente não somente por críticos e teóricos de literatura, mas também por um grande número de leitores.

Embora sua fama, no exterior, seja inferior à de escritores como Fiódor Dostoiévski, Lev Tolstói ou Anton Tchékhov, na Rússia, Púchkin já há quase dois séculos é considerado o grande símbolo da literatura nacional, chamado pelos críticos e leitores de o "nosso tudo", 377 ou o "sol da poesia russa", ${ }^{378}$ na famosa expressão do filósofo Odóievski. O reconhecimento do gênio puchkiniano na Rússia é incondicional, surgido o status de pai fundador, e como o escritor que definiu os rumos da literatura nacional. Assim, como assinala Marina Zaguidúllina, no seu livro O mito puchkiniano no final do século XX (em russo, Púchkinskii mif v kontsé XX vieka), a sua contribuição para a literatura russa pode ser comparada com a de Shakespeare para a inglesa ou a de Dante para a italiana. ${ }^{379}$ Um dos motivos da discrepância de como Púchkin é "percebido" dentro e fora da Rússia, como aponta Zaguidúllina, é o fato de seu legado ser

\footnotetext{
375 Ibid.

${ }^{376}$ Ibid., p. 22.

377 "Púchkin é o nosso tudo" (em russo, Púchkin - eto nache vsió), expressão do poeta Apollón Grigóriev, usada em 1859, no seu artigo Um olhar à literatura russa desde a morte de Púchkin (Vzgliad na rússkuiu literatúru so smiérti Púchkina).

378 “O sol da nossa poesia se pôs”, expressão cunhada pelo filósofo e escritor Vladímir Odóievski no artigo dedicado à morte do poeta (29 de janeiro de 1837), em Literatúrnye pribavliénia ("Suplementos literários"), do jornal Rússkii Invalid ("O veterano russo"). Posteriormente a expressão "o sol da poesia russa", referente a Púchkin, tornou-se clichê.

379 ZAGUIDÚllinA, M. Púchkinski mif $v$ kontsé XX vieka. Tcheliábinsk: Izdátelstvo Tcheliábinskovo
} Gossudárstvennovo Universiteta, 2001, p. 60. 
Serguei Dovlátov: texto de cultura na literatura russa contemporânea predominantemente poético, o que dificulta a tradução e a difusão de seus textos; ${ }^{380}$ outro é o fato de não possuir textos em prosa de grande volume. ${ }^{381}$

"Púchkin é um fenômeno extraordinário e, talvez, o único fenômeno do espírito russo", dizia Nikolai Gógol. ${ }^{382}$ Grande parcela de crítica afirma que um dos grandes méritos de Púchkin foi a criação, em sua obra, de uma imagem autêntica do caráter nacional russo, valendo-se de inspirações cotidianas e de crenças populares. ${ }^{383} \mathrm{O}$ escritor conseguiu reunir motivos nacionais russos à poesia universal e aos sentimentos universais, criando uma síntese percebida tanto em sua poesia como em sua prosa. No famoso Discurso puchkiniano (em russo, Púchkinskaia rietch) pronunciado em Moscou em 8 de junho de 1880, poucos dias depois da inauguração do monumento ao poeta, Fiódor Dostoiévski afirmou que Púchkin foi o “primeiro (...) que nos deu tipos artísticos da beleza russa, saídos diretamente do espírito russo", já que antes dele "nenhum escritor russo (...) havia se unido de um modo tão cordial e íntimo com o seu povo". ${ }^{384}$ Assim, os textos de Púchkin estão impregnados de figuras do povo, de alusões ao folclore, de provérbios e de expressões populares. A isso se atrela outra grande inovação de Púchkin, analisada no Capítulo 2 do presente trabalho: a introdução em sua obra de uma linguagem viva, antes não empregada pela "alta literatura" e a sua posterior "oficialização".

Os poemas e textos em prosa de Púchkin foram tão inovadores e revolucionários para o seu tempo que, em certa medida, determinaram as criações de praticamente todos os maiores escritores russos do século XIX. Como afirmou Dostoiévski no mencionado discurso, muitas das personagens de Lérmontov, Gógol, ${ }^{385}$ Turguêniev e Tolstói foram inspiradas em personagens puchkinianas, como Ievguéni Oniéguin, do romance em versos homônimo, Aleko, do poema Ciganos, ou Hermann, de A dama das espadas. ${ }^{386}$ De um modo geral, podemos afirmar que a maioria dos escritores e poetas do século XIX e do começo do século XX considerava-se herdeira do legado de Aleksándr Púchkin, reconhecendo seu gênio e sua importância para o desenvolvimento das letras russas. Isso pode ser percebido pelas inúmeras referências, citações e alusões à sua figura e às suas criações, além dos incontáveis estudos, ensaios e tributos que lhe foram dedicados. Entre os que dedicaram ensaios e textos a Púchkin, ou de alguma forma

\footnotetext{
${ }^{380}$ Como assinala Vladímir Nabókov, no seu ensaio Púchkin, ou A verdade e a verossimilhança (em russo, Púchkin, ili Pravda i Pravdopodóbie) “é indubitável que para um poeta sempre é mais difícil atravessar as fronteiras nacionais do que para um prosador" (NABOKOV, 1937).

${ }^{381}$ ZAGUIDÚLLINA. Op. cit., p. 62.

${ }^{382}$ GÓGOL. Op. cit., p. 50.

${ }^{383}$ LÓTMAN. Púchkin. Biográfia Pissátielia. Roman “Ievguéni Oniéguin”. Kommentárii. Op. cit., p. 119.

${ }^{384}$ DOSTOIÉVSKI, Fiódor. "Púchkinskaia rietch". IN: Pólnoe sobránie sotchiniénii, V. 26. Leningrado: Naúka, 1984, p. 130.

${ }^{385}$ Iúri Lótman menciona o curioso fato de que a ideia do enredo de dois famosos textos de Nikolai Gógol, o seu poema Almas mortas e a peça de teatro $O$ inspetor geral, lhe foi "dada de presente" por Púchkin, com quem o escritor mantinha amizade, nos anos 1830 (Op. cit.: 208).

386 Ibid.
} 
Serguei Dovlátov: texto de cultura na literatura russa contemporânea reverenciaram a sua obra, além de Gógol e Dostoiévski, podemos mencionar escritores e poetas, já considerados clássicos da literatura russa, como Marina Tsvetáieva, Dmítri Merejkóvski, Aleksándr Blok, Vladímir Nabókov, Anna Akhmátova, e muitos outros. ${ }^{387}$

A tendência de venerar o poeta perdurou também ao longo do séc. XX: Daniil Kharms, Andrei Platónov, Mikhaíl Bulgákov, entre outros, dedicaram-lhe seus textos. Na segunda metade do século passado, além de Dovlátov, entre os escritores que dedicaram textos a Púchkin, cabe destacar Andrei Siniávski, que escrevia sob o nome artístico de Abrám Terts, e o seu livro de ensaios, Passeios com Púchkin. Também é inquestionável a presença de motivos puchkinianos na obra de Joseph Brodsky.

Esses são apenas alguns exemplos de admiradores de Púchkin, o que demonstra a importância e o prestígio do poeta no âmbito da literatura russa até os nossos dias. ${ }^{388}$

É importante mencionar que, durante a vida de Púchkin, muitos de seus textos, em primeiro lugar, contos e novelas, foram submetidos a duras críticas, principalmente nos anos 1830, já no final de sua vida. Por um lado, o escritor fora acusado por parte dos críticos de orientação mais democrática, representantes de raznotchíntsy, ${ }^{389}$ que apenas começava a "ganhar voz" naquela época, de representar demais a nobreza da literatura russa. Por outro, quanto à sua prosa, o escritor fora acusado de simplificar demais a linguagem e de empregar palavras impróprias. Em 1834, o crítico literário Vissarion Belínski escreveu que "com o ano 1830 (...) de repente acabou o Período Puchkiniano, assim como acabou o próprio Púchkin, e junto com ele toda a sua influência". ${ }^{390}$ Ao analisar a incompreensão da obra de Púchkin nesse período por seus contemporâneos, Iúri Lótman chega à conclusão de que Púchkin havia se antecipado muito a seu tempo, e por isso "o brilho criativo puchkiniano não tinha eco em seu meio e na sua época".391

\footnotetext{
${ }^{387}$ Muitas citações dos grandes escritores e pensadores russos sobre Púchkin, desde os mencionados textos de Gógol e Dostoiévski até às expressões de Aleksándr Soljenítsyn e emigrados russos da Primeira onda, foram compilados nos dois volumes da coletânia $O$ sol da Rússia. Escritores russos sobre Púchkin (em russo, Sólntse Rossíi. Rússkie pissáteli o Púchkine), organizada por A. Romanienko (ROMANIENKO, A. (org.) Sólntse Rossíi. Rússkie pissáteli o Púchkine. Viek XIX. Moscou: Drujba naródov, 1999).

${ }^{388}$ Cabe mencionar que o nome e a obra do poeta continuam sendo atuais e relevantes também nos nossos dias, no século XXI: prova disso é o fato de que, por um lado, continuam ativamente as pesquisas referentes à figura e a obra de Púchkin, e também muitos escritores e poetas continuam a se inspirar no escritor clássico do século XIX. Por exemplo, o ciclo de contos da escritora Liudmila Petruchévskaia, Canções dos eslavos orientais (em russo, Piésni vostótchnykh slavián, 1990), foi inspirado e dialoga com o ciclo de poemas de Púchkin Canções dos eslavos ocidentais (em russo, Piésni západnykh slavián, 1835), que, por sua vez, se inspira em de La guzla, de Prosper Mérimée. Também o "texto de Púchkin" (púchkinski tiekst) e alusões à obra do poeta estão presentes na obra de Tatiana Tolstáia, em particular, no seu romance Kys (2000).

${ }^{389}$ Chamavam-se de raznotchínsty pessoas que possuiam formação, mas não pertenciam à aristocracia. Na literatura e no publicismo, os raznotchínsty costumavam contrapôr-se à nobreza, como portadores da nova ideologia progressista e liberal. Entre os mais famosos raznotchíntsty podemos mencionar os críticos literários e escirtores Vissarion Belínski e Nikolai Dobroliúbov, o filósofo Nikolai Tchernychévski.

${ }^{390}$ LÓTMAN. Púchkin. Biográfia Pissátielia. Roman "Ievguéni Oniéguin”. Kommentárii. Op. cit., p. 219 - 220.

${ }^{391}$ Ibid., 213.
} 
Serguei Dovlátov: texto de cultura na literatura russa contemporânea

No entanto, entre os leitores, o escritor sempre obteve reconhecimento. Desde os anos 1840 (ou seja, não muito depois de sua morte, que aconteceu em 1837), a obra de Púchkin começou a ser introduzida nas escolas russas, o que contribuiu consideravelmente ao aumento de sua notoriedade. Assim, o nome do poeta e sua obra pouco a pouco ficaram conhecidos em todas as camadas sociais, o que foi também estimulado pelas quedas das taxas de analfabetismo no país. ${ }^{392} \mathrm{Na}$ década de 1880, sua fama na Rússia já era gigantesca. Um dos emblemas desse reconhecimento foi o já citado monumento erguido em homenagem ao poeta na Praça Strastnáia (atualmente, Praça Púchkinskaia), no centro de Moscou, em 6 de junho de 1880 (no dia de seu aniversário), hoje um dos pontos mais visitados na cidade. Os recursos para a construção do monumento vieram de doações da população.

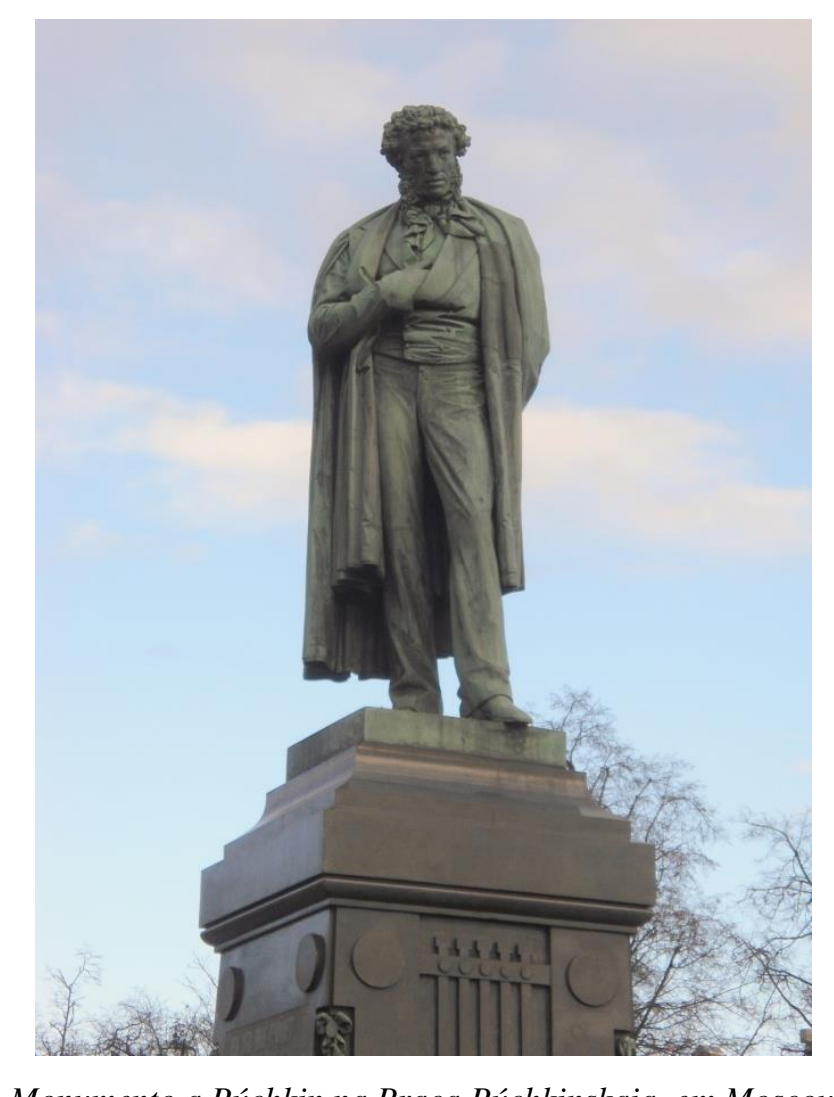

Monumento a Púchkin na Praça Púchkinskaia, em Moscou

A que se deve uma veneração e um amor tão incodicionais por parte da população russa? Além de reconhecimento como artista, logo após a morte do poeta começou a se consolidar o mito em torno de sua personalidade. Como assinala Zaguidúllina, a formação do mito iniciou-se em círculos intelectuais da elite russa, estendendo-se, com a diminuição do alfabetismo e a difusão de sua obra, a camadas sociais mais amplas. ${ }^{393}$

392 ZAGUIDÚLLINA. Op. Cit., p. 40.

${ }^{393}$ Ibid., p. 38. 
Serguei Dovlátov: texto de cultura na literatura russa contemporânea

Além disso, é preciso lembrar que na Rússia a literatura sempre foi "o assunto de grande importância política e nacional”, nas palavras de Svetlana Boym. ${ }^{394}$ Os literatos sempre tiveram uma grande infuência na vida do país, e é por isso que o número de monumentos a poetas podia competir com monumentos a czares e, posteriormente, na época soviética, com monumentos a líderes do partido. Ao se referir ao papel da literatura na vida política do país, Boym aponta que "não é por acaso que muitos dos líderes soviéticos do partido, inclusive os organizadores do Golpe de 1991, eram escritores reconhecidos, que escreviam sob nomes artísticos". 395

Cabe mencionar que os pesquisadores não têm uma resposta única ao porquê do surgimento do mito puchkiniano. Em grande medida, a morte repentina num duelo, no auge de sua carreira, contribuiu para isso: evidentemente, essa morte "heróica" e extemporânea mitificou a figura do poeta na imaginação popular. Nessa recepção da morte de Púchkin presenciamos traços da consciência mitológica, cujos rastros conservam-se na cultura. Assim, como aponta o filósofo, culturólogo, teórico e crítico literário Mikhaíl Epstein, “O melhor começo para um mito é uma morte prematura".396

Outro fator, que favoreceu o aspecto heróico do mito nas esferas populares, foi o fato de Púchkin ter sido morto pela mão de um estrangeiro, ou seja, alguém alheio à Rússia e à sua cultura: Púchkin foi ferido mortalmente, aos 37 anos de idade, por seu cunhado, oficial francês Georges Charles d'Anthès. Devido a essas cirtcunstâncias, a figura de Púchkin passou a ser interpretada como a de um mártir, o que favoreceu a sua "canonização". O motivo do duelo foi o fato de d'Anthès cortejar a esposa de Púchkin, Natália Gontcharova. Cabe mencionar aqui que, como se sabe pelas memórias dos amigos e contemporânes de Púchkin, o poeta tinha caráter explosivo, ofendia-se muito fácil (e também, num ataque de raiva, podia insultar o seu interlocutor), e ao longo de sua vida teve vários conflitos que levaram a duelos. ${ }^{397}$ Várias fontes indicam que o duelo podia ser evitado, e as razões da morte de Púchkin permitiram ao escritor e contemporâneo do poeta Faddei Bulgárin comentá-la da seguinte maneira: "Fazia-se de Byron, e pereceu como uma lebre". ${ }^{398}$ No entanto, no imaginário popular a figura de d'Anthès consolidouse como a de um grande vilão, inimigo da Rússia. Vemos aqui de novo um traço da consciência mitológica, já que na visão popular Púchkin e d'Anthès formaram um par de heróis antagonistas, um "paralelo mitológico", na terminologia de Lótman. 399

Como assinala Zaguidúllina, se a consolidação do mito começara nos anos 1840, e até meados dos anos 1850 a figura de Púchkin ainda não tinha muita importância social, já no final

\footnotetext{
${ }^{394}$ BOYM. Op. cit., p. 170.

395 Ibid.

${ }^{396}$ Apud ZAGUIDÚLliNA, Op. cit., p. 28.

${ }^{397}$ LÓTMAN. Púchkin. Biográfia Pissátielia. Roman “Ievguéni Oniéguin”. Kommentárii. Op. cit., p. 151.

${ }^{398}$ BÍTOV, Andrei. Púchkinskii tom. Moscou: AST, 2014, p. 3.

${ }^{399}$ LÓTMAN. Semiosfera. Op. cit., p. 672.
} 
Serguei Dovlátov: texto de cultura na literatura russa contemporânea do século XIX "passou a ocupar um lugar estável na escala de valores das camadas sociais mais variadas". ${ }^{400}$ Um dos sinais de tal consolidação do mito nesse período é o reflexo de sua obra e mesmo de sua biografia na arte popular: na época, foram bastante difundidos os lubki (sing., lubók), estampas tradicionais que narravam tanto o enredo dos contos e poemas de Púchkin quanto fatos marcantes de sua vida. Uma das chaves para explicar a ampla difusão da obra do poeta, do interesse e veneração da sua personalidade em todas as classes sociais está na acessibilidade de seus textos, já que o escritor usava a mesma linguagem para falar sobre assuntos universais com todos os leitores, seja os da elite russa, seja os das esferas populares.

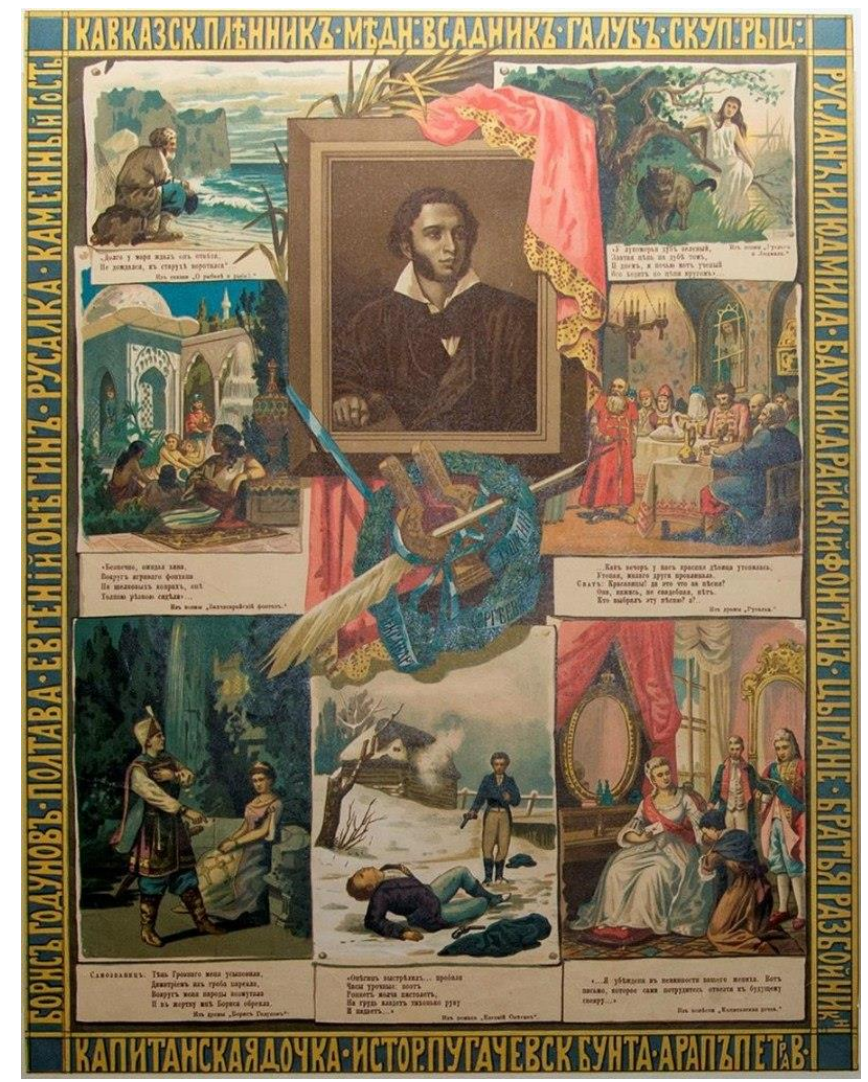

Exemplo de lubók do final de séc. XIX dedicado à obra de Púchkin, com imagens e citações de seus livros

Com a Revolução de Outubro de 1917 e o estabelecimento de um novo regime político, o mito passa por certas transformações: a figura de Púchkin ganha um novo significado e novos traços, conforme os objetivos da nova política e da ideologia do governo. Cabe lembrar aqui as palavras do filósofo e semioticista Roland Barthes, de que o mito "transforma a história na ideologia”, o que ocorre em grande parte na cultura moderna e se realiza hoje em vários aspectos da sociedade e da cultura, como na política, no cinema, na publicidade, etc. Assim, por um lado, o mito é orientado a mudar a realidade e, por outro lado, tem como objetivo criar uma tal 
Serguei Dovlátov: texto de cultura na literatura russa contemporânea imagem da realidade, que coincida com as aspirações dos portadores da consciência mitológica. ${ }^{401} \mathrm{O}$ mito soviético de Púchkin corresponde plenamente a esses propósitos.

A partir dos anos 1920, Púchkin passa a ser visto como um poeta do povo, o profeta da revolução e das ideias democráticas e socialistas. A imagem de um "Púchkin soviético" foi elaborada de modo bem cuidadoso: alguns fatos da vida do poeta foram retirados de seu contexto e manipulados de tal maneira que, de um poeta nobre, Púchkin tornou-se um poeta popular e extremamente politizado. Assim, foi dado maior enfoque a certos aspectos de sua biografia, como a suas opiniões democráticas, a sua amizade com os dezembristas, estes chamados de os primeiros revolucionários da história da Rússia, e a seus constantes conflitos com o governo czarista.

Ao mesmo tempo, foram eliminados da biografia oficial do poeta preconceitos sociais que ele possuía, típicos da aristocracia de sua época, assim como as opiniões mais conservadoras expressadas no final de vida. É muito importante sublinhar aqui que a nova compreensão da figura do poeta, a visão mais "social" de sua vida e de sua obra não foi apenas imposta pelo governo, mas desde o início foi apoiada ativamentes pelas massas, ou seja, o processo de transformação do mito foi recíproco e incentivado tanto "de cima" como "de baixo". O "mito soviético" de Púchkin teve uma recepção calorosa da população, que passou a ver nele não apenas um grande escritor, mas um grande cidadão da Rússia.

Pode-se dizer que o auge da veneração de Púchkin aconteceu nos anos 1930, no período máximo do grande expurgo do governo stalinista. O historiador alemão Karl Schlögel, no seu livro Terror e sonho. Moscou 1937 (título em alemão Terror und Traum. Moskau 1937), dedica um capítulo do livro à celebração do centenário da morte do poeta, em 1937. O livro analisa a complexa e contraditória convivência das repressões, terror, e ao mesmo tempo da fé num futuro próspero na sociedade soviética dos anos 1930. O título do capítulo é O festim nos tempos da peste, título de uma das pequenas tragédias escritas por Púchkin (título em russo, Pir vo vriémia tchumy), em 1830; portanto, o historiador faz uma alusão irônica tanto à obra do poeta quanto à então situação atual do país, já que o ano 1937 representou o máximo das repressões durante o grande expurgo. No capítulo, Shlögel mostra o caráter universal que tiveram os eventos comemorativos, o interesse de todos os cidadãos da União Soviética, independentemente de sua nação e posição social, e inclusive o interesse fora do país. Como assinala o autor, "nos eventos puchkinianos participaram tanto os centros de publicação do escritor quanto especialistas que estudavam a obra do poeta, como os kolkhózniks da aldeia de Strákhovo. ${ }^{402}$

\footnotetext{
${ }^{401}$ BARTHES. Ízbrannye. rabóty: Semiótika. Poétika. Op. cit., p. 111.

${ }^{402}$ SCHLÖGEL, Karl. Terror i mietchtá. Moskvá 1937. Moscou: ROSSPEN: Fond "Prezidiéntskii tsentr B.N. Iéltsina", 2011, p. 186.
} 
Serguei Dovlátov: texto de cultura na literatura russa contemporânea

Tal interesse por parte dos cidadãos soviéticos pode também ser comprovado pelo fato de que, durante o ano de 1936, a tiragem da obra de Púchkin alcançou 18,6 milhões de exemplares, ou seja, durante apenas um ano foram publicados mais livros do que em todo o período antes da Revolução, e os textos do poeta foram traduzidos e publicados em 52 línguas das nações da União Soviética. ${ }^{403}$

A novidade do período consiste na transformação de Púchkin num fenômeno da cultura de massa: a imagem e a obra de Púchkin foram assimiladas pela cultura de massa ainda já no século XIX (um exemplo disso são os mencionados lubki); no entanto, a partir dos anos 1930 a imagem do poeta começa a estar presente em todos os lugares e de todas as formas. Erguem-se novos monumentos a Púchkin, o seu nome é dado a ruas, praças e instituções de diferentes tipos. Nesse período, por exemplo, atrubuiu-se o nome de Púchkin ao Museu de Belas Artes de Moscou; também a Praça Strastnáia, onde se encontra o mencionado monumento ao poeta, foi renomeada como Praça Púchkinskaia, isto é, "Praça de Púchkin”. Além disso, o rosto do escritor aparece em cartazes, selos, rótulos e até produtos artesanais. Tal veneração passa por todo o país, em todas as repúblicas soviéticas: como assinala Schlögel, o aniversário é comemorado "nos espetáculos pomposos em teatros de ópera de Kíev e Tbilisi, em palácios de cultura de Tashkent e Asgabade". O historiador conclui que, graças à comemoração desse renascimento, Púchkin se tornou "ícone da cultura soviética". 404

Cabe comentar aqui a massiva renomeação de topônimos e a atribuição do nome de Púchkin a diferentes instituções, como teatros, museus, escolas, bibliotecas etc. Lótman assinala que, na Rússia, tal tradição (a de mudar nomes de topônimos) surgiu e se consolidou no séc. XVIII, na época do reinado de Pedro, o Grande. Como aponta o pesquisador, a tradição remonta aos tempos arcaicos e guarda traços da consciência mitológica: como na visão mitológica não há distinção entre o objeto e o seu nome, o ato de mudar o nome é concebido como criação de algo novo (no caso do mito puchkiniano do século XX, do novo próspero mundo socialista soviético), já que tal renomeação é compreendida como "a eliminação da coisa antiga e o nascimento no seu lugar de uma coisa nova, que corresponde melhor às aspirações do iniciador desse ato". 405

Ao criar "o novo mundo", a ideologia soviética stalinista, nas palavras de Schlögel, gerou um novo culto, que se tornou muito mais influente do que se imaginava:

...as comemorações puchkinianas criaram um culto que se baseava num fundamento mais amplo do que meramente político: no fundamento da cultura. (...) Essa era a autoridade de uma grande cultura, da qual tentava aproveitar-se o

\footnotetext{
403 Ibid.

404 Ibid., 187.

${ }^{405}$ LÓTMAN. Semiosfera. Op. cit., pp. 537 - 538.
} 
Serguei Dovlátov: texto de cultura na literatura russa contemporânea

poder fraco e experiente em usar violência para fortalecer o seu império. Era a autoridade e a ordem da cultura, na qual o povo buscava e às vezes conseguia encontrar refúgio em tempos de desassossego e perturbações. ${ }^{406}$

O mito puchkiniano superou, portanto, as fronteiras geográficas: paralelamente ao mito oficial soviético, no meio dos emigrados russos, a partir dos anos 1920, desenvolvia-se outra variante do mito ${ }^{407}$ do poeta. Conforme a consolidação do regime soviético, a emigração sentia mais e mais "a sua missão de portadora do espírito nacional russo, a conservadora das tradições da cultura e da liberdade". 408

Como para os soviéticos, para os emigrados russos, a figura de Púchkin também era pensada como símbolo e ícone da cultura russa, assim como um ponto de referência e um ideal tanto ético (devido à capacidade do poeta de integrar em sua obra tanto as tradições ocidentais, como a autêntica cultura russa) como estético (pela forma perfeita do seu verso). Em Púchkin, os emigrados viam um dos principais símbolos da Rússia pré-revolucionária, cujo legado devia ser resguardado. Tal postura vem expressa no artigo de Dmítri Merejkóvski Púchkin conosco (em russo, Púchkin s nami), escrito no ano do centenário da morte do poeta: "Se ele [Púchkin] existe, ela [a Rússia] existe. E por mais que nos assegurem que ela não existe mais, porque o próprio nome da Rússia foi apagado da terra, basta só lembrar Púchkin para certificar-se de que a Rússia existia, existe e vai existir (...) Ele é o pilar de fogo que nos leva pelo deserto do exílio à Terra natal". 409

Nessa frase, Merejkóvski expressa as opiniões da maioria dos representantes da colônia russa, e, como aponta o escritor Gleb Struve, "em geral, a emigração escolheu Púchkin como a bandeira da sua cultura". ${ }^{410}$ Desde 1925 o aniversário de Púchkin era comemorado em todos os centros da colônia russa, considerado o "dia da cultura russa". Também nos anos 1930, foi criada em Nova Iorque a Sociedade Puchkiniana (em inglês, Pushkin Society), que existe e funciona até hoje. Outro sinal da importância de Púchkin para os representantes da emigração é o fato de que, por exemplo, o círculo parisiense dos Merejkóvski foi chamado "A lâmpada verde” (em russo, Zeliónaia Lampa), em homenagem ao círculo literário que existia em São Petersburgo nos anos 1819 - 1820, e um de cujos membros era Púchkin. Galin Tihanov, em seu livro Narrativas do Exílio: Cosmopolitismo além da Imaginação Liberal, cita os seguintes dados, que demonstram o

\footnotetext{
${ }^{406}$ SCHLÖGEL. Op. cit., pp. $202-203$.

407 No seu trabalho, Marina Zaguidúllina sublinha que existe só um mito puchkiniano, e todas as manifestações desse mito em diferentes lugares e em diferentes épocas "são variantes do "mito básico", que é único na sua natureza sociocultural" (Op. cit., p. 8).

408 STRUVE. Op. cit., p. 42.

409 MEREJKÓVSKI, Dmítri. Púchkin s námi, 1937.

${ }^{410}$ STRUVE. Op. cit., p. 136.
} 
Serguei Dovlátov: texto de cultura na literatura russa contemporânea vivo interesse pela figura de Púchkin entre os emigrados: segundo as estimativas de M. Filin, os representantes da Primeira Onda de Emigração escreveram em torno de 100 livros e mais de 1500 artigos dedicados a Púchkin, e o centenário de sua morte foi comemorado em 231 cidades em 42 países nos 5 continentes. ${ }^{411}$ Em 1937, foram dedicados ao poeta artigos e ensaios de grandes representantes da literatura e crítica russas na emigração, como Marina Tsvetáieva, que na época morava em Paris (ensaio Meu Púchkin (em russo, Moi Púchkin)), Dmítri Merejkóvski (Púchkin conosco ${ }^{412}$ ), Vladímir Nabókov (Púchkin, ou A verdade e a verossimilhança), o crítico literário Alfred Bem (artigo O milagre de Púchkin (em russo, Tchudo Púchkina), entre outros.

Voltemos às caraterísticas do mito puchkiniano na União Soviética e vejamos com detalhe que "correções" em prol da ideologia sofreram a imagem e a biografia do poeta.

Nos anos 1820, Púchkin era conhecido por suas opiniões democráticas, baseadas na filosofia do Iluminismo, principalmente a de Jean-Jacques Rousseau, assim como pela proximidade com os círculos revolucionários da época e a amizade com os dezembristas. Embora o próprio escritor não participasse das sociedades secretas que existiam na época, conhecia bem muitos dos seus membros e, evidentemente, compartilhava as suas ideias, o que se refletia tanto em sua poesia, como nas cartas aos amigos. E entre os participantes da Revolta Dezembrista $^{413}$ havia muitos amigos da infância de Púchkin, seus condiscípulos da época do $\mathrm{Liceu}^{414}$ (dois amigos dezembristas mais famosos do poeta são Ivan Púschin e Wilhelm Küchelbecker; após a participação na revolta ambos foram condenados a vinte anos de trabalhos forçados na Sibéria). ${ }^{415} \mathrm{O}$ ambiente no qual vivia o escritor, as suas amizades e suas opiniões refletiram-se em sua obra (principalmente em sua poesia política), o que o levou a vários

\footnotetext{
411 TIHANOV, Galin. Narrativas do exílio: Cosmopolitismo além da imaginação liberal. São Carlos: Pedro \& João Editores, 2013, pp. $52-53$.

${ }^{412} \mathrm{O}$ artigo mais famoso de Merejkóvski dedicado ao poeta é o artigo Púchkin, publicado pela primeira vez em 1896. Nele, o escritor analisa a importância do poeta tanto para a tradição literária russa como para a universal, comparando o tamanho do gênio de Púchkin com o de Goethe. Para Merejkóvski, "toda a literatura russa deriva de Púchkin" (MEREJKÓVSKI, D. "Púchkin". IN: Viétchnye spútniki. Portriéty iz vsemírnoi literatúry. São Petersburgo: Naúka, 2007, p. 238).

${ }^{413}$ Chama-se de Revolta Dezembrista a tentativa de golpe de estado que aconteceu em São Petersburgo, no dia 14 de dezembro de 1825. Foi organizada pelo grupo de aristocratas russos com o objetivo de impedir a coroação de Nicolau I, após a morte do seu irmão mais velho Alexandre I. O plano dos rebeldes era eliminar a monarquia autoritária na Rússia, assim com a servidão.

${ }^{414}$ O Liceu Imperial de Tsárskoie Seló (em russo, Imperátorski Tsarskossiélski Litsei), fundado sob a ordem de Alexandre I, foi um colégio privilegiado para filhos dos aristocratas russos. O Liceu existiu de 1811 a 1843 , e Púchkin pertencia à primeira geração de seus alunos. O poeta sempre sublinhou a ifluência que exerceram nele o tempo passado no Liceu, seus professores e alunos, e dedicou a ele vários poemas e textos.

${ }^{415}$ Cabe mencionar que o próprio poeta, que dedicou vários poemas a seus amigos dezembristas, considerava como uns dos principais assuntos de sua vida, nas palavras de Lótman, "o papel do defensor dos dezembristas" (LÓtMAN. Púchkin. Biográfia Pissátielia. Roman "Ievguéni Oniéguin”. Op. cit., p. 131). Como se sabe, Púchkin chegou a falar do assunto com o czar, pedindo atenuação da pena para os dezembristas (Ibid.).
} 
Serguei Dovlátov: texto de cultura na literatura russa contemporânea

conflitos com o governo dos czares Alexandre I e Nicolau I, e a dois exílios. ${ }^{416}$ Cabe mencionar que ao longo da vida, as opiniões de Púchkin evoluíram: com a idade, após o fracasso da Revolta Dezembrista e o choque com o destino trágico dos seus participantes, ${ }^{417}$ o poeta passou a questionar a "visão romântica" dos dezembristas, e com ela a possibilidade de uma revolta na Rússia como caminho para mudar a sociedade. O poeta tinha um profundo interesse pela história da Rússia, e, como assinala Lótman, ao estudar a história da Rússia, Púchkin chega à ideia do passo natural do desenvolvimento histórico: segundo o pesquisador, Púchkin via a história como "um processo progressivo, determinado pelas causas profundamente ocultas e objetivas". 418 Reflexões de Púchkin a esse respeito estão presentes na obra do escritor dedicada aos acontecimentos e figuras históricas da Rússia, como no poema Poltava, na tragédia Boris Godunóv, ou na novela A filha do capitão.

Outro grande interesse do escritor, importante de se mencionar, é a cultura russa popular, as origens folclóricas, e, de um modo geral, "o espírito do povo", nas palavras de Lótman. ${ }^{419}$ Uma das ideias inovadoras de Púchkin foi a síntese em sua obra das tradições literárias europeias e da cultura popular russa. O poeta começou a estudar o folclore russo sistematicamente no seu exílio em Mikháilovskoe, onde, além de estudar a literatura dedicada ao tema, Púchkin anotava também os contos orais, que ouvia da sua babá, a serva Arina Rodiónovna, assim como de outros servos camponeses.

Como assinala Lótman, “o folclore é para Púchkin um caminho para a compreensão da psicologia do povo, e o passado histórico, estudado sem a subjetividade romântica, o meio de compreensão do presente". ${ }^{420}$ Um dos textos de Púchkin, em que confluem os dois temas, é a sua novela A filha do capitão. Nela, Púchkin estuda o tema da rebelião camponesa de $1772-1775$ sob o mando de Emelián Pugatchóv, chamada de "guerra camponesa", e discute o profundo problema do abismo cultural, que existia entre a nobreza russa e os camponeses. Em grande

\footnotetext{
${ }^{416}$ O primeiro exílio aconteceu em 1820, quando, devido a várias delações ao governo do czar Alexandre I sobre os poemas livres, epigramas e opiniões liberais do jovem poeta, Púchkin foi transferido de São Petersburgo ao serviço no sul do país, na chancelaria de Chisinau (capital da atual Moldávia), onde passou quatro anos, até 1824. Como assinala Iúri Lótman, o fato de Púchkin ser destinado ao serviço no sul, e não a um exílio em Sibéria ou nas Ilhas Solovki, foi o mérito dos amigos de Púchkin, como o historiador e escritor Nikolai Karamzin, o filósofo Piotr Tchaadáiev, entre outros, que conseguiram comutar o destino do poeta. O segundo exílio aconteceu em 1824. A razão formal para o exílio foi a carta interceptada pela polícia de Moscou, na qual o poeta confessava o seu interesse pelas "ideias ateístas" (LÓTMAN. Op. cit., p. 105). Púchkin foi exilado em sua propriedade de Mikháilovskoe, onde permaneceu até 1826.

417 Entre os participantes da Revolta, cinco foram condenados à morte e 120 aos trabalhos forçados ou ao confinamento na Sibéria. Lótman aponta que tal pena foi muito impactante para os contemporâneos, que esperavam clemência por parte do novo czar, pois na Rússia, com algunas poucas exceções (assim foi, por exemplo, o caso de Emelián Pugatchóv), não se aplicava a pena de morte desde a época da rainha Elizaveta Petrovna. Além do mais, todos os líderes da revolta pertenciam às famílias mais nobres da Rússia (LÓTMAN. Op. cit., p.128).

${ }^{418}$ LÓTMAN. Púchkin. Biográfia Pissátielia. Roman "Ievguéni Oniéguin". Op. cit., p. 139.

${ }^{419}$ LÓTMAN, Iú. "Osnovnye etápy razvítia rússkovo realizma". IN: O Rússkoi Literature. São Petesburgo: Iskusstvo - SPB, 2005, p. 535.

${ }^{420}$ LÓTMAN. Púchkin. Biográfia Pissátielia. Roman "Ievguéni Oniéguin”. Op. cit., p. 121.
} 
Serguei Dovlátov: texto de cultura na literatura russa contemporânea medida, o livro apresenta as reflexões do poeta após o fracasso dezembrista: no texto, percebemse as profundas dúvidas de Púchkin quanto à possibilidade de uma revolução sem a participação do povo, e ao mesmo tempo as dificuldades para compreender a mentalidade popular. Ao analisar os participantes da rebelião e os militares do governo que lutavam contra o exército dos rebeldes, Púchkin reflete sobre as origens e as razões que teriam levado à guerra, tentando ser objetivo, e chega à conclusão de que as duas partes tinham sua verdade e seu conceito de justiça e, portanto, que não havia como achar um culpado nem como resolver o conflito entre o camponês e o nobre.

Esses dois aspectos da vida e da obra do escritor, as opiniões liberais e o interesse pela cultura popular foram manipulados pela ideologia soviética. O novo governo precisava de um símbolo da cultura e do país, que fosse conhecido pela maioria da população e que, ao mesmo tempo, representasse a história da Rússia e pudesse transmitir essa nova ideologia soviética. Podemos resumir as principais transformações efetuadas pela ideologia soviética da seguinte maneira, extraíndo as principais teses:

1) Púchkin é um poeta popular. Foi esquecida a descendência nobre do escritor e eliminados da sua biografia oficial os preconceitos sociais que ele possuia, típicos para um aristocrata da época. Como se sabe, o próprio escritor orgulhava-se da história de sua linhagem, que contava com quase 600 anos, e em vida fora acusado várias vezes de "aristocratismo literário”. Assim, um dos seus adversários literários, o jornalista Nikolai Nadiéjdin, chamava Púchkin "o brilhante líder da literatura da nobreza". ${ }^{421}$ Para Púchkin, a memória do seu passado era um dos principais tesouros de um povo, que determinava a sua cultura, assim como a sua dignidade, o respeito por si mesmo, por isso o escritor via justamente na nobreza russa, com a sua história, os possíveis conservadores do patrimônio cultural, e considerava os aristocratas russos "uma fonte poderosa do futuro desenvolvimento social". ${ }^{422}$ No entanto, partindo do interesse de Púchkin pela cultura popular, na União Soviética foi desenvolvida a ideia do escritor como um poeta próximo ao povo, defensor dos camponeses.

Ao mesmo tempo surge o mito de uma babá como a principal e a mais relevante figura em sua vida, para dar suporte a essa imagem: sua babá, Arina Rodiónovna, realmente em grande medida inspirou o interesse de Púchkin pelo folclore russo e o poeta lhe dedicou vários poemas. Na URSS, os poemas dedicados à babá formam parte obrigatória e indispensável no programa educativo de literatura e de cultura na escola primária e secundária.

421 Ibid., p. 161.

422 Ibid. 
Serguei Dovlátov: texto de cultura na literatura russa contemporânea

2) Púchkin é um poeta da revolução e mártir do regime autoritário czarista. A amizade com os dezembristas, as opiniões democráticas e as relações tensas com o governo que o levaram ao exílio são colocados como determinantes na vida do escritor. Os poemas políticos de Púchkin, dedicados aos dezembristas, recebem a maior atenção e se tornam foco de estudos.

O enfoque em processos históricos, e na história da Rússia mais especificamente, sempre foram de grande interesse para o escritor, e em sua obra ele reflete sobre vários momentos da história do país. No entanto, na União Soviética, a profunda análise histórica de Púchkin e as suas ideias foram simplificadas e tratadas de tal maneira que se confirmava que o escritor, por exemplo, na novela A filha do capitão, apoiava o camponês que se revoltara contra o poder oficial, provando assim suas opiniões próximas ao regime comunista.

É curioso também comentar que papel recebe a figura de George Charles d'Anthès, que feriu mortalmente Púchkin no duelo. Como dito, desde o momento da morte do escritor, no imaginário popular, o jovem francês passa a ser visto como um vilão forasteiro. Na URSS, além de sublinhar o fato de que Púchkin havia sido morto na mão de um estrangeiro, aparece a interpretação de que d'Anthès era cúmplice do governo autoritário, praticamente dirigido para provocar o escritor e incentivar o duelo. Tal ponto de vista é expresso num dos artigos do jornal Pravda, dedicados ao centenário da morte de Púchkin, citados por Schlögel, onde d'Anthès é chamado de "biltre estrangeiro aristocrático, mercenário do czarismo". ${ }^{423}$

Como aponta Schlögel, o auge do antagonismo nacional entre d'Anthès e Púchkin no mito soviético aconteceu na época da luta contra o cosmopolitismo, nos anos 1948 - 1953 , quando o governo lutava contra as ideias pro-ocidentais, que parte da intelligentsia soviética partilhava. Também nesse período começou a se negar ativamente a influência da tradição ocidental na obra de Púchkin, e a se sublinhar a origem nacional russa. Assim, em 1949, durante as comemorações do aniversário de 150 anos de Púchkin, nas palavras do historiador, "o poeta converteu-se num nacionalista militante e estreito". 424

3) A descendência africana de Púchkin como símbolo de internacionalismo. Outro fato importante para a transformação ideológica da imagem do poeta foi o fato de que o bisavô de Púchkin, Abram Gannibal (1696 - 1781), fora africano, filho de um príncipe da Abissínia, escravizado na infância por turcos e posteriormente dado de presente ao imperador Pedro, o Grande. O próprio Púchkin gostava de lembrar as suas raízes africanas, e inclusive dedicou ao

\footnotetext{
${ }^{423}$ SCHLÖGEL. Op. cit., p. 191.
}

${ }^{424}$ Ibid., p. 203. 
Serguei Dovlátov: texto de cultura na literatura russa contemporânea

bisavô uma novela, em 1827, que após a morte do poeta recebeu o título $O$ negro de Pedro, o Grande (em russo, Arap Petrá Velíkovo). ${ }^{425}$

Na URSS, foi dada grande ênfase a esse fato, que passou a apoiar a ideia do internacionalismo e amizade entre diferentes nações, um dos pontos importantes da ideologia do país multinacional que unia várias nações e etnias, como era a União Soviética. Tal afirmação poderia parecer contraditória, tendo em conta a mencionada luta contra o cosmopolitismo e a interpretação da figura de d'Anthès. No entanto, se d'Anthès era francês, ou seja originário de um país capitalista e alheio à cultura e ideologia soviética, os povos africanos, assim como os povos latinoamericanos, eram vistos como amistosos, que representavam as regiões oprimidas e exploradas pelos regimes imperialistas e lutavam por sua liberdade.

4) Púchkin é um ser humano ideal, que não possui defeito algum. Foram esquecidos todos os fatos e qualificadores que pudessem, de alguma maneira, prejudicar a imagem do poeta. Assim, da biografia oficial soviética do poeta foi eliminado o fato de Púchkin ser "mulherengo": passou a ser esquecida a famosa "lista de Don Juan" de Púchkin, escrita a mão, na qual o poeta enumerava todas as mulheres pelas quais fora apaixonado ou tivera relações, assim como as menções dos numerosos relacionamentos e pedidos de casamento. Outro fato "esquecido" foi a vida boêmia que o poeta gostava de levar, que aparecem em vários materiais biográficos, assim como nos poemas de Púchkin, como na famosa Canção báquica (em russo, Vakhítcheskaia piésnia, 1825).

Também, como referido, desde a época do Liceu, Púchkin era famoso por ter um caráter explosivo e ser suscetível a qualquer crítica ou ironia, sempre disposto a brigar para defender a sua dignidade e o seu nome, o que sempre dificultou suas relações e ao longo da vida levou o poeta a uma "série de chamadas precipitadas a duelos" por ele convocados. ${ }^{426}$ No entanto, essas características de sua personalidade também foram deslocadas do foco de atenção e até a morte de Púchkin em duelo foi apresentada na União Soviética como uma morte heróica por um motivo elevado. Nesse período, chegou-se a defender não um duelo por causa dos ciúmes por sua mulher, mas por uma conspiração do governo contra o poeta. ${ }^{427}$

\footnotetext{
${ }^{425}$ O próprio autor não deu ao texto nenhum título.

${ }^{426}$ LÓTMAN. Púchkin. Biográfia Pissátielia. Roman “Ievguéni Oniéguin”. Kommentárii. Op. cit., p. 151.

${ }^{427}$ Como aponta Lótman, não há evidências da participação ou nem da aprovação por parte do czar nos rumores provocados pela posição insinuante de Púchkin e de sua mulher, devido aos cortejos de d'Anthès, que se discutiam ativamente pela alta sociedade. O pesquisador assinala que a única culpa que tinha Nicolau I era a criação "daquela atmosfera na Rússia, na qual Púchkin não podia sobreviver (...) e naquela falta da liberdade que gota por gota tirava a vida do poeta" (Ibid., p. 223). Aqui Lótman refere-se ao constante controle sob o poeta por parte dos gendarmes do governo, assim como à posição humilhante para Púchkin no serviço forçado na corte do czar, que levaram à tensão psicológica que aquele vivia no último período de sua vida, e que ainda mais agudizaram a sensibilidade do poeta a qualquer ofensa.
} 
Serguei Dovlátov: texto de cultura na literatura russa contemporânea

Como assinala Marina Zaguidúllina, o mito do Púchkin soviético foi consolidado completamente nos anos 1970: ${ }^{428}$ nessa época, em toda cidade soviética havia uma rua, praça ou avenida (ou até as três) com o nome de Púchkin; existiam uma ou várias instituições do governo nomeadas em sua homenagem (sejam teatro, museu, biblioteca, escola ou universidade), sem falar dos inúmeros bustos e monumentos.

No ensino médio, o estudo da biografia e da obra do escritor era obrigatório e, como resultado, para esse período na União Soviética não havia ninguém que não reconhecesse o retrato de Púchkin (sempre de suíças) e não soubesse de memória algum verso de seus poemas e fatos de sua biografia como: ter uma babá, ter bisavô africano e morrer depois de um duelo aos 37 anos. Assim, na consciência de uma pessoa comum, a biografia e a obra do escritor poderiam ser resumidas na seguinte fórmula-esteriótipo: "Púchkin é um grande e genial poeta de cabelo encaracolado e de suiças, que escreveu poemas alegres e radiosos sobre o amor, contos de fada para crianças, que cantou o inverno e o outono russos, autor do romance em versos Ievguéni Oniéguin, e que foi morto num duelo". 429
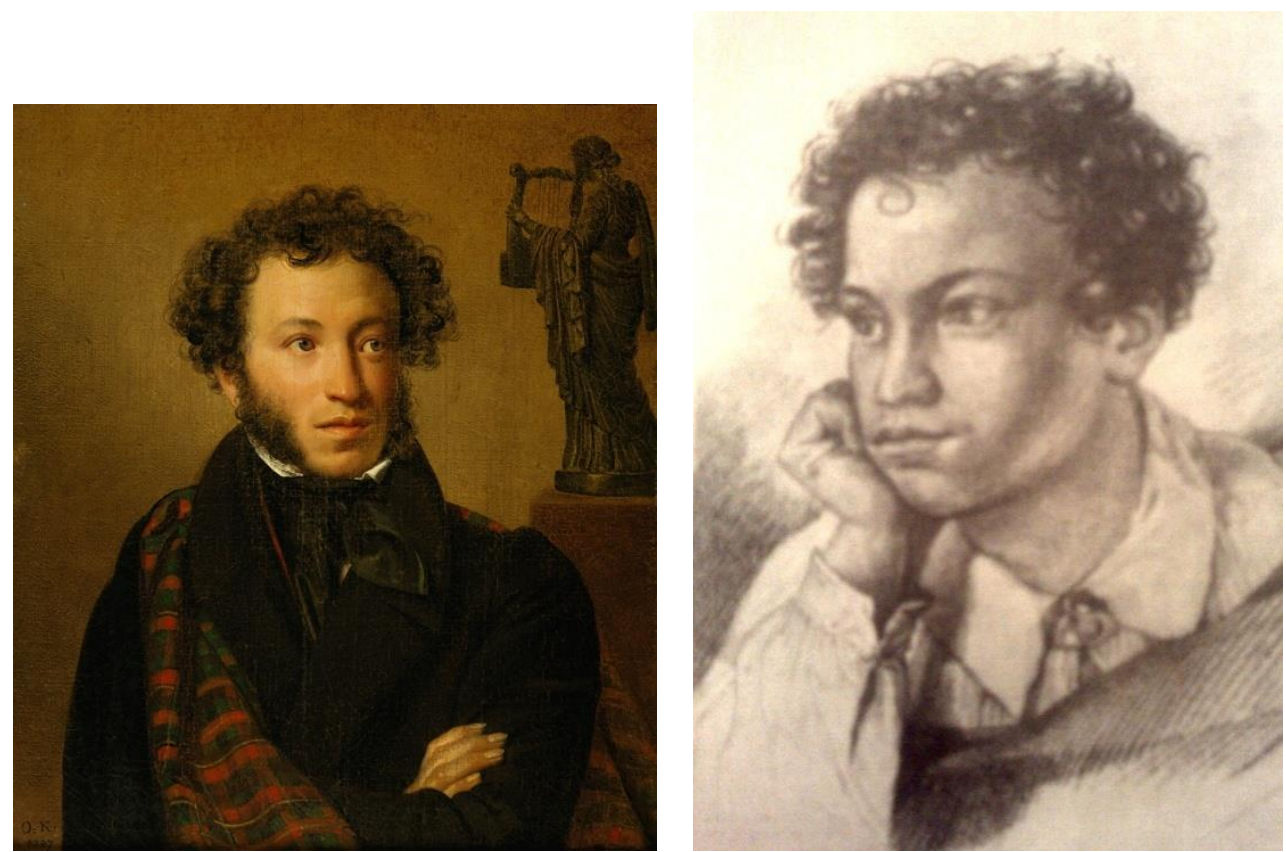

Dois famosos retratos de Púchkin, tradicionalmente colocados em escolas em salas de aula de literatura: a esquerda, o retrato feito por Orest Kipriénski (1827); ${ }^{430}$ a direita, o retrato de Púchkin na adolescência, atribuido a Karl Briullóv (1822).

\footnotetext{
428 ZAGUIDÚLLINA. Op. cit., p. 17.

${ }^{429}$ Ibid., p. 179.

${ }^{430} \mathrm{O}$ poeta dedicou ao retrato feito por Kipriénski um poema, Kipriénskomu (“A Kipriénski”, 1827), uma das linhas na qual põe: "Vejo-me como num espelho, mas esse espelho me adula" (Sebiá kak v ziérkale iá víju, no eto ziérkalo mnié lstit) (PÚCHKIN, A. Sotchiniénia v triokh tomakh. V. 1. Stikhotvoriénia. Skázki. Ruslán i Liudmila. Moscou: Khudójestvennaia literatura, 1985, p. 401).
} 
Serguei Dovlátov: texto de cultura na literatura russa contemporânea

No processo da formação do mito soviético, todos os lugares conservados que tinham relação com a vida do poeta receberam um status especial: os apartamentos em Moscou e São Petersburgo, onde Púchkin morou tornaram-se apartamentos-museu; também em 1949, com motivo do aniversário de 150 anos do poeta foi inaugurado o Museu Liceu, museu memorial no antigo prédio do Liceu Imperial, na cidade de Púchkin (o nome que recebeu a antiga Tsárskoe Seló). Em Moscou, trata-se do prédio na rua Arbat, onde Púchkin alugou um apartamento durante seis meses (de desembro de 1830 a maio de 1831), logo após o seu casamento com Natália Gontcharova; e em São Petersburgo, foi transformado em museu o apartamento na marginal do rio Moika, onde o poeta passou o último ano de sua vida (os Púchkin mudaram-se para esse apartamento em 1836). Também em 1949 foi inaugurado um parque museu em Bóldino, uma das propriedades da familia Púchkin desde o final do século XIV (após a morte do pai, Serguei Lvóvitch Púchkin, a propriedade foi herdada pelo irmão do poeta, Lev Serguéievitch). Um dos centros e a meca do mito soviético puchkiniano era a propriedade familiar dos Púchkin na aldeia de Mikháilovskoe. O poeta frequentou essa propriedade ao longo de sua vida e passou ali um exílio, em 1824-1826, e também em Mikháilovskoe, no Mosteiro Sviatogórski, encontra-se o seu túmulo.

A importância desse lugar, relacionado com o nome de Púchkin, para a cultura e a história da Rússia compreendia-se já no final do século XIX: em 1899, no ano do centéssimo aniversário do poeta, o governo comprou a propriedade dos seus herdeiros, e em 1911 ali foi inaugurado o primeiro museu da memória de Púchkin. No entanto, em 1918, após a Revolução, Mikháilovskoe, junto com outras propriedades da nobreza em sua volta, foi saqueado e queimado. Em 1922, o novo governo soviético conferem a Mikhálivoskoe, é igualmente a outra propriedade vizinha, Trigórskoe, onde moravam os amigos de Púchkin e onde ele havia passado bastante tempo, o status do patrimônio histórico. Para as comemorações do ano 1937, foram reconstruidas a casa-museu do poeta e algumas outras construções. Também nesse período fora ampliado o território do parque museu, que passou a incluir mais algumas aldeias em sua volta. Infelizmente, durante a Segunda Guerra Mundial, uma grande parte dos edifícios do complexo histórico foi arruinada. O parque cultural voltou a abrir-se em 1949, no ano de aniversário de 150 anos de Púchkin (para esse momento foram reconstruídas as principais construções de Mikháilovskoe e o Mosteiro Sviatogórski; outras partes do museu seriam reabertas mais tarde, já nos anos 1960). Como demonstra a história de Mikháilovskoe e seus arredores, de fato no parque museu não restou praticamente nada do período frequentado por Púchkin (a casa onde morava Púchkin fora reformada por seu filho ainda nos anos 1850 e perdera o aspecto que tinha em vida do poeta, e posteriormente a propriedade fora queimada e saqueada várias vezes). Também se conservaram poucos pertences do poeta e de sua familia, e a maior parte das peças do museu são 
Serguei Dovlátov: texto de cultura na literatura russa contemporânea ambientações da época. No entanto, o parque museu sempre foi um dos lugares do maior interesse turístico no país, e até hoje segue recebendo turistas.

Como aponta Dobrozrákova, em seu livro Mitos de Dovlátov e mitos sobre Dovlátov: problemas de morfologia e estilística (em russo, Mífy Dovlátova i mífy o Dovlátove: problémy morfológuii $i$ stilístiki), há muitas razões para afirmar que "na cultura russa existe um único supertexto (em russo, sverkhtiekst) de Mikháilovskoe, que reflete o locus artístico de Mikháilovskoe-Trigórskoe", e que começa a funcionar desde o ano 1817 (quando Púchkin pela primeira vez visitou Mikháilovskoe já adulto), no legado epistolar de Púchkin, e até os nossos dias, tanto em obra artística como em textos críticos, jornalísticos e científicos de autores modernos. ${ }^{431}$ O lugar de Mikháilovskoe-Trigórskoe como fenômeno da cultura russa é inseparável do nome de Púchkin, seus antepassados e fatos da biografia do poeta. No século XX, vários escritores dedicaram seus textos a esse lugar simbólico para a cultura russa; entre eles, podemos destacar o romance do escritor soviético I. Nóvikov Púchkin em Mikháilovskoe (em russo, Púchkin v Mikháilovskom), a peça de K. Paustóvski O nosso contemporâneo (em russo, Nach sovremiénnik), o ciclo de poesia de V. Sosnora Colinas de Púchkin (Púchkinskie góry), Parque cultural, de Dovlátov, ${ }^{432}$ entre outros.

Desde os anos 1970 e até o fim da União Soviética, o mito soviético de Púchkin existiu sem mudanças significativas. Já com a Perestroika e a posterior queda do regime soviético, se inicia uma nova onda de estudos sobre a vida e a obra do poeta. Como assinala Marina Zaguidúllina, é muito curioso que, apesar de Púchkin ter sido um dos emblemas da URSS, após o estabelecimento do novo regime político, sua personalidade não tenha perdido valor, assim como seu significado para a cultura russa. Isso diferentemente de outros ícones culturais que, tendo sido também incentivados pela ideologia oficial, acabaram destronados na Rússia póssoviética, como a figura do lider comunista Vladímir Lênin, ou a de outro escritor mitologizado na URSS, Maxim Górki, interesse por cuja obra diminuiu consideravelmente após a queda do regime. ${ }^{433}$ A pesquisadora aponta que o caso do mito de Púchkin é único em sua independência do regime político reintante no país. Zaguidúllina relaciona essa longevidade do mito de Púchkin com a própria essência da obra do poeta:

\footnotetext{
431 DOBROZRÁKOVA, G. Mífy Dovlátova $i$ mífy o Dovlátove: probliémy morfológuii $i$ stilístiki. Samara: Povóljskii Gosudárstviennyj Universtitiet Telekommunikátsii i Informátiki, 2008, p. 67.

${ }^{432}$ No caso da novela de Dovlátov, pode se dizer que ela se insere no texto de Mikháilovskoe por meio de várias ligações intertextuais com a obra de Púchkin e com os livros produzidos após a morte de Púchkin que são manifestações do mito puchkiniano (Ibid., pp. 97 - 98).

${ }^{433}$ Falando da "troca" de mitos após a queda de um regime ideológico e político, cabe citar aqui as palavras de Svetlana Boym, que, a respeito da obsessão Rússia pós-soviética dos anos 1990 pelas coisas e lugares relacionados com a família do czar, aponta que "se na União Soviética era venerada cada pedra que 'conhecera Lênin', atualmene é [venerada assim] cada pedra que 'conhecera o czar"” (BOYM, Op. cit., p. 66).
} 
Serguei Dovlátov: texto de cultura na literatura russa contemporânea

[A criação de Púchkin] está tão longe de qualquer "preocupação social" e pretensões morais de outros grandes escritores do século XIX, que nela, melhor, encontramos uma virtualidade crescente de significados e interpretações. Sacamse dos textos puchkinianos significados de todas as espécies, que geram um semfim de interpretações; o legado de Púchkin não pode ser "explicado" ou formulado conforme uma ideologia determinada, é inapanhável e fluido. ${ }^{434}$

Até os nossos dias, o interesse pela figura do poeta não enfraquece, nem entre os pesquisadores, nem entre os leitores. Desde os anos 1990, surgiram novas e varidadas abordagens da figura e da obra de Púchkin, que passaram a tratar de temas antes considerados tabus pela crítica literária oficial soviética. Em 1999, na Rússia, tiveram lugar as comemorações do aniversário de Púchkin de 200 anos, que de novo provaram a importância da figura de Púchkin para a cultura e a identidade nacionais. Nas palavras de Zaguidúllina, o mito puchkiniano em sua nova fase, no solo da Rússia pós-soviética, continua a guardar as suas principais caraterísticas:

Em geral, a Puchkiniana da época do aniversário [de 200 anos] representa a principal manifestação do mito sobre o Primeiro Poeta Nacional: o reconhecimento da perfeição de sua obra; um profundo interesse pela vida do génio que se estende ao interesse pelos lugares memoráveis, relacionados com Púchkin; "oferendas rituais" a Púchkin em forma de láureas poéticas, conferências dedicadas ao poeta, assim como obras de diferentes tipos de arte que refletem a sua vida e a sua obra. ${ }^{435}$

Se no âmbito acadêmico continuam a se desenvolver pesquisas sobre a obra do poeta, o interesse das pessoas comuns se expressa, além das vendas de edições da obra de Púchkin, no interesse pelas edições dedicadas à sua biografia, ${ }^{436}$ filmes documentários e artísticos dedicados a Púchkin, encenações teatrais e cinematográficas de sua obra. A imagem do poeta, assim como as personagens de seus livros mais famosos, de fácil reconhecimento para os portadores da cultura russa, também são usadas amplamente em publicidade e propagandas públicas. Tudo isso demonstra a importância que continua a ter a figura de Púchkin na cultura russa moderna.

\footnotetext{
434 ZAGUIDÚLLINA. Op. cit., p. 30.

${ }^{435}$ Ibid., p. 69.

436 As maiores livrarias on-line russas, como www.labirint.ru e www.ozon.ru, em resposta à busca "biografia de Púchkin", oferecem vários nomes de livros escritos nos últimos 20 anos, entre eles, tanto estudos históricos da biografia do poeta como livros de gênero de romance biográfico. Há vários exemplos de literatura de massa, dedicados à memória do poeta, entre eles, os livros intitulados A verdadeira biografia de Púchkin (em russo, Ístinnaia biográfia Púchkina, Vladímir Márotchkin, 2010), A mulher e a Musa: o segredo de Aleskandr Púchkin (em russo, Jená i Muza: taina Aleksandra Púchkina, Larissa Vassílieva, 2009) etc.
} 


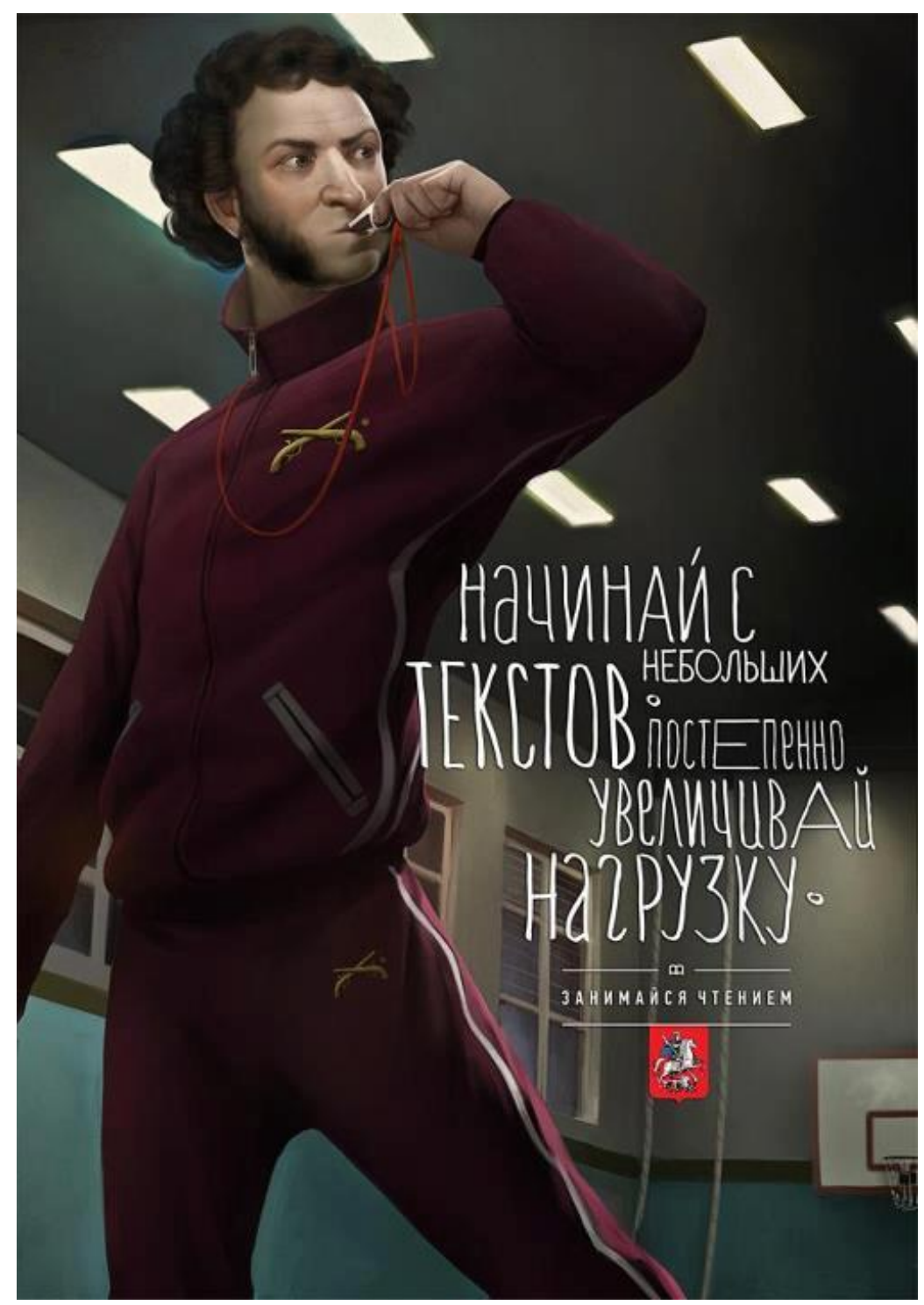

Propaganda pública de 2012 destinada a incentivar a leitura entre os adolescentes, na qual Púchkin é representado em forma de professor de educação física. O texo do cartaz diz: "Comece com textos pequenos e pouco a pouco aumente a carga”.

A presença artística de Púchkin desde o século XIX era tão grande e incondicional que de uma forma ou de outra a maioria dos poetas russos "pós-Púchkin" recorria ao legado puchkiniano. Evidentemente, nos círculos intelectuais da URSS se compreendia perfeitamente a simplificação ideológica que sofriam as interpretações da personalidade e da obra do poeta, o que não deixou de provocar uma reação. Para os que não concordavam com a visão soviética simplificada do gênio de Púchkin, o estudo aprofundado de sua obra além do programa oficial ideologizado, e uma visão e análise sob outro ângulo dos textos mais difundidos, tornaram-se uma forma de protesto contra a ideologia reinante e também uma forma de escape. Tais opiniões tomaram forma no âmbito da literatura não oficial nos anos 1960 - 1970: nessa época, muitos 
Serguei Dovlátov: texto de cultura na literatura russa contemporânea escritores dissidentes se interessam pelo estudo mais aprofundado da vida e da obra puchkiniana, buscando a possibilidade de se aproximar da imagem mais verdadeira do poeta. Os nomes mais significativos da geração dos escritores da literatura não oficial, que tentam abordar sob outro viés a figura e a obra de Púchkin são os de Joseph Brodsky, Abrám Terts (nome artístico do escritor Andrei Siniávski) e Serguei Dovlátov.

Joseph Brodsky é um dos poetas, cuja criação estabelece um profundo diálogo com o legado puchkiniano. Em geral, as imagens de Púchkin e as referências à sua obra aparecem ao longo de toda a carreira artística de Brodsky. Vale comentar um dos seus textos mais representativos em relação ao mito de Púchkin, escritos ainda no início de sua carreira. Em 1962, Brodsky escreveu o poema Iá pámiatnik sebe vozdvig inói ("Um monumento diferente ergui a mim”), uma evidente alusão ao texto programático de Púchkin, Exigi monumentum (1836), cuja primeira linha é Iá pámiatnik sebié vozdvig nerukotvórnyi ("Um monumento ergui a mim, obra extra-humana”). O poema de Púchkin, de estudo obrigatório na escola, apresenta reflexões sobre o sentido elevado e o destino da criação poética, bem como a importância do papel do poeta no mundo. Em sua versão, Brodsky a princípio aborda os mesmos temas, porém o seu pathos é distinto:

Я памятник воздвиг себе иной! К постыдному столетию - спиной. К любви своей потерянной - лицом. И грудь - велосипедным колесом. А ягодицы — к морю полуправд.

Какой ни окружай меня ландшафт, чего бы ни пришлось мне извинять, я облик свой не стану изменять. Мне высота и поза та мила. Меня туда усталость вознесла.

Ты, Муза, не вини меня за то. Рассудок мой теперь, как решето, а не богами налитый сосуд. Пускай меня низвергнут и снесут, пускай в самоуправстве обвинят, пускай меня разрушат, расчленят, -

в стране большой, на радость детворе из гипсового бюста во дворе сквозь белые незрячие глаза струей воды ударю в небеса.
Um monumento diferente ergui para mim! As costas viradas para o século vergonhoso. $\mathrm{O}$ rosto voltado para o amor perdido. $\mathrm{O}$ peito - a girar como roda de bicleta. As nádegas - a mirar o mar de falsidades.

Seja como for a paisagem que me rodeia, Seja o que for o que devo perdoar, Não vou mudar a minha imagem. Gosto daquela altura e daquela postura. Foi o cansanço que me ergueu ali.

Você, Musa, não me culpe pois A minha mente agora é como peneira E não um jarro enchido por deuses. Que me destronem e desmanchem, Que me acusem pelos desmandos, Que me destruam e me desmembrem, -

Num país grande, para a alegria da criançada, Do busto de gesso no pátio Através dos cegos olhos brancos Com um jato de agua golpearei o céu. 
Serguei Dovlátov: texto de cultura na literatura russa contemporânea

Se o monumento de Púchkin "é obra extra-humana", o monumento de Brodsky é extremamente "terreno" e até fisiológico, o que é sublinhado tanto pelo material do qual é feito o monumento (gesso, ou seja, não é um material nobre, como seria mármore ou bronze), como pelo léxico empregado, e as metáforas que representam partes do corpo humano. Quanto às ideias expressas no poema, por um lado, o herói lírico de Brodsky concorda com Púchkin que a criação do poeta é eterna, e o próprio autor está "acima" do mundo (e o monumento puchkiniano é mais alto do que o Pilar Alexandrino ${ }^{437}$ ), no entanto, o "eu lírico" brodskiano, à diferença do herói lírico de Púchkin, que acredita que vai ser lembrado e agradecido pelas pessoas, não espera gratidão do povo. Ao contrário, está preparado para ser demolido e arruinado por ele, e passar a ser esquecido num pátio, onde as únicas pessoas que se interessam pelo monumento de gesso são as crianças do local. Ao mesmo tempo, expressa-se a decisão de não se conformar com as convenções do seu entorno e seguir o seu rumo. Esse texto de Brodsky é muito representativo tanto pelo pathos dissidente, como pela tentativa de um olhar fora do padrão soviético em relação a um dos textos mais famosos de Púchkin.

Outro poema de Brodsky inspirado no texto de Púchkin, que vale a pena mencionar, é a sua interpretação irônica do poema lírico de Púchkin, Iá vas liubil (“Eu vos amei”, 1829). ${ }^{438}$ O poema foi escrito em 1974 e passou a formar parte do ciclo Vinte sonetos a Maria Stuart (em russo, Dvádtsat sonétov k Maríi Stuart). O poema, que também começa com a mesma linha que o texto de Púchkin, interpreta o amor num tom totalmente distinto. Brodsky conserva a forma tradicional do verso puchkiniano, mas inverte o tom do poema: se Púchkin, falando da sua examada usa um tom lírico e linguagem elevada, Brodsky ironiza e abaixa o tema, empregando palavras coloquiais e fazendo insinuações eróticas. As mudanças do tom e do conteúdo em comparação com o texto de Púchkin são sentidas já nas primeiras linhas do texto.

Я вас любил. Любовь ещё (возможно, что просто боль) сверлит мои мозги, Всё разлетелось к чёрту, на куски. Я застрелиться пробовал, но сложно с оружием. И далее, виски: в который вдарить? Портила не дрожь, но задумчивость. Чёрт! всё не по-людски! Я Вас любил так сильно, безнадежно,
Eu vos amei, o amor ainda (talvez, simplesmente, a dor) perfura o meu cérebro, Ao diabo, tudo em pedaços se quebrou Tentei dar-me um tiro, mas é difícil com arma. Além disso, as têmporas: em qual atiro? O que estragou não foi o tremor, mas a meditação. Caramba! Nada é como se deve!

\footnotetext{
${ }^{437}$ Citemos a primeira estrofe do poema de Púchkin em português, na tradução de José Casado: Um monumento ergui a mim, obra extra-humana. / Sua vereda o mato não há de ocultar. / Eleva-se bem mais sua cúpula ufana / Do que o alexandrino pilar (PÚCHKIN. Op. cit., p. 67).

${ }^{438}$ Eu vos amei. Ainda talvez vivo, / O amor não se apagou no peito meu; /Mas não vos seja de aflição motivo: / Entristecer-vos não desejo eu. / Eu vos amei, mudo, sem cor de espera, / Ora acanho, ora de ciúme a arder. / Eu vos amei com ternura sincera. / Deus queira amada assim venhais a ser (Ibid., p. 27) Tradução do russo de José Casado.
} 
Serguei Dovlátov: texto de cultura na literatura russa contemporânea

как дай Вам бог другими - - - но не даст!

Он, будучи на многое горазд, не сотворит - по Пармениду - дважды сей жар в груди, ширококостный хруст, чтоб пломбы в пасти плавились от жажды коснуться - "бюст" зачеркиваю - уст!
Eu vos amei tão forte, desesperadamente, que deus queira que outros - mas não vai querer!

Ele, sendo capaz de muitas coisas, não vai criar, segundo Parmênides, duas vezes esse calor no peito, a crepitação dos ossos, que os chumbos na boca se derretessem da sede

de tocar o "peito", riscado, os lábios!

Brodsky escolhe como tema de recriação poética dois poemas programáticos que até hoje se estudam obrigatoriamente na escola, interpretados na sala de aula de uma maneira bastante esquemática e superficial. Referências a Púchkin em outros textos de Brodsky, assim como as suas opiniões, demonstram o profundo respeito que ele tinha pelo poeta. Portanto, a ironia que se encontra nos dois textos e o rebaixamento intencional do seu pathos não são endereçados aos textos de Púchkin, mas à sua interpretação esquematizada e ideologizada. Na ironia de Brodsky reside a não aceitação da ideologia oficial referente ao mito de Púchkin.

Outro texto que aborda o mito de Púchkin, importante de se mencionar, é o livro de ensaios Passeios com Púchkin, de Abrám Terts. Esse livro, escrito por Andrei Siniávski na prisão, nos anos 1966 - 1968, ${ }^{439}$ foi uma das primeiras tentativas do destronamento do mito oficial puchkiniano.

No seu livro, o teórico e crítico literário aborda a criação e a personalidade de Púchkin de uma forma muito distinta tanto das abordagens soviéticas, como das abordagens dos escritores e críticos emigrados. Apontando que, para um portador médio da cultura soviética, a imagem de Púchkin "desfaz-se numa mancha popular com suíças", ${ }^{440}$ Siniávski tenta analisar a vida, o caráter humano de Púchkin e a sua obra sem os clichês comuns e noções tradicionais. Para isso, o autor frequentemente recorre à ironia e também demonstra as contradições que havia na obra e mesmo nas ideias do próprio Púchkin.

Assim, por exemplo, ao tratar do grande número de detalhes pouco importantes para o desenvolvimento do enredo em Ievguéni Oniéguin e das digressões do narrador no romance em versos, Siniávski argumenta a "falta de um sistema rigoroso, uma filosofia clara e uma disciplina intelectual". ${ }^{441}$ Assim, tendo como intenção polemizar com a interpretação soviética da figura de Púchkin, no seu livro, Siniávski analisa e frequentemente critica justamente Púchkin como escritor e o seu talento literário.Também o estilo e a linguagem que emprega Siniávski estão fora do padrão da crítica literária: o seu estilo de análise e interpretação é informal, e o autor

\footnotetext{
${ }^{439}$ O livro foi publicado pela primeira vez em 1973, em Londres, sob o nome artístico de Abrám Terts.

440 TERTS, Abrám. Progúlki s Púchkinym. Moscou: Globulus, Izd-vo NTS ENAS, 2005., p. 7.

${ }^{441}$ Ibid., p. 51.
} 
Serguei Dovlátov: texto de cultura na literatura russa contemporânea frequentemente emprega palavras de registro coloquial e gírias. Por exemplo, encontramos no texto as seguintes expressões: em um fragmento, Púchkin "com as finas perninhas eróticas, entrou correndo na grande poesia e fez ali um alvoroço", ${ }^{442}$ e em outro, "viu-se na condição de uma celebridade de cinema e começou, saltarinhando, a viver à vista de todo mundo". ${ }^{443}$ Como posteriormente confessava o próprio autor, o ensaio foi escrito de tal forma a provocar o interesse do leitor para a criação de Púchkin, e de nenhum modo para desacreditá-lo.

O livro de Siniávski foi publicado em russo pela primeira vez em Londres, após a emigração do seu autor (Siniávski emigrou em 1973); portanto, os representantes da emigração russa no exterior foram os primeiros a ler Passeios com Púchkin, e o texto provocou uma forte reação na colônia russa no Ocidente. Uma abordagem tão livre e fora do padrão do símbolo da cultura russa, e o estilo do texto, não podiam deixar de chocar os círculos literários da emigração. A visão de Siniávski foi considerada pelos representantes da Primeira e da Segunda Ondas de emigração um verdadeiro sacrilégio, uma "profanação das tradições e dos santuários", nas palavras de Roman Gul. ${ }^{444}$

O que provocou indignação não foi apenas o conteúdo do livro e a compreensão "não canônica" de Púchkin, mas também a linguagem empregada por seu autor, que foi chamada por Gul e por outros críticos de "linguagem de prisão". Como resposta a Siniávski, Gul publicou em Nóvyi jurnal, revista em que era o redator chefe, o seu artigo literário Passeios de um grosseirão com Púchkin, onde submeteu o livro de Siniávski a duras críticas, e chamou Abrám Terts de "grosseirão e desordeiro soviético" (soviétski khamo-khuligán). ${ }^{445}$ Mais tarde, em 1984, Aleksándr Soljenítsyn publicou o seu estudo ... Abala o teu tripé (em russo, ... Koliéblet tvoi trenójnik), no qual o escritor criticava as tentativas de "leitura nihilista de Púchkin", e em particular falava do livro de Siniávski.

Portanto, a maneira burlesca, irônica, com a qual foi escrito o ensaio, e o destronamento da imagem ideologizada de Púchkin, "o nosso tudo" soviético, por meio de sua carnavalização, não encontrou simpatia entre as primeiras gerações de emigrantes, para os quais Púchkin era um grande poeta, filósofo e artista, ${ }^{446}$ e não uma figura de propaganda. Os emigrados desconheciam a visão soviética de Púchkin, na qual o poeta, visto como lutador pela libertação dos camponeses, próximo às ideias comunistas e acusador do czarismo, tornou-se "figura de

\footnotetext{
442 Ibid., p. 13.

${ }^{443}$ Ibid., p. 34.

${ }^{444}$ GUL, R. "Progúlki khama s Púchkinym”. IN: Nóvyi jurnal. Nova Iorque, 1976, № 24.

445 Ibid.

${ }^{446}$ Nas palavras de Merejkóvski, “em Púchkin o pensador e o artista confluem num ser único” (MEREJKÓVSKI. Op. cit., p. 294).
} 
Serguei Dovlátov: texto de cultura na literatura russa contemporânea propaganda comunista”, nas palavras de Dobrozrákova. ${ }^{447}$ Por isso, a intenção de Siniávski foi vista por eles apenas como um ato de desacreditação de Púchkin.

O livro teve uma recepção bem mais cálida por parte de outros escritores dissidentes que pertenciam à geração de Siniávski, o que se explica justamente pela sua pertinência ao mesmo sistema cultural e pelo conhecimento do mito soviético. Os emigrados soviéticos conseguiram ver na interpretação de Siniávski, ao invés da tentativa de destronamento de Púchkin, o pathos dissidente do autor do livro e o seu desacordo com a postura soviética em relação à figura e à obra do poeta.

Tal discrepância em relação ao legado literário e cultural russo e à figura de Púchkin como o seu símbolo principal, que existia entre os representantes das primeiras ondas e da Terceira Onda de emigração, está determinada pela diferença entre a cultura da emigração russa e a cultura soviética, tal como explicitado no Capítulo I. A expressividade cultural do ensaio de Siniávski como texto de cultura, atenta à realidade soviética e desconhecida pelos portadores da cultura russa na emigração, não permitiu aos leitores emigrados apreciar e compreender a interpretação inusitada de Siniávski da figura e da obra do poeta.

Outra tentativa de destronamento do mito soviético de Púchkin foi empreendida por Serguei Dovlátov quase dez anos depois, em sua novela Parque cultural. Cabe mencionar que, à diferença do livro de Siniávski, a novela de Dovlátov não provocou rejeição e críticas por parte das gerações mais velhas de emigrados. Em primeiro lugar isso tem a ver com o fato de que, no texto de Dovlátov, há uma clara distinção entre o "Púchkin soviético", introduzido na mente de cada soviético desde criança como uma tabuada de multiplicações (um dos focos da ironia do autor), e o "Púchkin verdadeiro", que se revela para o leitor ao longo da narrativa. Vejamos com detalhe como é abordado o mito puchkiniano em Parque cultural.

A novela de Dovlátov foi escrita quase dez anos depois do livro de ensaios de Siniávski (o livro foi publicado pela primeira vez em russo nos EUA em 1983). Nela, o autor relata e reelabora a própria experiência de trabalho como guia no parque histórico-literário Mikháilovskoe-Trigórskoe, a antiga propriedade da família dos Púchkin, conhecido entre turistas como Parque cultural de Púchkin (em russo, Púchkinski zapoviédnik). Como já apontado, vários pesquisadores concordam em que a novela Parque cultural é um dos textos mais elaborados de Dovlátov, cuja estutura comprende várias camadas de significados: literária, histórica, biográfica e mitológica.

${ }^{447}$ DOBROZRÁKOVA. Mífy Dovlátova i mífy o Dovlátove: probliémy morfológuii i stilístiki. Op. cit., p. 22. 
Serguei Dovlátov: texto de cultura na literatura russa contemporânea

A reflexão de Dovlátov incide não apenas sobre esse patrimônio literário da Rússia, representado pela figura de Púchkin, mas também sobre a sua reapropriação pela literatura contemporânea. Além disso, Púchkin personifica no texto de Dovlátov o próprio fazer literário, e o ato da escritura, que permitem ao escritor a superação de si mesmo e do mundo que o cercam. Outros escritores clássicos do Século XIX e do "Século de Prata", mencionados no texto, também são compreendidos como genuínos herdeiros de Púchkin. A esses representantes da literatura russa contrapõe-se a crítica de Dovlátov à escritores contemporâneos pertencentes à literatura oficial soviética: para eles, na visão de Dovlátov, o fazer literário é apenas uma maneira de prestígio e um compromisso com a ideologia dominante. Os defeitos e vícios dessa geração de escritores soviéticos, e a disposição de "se alinharem ideologicamente" parecem personificados na novela na personagem do literato Stássik Potótski: "Suas composições eram triviais, ideologicamente íntegras, primitivas. Em cada uma delas, ouvia-se algo familiar. Uma sólida armadura de literatura de segunda mão protegia suas obras da censura. Soavam convincentes, como citações". 448

Ao mesmo tempo, o momento histórico no qual se desenvolve a fábula expõe as principais características do período de estagnação brejneviana dos anos 1970, como a censura ideológica, perseguições de dissidentes, antissemitismo, a massiva emigração, o problema de alcoolismo, entre outros.

Por outro lado, Serguei Dovlátov reelabora artísticamente nessa novela a sua própria experiência de vida: o escritor de fato passou dois verões trabalhando no parque museu como guia, vivendo na aldeia de Beriózino, ao lado de Mikháilovskoe; e as principais personagens do texto (como Mikhal Iványtch, Volódia Mitrofánov, Valera Márkov, Stássik Potótski) possuem seus protótipos reais.

Deve-se destacar também que o centro e o núcleo do mito soviético de Púchkin em Parque cultural é o próprio parque cultural de Mikháilovskoe-Trigórskoe. Quando Boris Alikhánov, protagonista da novela e espécie de alter ego do próprio Dovlátov, chega às Colinas de Púchkin para trabalhar como guia, o que encontra é uma espécie de parque de diversão, que Jekaterina Young, pesquisadora estadounidense da obra de Dovlátov, chama de Pushkinland, por analogia com Disneyland. ${ }^{449}$ Nele, os turistas, sorridentes, tiram fotos no túmulo de Púchkin, e a atmosfera do parque museu é tão grotesca, que o protagonista, e com ele o leitor, constantemente têm a sensação de que estão num palco, entre atores e cenários teatrais. O caráter teatral e de simulacro do parque cultural, é um dos leitmotifs da narrativa. Abundam no texto metáforas que remetem ao léxico do teatro: o Krêmlin da cidade de Pskóv (ao lado da qual econtra-se o

${ }^{448}$ DOVLÁTOV. Zapoviédnik. Op. cit., p. 210.

${ }^{449}$ YOUNG, Jekaterina. Sergei Dovlatov and His Narrative Masks. Northwestern University Press, 2009 , p. 14. 
Serguei Dovlátov: texto de cultura na literatura russa contemporânea complexo histórico) lembra "uma maquete de enormes dimensões", ${ }^{450}$ e as vacas que pastam ao lado da aldeia de Sosnovo parecem "achatadas como num cenário teatral". 451

A teatralidade do parque museu não se limita à cenografia; em várias situações, os funcionários do parque parecem atores, e um dos temas recorrentes nos fragmentos dedicados ao complexo histórico é o tema do disfarce e do simulacro: ali, até os garçons da lanchonete levam enormes suíças de feltro, ${ }^{452}$ como que fantasiados de Púchkin; da mesma forma, os funcionários do museu atuam como atores, ao escolher um papel:

Encontrei a curadora do museu e me apresentei. A Viktória Albiértovna era possível dar uns quarenta anos. Uma saia comprida com babados, uns cachos descoloridos, um camafeu, uma sombrinha: um quadrinho pretensioso de Benois. Este estilo em extinção da nobreza provinciana era ali cultivado visivelmente e de propósito. Em cada estudioso local, manifestava-se algum traço típico deste estilo. Um prendia no peito um xale cigano de tamanho fantástico. Outro pendurava nas costas um requintado chapéu de palha. A um terceiro cabia um ridículo leque de plumas. $^{453}$

Outra caráterística do parque cultural dovlatoviano importante de ser referido é a especulação com a imagem de Púchkin, que aparece em todos os lugares, inclusive nos mais impróprios: "A cada passo, eu via imagens de Púchkin. Até ao lado da misteriosa guarita de tijolos com a placa "Inflamável!". A semelhança limitava-se às suíças". ${ }^{454}$ Esse fragmento lembra-nos a expressão de Andrei Siniávski, ao mencionar a "mancha popular com suíças", referindo-se a como é percebido Púchkin pela cultura soviética.

A adoração do poeta tem caráter de lei no local, e, como percebe o protagonista, o amor a Púchkin acaba por ser a divisa mais valorizada do parque cultural. Cada um precisa provar o seu amor pelo poeta, que serve como uma espécie de senha para formar parte do "santuário":

Expliquei a razão da minha vinda. Com um sorriso cético, convidou-me para ir a um escritório independente.

— O senhor gosta de Púchkin?

Senti uma irritação abafada.

- Gosto.

Mas desse jeito não é difícil deixar de gostar, pensei.

— E posso saber por quê?

\footnotetext{
${ }^{450}$ DOVLÁTOV. Zapoviédnik. Op. cit., p. 178.

451 Ibid., p. 194.

452 Ibid., 176.

453 Ibid., 198.

454 Ibid., 189.
} 
Serguei Dovlátov: texto de cultura na literatura russa contemporânea

Senti um olhar irônico. Evidentemente, o amor a Púchkin era ali a moeda mais usada. E se, de repente, eu fosse um falsificador? ${ }^{455}$

No entanto, tal amor a Púchkin por parte dos funcionários do museu e dos turistas acaba por ser uma espécie de trapaça. Quando Alikhánov tenta explicar à personagem da metodologista Marianna Petrovna as razões pelas quais ele gosta de Púchkin, a conversa beira o nonsense e torna-se absurda, pois Alikhánov está diante de uma incompreensão total por parte da sua interlocutora, já que a resposta que se espera não supõe nada além da afirmação de que "Púchkin é o nosso orgulho":

- O que Goethe tem com isto? — perguntou Marianna. — E o que tem a ver a Renascença?

- Não tem nada a ver! - finalmente, explodi. - Goethe não tem absolutamente nada a ver! E Renascença era o nome do cavalo de Dom Quixote! Que também não tem nada a ver! E, pelo visto, eu também não tenho nada a ver!...

- Acalme-se - sussurrou Marianna. - Que nervoso... Eu apenas perguntei por que o senhor gosta de Púchkin?

- Amar em público é uma obscenidade! - gritei. - Há um termo especial na sexologia para isso.

Com a mão trêmula, ela estendeu-me um copo de água. Afastei-o.

— E a senhora mesma amou a alguém? Alguma vez na vida?

Não devia ter falado aquilo: irá se desfazer em pranto e gritar:

"Tenho trinta e quatro anos e sou uma donzela solitária!...".

- Púchkin é o nosso orgulho - disse ela. - Não é apenas um grande poeta, mas também um grande cidadão... ${ }^{456}$

Em geral, no parque museu estão concentrados todos os clichês e lugares-comuns do mito soviético. Dovlátov parodia o caráter politizado do interesse pela ideologia do "Púchkin soviético", cujos rastros os guias do museu encontram até na lírica amorosa. Assim, a personagem Aurora, em sua excursão, justamente interpreta em sentido político o mencionado texto do poema $E$ u vos amei: "Reflitam, camaradas!... 'Eu vos amei com ternura sincera...' Aleksándr Serguéievitch contrapôs ao mundo das relações escravocratas este inspirado hino de desinteresse...". ${ }^{457}$

Outro lugar-comum do mito puchkiniano que não negligenciado por Dovlátov é o bisavô africano do poeta. O tema do clichê do bisavô entrelaça-se com o tema do simulacro do museu. Passeando pelo museu, o protagonista percebe que ali não há praticamente nenhum item verdadeiro, que realmente pertencera ao poeta ou à sua família: a maioria das peças é apenas de

\footnotetext{
455 Ibid., $190-191$.

456 Ibid., p. 192.

457 Ibid., p. 181.
} 
época, e o retrato de Abrám Gannibal, seu famoso bisavô, torna-se o retrato de outra pessoa. Os funcionários do museu estão cientes dessa farsa e colaboram para manter a falsa cenografia:

— ... tiraram o retrato de Gannibal. ${ }^{458}$

- Por quê?

- Um pesquisador insiste que não é Gannibal. Diz que as condecorações não coincidem. Diz que é o general Zakomiélski.

— E quem é na verdade?

- Realmente é Zakomiélski.

- Mas por que ele está tão moreno?

- Ele guerreava contra os asiáticos, no sul. Lá faz calor. Então ficou moreno. Também, as tintas escurecem com o tempo.

— Então fizeram bem em tirar o retrato, não?

- Ah, que diferença faz: Gannibal, Zakomiélski... Os turistas querem ver Gannibal. Eles pagam por isso. E que raios vão fazer com Zakomiélski? Por isso o nosso diretor colocou Gannibal... Quer dizer, colocou Zakomiélski e, embaixo, o nome de Gannibal. E um pesquisador não gostou disso... ${ }^{459}$

Cabe mencionar que nesse fragmento Dovlátov faz referência a um fato documental: realmente, até hoje discute-se a figura representada, no retrato que historicamente era atribuido a Abrám Gannibal. Outra hipótese sustenta que o homem retratado não é Abrám Gannibal, mas o barão Ivan Meller-Zakomiélski, de acordo com as condecorações e a farda. Até hoje os historiadores não chegaram a uma conclusão definitiva a esse respeito.

\footnotetext{
458 Abrám Gannibal (1696 - 1781), bisavô de Púchkin. Filho de um conde etíope, aos sete anos de idade foi capturado pelos turcos e levado a Constantinopla, de onde foi levado à Russia e, em 1706, dado de presente ao czar Pedro, o Grande. Apadrinhado por ele, sempre foi muito próximo ao czar, sendo seu secretário e ajudante. Estudou engenharia militar na França e, desde 1756, foi o principal engenheiro militar do exército russo. Desde 1759, foi général en chef. Púchkin dedicou ao seu famoso antepassado a novela $O$ negro de Pedro, o Grande, de 1827. ${ }^{459}$ Ibid., p. $181-182$.
} 


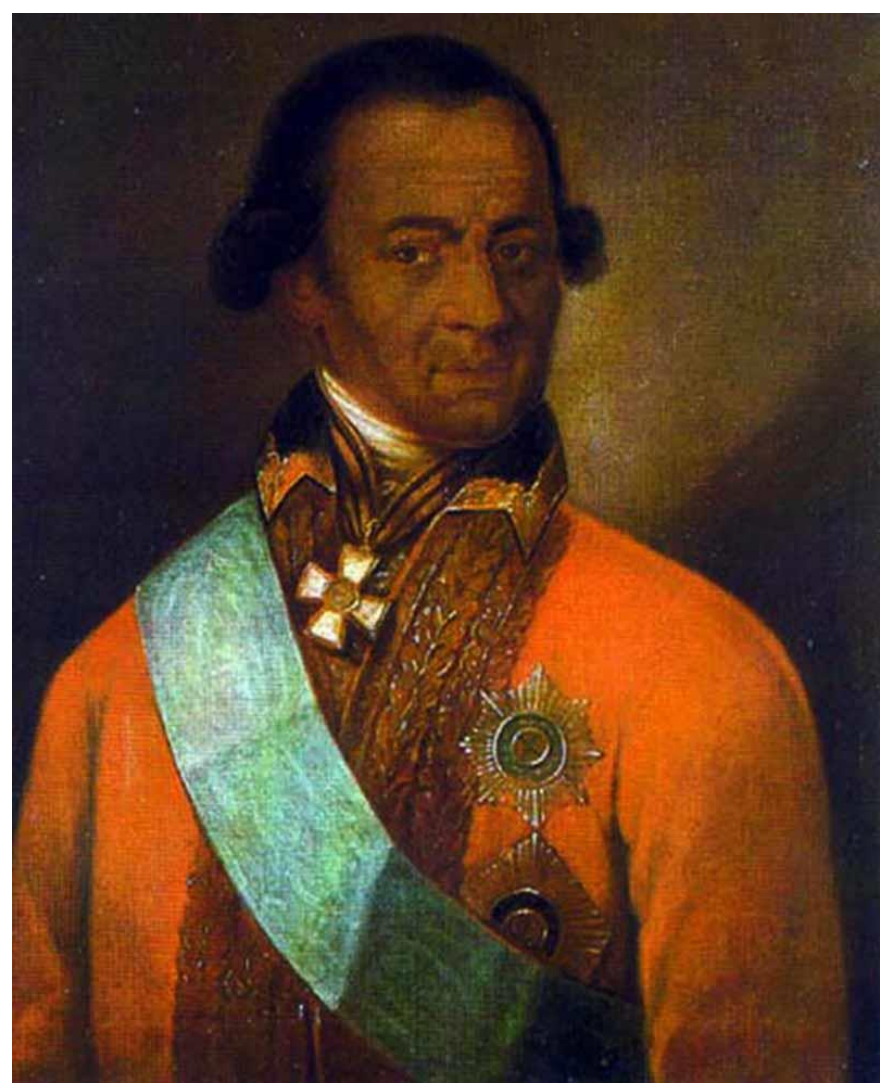

Retrato de Abrám Gannibal / Iván Meller-Zakomiélski

Nem a natureza, único elemento que de fato sobrou da época de Púchkin, nas palavras de uma das funcionárias do museu, escapa das transformações e "melhorias", feitas para atrair turistas: até as pedras na alameda não são reais, mas colocadas depois, com o propósito de fazer mais pitoresco o passeio. É curioso que no texto de Dovlátov o protagonista num certo momento menciona a Escola Semiótica de Tártu-Moscou de Lótman, justamente fazendo referências às tentativas de "decorar" a natureza do parque por parte da administração do museu: "Caprichos bobos do camarada Guéitchenko. ${ }^{460}$ Quer fazer um parque grandioso de cultura e diversão. Colocou uma corrente numa árvore para dar um colorido local. Dizem que os estudantes de Tártu roubaram a corrente. E a jogaram no fundo do lago. Fizeram bem, os estruturalistas!". 461

A corrente que os estudantes de Tártu jogam fora foi colocada pela administração numa árvore com o propósito de fazer referência ao fragmento do poema Ruslan e Liudmila. Nele, descreve-se a famosa imagem de Lukomórie, região de um conto maravilhoso do folclore russo, onde há um carvalho com uma corrente de ouro dependurada. Esses versos do poema são de estudo obrigatório em qualquer escola russa e, portanto, familiares a qualquer russo. Tal referência não poderia escapar aos turistas.

${ }^{460}$ Semion Guéitchenko (1903-1993), escritor e pesquisador soviético, estudioso de Púchkin. De 1945 a 1993 , diretor do parque museu Mikháilovskoe. Autor de vários artigos e pesquisas dedicados ao legado de Púchkin.

${ }^{461}$ Ibid., p. 236. 
Serguei Dovlátov: texto de cultura na literatura russa contemporânea

Outro clichê do mito soviético é a imagem da babá como uma das principais figuras na vida e na criação do poeta. No fragmento da novela dedicado à babá, a paródia do mito oficial penetra na literatura. A duplicação paródica ocorre no momento no qual, durante uma excursão, Boris Alikhánov, ao invés do poema de Púchkin dedicado à babá, por um lapso, cita $O$ poema à $m \tilde{a} e$, de Serguei Iessiênin, ${ }^{462}$ outro texto emblemático da literatura russa, que deveriam conhecer todos os que haviam estudado na escola soviética:

Passo para o quarto de Arina Rodiónovna... "A única pessoa realmente próxima foi a babá..." Tudo como determinado... "Era, ao mesmo tempo, indulgente e rabugenta, ingenuamente religiosa $\mathrm{e}$ extremamente prática..." O baixo-relevo de Seriakov... "Quando the ofereceram a alforria, recusou..."

E, finalmente:

- O poeta dirigia-se constantemente à babá em seus poemas. Todo mundo conhece, por exemplo, estes versos afetuosos...

E aqui, por um instante, me distraí. E estremeci ao ouvir a minha própria voz:

Você está ainda viva, minha velhinha,

Também estou vivo, salve, salve! ${ }^{463}$

No entanto, nenhum dos turistas percebe a substituição feita pelo guia: "Pelo silêncio que se produziu, eu esperava uma tempestade. Todos estavam quietos. Os rostos estavam emocionados e sérios. E apenas um turista idoso pronunciou significativamente: - É, havia pessoas... $" 464$

Nesse fragmento, Alikhánov descobre outra caraterística do museu, recalcada pela narrativa: ali, o mito falso de Púchkin é alimentado não apenas pelos funcionários, mas também pelos próprios turistas, que na realidade são indiferentes à literatura, à vida e à obra do poeta. Para os visitantes do parque cultural, Púchkin é apenas um símbolo da cultura e, ao estarem ali, além de descansar, eles querem apenas ter a sensação de "terem estado lá". Ao longo da narrativa, protagonista e leitor não podem se desfazer da conclusão de que todos ao seu redor vivenciam tão somente o conjunto de clichês reunidos no parque cultural a respeito do poeta. Nesse sentido, como assinala Aleksandr Guénis, “o único lugar em Parque cultural onde não há Púchkin, é o próprio parque museu". ${ }^{65}$

A imagem do "Púchkin soviético" naquele museu é apenas uma das tantas representações da figura do poeta que encontramos em Parque cultural. Assim, passeando pelos lugares da vida

\footnotetext{
${ }^{462}$ Serguei Essiênin (1895-1925), poeta russo, representante da poesia do imaginismo. As primeiras estrofes deste poema, "Você está ainda viva, minha velhinha" (Ty jivá eschó, moiá starúchka, 1924), entram no programa de literatura do ensino médio e são familiares a todo conhecedor da cultura russa.

${ }^{463}$ Ibid., p. $205-206$.

${ }^{464}$ Ibid.

${ }^{465}$ GUÉNIS. Púchkin. Op. cit., p. 328.
} 
Serguei Dovlátov: texto de cultura na literatura russa contemporânea de Púchkin e trabalhando na biblioteca do museu, lendo memórias dos contemporâneos do poeta, o protagonista vai descobrindo o Púchkin "verdadeiro", que nada tem em comum com o mito soviético. Ao conhecer melhor a sua biografia e a obra através de livros raros da biblioteca do museu, Alikhánov descobre características de Púchkin ignoradas pelo mito oficial. A postura filosófica e ética do poeta, muito eclipsada pela imagem oficial ideologizada, pode ser resumida nas palavras de uma das funcionárias do museu, ao referir que "Púchkin não era apenas um grande poeta, mas também um grande cidadão": 466

Na biblioteca local, achei uns dez livros raros sobre Púchkin. Além disso, reli a prosa e os artigos. O que mais me intrigou foi a indiferença olímpica de Púchkin. A prontidão para aceitar e expressar qualquer ponto de vista. A aspiração inabalável à objetividade suprema e definitiva. Como a lua que ilumina o caminho tanto do predador como da vítima.

Não era um monarquista, um conspirador, um cristão, era apenas um poeta, um gênio, e compartilhava do movimento geral da vida. ${ }^{467}$

Nesse fragmento, como analisado no Capítulo II do presente trabalho, pode-se depreender que Dovlátov expõe os seus próprios ideais éticos e estéticos, a partir dos quais ele se sente herdeiro de Púchkin. O protagonista, o herói autobiográfico de Dovlátov, sente o poeta como uma figura muito próxima por seu modo de pensar e de viver. À medida que Alikhánov descobre informações sobre Púchkin, mais afastada se torna a imagem da oficial, cultuada no museu. O protagonista passa então a deconstruir o Púchkin oficial: "Quanto melhor eu conhecia Púchkin, menos eu queria falar sobre ele. Ainda mais num nível tão vergonhoso. Mecanicamente, eu cumpria meu papel, recebendo por ele uma boa retribuição". 468

Ao mesmo tempo, para o protagonista se revela outra faceta da personalidade de Púchkin: a da pessoa real, com suas virtudes e vícios, suas crises amorosas, problemas com o governo, e para quem a aldeia de Mikháilovskoe significava um lugar de refúgio nos tempos tempestuosos, e onde escreveu alguns de seus melhores textos.

A única pessoa no parque cultural que, na opinião de Alikhánov, pode compreender essa descoberta de um “outro" Púchkin, é a sua mulher, Tânia, que vem visitá-lo em Mikháilovskoe: "Então me dirigia a ela. Contei-lhe sobre um homem baixinho e genial em que Deus e o diabo coexistiam tão tranquilamente. Ele pairava alto, mas foi vítima de um sentimento banal e mundano. Criava obras-primas, mas faleceu como um herói de um romance de segunda" ${ }^{469}$

\footnotetext{
466 DOVLÁTOV. Zapoviédnik. Op. cit., p. 192.

467 Ibid., p. 216.

${ }^{468}$ Ibid.

${ }^{469}$ Ibid., 236.
} 
Serguei Dovlátov: texto de cultura na literatura russa contemporânea

Aqui cabe analisar outra representação da figura de Púchkin na novela. A biografia do poeta se retrata também na trajetória do protagonista de Parque cultural. Dovlátov cria paralelos entre as biografias de Púchkin e de Alikhánov, e os acontecimentos espelhados na vida dos dois heróis lhe servem como procedimentos artísticos para o desenvolvimento da narrativa.

Alikhánov, um escritor fracassado, desprezado por editoras e jornais em razão de suas opiniões dissidentes e as crises de alcoolismo, vigiado pela KGB e em pleno processo de divórcio, chega ao complexo Mikháilovskoe-Trigórskoe para se evadir dos seus problemas. Para o herói, o parque museu, além de ser a última opção de trabalho, também lhe parece um lugar oportuno para ponderar sobre a sua vida, longe da família e de Leningrado.

Na efabulação literária, Dovlátov altera a ordem cronológica de acontecimentos da vida de Púchkin, para centrar o enredo de Parque cultural no cronotopo do parque museu. Assim, na novela, o autor "mistura" acontecimentos históricos, que tiveram lugar durante o exílio de Púchkin em Mikháilovskoe, em 1824 - 1826, com o período que o poeta passou em sua outra propriedade, Bóldino, na região de Níjni Nóvgorod, no outono de 1830. O período que Púchkin passou em Bóldino, de setembro a dezembro de 1830 (o poeta ficou preso na sua propriedade devido à quarentena estabelecida em São Petersburgo por causa da epidémia de cólera), é considerado o período mais produtivo de sua criação, quando foram terminados Ievguéni Oniéguin, o ciclo Contos de Biélkin, bem como as Pequenas Tragédias, entre outros textos. Ao mesmo tempo, no outono de 1830, Púchkin passou por um período tenso de relações com a noiva e futura esposa Natália Gontcharova - como assinala Lótman, devido a uma discussão com a futura sogra: o poeta estava prestes a terminar o noivado ao sair para Bóldino. ${ }^{470}$

No parque museu, ao estudar a biografia de Púchkin, o protagonista faz alusão a semelhanças entre a vida do poeta e a sua: os dois tinham por volta de 30 anos quando chegaram a Mikháilovskoe; para ambos, a estada em Mikháilovskoe era uma forma de exílio. Ao mesmo tempo, procuravam um refúgio, um lugar para ficar longe das mazelas da vida, para poderem, além de repensar a sua vida, trabalhar e escrever. Alikhánov, como Púchkin, tinha embates com o poder devido às suas opiniões liberais, e, assim, embates com a censura e a publicação de sua obra. Para os dois, o período em Mikháilovskoe é marcado por uma crise amorosa: se Púchkin colocava sob dúvida o casamento, o protagonista também se encontrava numa situação afetiva ambígua em sua relação amorosa com a mulher. A esse respeito, Aleksándr Guénis, ao apontar as semelhanças entre a biografia de Púchkin e a da personagem principal de Parque cultural, salienta essa incerteza nas relações amorosas de Púchkin e de Alikhánov, e nomeia Tânia, a

\footnotetext{
${ }^{470}$ LÓtMAN. Púchkin. Biográfia Pissátielia. Roman “Ievguéni Oniéguin”. Kommentárii. Op. cit., p. 169.
} 
Serguei Dovlátov: texto de cultura na literatura russa contemporânea

mulher de Alikhánov, e Natália Gontcharova, a futura esposa de Púchkin, de "esposas que ora existem, ora não". ${ }^{471}$

Da mesma forma, durante a estada em Mikháilovskoe, Alikhánov, que ali chegou em plena crise criativa, recupera a inspiração e volta a escrever, ou seja, para ele, como para Púchkin, o "exílio" no parque museu também acaba por se tornar um período produtivo.

Quanto às relações tensas com o governo, a personagem de Alikhánov possui o seu próprio "Benckendorff”. Como se sabe, a vigilância de Púchkin e a censura de sua obra eram realizadas principalmente por Aleksándr Benckendorff, chefe da gendarmaria russa durante o reinado do czar Nicolau I, e por seus subordinados. Após a volta do poeta do exílio em Mikháilovskoe, em 1826, e o encontro e conversa com o czar, Nicolau I "como gesto de perdão", liberou Púchkin do procedimento da censura comum, alterado pela censura pessoal do czar. Evidentemente, o czar não seria aquele a ler cada poema de Púchkin, e a pessoa que de fato se encarregou de revisar toda a obra de poeta e acompanhar de perto a sua vida foi Benckendorff. Como aponta Lótman, “de Benckendorff dependia o destino da obra de Púchkin e também o próprio destino do poeta". ${ }^{472}$ Embora o trato do chefe da gendarmaria à primeira vista fosse paternal e benevolente, o poeta sofria muito com a vigilância por parte do governo, assim como com a necessidade humilhante de mostrar regularmente a sua obra e dar explicações a Benckendorff.

Dovlátov dedica um fragmento em Parque cultural a Benckendorff, quando uma das turistas fica indignada com a ignorância de Alikhánov-guia, que demonstra não saber a data exata de nascimento de Benckendorff. Nesse interesse dos turistas pelos detalhes insingificantes para a compreensão da arte literária de Púchkin, de novo aparece a ideia de simulacro com relação ao "amor a Púchkin":

No terceiro dia de trabalho, uma mulher de óculos perguntou-me:

— Quando nasceu Benckendorff?

— Lá por 1770 — respondi.

A construção que utilizei ressoava insegurança.

— E mais concretamente? - perguntou a mulher.

— Infelizmente — disse - esqueci...

Para que estou mentindo, pensei. Poderia ter falado sinceramente: "Sei lá!"’.. Não foi uma ocasião de regozijo tão grande o nascimento de Benckendorff.

- Aleksándr Khristofórovitch Benckendorff — pronunciou a mulher com censura - nasceu em 1784. Além do mais, em junho...

Acenei com a cabeça para demonstrar que considerava a informação valiosa.

\footnotetext{
${ }^{471}$ GUÉNIS. "Púchkin”. Op. cit., p. 329.

${ }^{472}$ LÓTMAN. Púchkin. Biográfia Pissátielia. Roman “Ievguéni Oniéguin”. Kommentárii. Op. cit., p. 132.
} 
Serguei Dovlátov: texto de cultura na literatura russa contemporânea

Desde esse instante, a mulher não parou de sorrir ironicamente. Como se a minha indiferença por Benckendorff demonstrasse uma completa indigência intelectual... ${ }^{473}$

Em Parque cultural, quem vigia Alikhánov e mantém com ele conversas educativas em tom paternal é o camarada Beliáiev, major da KGB da região, “onisciente e perspicaz”, que sabe de tudo o que acontece na vida de Alikhánov e até de seus planos. Os propósitos educativos no trabalho da KGB são sublinhados no texto, em tom irônico, várias vezes. Assim, no escritório do major, Alikhánov vê um retrato, que a princípio atribui a Félix Dzerjínski, fundador da Tcheká, e depois, em meio à conversa com Beliáiev, da-se conta de que é Anton Makárenko, pedagogo soviético de renome. Também, em seu discurso, Beliáiev demostra a sua preocupação pelo destino de Alikhánov, que, segundo o major, até lhe causa insônia:

- Sinto: a coisa está mal. Sinto: o rapaz deu um passo em falso. Um caminho tortuoso o levou para onde não sei deve ir... Acredite, acordo no meio da noite. Tomka, digo à minha esposa, um jovem decente deu um passo em falso. É preciso ajudar... E a minha Tomka é humana. Grita: Vitálik, ajude. Faça algo educativo. Dá pena: o rapaz é nosso. No fundo, é são. Não recorra a métodos severos, pois os órgãos não apenas castigam. Os órgãos educam... ${ }^{474}$

No entanto, é curioso que, ao longo da conversa, depois de beber, o pathos "educativo" do major "muda de direção" para o caminho oposto: assim, em vez de "educar" Alikhánov e convencê-lo a ficar na União Soviética, Beliáiev começa a desenvolver opiniões dissidentes, sugerindo que Alikhánov emigrasse. Isso confere um tom absurdo e burlesco a toda a conversa entre as personagens, remetendo a tessitura narrativa para o plano o riso e para o efeito de derrisão na crítica à ideologia oficial. Como assinala Aleksándr Guénis, em seu romance Dovlátov e o seu entorno, "Dovlátov desconceitualizou o poder soviético. No fundo, ele disse aquilo que todo o mundo já sabia: a ideia na qual se apoia o país, já não existe mais". ${ }^{475}$

O narrador-personagem explora as semelhanças de sua biografia e a de Púchkin: após a difícil conversa com a mulher e a sua partida do parque cultural, Alikhánov, no começo de sua dipsomania que durará alguns dias, relembra Púchkin para animar-se:

Dizia a mim mesmo:

- Púchkin também tinha dívidas e relações nada boas com o Estado. E também teve um problema com a esposa. Sem falar de seu caráter difícil...

E tudo bem. Abriram o parque cultural. Há quarenta pessoas trabalhando como guias. E todos amam loucamente Púchkin... ${ }^{476}$

\footnotetext{
${ }^{473}$ DOVLÁTOV. Zapoviédnik. Op. cit., p. 205.

474 Ibid., p. 271.

${ }^{475}$ GUÉNIS. Dovlátov i okriéstnosti. Op. cit., p. 36.

${ }^{476}$ DOVLÁTOV. Zapoviédnik. Op. cit., pp. 255 - 256.
} 
No entanto, é importante sublinhar que, mesmo tecendo essas semelhanças biográficas, em nenhum momento o narrador se espelha na genialidade literária de Púchkin. Ao contrário, no texto, várias vezes o protagonista se autoavalia ou é avaliado por outros como um escritor mediano. Assim, Tânia, em resposta irônica às palavras do marido de que ter vícios é próprio a pessoas geniais, aponta que pelo visto Alikhánov é genial pela metade: "Então você é um gênio pela metade — consentiu minha mulher. — Pois vícios você tem aos montes ...". 477

Apenas em uma passagem da novela Alikhánov atreve-se a "provar" o papel de um escritor genial e as duas imagens - a de Púchkin e a de Alikhánov - se transformam numa só, mas por meio de um tom grotesco, alicerçado no efeito do álcool: durante a sua bebedeira de vários dias, Alikhánov e seu companheiro de boemia, o fotógrafo Valera, num delírio alcoólico, começam a se apresentar como Púchkin e Baratýnski:478 "Perdemos algumas vezes o envelope com o dinheiro. Abraçávamos o sanfoneiro do dia anterior. Fomos vistos por todos os funcionários responsáveis pelo centro turístico. Conforme contou depois Natella, dizíamos ser Púchkin e Baratýnski”. ${ }^{479}$

Essa cena, embora bufa e em tom de derrisão, pode ser considerada como um procedimento importante no fluxo da narrativa: logo depois dessa cena o protagonista decide partir para Leningrado, para se despedir da mulher e da filha, que emigrariam para os Estados Unidos, para não voltar mais.

Como se vê, Aleksándr Púchkin constitui um dos eixos principais da novela. No entanto, a presença do poeta não se limita às suas repesentações no parque cultural (a "oficial", soviética, e a "verdadeira", que se revela através de Alikhánov), e na vida do protagonista. A novela é permeada de citações, alusões às obras de Púchkin, já analisadas no capítulo anterior.

Dessa forma, através de uma oposição entre o "Púchkin indivíduo" ou "Púchkin escritor" e o "Púchkin soviético", Dovlátov destrona o mito soviético de Púchkin, ao demonstrar em camadas de significação a desconstrução da imagem vigente no "parque de diversões" de Mikháilovskoe. Como dito, a novela foi bem acolhida pelos leitores emigrados russos, inclusive pelas gerações mais velhas, justamente por aparentar essa clara fronteira entre a figura de Púchkin e o seu mito ideologizado. Porém, como se sabe, muitos funcionários do parque cultural, colegas de Dovlátov, ficaram ofendidos com o livro e viram nele uma calúnia. Assim, como lembravam os funcionários entrevistados para o livro Dovlátov, aquele mais ofendido com a novela de Dovlátov foi o diretor do parque museu, Semion Guéitchenko, citado na novela. ${ }^{480}$

\footnotetext{
477 Ibid., 222.

${ }^{478}$ Ievguéni Baratynski (1800-1844), um dos poetas russos mais importantes da primeira metade do século XIX.

${ }^{479}$ Ibid., p. 265.

${ }^{480}$ KOVÁLOVA. Op. cit., p. 290.
} 
Serguei Dovlátov: texto de cultura na literatura russa contemporânea

Porém, não se pode esquecer das palavras do próprio escritor, destinadas ao editor Igor Iefímov, no sentido de que a imagem do parque cultural não deveria se limitar apenas àquele parque museu. Dovlátov cria uma metáfora, na qual se concentram as caraterísticas próprias da cultura e da vida russa em geral, próprias da época, outras, seculares. Além do mito de Púchkin, Parque cultural evoca outros fenômenos da cultura russa, que também remetem à leitura da novela como um texto da cultura. Entre esses fenômenos, podemos distinguir o álcoolismo como meio de conceitualização do universo cultural russo, o antissemitismo e o fenômeno da Terceira Onda de Emigração e o fenômeno da literatura (e cultura) não oficial.

O fenômeno da massiva emigração nos anos 1970 - 1980 foi analisado no Capítulo 1. Como vimos, quem emigrava do país na época eram, em primeiro lugar, cidadãos soviéticos de origem judia, que tinham direito a pedir liberação para emigrar. Na novela, o escritor usa como base literária a própria experiência biográfica.

Embora o próprio Dovlátov fora forçado a emigrar pelas autoridades, a sua esposa, que emigrou seis meses antes, Elena Dovlátova (sobrenome de solteira, Ritman), também sendo judia, saiu do país usando esse mesmo direito. Apesar de tal gesto "liberal" por parte das autoridades, o de permitir a repatriação dos judeus, como testemunham todos os emigrados desse período, o processo de trâmite dos documentos para viajar era extremamente burocratizado, e impunha todos os possíveis obstáculos e entraves para quem quisesse solicitar o visto. $\mathrm{Na}$ novela, quem enfrenta o sistema burocrático soviético é a personagem de Tânia, que conta a Alikhánov a sua experiência de percorrer os gabinetes dos funcionários. Para facilitar o processo e resolver alguns assuntos, Tânia frequentemente tem que recorrer à propina, muito comum no sistema burocrático da Rússia, aliás, até os nossos dias:

Tânia percorria gabinetes, cumprindo todas as formalidades. Queixava-se dos burocratas e dos estelionatários.

- Tenho na minha bolsa - dizia — dez barras de chocolate, quatro ingressos para o concerto de Kobzon ${ }^{481}$ e três exemplares de Tsvetáieva... ${ }^{482}$

O caráter absurdo do burocratismo soviético é sublinhado em várias cenas da novela, tornando-se objeto de ironia e piada. Assim, nos documentos que deve assinar o pai (a personagem de Alikhánov), para atestar que não está contra a emigração da filha, a criança é

\footnotetext{
${ }^{481}$ Ióssif Kobzon (nasc. em 1937), cantor russo.

${ }^{482}$ DOVLÁTOV. Zapoviédnik. Op. cit., p. 254.
} 
Serguei Dovlátov: texto de cultura na literatura russa contemporânea tratada com as mesmas palavras e fórmulas com as quais normalmente se descrevem objetos e coisas em documentos formais:

Tânia precisava de um atestado dizendo que eu permitia que ela levasse nossa filha. E que não tinha pretensões financeiras.

Tânia ditou-me algumas frases formais. Retive na memória tal formulação: "A criança, na quantidade de uma..."

Por um lado, isso confere riso à narrativa devido à alogicidade da frase, mas, por outro, revela o caráter objetificante do sistema burocrático soviético, a tratar seus cidadãos como coisas.

Uma das caraterísticas imanentes do Estado soviético, cujos traços continuam presentes na realidade russa de nossos dias, era o seu caráter restritivo: era comum proibir-se coisas que não necessáriamente poderiam perjudicar a ordem do Estado, mas apenas não se encaixavam no paradigma oficial. Uma das esferas, em que mais se sentia essa peculiaridade do poder soviético era a burocracia. Como aponta Aleksándr Fedúlov, no país "existia um sistema de proibições para tudo o que não tinha 'aprovação de cima'". 484

Na novela, isso se reflete, por exemplo, em pequenos detalhes narrativos, como o fato de o policial de alfândega no aeroporto não deixar Tânia levar embora coisas que de fato não podiam representar nenhum valor além de sentimental, como o colar de âmbar (material muito comum na região soviética do Báltico; acessórios de âmbrar eram lembranças típicas que pessoas costumavam trazer de ali), ou a foto do seu marido: "Tânia aproximou-se da barreira umas quatro vezes. Passou-me as coisas detidas pela alfândega. Entre elas: um colar de âmbar, minha foto do exército e um romance de Gladílin ${ }^{485}$ com uma dedicatória". 486

O fato de deter um livro de um escritor dissidente, que para o momento já havia emigrado, também resulta alógico no contexto da situação, já que em vez de apreender o livro, o policial devolve-o aos amigos de Tânia, que ficam na União Soviética.

Como já referido, quem podia solicitar permissão para sair eram judeus, e na época era comum as pessoas "buscarem" origens judias na sua árvore genealógica, assim como tornaramse habituais as fraudes com falsificação do parentesco com judeus, ou o estabelecimento de matrimônios fictícios. A personagem de Alikhánov que, como assinala, também "pertence a uma simpática minoria étnica" (a personagem chama de "simpática" a sua nacionalidade justamente pela possibilidade de emigrar), tece ironia com relação à prática de evocar parentes distantes de

\footnotetext{
483 Ibid.

${ }^{484}$ FEDÚLOV. Op. cit., p. 37.

${ }^{485}$ Anatóli Gladílin (nasc. em 1935), escritor e dissidente soviético que emigrou da União Soviética em 1976.

${ }^{486}$ DOVLÁTOV. Zapoviédnik. Op. cit., p. 276.
} 
Serguei Dovlátov: texto de cultura na literatura russa contemporânea origem judia para convencer as autoridades de conceder o visto: " — Tânia — eu disse —, sou uma pessoa leviana. Qualquer aventura me convém. (...) Mas percorrer órgãos públicos. Explicar, certificar. A terra natal histórica... ${ }^{487} \mathrm{O}$ apelo aos antepassados... A tia Fânia Tsiperóvitch...". 488

Ou seja, na tentativa de receber a permissão para emigrar, como prova da origem judia, podia-se apelar para o fato de ter uma tia judia (Fânia Tsiperóvitch são nome e sobrenome judeus comuns). Da mesma forma, ao falar dos seus planos de emigrar, a personagem do literato Potótski afirma que tem 1/32 do sangue judeu, o que, em teoria, lhe permitiria solicitar repatriação. E o major Beliáiev, falando do assunto, com pesar constata que não teria como sair:

- E ainda, como se diz, fora dos protocolos. Eu, no seu lugar, dava o fora daqui enquanto estão deixando sair. Você se uniria de novo a sua mulher, e tchauzinho... Eu mesmo não tenho nenhuma chance. Com a minha cara de Riazan não vão me liberar... Mas a você eu aconselho. Pense bem. Isso fica entre nós, sigilo absoluto... ${ }^{489}$

Aqui o major se refere ao fato de ter um rostro de traços eslavos, provavelmente de camponês russo, o que exclui a possibilidade de se passar por judeu.

Outra possibilidade de emigrar era casamento com alguém de origem judia, variante na qual pensa, no delírio alcoólico, a personagem de Valera Márkov:

Um fulano me disse outro dia: estão liberando os judeus. Falei pra minha esposa: "Verka, este é o Cabo da Boa Esperança...". Minha esposa é simples, do povo. Zomba de mim. Diz: "Olhe pra esse focinho de bandido. Tipos como você não deixam nem entrar no cinema. E agora inventou de ir para Israel!...". Mas eu me aconselhei com um sujeito. Ele recomenda que me case temporariamente com uma judia. Daí é mais fácil. Há poucas turistas estrangeiras, mas judias aparecem de vez em quando. Tem uma no centro turístico. Chama-se Natella. Parece que é judia, embora tome umas e outras... ${ }^{490}$

Nesse fragmento, vemos também um dos estereótipos comuns existentes em relação a judeus, de que eles não costumam beber. Realmente, em comparação com a população russa, os casos de judeus ${ }^{491}$ que padeciam alcoolismo eram bastante raros. ${ }^{492}$ Quando o major Beliáiev

\footnotetext{
${ }^{487}$ Refere-se à repatriação judia em Israel.

488 Ibid., p. 241.

489 Ibid., p. 273.

490 Ibid., p. 261.

491 Outras nações que, na visão popular, não se associavam com o problema de alcoolismo eram, por exemplo, tártaros, assim como outras etnias das regiões historicamente muçulmanas.

492 Porém, aqui cabe mencionar o caso do próprio Dovlátov, que inclusive chegou a ironizar o seu vício, não típico para alguém de origem judia.
} 
fala do problema de alcoolismo na União Soviética, também menciona essa caraterística dos judeus:

Chegará o dia em que todos ficarão bêbados, sem exceção. Desde um soldado raso até o marechal Gretchko. Desde um operário até o ministro da indústria pesada. Todos, salvo algumas mulheres e crianças e, talvez, os judeus. $\mathrm{O}$ que, evidentemente, não será suficiente para a construção de comunismo... ${ }^{493}$

Uma das razões da emigração judia da União Soviética era o problema do antissemitismo existente no país, apoiado inclusive em nível oficial. Em geral, em Parque cultural, à diferença de outros textos de Dovátov, como, por exemplo, A mala ou $A$ troca,${ }^{494}$ não há muitas alusões a esse fenômeno da realidade soviética. Porém, há alguns indícios que indicam ao leitor a existência de antissemitismo. Assim, Mikhal Iványtch, apesar de afirmar que "tem respeito pelos judeus", aprova a matança dos judeus pelos nazistas durante a Segunda Guerra:

...O meu velho fazia aguardente em casa. Trocava com os fascistas pelas conservas... Ainda que os jides e os ciganos eles... sabe como é...

- Fuzilaram?

- Levaram para sempre. Ordens são ordens...

— E você está dizendo que não faziam nada de ruim...

— Não faziam mesmo, juro por Deus. Os jides e os ciganos, como cabia...

- Mas o que os judeus fizeram para você?

- Respeito os judeus. Daria uma dúzia de ucranianinhos por um judeu. Mas os ciganos estrangularia com as próprias mãos. ${ }^{495}$

Nesse fragmento, o autor de certa forma denuncia, ainda que de forma irônica, a xenofobia "geral" da personagem, que se estende a outras nacionalidades. Porém, a própria palavra pejorativa jid, amplamente usada pela população na linguagem do dia a dia (porém considerada vulgar no círculos de intelligentsia), aponta para a existência do problema de antissemitismo.

Outro indício que encontramos no texto é o fato de que, na onda da liberação para os judeus, muitas pessoas começam a revelar a sua origem judia, para poderem emigrar. Esse fenômeno também se torna objeto da ironia do autor, como no caso de um dos colegas de Tânia: "Róschin está se preparando para partir para Israel. Acredita? Acabou que Róschin era Stackelberg. E agora seu nome não é Dima, mas Mordkhe". 496

\footnotetext{
493 Ibid., p. 272.

494 Sendo judeu por parte do pai (e em pasaportes soviéticos existia a coluna "nacionalidade"; a nacionalidade normalmente coincidia com a nacionalidade do pai), com certeza, Dovlátov teve várias situações, nas quais sentiu na própria pele as manifestações de antissemitismo durante a vida na União Soviética.

495 Ibid., pp. $219-220$.

496 Ibid., p. 234.
} 
Serguei Dovlátov: texto de cultura na literatura russa contemporânea

Esses fragmentos demonstram como o texto de Dovlátov faz reverberar os traços históricos e culturais de uma época, os desdobramentos desses fenômenos históricos e sociais na cultura e na visão de mundo dos cidadãos soviéticos. A emigração da população ativa, em muitos casos de representantes dos círculos intelectuais do país (como foi referido no Capítulo I, para as autoridades, a emigração forçada também era uma maneira de se livrar de pessoas “indesejáveis", de opiniões dissidentes, sem recorrer a métodos repressivos), na época não podia deixar de acentuar marcas profundas na concepção da emigração da cultura soviética. Na visão popular, a emigração dos anos 1970 se associava ou com os judeus, ou, no caso dos representantes da intelligentsia, tornava-se prova de intelectualidade e sucesso na vida, como o demonstra o seguinte fragmento do romance $A$ mala: "Antes, para ser um homem completo, era preciso ter um casaco de pele e grau acadêmico de doutor. Agora se somou a isso um visto para Israel. Todo intelligent sonhava com ele. Mesmo se não tivesse planos para emigrar" ${ }^{497}$ Ou seja, a possibilidade de emigrar, mesmo se a pessoa em questão não pensasse em usá-la, permitia "elevar" o status do portador do visto nos olhos de seus conhecidos.

O tema do alcoolismo merece atenção. Trata-se um dos tópicos recorrentes na criação literária de Dovlátov. Sabe-se que o próprio escritor padecia do vício desde a juventude, e o tema do alcoolismo sempre foi muito presente em toda sua obra.

O alcoolismo pode desempenhar diferentes funções nos textos de Dovlátov. Por um lado, é um atributo frequentemente usado pelo escritor para caraterizar suas personagens sem dar outras explicações adicionais. O caráter da bebida que consome a personagem pode promover a compreenção de seu status social, nível de ensino, etc.

Assim, por exemplo, no romance A mala, o narrador-protagonista Dovlátov, para ilustrar o abismo social que há entre ele, "fracassado crônico", como ele mesmo se autodefine, e seu amigo de infância Andrei, um matemático bem sucedido, apenas enumera as bebidas que preferia o grupo de amigos de cada um, além da frequência de consumo da bebida alcoólica. Se os conhecidos de Andrei, pessoas que pertenciam à classe média alta soviética, de vez em quando bebiam conhaque e champagne, os amigos de Serguei, representantes de círculo boêmio e semi-marginal, consumiam constantemente vinho do Porto barato, produzido na União Soviética (em russo, rózovyi portvéin). ${ }^{498}$

Da mesma forma, a caracterização da personagem Mikhal Iványtch, em Parque cultural, se dá por meio de sua interpretação de quem é gente culta: "No ano passado uns judeus moraram

\footnotetext{
${ }^{497}$ DOVLÁTOV. Tchemodán. Op. cit., p. 356.

${ }^{498}$ Ibid., 338.
} 
Serguei Dovlátov: texto de cultura na literatura russa contemporânea aqui. Não posso dizer nada de mau, gente culta... Nada de álcool de limpeza ou de água de colônia... Só branco, tinto e cerveja". 499

Aqui o autor refere-se ao costume comum entre os alcoólatras de beber, na falta de bebida alcoólica, outros líquidos que contêm álcool. Evidentemente, o personagem de Mikhal Iványtch, também ocorria beber esses líquidos. Da mesma forma, Valera Márkov, no dia seguinte depois da bebedeira, pede para a sua mulher trazer pelo menos água de colônia, a fim de tirar a ressaca.

Em geral, nos textos de Dovlátov são descritos vários costumes e peculiaridades da vida dos alcoólatras na União Soviética, assim como diferentes fases do estado de embriaguez e da ressaca; citam-se, por exemplo, nomes das bebidas mais consumidas. É impossível negar a expansão do alcoolismo na época. Como aponta Svetlana Boym, nos anos 1970, ou seja, na época da estagnação brejneviana, o número de pessoas que padecia de alcoolismo aumentou considerávelmente, e esse mal "era admitido com um fato da vida". ${ }^{500}$ Como se vê, a maioria das personagens masculinas descritas na novela, em um momento ou em outro, sofre de dipsomania, o que é visto pelo protagonista e por outras personagens como algo costumeiro. Da mesma forma, reagem os funcionários do parque cultural à dipsomania do protagonista: ninguém está assombrado ou indignado com alguns dias de bebedeira de Alikhánov e as suas peregrinações sob o efeito de álcool pelo espaço do parque cultural. Pelo contrário, como assinala o protagonista, "ali uma bebedeira não seria capaz de surpreender ninguém". ${ }^{501}$

Nas descrições das personagens que apresentam problemas com o vício, é impossível não perceber a condescendência e, inclusive, certa simpatia do autor por elas. Nisso, por um lado, manifesta-se o princípio ético de Dovlátov, herdado de Tchékhov, de evitar em sua obra todo tipo de julgamentos. Por outro lado, como dito, devido a tal expansão do alcoolismo no país, apresentar esse vício é compreendido no mundo artístico do escritor como norma. Até mesmo o major da KGB, em seu escritório, oferece ao protagonista uma dose de vodka.

Nos textos de Dovlátov, pelo contrário, as pessoas que não bebem podem provocar suspeitas por parte das personagens. Assim, como atesta o protagonista da novela A troca, para ele na aparência impecável das pessoas “cultas", que declaram não terem vícios (e por isso em sua casa uma garrafa aberta de vodka pode permanecer durante meses pela metade, sem ser consumida), há um sinal de hipocrisia:

Conheço essas casas cultas. Ícones, samovares, Nefertitis... Alguns cacos significativos... Um monte de livros, e todos novinhos. E a vodka, tem no fundo

\footnotetext{
${ }^{499}$ DOVLÁTOV. Zapoviédnik. Op. cit., p. 195.

${ }^{500}$ BOYM. Op. cit., p. 149.

${ }^{501}$ DOVLÁTOV. Zapoviédnik. Op. cit., p. 268.
} 
Serguei Dovlátov: texto de cultura na literatura russa contemporânea

da garrafa. Sempre no fundo da garrafa. Mas de onde aparece? Alguém trouxe?

Não bebeu até o fim? Resolveu ocupar-se de assuntos mais importantes? ? $^{502}$

Com a condescendência do autor com os vícios de suas personagens está relacionada outra função importante que desempenha a bebida alcoólica na obra de Dovlátov: o álcool contribui para a harmonização da personagem com a realidade ao seu redor. Essa função não se refere apenas ao mundo artístico do escritor, mas à vida das pessoas em geral. Tal percepção do efeito do álcool existe, inclusive, na visão de mundo popular russa, o que se manifesta em vários provérbios e refrões relacionados com o tema, como "O vinho alegra o coração" (em russo, Vinó vesselit siérdtse), entre outros. ${ }^{503}$

Um dos principais traços da época de estagnação era a recessão econômica, a conservação do regime político e o consequente aumento do controle por parte do partido de todas as esferas da vida na URSS, além da guerra fria e a decadência da esfera agrária. ${ }^{504}$ Devido ao declínio na esfera agrária, vários kolhkozes e sovkhozes ${ }^{505}$ entravam na época em abandono. Por isso, por um lado, acontecia uma intensa migração dos camponeses para as grandes cidades, e, por outro, a falta de perspectivas e de trabalho provocava o aumento de alcoolismo na província. Outra camada social, que encontrava uma forma de sublimação no consumo de bebidas alcoólicas eram os intelectuais; eram simpatizantes da cultura não oficial e dissidentes, que sofriam de perseguições políticas e ideológicas e não podiam trabalhar livremente, como era o caso do próprio Dovlátov e seu círculo de conhecidos (e, no caso de Parque cultural, do protagonista Alikhánov e seus amigos). A tal fato se refere a afirmação do protagonista de que a bebedeira não podia supreender ninguém no parque cultural: por um lado, Mikháilovskoe era rodeado por aldeias, onde o alcoolismo era habitual, e, por outro, entre os funcionários do parque cultural, havia vários representantes de intelligentsia e da cultura não oficial que, como o herói Alikhánov, não podiam encontrar trabalho em outras esferas.

A função "harmonizadora" do álcool é evidente para o autor, que fala abertamente dela, como, por exemplo, na cena da despedida de Alikhánov da família: “Antes de ir pegar o chá, bebi uma e fiquei um pouco melhor. Há dezenas de livros sobre os males do álcool. Sobre seus benefícios, nenhuma brochura. Parece-me um erro". ${ }^{506}$ Parece-nos que a simpatia do autor por

\footnotetext{
${ }^{502}$ DOVLÁTOV. Kompromiss. Op. cit., p. 248.

${ }^{503}$ DAL, V. Poslóvitsy rússkovo naroda. Moscou: Astrel, 2005, p. 574.
}

A importância da bebida alcoólica na cultura popular russa pode ser comprovada no fato de que na coletânea de provérbios e refrões russos do etnógrafo e folclorista russo Vladímir Dal Provérbios do povo russo (em russo, Poslóvitsy rússkovo naroda) há mais de 300 itens dedicados ao tema de bebida.

${ }^{504}$ FEDÚLOV. Op. cit., p. 63.

${ }^{505}$ Kolkhozes e sovkhozes eram dois tipos de organização da propriedade rural. Se kolkhoz (em russo, abreviação de Kollektívnoe khoziáistvo, "economia coletiva") era um tipo de cooperativa agrícola, e o lucro era dividido entre os membros do kolkhoz e o Estado, sovkhoz (em russo, Soviétskoe khoziáistvo, "economia soviética") pertencia ao Estado, e seus trabalhadores cobravam salário fixo.

${ }^{506}$ DOVLÁTOV. Zapoviédnik. Op. cit., p. 275. 
Serguei Dovlátov: texto de cultura na literatura russa contemporânea suas personagens alcoólatras está relacionada também com essa função do álcool, ou melhor, com a necessidade das personagens de buscarem tal harmonia na bebida, o que confere a elas um efeito trágico e de certa compaixão. Além do protagonista, pode-se encontrar ums tragicidade subliminar também em personagens, à primeira vista cômicas, como a de Mikhal Iványtch, Valera Márkov, Volódia Mitrofánov e até Stássik Potótski (que também sofre por causa do seu fiasco literário e a impossibilidade de levar a vida que gostaria de levar).

Cabe comentar também o caráter peculiar da personagem Mikhal Iványtch, conhecido por seu alcoolismo na aldeia onde mora. À diferença de outras personagens da novela, em cuja vida os períodos de dipsomania são vistos como crises que transtornam o decurso normal da vida, Mikhal Iványtch quase nunca está sóbrio, e a sua visão de mundo em geral gira em torno do vício do álcool. Para ele, a bebida é a principal referência para tudo, inclusive para medir o preço das coisas. Assim, a personagem pode estimar o preço do alugel que lhe propõe Alikhánov apenas depois de "traduzir" esse valor em bebida:

— Quanto devo pagar?

- Ah, nada.

- Como assim? - perguntei.

- Assim mesmo. Por seis garrafas do veneno o espaço é seu. conviriam?

- Podemos combinar algo mais concreto? Digamos, vinte rublos lhe

O senhorio refletiu:

— Isso será quanto?

- Estou lhe dizendo, vinte rublos.

- E se traduzir isso em bebida? Por um rublo e quatro copeques?

- Dezenove garrafas de Rosé capitoso. ${ }^{507} \mathrm{Um}$ maço de Bielomor. Duas caixas de fósforos - escandiu Tólik.

— E dois rublos para esquentar — precisou Mikhal Iványtch. ${ }^{508}$

É curioso que, como aponta o protagonista, na aldeia as pessoas tivessem inveja de Mikhal Iványtch que, por não ter nenhuma economia ou responsabilidades, podia entregar-se ao vício e beber sem parar. Tal utilização dessa temática como recurso construtivo do texto, por um lado, demonstra a relatividade dos conceitos de norma / absurdo no mundo artístico de Dovlátov (já que, pela lógica, as pessoas deveriam sentir pena ou indignação pela personagem, e não inveja), e, por outro, reafirma a função "harmonizadora" da bebida na vida das personagens. Da mesma forma, a própria personagem Mikhal Iványtch, nos raros momentos de sobriedade, demonstrava o rancor e descontamento com a vida:

\footnotetext{
${ }^{507}$ Vermute produzido na URSS.

508 Ibid., p. 197.
} 
Serguei Dovlátov: texto de cultura na literatura russa contemporânea

Eu o vi sóbrio duas vezes. Nesses dias paradoxais, Mikhal Iványtch ligava ao mesmo tempo o rádio e a televisão. Deitava-se de calças, tirava uma caixa do bolo Skazka. E começava a ler os cartões postais recebidos ao longo de sua vida. Lia e comentava:

“...Olá, querido padrinho!... Bom, olá, olá, filho de uma vaca bem puta!.. Desejo-lhe sucesso no trabalho... Me deseja sucesso, no cu da sua mãe... Fico por aqui, sempre seu, Rádik... Sempre seu, sempre seu... Para que raios preciso de você?..."

Mikhal Iványtch não é a única personagem da novela, cujo caráter e percepção do mundo modificam-se sob o efeito de álcool. Ao se referir às mudanças que acontecem no caráter do protagonista Alikhánov em estado de embriaguez, a personagem de Potótski assinala que "Borka sóbrio e Borka bêbado são duas pessoas tão diferentes que nem se conhecem uma à outra". 510 Bêbado, o protagonista, que em geral não tem muitas ilusões quanto ao tamanho do seu talento e se considera um escritor mediano, atreve-se a "provar" a máscara de um gênio não compreendido e até "eleva-se", de forma bufa, à altura de Púchkin, durante as suas "peregrinações alcoólicas" com Valera: "Perdemos algumas vezes o envelope com o dinheiro. Abraçávamos o sanfoneiro do dia anterior. Fomos vistos por todos os funcionários responsáveis pelo centro turístico. Conforme contou depois Natella, dizíamos ser Púchkin e Baratýnski”. ${ }^{511}$

Dessa caraterística da embriaguez provém o antígo provérbio russo, usado amplamente até os nossos dias, "O que o sóbrio tem na mente, o bêbado tem na ponta da língua" (em russo, Tchto u triézvovo na umié, u piánovo na iazyké). ${ }^{512}$ Assim, o protagonista e outras personagens em estado de embriaguez (como Valera Márkov, ou o major Beliáiev), "verbalizam” os seus pensamentos e desejos.

Além das transformações grotescas e hiperbólicas que experimentam as personagens, e, principalmente, o protagonista Alikhánov, os momentos de dipsomania exibem outra função de álcool na criação de Dovlátov: a bebida confere às suas personagens a possibilidade de viverem uma experiência transcendental, de enxergar o mundo sob outro ângulo. Assim, por exemplo, de forma grotesca, acontece a "iniciação" do protagonista. Referimo-nos aqui ao ritual arcaico de iniação dos heróis mitológicos, que normalmente marcava a madurez do herói.

Como aponta Eleazar Meletínski, o processo de iniciação pode se realizar de diferentes formas: o herói pode, por exemplo, fazer uma viagem ao mundo do além (ou seja, a iniciação compreende a morte e o posterior renascimento do herói), ou travar uma batalha com um monstro, entre outros. ${ }^{513}$ O protagonista de Parque cultural, em estado de embriaguez, por um

\footnotetext{
509 Ibid., pp. $201-202$.

510 Ibid., p. 220.

511 Ibid., p. 265.

512 DAL. Op. cit., p. 574.

${ }^{513}$ MELETÍNSKI. Op. cit., p. 35.
} 
Serguei Dovlátov: texto de cultura na literatura russa contemporânea lado, passa uns dias no mundo transformado pelo álcool. Ao mesmo tempo, no texto, há indícios de que o alcoolismo é compreendido pelo autor como uma forma de batalha: assim, a personagem Potótski está "extenuada" depois de uma semana de bebedeira, e o protagonista tenta resistir à lembrança da vodka que "se aproxima como nuvem de chuva". 514 Ou seja, confluem aqui os dois motivos mitológicos: a viagem para outro mundo, transformado pelo álcool, e a luta com o mónstro (a bebida).

No fragmento seguinte, quando o protagonista se embriaga pela primeira vez depois de um longo período, após a partida da mulher, a função "transcendental" do álcool se junta à sua função "harmonizadora":

Então, tudo mudou. O bosque se abriu, abraçou-me e me aceitou em seu seio aquecido. Por um tempo fiz parte da harmonia do universo. $\mathrm{O}$ gosto amargo da baga parecia inseparável do cheiro úmido da grama. As folhas sobre a cabeça vibravam levemente com o tinir dos mosquitos. Nuvens pairavam como na tela de cinema. E até a teia de aranha parecia um adorno...

Estava a ponto de chorar, embora ainda compreendesse que era o efeito do álcool. Pelo visto, a harmonia escondia-se no fundo da garrafa... ${ }^{515}$

Além de se sentir em harmonia com o mundo ao seu redor e poder verbalizar alguns dos seus desejos inconscientes (no caso, o desejo de ser considerado um génio literário), em estado de embriaguez, em delírio alcoólico, abrem-se para a personagem os sentidos subliminares dos acontecimentos de sua vida. Isso acontece durante a dipsomania da personagem já em Lenigrado, no final da novela, quandoTânia lhe telefona da Áustria (ponto de passagem rumo a Estados Unidos).

Os pesquisadores da obra de Dovlátov, N. Orlova e A. Petrienko, no seu livro Modelos semióticos e folclóricos do mundo cômico de Serguei Dovlátov (em russo, Semiotítcheskie e folklórnye modéli smekhovóvo mira Serguéia Dovlátova), referindo-se à função "transcendental" do álcool, assinalam:

o "fator alcoólico", (...) em primeiro lugar, é destinado a travestir , estranhar, carnavalizar e acentuar de um modo grotesco. $\mathrm{O}$ estado de embriaguez permite à personagem enxergar o mundo com um outro olhar, provoca um "deslocamento da realidade", destrói a precepção da vida habitual e corrente, destrói o sistema sígnico de estereótipos estabelecidos e ajuda a revelar os sentidos ocultos. ${ }^{516}$

\footnotetext{
${ }^{514}$ DOVLÁTOV. Zapoviédnik. Op. cit., p. 256.

${ }^{515}$ Ibid., 255.

${ }^{516}$ ORLOVA. Op. cit., p. 130.
} 
Serguei Dovlátov: texto de cultura na literatura russa contemporânea

Como se vê, no tema do alcoolismo na criação de Dovlátov expressa, por um lado, o vício do próprio escritor como elemento biográfico transformado como procedimento literário em sua ficção, e, por outro, faz alusão ao momento histórico-social (o problema de alcoolismo durante a época de estagnação brejneviana) e ao fenômeno do alcoolismo como conceito cultural. A importância desse tema na cultura russa se manifesta tanto em numerosos provérbios e refrões que existem na língua, como em vários estereótipos relacionados com a bebida.

Foram aqui expostos alguns dos fenômenos da cultura russa e soviética flagrantes na novela Parque cultural, que nos permitem analisá-la como texto de cultura, segundo a concepção de Iú. Lótman. Outros aspectos da vida e da cultura russa presentes nesse texto serão ainda postos em destaque nos comentários à tradução da novela, que vai a seguir. 


\section{Parte II - Tradução e criação}




\section{Capítulo IV. De Zapoviédnik a Parque cultural}

A seguir, apresentamos a nossa variante da tradução para o português brasileiro da novela Zapoviédnik, de Serguei Dovlátov, com notas e comentários. 


\section{Parque cultural}

À minha mulher, que tinha razão.

Ao meio-dia chegamos em Luga ${ }^{517}$ Paramos na praça da rodoviária. A jovem guia trocou o tom elevado por um mais prático:

- Ali à esquerda tem um lugarzinho...

Meu vizinho levantou-se, interessado:

— Quer dizer, o banheiro?

Ficou me torturando o caminho todo: "Material branqueador, de 6 letras?... Animal artiodátilo em extinção?... Esquiador austríaco?...".

Os turistas saíram para a praça ensolarada?. O motorista fechou a porta e se acocorou ao lado do radiador.

A rodoviária... Um prédio amarelo meio sujo com colunas, relógio e letras trêmulas de neón descoradas pelo sol...

Atravessei o vestíbulo que tinha uma banca de jornais e lixos maciços de cimento. Intuitivamente, descobri a lanchonete.

- É com o garçom - pronunciou molemente a balconista. Em seu peito inclinado balançava um saca-rolhas.

Sentei-me ao lado da porta. Em um minuto, apareceu o garçom com enormes suíças de feltro. ${ }^{518}$

-O que o senhor deseja?

— Desejo - eu disse - que todos sejam bons, modestos e gentis.

$\mathrm{O}$ garçom, farto da diversidade da vida, guardou silêncio.

- Desejo cem gramas de vodka, uma cerveja e dois sanduíches.

- Sanduíches de quê?

— De linguiça, talvez...

Tirei o maço de cigarros, acendi um. As mãos tremiam feio. "Tomara que eu não deixe cair o copo..." Como se não bastasse, nesse momento, sentaram-se ao meu lado duas velhas de aspecto culto. Acho que eram do nosso ônibus.

$\mathrm{O}$ garçom trouxe um pequeno jarro, uma garrafa e dois bombons.

— Os sanduíches acabaram — pronunciou em tom fingidamente trágico.

\footnotetext{
${ }^{517}$ Luga: cidade na região de São Petersburgo.

518 Alusão ao aspecto físico do poeta Aleksándr Púchkin (1799-1837), sempre retratado com suíças.
} 
Serguei Dovlátov: texto de cultura na literatura russa contemporânea

Paguei a conta. Levantei e, no ato, abaixei o copo. As mãos tremiam como se eu fosse um epiléptico. As velhas observavam-me com nojo. Tentei sorrir:

— Tentem olhar para mim com amor!

As velhas se sobressaltaram e mudaram de lugar. Ouvi indistintas interjeições de repreensão.

Que se danem, pensei. Apanhei o copo com as duas mãos, virei. Fazendo frufru, desembrulhei um bombom.

Senti-me um pouco melhor. Nascia em mim uma falsa elevação de espírito. Enfiei a garrafa de cerveja no bolso. Depois, levantei-me, quase derrubando a cadeira. Ou melhor, uma poltrona de duralumínio. As velhas continuavam a me observar assustadas.

Saí para a praça. A cerca do jardim estava coberta com painéis de compensado deformados. Os gráficos prometiam, num futuro próximo, montanhas de carne, lã, ovos e outras intimidades.

Os homens fumavam ao lado do ônibus. As mulheres acomodavam-se com ruído. A guia tomava um sorvete na sombra. Fui em sua direção.

- Vamos nos conhecer.

— Aurora — disse ela, estendendo a mão pegajosa.

— E eu sou o navio-tanque Derbent. ${ }^{519}$

A moça não se ofendeu.

— Todo mundo tira sarro do meu nome. Estou acostumada... O senhor está bem? Está vermelho!

— Asseguro-lhe que é só por fora. Por dentro sou um democrata constitucional. ${ }^{520}$

— Não, sério, está se sentindo mal?

— Bebo muito... Quer cerveja?

- E por que bebe?

O que eu podia responder?

—É um segredo — digo —, um pequeno segredo.

- Vai trabalhar no parque museu?

- Exatamente.

— Eu logo imaginei.

— Será que eu tenho cara de filólogo?

519 Tánker Derbent (1938), novela do escritor soviético Iúri Krymov (1908-1941), considerada uma das obras clássicas do realismo socialista soviético. Alusão irônica ao navio Aurora, que disparou o primeiro tiro da Revolução de Outubro de 1917.

520 Democrata constitucional, ou, abreviação em russo, kadiet, membro do Partido Democrata Constitucional (Konstitutsiónnaia Demokratítcheskaia Pártia), uma força política importante na Rússia do começo do século XX. 
Serguei Dovlátov: texto de cultura na literatura russa contemporânea

- É que o Mitrofánov o acompanhava. É um puchkinista extremamente erudito. O senhor o conhece bem?

- Bem, mais por seu lado ruim.

- Como assim?

— Não dê atenção às minhas palavras.

— O senhor precisa ler Górdin, Schógolev, Tsiavlóvskaia... ${ }^{521}$ As memórias de Kern... ${ }^{522}$ E alguma brochura popular sobre os males do álcool.

— Sabe, já li tanto sobre os males do álcool! Decidi definitivamente parar de... ler.

- É impossível conversar com o senhor.

O motorista olhou em nossa direção. Os excursionistas tomaram seus assentos.

Aurora terminou o sorvete, limpou os dedos.

— No verão - disse —, no parque, pagam bastante bem. Mitrofánov ganha em torno de duzentos rublos.

- Duzentos rublos a mais do que ele vale.

- Ainda por cima é maldoso!

- Com essa vida, qualquer um seria.

O motorista buzinou duas vezes.

— Vamos — disse Aurora.

O ônibus para Lvóv estava apertado. Os assentos de percalina iam esquentando. As cortinas amarelas aumentavam a sensação de abafo.

Eu estava folheando Os diários, de Aleksei Vulf. ${ }^{523}$ Ali se falava de Púchkin de um modo amigável, às vezes até condescendente. Trata-se de uma proximidade nociva para o ponto de vista. É óbvio que os gênios têm amigos. Mas quem irá acreditar que seu amigo é um gênio?!

Peguei no sono. Ouviam-se informações vagas e desnecessárias sobre a mãe de Ryliéiev... 524

Acordaram-me já em Pskóv. Os muros recém-estucados do Krêmlin inspiravam tédio. Os designers puseram sobre o arco central um emblema de ferro detestável, de aspecto báltico. O Krêmlin lembrava uma maquete de enormes dimensões.

Numa das alas, encontrava-se a agência turística local. Aurora carimbou alguns papéis e nos levaram ao Hera, o restaurante mais luxuoso do lugar.

\footnotetext{
521 Arkádi Górdin (1913-1997), Pável Schógolev (1877-1931), Tatiana Tsiavlóvskaia (1897-1978), puchkinistas soviéticos.

${ }^{522}$ Anna Kern (1800-1879), nobre russa, autora de memórias, famosa principalmente pelas relações românticas que teve com Púchkin: o escritor dedicou a ela vários poémas líricos.

${ }^{523}$ Aleksei Vulf (1805-1881), autor de memórias e amigo íntimo de Púchkin

${ }^{524}$ Kondráti Ryliéiev (1795-1826), poeta russo, um dos cinco líderes executados da Revolta Dezembrista.
} 
Eu estava indeciso: beber ou não beber? Se bebesse, acordaria muito mal no dia seguinte. Estava sem fome...

Saí para o bulevar. As tílias farfalhavam num tom baixo e pesado.

Há muito tempo me certifiquei de algo: basta começar a pensar e a gente logo se lembra de algo triste. Por exemplo, a última conversa com minha esposa...

— Até seu amor pelas palavras, esse amor louco, doentio, patológico... é falso. É apenas uma tentativa de justificar a vida que você leva. E você leva uma vida de escritor famoso sem a menor condição para isso. Com seus vícios, deveria ser, no mínimo, um Hemingway.

— Você acha mesmo que ele é um bom escritor? E Jack London, você também acha que ele é um bom escritor?

— Céus! O que Jack London tem a ver com isso? A minha única bota está no prego... Eu posso perdoar tudo. E a pobreza não me assusta... Tudo, menos a traição!

- O que você quer dizer com isso?

- Sua eterna bebedeira. Seu... Nem quero falar. Não se pode ser artista à custa de outra pessoa. Isso é infame! Você fala tanto de nobreza! Mas você mesmo é uma pessoa fria, cruel, maliciosa...

- Não esqueça que faz vinte anos que escrevo.

— Quer escrever um grande livro? Um entre milhões consegue fazê-lo!

— E daí? Do ponto de vista moral, uma tentativa fracassada equivale a um grande livro. Se quiser, moralmente é até superior. Pois exclui a remuneração...

— São palavras. Palavras lindas e infinitas... Cansei. Eu tenho uma filha pela qual sou responsável...

— Eu também tenho uma filha.

- Que você ignora durante meses. Para você, somos duas estranhas.

(Em conversas com as mulheres, há um momento doloroso. Você cita fatos, razões, argumentos. Você apela para a lógica, o bom senso. E, de repente, descobre que o som de sua própria voz lhe dá asco...)

— Nunca fiz uma maldade de propósito - eu disse. 
Serguei Dovlátov: texto de cultura na literatura russa contemporânea

Sentei-me num banco inclinado. Tirei a caneta e o bloco de anotações. Um minuto depois, escrevi:

Querida, estou nas Colinas de Púchkin,

Sem você perto de mim, é só desânimo e tédio,

Vagueio pelo parque como um néscio.

E um medo maltrata minha alma até o âmago...

E por aí vai.

Meu poema ultrapassava um pouco a realidade. Faltavam uns cem quilômetros para as Colinas de Púchkin.

Entrei numa vendinha. Comprei um envelope com um retrato de Fernão de Magalhães. Sem saber nem para quê, perguntei:

— O senhor não sabe como Magalhães veio parar aqui?

O vendedor respondeu, pensativo:

— Talvez por ter morrido... Ou lhe deram a ordem de herói...

Colei o selo, lacrei, pus na caixa postal...

Às seis horas chegamos ao prédio do centro turístico. Até ali tínhamos visto colinas, um riozinho, um amplo horizonte e um bosque margeando. Enfim, a paisagem russa sem excessos. O tipo de singeleza que inspira um sentimento de amargura inexplicável.

Este sentimento sempre me pareceu suspeito. Em geral, a paixão pelos objetos inanimados me irrita... (Abri mentalmente o caderno de anotações.) Há algo defeituoso estranho em numismatas, filatelistas, viajantes inveterados, amantes de cactos e de peixes de aquário. A paciência sonolenta do pescador, a bravura vã e sem motivo do alpinista, a confiança altiva do dono de um poodle gigante são estranhas para mim...

Dizem que os judeus são indiferentes à natureza. Isso dito assim soa como um dos reproches que são feitos à nação judia. Dizem que os judeus, por não ter sua própria natureza, são indiferentes à alheia. Bem, pode ser que seja assim. Pelo visto, é desse jeito que se manifesta em mim a mistura de sangue judeu...

Enfim, não gosto de contempladores cheios de entusiamo. E não confio muito em seus enlevos. Acho que o amor por bétulas triunfa à custa do amor pelo ser humano. E se desenvolve como um substituto do patriotismo...

Concordo, amamos e lamentamos mais intensamente uma mãe doente e paralítica. No entanto, deleitar-se com seus sofrimentos, expressá-los esteticamente, é uma baixeza.

Enfim... 
Serguei Dovlátov: texto de cultura na literatura russa contemporânea

Chegamos ao centro turístico. Algum idiota construiu-o a quatro quilômetros da represa. Há açudes, lagos, o famoso riacho, mas o centro fica exposto ao sol. Contudo, há quartos com chuveiro. Só que raramente tem água quente...

Entramos na agência de turismo. Lá estava sentada uma dama, o sonho de qualquer oficial aposentado. Aurora passou para ela o talão de viagem. Assinou, recebeu os vales de almoço para o grupo. Cochichou algo no ouvido daquela loira suntuosa, que imediatamente olhou para mim. O olhar continha um interesse fugaz e obstinado, uma preocupação prática e uma leve inquietação. Ela até ficou mais ereta. Os papéis farfalharam com mais força.

— Vocês não se conhecem? — perguntou Aurora.

Eu cheguei mais perto.

- Quero trabalhar no parque cultural.

— Precisamos de gente — disse a loira.

No fim de sua réplica, sentia-se claramente a presença de reticências. Quer dizer, de fato precisamos de bons profissionais, altamente qualificados. Pessoas ocasionais não são necessárias...

— Conhece a exposição? — perguntou a loira e, de repente, se apresentou: — Galina Aleksándrovna.

— Estive aqui umas três vezes.

- É pouco.

— Concordo. Por isso vim de novo...

— É preciso preparar-se bem. Estudar com afinco o manual. Há tanta coisa inexplorada na vida de Púchkin... Algumas coisas mudaram desde o ano passado...

— Na vida de Púchkin? — estranhei.

— Desculpem-me — interrompeu Aurora. — Os turistas estão me esperando. Boa sorte...

Ela desapareceu, jovem, viva, genuína... No dia seguinte, numa das salas do museu, eu ouviria sua voz pura de moça:

"Reflitam, camaradas!... 'Eu vos amei com ternura sincera..." 525 Aleksándr Serguéievitch contrapôs ao mundo das relações escravocratas este inspirado hino de desinteresse..."

— Não na vida de Púchkin — disse a loira, irritada —, mas na exposição do museu. Por exemplo, tiraram o retrato de Gannibal. ${ }^{526}$

\footnotetext{
${ }^{525}$ Linha do famoso poema lírico de Púchkin Eu vos amei. Ainda talvez vivo... (1829): Eu vos amei. Ainda talvez vivo, / O amor não se apagou no peito meu; /Mas não vos seja de aflição motivo: / Entristecer-vos não desejo eu. / Eu vos amei, mudo, sem cor de espera, / Ora acanho, ora de ciúme a arder. / Eu vos amei com ternura sincera. I Deus queira amada assim venhais a ser. (Citamos aqui a tradução do russo de José Casado.)

${ }^{526}$ Abrám Gannibal (1696 - 1781), famoso bisavô de Púchkin. Filho de um conde etíope, aos sete anos de idade foi capturado pelos turcos e levado a Constantinopla, de onde foi levado à Russia e, em 1706, dado de presente ao czar Pedro, o Grande. Apadrinhado por Pedro, o Grande, sempre foi muito próximo ao czar, sendo seu secretário e
} 
— Por quê?

— Um pesquisador insiste que não é Gannibal. Diz que as condecorações não coincidem.

Diz que é o general Zakomiélski.

— E quem é na verdade?

— Realmente é Zakomiélski.

— Mas por que ele está tão moreno?

— Ele guerreava contra os asiáticos, no sul. Lá faz calor. Então ficou moreno. Também, as tintas escurecem com o tempo.

— Então fizeram bem em tirar o retrato, não?

- Ah, que diferença faz: Gannibal, Zakomiélski... Os turistas querem ver Gannibal. Eles pagam por isso. E que raios vão fazer com Zakomiélski? Por isso o nosso diretor colocou Gannibal... Quer dizer, colocou Zakomiélski e, embaixo, o nome de Gannibal. E um pesquisador não gostou disso... Desculpe, o senhor é casado?

Galina Aleksándrovna pronunciou esta frase de supetão e, eu até diria, timidamente.

— Divorciado, por quê?

- As nossas moças fazem perguntas.

— Que moças?

— Não estão aqui agora. A contadora, a metodologista, as guias...

— Mas por que se interessariam por mim?

— Não é pelo senhor. Elas se interessam por todos. Aqui há muitas solteiras. Os rapazes foram embora... E quem as nossas moças veem por aqui? Turistas? E esses turistas servem de quê? Se a excursão é de oito dias, ainda vai. Mas muitos vêm de Leningrado apenas por um dia. Ou três... O senhor ficará por muito tempo?

- Até o outono. Se tudo correr bem.

— Onde está hospedado? Quer que eu ligue para o hotel? Temos dois hotéis aqui: um bom e um ruim. Qual prefere?

— Neste caso, é preciso pensar.

— O bom é mais caro - explicou Galina.

— Está bem, de qualquer maneira não tenho dinheiro...

Ela ligou na hora para algum lugar. Ficou convencendo alguém de algo durante um bom tempo. Finalmente, a questão foi resolvida. E meu sobrenome foi anotado num canto.

- Vou acompanhá-lo.

ajudante. Estudou engenharia militar na França e, desde 1756, foi o principal engenheiro militar do exército russo. Desde 1759, foi général en chef. Púchkin dedicou ao seu famoso antepassado a novela Arap Petrá Velíkovo (O negro de Pedro Grande), de 1827. 
Serguei Dovlátov: texto de cultura na literatura russa contemporânea

Fazia tempo que eu não era objeto de cuidados femininos tão intensos. Depois estes se manifestariam de forma ainda mais insistente. E até se converteriam em pressão.

No início, eu atribuí isso à minha individualidade embaçada. Depois, certifiquei-me de quanto era enorme o déficit do gênero masculino na região. O tratorista local, de pernas tortas e cachos como de uma prostituta de estação, era rodeado de admiradoras coradas e impertinentes.

- Estou morrendo por uma cerveja! - dizia ele molemente.

$\mathrm{E}$ as moças corriam para pegar a cerveja...

Gália trancou a porta da agência de turismo. Rumamos para o povoado através do bosque.

— O senhor gosta de Púchkin? — perguntou Gália subitamente.

- Gosto... O cavaleiro de bronze, a prosa...

- E a poesia?

- Gosto muito de seus poemas tardios.

- E dos primeiros?

— Também gosto — capitulei.

— Aqui tudo vive e respira Púchkin — disse Gália —, literalmente cada raminho, cada talo de grama. Você até espera que neste instante ele apareça virando a esquina... A cartola, o sobretudo, o perfil tão familiar...

No entanto, quem surgiu virando a esquina foi Liónia Guriánov, o ex-dedo-duro da universidade.

— Borka, seu filho da mãe — gritou como um possesso —, é você mesmo?!

Respondi com uma cordialidade inesperada. Mais um canalha que me pega de surpresa. Nunca tenho tempo para me concentrar...

— Sabia que você ia vir — Guriánov não se continha...

Depois me contaram a tal história. Houve ali uma festa de arromba no começo da temporada. Casamento ou aniversário de alguém. Estava presente um funcionário local da KGB. Começaram a falar de mim. Algum amigo comum disse:

— Ele está em Tállin.

Retrucaram:

- Não, faz um ano que está em Leningrado.

— Ouvi dizer que está em Riga na casa de Krassílnikov...

Surgiam novas e novas versões. 
Serguei Dovlátov: texto de cultura na literatura russa contemporânea

O kgbista comia compenetrado o seu pato guisado. Depois, soergueu a cabeça e disse de passagem:

— A informação que tenho é que ele está prestes a ir às Colinas de Púchkin.

\begin{abstract}
$* * *$
— Estão me esperando — disse Guriánov, como se eu o estivesse detendo.

Ele olhou para Gália.
\end{abstract}

— Você está mais bonita. Pelo jeito, colocou uma dentadura?

Seus bolsos alargavam-se, pesados.

- Que escroto! - disse de súbito Galina. E, um minuto depois: - Que bom que Púchkin não está vendo isso.

— Sim — disse eu —, é bom mesmo.

Três estabelecimentos ocupavam o andar térreo do hotel Drujba. Uma mercearia, um salão de cabelereiro e o restaurante Lukomórie. ${ }^{527}$ Pensei que seria preciso convidar Galina por sua ajuda. Trouxe uma merreca comigo. Um gesto generoso ameaçava uma catástrofe.

Fiquei calado.

Chegamos até o balcão onde ficava a administradora. Gália me apresentou. A mulher estendeu uma chave pesada com o número 231.

— E amanhã procure um quarto — disse Galina. — Pode ser no povoado... Pode ser em Vorónitch, mas lá é caro... Ou numa das aldeias próximas: Sávkino, Gáiki...

— Obrigado, me ajudou demais.

- Bem, vou embora.

A frase terminou com uma interrogação quase imperceptível: "Bom, vou embora?”.

- Quer que a acompanhe?

- Moro num bairro residencial — reagiu misteriosamente a moça.

E depois, em alto e bom som, até demais:

— Não precisa me acompanhar... E não pense que sou desse tipo...

Ela retirou-se, acenando com dignidade à administradora.

Subi ao segundo andar e abri a porta. A cama tinha sido feita com cuidado. O alto-falante emitia sons entrecortados. Cabides balançavam no cabideiro do armário embutido escancarado.

Nesse quarto, nesse barquinho apertado eu rumava para as águas desconhecidas da vida independente de solteiro.

${ }^{527}$ Lukomórie, região de um conto maravilhoso do folclore russo, mencionado no poema de Púchkin Ruslan $e$ Liudmila. 
Serguei Dovlátov: texto de cultura na literatura russa contemporânea

Tomei banho, tirando o resíduo coceguento dos cuidados de Gália, a camada do aperto úmido do ônibus, a crosta do festim de dias a fio.

O humor melhorou sensivelmente. O banho frio funcionou como um grito repentino.

Sequei-me, pus uma calça esportiva e acendi um cigarro.

No corredor, ouviam-se ruídos de passos. Em algum lugar, soava uma música. Do lado de fora, passavam uns caminhões e um sem-número de motocicletas fazendo barulho.

Deitei-me por cima do cobertor, abri um pequeno tomo cinza de Víktor Likhonóssov. ${ }^{528}$ Decidi, por fim, entender por mim mesmo o que era essa tal prosa rural. Tentei prover-me de uma espécie de guia...

Lendo, cochilei sem perceber. Quando acordei, eram duas da madrugada. A penumbra da alvorada de verão inundava o quarto. Já era possível contar as folhas do ficus na janela.

Decidi ponderar tudo com calma. Tentar dissipar a sensação de catástrofe, de um beco sem saída.

A vida estendia-se ao redor como um imenso campo minado. E eu estava bem no meio. Era preciso dividir este campo em setores e por mãos à obra. Romper a corrente de circunstâncias dramáticas. Analisar a sensação de fiasco. Estudar cada fator separadamente.

Um homem escreve contos há vinte anos. Está convencido de que começou a escrever por certas razões. As pessoas nas quais confia estão dispostas a confirmar isso.

Não o publicam, não o editam. Não aceitam à sua companhia. À sua quadrilha de bandidos. Mas será que foi com isso que ele sonhou quando soletrou as primeiras linhas?

Você procura justiça? Fique calmo, essa fruta não cresce aqui. Algumas verdades radiantes deveriam mudar o mundo para melhor, e o que acontece na realidade?...

Você tem uma dezena de leitores. Deus queira que sejam até menos...

Não lhe pagam, e isso que é pior. Dinheiro significa liberdade, espaço, caprichos... Tendo dinheiro, é tão fácil aguentar a pobreza...

Aprenda a ganhá-lo sem ser hipócrita. Vá trabalhar de carregador e escreva de madrugada. Mandelstam ${ }^{529}$ dizia que as pessoas sempre conservam o que lhes é sagrado . Então escreva...

Você tem o dom, mas poderia não tê-lo. Escreva, crie uma obra-prima. Provoque uma comoção na alma do leitor. Numa pessoa que seja... É uma tarefa para toda uma vida.

E se não der certo? Bem, você mesmo dizia que, no sentido moral, uma tentativa que fracassa é ainda mais nobre. No mínimo, por não ser remunerada.

\footnotetext{
528 Víktor Likhonóssov (nasc. em 1936), escritor soviético e russo, representante da chamada "prosa camponesa" (em russo, dereviénskaia proza).

${ }^{529}$ Óssip Mandelstam (1891 - 1938), poeta russo.
} 
Serguei Dovlátov: texto de cultura na literatura russa contemporânea

Escreva, já que começou a fazê-lo, carregue este peso. Quanto mais pesado, melhor...

As dívidas o oprimem? E quem não as tem?! Não se aflija. Pois é a única coisa que o vincula de verdade às pessoas...

Ao olhar para trás, vê ruínas? Era esperado. Quem vive no mundo das palavras não se dá bem com as coisas.

Você inveja qualquer um que chame a si mesmo de escritor. Que possa confirmá-lo com documentos, tirar um certificado .

Mas o que escrevem os seus contemporâneos? Na obra do escritor Vólin você descobriu:

"...Foi compreensivelmente claro para mim..."

E na mesma página:

“...Com uma clareza incompreensível Kim sentiu...”

A palavra está de pernas para o ar. Todo o conteúdo despencou. Ou melhor, nem há conteúdo. As palavras amontoam-se intangíveis, como a sombra de uma garrafa vazia...

Ah, mas não é isso, não é disso que se trata!... Estou cansado de seus eternos subterfúgios!...

É impossível viver. É preciso ora viver, ora escrever. Ora palavra, ora trabalho. Mas o seu trabalho é a palavra. E qualquer Trabalho, com maiúscula, é detestada por você. À sua volta, há uma zona de espaço morto. Ali morre tudo o que atrapalha o trabalho. Ali perecem esperanças, ilusões, memórias. Ali reina um materialismo miserável, indiscutível e de sentido único.

E, de novo, não é isso, não é isso.

Em que você transformou sua mulher? Era ingênua, coquete, gostava de se divertir. Você a fez ciumenta, desconfiada, nervosa. Sua frase costumeira: “O que você quer dizer com isso?" é um monumento de sua sagacidade.

Suas indecências chegavam a ser engraçadas. Lembra quando você chegou a sua casa pelas quatro da madrugada e começou a desamarrar os sapatos. Sua mulher acordou e gemeu:

- Meu Deus, para onde vai tão cedo?!

—É verdade, é um pouco cedo, é um pouco cedo — você murmurou.

E depois tirou a roupa depressa e deitou-se...

Bem, adianta falar sobre isso?... 
Serguei Dovlátov: texto de cultura na literatura russa contemporânea

Manhã. Passos abafados pela passadeira vermelha. Um balbucio repentino e entrecortado no alto-falante. Ruído de água atrás da parede. Caminhões do lado de fora. O grito súbito e distante de um galo...

Na infância, o verão era marcado por sons de apitos de locomotivas a vapor. Casas de campo suburbanas... Cheiro de queimado da estação e da areia quente. Pingue-pongue embaixo das árvores... O ruído tenso e sonoro da bolinha. As danças no terraço (o irmão mais velho o encarregou de dar corda na vitrola)... Glieb Románov... ${ }^{530}$ Rugena Sikora... 531 "Esta canção de dois soldi, de dois groches...", 532 "Sonhei acordado com você em Bucareste...".533

A praia queimada pelo sol... Folhas duras de espargâneo... Calções compridos e marcas de elástico nas panturrilhas... A areia que entrou na sandália...

Bateram na porta:

— O telefone!

- É engano - digo.

— O senhor é Alikhánov?

Acompanharam-me até o quarto da governanta. Peguei o telefone.

— O senhor estava dormindo? — perguntou Galina.

Neguei enfaticamente.

Faz tempo que percebi que as pessoas reagem a essa pergunta com demasiado pudor. Pergunte a alguém: "Você costuma cair na bebedeira?", e o sujeito responde tranquilamente: não, por quê? Ou talvez concorde, com vontade. Mas, diante da pergunta: "Você estava dormindo?", a maioria se sente quase insultado. Feito uma tentativa de flagrar um homem cometendo um crime...

- Arranjei um quarto.

- Muito obrigado.

— Na aldeia de Sosnovo. A cinco minutos da base turística. Entrada independente.

— Isso é o mais importante.

— Só uma coisa, o senhorio bebe...

- Mais uma vantagem.

— Guarde seu sobrenome: Sorókin. Mikhail Iványth... Vá pelo centro turístico, ao longo do barranco. Do monte já dá para ver a aldeia. É a quarta casa... Ou, talvez, a quinta. Bom, o senhor vai achar. Há um depósito de lixo ao lado.

\footnotetext{
530 Gliéb Románov (1920-1967), ator e cantor soviético.

${ }^{531}$ Rugena Sikora (1918-2006), cantora soviética de origem tcheca.

${ }^{532}$ Estrofe da versão russa da canção italiana Una canzone da due soldi. Soldi, do italiano, "dinheiro", groch, do russo, "tostão".

${ }^{533}$ Canção interpretada por Sidi Tal (1912 - 1983), cantora de origem judia, popular na União Soviética.
} 
- Obrigado, querida.

Seu tom mudou bruscamente:

— Não sou sua querida! Ah, que coisa... Querida... Veja só... Agora inventou de achar uma querida...

Volta e meia me surpreendia com essas mudanças súbitas de Gália. A simpatia viva, a cordialidade e a sinceridade alternavam-se com entonações gritantes de castidade ofendida. Uma linguagem normal e, de repente, uma fala esganiçada e caipira...

— E não pense nada desse tipo!

— Desse tipo, jamais. E, mais uma vez, obrigado...

Parti para o centro turístico. Dessa vez, havia bastante gente. Carros variegados em volta. Turistas de chapéu de sol flanavam em grupos ou sozinhos. Formou-se uma fila ao lado da banca de jornais. Das janelas abertas do refeitório chegavam o tinido de louça e o som estridente dos bancos de metal. Lá brincavam vira-latas bem nutridos.

A cada passo, eu via imagens de Púchkin. Até ao lado da misteriosa guarita de tijolos com a placa "Inflamável!". A semelhança limitava-se às suíças. O tamanho delas variava livremente. Não é de hoje que percebi: nossos artistas têm fetiches pelos quais se esforçam e se entusiasmam infinitamente. Em primeiro lugar, aparecem a barba de Karl Marx e a testa de Ilitch. ${ }^{534}$

O alto-falante estava ligado em potência máxima:

- Atenção! Está no ar a rádio do centro turístico das Colinas de Púchkin. Anunciaremos a ordem do dia...

Entrei na agência turística. Os turistas assediavam Galina. Ela me fez um sinal com a mão para que esperasse.

Peguei da prateleira a brochura A pérola da Crimea. Tirei um cigarro.

Os guias recebiam alguns papéis e se retiravam. Atrás deles, os turistas corriam na direção dos ônibus. Algumas famílias “independentes” queriam juntar-se aos grupos. Uma moça alta e magrinha os atendia.

Um homem de chapéu tirolês aproximou-se timidamente.

- Desculpe, posso fazer uma pergunta?

- Pois não.

— São as lonjuras?

- Como?

— Estou perguntando, são as lonjuras? — o tirolês me levou até a janela aberta.

— Em que sentido?

\footnotetext{
${ }^{534}$ Ilitch é o patronímico de Vladímir Lênin e se tornou seu apelido na cultura popular.
} 
Serguei Dovlátov: texto de cultura na literatura russa contemporânea

— No sentido direto. Gostaria de saber se são ou não são as lonjuras. Se não são, digame.

— Não compreendo.

O homem ruborizou-se um pouco e começou a explicar às pressas:

— Eu tinha um cartão postal... Sou filocartista...

- O quê?

— Filocartista. Coleciono cartões postais. Philos, amor, cartos...

— Entendi.

— Tenho um postal colorido, "As lonjuras de Pskóv". E agora estou aqui. Quero perguntar: são as lonjuras?

— De certo modo, são - disse.

— Típicas de Pskóv?

- Algo assim.

O homem afastou-se, radiante.

Passou a hora do pico. A agência esvaziou-se.

- A cada verão aumenta o número de turistas - esclareceu Galina.

E, depois, elevando um pouco a voz:

— Cumpriu-se a profecia: "Seu atalho o mato não há de ocultar!..."535

Não há mesmo, pensei. Como o coitado vai ficar oculto? Já não sei há quanto tempo está sendo pisoteado por uma legião de turistas...

— De manhã aqui é uma zona — disse Galina.

De novo, surpreendi-me com a mudança súbita de seu vocabulário.

Gália me apresentou à instrutora da agência, Liudmila. Vou deleitar-me em segredo com suas pernas lisas até o fim da temporada. Liuda ${ }^{536}$ se comportava de um modo muito previsível e amigável. Isso se explicava pelo fato de ela ter um namorado. A constante prontidão para reações indignadas não a enfeava. Naquela época, o namorado estava na prisão...

Depois, apareceu uma mulher nada atraente, de uns trinta anos, a metodologista. Seu nome era Marianna Petrovna. Marianna tinha um rosto descuidado sem defeitos e um corpo imperceptivelmente feio.

Expliquei a razão da minha vinda. Com um sorriso cético, convidou-me para ir a um escritório independente.

— O senhor gosta de Púchkin?

Senti uma irritação abafada.

\footnotetext{
535 Citação deturpada do verso de Púchkin. Na tradução de José Casado: "Sua vereda o mato não há de ocultar." ${ }^{536}$ Diminutivo de Liudmila.
} 
- Gosto.

Mas desse jeito não é difícil deixar de gostar, pensei.

- E posso saber por quê?

Senti um olhar irônico. Evidentemente, o amor a Púchkin era ali a moeda mais usada. E se, de repente, eu fosse um falsificador?

- Como assim?

— Por que o senhor gosta de Púchkin?

- Vamos parar com este exame idiota - não aguentei. - Terminei o ensino médio. Depois a universidade. [Aqui exagerei um pouco. Fui expulso no terceiro ano.] Li algumas coisas. Enfim, conheço o assunto... Além do mais, apenas pretendo trabalhar como guia...

Por sorte, meu tom áspero passou despercebido. Como provei mais tarde, ali uma grosseria óbvia passava mais facilmente impune do que uma insolência imaginária...

- Mas, mesmo assim? - Marianna esperava uma resposta. Embora a resposta fosse conhecida por ela de antemão.

— Está bem, vou tentar... Bem, escute. Púchkin é a nossa Renascença tardia. Como Goethe foi para Weimar. Eles encarregaram-se daquilo que o Ocidente assimilou entre os séculos XV e XVII. Púchkin soube expressar motivos sociais em forma de tragédia, caraterística da Renascença. Ele e Goethe como que viveram em várias épocas. Werther é um tributo ao sentimentalismo. O prisioneiro do Cáucaso é uma obra tipicamente byroniana. Mas Fausto, digamos, já é elisabetano. E As pequenas tragédias dão continuidade, naturalmente, a um dos gêneros da Renascença. Assim também é a lírica de Púchkin. E, quando esta é amarga, não é no estilo de Byron, mas, me parece, no estilo dos sonetos de Shakespeare... Estou expondo claramente?

- O que Goethe tem com isto? - perguntou Marianna. - E o que tem a ver a Renascença?

— Não tem nada a ver! — finalmente, explodi. — Goethe não tem absolutamente nada a ver! E Renascença era o nome do cavalo de Dom Quixote! Que também não tem nada a ver! E, pelo visto, eu também não tenho nada a ver!...

- Acalme-se - sussurrou Marianna. - Que nervoso... Eu apenas perguntei por que o senhor ama Púchkin?

— Amar em público é uma obscenidade! — gritei. — Há um termo especial na sexologia para isso.

Com a mão trêmula, ela estendeu-me um copo de água. Afastei-o.

— E a senhora mesma amou a alguém? Alguma vez na vida?

Não devia ter falado aquilo: irá se desfazer em pranto e gritar: 
Serguei Dovlátov: texto de cultura na literatura russa contemporânea

“Tenho trinta e quatro anos e sou uma donzela solitária!...”.

- Púchkin é o nosso orgulho - disse ela. - Não é apenas um grande poeta, mas também um grande cidadão...

Ao que parece, essa era a resposta pronta e evidente à sua pergunta boba.

Só isso? pensei.

— Estude o manual. E esta é a lista de livros. Estão na sala de leitura. E informe Galina Aleksándrovna que a nossa entrevista correu bem...

Fiquei sem jeito.

— Obrigado e perdoe-me por ter perdido o controle.

Dobrei o manual e o pus no bolso.

— Cuidado, temos apenas três exemplares.

Tirei o manual e tentei alisá-lo.

- Mais uma coisa - Marianna baixou a voz. - O senhor perguntou sobre o amor...

— Foi a senhora que perguntou sobre o amor.

— Não, foi o senhor que perguntou sobre o amor... Pelo que entendo, interessa-lhe saber se sou casada, Pois eu sou casada!

- A senhora matou minha derradeira esperança — disse eu indo embora.

No corredor, Galina me apresentou à guia Natella. De novo, um raio inesperado de interesse:

— Vai trabalhar conosco?

- Vou tentar.

— Tem cigarro?

Saímos para o terraço.

Natella tinha vindo de Moscou, movida por fins românticos, ou melhor, aventureiros. Engenheira-física de formação, trabalhava como professora numa escola. Decidira passar ali seus três meses de férias. Lamentava ter vindo. No parque museu, há tumulto. Os guias e os metodologistas são malucos. Os turistas porcos e ignorantes. Todos veneram Púchkin. E veneram seu amor a Púchkin. E o amor ao seu amor. A única pessoa decente é Márkov...

— Quem é Márkov?

— O fotógrafo. Um bebum inveterado. Vou lhe apresentar. Me ensinou a beber Agdám. ${ }^{537}$ É uma coisa fantástica! Vai ensinar ao senhor também...

- Agradeço muito. Mas receio que, neste assunto, eu mesmo sou mestre.

- Vamos tomar uma algum dia! Direto na natureza...

— Fechado.

${ }^{537}$ Vinho azerbaijano. 
Serguei Dovlátov: texto de cultura na literatura russa contemporânea

— O senhor é um homem perigoso.

— Isso significa?

— Senti isso na hora. O senhor é um homem terrivelmente perigoso.

— Em estado de embriaguez?

— Não estou falando disso.

- Não compreendo.

- Amar alguém como o senhor é perigoso.

E Natella me empurrou com o joelho e quase me machucou...

Meu Deus, pensei, aqui todos são loucos. Até os que consideram os demais loucos são loucos...

— Tome um pouco de Agdám e acalme-se — disse eu. - Não represento nenhum perigo para a senhora...

— Isso a gente ainda verá — Natella deu uma risada histérica.

Depois, coquete, agitou a bolsa de pano com a imagem de James Bond e se foi.

Dirigi-me a Sosnovo. O caminho ia ao topo do morro volteando o triste campo. Em suas bordas, viam-se pedregulhos escuros em montes disformes. À esquerda, surgia um barranco coberto de arbustos. Descendo a montanha, vi algumas isbás rodeadas de bétulas. À parte, vacas monocromáticas perambulavam, achatadas como num cenário teatral. Ovelhas sujas com caras decadentistas beliscavam languidamente o capim. Em cima dos telhados, gralhas revoavam.

Eu ia pela aldeia na expectativa de encontrar alguém. As casas cinzentas e não pintadas tinham um aspecto deplorável. As estacas das sebes tortas eram coroadas com vasos de barro. Pintinhos agitavam-se dentro dos cercados cobertos com polietileno. Galinhas passeavam com um passo nervoso de desenho animado. Cachorros baixotes e peludos latiam sonoramente.

Atravessei a aldeia, voltei-me. Detive-me perto de uma das casas. A porta deu uma batida, e no terraço surgiu um homem vestido numa camisa militar de ferroviário toda surrada.

Perguntei como encontrar Sorókin.

— Meu nome é Tólik — disse.

Apresentei-me e voltei a explicar que procurava Sorókin.

— E onde ele mora? — perguntou Tólik.

— Na aldeia de Sosnovo.

- Mas aqui é Sosnovo.

— Eu sei. Então, como posso achá-lo?

— Seria Timokha, o Sorókin?

— Seu nome é Mikhal Iványtch.

— O Timokha morreu faz um ano. Congelou, bêbado... 
- Gostaria de achar Sorókin...

— Pelo visto, bebeu pouco. Senão, teria sobrevivido...

— E para achar Sorókin...

— Por acaso não é o Michka?

— Seu nome é Mikhal Iványtch.

— Então é o Michka. O genro da Dolikha. Conhece a Dolikha, a mal ajambrada?

— Não sou daqui.

— Não é de Opotchka por acaso?

— De Leningrado.

- Ah, sei, ouvi falar...

— Então, como acho Mikhal Iványtch?

—É o Michka?

- Exatamente.

Tólik urinou do terraço, ativamente e sem timidez. Depois entreabriu a porta e ordenou:

— Alô! Iványtch, seu folgadão! Tem aqui alguém pra você.

E, dando uma piscadinha a mim, acrescentou:

- Da polícia, por causa dos mantimentos...

Na hora, apareceu um focinho roxo, generosamente adornado de olhos azuis:

— Isso... Quem?... É sobre a espingarda?

- Disseram que o senhor está alugando um quarto.

No rosto de Mikhal Iványtch, havia uma expressão de forte confusão. Depois, pude certificar-me que era sua reação comum a qualquer declaração, até a mais inofensiva.

— Um quarto?... Para quê?

- Eu trabalho no parque cultural. Quero alugar um quarto. Provisoriamente. Até o outono. O senhor tem um quarto livre?

- A casa é da minha mãe. Registrada no nome da minha mãe. E minha mãe está em Pskóv. Tem as pernas inchadas...

— Então o senhor não aluga um quarto?

— No ano passado uns judeus moraram aqui. Não posso dizer nada de mau, gente culta... Nada de álcool de limpeza ou de água de colônia... Só branco, tinto e cerveja... Eu, particularmente, tenho respeito por judeus.

— Eles crucificaram Cristo - intrometeu-se Tólik.

- Mas isso foi faz tempo! — gritou Mikhal Iványtch. - Isso foi ainda antes da revolução...

— Está alugando um quarto ou não? 
Serguei Dovlátov: texto de cultura na literatura russa contemporânea

- Acompanhe o homem - ordenou Tólik fechando a braguilha.

Fomos os três pela rua da aldeia. Ao lado da sebe, achava-se uma fulana de paletó masculino com a Ordem da Estrela Vermelha na lapela.

—Zina, me empreste cinco pratas! — gritou Mikhal Iványtch.

A fulana acenou negativamente com a mão.

- Vai morrer do vinho... Ouviu que saiu um novo decreto? Vão enforcar todos os bebuns na trave!...

— Aonde?! - Mikhal Iványtch caiu na gargalhada. — Vai faltar metal. Toda a nossa metalurgia vai se ferrar...

E depois acrescentou:

- Sua velha vadia. Tente de novo pedir lenha pra mim... Trabalho na zona florestal, sou drujbista.

— Quem? Não entendi.

— Tenho uma serra elétrica... Drujba... ${ }^{538}$ Zás e dez rublos no bolso.

- Drujbista — resmungava a mulher —, é com o vinho que tem amizade... Não emborque até morrer...

— Tá difícil — disse Mikhal Iványtch, quase como se lamentando.

Era um homem esbelto, de ombros largos. Nem a roupa rasgada e suja seria capaz de enfeá-lo de verdade. Rosto pardo, clavículas magras e fortes embaixo da camisa aberta, passo leve e decidido... Sem querer, admirava-o.

A casa de Mikhal Iványtch dava uma impressão horrível. Nuvens ao fundo, uma antena torta negrejando. O telhado caído em algumas partes desnudava vigas escuras e irregulares. As paredes eram forradas negligentemente de compensado. Os vidros rachados cobertos com jornal. Das inúmeras frestas, saía estopa suja.

No quarto do senhorio, sentia-se cheiro de comida azeda. Em cima da mesa vi um retrato colorido de Mao, da revista Ogoniok. ${ }^{539}$ Ao lado, Gagárin exibia-se num sorriso largo. Na pia, com rodelas pretas de esmalte quebrado, flutuavam uns macarrões. $\mathrm{O}$ relógio de pêndulo estava parado. O ferro que servia de contrapeso tocava o chão.

Dois gatos de aspecto heráldico, um preto como carvão e outro branco-rosado, flanavam dengosos pela mesa, contornando os pratos. O dono os expulsou com uma bota de feltro que lhe caiu na mão. Retiniram estilhaços. Com um rugido louco, os gatos saíram voando para um canto escuro.

\footnotetext{
${ }^{538}$ Drujba (em português, "amizade"), marca de serra elétrica.

539 Ogoniok ("Luzinha”), uma das mais antigas revistas ilustradas russas.
} 
Serguei Dovlátov: texto de cultura na literatura russa contemporânea

O quarto vizinho tinha um aspecto ainda mais repugnante. No meio, o teto pendia de modo ameaçador. Duas camas de metal estavam entulhadas de trapos e de peles de ovelha fedorentos. Por toda parte cintilavam pontas de cigarro e cascas de ovo.

Francamente, fiquei um pouco desnorteado. Deveria ter dito sem rodeios: "Não me convém...". Mas, pelo visto, apesar de tudo, sou um homem gentil. E eu disse algo lírico:

- As janelas dão para o sul?

— Bem para o sul — consentiu Tólik.

Atrás da janela vi, uma casa de banho quase arruinada.

- O mais importante é que há uma entrada independente.

— Tem entrada independente — concordou Mikhal Iványtch —, mas está fechada com tábuas.

—É uma pena.

— Ein moment — ${ }^{540}$ disse o dono, arrancando e arrombando a porta com o pé.

- Quanto devo pagar?

- Ah, nada.

— Como assim? — perguntei.

- Assim mesmo. Por seis garrafas do veneno o espaço é seu.

- Podemos combinar algo mais concreto? Digamos, vinte rublos lhe conviriam?

O senhorio refletiu:

— Isso será quanto?

— Estou lhe dizendo, vinte rublos.

— E se traduzir isso em bebida? Por um rublo e quatro copeques?

- Dezenove garrafas de Rosé capitoso. ${ }^{541}$ Um maço de Bielomor. Duas caixas de fósforos - escandiu Tólik.

— E dois rublos para esquentar — precisou Mikhal Iványtch.

Tirei o dinheiro.

— Deseja ver o toalete?

— Depois. Então, combinado? Onde deixa a chave?

— Não tem chave — disse Mikhal Iványtch. - Foi perdida. Peraí, não vá embora, a gente vai rapidinho.

— Tenho coisas para resolver no centro turístico. Fica para a próxima...

- Como quiser. Vou passar pela base à noite. Preciso dar um tapa na bunda da Lizka.

- Quem é Lizka?

540 "Um momento", do alemão.

${ }^{541}$ Vermute produzido na URSS. 
Serguei Dovlátov: texto de cultura na literatura russa contemporânea

— É a minha mulé. Quer dizer, esposa. Trabalha de governanta no centro turístico. A gente tá separado.

— Mas então o senhor tenciona bater nela?

— Em quem?... Enforcar seria pouco, mas não quero me meter. Queriam tirar a minha espingarda, parece que eu ameaçava dar um tiro nela... Pensei que você veio por causa da espingarda.

— Dá pena gastar cartuchos nela - intrometeu-se Tólik.

— Nem me diga — concordou Mikhal Iványtch. — Pois eu posso estrangular mesmo com as mãos, se precisar... Encontrei ela no inverno, uma coisa, outra, na boa... Começou a gritar: “Ai, Míchenka, não vou mais, ai, me solte...”. O major Djafárov me chamou e disse:

"Seu sobrenome?"

E eu para ele:

"Cu de lobisome."

Deram quinze dias de cadeia, sem cigarrinho, sem nada... Tava cagando e andando... E cadeia não é trabalho... Lizka escreveu um papel ao procurador, algo assim, prendam o homem, se não, vai me matar... E pra que matar?...

- Vai fazer um escarcéu — concordou Tólik. E concluiu: — Bem, vamos! Ou a mercearia da aldeia vai fechar.

Os amigos, amantes da vida, repelentes e belicosos como erva daninha, dirigiram-se ao bairro residencial...

E eu fiquei na biblioteca até ela ser fechada.

Foram precisos três dias para preparar a excursão. Galina me apresentou aos dois melhores guias, na sua opinião. Percorri com eles o parque museu, dando ouvidos e anotando uma coisa ou outra.

O parque cultural contava com três lugares comemorativos. A casa e a propriedade dos Púchkin em Mikháilovskoe. Trigórskoe, onde moravam os amigos do poeta e aonde ele ia quase todo dia. E, finalmente, o mosteiro com a sepultura familiar dos Púchkin-Gannibal.

A excursão para Mikháilovskoe consistia em algumas partes. A história da propriedade. O segundo exílio do poeta. Arina Rodiónovna. ${ }^{542}$ A família Púchkin. Os amigos que visitaram o poeta no exílio. A Revolta Dezembrista. ${ }^{543}$ E o escritório com um breve panorama da obra de Púchkin.

\footnotetext{
542 Arina Rodiónovna Iákovleva (1758 - 1828), babá de Púchkin, a quem o poeta dedicou vários poemas.

543 Durante a Revolta Dezembrista, ocorrida no dia 14 de dezembro de 1825, oficiais do exército russo empreenderam uma tentativa de golpe de Estado, num protesto contra a coroação do czar Nikolai I. Púchkin era amigo de muitos dos participantes da revolta e posteriormente lhes dedicou vários poemas, mas não participou da insurreição.
} 
Serguei Dovlátov: texto de cultura na literatura russa contemporânea

Encontrei a curadora do museu e me apresentei. A Viktória Albiértovna era possível dar uns quarenta anos. Uma saia comprida com babados, uns cachos descoloridos, um camafeu, uma sombrinha: um quadrinho pretensioso de Benois. Este estilo em extinção da nobreza provinciana era ali cultivado visivelmente e de propósito. Em cada estudioso local, manifestava-se algum traço típico deste estilo. Um prendia no peito um xale cigano de tamanho fantástico. Outro pendurava nas costas um requintado chapéu de palha. A um terceiro cabia um ridículo leque de plumas.

Viktória Albiértovna conversava comigo com um sorriso desconfiado. Eu já começava a acostumar-me com isso. Todos os seguidores do culto a Púchkin eram extraordinariamente ciumentos. Púchkin era sua propriedade coletiva, seu amado adorado, sua obra acalentada com carinho. Qualquer atentado a essa relíquia pessoal irritava-os. Apressavam-se a certificar-se da minha ignorância, cinismo e cobiça.

— Por que o senhor veio? - perguntou a curadora.

- Para ganhar um dinheirinho fácil.

Viktória Albiértovna quase perdeu os sentidos.

- Desculpe, foi uma piada.

- As piadas são totalmente inoportunas aqui.

- Concordo. Posso fazer uma pergunta? Quais objetos expostos no museu são autênticos?

- Será que isso é importante?

— Acho que sim. Pois um museu não é um teatro.

- Aqui tudo é autêntico. O rio, as colinas e as árvores são contemporâneos de Púchkin. De seus interlocutores e amigos. Toda a admirável natureza destas paragens...

— Estou me referindo às peças do museu — interrompi —, a maioria delas é comentada no manual de maneira evasiva:

"A louça descoberta no território da propriedade...".

- O que lhe interessa concretamente? O que gostaria de ver?

- Bem, pertences pessoais... Se houver...

— A quem está endereçando suas reclamações?

- Mas que reclamações eu poderia ter?! E ainda mais dirigi-las à senhora! Eu só perguntei...

— Pertences de Púchkin?... O museu foi criado dezenas de anos depois de sua morte...

— E é assim — disse - é como sempre acontece. Primeiro, matam uma pessoa e depois começam a procurar seus pertences. Assim foi com Dostoiévski, com Iessiênin... Assim será com Pasternak. Reconsiderarão e começarão a procurar os pertences de Soljenítsyn... 
Serguei Dovlátov: texto de cultura na literatura russa contemporânea

- Mas nós recriamos o colorido, a atmosfera - disse a curadora.

— Entendi. A estante é autêntica?

- Pelo menos, é daquela época.

- E o retrato de Byron?

—É autêntico - alegrou-se Viktória Albiértovna. — Dado de presente pelos Vulf... Há uma inscrição ali... Veja só, que caprichoso. Os pertences, os pertences... Na minha opinião, é um interesse doentio...

Senti-me como um ladrão flagrado em apartamento alheio.

— E que tipo de museu existiria sem isso? Sem o interesse doentio? Interesse saudável só existe por presunto...

- A natureza é pouco para o senhor? É pouco saber que ele andava por estas colinas? Nadava neste rio? Admirava este panorama maravilhoso?...

Para que fui pegar no pé dela, pensei.

— Entendi. Obrigado, Vika.

De súbito, ela se abaixou. Arrancou uns fiapos de grama. Fustigou-me sensivelmente o rosto. Deu uma risada curta e nervosa e retirou-se levantando a saia máxi com babados.

Juntei-me a um grupo que ia a Trigórskoe.

De forma inesperada, gostei do casal de curadores da propriedade. Sendo casados, podiam permitir-se o luxo da bondade. Polina Fiódorovna parecia autoritária, enérgica e um pouco presunçosa. Kólia era uma jamanta desengonçada, tímido, e mantinha-se em segundo plano.

Trigórskoe conservava certa distância. Os superiores raramente passavam por ali. A exposição era construída de forma lógica e bela. O jovem Púchkin, as encantadoras senhoritas apaixonadas, a ambiência dos elegantes galanteios de verão...

Percorri o parque. Depois, desci até o rio. Verdejavam árvores caídas. Passavam flutuando nuvens ligeiras.

Queria banhar-me, mas, a essa altura, chegou o ônibus de linha.

Fui ao mosteiro de Sviatogórski. Velhas vendiam flores no portão. Comprei algumas tulipas e subi até o túmulo. Os turistas tiravam fotos junto à grade. Seus rostos sorridentes pareciam asquerosos. Ao lado, instalaram-se dois fracassados com cavaletes.

Pus as flores e fui embora. Precisava ver a exposição da catedral de Uspiénski. Nos frescos nichos de pedra, ressoava um eco. Sob as abóbadas, cochilavam pombos. A catedral era real, baixa e graciosa. Num canto da sala central, cintilava palidamente um sino quebrado. Um dos turistas batia sonoramente nele com uma chave... 
Serguei Dovlátov: texto de cultura na literatura russa contemporânea

Na capela do sul, vi o famoso desenho de Bruni. ${ }^{544}$ Sobressaía ali também a máscara mortuária. Dois quadros enormes recriavam o rapto secreto e o enterro. Aleksándr Turguêniev 545 parecia uma dama...

Chegou um grupo de turistas. Dirigi-me à saída. Ouvia-se atrás:

- A história da cultura não conhece outro acontecimento de igual tragicidade... $\mathrm{O}$ czarismo pelas mãos de um jovem travesso da alta sociedade...

Comecei a morar na casa de Mikhal Iványtch. Ele bebia sem parar. Até o entorpecimento, a paralisia, o delírio. Tendo em mente que delirava exclusivamente com palavrões. Praguejava com o mesmo sentimento com o qual as pessoas idosas e cultas cantarolam a meia voz. Ou seja, para si mesmo, sem esperar aprovação ou protesto.

Eu o vi sóbrio duas vezes. Nesses dias paradoxais, Mikhal Iványtch ligava ao mesmo tempo o rádio e a televisão. Deitava-se de calças, tirava uma caixa do bolo Skazka. ${ }^{546} \mathrm{E}$ começava a ler os cartões postais recebidos ao longo de sua vida. Lia e comentava:

“...Olá, querido padrinho!... Bom, olá, olá, filho de uma vaca bem puta!.. Desejo-lhe sucesso no trabalho... Me deseja sucesso, no cu da sua mãe... Fico por aqui, sempre seu, Rádik... Sempre seu, sempre seu... Para que raios preciso de você?..."

$\mathrm{Na}$ aldeia, não gostavam do Mikhal Iványtch, tinham inveja dele. Falavam também da bebedeira. Ah, diziam, eu beberia até morrer. Ui, como eu beberia, minha gente! Eu viraria todas... Mas tenho que pagar as contas da casa... Mas, para ele, dá na mesma... Mikhal Iványtch não tinha nada. Tinha apenas dois cachorros magros que volta e meia sumiam por um tempão, uma macieira raquítica e um canteiro de cebolinha.

Uma vez, num fim de uma tarde chuvosa, travamos uma conversa:

— Micha, você amava sua esposa?

— Quem?? A esposa? Quer dizer, a mulher? Significa, a Lizka? - alarmou-se Mikhal Iványtch.

— A Liza. Elizaveta Prókhorovna.

- E pra que amá-la? Bastava dar conta do recado e tocar em frente...

- Mas o que o atraía nela?

Mikhal Iványtch ficou pensativo por um bom tempo.

\footnotetext{
${ }^{544}$ Fiódor Bruni (1799 - 1875), pintor russo de origem italiana.

${ }^{545}$ Aleksándr Turguêniev (1784 - 1846), homem de Estado e historiador russo. Era amigo de Púchkin e foi quem levou o corpo do poeta a seu sepulcro familiar, ao mosteiro de Sviatogórski.

${ }^{546}$ Em russo, "Conto de fadas", uma espécie de pão de ló com creme.
} 
Serguei Dovlátov: texto de cultura na literatura russa contemporânea

— Ela dormia quieta — pronunciou —, sem barulho, como uma lagarta...

Eu comprava leite na casa vizinha, a casa dos Nikítin. Estes viviam bem. Uma televisão, A desconhecida de Kramskói... ${ }^{547} \mathrm{O}$ dono da casa começava a cuidar dos afazeres às cinco da manhã. Reparava a cerca, cavava a horta. Uma vez vi uma bezerra pendurada pelas patas. O dono estava tirando a pele. E a faca, tão branca, em sangue...

Mikhal Iványtch desprezava os Nikítin. E eles a ele, reciprocamente.

- Continua bebendo? - inteirava-se Nadiejda Fiódorovna, mexendo a comida para as galinhas numa tina.

— Vi-o no centro turístico — disse Nikítin manejando a garlopa - de manhã, depois de já ter tomado uma.

Não queria fazer-lhes coro.

— Em compensação, ele é bondoso.

— Bondoso — concordou Nikítin —, quase matou a mulher a facadas. Queimou todos os vestidos dela. Os menininhos andam de tênis leves no inverno... Mas, quanto ao resto, ele é bonzinho.

— Micha é uma pessoa insensata, eu compreendo, mas ele é bondoso e culto, no fundo...

De fato, havia algo de aristocrático em Mikhal Iványtch. Ele não negociava as garrafas vazias, jogava-as no lixo.

— Estou com vergonha — dizia — , como vou fazer, é como se fosse um indigente...

Uma vez acordou muito mal. Queixou-se:

— Tô todo tremendo.

Dei-lhe um rublo. Na hora do almoço perguntei:

—E aí, melhorou?

- O quê?

— Tomou uma para a ressaca?

— Tomei. Como se tivesse jogado na frigideira, até chiou!

À tardinha, ficou mal de novo.

— Vou até o Nikítin. Ou me dará um rublo, ou servirá uma.

Saí para o terraço. Ouvi a conversa:

—Vizinho, sua peste, me dê cinco paus.

— Você está me devendo desde Pokrov. ${ }^{548}$

- Vou devolver.

\footnotetext{
${ }^{547}$ Retrato famoso do pintor russo Ivan Kramskói (1837-1887), sua reprodução era encontrada em muitas casas como um objeto de decoração.

${ }^{548}$ Pokrov ("Proteção da Mãe de Deus"), festa religiosa ortodoxa celebrada em 14 de outubro.
} 
— Devolva, então iremos conversar.

- Vou trazer do meu adiantamento.

— Que adiantamento? Já faz tempo que as leis trabalhistas lhe deram um pé na bunda.

- Que se danem!... Mesmo assim, me dê cinco rublos. Dê por princípio, caramba! Mostre o nosso caráter soviético!

- Para a vodka, não é?

- O quê? Para um negócio meu...

— Que negócio você pode ter, seu parasita?

Mikhal Iványtch tinha dificuldade para mentir, estava enfraquecido.

- Preciso beber - diz.

— Não vou dar. Se quiser, pode ficar ofendido, mas não vou dar!

- Mas eu vou devolver do adiantamento.

— Não vou dar.

E, para terminar a conversa, Nikítin entra na isbá batendo a porta pesada com uma caixa postal azul pregada a ela.

— Você vai ver só, vizinho! — disse Mikhal Iványtch, indignado. — Vai ver só! Vai ver! Oh, se vai ver! Vai se lembrar desta conversa!...

Nenhuma palavra em resposta. As galinhas perambulando. Os feixes dourados de cebola sobre o terraço...

- Vou arrumar uma vida alegre pra você! Você vai...

Mikhal Iványtch, de rosto vermelho, eriçado, continua a vociferar:

— Esqueceu?! Esqueceu tudo, patife?! Tudinho?!

- Esqueci o quê? - pondo-se para fora, Nikítin disse.

- Se esqueceu, a gente faz você lembrar!

— O que é que eu esqueci, então?

- Faremos você lembrar tudo. Vai lembrar o ano de 1917! Vamos fazer... Vamos deskulakizar $^{549}$ você, seu peste! Vamos deskulakizar todos os membros do partido! Vamos mandar você a Theká, ${ }^{550}$ como aquele... Como o Makhnó... ${ }^{551}$ Lá, rapidinho...

E, depois de uma pausa:

— Vizinho, dê uma força, me dê cinco rublinhos... Bom, três... Imploro, por Deus Jesus Cristo... Seu cuzão...

\footnotetext{
549 "Deskulakização" (em russo, raskulátchivanie), uma política oficial de repressão aos kulaki, camponeses abastados, que começo em 1918 e perdurou até os anos 1930.

${ }^{550}$ Tcheká (abreviação de Tchrezvytcháinaia Komíssia, "Comissão Extraordinária”), primeira polícia secreta da União Soviética.

${ }^{551}$ Néstor Makhnó (1888 -1934), líder anarco-comunista ucraniano.
} 
Finalmente, atrevi-me a começar a trabalhar. Coube-me um grupo de turistas da região do Báltico. Eram pessoas reservadas e disciplinadas. Escutavam com satisfação, não faziam perguntas. Eu tentava usar frases curtas e não tinha certeza de que me entendiam.

Mais tarde, deram-me instruções minuciosas. Os turistas de Riga são os mais educados. A qualquer coisa que se diga, eles sorriem e acenam com a cabeça. Se fazem perguntas, elas são, como se diz, estatísticas. Quantos servos tinha Púchkin? Que renda dava Mikháilovskoe? Quanto custou a reforma da casa senhorial?

Os caucasianos portam-se de um modo diferente. Eles não escutam em absoluto. Conversam entre si e riem às gargalhadas. No caminho para Trigórskoe, olham com carinho para as ovelhas. Evidentemente, farejam um potencial churrasco. Se fazem perguntas, são totalmente imprevisíveis. Por exemplo: "Por qual motivo Púchkin duelou com Lêrmontov?”.

Quanto aos compatriotas, é preciso diferenciá-los. Aos trabalhadores, o melhor é expor de uma maneira curta e simples. Ser mais atencioso com os funcionários públicos. Entre eles, às vezes, há pessoas bastante eruditas, que leram Píkul, ${ }^{552}$ Rojdiéstvenski, ${ }^{553}$ Méilakh $^{554}$. Que tiraram informações absurdas de Nóvikov... ${ }^{55}$

Os da intelligentsia são os mais cricris e traiçoeiros. Preparando-se para a viagem turística, o intelectual estuda com afinco os manuais. Algum fato insignificante crava-se na sua mente. Um parentesco distante. Uma extravagância engraçada, uma frase, um caso... Uma citação irrelevante, etc.

No terceiro dia de trabalho, uma mulher de óculos perguntou-me:

— Quando nasceu Benckendorff? ${ }^{556}$

— Lá por 1770 — respondi.

A construção que utilizei ressoava insegurança.

— E mais concretamente? — perguntou a mulher.

— Infelizmente - disse - esqueci...

Para que estou mentindo, pensei. Poderia ter falado sinceramente: "Sei lá!”... Não foi uma ocasião de regozijo tão grande o nascimento de Benckendorff.

\footnotetext{
552 Valentin Píkul (1928 -1990), escritor soviético, autor de novelas históricas populares.

${ }^{553}$ Róbert Rojdiéstvenski (1932-1994), poeta soviético.

${ }^{554}$ Boris Méilakh (1909-1987), critico literário e puchkinista soviético.

${ }^{555}$ Ivan Nóvikov (1877 -1959), escritor soviético que dedicou vários livros a Púchkin.

556 Aleksándr Benckendorff (1782 - 1844), homem do Estado russo, chefe da gendarmeria russa durante o governo do czar Nicolau I.
} 
Serguei Dovlátov: texto de cultura na literatura russa contemporânea

- Aleksándr Khristofórovitch Benckendorff — pronunciou a mulher com censura nasceu em 1784. Além do mais, em junho...

Acenei com a cabeça para demonstrar que considerava a informação valiosa.

Desde esse instante, a mulher não parou de sorrir ironicamente. Como se a minha indiferença por Benckendorff demonstrasse uma completa indigência intelectual...

Comecei a trabalhar. Normalmente, os metodologistas não participam da primeira excursão. Dão à gente uma oportunidade de habituar-se, de sentir-se mais seguro. Foi o que me salvou. Porque aconteceu o seguinte.

Atravessei tranquilamente a antessala. Mostrei o desenho do agrimensor Ivanov. Falei sobre o primeiro exílio. Depois sobre o segundo. Passei para o quarto de Arina Rodiónovna... “A única pessoa realmente próxima resultou ser a babá...” Tudo como determinado... "Era, ao mesmo tempo, indulgente e rabugenta, ingenuamente religiosa e extremamente prática..." $\mathrm{O}$ baixo-relevo de Seriakov... "Quando the ofereceram a alforria, recusou..."

$\mathrm{E}$, finalmente:

- O poeta dirigia-se constantemente à babá em seus poemas. Todo mundo conhece, por exemplo, estes versos afetuosos...

E aqui, por um instante, me distraí. E estremeci ao ouvir a minha própria voz:

Você está ainda viva, minha velhinha,

Também estou vivo, salve, salve!

Que flutue sobre sua isbá...

Fiquei petrificado. Agora alguém vai gritar: "Seu louco, seu ignorante! É Iessiênin, Carta à mãe...".

Continuei declamando, pensando em estado febril:

"Sim, camaradas, vocês têm toda razão. Claro que é Iessiênin. Realmente, é Carta à mãe. Mas vejam só como a lírica de Serguei Iessiênin é próxima à entonação de Púchkin! Como se realiza de um modo orgânico na poética de Iessiênin...”, etc.

Continuei declamando. Em algum lugar, no fim, brilhava uma faca finlandesa, ameaçadora... "Tra-ta-tita-tam na briga no botequim, tra-ta-tam a faca finlandesa embaixo do coração..." A um centímentro desta lâmina cintilando de modo ameaçador consegui me refrear. Pelo silêncio que se produziu, eu esperava uma tempestade. Todos estavam quietos. Os rostos estavam emocionados e sérios. E apenas um turista idoso pronunciou significativamente:

- É, havia pessoas... 
Serguei Dovlátov: texto de cultura na literatura russa contemporânea Na sala seguinte, atribuí Mnemozine ${ }^{557}$ a Délvig. Depois, chamei Serguei Lvóvitch de Serguei Aleksándrovitch. (Pelo visto, Iessiênin ocupou meu subconsciente por muito tempo.) Mas tudo isso eram puras ninharias. Sem falar das três hipóteses literárias duvidosas.

Em Trigórskoe e no mosteiro, a excursão correu bem. Era preciso fazer passagens lógicas de uma sala para outra. Pensar nas assim chamadas ligações. Só não conseguia, e por um bom tempo, resolver um caso: entre o quarto de $\mathrm{Zizie}^{558}$ e a sala. Por fim, inventei esta malfadada ligação. E, desde então, passei a usá-la sem exceção:

"Meus amigos! Estou vendo que aqui está muito apertado. Prossigamos para a próxima sala!...”.

Ao mesmo tempo, eu acompanhava as excursões dos outros. Em cada uma achava algo curioso para mim. Fiz amizade com os guias de Leningrado. Já fazia anos que vinham ao parque museu para passar o verão.

Um deles era Volódia Mitrofánov. Foi ele quem fez minha propaganda. E veio depois de mim. Gostaria de dar mais de detalhes desse indivíduo.

$\mathrm{Na}$ época da escola, Mitrofánov era famoso por ter uma "memória de espelho", como dizem. Com facilidade decorava capítulos inteiros dos manuais. Apresentavam-no como uma criança prodígio. Além disso, Deus deu-lhe um desejo insaciável de saber. Nele, reuniam-se uma curiosidade extraordinária e uma memória fenomenal. Esperava-o uma carreira científica brilhante.

A Mitrofánov interessava tudo: biologia, geografia, teoria de campos, ventriloquia, filatelia, suprematismo, noções de adestramento... Lia três livros sérios ao dia... Terminou a escola de modo magnífico e ingressou com facilidade na Faculdade de Letras.

O professores da universidade estavam perplexos. Mitrofánov sabia absolutamente tudo e exigia novos conhecimentos. A serviço de Mitrofánov, grandes estudiosos passavam dias sentados em bibliotecas estudando teorias e áreas esquecidas das ciências. Além disso, Mitrofánov assistia a palestras nas Faculdades de Direito, de Biologia e de Química.

A memória única combinada à sede ilimitada de conhecimentos fazia milagres. Mas aí surgiu uma circunstância surpreendente. Com estas duas características, a personalidade de Mitrofánov esgotava-se de todo. Era um gênio do conhecimento puro.

Logo seu primeiro trabalho de conclusão de ano letivo ficou inacabado. Mais do que isso, ele tinha escrito apenas a primeira frase. Ou melhor, o começo da primeira frase. Ou seja: "Como sabemos...". Neste ponto, o trabalho genialmente pensado foi interrompido.

\footnotetext{
${ }^{557}$ Mnemozine, almanaque literário editado em Moscou por Vladímir Odoiévski e Wilhelm Kuchelbecker, de 1824 a 1825 .

${ }^{558}$ Zizie, apelido carinhoso de Evpráksia Vulf (1809 - 1883), vizinha e amiga próxima de Púchkin.
} 
Serguei Dovlátov: texto de cultura na literatura russa contemporânea

Mitrofánov cresceu como um preguiçoso fora do comum, se é possível chamar assim uma pessoa que tinha lido dez mil livros.

Mitrofánov não se lavava, não fazia a barba, não participava dos Sábados Comunistas. ${ }^{559}$ Não devolvia o dinheiro emprestado e não atava os cordões dos sapatos. Tinha preguiça de pôr um boné. Apenas o pousava em cima da cabeça.

Ao kolkhoz ${ }^{560}$ ele não ia. Simplesmente não comparecia, sem nenhuma justificativa.

Expulsaram Mitrofánov da universidade. Os amigos tentaram arrumar-lhe um trabalho. Por algum tempo foi secretário particular do acadêmico Fírsov. A princípio, tudo ia muito bem. Ficava horas a fio na biblioteca da Academia de Ciências. Escolhia para Fírsov os materiais necessários. Com gosto, compartilhava a informação que já tinha na memória. $\mathrm{O}$ cientista idoso voltou à vida. Propôs a Volódia que explorassem juntos a teoria do hidratopiromorfismo diatonal. (Ou algo do gênero.) $\mathrm{O}$ acadêmico disse:

- O senhor vai anotar. Sou míope.

No dia seguinte, Mitrofánov desapareceu. Estava com preguiça de anotar.

Levou a vida na flauta por uns meses. Leu mais uns trezentos livros. Aprendeu duas línguas, romeno e hindi.

Almoçava nos amigos, oferecendo palestras vivas e prolixas em retribuição. Davam-lhe roupa usada...

Depois, tentaram colocar Mitrofánov no estúdio de cinema Lenfilm. Fizeram mais: criaram um título especialmente para ele: "consultor de todo tipo de questão".

Foi uma sorte extraordinária. Mitrofánov conhecia vestimentas e costumes de todas as épocas. A fauna de qualquer canto do planeta. Os mínimos detalhes dos acontecimentos préhistóricos. As réplicas curiosas dos homens de Estado do segundo escalão. Sabia quantos botões havia na camisola de Talleyrand. Lembrava como se chamava a mulher de Lomonóssov...

Mas Mitrofánov não conseguiu preencher o questionário. Nem sequer as partes em que pediam apenas para "sublinhar o necessário". Deu-lhe preguiça...

Colocaram-no como vigia num cinema. Trabalho noturno. Podia fazer o que desse na veneta: podia dormir, ler, pensar. Mitrofánov só tinha uma obrigação: depois da meia-noite, precisava desligar um interruptor. Mitrofánov se esquecia de desligá-lo. Ou ficava com preguiça. Demitiram-no...

Tempos depois, soubemos com amargura que Mitrofánov não era simplesmente um indolente. Descobriu-se que tinha uma rara doença, abulia. Ou seja, uma atrofia total da vontade.

\footnotetext{
${ }^{559}$ Os Sábados comunistas (em russo, Subbótniki) eram dias de trabalho não remunerado na União Soviética.

560 Kolkhoz (abreviação de kollektívnoe khoziáistvo, "propriedade coletiva") era um tipo de propriedade rural coletiva, típica da antiga União Soviética, no qual os camponeses formavam uma cooperativa agrícola.
} 
Serguei Dovlátov: texto de cultura na literatura russa contemporânea

Era um fenômeno do mundo vegetal. Uma flor vistosa e caprichosa. Um crisântemo não pode se plantar e se regar por conta própria...

Finalmente Mitrofánov ouviu falar do parque cultural Púchkin. Chegou, sondou. E descobriu que esta era a única instituição onde poderia ter alguma serventia.

O que se exige de um guia? Uma história viva e impressionante. E nada mais.

Mitrofánov sabia contar histórias. Suas explicações eram repletas de paralelos inesperados, hipóteses deslumbrantes, informações raras de arquivos e citações em seis idiomas.

Suas excursões eram duas vezes mais longas do que as normais. Às vezes, os turistas desmaiavam de tensão.

Havia, claro, algumas dificuldades. Mitrofánov tinha preguiça de subir o Monte de Sávkin. Os turistas escalavam o monte, e Mitrofánov, do sopé, gritava:

- Como acontece há anos e anos, este morro grande e verde levanta-se sobre o rio Sórot. A surpreendente simetria de sua forma fala de sua origem artificial. Quanto à etimologia da palavra "Sórot", ela é muito curiosa. Embora não seja muito decorosa...

Certa vez, os excursionistas estenderam uma capa de couro sintético e arrastaram Mitrofánov até o topo. Contente, ele sorria e ia contando:

- A lenda diz que aqui jazia um dos mosteiros de Vorónitch...

No parque museu, valorizavam-no...

Outra personalidade digna de nota era Stássik Potótski. Nascera na cidade de Tcheboksáry. Até os dezesseis anos, não se destacou. Jogava hóquei sem pensar em problemas sérios. Finalmente, foi parar em Leningrado com uma delegação de jovens atletas.

Logo no primeiro dia uma arrumadeira do hotel Sókol o desvirginou. Teve sorte. Era velha e sensível. Ofereceu ao júnior vinho Alabachly. Sussurrava ao rapaz choroso, bêbado e apaixonado:

- Veja só, pequeno, uma fodazinha...

Potótski logo compreendeu que no mundo existem duas coisas pelas quais vale a pena viver: vinho e mulheres. O resto não merece atenção. Mas as mulheres e o vinho custam dinheiro. Portanto, é preciso saber ganhá-lo. De preferência, sem muito esforço e sendo bem pago. E também sem parar na prisão...

Decidiu tornar-se um literato. Leu doze livros contemporâneos. Estava convencido de que podia escrever igual. Comprou um caderno grosso, uma caneta-tinteiro e uma recarga de reserva.

De cara, sua primeira obra foi publicada na revista Iúnost. O conto se chamava A vitória de Churka Tchemodánov. O jovem jogador de hóquei Tchemodánov achou-se importante e 
Serguei Dovlátov: texto de cultura na literatura russa contemporânea largou os estudos. Depois caiu em si. Começou a estudar bem e a jogar hóquei ainda melhor. A obra terminava assim:

“- O principal, Churka, é ser um homem — disse Lukiánytch e foi-se embora.

Por longo tempo, Churka seguiu-o com os olhos..."

O conto era surpreendentemente medíocre. Dezenas, centenas de suas cópias enfeitavam as revistas juvenis. Trataram Potótski com condescendência. Por ser um autor da província, pelo visto, merecia um desconto.

Ao longo de um ano, conseguiu publicar sete contos e uma novela. Suas composições eram triviais, ideologicamente íntegras, primitivas. Em cada uma delas, ouvia-se algo familiar. Uma sólida armadura de literatura de segunda mão protegia suas obras da censura. Soavam convincentes, como citações. O que mais saltava aos olhos eram os defeitos estilísticos e os erros de digitação:

"Em outubro Michutka compriu treze anos..." (Conto A desgraça de Michutka).

“- Que descanse em pás! - concluiu seu discurso Odintsov...” (Conto A fumaça sobe até o céu).

“- Não me ponha entradas — pronunciou em tom ameaçador Lepkó...” (Novela As gaivotas vão até o horizonte.)

Mais tarde, Potótski me dizia:

“... Sou um escritor, porra, tipo Tchékhov. O Tchékhov tinha toda a razão. Pode-se escrever um conto sobre qualquer coisa. Tem um monte de enredos. Tomemos qualquer profissão. Por exemplo, médico. Aqui está. Um cirurgião, porra, faz uma operação. E reconhece no paciente o seu rival. O cara com o qual a sua mulher o traiu. O cirurgião está diante da porra de um dilema moral. Ou salvar o homem, ou cortar-lhe... Não, isso é demais, isso já é um exagero, porra... Enfim, o cirurgião hesita. E depois pega o bisturi e faz um milagre. E o final, porra, é o seguinte: 'Por longo tempo, a enfermeira seguiu-o com os olhos...' Ou, por exemplo, sobre o mar," dizia Potótski, "nada mais fácil... O marinheiro, porra, se aposenta. Deixa o querido navio. Deixa no barco seus amigos, seu passado, sua juventude. Sombrio, ele caminha pelas margens do Fontanka. ${ }^{561} \mathrm{E}$ vê, porra, um moleque se afogando. O marinheiro, sem pensar, se joga no abismo gelado. Arriscando a vida, tira o menino dali... O final é assim: 'Vitka nunca mais se esqueceu dessa mão. Uma mão larga, calosa, com uma âncora azul tatuada no pulso...' Quer dizer, o marinheiro é sempre o marinheiro, mesmo quando está aposentado, porra...”.

Potótski redigia um conto por dia. Saiu um livro seu. Chamava-se A felicidade dos caminhos difíceis. Os críticos fizeram resenhas benevolentes, apontando indulgentemente para a origem provinciana do autor.

${ }^{561}$ Um dos afluentes do rio Nevá que cruza o centro de São Petersburgo. 
Serguei Dovlátov: texto de cultura na literatura russa contemporânea

Stássik decidiu saír de Tcheboksáry. Queria criar asas. Mudou-se para Leningrado. Apaixonou-se pelo restaurante Europa e por duas modelos.

Em Leningrado, receberam sua obra com certa frieza. Lá, os estereótipos eram um pouco mais elevados. Não pagavam por falta de talento. O talento punha todos de sobreaviso. A genialidade gerava pavor. O que parecia ser mais rentável eram as "capacidades literárias evidentes”. Potótski não tinha capacidades evidentes. Algo cintilava em suas obras, perpassava, tremeluzia. Algumas frases fortuitas, certas réplicas... 'Uma cabeça de alho nacarina...', 'as pernas parafinadas da aeromoça...'. No entanto, capacidades evidentes ele não tinha.

Pararam de publicá-lo. Aquilo que se perdoava a um novato provinciano irritava no escritor da capital. Stássik começou a beber, e não no Europa, mas em porões, com os artistas. E não com modelos, mas com a arrumadeira do hotel, sua velha conhecida. (Agora ela vendia frutas em um tabuleiro...)

Permaneceu assim bebendo por uns quatro anos. Ficou um ano preso por vadiagem. A arrumadeira (e também trabalhadora do comércio) abandonou-o. Ora Stássik espancava-a, ora roubava-a...

Sua roupa virou trapos. Os amigos pararam de emprestar-lhe dinheiro e não lhe davam mais as calças imprestáveis. A polícia de novo ameaçava prendê-lo por violar as regras de residência. ${ }^{562}$ Alguém lhe deu a ideia de ir ao parque museu. Stássik animou-se. Preparou-se. Começou a conduzir excursões, e o fazia bastante bem. $\mathrm{O}$ seu principal trunfo era a intimidade em tom confidente:

“A tragédia pessoal de Púchkin até hoje ressoa em nós com uma dor torturante da alma...".

Potótski adornava seus monólogos com detalhes fantásticos. Representava a cena do duelo. Uma vez até caiu na grama. Concluía a excursão com uma invencionice misteriosa e metafísica:

"Finalmente, depois de uma doença longa e penosa, o grande cidadão da Rússia faleceu. Mas d'Anthès ${ }^{563}$ ainda está vivo, camaradas...".

Passava temporadas bebendo e largava o trabalho. Mendigava níqueis na escada da entrada do boteco. Colhia garrafas vazias em moitas. Dormia na lápide rachada de Aleksei Nikoláievitch Vulf.

O capitão de polícia Chatkó, ao encontrá-lo, dizia em tom de reprovação:

"Potótski, seu aspecto perturba a harmonia deste lugar...".

\footnotetext{
${ }^{562} \mathrm{Na}$ União Soviética, autorização oficial para residir na cidade. Na época, uma pessoa não podia se mudar de uma cidade para outra sem avisar autoridades e realizar trámites burocráticos necessários.

${ }^{563}$ Georges-Charles d'Anthès (1812 - 1895), oficial militar francês, famoso por ter ferido mortalmente Púchkin num duelo.
} 
Serguei Dovlátov: texto de cultura na literatura russa contemporânea

Depois Potótski inventou um novo truque. Vagueava pelo mosteiro. Aguardava um novo grupo de turistas ao lado do túmulo. Esperava até o fim de excursão. Chamava o monitor e dizia em voz baixa:

“Antr nu! ${ }^{564}$ Entre nós! Reúnam trinta copeques por cabeça. Vou mostrar-lhes o verdadeiro túmulo de Púchkin que os bolcheviques estão escondendo do povo!”.

Depois levava o grupo ao bosque e mostrava aos excursionistas uma colininha sem graça. Às vezes, algum turista escrupuloso perguntava:

- Mas para que estão escondendo o verdadeiro túmulo?

— Para quê? — Potótski dava um sorriso sarcástico. — Interessa-lhe saber para quê? Camaradas, ao cidadão interessa saber para quê!

- Ah, sim, eu compreendo, eu compreendo - balbuciava o turista...

No dia da minha chegada, Stássik estava extenuado depois de uma semana de bebedeira. Pediu-me um rublo e as sandálias perfuradas marrons. Então, contou-me uma história dramática:

- Cara, quase fiquei rico. Inventei um truque fora de série. Escuta, a ideia é esta. Conheço um trouxa qualquer. Ele tem carro, dinheiro, porra, e por aí vai. Pegamos uma safada (note-se: só uma) e vamos ao ar livre mesmo. Ali, nós dois marcamos o território...

— Não entendi.

— Cada um vai com ela... De manhã corro até ele. “Cara, o meu tá pingando.” Ele entra em pânico. Então digo: "Dá pra quebrar o galho, porra. Vai custar apenas vinte e cinco rublos". O trouxa pula de alegria. Eu pego uma seringa com água da torneira. Dou uma injeção na bunda dele e na minha. O trouxa, agradecido, me passa a grana. E nos despedimos como amigos. E a piranha ganha uma meia-calça de sete rublos. Dezoito rublos de lucro. Tudo foi pensado de um jeito genial. Operação “gonorreia fictícia”... Pois você acredita, deu errado, porra...

- Como assim?

- A princípio, tudo ia bem. O trouxa gostou muito de mim. Pegamos conhaque, uns lanches. Contratei a Milka, a vesga, do Vítiaz... Fomos, porra, ao ar livre. Enchemos a lata, marcamos o território. E o que você imagina? Na manhã seguinte, o trouxa mesmo vem correndo até mim: "Cara," grita, "o meu pinto está pingando!..." Entra no carro, porra, e vai embora. Corro à policlínica, até o Fima. Explico a situação. O Fima me diz: "Vinte e cinco rublos!..." Nossa mãe! Onde vou achá-los?! Passei por toda a região de Pskóv, mal consegui juntar. Fiquei onze dias sem beber... Depois desjejuei, porra... O que você acha, a propósito?

- A propósito do ar livre?

— A propósito da bebida.

${ }^{564}$ Corruptela do francês entre nous, "entre nós". 
Serguei Dovlátov: texto de cultura na literatura russa contemporânea

Agitei os braços. É que, para mim, basta começar. Não sei parar. Um caminhão sem freios...

Stássik fez o rublo de metal saltar em sua mão e foi-se embora...

— Amanhã vão avaliá-lo - disse Galina.

— Já?

— Na minha opinião, o senhor já está pronto. Para que adiar?

Ao notar Viktória Albiértovna entre os turistas, fiquei, a princípio nervoso. O sorriso que Vika exibia podia ser amigável ou irônico.

Pouco a pouco, recobrei o ânimo. Dei com um grupo exigente. Ativistas da DOSAAF, ${ }^{565}$ de Torjok. Faziam perguntas sem parar.

— Este — digo — é o famoso retrato feito por Kipriénski... Foi encomendado por Délvig... Uma interpretação elevada... Traços de uma beleza romântica... "Vejo-me como num espelho..."566 Púchkin o comprou da viúva do barão...

- Quando? Em que ano?

- Acho que em 1830.

- E quanto custou?

— Que diferença faz?! — não me contive.

Vika me soprava algo, movendo silenciosamente os lábios.

Passamos ao escritório. Mostro o retrato de Byron, a bengala, a estante... Passo à obra... "Um período intenso... Artigos... Projeto da revista...”, Boris Godunóv, Ciganos... Biblioteca... "Logo morrerei completamente, mas amando a minha sombra...", 567 etc.

De repente ouço:

— As pistolas são verdadeiras?

— Sim, é o autêntico jogo de duelo do sistema de Lepage.

A mesma voz:

— De Lepage? E eu pensei que era de Púchkin.

Explico:

\footnotetext{
565 Abreviação de Dobrovólnoe Óbschestvo Sodiéistiva Ármii, Aviátsii i Flótu ("Sociedade Voluntária para Assistência ao Exército, Aeronáutica e Marinha"), uma associação voluntária público-privada auto administrada cujo objetivo é promover o fortalecimento da "capacidade de defesa" do país e a segurança nacional.

566 Verso do poema de Púchkin Kipriénskomu ("A Kipriénski”), dedicado ao retrato feito por Orest Kipriénski, em 1827.

${ }^{567}$ Estrofe do poema de Púchkin André Chénier (1825).
} 
Serguei Dovlátov: texto de cultura na literatura russa contemporânea

— As pistolas são daquela época. São sistemas do famoso armeiro Lepage. Púchkin sabia e gostava de boas armas. Tinha pistolas iguais...

- E o calibre?

- O que tem o calibre?

- Interessa-me o calibre.

- O calibre é conveniente - digo.

— Ótimo - repentinamente o turista acalmou-se.

Enquanto o meu grupo visitava a casa da babá, Viktória Albiértovna cochichava:

— O senhor expõe bem, de um modo desembaraçado... Tem a sua própria atitude. Mas às vezes... Fico simplesmente horrorizada... Você chamou Púchkin de macaco louco...

— Não foi exatamente assim.

— Imploro: seja mais comedido.

- Vou tentar.

— Mas, no geral, não está nada mal...

Comecei a guiar excursões regularmente. Às vezes, duas excursões por turno. Evidentemente, estavam contentes comigo. Quando vinham homens de cultura, professores, intelectuais, quem trabalhava com eles era eu. Minhas excursões distinguiam-se sempre por algo. Por exemplo, por "uma maneira livre de expor", como apontava a curadora de Trigórskoe. Ali, na certa, manifestava-se parte considerável de meu talento dramático. Embora eu tivesse decorado o texto da excursão em cinco dias, conseguia com destreza simular uma reação emocionada. Fingia gaguejar, como que em busca de formulações, cometia lapsos de linguagem, gesticulava, enriquecendo meus improvisos minuciosamente elaborados com aforismos de Gukóvski e Schiógolev. Quanto mais conhecia Púchkin, menos queria falar sobre ele. Ainda mais num nível tão vergonhoso. Desempenhava mecanicamente o meu papel, recebendo por ele uma razoável remuneração. (Uma excursão completa custava cerca de oito rublos.)

Na biblioteca local, achei uns dez livros raros sobre Púchkin. Além disso, reli a prosa e os artigos. O que mais me intrigou foi a indiferença olímpica de Púchkin. A prontidão para aceitar e expressar qualquer ponto de vista. A aspiração inabalável à objetividade suprema e definitiva. Como a lua que ilumina o caminho tanto do predador como da vítima.

Não era um monarquista, um conspirador, um cristão, era apenas um poeta, um gênio, e compartilhava do movimento geral da vida. 
Serguei Dovlátov: texto de cultura na literatura russa contemporânea

Sua literatura está acima da moral. Ela ultrapassa a moral e toma seu lugar. Sua literatura é como uma prece, como a natureza... Aliás, não sou crítico literário.

Meu trabalho começava às nove. Estávamos sentados no escritório à espera de clientes. As conversas giravam em torno de Púchkin e de turistas. Com mais frequência, de turistas. De sua ingorância gritante.

"Acredita que um sujeito me perguntou quem era Boris Godunóv?..."

Eu pessoalmente não sentia irritação em situações como essa. Ou melhor, até sentia, mas me continha. Os turistas vinham para descansar. O sindicato local impôs-lhes umas putiovkas ${ }^{568}$ baratas. Eram pessoas propriamente indiferentes à poesia. Para eles, Púchkin não passava um símbolo da cultura. Para eles, o importante era ter a sensação de "eu estive aqui". Era preciso deixar uma marca em sua memória. Pôr sua assinatura no livro da espiritualidade...

Minha obrigação consistia em lhes dar este prazer, sem cansá-los demais. E em troca, recebia sete rublos e sessenta copeques e uma anotação comovente no livro de notas:

"Vimos Púchkin diante de nossos olhos graças ao guia fulano de tal e a seus modestos conhecimentos...".

Meus dias eram monótonos. As excursões terminavam às duas. Eu almoçava em Lukomórie e ia para casa. Algumas vezes Mitrofánov e Potótski convidavam-me para tomar algo. Eu recusava. Não implicava grande esforço da minha parte. Do primeiro cálice abstenhome facilmente. Mas não sei parar. O motor é bom, mas os freios falham...

Não escrevia a minha mulher e a minha filha. Não fazia sentido. Pensava que seria melhor esperar um pouco e depois a gente se veria...

Enfim, a vida, de algum modo, entrou nos eixos. Tentava refletir menos sobre temas abstratos. Minhas desgraças estavam fora do campo de visão. Em algum lugar lá atrás. Enquanto não se olha para trás, você está tranquilo. E é possível não olhar para trás...

Enquanto isso, li Likhonóssov. Sem sombra de dúvida, um bom escritor. Talentoso, brilhante, plástico. Reproduz com maestria a fala viva. (Se Tolstói tivesse ouvido um elogio desses!) E, mesmo assim, lá no fundo, persistia uma sensação desagradável, triste, impertinente. Um motivo caquético e enfadonho: "Cadê você, Rus?! Para onde tudo se foi?! Cadê as modinhas, os rúchniks, ${ }^{569}$ os kokóchniks?! ${ }^{570}$ Cadê a hospitalidade, a audácia e o ímpeto?! Cadê os samovares, os ícones, os devotos, os iuródvis?! ${ }^{571}$ Cadê os estrujões, as carpas, o mel, o caviar?! Cadê os cavalos habituais, caramba?! Cadê o pudor casto?"

Os miolos queimando:

\footnotetext{
${ }^{568}$ Putiovka, férias subsidiadas pelo sindicato.

${ }^{569}$ Um tipo de toalha de pano de linho, objeto de cultura popular dos eslavos orientais.

${ }^{570}$ Adereço de cabeça tradicional para mulheres.

${ }^{571}$ Pessoa religiosa louca que era considerada ter dom de vidente.
} 
Serguei Dovlátov: texto de cultura na literatura russa contemporânea

"Cadê você, Rus?! Onde se meteu?! Quem a desfigurou?!"

Quem, quem... Sabe-se quem foi...

Nem é preciso queimar os miolos nesse ponto...

A relação com Mikhal Iványtch era simples e racional. No começo, ele vinha me visitar com frequência. Tirava umas garrafas dos bolsos. Eu abanava os braços. Ele bebia do gargalo mesmo, murmurando algo verborragicamente. Dava certo trabalho captar o sentido de seus monólogos prolixos.

Em geral, a fala de Micha era organizada de uma maneira notável. Pronunciava, de modo bem articulado e cuidadoso, apenas sustantivos e verbos. Principalmente, em combinações obscenas. Quanto aos complementos, Mikhal Iványtch os usava de modo totalmente arbitrário. Do jeito que aparecessem. Já nem falo das preposições, partículas e conjunções. Criava-as na hora. Sua fala era como a música clássica, a pintura abstrata ou o canto do pintassilgo. As emoções evidentemente predominavam sobre o sentido.

Suponhamos que eu dissesse:

- Micha, você devia deixar de beber, pelo menos por um tempo.

Em resposta, ressoava:

- Aquele tal veado sei lá de onde... Pegou cinco paus e partiu prum covil... O adiantamento tá no depósito... Como que posso parar de beber?... Não serve um nada ... Nem a alma se levanta...

Os discursos de Micha lembravam os experimentos fonéticos da escola de Riémizov. ${ }^{572}$

Chamava mulheres tagarelas de carriolas. Donas de casa ruins de trastes. Esposas infiéis de galináceas. Cerveja e vodka de papalvo, veneno e querosene. Jovens de mijadeiros.

"A tropa de mijadeiros despertou na base turística."

O que significa: os jovens, baderneiros menores de idade, estão fazendo travessuras e só Deus sabe o quê...

Nossa relação foi construída de um modo bem organizado. Micha ${ }^{573}$ apanhava para mim cebola, creme azedo, cogumelos e batata na casa da sogra. Recusava com indignação meu pagamento. Em troca, toda manhã eu lhe dava um rublo para o vinho. E eu o continha nas tentativas de atirar na mulher, Liza. Às vezes, com risco de vida para mim.

O resultado é que ficávamos quites.

Nunca consegui compreender sua personalidade. Aparentemente, era desajeitado, bondoso, atrapalhado. Uma vez, enforcou dois gatos numa sorveira. Fez a forca com linha de pesca .

\footnotetext{
572 Aleksei Riémizov (1877 - 1957), escritor russo, conhecido por suas experimentações estilísticas.

${ }^{573}$ Apelido de Mikhaíl.
} 
Serguei Dovlátov: texto de cultura na literatura russa contemporânea

— Estão pululando — disse —, nas cuspideiras, debulhando pra todo lado.

Uma vez, sem querer, tranquei a porta por dentro com o ferrolho. E ele ficou até de manhã sentado no terraço, com receio de me acordar...

Era desajeitado tanto em sua bondade quanto em seu rancor. Xingava os superiores na cara das piores palavras. Mas, passando ao lado da imagem de Friedrich Engels, tirava o chapéu. Amaldiçoava sem parar o ditador da Rodésia do Sul, Ian Smith. Mas sentia carinho e respeito pela balconista do boteco que invariavelmente o enganava na conta.

"Sem isso não dá, ordens são ordens!"

Seu esconjuro mais terrível era:

"Tá trabalhando para os capitalistas!".

Uma vez, o policial Doveiko privou Micha, bêbado, de uma baioneta alemã.

— Tá servindo para os capitalistas, parasita! — gritava Mikhal Iványtch.

A mulher e a sogra, na sua ausência, levaram-lhe o rádio.

— De qualquer jeito, não vão ganhar um obrigada dos capitalistas — assegurava Mikhal Iványtch.

Não tive mais de duas conversas com ele . - Lembro - Micha dizia [o texto foi um pouco enobrecido]:

— Era moleque quando os alemães estavam aqui. Não faziam nada de ruim, não, digo sinceramente. Levaram as galinhas, o porco do avô Timokha... Mas não faziam coisa ruim. E não tocavam na mulherada. Elas até começaram a ofender-se. O meu velho fazia aguardente em casa. Trocava com os fascistas pelas conservas... Ainda que os jides ${ }^{574}$ e os ciganos eles... sabe como é...

— Fuzilaram?

— Levaram para sempre. Ordens são ordens...

— E você está dizendo que não faziam nada de ruim...

— Não faziam mesmo, juro por Deus. Os jides e os ciganos, como cabia...

- Mas o que os judeus fizeram para você?

- Respeito os judeus. Daria uma dúzia de ucranianinhos por um judeu. Mas os ciganos estrangularia com as próprias mãos.

— Por quê?

— Como assim por quê? Tá brincando? Cigano é cigano... 
Serguei Dovlátov: texto de cultura na literatura russa contemporânea

Em julho, comecei a escrever. Eram esboços estranhos, diálogos, buscas por um tom. Algo como um esquema, com figuras e enredos vagamente delineados. Amor infeliz, dívidas, casamento, criação, conflito com o Estado. Além disso, como dizia Dostoiévski, um matiz de significado supremo.

Pensava que meus infortúnios se dissolveriam nesse passatempo. Já acontecera antes, nos anos de formação literária. Acho que isso se chama sublimação. É quando você tenta transferir à literatura a responsabilidade por seus pecados. O homem compõe Rei Lear e depois pode ficar um ano sem desembainhar a espada...

Passado um tempo, enviei setenta rublos a minha mulher. Comprei uma camisa: tratandose de mim, um ato sem precedentes.

Chegavam rumores de publicações no Ocidente. Procurava não pensar nisso. Pois, para mim, era indiferente o que se passava no outro mundo. Diria assim mesmo caso me intimassem...

Além disso, enviei algumas cartas sobre as dívidas. Dizendo que estava empregado, que logo devolveria, que sentia muito...

Todos os credores reagiram de um modo nobre: não tenha pressa, dinheiro não falta, quando ganhar, vai devolver...

Enfim, a vida atingiu certo equilíbrio. Parecia mais consciente e lógica. Porque o pior não é o pesadelo e a sensação de beco sem saída. O mais terrível é o caos...

Basta viver uma semana sem vodka e o estramônio se dissipa. A vida ganha contornos relativamente precisos. Até os aborrecimentos parecem ser fenômenos justificados.

Tinha muito medo de romper este equilíbrio frágil. Respondia grosseiramente quando me chamavam para beber. Irritava-me quando as moças puxavam conversa comigo na agência de turismo.

\section{Potótski dizia:}

— Borka sóbrio e Borka bêbado são duas pessoas tão diferentes que nem se conhecem uma a outra...

Mesmo assim, eu sentia: isto não pode continuar para sempre. Não se pode escapar dos problemas da vida... As pessoas fracas suportam a vida, as fortes a dominam... Se não se vive corretamente, cedo ou tarde algo acontecerá...

$$
* * *
$$

Manhã. Leite com espuma azulada. Latidos de cachorros, tinir de baldes...

Atrás da parede, a voz de ressaca do Micha:

— Filhinho, empreste um rublozinho! 
Serguei Dovlátov: texto de cultura na literatura russa contemporânea

Despejei-lhe as moedas que me restavam, dei comida aos cachorros.

$\mathrm{Na}$ base turística, do outro lado da colina, tocava a radiola. No céu claro passavam gralhas. Ao pé da montanha, sobre o pântano, estendia-se a neblina. Na grama verde, como bolotas cinzas, jaziam ovelhas.

Fui até o centro turístico através do campo. Nos sapatos, molhados do orvalho, a areia amarelava. Do arvoredo, sopravam o frescor e a fumaça.

Sob as janelas da agência de excursões, sentavam-se turistas. No banquinho, deitava-se Mitrofánov, coberto com um jornal. Até dormindo se via o quanto era preguiçoso...

Subi ao terraço. No pequeno saguão, amontovoam-se guias. Alguém me cumprimentou. Alguém me pediu fogo. Dima Baránov disse: "O que houve?...".

Embaixo do quadro do pintor local, Schúkin, um sujeito feio, horrível, repulsivo (cartola, cavalo, gênio, altura a perder de vista, estava a minha mulher, sorridente...

E, nesse instante, minha estabilidade miserável chegou ao fim. Compreendi o que me esperava. Lembrei-me da nossa última conversa...

Havíamos nos divorciado um ano e meio atrás. O divórcio moderno, elegante, é como uma trégua. Uma trégua que nem sempre termina com fogos de artifício...

Lembro que o juíz Tchikvaídze dirigiu-se a minha ex-mulher:

- A senhora tem em vista alguma parte dos bens?

— Não — respondeu Tatiana.

E acrescentou:

— Na ausência dos bens mencionados...

Desde então, passamos a nos encontrar de quando em vez, como bons conhecidos. Mas isso me pareceu falso, então me mandei para Tállin.

Um ano depois, nos encontramos de novo. Nossa filha ficou doente, e Tânia mudou-se para o meu apartamento. Já não era mais amor, era sina...

Vivíamos na miséria, brigávamos frequentemente. Uma panela transbordando de irritações mútuas, gorgolejando baixo, no fogo lento...

Tânia, nitidamente, vinculava a imagem de gênio não reconhecido à ideia de ascetismo. E eu, para usar de um eufemismo, era demasiadamente sociável.

Eu dizia: 
Serguei Dovlátov: texto de cultura na literatura russa contemporânea

- Púchkin paquerava mulheres... Dostoiévski era viciado em jogos de azar... Iessiênin era farrista e brigava em restaurantes... Os vícios são tão próprios aos homens geniais quanto as virtudes...

— Então você é um gênio pela metade — consentiu minha mulher. — Pois vícios você tem aos montes ...

Ainda tentávamos o equilíbrio às margens da separação. Dizem que os matrimônios assim são os mais duradouros.

No entanto, a amizade acabou. Não se pode dizer “Oi, querida!” a uma mulher à qual já se sussurrou sabe lá Deus o quê. Não soa bem...

Então, o que trouxe com os meus trinta anos, celebrados com fervor no restaurante Dniepr? Levava uma vida de artista livre. Quer dizer, não tinha emprego fixo, ganhava a vida com jornalismo e revisões literárias de memórias de generais. Tinha um apartamento com janelas que davam para um lixão. Uma escrivaninha, um sofá, uns halteres, uma radiola Tonus. (Tonus é um bom sobrenomepara um gerente de mercearia.) Uma máquina de escrever, um violão, um retrato de Hemingway, alguns cachimbos num copo de cerâmica. Uma luminária, um armário, duas cadeiras da época dos brontossauros e também o gato Iefim, que eu respeitava muito pela sua delicadeza. À diferença de meus melhores amigos e conhecidos, ele aspirava a ser um homem...

Tânia morava no quarto vizinho. Minha filha estava doente: melhorava e então adoecia outra vez.

O meu amigo Bernóvitch dizia:

- Aos trinta anos o artista deve ter todos os problemas resolvidos. Exceto um: como escrever?

$\mathrm{Eu}$, em resposta, declarava que os problemas principais são insolúveis. Por exemplo, o conflito entre pais e filhos. A contradição entre o sentimento e o dever...

Entre nós havia uma confusão terminológica.

No fim, Bernóvitch acabava sempre dizendo:

— Você não é feito para o casamento...

E mesmo assim, já há dez anos que estamos casados. Quase dez anos...

Tatiana apareceu em minha vida como o nascer do Sol. Quer dizer, de um modo tranquilo, belo, sem emoções excessivas. O que havia de excessivo nela era a indiferença. Com sua indiferença ilimitada, ela lembrava um fenômeno vivo de natureza...

Lobánov, um artista plástico, estava celebrando o aniversário de seu hamster. $\mathrm{Na}$ mansarda com teto inclinado, apinhavam-se umas doze pessoas. Todos esperavam Tselkov, que não veio. Estavam sentados no chão, embora houvesse cadeiras para todo mundo. De noite, as 
Serguei Dovlátov: texto de cultura na literatura russa contemporânea conversas à mesa já tinham quase se transformado em pancadaria. Um homem de cabeça raspada vestido numa camisa listrada de marinheiro berrava a toda força:

— Falo mais uma vez, a cor é um fenômeno ideológico!...

(Mais tarde, foi esclarecido que não se tratava de nenhum artista, mas de um perito em mercadorias da Apráksin dvor. ${ }^{575}$ )

Esta frase inocente, por alguma razão, deixou furioso um dos convidados, um calígrafo. Atirou-se, entre socos, ao perito. Mas este, como todos os homens de cabeça raspada, era um hércules e agiu categoricamente. No ato, tirou da boca o dente postiço que se prendia com um pino de junta... Embrulhou-o rapidamente no lenço. Enfiou-o no bolso. E, finalmente, tomou a postura de boxeador.

Nesse ínterim, o calígrafo já tinha esfriado.

Estava comendo peixe recheado, exclamando a cada momento:

- Que peixe excelente! Queria me casar e ter três filhos com ele...

Imediatamente notei Tânia. ${ }^{576}$ Imediatamente memorizei seu rosto, preocupado e indiferente a um tempo. (Desde a juventude, não compreendo como numa mulher podem conviver a indiferença e a preocupação...)

No rosto pálido, sobressaía o batom. O sorriso era infantil e um pouco inquieto.

Em seguida, alguém cantou, imitando, aplicado, um ladrão reincidente. Alguém trouxe um diplomata estrangeiro que revelou ser um marinheiro grego. O poeta Karpóvski mentia com requinte. Disse, por exemplo, que o haviam expulsado do PEN club internacional por causa de uma insolência artística...

Tomei Tatiana pela mão e disse:

- Vamos embora!

(A melhor maneira de vencer a timidez inata é portar-se com a maior segurança possível.)

Tânia consentiu sem hesitar. E não como uma conspiradora. Mas como uma criança exemplar. Como uma mocinha jovem que obedece com gosto aos adultos.

Dei um passo em direção à porta, escancarei-a e fiquei pasmo. À frente, brilhava o telhado, molhado e inclinado. No céu alto e pálido, em segundo plano, enegreciam antenas.

No ateliê havia três portas. Uma levava ao elevador. Outra às profundezas do sistema de aquecimento. E a terceira ao telhado.

Não queria retornar. Além do mais, a julgar pela potência das vozes, a festa beirava a briga.

Só mais tarde, pus-me a caminhar pelo telhado, que estalava. Tânia me seguiu.

\footnotetext{
${ }^{575}$ Um dos mais antigos centros comerciais São Petersburgo.

576 Apelido de Tatiana.
} 
Serguei Dovlátov: texto de cultura na literatura russa contemporânea — Faz tanto tempo — disse — que eu queria um cenário romântico.

Sob nossos pés, havia um sapato roto largado. Um triste gato cinza mantinha o equilíbrio na borda estreita.

Perguntei:

— Já esteve alguma vez no telhado?

— Nunca na vida - respondeu Tânia.

E acrescentou:

— Mas sempre tive uma inveja terrível de Terechkova... ${ }^{577}$

- Ali está a Catedral de Nossa Senhora de Kazan... E atrás dela, o Almirantado... E esse é o Teatro Púchkin...

Aproximamo-nos à grade. Longe, lá embaixo, a cidade noturna fazia ruído. De cima, a rua parecia sem personalidade. Os bondes iluminados animavam-se ligeiramente.

- Precisamos sair daqui — disse.

— Acha que a briga já acabou?

— Acho que não... Como veio parar aqui? Quer dizer, nesta turma?

- Pelo meu ex-marido.

— Ele é o que, artista?

— Não exatamente... Na verdade, é um cafajeste. E você?

— Eu, o quê?

- Como veio parar aqui?

- Fui atiçado por Lobánov. Comprei, por esnobismo, um quadro dele. Algo branco... com orelhinhas... Um tipo de lula... Chama-se $O$ vetor do silêncio... Há pintores talentosos entre eles?

— Sim. Tselkóv, por exemplo.

— Qual é? O de calça jeans?

- Tselkóv é o que não veio.

— Entendi — disse.

- Outro se enforcou pouco tempo atrás. Chamava-se Peixe. Era seu apelido... Então, de repente, enforcou-se.

— Ah, meu Deus! Por quê? Um amor infeliz?

— O Peixe tinha mais de trinta anos. Seus quadros não vendiam.

- Quadros bons?

- Não muito. Agora trabalha como revisor.

— Quem?! — exclamei.

577 Valentina Terechkova (1937), primeira mulher cosmonauta russa, realizou seu voo em 1966. 
Serguei Dovlátov: texto de cultura na literatura russa contemporânea

— O Peixe. Conseguiram salvá-lo. Seu vizinho passou para pegar um cigarro...

— Precisamos sair daqui — disse.

Com passos miúdos, aproximei-me da janelinha do sótão. Escancarei-a. Estendi a mão para a moça:

- Cuidado!

Tânia deslizou com facilidade pelo vão da janela. Segui-a. O sótão era escuro e poeirento. Passamos por cima de canos cobertos de feltro. Nos inclinamos por baixo dos varais de roupas. Ao alcançar a escada de serviço, descemos. Depois, por entre os pátios de passagem, chegamos até o ponto de táxi.

Estava chovendo e pensei: ei-la, a famosa tradição literária petersburguesa. Toda esta "escola" tão celebrada não passa de descrição do tempo ruim. Todo o "brilho opaco de seu estilo" é o asfalto molhado depois da chuva...

Depois perguntei:

— E como estão os seus pais? Devem estar preocupados.

Já havia uns quinze anos que eu fazia essa pergunta boba a moças bonitas. Três entre cinco respondiam:

"Moro sozinha. Então, não tem ninguém para se preocupar comigo...".

Essa era a resposta que esperava receber. Uma verdade antiga diz: é mais fácil lutar no território inimigo...

— Não tenho pais — respondeu Tânia tristemente.

Fiquei sem graça.

- Desculpe-me pela inconveniência.

- Moram em Ialta - acrescentou Tânia. - Papai é secretário do comitê municipal do partido.

À essa altura, chegou o táxi.

- Aonde vamos? - perguntou o taxista sem se virar.

- Rua Dzerjínski, 8.

O motorista mexeu os ombros, descontente:

- Poderiam ir a pé.

— Depois acertamos - eu disse...

O motorista virou-se e escandiu:

- Agradeço muito, meu senhor! Nunca esquecerei essa generosidade...

Chegamos até o prédio de Tânia. Sua fachada de tijolos ultrapassava em um metro a linha dos prédios. Quatro amplas janelas vitorianas eram ligadas por uma balaustrada.

O motorista virou-se e partiu dizendo: 
Serguei Dovlátov: texto de cultura na literatura russa contemporânea

- Auf Wiedersehen... ${ }^{578}$

Os degraus inclinados levavam a uma porta pesada, forrada de lona alcatroada...

Já tinha estado mil vezes em situações semelhantes. Mesmo assim, sentia-me nervoso. Agora ela vai subir a escada da entrada e eu ouvirei:

“Obrigada por ter-me acompanhado...".

Depois disso, seria preciso ir embora. Ficar na entrada seria indecoroso... Perguntar: "Poderia me servir uma xicarazinha de chá?" uma vergonha!...

Meu amigo Bernóvitch dizia:

“O bom é ir quando convidam . É horrível quando não convidam. Mas o melhor é quando convidam e você não vai...".

Tânia entreabriu a porta:

— Obrigada pelo telhado!

— Sabe o que lamento? - eu disse. — Sobrou muita bebida... Lá, no ateliê...

Enquanto isso, como se por acaso, atravessei a soleira.

— Tenho vinho — disse Tânia —, escondo do meu primo. Ele vem com uma garrafa, e eu ponho metade no armário. Tem problemas de fígado...

— Você me deixou intrigado — disse.

— Compreendo — disse Tânia. — É que meu tio é um alcoólatra crônico...

Entramos no elevador. Em cada andar uma luzinha piscava. Tânia olhava atentamente para suas sandálias. A propósito, sandálias caras da marca Rochas...

Atrás dela, vi um palavrão escrito com giz. Uma injúria sem destinatário. Um fenômeno da arte pura...

Depois, silenciosamente, quase às escondidas, passamos pelo corredor. Farfalhando, eu roçava as mangas no papel de parede.

— Como você é enorme — cochichou Tânia.

— E como você é observadora...

Depois fomos parar num quarto inesperadamente amplo. Vi uma Nefertiti de gesso, um calendário estrangeiro com uma moça de sutiã cor-de-rosa, um cartaz de companhia de aviação transatlântica. Na escrivaninha, enrubesciam novelos de lã de tricô...

Tânia tirou uma garrafa de vinho tinto, uma maçã, khalvá, e um queijo úmido e enrugado. Perguntei:

— Onde você trabalha?

— Na administração da Universidade de Mecânica e Ótica de Leningrado, e você?

- Sou repórter.

578 “Adeus”, em alemão. 
— Jornalista?

— Não, repórter mesmo. O jornalismo é feito de estilo, de ideias, de questões... E o repórter transmite fatos. O mais importante para o reporter é não produzir uma mentira. Nisso consiste o pathos de seu trabalho. O estilo máximo para o repórter é a mudez. Nela se encontra uma quantidade mínima de mentiras.

A conversa passava a ser significativa.

Em geral, eu não gostava de falar sobre assuntos literários. Nesse sentido, como se diz, guardava a castidade. E, rebaixando um pouco meu trabalho, alcançava o efeito oposto. Assim me parecia...

O vinho fora bebido, a maçã cortada em gomos. Houve uma pausa, o que, numa situação dessas, era algo destruidor...

Por incrível que pareça, senti algo semelhante ao amor.

Se pensarmos: de onde?! De que lixo?! De que profundezas da vida miserável, bruta?! Em que solo cansado, escasso, nascem essas flores tropicais?! Embaixo dos raios de que sol?!

Alguns ateliês cheios de trastes, de moças vestidas de forma vulgar... Violão, vodka, um frondismo lamentável... E de repente — ah, meu Deus! — o amor...

Como Deus é inescrupuloso, no sentido positivo do termo, esse Rei do universo!...

Depois, Tânia falou muito baixo:

- Vamos conversar, simplesmente conversar...

Três minutos antes, eu, sem perceber, tinha tirado os sapatos.

— Teoricamente - digo — é possível. Na prática, não...

Ao mesmo tempo, amaldiçoo em voz baixa o zíper quebrado da minha blusa...

Cairei mil vezes neste buraco. E mil vezes morrerei de medo.

O único consolo é que esse medo dura menos que um cigarro. A ponta do cigarro ainda está fumegando e você já é um herói...

Depois tudo ficou bem apertado e, na manhã seguinte, restaram palavras torturantes na memória. E o mais importante: a manhã chegou tal qual é, com os contornos dos objetos surgindo das trevas. Uma manhã sem a decepção que eu esperava e da qual tinha medo.

Lembro que eu até disse:

— A manhã cai bem em você...

Ficou mesmo bem mais bonita sem maquiagem.

Assim tudo começou. E já dura dez anos. Um pouco menos de dez anos...

No começo, ficava vez ou outra na casa da Tânia. Durante a semana, eu trabalhava de manhã até a noite. Depois, dava uma chegada em algum amigo. Passava um tempo com minha turma, conversava sobre Nabókov, Joyce, sobre hóquei, sobre terriers pretos... 
Quando eu enchia a cara, ligava para ela.

— É a mística! — eu gritava ao telefone. — É a verdadeira mística... Basta eu ligar e você vem dizendo que já são duas da madrugada...

Depois, eu ia cambaleando até a sua casa. A casa sobressaía visivelmente da fileira, como se desse um passo na minha direção.

Tânia surpreendia-me com sua obediência silenciosa. Eu não sabia dizer o que mais a definia: a apatia, a submissão ou o orgulho?

Ela nunca perguntava:

"Quando você vai vir?"

$\mathrm{Ou}:$

"Por que não telefonou?"

Deixava-me pasmo sua prontidão inabalável para o amor, para as conversas, para as distrações. E, também, sua total ausência de iniciativa nesse campo...

Era calada e calma. Calada sem tensão e calma sem ameaça. Era a calma calada do oceano que ouve indiferente os gritos das gaivotas...

Como todos os homens frívolos, eu não era um sujeito ruim. Logo me arrependia ou fazia piadas. Dizia:

- Existem namorados residentes e ambulatoriais. Eu, por exemplo, sou o tipo ambulatorial...

E depois:

— O que você viu em mim?! Deveria encontrar uma boa pessoa! Algum militar...

— Falta estímulo — dizia Tânia. —É chato amar uma boa pessoa...

Vivemos numa época surpreendente. "Boa pessoa" nos soa como um insulto. "Pelo menos, é boa pessoa", falam do namorado que aparenta ser uma evidente nulidade...

Passou um ano. Eu ia à casa de Tânia com cada vez mais frequência. Os vizinhos cumprimentavam-me educadamente e me chamavam ao telefone.

Comecei a ter ali minhas próprias coisas. Escova de dentes num copo de cerâmica, cinzeiro e chinelos. Uma dia, coloquei a foto do escritor americano Bellow em cima da mesa.

— Belóv? - perguntou Tânia. — Da Nóvyi mir? ${ }^{579}$

— Ele mesmo — digo...

Está bem, pensava, suponhamos que eu me case. Me casarei por sentimento de dever. Suponhamos que tudo fique bem. Contanto que para ambos.

Na realidade, já estávamos casados, e tudo ia bem.

\footnotetext{
${ }^{579}$ Nóvyi mir ("Novo mundo"), revista literária mensal, publicada em Moscou desde 1925.
} 
Serguei Dovlátov: texto de cultura na literatura russa contemporânea

Uma união privada de responsabilidades. Justamente no que consiste a garantia de sua durabilidade...

Mas cadê o amor? O ciúme e a falta de sono? Cadê o transbordamento de sentimentos? As cartas não enviadas, borradas de lágrimas? O desfalecimento ao ver seu pequeno pezinho? Os cupidos, os anjinhos e outros figurantes desse show arrebatador? Cadê, no final das contas, o ramo de flores por um rublo e trinta copeques?!...

De fato, nem sei o que é amor. Há uma ausência absoluta de critérios. Um amor infeliz, isso ainda posso compreender. E se tudo está bem? Na minha opinião, isso provoca suspeitas. Existe na sensação de regra uma espécie de ardil. Mesmo assim, o mais assustador ainda é o caos...

Suponhamos que a gente se case no cartório. Mas isto será amoral. Porque a moral não suporta pressão...

A moral deve decorrer logicamente da nossa natureza. Como acontece em Shakespeare:

"Natureza, tu és a minha deusa!".

Aliás, quem diz isso? Edmund! Um canalha de marca maior...

Eis que tudo se embaraça de forma inacreditável.

No entanto, uma pergunta. Quem ousará acusar o açor ou o lobo por ser amoral? Quem chamará de amoral o pântano, a nevasca, o calor do deserto?...

A moral forçada é um desafio às forças da natureza. Enfim, se eu casar por sentimento de dever, será amoral...

Uma vez, Tânia me ligou. Por sua própria iniciativa. A julgar por seu caráter, era quase uma sabotagem.

- Você está livre?

— Infelizmente, não — disse. — Estou no teletipo...

Fazia uns três anos que eu recusava qualquer proposta inesperada. A palavra misteriosa "teletipo" deveria soar convincente.

- Meu primo chegou. Faz tempo que queria apresentar vocês.

— Está bem — disse. — Eu irei.

E por que não fazer amizade com um amigo de copo?!

À noite, dei uma chegada na casa de Tânia. Tomara uns goles para ter coragem. E depois uns outros. Às sete, toquei na sua porta. Passado um minuto, após um tumulto incômodo no corredor, vi o primo.

Estava sentado como os policiais, os agitadores e os visitantes noturnos. Quer dizer, de lado, com o rabo do olho na mesa de jantar.

O primão produziu uma impressão forte. 
Serguei Dovlátov: texto de cultura na literatura russa contemporânea

Sobre os penhascos dos ombros erguia-se um rosto pardo de tijolo. Seu cocuruto coroava-se com um canteiro de grama áspera e poeirenta do ano passado. As abóbadas moldadas das orelhas perdiam-se na penumbra. Ao posto avançado da testa larga e sólida faltavam seteiras. Os lábios descerrados pareciam um barranco. Os charcos brilhantes dos olhos, cobertos de uma crosta de gelo, lançavam uma indagação. A boca insondável, como uma fenda no rochedo, guardava uma ameaça.

O primão levantou-se e, como um cruzador, avançou o braço esquerdo. Quase gemi quando as garras de ferro apertaram a minha mão.

Depois, ele desabou na cadeira, que rangeu. Moveram-se as mós de granito. Um terremoto curto e destruidor reduziu instantaneamente o rosto do homem a ruínas, em meio às quais floresceua flor escarlate e pálida de um sorriso, que logo murchou.

O primo apresentou-se com importância:

— Erich Maria. ${ }^{580}$

— Boris - respondi, num sorriso frouxo.

— Então, agora vocês se conhecem — disse Tânia.

E foi cuidar da cozinha.

Eu estava calado, como que esmagado por uma carga pesada. Depois, senti fixo em mim um olhar frio, como um cano de revólver.

O braço de ferro pousou no meu ombro. O meu paletozinho na hora ficou estreito.

Lembro que gritei algo sem nexo. Algo insuportavelemente culto:

— Está se esquecendo, maestro!

— Silêncio! — pronunciou em um tom ameaçador o sujeito sentado em minha frente.

E então:

— Porque você não se casa, canalha?! Porque está enrolando, calhorda?!

"Se essa é a minha consciência," pensei, "então não é nada atraente..."

Comecei a perder a noção da realidade. Os contornos do real dissolveram irremediavelmente. O primo-paisagem lançava-se, interessado, ao vinho.

Ouvi o tinido do bonde do lado de fora. Ao mover os cotovelos, ajeitei a roupa.

Em seguida, expressei-me da maneira mais imponente possível:

- Escuta aí, primo, por favor, sem violência! Faz tempo que planejo discutir de modo construtivo o tema do casamento. Tenho champanhe na bolsa. Um momento...

E coloquei firme a garrafa na mesa lisa e polida.

Foi assim que nos casamos.

\footnotetext{
${ }^{580}$ Alusão ao nome do escritor alemão Erich Maria Remarque (1898 - 1970), popular na União Soviética.
} 
Serguei Dovlátov: texto de cultura na literatura russa contemporânea

O nome do primo, como se soube depois, era Èdik Malínin. Èdik trabalhava como treinador de sambo ${ }^{581}$ numa associação de surdos-mudos.

Naquela noite, evidentemente, bebi demais. Ainda antes de chegar à casa de Tatiana. E então imaginei Deus sabe o quê...

Casamos oficialmente em junho. Antes de partir para o litoral de Riga. Não fosse assim, não poderíamos nos registrar no hotel...

Passaram-se anos. Não me publicavam. Eu bebia cada vez mais. E encontrava cada vez mais justificativas para isso.

Por vezes, ficávamos longos períodos vivendo apenas à custa do salário de Tânia.

Em nosso casamento, reuniam-se traços de esbanjamento e de miséria. Tínhamos duas casas separadas. A cinco paradas do bonde. Tânia tinha um espaço de vinte e cinco metros quadrados num apartamento comunal. E eu dois quartinhos apertados, de seis e de oito metros. Falando pomposamente, escritório e dormitório.

Uns três anos mais tarde, trocamos tudo isso por um apartamento decente de dois aposentos.

Tânia era uma mulher misteriosa. Eu sabia tão pouco dela que me surpreendia continuamente. Qualquer fato de sua vida causava-me a impressão de algo sensacional.

Uma vez, surpreendi-me com sua declaração política inesperadamente sólida. Eu não tinha a mínima ideia de suas opiniões. Lembro que, quando a imagem do camarada Gríchin ${ }^{582}$ surgiu num documentário, minha mulher disse:

— Dá para condená-lo só pela fisionomia.

Assim, estabeleceu-se entre nós uma cumplicidade parcial na dissidência.

No entanto, brigávamos sem parar. Eu eu me tornava cada vez mais irritadiço. Era, ao mesmo tempo, um gênio não reconhecido e um terrível largadão. Eu escrevia novelas impressionistas e as mantinha em minha gaveta. E, por dinheiro, escrevia textos literários sobre o exército e a frota.

Sabia que tudo isso desagradava Tânia.

Bernóvitch repetia com impertinência:

— Aos trinta anos todos os problemas devem ter sido resolvidos, menos os criativos...

Não conseguia fazê-lo. Minhas dívidas atravessavam facilmente o limite que marca o início da apatia. Já havia tempo que os burocratas literários tinham me inscrito numa lista infame qualquer. E realizar-me por completo nas relações familiares eu não queria e não podia.

\footnotetext{
${ }^{581}$ Arte marcial e sistema de defesa pessoal desenvolvido na União Soviética.

582 Víktor Gríchin (1914-1992), político soviético.
} 
Serguei Dovlátov: texto de cultura na literatura russa contemporânea

A cada dia que passava, minha mulher falava com mais frequência em emigrar. Eu me vi num emaranhado insolúvel e mandei-me às Colinas de Púchkin...

Formalmente estava solteiro, saudável, continuava sendo membro da União dos Jornalistas. Pertencia a uma simpática minoria étnica. ${ }^{583}$ Meu talento literário era reconhecido até por Gránin ${ }^{584}$ e Rytkheu. ${ }^{585}$

Formalmente, era um artista completo.

Efetivamente, estava à beira de uma crise nervosa.

$$
* * *
$$

E então ela chegou, tão subitamente que até perdi os sentidos. Apareceu diante de mim toda sorridente, como se tudo estivesse bem.

Ouço:

- Você pegou um bronzeado...

E depois, se não me engano:

- Meu querido...

Pergunto:

— Como está Macha?

- Faz um tempinho que arranhou uma bochecha, tão desobediente... Trouxe umas conservas...

- Vai ficar muito tempo?

— Na segunda preciso voltar ao trabalho.

- Você pode ficar doente.

— E por que ficaria doente? — estranhou Tânia.

E acrescentou:

— A propósito, já estou doente...

Que baita lógica, pensei...

— E também seria inconveniente — diz Tânia. — A Sima está de férias. Róschin está se preparando para partir para Israel. Acredita? acabou que Róschin era Stackelberg. E agora seu nome não é Dima, mas Mordkhe. Juro pra você...

- Eu acredito.

— Os Súris escrevem que Liova tem um bom trabalho em Boston...

\footnotetext{
${ }^{583} \mathrm{O}$ protagonista refere-se ao fato de ser de origem judia. Na União Soviética, no documento de identidade marcava-se a nacionalidade do seu portador.

${ }^{584}$ Daniil Gránin (1919), escritor russo.

${ }^{585}$ Iúri Rytkhéu (1930 - 2008), escritor russo e tchuktche.
} 
Serguei Dovlátov: texto de cultura na literatura russa contemporânea

- O que acha de eu pedir uma folga?

- Para quê? Eu quero ouvir você. Quero ver você trabalhando.

— Não é trabalho. É um quebra-galho... Por outro lado, faz vinte anos que escrevo contos e você não se interessa nem um pouco por eles...

- Antes você dizia que fazia quinze. Agora já são vinte. Embora tenha passado menos de um ano...

Ela tem o dom surpreendente de me fazer sair do sério. Mas seria estúpido brigar. As pessoas brigam na plenitude da vida...

- Estamos aqui como animadores. Ajudamos os trabalhadores a descansar com um pouco de cultura.

— Interessante. E os colegas, são bons?

— De todo tipo. Tem uma da região, Larissa. Todo dia soluça no túmulo de Púchkin. Vê o túmulo e... chora.

- Finge?

- Não creio... Uma vez os turistas lhe deram um conjunto de cozinha de quarenta e seis rublos.

— Pois eu não recusaria...

Nesse momento, Galina pronunciou meu sobrenome. Chegaram uns turistas de Lípetsk.

Disse a Tatiana:

— Pode deixar as coisas aqui.

— Tenho só uma bolsa.

— Então, deixe-a aqui...

Dirigimo-nos ao ônibus azul, salpicado de lama. Cumprimentei o motorista e dei um lugar à minha mulher. Depois, voltei-me para os turistas:

- Bom dia! A administração, os curadores e os funcionários do parque museu mandam lembranças. Encarregaram-me de acompanhar vocês. Meu nome é... Hoje vamos...

Etc.

Depois, expliquei ao motorista como ir a Mikháilovskoe. O ônibus pôs-se em movimento. Nas curvas, chegavam sons da radiola:

$$
\begin{aligned}
& \text { Dê fogo como Prometeu, } \\
& \text { dê fogo sem escolha, } \\
& \text { e não poupe às pessoas } \\
& \text { o fogo de sua alma... }
\end{aligned}
$$

Ao contornarmos um rochedo decorativo num cruzamento, falei em tom maldoso:

\footnotetext{
586 Canção popular da época.
} 
Serguei Dovlátov: texto de cultura na literatura russa contemporânea — Não prestem atenção. Não é nada, é só para decoração...

E, mais baixo, à minha mulher:

- Caprichos bobos do camarada Guéitchenko. ${ }^{587}$ Quer fazer um parque grandioso de cultura e diversão. Colocou uma corrente ${ }^{588}$ numa árvore para dar um colorido local. Dizem que os estudantes de Tártu roubaram a corrente. E a jogaram no fundo do lago. Fizeram bem, os estruturalistas!...

Guiava a excursão olhando a cada momento para minha mulher. Seu rosto, tão atento e até um pouco desconcertado, assombrou-me de novo. Os lábios pálidos, a sombra dos cílios, o olhar aflito...

Então me dirigi a ela. Contei-lhe sobre um homem baixinho e genial em que Deus e o diabo coexistiam tão tranquilamente. Ele pairava alto, mas foi vítima de um sentimento banal e mundano. Criava obras-primas, mas faleceu como um herói de um romance de segunda. E assim deu a Bulgárin ${ }^{589}$ um motivo legítimo para escrever:

"Era um grande homem, mas morreu como uma lebre...".

Caminhamos pela beira do lago. No sopé do morro, vislumbrava-se mais um rochedo. Decorado com outra citação em caligrafia eslava. Os turistas rodearam a pedra e puseram-se a fotografá-la com avidez.

Acendi um cigarro. Tânia aproximou-se de mim.

O dia estava ensolarado, ventilado, fresco. O grupo que se alongava ao longo da margem nos alcançava. Era preciso apressar-se.

Aproximou-se um homem gordo com um caderninho:

— Mil desculpas, mas quais eram os nomes dos filhos de Púchkin?

- Aleksándr e Grigóri.

— E o mais velho era...

— Aleksándr — eu disse.

— E o patronímico? ${ }^{590}$

— Aleksándrovitch, obviamente.

— E o mais novo?

- O mais novo o quê?

— Qual era o patronímico do mais novo?

Olhei, impotente, para a Tânia. Minha mulher não sorria, estava triste e concentrada.

\footnotetext{
587 Semion Guéitchenko (1903-1993), escritor e pesquisador soviético, estudioso de Púchkin. Desde 1945, diretor do parque museu Mikháilovskoe. Autor de vários artigos e pesquisas dedicados ao legado de Púchkin.

588 A corrente na árvore é uma alusão ao famoso fragmento do poema de Púchkin Ruslan e Liudmila, "No Lukomórie há um carvalho verde, naquele carvalho há uma corrente dourada...".

${ }^{589}$ Faddei Bulgárin (1789 -1859), escritor, jornalista, crítico literário e editor russo, contemporâneo de Púchkin.

${ }^{590}$ Em russo, o patronímico, que acompanha o prenome, é formado pelo nome do pai.
} 
Serguei Dovlátov: texto de cultura na literatura russa contemporânea

— Ah, pois é - deu-se conta o turista.

Era preciso apressar-se.

— Vamos andando, camaradas — gritei, enérgico —, marchem até a próxima citação!...

Em Trigórskoe, a excursão desenrolou-se sem dificuldades e até com entusiasmo. Para o que contribuíram em grande medida, volto a dizer, o caráter e a lógica da exposição.

Verdade seja dita: desconcertou-me a exigência de uma dama. Queria ouvir a romança Do instante mágico hei lembrança. ${ }^{591}$ Respondi que não sabia cantá-la. A dama insistiu. Quem me salvou foi o gordo do caderninho. Posso cantar, disse...

— Só que não aqui, por favor — pedi —, mas no ônibus.

(No caminho de volta o gordo realmente pôs-se a cantar. Esse babaca acabou se mostrando um excelente tenor...)

Notei que Tânia estava cansada. Decidi pular o parque Trigórski. Já tinha tido a ocasião de fazê-lo antes. Dirigi-me aos turistas:

"Quem dos presentes já esteve no parque cultural?".

Normalmente, ninguém tinha estado. Então, podia-se transgredir o programa sem risco...

Os meus turistas desceram o morro correndo. Cada qual se apressava para ser o primeiro a subir no ônibus, embora houvesse lugares o suficiente e os assentos já tivessem sido distribuídos. Enquanto visitávamos Trigórskoe, nossos motoristas tiveram tempo de banhar-se no lago. Seus cabelos estavam molhados.

— Vamos ao mosteiro - falei. — Depois do estacionamento, à esquerda...

O motorista, um jovem, acenou com a cabeça e perguntou:

— Ficarão muito tempo por lá?

- Uma meia hora, no máximo.

No mosteiro, apresentei Tânia ao curador Lóguinov. Diziam que Nikolai Vladímirovitch era religioso e até praticava ritos. Queria conversar com ele sobre a fé e esperava um momento oportuno. Ele parecia alegre e calmo, e eu sentia tanta falta disso...

Terminei a excursão na parte sul da igreja, ao lado do desenho de Bruni. Um desfecho ao lado do túmulo seria mais espetacular, mas preferi dispensar o grupo. Minha mulher se deteve um instante perto da grade e então se voltou para mim.

— Tudo isto é tão absurdo e triste — disse.

Não perguntei a que se referia. Estava cansado. Melhor, sentia-me muito tenso. Sabia que ela não tinha vindo por acaso.

— Vamos jantar em Lukomórie?

— Eu até beberia um pouco — disse Tânia...

\footnotetext{
${ }^{591}$ Famoso poema lírico de Púchkin dedicado a Anna Kern (1825), posteriormente transformado em romança.
} 
O salão estava deserto e abafado. Os dois enormes ventiladores não funcionavam. As paredes eram decoradas com relevos de madeira. Os poucos visitantes constituíam dois grupos. A nobreza de fora, de jeans, e o público local, de aspecto bem mais rude. Os forasteiros almoçavam. Os locais bebiam.

Sentamo-nos perto da janela.

— Esqueci de perguntar, como veio pra cá? Ou melhor, não tive tempo.

— Simples, de ônibus noturno.

— Poderia ter vindo com algum dos guias, de graça.

— Não os conheço.

— Eu tampouco. Na próxima vez, combinaremos de antemão.

- Na próxima vez, você irá. No final das contas, é bastante cansativo.

— Arrependeu-se de ter vindo?

— De jeito nenhum! É maravilhoso aqui...

Chegou uma garçonete com um bloco minúsculo.

Eu conhecia essa garota. Os guias apelidaram-na de Bismarck.

— Então? — disse ela.

E calou-se, totalmente sem forças.

— Poderia ser um pouco mais cortês? - eu disse. — Abra uma exceção. Minha mulher veio me visitar.

- E o que é que eu fiz?

- Pare, imploro a você, pare...

Tatiana pediu panquecas, vinho, bombons...

— Vamos discutir tudo. Vamos conversar com calma.

— Eu não vou. Eles que caiam fora do país.

— Eles quem? — perguntou Tânia.

— Aqueles que me envenenam a vida. Então, eles que se vão...

— Vão por você na cadeia.

— Que ponham. Se a literatura é um fazer censurável, nosso lugar é na prisão... E, a propósito, já não põem mais ninguém na cadeia por causa da literatura...

— Khéifets ${ }^{592}$ nem publicou seu trabalho, mas mesmo assim o prenderam.

${ }_{592}$ Mikhaíl Khéifetz (nascido em 1934), escritor dissidente russo. 
Serguei Dovlátov: texto de cultura na literatura russa contemporânea

— Prenderam-no justamente porque não tinha nada publicado. Devia ter publicado na Gráni. Ou na Kontinent. ${ }^{593}$ E agora não há ninguém para intervir. De outra forma, poderiam ter feito algum barulho no Ocidente...

- Tem certeza?

- De quê?

— De que Micha Khéifets interessa ao mundo ocidental?

— E por que não? Escreveram sobre Bukóvski. Escreveram sobre Kuznetsóv... ${ }^{594}$

— Isso tudo é jogo político. É preciso pensar na vida real.

— Digo mais uma vez, eu não vou embora.

— Explique, por quê?

— Não há o que explicar... É minha língua, meu povo, meu país louco... Imagina, eu amo até mesmo os policiais.

- O amor é a liberdade. Enquanto as portas estão abertas, está tudo bem. Mas, se as portas são trancadas por fora, já é prisão...

- Mas agora permitem sair.

- Quero aproveitar o momento. Estou de saco cheio. Estou farta de ficar em filas para comprar qualquer porcaria. Farta de andar de meia rasgada. Farta de me alegrar com salsichão... O que o prende aqui? O Hermitage, o Nevá, as bétulas?

— Pouco me importo com as bétulas.

— Então, o quê?

- A língua. Na língua do outro, perdemos oitenta por cento de nossa personalidade. Perdemos a habilidade de fazer piada, de ironizar. Só isto já me dá calafrios.

— Eu já não estou para brincadeiras. Pense na Macha. Imagine o que a espera aqui.

— Você está exagerando. Milhões de pessoas vivem, trabalham e são plenamente felizes.

- Que esses milhões fiquem aqui. Estou falando de você. De qualquer forma, não publicam seu trabalho.

— Mas meus leitores estão aqui. E lá... Quem vai querer ler meus contos em Chicago?

— E quem os quer aqui? A garçonete do Lukomórie, que nem o cardápio lê?

— Todos. É que as pessoas ainda não se dão conta disto.

— Será sempre assim.

— Você está equivocada.

\footnotetext{
${ }^{593}$ Gráni, Kontinent, revistas literárias e políticas, publicadas em russo no exterior. Após a queda da União Soviética, as duas revistas passaram a ser publicadas na Rússia.

${ }^{594}$ Vladímir Bukóvski (1942) e Anatóli Kuznetsóv (1929 - 1979), escritores dissidentes russos.
} 
Serguei Dovlátov: texto de cultura na literatura russa contemporânea

- Compreenda, daqui a dez anos serei uma velha. Já sei tudo de antemão. Cada dia vivido é um degrau para o futuro. E todos os degraus são iguais. Cinza, gastos, abruptos... Quero outra vida, sonho com algo inusitado. Que seja um drama, uma tragédia... Será um drama inusitado...

Quantas vezes já havíamos falado sobre esse tema... Eu debatia, expunha algumas razões. Apresentava alguns argumentos morais, espirituais, psicológicos. Tentava provar algo.

Mas sabia que todas as minhas considerações eram falsas. Não era nada daquilo. Simplesmente eu não conseguia decidir-me. Assustava-me um passo tão sério e irreversível. Pois é como nascer de novo. E, ainda por cima, por vontade própria. A maioria das pessoas nem se casar consegue direito...

Por toda a minha vida, odiei tomar atitudes de qualquer natureza. A palavra "ativista" soa para mim como um insulto. Como que vivi na voz passiva. Passivamente, segui as circunstâncias. Isso me ajudou a achar justificativas para tudo.

Qualquer passo decisivo implica responsabilidade. Então, deixe que os outros respondam por isso. A inação é o único estado moral possível... Meu ideal era ser um pescador. Passar a vida sentado à beira de um rio. De preferência, sem troféus...

Eu não acreditava que Tânia seria capaz de ir sem mim. A América, como eu supunha, era, para ela, sinônimo de divórcio. Do divórcio que, formalmente, já havia acontecido. E que perdeu força, como o álcool dissipado.

Antes as mulheres diziam: "Vou achar um sujeito rico e bonito, e aí você vai ver". Agora dizem: "Vou embora para a América"...

A América era uma ficção para mim. Algo como uma miragem. Um filme meio esquecido com participações do tigre Akbar e de Chaplin...

— Tânia - eu disse —, sou uma pessoa leviana. Qualquer aventura me convém. Se ali aparecesse [afastei a cortina] um Caravelle ou um Boeing... ${ }^{595}$ eu subiria e partiria. Apenas para dar uma olhada na Broadway. Mas percorrer órgãos públicos. Explicar, certificar. A terra natal histórica... ${ }^{596} \mathrm{O}$ apelo aos antepassados... A tia Fânia Tsiperóvitch...

Trouxeram a comida e a bebida.

— Então, deseje boa sorte a nós... Olhe, no cardápio “almôndegas” está escrito com “h”...

- Como?

—É que eu vim para me despedir. Se não concorda, vamos sem você. Está decidido.

— E a Macha?

— O que tem a Macha? É por ela que estou fazendo tudo isso. Você dará um atestado...

\footnotetext{
595 Marcas de aviões.

${ }^{596}$ Refere-se à repatriação judia em Israel.
} 
— Que atestado? Espere, vamos beber...

- De que você não tem pretensões financeiras. Ou tem alguma?

-É um disparate...

— Então, vai dar o atestado?

— E se não der?

— Não deixarão Macha sair.

— E você irá sozinha?

— Não sei... Não... Acho que você não vai fazer uma coisa dessas. No fundo, você não é uma pessoa má.

- $\mathrm{O}$ que a bondade tem a ver com isso? Estamos falando de uma pessoa viva. E se minha filha crescer e disser... Como pode decidir por ela?

—É quem deve decidir, então? Você? Você arruinou a sua vida, arruinou a minha vida...

— Não é tão irremediável.

- Aconselho que pense melhor.

— Não tenho no que pensar... E estes atestados idiotas... Para que você puxou tudo isso? Já não bebo, trabalho... A vida vai se arranjar, você vai ver.

— Você mesmo disse: "Quem um dia deu de beber, beberá sempre!".

— Não fui eu. Foi algum inglês... Maldito seja!

— Não importa... Alguém está cumprimentando você.

Olhei para trás. Na porta, estavam Mitrofánov e Potótski. Alegrei-me por poder interromper a conversa. E se pudesse metê-la na cama? pensei...

— Apresento-lhes a minha esposa — disse —, sentem-se.

Stássik inclinou-se cerimoniosamente:

— Literato Potótski. Membro da US SS dos escritores. ${ }^{597}$

Mitrofánov fez um aceno com a cabeça em silêncio.

- Sentem-se.

— Já andei sentado — expressou-se com humor ${ }^{598}$ Potótski.

Mitrofánov permanecia em silêncio.

Compreendi que não tinham dinheiro e falei:

- Como minha esposa chegou, hoje é por minha conta.

\footnotetext{
597 Refere-se à União dos Escritores Soviéticos. Uma ironia feita entre a União dos Escritores Soviéticos (Soiuz soviétskikh pissátelei) e o SS (Schutztaffel), exército nazista.

${ }^{598}$ A personagem refere-se ao seu passado na prisão (em russo, usam a expressão “sentar na prisão”).
} 
Serguei Dovlátov: texto de cultura na literatura russa contemporânea

E fui ao bar pegar cerveja. Quando voltei, Potótski dizia animado alguma coisa à minha mulher. Compreendi que se tratava de seu talento e dos abusos da censura. O que não o impediu de desviar-se do assunto:

— Cerveja? Temo que não dê para irrigar...

Tive que ir buscar vodka. Neste ínterem, a garçonete trouxe os sanduíches e a salada.

Potótski ficou extremamente animado.

— Para mim, uma cheia — disse e acrescentou: — Gosto das cheiinhas.

Volódia continuava calado. Stássik percebeu o meu olhar de surpresa. Explicou apontando para Mitrofánov:

-É que uma vespa entrou na boca dele.

— Ah, meu Deus — disse minha mulher. - Ainda continua aí?

- Não, não é isso. É que ele estava terminando a excursão pelo mosteiro e, nesse instante, uma vespa entrou na boca dele. O Vovka, me perdoem, soltou um escarro, mas a vespa teve tempo de picá-lo. Agora não pode falar, dói.

— E também dói para engolir? — perguntou Tânia.

Volódia abanou a cabeça energicamente.

— Não dói para engolir — explicou Potótski.

Servi vodka a eles. Evidentemente, essa companhia incomodava minha mulher.

— O que acha do nosso parque cultural? - perguntou Potótski.

— Tem lugares maravilhosos. A vista do monte de Sávkin, a alameda Kern...

De repente, Mitrofánov ficou tenso.

— I-ão — pronunciou.

- Como? - perguntou minha mulher.

— I-ão — repetiu Mitrofánov.

— Ele quer dizer "ficção" - esclareceu Potótski. - Ele está tentando dizer que a alameda Kern é uma invenção de Guéitchenko. Quer dizer, a alameda existe, claro. Uma típica alameda de tílias. Mas Kern não tem nada a ver com isso. Talvez ela nunca tenha chegado nem perto dali.

- E eu gosto de pensar que foi justamente ali onde Púchkin declarou-se a ela.

- Era uma devassa - precisou Potótski com aspereza.

— U-a fa-i-a — acrescentou Mitrofánov.

— Volódia quer dizer "uma vadia". E, mesmo falando grosseiramente, ele tem razão. Anna Petrovna tinha dezenas de amantes. Quanto vale camarada Glinka... E Nikitenko? Agora, andar com um censor já é demais!

- A censura era diferente - disse minha mulher. 
Serguei Dovlátov: texto de cultura na literatura russa contemporânea

— Qualquer censura é crime — Stássik agarrou-se ao tema que lhe era próximo.

Virou outra e esquentou mais.

- Toda a minha vida é uma luta contra a censura — dizia. - Qualquer censura é uma zombaria com o artista... A censura provoca em mim um protesto alcoólico!... Vamos brindar à abolição da censura!

Stássik virou mais uma e baixou enigmaticamente a voz:

— Antr nu! Entre nós! Há tempos que aguardo os planos de emigração. Tenho exatamente uma parte sobre trinda e duas de sangue judeu. Almejo o posto de conselheiro do presidente. Guardo a receita perdidado priánik de Tula... ${ }^{599}$

— E-feu a fa-a — disse Mitrofánov.

— Como assim "encheu a cara"? — retrucou Potótski. — Sim, eu bebi. Sim, estou um pouco relaxado. Emocionado com a companhia de uma linda dama. Mas, ideologicamente, estou sóbrio...

Fez-se uma pausa penosa. Em seguida, alguém colocou uma moeda na fenda do aparelho de som Meloman. Ressoaram os gritos lancinantes de Anatóli Koroliov: 600

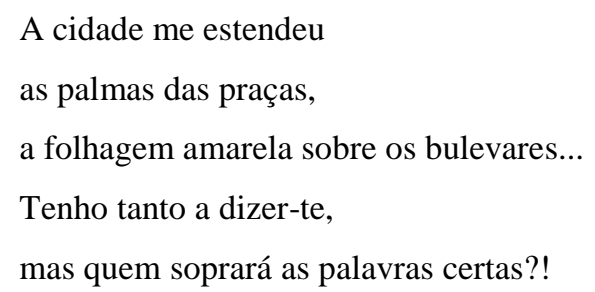

— Precisamos ir — disse eu. — Peço mais vodka?

Stássik baixou os olhos. Mitrofánov acenou energicamente com a cabeça.

Pedi, paguei a conta, e nos levantamos.

Potótski ergueu-se num pulo e fez um estalido com os saltos gastos dos sapatos.

- Como diziam meus antepassados, os nobres poloneses, do widzenia! ${ }^{601}$

Mitrofánov sorriu tristemente...

O caminho mais curto conduzia-se pelo bosque. Atrás das árvores, sentiam-se a umidade e o frescor. Inúmeros ciclistas nos ultrapassaram. A vereda estava entulhada de raízes de pinheiros. Os aros das bicicletas tiniam rispidamente.

Tânia dizia:

- Pode ser que minha decisão seja uma aventura ou até uma loucura. Mas não posso mais...

Seu desespero me assustava. Mas o que dizer?

\footnotetext{
599 A região da cidade de Tula é famosa por seus priániks, bolinhos de mel. ${ }^{600}$ Anatóli Koroliov (1942 - 1991), cantor popular soviético.

601 "Adeus", em polonês.
} 
Serguei Dovlátov: texto de cultura na literatura russa contemporânea

— Lembra como a levei embora da casa de nossos amigos? Levei você nos braços, depois a deixei cair... Naquela época, estava tudo bem. E ficará tudo bem de novo.

—Éramos pessoas totalmente diferentes. Estou envelhecendo.

- De jeito nenhum...

Tânia calou-se. E eu, como sempre, caí em meditação:

- O único caminho honesto é o caminho dos erros, das decepções e das esperanças. A vida é uma descoberta, pela própria experiência, das fronteiras do bem e do mal... Não há outro caminho... Eu cheguei a algo... Acho que ainda não é tarde...

- São palavras.

- As palavras são a minha profissão.

— Isso também são palavras. Tudo já está decidido. Venha com a gente. Vai ter outra vida...

— Para um escritor, isso seria a morte.

— Há muitos russos lá.

- São uns derrotistas. Um bando de coitados derrotistas. Até Nabókov é um talento perdido. E o que dizer do tal Zúrov?

— Quem é Zúrov?

- Havia certo...

— De que estamos falando?! Tudo já está decidido. Na quinta feira, dou entrada nos documentos.

Involuntariamente, calculei quanto tempo restava até quinta-feira.

E de repente senti uma dor tão aguda, uma amargura tão inefável, que até perdi os sentidos. Disse:

— Tânia, perdoe-me, não vá embora.

— Já é tarde, querido...

Deixei-a para trás e, avançando, comecei a chorar. Ou melhor, não comecei, parei de conter-me. Caminhava repetindo: “Deus! Deus! Por que esse castigo?”. E eu mesmo respondia: "Como por quê? Por tudo. Por toda a sua vida imunda, preguiçosa e despreocupada...".

Minha mulher ia atrás, distante, decidida, corajosa. Bem longe daquela tolinha que eu conhecera, como se verificou...

Subimos ao topo do morro. Apontei para a casa onde morava. Da chaminé erguia-se verticalmente uma fumaça leve. Isso significava que o senhorio estava em casa.

Passamos pela rua da aldeia, e todos nos cumprimentaram afavelmente. Eu percebera havia tempos que, juntos, suscitávamos simpatia nas pessoas ao redor. Quando estava sozinho, era totalmente diferente. 
Serguei Dovlátov: texto de cultura na literatura russa contemporânea

E nesse ponto Nadiejda Fiódorovna disse:

- Venham pegar leite amanhã...

Tânia divertia-se com os galos e os cachorros peludos, e, quando vimos um peru, não houve limites para a admiração dela:

— Que altivez! Que presunção!... E com uma aparência tão repugnante. Galos e gansos também se gabam, mas esse aí... Ah, meu Deus, como se parece com Isakson!

Ao nos ver, Mikhal Iványtch ficou demasiadamente animado. Com cara de sofredor, ele abotoou a camisa no pescoço pardo. Com isso, as pontas amassadas do colarinho viraram. Depois, sabe-se lá por que, pôs o boné.

— Borka e eu vivemos direito — ele dizia —, no comportamento e em tudo mais... Quer dizer, nada de branco, tinto ou cerveja... Sem falar de água de colônia... Ele lê livros sem parar. Lê tanto que morrerá como um tolo — concluiu Mikhal Iványtch de forma abrupta.

Decidi neutralizá-lo de algum modo. Chamei-o na antessala:

— Micha, está precisando de dinheiro?

— Quem? Pois bem... Tá bom...

Dei-lhe três rublos.

— Vítiaz fica aberto até as onze — disse Mikhal Iványtch —, vou chegar a tempo. Ou vou pegar a égua do Liokha... Ah, onde estavam? No bairro, o vinho de maçã custa um rublo e catorze... Então eu vou. Peguem aí o toucinho e a cebola — gritou já da porta.

Ficamos a sós. Tânia lançou um olhar assustado ao recinto:

— Tem certeza de que é um quarto habitável?

- Antes, duvidava. Andei arrumando aqui. Se visse o que era antes.

— O telhado está furado.

— Quando o tempo está bom, nem se percebe. E, parece, não há previsão de chuvas.

- E buracos no chão.

- Agora está melhor. Antes cachorros abandonados entravam pelas fendas.

- Mas as fendas não foram tapadas.

— Em compensação, amansei os cachorros.

Tânia tocou o cobertor:

- Meu Deus, com o que você se cobre!

— Agora está calor. Não é preciso se cobrir. Pelo menos, para você.

— Foi um elogio?

- Algo assim.

— Você emagreceu.

- Ando muito. 
- Caiu-lhe bem.

- Além disso, tenho olhos bastante grandes...

- Que conversa terrivelmente tola — disse Tânia.

- Melhor assim. Meu desejo é chegar ao idiotismo total. Comprar um aquário com peixes, uma palmeira num vaso de madeira...

- Para que quer um aquário?

— E para que quero uma palmeira?

- Vamos começar com o aquário.

— Sempre sonhei em ter um par de peixinhos dourados adestrados...

- E a palmeira?

— Pode-se desenhar uma palmeira. E guardá-la na sacada.

— E eu pergunto: temos uma sacada?

- Tampouco temos uma palmeira...

— Meu Deus, o que estou perguntando? E de que estamos falando?!

— Realmente, do que devemos falar?! Ainda mais que tudo já está decidido.

Olhei para as janelas. Não havia cortinas. Qualquer um podia dar uma espiada da rua. Na aldeia, essas coisas costumam acontecer.

Daria para puxar o armário para lá, pensei. Olhei ao redor, não havia nenhum armário...

— Que há de novo em Leningrado? — perguntei.

— Já falei. Uns se preparam para ir embora, outros os desprezam por isso.

— O Mítia não tem ligado?

— Liga de vez em quando. As coisas entre Galina e ele não vão nada bem. Surgiu um iugoslavo. Ou um húngaro, não lembro... Se chama Aquiles.

— Talvez um grego antigo?

— Não, lembro que é alguém do bloco socialista... Enfim, o Mítia está furioso. Ficou muito bravo, como você. Queria bater em Krein.

- E este?

— E o Jênia lhe disse: "Mítia, eu não tenho nada a temer, pois você tem chifres. Portanto, não é carnívoro...” Mal conseguiram apartá-los.

— Não deveriam.

Ficamos calados por um tempo.

Continuava a pensar: com que cobrir as janelas? De maneira que parecesse natural e desenvolto...

Estamos casados há dez anos e ainda morro de medo. Temo que Tânia arranque bruscamente a mão e diga: "Só faltava essa!..." 
Serguei Dovlátov: texto de cultura na literatura russa contemporânea

No entanto, tive tempo de tirar os sapatos. Sempre tiro os sapatos com antecipação, para não distrair-me depois. Para não ter de dizer: "Só um momento, que vou tirar os sapatos...”. No nervosismo, os cordões não se desamarram... Acho que já estraguei uns mil cordões no ímpeto da paixão...

- Além disso, conheci um dissidente famoso, Gúriev. Talvez você tenha ouvido falar dele, as rádios ocidentais o mencionaram algumas vezes. Foi a Frida quem nos apresentou. Estivemos na casa dele, na rua Púchkinskaia. Pedimos conselhos a ele sobre nossa partida. Eles têm um monte de ícones em casa...

— Então, é judeu.

- Parece que sim. Mas o sobrenome é russo, Gúriev.

— E é isso que gera suspeitas. Gúriev, Guriévitch...

— Tem algo contra os judeus?

— Não, nada. Além do mais, esse aí é russo. Conheço desde 1965.

— Então, está me passando um trote de novo?

—É que sou brincalhão.

- Gúriev é tão inteligente. Disse que a Rússia está vivendo a época do renascimento cristão. Que é um processo irreversível. Que, entre as pessoas da cidade, 60\% são religiosas. E, do campo, $75 \%$.

— Por exemplo, Mikhal Iványtch.

— Não conheço Mikhal Iványtch. Mas passa uma boa impressão.

- Sim, não é mau. Mas tem pouco de santidade.

— Gúriev nos serviu café instantâneo. Disse: "Você está colocando demais... Não que eu esteja poupando, é que o gosto muda...". E, quando estávamos para ir embora, disse: "Vou acompanhar vocês até o ônibus. De vez em quando, aparecem uns desordeiros por aqui. Está cheio de arruaceiros...”. E a Frida respondeu: "Nada de mais, apenas 40\%...”. Gúriev ofendeu-se e desistiu de nos acompanhar... O que está fazendo?! Pelo menos apague a luz!

- Para quê?

- As pessoas fazem assim.

- Posso tampar a janela com o paletó. E o abajur vou cobrir com o boné. Vai virar um abajur de cabeceira.

- O lugar não é higiénico.

— Como se você tivesse vindo da Andaluzia!

— Não olhe.

- Acha que ando vendo muita beleza por aqui?

— Minha meia-calça está rasgada. 
Serguei Dovlátov: texto de cultura na literatura russa contemporânea

— Tire-a da minha vista!

— Lá vamos nós — ofendeu-se Tânia. - Vim para termos uma conversa séria.

— Ah, esqueça isso pelo menos por meia hora...

$\mathrm{Na}$ antessala, ouviram-se passos. Micha tinha voltado. Deitou-se na cama resmungando.

Temia que começasse a falar palavrões. Meus receios confirmaram-se.

— E se ligássemos o rádio? — disse Tânia.

— Não tem rádio. Tem uma amoladeira elétrica...

Micha demorou a se acalmar. Em seus palavrões, notava-se um tom filosófico. Escutei, por exemplo:

"Ah, minhas bolas boiando nas marolas...".

Finalmente, tudo ficou silencioso. Estávamos juntos de novo. De repente, Tânia ficou barulhenta. Eu disse:

- Você grita demais. Cuidado para não acordar o Micha.

- E o que posso fazer?

- Pense em outra coisa. Eu sempre penso em vários tipos de problemas. Em dívidas, em doenças, no fato de não me publicarem.

- E eu penso em você. Você é o meu maior problema.

— Quer um pouco de toucinho da fazenda?

— Não. Sabe o que quero?

- Posso imaginar...

Tânia chorou de novo. Ela dizia cada coisa que eu só conseguia pensar nisto: tomara que não acorde o senhorio. Ele ficaria espantado...

Depois sentimos cheiro de queimado. Meu boné importado estava em chamas. Desliguei o abajur, mas já tinha amanhecido. O oleado brilhava sobre a mesa.

— Às nove e meia — disse minha mulher — parte o primeiro ônibus. E o seguinte às quatro. Ainda preciso buscar a Macha...

- Vou mandá-la de graça. Às dez sai a excursão Palmira do Norte, de três dias.

- Acha que é conveniente?

— Claro. Eles têm um enorme Ikarus, ${ }^{602}$ de luxo. Sempre há lugares livres.

— Talvez precise dar um agrado ao motorista?

— Isso é assunto meu. Temos as nossas contas... Bom, vou buscar leite.

${ }^{602}$ Marca de ônibus. 
- Ponha a calça.

- Boa ideia...

Nadiejda Fiódorovna já cuidava da horta. Sobre as folhas de batata erguia-se seu enorme traseiro. Perguntou:

— Então, é sua namorada?

- Esposa - disse eu.

— Não acredito. Bonita demais.

A mulher mediu-me com um olhar zombeteiro:

—É bom ser machão. Quanto mais feio, mais bonita é a mulher.

— E o que tenho de tão feio?

— Parece o Stálin...

$\mathrm{Na}$ aldeia, não gostavam de Stálin. Já havia tempo que eu percebera isso. Pelo visto, lembravam-se da coletivização e de outros truques de Stálin. Se a nossa intelligentsia criativa aprendesse algo com os camponeses analfabetos... Dizem que, no Palácio das Artes de Leningrado, aplaudiram quando Stálin apareceu na tela.

Já eu sempre o detestei. Muito antes das reformas de Khruschóv. Antes mesmo de aprender a ler. O mérito é da consciência política de minha mãe. Minha mãe, uma armênia de Tbilisi, criticava Stálin continuamente. No entanto, de um jeito bastante peculiar. Dizia com convicção:

"Nenhum georgiano pode ser um homem decente!...".

Voltei tentando não derramar o leite. Tânia levantou-se, lavou-se, fez a cama. Mikhal Iványtch consertava a serra elétrica dando uns gemidos. Sentia-se cheiro de fumaça, de grama e de trevo aquecido ao sol.

Entornei o leite, cortei o pão, peguei a cebolinha e os ovos cozidos. Tânia examinava meu boné estragado.

- Quer que ponha um remendo de couro?

— Para quê? Já está calor.

— Vou mandar um novo pra você.

- Melhor mandar cianureto.

— Não, sério, quer que mande o quê?

— Como vou saber o que estão vendendo na América?... Não vamos falar sobre isso...

Chegamos ao centro turístico por volta das nove. O motorista já tinha trazido o ônibus até a bifurcação. Os turistas colocavam as bolsas e malas no porta-malas. Alguns pegaram os assentos da janela. Aproximei-me do motorista, que eu conhecia:

— Tem algum lugar livre? 
Serguei Dovlátov: texto de cultura na literatura russa contemporânea

- Para você, vamos arrumar.

- Quero mandar minha mulher para Leningrado.

- Compreendo. Eu mandaria a minha para Kamtchatka. Ou, em vez de Terechkova, para a Lua...

O motorista vestia uma bonita camisa importada. Em geral, os motoristas de ônibus de excursões são razoavelmente cultos. A maioria deles poderia facilmente substituir os guias. Só que receberiam bem menos...

De repente, percebi que Tânia estava conversando com Marianna Petrovna. Por alguma razão, sempre fico preocupado quando duas mulheres ficam a sós. Principalmente quando uma delas é a minha mulher.

— Bom — disse ao motorista —, combinado. Deixe-a no canal Obvódny.

— Lá não é muito fundo — riu o motorista...

E se eu também embarcasse e fosse embora, pensei. E algum dos guias levaria minhas coisas depois. Só que vamos viver com o quê? E como?...

Galina passou ao nosso lado. Fez um acenou rápido na direção da minha mulher:

- Meu Deus, que feiinha!...

Fiquei calado. Mas mentalmente incendiei seus caracóis descoloridos com água oxigenada.

Chegou o instrutor de educação física, Serioga Iefímov.

— Perdão — disse —, é para a senhora.

E deu a Tânia um vidro de airela.

Precisávamos nos despedir.

— Ligue — disse Tânia.

Acenei com a cabeça.

— Tem como telefonar?

— Claro. Dê um beijo na Macha. Quanto tempo vai levar tudo isso?

—É difícil dizer. Um mês, dois... Pense.

- Vou ligar.

$\mathrm{O}$ motorista subiu à cabine. $\mathrm{O}$ motor importado pôs-se a zumbir, confiante. Pronunciei algo incompreensível.

— Eu também — disse Tânia...

O ônibus pôs-se em marcha e logo dobrou a esquina. Em um minuto, sua lateral escarlate passou feito um relâmpago por entre as árvores de Lúgovka.

Passei na agência. Meu grupo de Kíev só chegaria ao meio-dia. Tive que voltar para casa. 
Serguei Dovlátov: texto de cultura na literatura russa contemporânea

Vi os grampos de Tânia em cima da mesa. Duas xícaras sujas de leite, restos de pão e de cascas de ovo. Sentia-se um cheiro quase imperceptível de queimado e de cosméticos.

Ao despedir-se, Tânia disse: "Eu também...". O resto foi abafado pelo barulho do motor...

Passei pelo quarto de Mikhal Iványtch. Ele não estava. Em cima da cama suja, cintilava uma espingarda. Uma espingarda pesada de Tula, de dois canos e cabo vermelho. Apanhei a espingarda e pensei: será que não está na hora de eu estourar meus miolos?...

$$
* * *
$$

Junho desenrolou-se seco e claro, a grama farfalhava sob os pés. Nas sacadas do centro turístico, secavam toalhas multicolores. Ressoavam as batidas elásticas das bolas de tênis. Perto dos parapeitos das largas entradas dos edifícios, enrubesciam bicicletas com aros brilhantes. Do alto-falante da janelinha do sótão, soavam tangos antigos. A melodia parecia desenhada em linhas pontilhadas...

A batida das bolas, o cheiro da grama aquecida, a geometria das bicicletas deram as feições inesquecíveis àquele junho sombrio...

Liguei duas vezes para Tânia. Nas duas vezes, surgiu uma sensação incômoda. Era perceptível que sua vida ganhara outro ritmo, que, para mim, era novo. Sentia-me um pouco ridículo, como um torcedor que se meteu dentro do campo de futebol.

Em nosso apartamento, ouviam-se vozes estranhas. Tânia fazia-me perguntas inesperadas. Por exemplo:

— Onde estão as contas de eletricidade?

Ou:

— Você me reprovaria se eu vendesse minha corrente de ouro?

Nem sabia que a minha mulher tinha joias...

Tânia percorria gabinetes, cumprindo todas as formalidades. Queixava-se dos burocratas e dos estelionatários.

- Tenho na minha bolsa - dizia — dez barras de chocolate, quatro ingressos para o concerto de Kobzon ${ }^{603}$ e três exemplares de Tsvetáieva...

Tânia parecia animada e quase feliz.

O que eu podia lhe dizer? Pedir pela décima vez: "Não vá embora"?

Sua absorção nos próprios assuntos humilhava-me. E eu ali com meus problemas quase dissidentes?!

Tânia não tinha tempo para mim. Pela primeira vez, algo sério acontecia...

${ }^{603}$ Ióssif Kobzon (nasc. em 1937), cantor russo. 
Serguei Dovlátov: texto de cultura na literatura russa contemporânea

Uma vez, ela mesma me ligou. Por sorte, eu estava no centro turístico. Mais precisamente, na biblioteca do edifício central. Tive que atravessar correndo o terreno todo. Tânia precisava de um atestado dizendo que eu permitia que ela levasse nossa filha. E que não tinha pretensões financeiras.

Tânia ditou-me algumas frases formais. Retive na memória tal formulação: "A criança, na quantidade de uma...".

- Autentique no cartório local e envie para mim. É a maneira mais fácil.

- Posso ir até aí.

- Agora não é necessário.

Fez-se uma pausa.

- Mas teremos tempo de nos despedir?

- Claro. Não pense que...

Tânia estava quase se justificando. Sentia vergonha pela sua negligência. Por esse apressado "Não é necessário...".

Aparentemente, eu tinha me tornado um problema torturante para ela, o qual estava sendo resolvido. Ou seja, uma etapa superada. Com todos os meus defeitos e méritos, que agora não tinham importância...

Naquele dia, embebedei-me. Comprei uma garrafa de vodka Moskóvskaia e tomei-a sozinho.

Não estava com vontade de chamar o Micha. As conversas com Mikhal Iványtch exigiam um esforço grande demais. Lembravam as conversas que eu tinha com o professor Likhatchóv. ${ }^{604}$ Só que a Likhatchóv eu tentava parecer o mais inteligente possível. E a Micha, ao contrário, o mais acessível e simples.

Por exemplo, Mikhal Iványtch perguntava:

- Sabe pra que cortam as bolas dos judeus? Para que a base funcione melhor...

E eu concordava, pacífico:

— Pois é... Deve ser por isso mesmo...

Em suma, fui a um bosque perto dos banhos. Sentei-me encostado numa bétula. E bebi a garrafa toda de Moskóvskaia, sem beliscar nada. Fumava um cigarro atrás do outro e mastigava bagas de sorveira...

${ }^{604}$ Dmítri Likhatchóv (1906 - 1999), filólogo, crítico de arte e roteirista soviético e russo. Foi membro da Acadêmia de Ciências da Rússia. 
Serguei Dovlátov: texto de cultura na literatura russa contemporânea

O mundo demorou a mudar de feição. Primeiro, incomodavam-me os mosquitos. Alguma coisa viscosa rastejava em direção às pernas das calças. E a grama parecia um tanto úmida.

Então, tudo mudou. O bosque abriu-se, abraçou-me e aceitou-me em seu seio aquecido. Por um tempo, fiz parte da harmonia do universo. O gosto amargo da baga parecia inseparável do cheiro úmido da grama. As folhas sobre a cabeça vibravam levemente com o tinir dos mosquitos. Nuvens pairavam como na tela de cinema. E até a teia de aranha parecia um adorno...

Estava a ponto de chorar, embora ainda compreendesse que era o efeito do álcool. Pelo visto, a harmonia escondia-se no fundo da garrafa...

Dizia a mim mesmo:

— Púchkin também tinha dívidas e relações nada boas com o Estado. E também teve um problema com a esposa. Sem falar de seu caráter difícil...

E tudo bem. Abriram o parque cultural. Há quarenta pessoas trabalhando como guias. E todos amam loucamente Púchkin...

Surge uma pergunta: e onde vocês estavam antes?... E quem vocês, em uníssono, desprezam agora?...

Não cheguei a responder às minhas questões. Caí no sono...

Quando acordei, era por volta das oito. Galhos e raminhos negrejavam tendo ao fundo nuvens pálidas e cinza... Os insetos reviviam... A teia de aranha roçou meu rosto...

Levantei-me sentindo o peso da roupa molhada.

Os fósforos ficaram úmidos. O dinheiro também. E o principal: sobrara quase nada, apenas seis rublos. A lembrança da vodka aproximava-se como uma nuvem de chuva...

Não queria ir pelo centro turístico. Àquela hora, por ali perambulavam metodologistas e guias. Cada qual era capaz de travar uma conversa profissional sobre o diretor do Liceu, Iegor Antónovitch Enguelgardt. ${ }^{605}$

Tive que contornar o centro turístico e pegar a estrada pelo bosque.

Também tive medo de passar pelo pátio do mosteiro. A atmosfera de um mosteiro é insuportável para alguém de ressaca.

Desse modo, também desci o morro pelo bosque. Ou melhor, por uma vereda escarpada.

Senti-me melhor apenas na entrada do restaurante Vítiaz. Com os bêbados locais ao fundo, eu parecia um pedante.

A porta estava escancarada e escorada num tijolo de sílica. $\mathrm{Na}$ antessala, ao lado do espelho, sobressaía uma figura ridícula de madeira, obra do major aposentado Goldstein. Na placa de cobre estava indicado: Abram Saúlovitch Goldstein. Depois, entre aspas: "O russo".

\footnotetext{
${ }^{605}$ Iegor Enguelgardt (1775 - 1862), escritor e pedagogo russo. Entre 1816 e 1823 foi diretor do Liceu Imperial de Tsárskoie Seló, onde estudou Púchkin. O poeta dedicou vários de seus poemas ao Liceu.
} 
Serguei Dovlátov: texto de cultura na literatura russa contemporânea

A figura do russo lembrava ao mesmo tempo Mefistófeles e Baba Iagá. ${ }^{606} \mathrm{O}$ elmo de madeira foi pintado com guache prateada.

Perto do balcão do bufê, amontoavam-se umas oito pessoas. Rublos amassados eram colocados em silêncio sobre o balcão. O troco caía sonoramente no pires com a borda quebrada.

Dois ou três grupos acomodavam-se no salão, ao lado da parede. Ali, excitados, gesticulavam, tossiam e riam. Eram os operários da base turística, enfermeiros do hospício e cavalariços da indústria madeireira.

A intelligentsia local — o projecionista, o restaurador, o recreador — bebia à parte. De cara com a parede, sentava-se um rapaz desconhecido de camisa polo e jeans nacionais. Seus caracóis ruivos jaziam nos ombros.

Chegou a minha vez de pedir no balcão. Sentia o familiar tremor da ressaca. Sob o casaco molhado, debatia uma alma órfã e agoniada...

Eu tinha que gastar os seis rublos de maneira eficaz. Fazê-los durar por um bom tempo.

Pedi uma garrafa de vinho do Porto e dois bombons de chocolate. Daria para fazer três vezes esse pedido. E ainda sobrariam uns vinte copeques para o cigarro.

Sentei-me ao lado da janela. Agora já não havia mais nenhuma pressa.

$\mathrm{Na}$ rua, dois ciganos descarregavam caixas de pão de um automóvel. O carteiro subia o morro em sua bicicleta motorizada. Cachorros abandonados rolavam na poeira.

Pus mãos à obra. Fiz uma anotação mental positiva: as mãos quase não tremiam mais. O que já era um bom sinal...

O vinho espalhava-se como uma boa notícia, colorindo o mundo de tons de ternura e de condescendência.

O que me espera no futuro é o divórcio, as dívidas, o fracasso literário... Mas existem no mundo esses enigmáticos ciganos com pão... Duas velhas com rostos escuros perto da policlínica... Um diazinho úmido e cada vez mais frio... Vinho, um minuto de folga, a terra natal...

Entre o burburinho, ouviu-se de repente:

— Moscou falando! Moscou falando! Vocês estão ouvindo A alvorada dos Pioneiros... Ao microfone, o cabeludo Ievstikhéiev... Suas palavras soam como uma censura digna dos falcões do Pentágono...

Olhei ao redor. As falas misteriosas vinham do rapagão de camisa verde. Continuava sentado virado para a parede. Mesmo o olhando por trás, dava para perceber o quanto estava embriagado. Sua nuca coberta de cachos revelava algum tipo de impaciência agressiva. Estava quase gritando:

\footnotetext{
${ }^{606}$ Baba Iagá, bruxa do folclore russo.
} 
Serguei Dovlátov: texto de cultura na literatura russa contemporânea

— Mas eu digo: não! Não, digo não aos predadores imperialistas que foram além das medidas! Não, repitam comigo os trabalhadores do complexo industrial de celulose dos Urais... ${ }^{607}$ Não existe felicidade no mundo, queridos ouvintes! Sou eu quem diz isso, o único sobrevivente da $316^{\mathrm{a}}$ Divisão de atiradores de Panfílov... ${ }^{608} \mathrm{E}$ assim dizia Zaratustra...

Começaram a aguçar os ouvidos. Aliás, sem grande interesse.

O rapaz levantou a voz:

— Estão olhando o quê, trastes?! Querem contemplar a morte do soldado da guarda do Regimento de artilharia de Maikop, ${ }^{609}$ o visconde de Bragelonne?! ${ }^{610}$ Pois não, concederei essa chance aos senhores... Camarada Rappoport, ${ }^{611}$ introduza o preso!...

As pessoas em volta reagiram com calma. Embora com os "trastes", sem dúvida, ele se referisse a eles.

Uma voz de fez ouvirde um canto do salão:

- Valera ${ }^{612}$ encheu a lata...

Valera respondeu de pronto:

- O direito ao descanso é garantido pela Constitução... Como nas melhores casas de Paris e Bruxelas... Então por que querem transformar a ciência numa serviçal da teologia?! Mantenham-se dentro das prescrições do XX Congresso!... ${ }^{613}$ Ouçam a Alvorada dos Pioneiros... Gmýria ${ }^{614}$ lê o texto...

- Quem? - perguntaram do canto.

- O barão Kleinmíkhel, queridinha!...

Nem bem dei uma espiada no rapagão, senti-me em estado de alerta. E, olhando-o com atenção, a sensação intensificou-se.

De cabelo comprido, desajeitado e magricela, ele produzia a impressão de alguém se fingindo de esquizofrênico. Além disso, estava obcecado numa coisa: queria ser desmascarado o quanto antes.

\footnotetext{
${ }^{607}$ Complexo industrial de celulose de Víchera, no rio Víchera, na região dos Urais, construido nos começo dos anos 1930 por prisioneiros do Campo de prisão de Víchera (Vícherski ispravítelno-trudovói láguer, ou Vícherlag). Um dos prisioneiros mais famosos de Vícherlag foi o escritor russo Varlám Chalámov, que esteve ali nos anos 1929 1932.

${ }^{608}$ A $316^{\mathrm{a}}$ Divisão de atiradores do Exército Soviético, liderada pelo general-major Ivan Panfílov, famosa por sua atuação durante a Segunda Guerra Mundial, e em primeiro lugar pela defesa da entrada em Moscou, na região de Volokolamsk, no dia de 16 de novembro de 1941. A heroica defesa posteriormente foi chamada de "façanha de panfilovtsy".

${ }^{609}$ Pelo visto a personagem se refere ao regimento da $9^{\text {a }}$ divisão de atiradores, que participou da liberação da cidade de Maikop, no Cáucaso, da ocupação nazista, em 29 de janeiro de 1943, durante a Segunda Guerra MUndial.

${ }^{610}$ Personagem do romance de Alexandre Dumas $O$ visconde de Bragelonne, a última parte da trilogia de D'Artagnan e os três mosqueteiros.

${ }^{611}$ Sobrenome típico judeu.

${ }^{612}$ Apelido de Valéri.

${ }^{613}$ Nikita Khruschóv (1894-1964) denunciou as atrocidades cometidas por Stálin no XX Congresso do Partido Comunista da URSS (14 e 25 de fevereiro de 1956).

${ }^{614}$ Boris Gmýria (1903 - 1969), famoso cantor de ópera soviético de origem ucraniana.
} 
Serguei Dovlátov: texto de cultura na literatura russa contemporânea

Poderia passar por doente mental, não fosse o sorriso triunfante e a expressão de bufonaria habitual. Uma espécie de descaramento astuto e sagaz transparecia em seus monólogos lunáticos. Nessa confusão nauseante de cabeçalhos de jornais, slogans, citações desconhecidas...

Tudo isso parecia um alto-falante quebrado. O rapaz expressava-se de modo claro, entrecortado, com uma ênfase doentia e certa força dramática...

Estava embriagado, mas nisso também havia alguma astúcia...

Sequer percebi que ele se aproximava. Um segundo antes, estava sentado virado para a parede. E, de repente, olhava-me por trás dos ombros:

— Vamos nos conhecer, Valéri Márkov!... Um transgressor calunioso da ordem pública...

- Ah, ouvi falar.

— Estava em lugares não tão distantes. ${ }^{615} \mathrm{O}$ diagnóstico é alcoolismo crônico!...

Inclinei a garrafa, hospitaleiro. Em suas mãos, milagrosamente, surgiu um copo.

- Muito grato - disse ele. - Tudo isso, como eu espero, foi comprado pelo preço da degradação moral?

— Pare com isso — eu disse. — Ou melhor, vamos beber.

Ouvi em resposta:

- Agradeço e vou aderir, como Chepílov... ${ }^{616}$

Terminamos o vinho.

— Um bálsamo para as feridas — disse Márkov.

— Tenho uns quatro rublos. A perspectiva de futuro é nebulosa...

— Dinheiro não é problema! - gritou o meu companheiro de farra.

Levantou-se num salto e correu à mesa abandonada. Voltou com um envelope para papel fotográfico preto e amassado. Despejou dele um monte de dinheiro. Deu uma piscada e disse:

— São incontáveis os diamantes das cavernas de pedra!... ${ }^{617}$

E, em seguida, com uma timidez súbita na voz:

— Os bolsos se alargam, que feio...

Márkov acariciou suas coxas coladas aos jeans. Seus pés calçavam sapatinhos de verniz de concerto.

Que figura, pensei.

Nesse momento, começou a compartilhar seus problemas:

\footnotetext{
${ }^{615}$ Referência à prisão.

${ }^{616}$ Dmítri Chepílov (1905 - 1995), político soviético, secretário do Comité Central do PCUS (Partido Comunista da União Soviética). Aderiu a Malenkóv, Mólotov, Kaganóvitch quando estes foram afastados do Comitê Central (1957).

${ }^{617}$ Citação da Canção da Índia, da ópera Sadkó, de Rímski-Kórsakov.
} 
Serguei Dovlátov: texto de cultura na literatura russa contemporânea

— Ganho muito... Nem bem saio de uma bebedeira, vem grana aos montes... Cada foto, um rublo. Só de manhã ganho trinta rublos... Até de noite, já fiz cem... E sem nenhum controle sobre as finanças... O que resta fazer?... Beber... Surge a anomalia magnética de Kursk. ${ }^{618}$ Um dia de trabalho, uma semana de bebedeira... Para os outros, a vodka é domingo. Para mim, são dias da semana monótonos... Ora desintoxicação, ora xadrez, dissidência pura... A esposa, claro, está descontente. Vamos arranjar uma vaca, diz ela... Ou uma criança... Desde que que não beba. Mas, por enquanto, eu me abstenho. Quer dizer, sigo bebendo...

Márkov enfiou o dinheiro de volta no envelope. Duas ou três notas caíram ao chão. Ficou com preguiça de agachar-se. Em sua postura aristocrática, o mocinho lembrava Mikhal Iványtch.

Chegamos ao balcão, pedimos uma garrafa de Agdám. Queria pagar. Meu companheiro levantou a voz:

— Tirem as mãos da Cuba socialista!

E, orgulhoso, atirou três rublos ao balcão...

O bêbado russo é uma coisa extraordinária. Tendo dinheiro, prefere tomar um veneno por um rublo e quarenta. Mas o troco não pega... Eu mesmo sou assim...

Voltamos à janela. A quantidade de pessoas aumentou sensivelmente. Alguém até deu de tocar sanfona.

— Reconheço-te, Rus! — exclamou Márkov e acrescentou baixinho: — Detesto... Detesto esses trastes de Pskóv!... Pardon, primeiro bebamos.

Tomamos uns goles. Estava mais barulhento. A sanfona emitia sons estridentes.

Meu novo conhecido gritava, excitado:

- Olhe para esta humanidade progressista! Para essas caras estúpidas! Essas sombras dos antepassados esquecidos!... ${ }^{619}$ Vivo aqui como um raio de luz no reino da escuridão... ${ }^{620}$ Ah, e se formos escravizados por militaristas americanos! Talvez começássemos a viver como pessoas, assim como os tchecos...

Bateu com a mão sobre a mesa:

- Quero liberdade! Quero a arte abstrata e o dodecacofonismo!... Vou dizer-lhe uma coisa...

Inclinou-se e começou a cochichar com a voz rouca:

— Vou dizer como a um amigo... Queria dar o fora daqui para qualquer lugar. Nem que seja para a Rodésia do Sul. Apenas o mais longe possível da nossa aldeia... Mas como?! A

\footnotetext{
${ }^{618}$ Anomalia magnética situada nãs regiões das cidades de Kursk, Biélgorod e Oriol, devido à abundância de mineriais de ferro na região. É a maior anomalia magnética da Terra.

${ }^{619}$ Sombras dos antepassados esquecidos (título em russo, Tiéni zabýtykh priédkov), nome de filme de Serguei Paradjánov (1965).

${ }^{620}$ Raio de luz no reino da escuridão (em russo, Lutch sviéta v tiómnom tsarstve), artigo do crítico literário Nikolai Dobroliúbov, dedicado à peça de Aleskándr Ostróvski A tempestade (em russo, Grozá) (1859).
} 
Serguei Dovlátov: texto de cultura na literatura russa contemporânea fronteira está fechada! Dia e noite sob a guarda de Karatsupa... ${ }^{621}$ Ir ao estrangeiro como marinheiro o conselho da aldeia não deixaria... Casar com uma turista estrangeira? Com alguma puta da Grécia antiga? E onde vou achá-la?... Um fulano me disse outro dia: estão liberando os judeus. Falei pra minha esposa: "Verka, este é o cabo da boa esperança...”. Minha esposa é simples, do povo. Zomba de mim. Diz: "Olhe pra esse focinho de bandido. Tipos como você não deixam nem entrar no cinema. E agora inventou de ir para Israel!...”. Mas eu me aconselhei com um sujeito. Ele recomenda que me case temporariamente com uma judia. Daí é mais fácil. Há poucas turistas estrangeiras, mas judias aparecem de vez em quando. Tem uma no centro turístico. Chama-se Natella. Parece que é judia, embora tome umas e outras...

Márkov acendeu o cigarro, quebrando os fósforos. Comecei a ficar alto. O Agdám errava por meus vasos sanguíneos. Os gritos misturavam-se ao burburinho pacífico que ia aumentando.

Meu companheiro de farra não estava mais bêbado que antes. E sua loucura até diminuiu.

Fomos buscar vinho duas vezes. Numa das vezes, ocuparam nossos lugares. Mas Márkov fez um escândalo, e eles foram embora.

Atrás deles, soaram gritos:

— Tirem as mãos do Vietnã e do Camboja! A fronteira está fechada! Karatsupa não dorme! Salvo as pessoas de nacionalidade judia...

Nossa mesa estava coberta de embalagens de bombons. Jogávamos as cinzas num pires sujo.

Márkov continuava:

- Antes pensava em ir à Turquia de canoa. Até comprei um atlas. Mas é que vão me afogar, bastardos... Então, isso ficou no passado. Como se diz, passado e pensamentos... ${ }^{622}$ Agora, conto mais com os judeus... Uma vez viramos uma, Natella e eu, perto do rio. Eu digo: vamos casar, eu e você. Ela diz: você é um selvagem, e feio. Terra preta ${ }^{623}$ se arrebata dentro de você, diz... E em nossas paragens, a propósito, nem sequer ouviram falar de terra preta... Mas eu fiquei quieto. E até a encoxei um pouco. Ela grita: me deixe! Aqui podem ver... E eu digo: assim viviam os nossos antepassados eslavos... Enfim, não deu certo... Talvez devesse ter falado numa boa? Tipo, você é uma pessoa de nacionalidade judia. Então auxilie um dissidente russo por conta de Israel...

Márkov voltou a tirar seu envelope preto. Não consegui gastar os quatro rublos...

\footnotetext{
${ }^{621}$ Nikita Karatsupa (1910-1994), coronel, herói da União Soviética. Conhecido por suas incursões contra os trangressores de fronteira.

${ }^{622}$ Alusão ao livro Passado e pensamentos (em russo, Bylóe i dúmy) (1868), de Aleksandr Herzen.

${ }^{623}$ Terra preta (em russo, tchenoziom), solo fértil das estepes e das pradarias do sul do país. A personagem de Natella insinua aqui a descendência camponesa de Valera (as regiões de terra preta são principalmente agrárias).
} 
Serguei Dovlátov: texto de cultura na literatura russa contemporânea

Agora ambos falávamos, interrompendo um ao outro. Contava sobre minhas desgraças. Por mais vergonhoso que seja admitir, eu refletia sobre literatura.

Márkov voltou-se para o salão:

— Tirem os chapéus, senhores! Diante de vocês está um gênio!...

Os ventiladores faziam correr pelo salão nuvens de fumaça. Nas vozes embriagadas, os sons do aparelho Melomano desapareciam. Os homens da indústria madeireira acenderam uma fogueira num prato de faiança. Embaixo das mesas, cachorros perambulavam...

Tudo ia se tornando vago ante meus olhos. Do que falava Márkov chegavam palavras esparsas:

— Avante, ao Ocidente!... Os tanques vão em losango!... ${ }^{624}$ Só quem anda alcança!...

Depois, avizinhou-se o fulano embriagado com a sanfona. Seus odres roseavam intimamente. Lágrimas escorriam pelas bochechas do sanfoneiro. Ele perguntou:

- Por que descontaram seis rublos do meu salário?! Por que não me deixaram folgar conforme o atestado médico?!

— Beba, Tarássytch — Márkov moveu a garrafa em sua direção. — Beba e não se aflija. Seis rublos é uma mixaria...

- Mixaria? - zangou-se de repente o sanfoneiro. - O pessoal se mata de trabalhar, e pra esse aí não passa de uma mixaria! E estas minhas mãos trabalhadoras entraram em cana por nada... Artigo 92, não utilização de instrumentos adequados...

Márkov, em resposta, cantou cordialmente:

— Não chore, menina! A tempestade vai passar... ${ }^{625}$

Num segundo, já apartavam dois cavalariços. A sanfona desabou no chão, fazendo um barulhão.

Eu queria me levantar e não podia.

Então, o banco de duralumínio onde me sentava saiu voando. Ao cair, arranquei a pesada cortina marrom.

Não conseguia me levantar. Mesmo que, pelo visto, estivessem batendo em Márkov. Eu ouvia seus gritos dramáticos:

— Me soltem, seus cães! Finita la commedia!...

Não que tivessem me enxotado do restaurante. Eu mesmo saí me arrastando, coberto com o reposteiro. Depois bati com a testa contra o batente, e tudo escureceu...

\footnotetext{
${ }^{624}$ Os tanques vão em losango (em russo, Tánki idut rómbom), romance do escritor soviético Anatóli Anániev (1925 - 2001) escrito em 1963.

${ }^{625}$ Canção de Lev Lêschenko (1942), famosa na época.
} 
Acordei num recinto desconhecido. Já estava claro. Um relógio de pêndulo tiquetaqueava, preso a um escopro em lugar do contrapeso.

Estava coberto com a mesma cortina marrom. Ao meu lado, no chão, encontrava-se Márkov. Pelo visto, tinha me concedido sua cama.

Minha cabeça estava doendo. Sentia um arranhão profundo na testa.

O cheiro um pouco azedo da casa de aldeia dava certo enjoo.

Dei um gemido. Márkov sorgueu-se.

— Está vivo? - perguntou.

— Parece que sim. E você?

— O estado — enfrento a tempestade!... ${ }^{626}$ Qual é o seu peso?

— Não sei. Por quê?

- Mal consegui carregar...

Entreabriu-se a porta e entrou uma mulher com uma tigela de barro.

— Vera - gritou Márkov —, dê uma dose para curar a ressaca! Sei que você tem. Para que este caminho de sofrimento? ${ }^{627}$ Dê de uma vez! Melhor evitar a época transitória do socialismo desenvolvido...

— Tomem leite — disse Vera.

Cumprimentei-a com dignidade. Márkov suspirou:

— Tive o azar de nascer nestes confins de taiga...

Vera era uma mulher pálida, extenuada, com mãos pesadas. Rabugenta, como invariavelmente são todas as mulheres de alcoólatras.

Em seu rosto, refletiu-se uma mágoa profunda e definitiva.

Sentia-me sem jeito também por ter ocupado a cama dos donos da casa. Ainda mais, eu estava sem calças. Mas o casaco estava no lugar...

— Desculpe o incômodo - falei.

— Tudo bem — disse Vera. — Já estamos acostumados.

Era uma casa típica de aldeia. As paredes foram matizadas de reproduções da revista Ogoniok. No canto, ocultavam uma televisão com a lente opaca. A mesa estava coberta com um oleado azul desbotado. Em cima da cabeceira, via-se o retrato de Julius Fucik. ${ }^{628}$ Um gato passeava por entre as cadeiras. Movia-se sem som, como num desenho animado...

\footnotetext{
626 "Afronto a tempestade" (Em russo, Idu na grozu), filme soviético de 1965 de Serguei Mikaelyan.

${ }^{627}$ O caminho do sofrimento (em russo, Khojdiênie po mukam), trilogia do escritor Aleksei Tolstói (1883 - 1945).

${ }^{628}$ Julius Fucik (1903 - 1943), jornalista e escritor tchecoslovaco, membro do Partido Comunista.
} 
Serguei Dovlátov: texto de cultura na literatura russa contemporânea

— E onde está a minha calça? — perguntei.

— Foi a Vera quem despiu você — respondeu Márkov —, pergunte para ela.

— Tirei as calças — explicou Vera —, mas, na hora do paletó, fiquei com vergonha...

Não tive forças para compreender sua declaração.

—É lógico — manifestou-se Márkov.

— Está na entrada, vou trazer...

- Melhor trazer algo pra ressaca!...

Márkov elevou ligeiramente a voz. A presunção e a humilhação alternavam-se nele constantemente. Dizia:

- O dissidente russo precisa beber para tirar a ressaca, ou você acha o quê?! O acadêmico Sákharov ${ }^{629}$ não elogiará você por isso...

Um minuto depois:

— Vera, dê água de colônia! Mas uma água de colônia de qualidade...

Vera trouxe a calça. Vesti-me. Enfiei os pés nos sapatos depois de sacudir as agulhas de pinheiro. Sentindo náuseas, acendi um cigarro...

$\mathrm{O}$ amargor matinal me fazia esquecer a vergonha da véspera.

Márkov sentia-se muito bem. Tive a impressão de que só gemia para fazer um drama.

Perguntei:

— E onde está o envelope com o dinheiro?

— Psiiiu... No sótão — respondeu Márkov e acrescentou alto: — Vamos! Não adianta esperar clemências da natureza. Apanhá-los, eis o nosso objetivo!... ${ }^{630}$

Falei:

- Vera, me desculpe que tudo tenha se dado dessa maneira. Espero que ainda nos vejamos... em outra situação...

— Pra onde vai? - perguntou Vera. — De novo?! O senhor faça o favor de cuidar do meu "Pinóquio".

Dei um sorriso meio torto, querendo dizer que sou um péssimo pedagogo...

Naquele dia, percorremos quatro botecos. Com pedidos de desculpas, devolvemos a cortina marrom. Bebemos na estação de barcos, na cabine do projecionista e junto às grades do mosteiro.

Márkov esvaziou a sexta garrafa e disse:

— Tenho a ideia de erguer aqui um modesto obelisco!

E pôs a garrafa em cima de um monte...

\footnotetext{
${ }^{629}$ Andrei Sákharov (1921 - 1989), físico nuclear soviético e famoso dissidente e defensor de direitos humanos. 630 "Não adianta [...] eis o nosso objetivo", palavras do biólogo I. V. Mitchúrin (1855-1935).
} 
Serguei Dovlátov: texto de cultura na literatura russa contemporânea

Perdemos algumas vezes o envelope com o dinheiro. Abraçávamos o sanfoneiro do dia anterior. Fomos vistos por todos os funcionários responsáveis pelo centro turístico. Conforme contou depois Natella, dizíamos ser Púchkin e Baratýnski... ${ }^{631}$

Até Mikhal Iványtch preferiu manter distância. Embora o tivéssemos convidado. Ele disse:

- Conheço o Valera. Se beber com ele, vai curar a ressaca na delegacia.

Mitrofánov e Potótski, por sorte, tinham ido em excursão a Bóldino... ${ }^{632}$

Adormecemos num palheiro qualquer em Petróvskoe. Na manhã seguinte, todo esse pesadelo repetiu-se. Até os cavalariços da indústria madeireira esquivavam-se, assustados.

Como se não bastasse, Márkov andava com um abajur roxo na cabeça. E eu sem a manga esquerda da camisa.

Lóguinov aproximou-se de nós perto do mercado e perguntou:

— E por que é que você está sem manga?

- Fiquei com calor e joguei fora — respondi.

O curador do mosteiro refletiu e nos benzeu. Então, Márkov disse:

— Não devia ter feito isso... Agora, em vez de Deus, temos o Comitê Central de Lênin. Mas estas putas também terão seu grande expurgo...

Lóguinov fez o sinal da cruz, todo confuso, e foi-se depressa.

E continuamos a perambular pelo parque museu.

$$
* * *
$$

Só fui parar em casa no fim da semana. E depois fiquei um dia sem me mexer. Mikhal Iványtch oferecia vinho. Eu virava o rosto para a parede, em silêncio.

Em seguida, apareceu uma moça do centro turístico, Liuda.

— Chegou um telegrama para o senhor — disse. — E também está à sua procura o major Beliáiev.

— Quém é Beliáiev? De onde?

— Nosso paizinho diz que é do Ministério do Interior...

— Só me faltava essa!... Diga-lhe que estou doente. Que fui a Pskóv e fiquei doente...

- Ele sabe.

- $\mathrm{O}$ que ele sabe?

\footnotetext{
${ }^{631}$ Ievguéni Baratýnski (1800 - 1844), poeta russo, contemporâneo e amigo de Púchkin.

${ }^{632}$ Bóldino, situado na região de Níjni Nóvgorod, era uma propriedade de Púchkin.
} 
Serguei Dovlátov: texto de cultura na literatura russa contemporânea

— Que já faz alguns dias que o senhor está doente. Disse que, assim que voltasse a si, lhe fizesse uma visita.

- Onde?

— No escritorio, ao lado do correio. Qualquer um indicará onde é. E aqui está o telegrama.

A moça virou-se, acanhada . Depois tirou do sutiã um pedacinho de papel azul, dobrado até ficar do tamanho de um selo.

Desdobrei o telegrama, que estava quente, e o li:

"Partimos quarta-feira à noite. Tânia. Macha".

Apenas seis palavras e umas cifras incompreensíveis.

— Que dia é hoje?

— De manhã era terça feira — brincou Liuda.

- Quando recebeu o telegrama?

- A Mariana o trouxe de Vorónitch.

— Quando?

— Estou lhe dizendo, no sábado.

Eu queria dizer: "E onde vocês se meteram?", mas mudei de ideia. Eles estavam no lugar de sempre. Mas onde eu estava?

Não podia partir de ônibus antes de anoitecer. E levaria umas seis horas para chegar a Leningrado...

— Ele também sabe do telegrama — disse Liúda.

- Quem?

- O camarada Beliáiev.

Liuda orgulhava-se um pouco da perspicácia e da onisciência do infeliz major.

— O camarada Beliáiev disse que passasse lá antes de partir. Se não, vai levar uma fodidela... Expressou-se assim mesmo...

- Que cortesia mais antiquada! - eu disse...

Pus-me a pensar febrilmente. Só tinha uns quatro rublos. Os míticos quatro rublos. O estado de saúde era deplorável...

— Liúda — perguntei —, tem algum dinheiro?

— Uns quarenta copeques... Vim de bicicleta...

— Isso quer dizer?

— Pegue a minha bicicleta, e eu irei a pé. Deixe-a com alguém da aldeia.

A última vez que eu tinha andado de bicicleta estava na escola. Naquela época, parecia divertido. Mas, pelo visto, envelheci. 
Serguei Dovlátov: texto de cultura na literatura russa contemporânea

As raízes dos pinheiros cruzavam meu caminho. A bicicleta, saltitando, retinia. $\mathrm{O}$ assento pequeno e duro ofendia meu traseiro. As rodas afundavam-se na areia úmida. Minhas vísceras cansadas reagiam com espasmos a cada solavanco.

Entrei no centro turístico, apoiando a bicicleta na parede.

Galina estava sozinha. Olhando para mim sem espanto, perguntou:

- Recebeu o telegrama?..

Imagino que ali uma bebedeira não seria capaz de surpreender ninguém.

Eu disse:

— Dê-me trinta rublos do cofre. Devolverei em duas semanas... Só não me faça perguntas.

— Mas eu já sei de tudo. Sua esposa traiu a Pátria.

— Infelizmente — disse eu.

- E agora vai embora para o Ocidente.

— Parece que sim.

- E o senhor fica?

— Sim, eu fico. A senhora já sabe disso...

- E vai continuar trabalhando?

— Claro. Se não me demitirem...

— É verdade que em Israel só moram judeus?... Escuta, está se sentindo mal?! Quer água?

— Água não vai ajudar neste caso. E quanto ao dinheiro?

- Mas por que do cofre? Tenho dinheiro...

Queria beijar Galina, mas me contive. A reação era imprevisível.

Subi na bicicleta e parti rumo ao mosteiro.

O dia estava quente, mas nublado. As sombras das árvores mal se destacavam do asfalto cinza. Os turistas caminhavam pela beira da estrada. Alguns deles vestiam casacos impermeáveis.

Dirigi-me à encosta de areia. Estava difícil segurar o guidão. Ao lado, pedregulhos cinza descorados passavam a toda...

Sem demora, indicaram-me o escritório do Departamento do Ministério do Interior.

— É o prédio depois do correio - acenou com o braço a faxineira do Lukomórie. — Tá vendo a bandeira no telhado?...

Segui adiante. 
Serguei Dovlátov: texto de cultura na literatura russa contemporânea

As portas do departamento de correio estavam escancaradas. Ali também ficavam duas cabines de telefones interurbanos. Uma delas estava ocupada. Uma loira com as pernas gordas gritava gesticulando:

— Tatússia, está me ouvindo?! Não aconselho a vir... O tempo não está lá aquelas coisas... E o mais importante: não tem homem nenhum... Alô! Está me ouvindo?! Tem muitas meninas indo embora sem nem ter aproveitado...

Detive-me e agucei o ouvido. Tirei mentalmente uma caneta...

Pensando bem, é tudo tão horrível, mas ainda estou vivo. E, talvez, a última coisa que morra no ser humano seja a baixeza. A habilidade de reagir a loiras tingidas e a paixão pela escrita...

$\mathrm{Na}$ entrada do departamento, topei com Guriánov. Quase nos chocamos, e ele não tinha onde meter-se.

Na universidade, chamavam Liónia de Liónia-Dedo-duro. Sua principal obrigação era a vigilância dos estrangeiros.

Além disso, Guriánov era famoso por sua ignorância evidente. Uma vez, o professor Biályi o examinava. A Guriánov coube falar sobre os Contos de Biélkin. ${ }^{633}$

Liónia tentou passar para um tema mais amplo. Começou a falar do regime czarista.

Mas o examinador perguntou:

— O senhor leu os Contos de Biélkin?

— Não tive ocasião — respondeu Liónia. — O senhor recomenda?

— Sim — conteve-se Biályi. — Recomendo com insistência que leia esse livro...

Passado um mês, Liónia foi à sala de Biályi e disse:

— Li. Muito obrigado. Gostei de muita coisa.

— E de quê gostou? Interessou-se Biályi.

Liónia forçou a memória, lembrou e respondeu:

- A novela Dombróvski. ${ }^{634}$

E, agora, eu e ele nos encontramos na entrada da Tcheká.

Primeiro, ele ficou um pouco confuso. Nem sequer queria cumprimentar-me. Fez um movimento brusco. Mas era difícil desencontrar-se na entrada do prédio. Então, Liónia disse:

— Bom, olá, olá... Beliáiev o espera...

Queria mostrar que tudo estava bem. Como se tivéssemos nos encontrado num consultório médico, e não na Gestapo.

\footnotetext{
${ }^{633}$ Ciclo de contos de Aleksandr Púchkin, escrito em 1830.

${ }^{634}$ Iúri Dombróvski (1909-1978), escritor, poeta e crítico literário soviético. A personagem confunde o sobrenome do escritor soviético e o título da novela Dubróvski, de Púchkin.
} 
Perguntei:

- É seu chefe?

— Quem?

— Beliáiev. Ou é seu subordinado?

— Sem ironia — disse Guriánov.

Em sua voz, soavam as notas severas do chefe.

— E lembre. A KGB agora é uma organização mais progressista. A força mais verdadeira do Estado. E, a propósito, a mais humana... Se soubesse que pessoas são!...

— Vou saber já, já — disse.

— Você é infantil demais — disse Guriánov. — Isso pode terminar mal...

Não era nada fácil ouvir tudo aquilo de ressaca!

Contornei-o, virei-me e disse:

— E você é um merda, Guriánytch! Um merda, um ignorante e um cafajeste! E sempre será um cafajeste, mesmo se for nomeado tenente... Sabe por que você é um alcaguete? Porque as mulheres não gostam de você...

Guriánov recuou. Ele queria adotar um tom entre a indiferença e a superioridade, mas tudo acabou em grosseria.

E eu senti um enorme alívio. Afinal, o que pode ser mais belo do que uma liberação súbita da fala?!

Guriánov não estava preparado para insultos. E por isso começou a falar num tom natural e humano:

- Humilhar um camarada é a coisa mais simples... Pois você não sabe como começou tudo isso...

Passou para um sussurro sonoro:

— Quase fui preso quando era moleque. Os órgãos realmente me salvaram. Deram um documento para eu entrar na universidade. Agora, prometeram me dar residência. Pois eu mesmo sou de Kulunda... Esteve alguma vez em Kulunda? É um prazer abaixo da média...

— Ah — disse. - Então, está claro... Kulunda muda tudo...

Acabo sempre ouvindo desabafos de monstros. Significa que há algo em mim que predispõe à loucura...

- Adéus, Gurian, carregue sua pesada cruz...

Apertei a simpática campainha cor-de-rosa. Uma senhora tristonha, de idade indefinida, abriu a porta. Deu-me passagem, em silêncio, para a próxima sala. 
Serguei Dovlátov: texto de cultura na literatura russa contemporânea

Vi um cofre, o retrato de Dzerjínski, ${ }^{635}$ cortinas marrons. Tão parecidas com as do restaurante que senti um ligeiro enjoo.

Sentei-me na poltrona, tirei um cigarro. Fiquei sozinho por um minuto ou dois. Depois, uma das cortinas moveu-se. Dali saiu um homem de uns trinta e seis anos e dei-me uma baita reprimenda:

- Por acaso sugeri que sentasse?

Levantei-me.

- Sente-se.

Sentei-me.

O homem declarou ainda mais contrariado:

- Por acaso sugeri que fumasse?

Movi-me na direção do cesto de lixo, mas logo ouvi:

- Fume...

Em seguida, ele sentou-se e fixou em mim um olhar longo, triste, quase trágico. Seu sorriso expressava a imperfeição do mundo e o pesado fardo da responsabilidade pelos pecados alheios. No entanto, o rosto permanecia medíocre, como o botão de uma cueca.

$\mathrm{O}$ retrato sobre sua cabeça parecia mais animado. (Apenas no meio da conversa compreendi que não era Dzerjínski, mas Makárenko. ${ }^{636}$ )

Finalmente, disse:

- Sabe por que o chamei aqui? Não tem ideia? Perfeito. Pergunte. Com clareza, à maneira militar. Para que você, Beliáiev, me chamou? E eu responderei da mesma forma: com clareza, à maneira militar: não sei. Não tenho a menor ideia. Sinto: a coisa está mal. Sinto: o rapaz deu um passo em falso. Um caminho tortuoso o levou para onde não se deve ir... Acredite, acordo no meio da noite. Tomka, digo à minha esposa, um jovem decente deu um passo em falso. É preciso ajudar... E a minha Tomka é humana. Grita: Vitálik, ajude. Faça algo educativo. Dá pena: o rapaz é nosso. No fundo, é são. Não recorra a métodos severos, pois os órgãos não apenas castigam. Os órgãos educam... E eu grito: a situação internacional é complicada. O meio capitalista influencia. O rapaz foi longe demais. Colabora nessa tal... como que é... eh... Continental. ${ }^{637}$ É como a Rádio Liberty... Tornou-se um traidor literário, igual a Soljenítsyn. E ainda mais, começou a beber com Valera, o escrotão... Pois é, a mulher fez uma sacanagem, preparou-se para ir para Israel... Mas é razão para beber assim?... Enfim, estou desnorteado...

Beliáiev falou por uns quinze minutos. Em seus olhos, eu juro, brilhavam lágrimas...

\footnotetext{
${ }^{635}$ Félix Dzerjínski (1877 - 1926), fundador da Tcheká.

636 Anton Makárenko (1888 - 1939), pedagogo e escritor soviético.

${ }^{637}$ Beliáiev confunde o nome da revista Kontinent com o nome de restaurante, Continental.
} 
Serguei Dovlátov: texto de cultura na literatura russa contemporânea

Depois, olhou de esguelha para a porta e pegou uns copos:

— Vamos relaxar um pouco. Não faz mal... se for com moderação...

A vodka estava morna. Para acompanhar, comemos biscoito Nóvost. ${ }^{638}$

De modo abrupto e entrecortado, tocou o telefone.

- Major Beliáiev na linha... Às quatro e meia? Estarei... E digam que os tiras não se metam nesse assunto...

Virou-se para mim:

— Onde paramos?... Acha que os órgãos não percebem esse covil? Os órgãos percebem mais do que o acadêmico Sákharov. Mas onde está a saída real? No quê? Na restauração do capitalismo?... Suponhamos que eu tenha lido seu festejado samizdat. ${ }^{639}$ Não é menos merda que a revista Známia. ${ }^{640}$ Tudo é posto de cabeça para baixo. Onde é branco ali está preto, onde é preto ali está branco... Por exemplo, o problema da agricultura. Suponhamos que dê para abolir os kolkhozes. Distribuir a terra entre os camponeses, e coisas do tipo. Mas, primeiro, pergunte: o que acham os camponeses? Querem mesmo receber essa terra?... Para que raio vão querer essa terra de merda?! Pergunte para o mesmo Valéra escrotão. Percorra as aldeias nas cercanias do parque museu. Apenas o velho Timokha lembra como atrelar um cavalo. Esqueceram quando se deve semear cada coisa. Não são capazes de assar um simples pão... O negócio é que qualquer camponês trocaria sem pestanejar essa terra por uma garrafinha de vodka de $250 \mathrm{ml}$. Sem falar na de meio litro..

Beliáiev tirou os copos e já não os guardou. Ficou mais rosado. Seu raciocínio desenrolava-se impetuosamente pela dissidência.

O telefone tocou duas vezes. Beliáiev apertou o botão seletor:

— Valéria Iánovna! Não passe nenhuma ligação...

Pôs-se a falar de modo apressado, apaixonado e maldoso:

- Quer saber o que dará fim ao poder soviético? Vou lhe dizer. O fim virá com a vodka. Atualmente, acho, uns $60 \%$ dos trabalhadores enchem a cara à tardinha. E os índices crescem. Chegará o dia em que todos ficarão bêbados, sem exceção. Desde um soldado raso até o marechal Gretchko. Desde um operário até o ministro da indústria pesada. Todos, salvo algumas mulheres e crianças e, talvez, os judeus. O que, evidentemente, não será suficiente para a construção de comunismo... E todo o carrossel irá parar. Usinas, fábricas, estações de máquinas e de tratores... E, então, virá um novo jugo tártaro-mongol. Só que, desta vez, do Ocidente. Encabeçado pelo camarada Kissinger...

\footnotetext{
${ }^{638}$ Em russo, "Novidade".

${ }^{639}$ Cópias clandestinas de livros proibidos pelo governo soviético.

${ }^{640}$ Známia ("Bandeira”), revista literária, social e política.
} 
Serguei Dovlátov: texto de cultura na literatura russa contemporânea

Beliáiev olhou para o relógio:

- Sei que você pensa em ir a Leningrado. Este é o conselho que tenho para lhe dar: não faça barulho. Dizendo de modo cortês, não dê um pio. Os órgãos educam, educam, mas também, por uma besteira, podem castigar. E o seu dossiê é mais forte do que Fausto de Goethe. Tem material para uns quarenta anos de cadeia... E lembre que um processo penal não é como uma calça. Um processo penal se faz em cinco minutos. Um piscar de olhos e você já está nas instalações do comunismo... Então, porte-se de forma pacífica... E, mais uma vez, no que se refere à bebedeira. Beba, mas com moderação, faça intervalos. E não se meta com esse lunático do Márkov. Valera é daqui, não vão tocar nele. E você tem esposa no Ocidente. Além disso, textos na imprensa branca. Um dossiê completo de discursos. Olhe bem, que a coisa pode ficar feia... Enfim, beba de orelha em pé. E, agora, tomemos a última...

Viramos outra.

- O senhor pode ir - o major passou a me tratar de um modo mais oficial.

— Obrigado — disse eu.

Essa foi a única palavra que pronunciei durante meia-hora.

Beliáiev deu um sorriso:

- A conversa foi realizada num alto nível ideológico e político.

Já na porta, acrescentou, sussurrando:

- E ainda, como se diz, fora dos protocolos. Eu, no seu lugar, dava o fora daqui enquanto estão deixando sair. Você se uniria de novo a sua mulher, e tchauzinho... Eu mesmo não tenho nenhuma chance. Com a minha cara de Riazan não vão me liberar... Mas a você eu aconselho. Pense bem. Isso fica entre nós, sigilo absoluto...

Apertei sua mão, acenei à mulher carrancuda e saí para a rua inundada de sol.

Caminhava e pensava: o mundo está dominado pela loucura. A loucura tornou-se norma. E a norma provoca a sensação de milagre...

Deixei a bicicleta no correio. Disse que era para a Liúda, de Beriózino. Subi o morro a pé. E, finalmente, depois da longa espera do ônibus de linha, parti para Leningrado.

No caminho, adormeci e acordei com uma terrível dor de cabeça...

$* * *$

Leningrado se mostra pouco a pouco: árvores descoloridas, bondes barulhentos, prédios de tijolo meio sorumbáticos. À luz da manhã, mal se distinguem as letras trêmulas de néon. A multidão disforme anima em sua indiferença. 
Serguei Dovlátov: texto de cultura na literatura russa contemporânea

Em um minuto, você já é de novo um habitante da cidade. E apenas a areia nas sandálias o faz lembrar o verão rural...

A dor de cabeça me impediu de alegrar-me, como de costume, com a pressa leningradense, com o vento do rio e com a harmonia das ruas de pedra. Depois das colinas que já haviam me enfastiado, uma mísera calçada valia muito...

Desci do ônibus na praça Plóschad Mira. Em seguida, parei um táxi e, em quinze minutos, já estava em casa.

Abriu-me a porta uma mulher desconhecida, risonha, vestida numa camisa listrada:

— Você veio da parte dos Chakhnóvitch? Para buscar a cafeteira?

- Não.

- Seu sobrenome é Azarkh?

— Sou o marido da Tânia — disse...

Tânia apareceu com uma toalha marrom na cabeça. Então apareceu minha filha, pálida, com olhos assustados. Disse:

- Ah, é o papai.

A casa estava cheia de personalidades enigmáticas. Entre todos os presentes, reconheci apenas o musicólogo Lázariev, e também o especulador Beluga.

O apartamento estava barulhento. Um sujeito careca desconhecido conversava ao telefone. Repetia sem parar:

- Isso não tem importância prática...

Todos, um atrás do outro, punham-se a falar com Tânia. Um velho magro e barbudo quase gritava:

- Espero, senhores, que aqui todos sejam dos nossos?! Então, permitam-me deixar os disfarces de lado. Preciso entregar algo a Aleksándr Issáievitch Soljenítsyn...

Depois o velho escandiu, com a voz bem treinada:

- Autorizo a Soljenítsyn publicar, sem cortes, o meu poema de guerra Liúska. Os honorários que me correspondem eu deixo à Fundação Soljenítsyn. Está categoricamente proibido mencionar meu sobrenome real. O meu nome artístico é Andrei Kolýmski!...

Nas mesas e nos peitoris da janelas, amontoavam-se garrafas. Não havia pessoas visivelmente bêbadas. Todos estavam unidos a algo comum, embora ali não houvesse apenas judeus. Alguém reunia assinaturas desconhecidas, agitando um bloco verde.

$\mathrm{Na}$ cozinha, as malas estavam enfileiradas. Malas novas com fechos de metal. Provocaram em mim uma sensação de beco sem saída...

Na cama, havia um violão largado... 
Serguei Dovlátov: texto de cultura na literatura russa contemporânea

Nas conversas, distinguiam-se os temos "seção de vistos e de registro", "HIAS", 641 "voo de Berlim”, “declaração alfandegária”...

Sentia-me um completo inútil. E até alegrei-me quando uma mulher me encarregou de buscar o chá.

Antes de ir pegar o chá, bebi uma e fiquei um pouco melhor. Há dezenas de livros sobre os males do álcool. Sobre seus benefícios, nenhuma brochura. Parece-me um erro...

Passaram-se algumas horas. Tânia estava empacotando a máquina fotográfica esquecida. Macha presenteava as visitas com umas pedrinhas do Mar Negro.

Vez ou outra, elas se aproximavam de mim. Trocávamos algumas palavras sem nexo:

— Não fique triste, escreva... Tudo ficará bem...

Eu tinha consciência: o pesadelo começará amanhã. E até pensei: pelo menos me restará a bebida...

Macha disse:

— Nos deram uns dólares. Quer ver?

Eu falei:

- Quero...

Depois, discutiram alguma notícia de uma rádio de Israel.

As pessoas iam e vinham. Tânia anotava endereços e incumbências...

Tampouco passamos sem um escândalo. O rapaz careca, bêbado, gritou:

— E aí, estão fugindo para não verem o barco afundar?!

Mas logo retrucaram:

— Então, o barco está afundando? Estamos ouvindo isso de um membro do partido?!

- Sou apartidário - reagiu o escandaloso. - E me ofende o fato dedeixarem sair apenas os judeus!

— Por acaso não é judeu?

- Sou - respondeu o careca...

Escolhi um momento oportuno e disse:

— Tânia, quando estiver na América, procure Carl Proffer. ${ }^{642}$ Ele queria publicar meu livro.

— Devo dizer que publique?

— Sim, o quanto antes. Não tenho nada a perder.

— Vou lhe escrever tudo nas entrelinhas...

${ }^{641}$ HIAS, abreviação em inglês da Associação de Ajuda para Imigrantes Judeus, Hebrew Immigrant Aid Society.

${ }^{642}$ Carl Proffer (1938 - 1984), eslavista norte-americano, professor de russo da Universidade de Michigan e cofundador da editora Ardis, que se especializara na publicação de obras proibidas na União Soviética, tanto traduzidas como em russo. 
Serguei Dovlátov: texto de cultura na literatura russa contemporânea

Nesse ponto, Lázariev avisou que já deram seis. Era preciso partir para o aeroporto. Pedimos alguns táxis, entramos e chegamos todos quase ao mesmo tempo.

Tânia e Macha atravessaram imediatamente a barreira para preencher as declarações. Ficamos perambulando pelas salas. Alguém havia trazido uma garrafa de vodka.

Beluga aproximou-se de mim e disse:

- Faz bem em não cair em desespero.

Respondi:

— Só faltava essa! Casarei com uma mais nova e terei um monte de filhos.

Beluga surpreendeu-se e meneou a cabeça...

Tânia aproximou-se da barreira umas quatro vezes. Passou-me as coisas detidas pela alfândega. Entre elas: um colar de âmbar, minha foto do exército e um romance de Gladílin ${ }^{643}$ com uma dedicatória.

O fato de terem devolvido a foto deixou Micha Lázariev furioso . Ele disse:

— Que truques são esses?! Onde está a justiça?

Beluga retrucou:

- Se houvesse justiça, para que as pessoas iriam embora?!

De novo, escolhi um momento oportuno e disse a Tânia:

- O que acha, vamos nos ver de novo?

- Sim, tenho certeza. Tenho certeza absoluta.

— Então, talvez, eu acredite que Deus existe.

- Vamos nos ver. Deus existe...

Gostaria de acreditar nela. Estava pronto para acreditar... Mas por que devia acreditar nela justamente agora? Eu não acreditava quando ela me dizia que Alberto Morávia era um bom escritor...

Depois, todos subimos a um terraço. Olhávamos de longe para Tânia e Macha entrando no ônibus.

O tempo parou. Senti, nesses parcos segundos, um limite entre o passado e o futuro.

O ônibus pôs-se em marcha.

E agora eu podia ir para casa, sem despedir-me...

Passei onze dias fechado no apartamento, bebendo. Desci três vezes atrás de mais bebida. Quando me telefonavam, eu respondia:

— Não posso falar...

Não tinha firmeza o suficiente para desligar o telefone. Estou sempre à espera de alguma coisa...

${ }^{643}$ Anatóli Gladílin (nasc. em 1935), escritor e dissidente soviético que emigrou da União Soviética em 1976. 
Serguei Dovlátov: texto de cultura na literatura russa contemporânea

No quarto dia, chegou a polícia. De manhã, bateram à porta, embora a campainha funcionasse. Por sorte, a porta estava fechada com a corrente. No vão, brilhou a pala laqueada do chapéu do policial. Pude ouvir um tossido seguro e impaciente.

Eu não temia a polícia. Simplesmente não podia falar com autoridades. Só o meu aspecto já seria o suficiente... Perguntei:

- O que aconteceu? Mostre o mandado... Existe a lei da inviolabilidade da residência...

O policial proferiu com ameaça:

— Mandado não é problema.

Ese foi no mesmo instante. E eu voltei às minhas garrafas. Em cada uma delas, ocultavam-se milagres...

Passaram-se vinte minutos. Algo me fez olhar pela janela. Uma patrulha de polícia atravessava o pátio. Pelo que pude notar, eram umas dez pessoas.

Ouvi seus passos pesados na escada. Depois, tocaram em casa de um modo brusco e impaciente.

Eu não reagi.

O que podiam fazer? Forçar a antiga porta petersburguesa? A rua Rubinstein inteira acorreria por causa do barulho...

Os policiais ficaram no corredor por cerca de uma hora. Um deles gritou no buraco da fechadura:

- Dê explicações sobre as seguintes cláusulas do Código Penal: manutenção de prostíbulo, parasitismo, insubordinação às autoridades...

Havia tantas cláusulas que decidi não pensar no assunto.

Os policiais demoravam a ir embora. Um deles mostrou ser um bom psicólogo. Bateu à porta e gritou:

— Posso pedir um copo de água gelada?

Pelo visto, contava com meu lado sentimental. Ou com a força mágica do absurdo...

Eu não reagi.

Finalmente, os policiais enfiaram por baixo da porta uma folha de papel e se mandaram. Vi-os cruzando o pátio. Dessa vez, contei-os. Seis palas cintilando ao sol.

O papel era uma notificação, que examinei por uns três minutos. No fim, dizia: “o comparecimento é obrigatório". O sobrenome do juiz de instrução não foi mencionado. Tampouco o título do processo pelo qual eu era chamado. Nem sequer estava indicado quem eu era: testemunha, réu ou vítima. Apenas a data e a hora.

Eu sabia que notificações assim não eram válidas. Foi Ígor Iefímov quem me ensinou. Joguei a notificação no lixo... 
Serguei Dovlátov: texto de cultura na literatura russa contemporânea

A polícia ainda apareceu umas quatro vezes. E eu sempre me inteirava de sua chegada com antecipação. Smirnóv, um bebum, avisava-me.

Guena Smirnóv era um jornalista decadente. Morava em frente ao meu prédio. Passava dias bebendo Chartreuse junto à janela. E observando a rua com curiosisade.

Eu morava nos fundos do pátio, no quinto andar, sem elevador. Do portão até a nossa entrada, davam uns cem metros.

Se uma patrulha de polícia entrava no pátio, Smirnóv afastava a garrafa. Telefonava-me e pronunciava nitidamente uma única frase:

- As putas estão chegando!

Depois disso, eu dava mais uma conferida nas trancas e ia à cozinha, bem longe da porta de entrada.

Quando a polícia se retirava, eu olhava para fora pela cortina. Na distante janela da frente, eu avistava Smirnóv. Ela saudava-me com a garrafa...

No décimo primeiro dia, comecei a ter alucinações. Não eram demônios, mas meros gatos. Alguns eram brancos e cinza.

Depois, desabou em mim uma chuva de vermezinhos. Na barriga, apareceram manchas cor-de-rosa. As palmas começaram a descascar.

A bebida acabou. O dinheiro acabou. Não tinha forças para mover-me e agir.

O que restava fazer? Deitar na cama, cobrir-me até a cabeça e esperar. Cedo ou tarde, tudo isso tinha que acabar. Meu coração é sadio, pois me fez passar intacto por centenas de bebedeiras.

O motor é bom. Pena que não haja freios. Eu só paro na sarjeta...

Cobri-me até a cabeça e fiquei em silêncio. Em meus pés, agitavam-se répteis enigmáticos e pegajosos. Na escuridão, tilintavam estranhos chocalhos.

Pelo cobertor, desfilavam cifras e letras. De vez em quando, compunham frases curtas. Uma vez li:

"Só a morte é irremediável!...".

Não é uma ideia tão boba, se pensarmos bem...

E, nesse momento, tocou o telefone. Na hora compreendi quem era. Sabia que era Tânia. Sabia, e pronto.

Ergui o gancho. Do caos, surgiu flutuando a voz calma de Tânia:

— Olá! Estamos na Áustria. Tudo vai bem conosco... Está bêbado?

Zanguei-me:

— Por quem está me tomando?!

— Vieram nos buscar. Aqui há muitos conhecidos. Todos mandam lembranças... 
Serguei Dovlátov: texto de cultura na literatura russa contemporânea

Estava descalço, ao lado do telefone, e não dizia nada. Do lado de fora, estrondeava um perfurador. No espelho, refletia-se o velho sobretudo.

Só perguntei:

- Vamos nos encontrar ainda?

— Sim... Se você nos ama...

Nem perguntei: onde vamos nos encontrar? Isso não tinha importância. Talvez, no paraíso. O paraíso é precisamente o lugar do encontro. E nada mais. Uma câmara comum onde se pode encontrar a pessoa amada...

De repente, vi o mundo como um todo. Tudo acontecia ao mesmo tempo. Tudo se realizava diante dos meus olhos...

Minha mulher disse:

— Sim, se você nos ama...

— O que o amor tem a ver com isso? — perguntei.

E depois acrescentei:

- O amor é para os jovens, para os militares e para os atletas... Aqui tudo é bem mais complicado. Já não se trata de amor, mas do destino...

Então algo deu um estalido, e tudo ficou em silêncio.

Agora, era preciso adormecer no quarto vazio e abafado...

Junho de 1983

Nova York 
Serguei Dovlátov: texto de cultura na literatura russa contemporânea

\section{Estratégias da tradução e da transferência cultural}

Uma parte crucial de trabalho desta tese foi a tradução para o português da novela Parque cultural. O próprio Dovlátov, nas cartas a seus amigos, dizia que considerava Parque cultural dificilmente traduzível para outras línguas, devido a sua estreita vinculação tanto com a língua, quanto com a cultura russa. ${ }^{644}$ Porém, apesar da opinião um tanto pessimista do autor, a novela foi traduzida e teve sucesso em vários idiomas, entre eles o inglês, o francês e o italiano.

Durante o nosso trabalho, usamos as respetivas traduções para o inglês, o francês e o italiano, para fazer cotejo com o texto original e também para poder analisar e levar em consideração as estratégias empregadas pelos tradutores. Também no trabalho com a tradução da novela usamos como material de apoio para compreender as possíveis estratégias de transferência do humor do escritor, as traduções de outros livros de Dovlátov feitas para o inglês e o espanhol dos romances A mala e Os nossos.

A tradução de um texto do gênero humorístico sempre representa um desafio a mais para o tradutor, devido às especificidades da transmissão do efeito humorístico e também às peculiaridades do humor nacional que cada cultura possui. Vejamos os pressupostos teóricos dos Estudos da Tradução referentes à tradução e transmissão do humor.

No campo teórico, os estudos do humor têm caráter interdisciplinar, e estão em estreita relação tanto com a linguística, quanto com a psicologia e sociologia, dentre outras disciplinas. Tal interdisciplinaridade se deve ao fato de que o humor está relacionado com muitos aspectos da vida e até da fisiologia humanas: como aponta Jeroen Vandaele, pesquisador na área dos estudos da tradução do humor e professor da Universidade de Oslo, o humor tem ligações com partes primitivas do cérebro humano que são associadas à socialização, às emoções compartilhadas e à redução do perigo ou da hostilidade. ${ }^{645}$

O valor social do humor e a sua importância para as relações dentro da sociedade e da cultura de uma dada nação são assinalados por muitos pesquisadores de todas as citadas áreas. Por exemplo, como menciona Arlete Cavaliere em seu estudo sobre a comicidade e a paródia no teatro russo, já desde a primeira metade do século $\mathrm{XX}$ estudiosos russos como Bakhtin e

\footnotetext{
${ }^{644}$ DOVLÁTOV. Epistoliárnyi roman. Op. cit., p. 406.

645 VANDAELE, Jeroen. "Humor in translation". IN: Handbook of Translation Studies. Vol 1. Amsterdam \& Philadelphia: John Benjamins, 2010, p. 148.
} 
Serguei Dovlátov: texto de cultura na literatura russa contemporânea Likhatchóv ${ }^{646}$ abordavam a questão do humor e do riso no âmbito da tradição popular e da concepção do riso como "um dos elementos essenciais para uma compreensão não apenas da natureza do homem em si mesmo, mas também da relação íntima entre o riso e os fatos de uma dada cultura como um todo, particularmente os fatos da linguagem, da literatura e da arte em geral". 647

A estreita relação do humor com a cultura e com a sociedade determina seu caráter implícito: o humor se baseia num conhecimento implícito que possuem os portadores da cultura na qual ele é produzido, ou seja, depende de esquemas culturais implícitos.

Patrick Zabalbeascoa, teórico da tradução e especialista na área de tradução do humor, propõe uma tipologia de piadas para a tradução (em inglês, joke types for translation), em seu trabalho Humor and translation - an interdiscipline. Como aponta o pesquisador, evidentemente existe um tipo de piada "inter" ou "binacional", para a qual os portadores de diferentes culturas possuem o mesmo conhecimento, valores e gostos que são necessários para compreendê-la e apreciá-la da mesma maneira. ${ }^{648}$ No caso de tal piada, a transferência do humor na tradução acontece sem a necessidade de fazer algum tipo de adaptação. Mas, na maioria dos casos, a compreensão do humor acaba sendo restringida pela visão de mundo, conhecimentos e hábitos da cultura na qual foi produzido.

Como um exemplo de piada “internacional", perfeitamente compreensível para portadores de várias culturas, podemos citar o fragmento de Parque cultural no qual a personagem Tânia conta sobre uma briga entre seus conhecidos, quando um deles foi traído pela esposa: "E o Jénia lhe disse: 'Mítia, eu não tenho nada a temer, pois você tem chifres. Portanto, não é carnívoro"”. ${ }^{649}$ Aqui o autor faz referência à metáfora existente em várias culturas de que o homem traído pela esposa possui chifres, e relacionado a isso está a expressão pejorativa em russo rogonóssiets (“chifrudo", ou “corno”, em português).

O caráter implícito e conotativo do humor leva alguns pesquisadores à opinião de sua absoluta ou relativa intraduzibilidade, normalmente relacionados com suas características linguísticas e culturais. ${ }^{650}$ Existem duas tradições na abordagem da tradução do humor: a prescritiva e a descritiva. A tradição prescritiva valoriza a tradução fiel ao texto original. Um dos seus adeptos, Jürgen von Stackelberg, caracteriza assim a postura prescritivista: "A questão é (...): o tradutor tem a autorização de nos fazer rir de suas próprias ideias em vez das ideias do

\footnotetext{
${ }^{646}$ Dmítri Likhatchóv (1906-1999), filólogo e teórico das artes, autor de vários estudos sobre a literatura e cultura russa.

${ }^{647}$ CAVALIERE. Op. cit., p. 12.

${ }^{648}$ ZABALBEASCOA, Patrick. "Humor and translation - an interdiscipline”. IN: Humor, № 18 - 2. Berlin: Walter de Gruyter, 2005, p.189.

${ }^{649}$ DOVLÁTOV. Zapoviédnik. Op. cit., p. 248.

${ }^{650}$ VANDAELE. Op. cit., p. 149.
} 
Serguei Dovlátov: texto de cultura na literatura russa contemporânea autor? Não achamos que seja assim". ${ }^{651}$ Tal opinião exerce uma pressão considerável no tradutor e leva a conclusões bastante pessimistas, ou seja, aceita a intraduzibilidade do humor.

Já na abordagem descritiva são consideradas as relações entre culturas, grupos, sistemas e tradutores, e, no caso de dificuldades no processo de tradução, procuram-se soluções que digam algo sobre o contato entre estas culturas, grupos e agentes. Assim, a comparação descritiva entre o texto de partida e o texto de chegada não vê o humor como uma categoria homogênea, mas estuda suas características cognitivas, emocionais, sociais e interpessoais.

Na tradução do humor, uma das especificidades cruciais consiste em que a recepção do cômico depende não tanto da forma linguística na qual é expresso, mas, principalmente, da contextualização do sujeito receptor (ou seja, do leitor do texto) na cultura correspondente. Por isso, até uma ótima tradução no aspecto da língua pode não levar a uma recepção adequada do cômico, o que se expressará na diferença das reações do leitor do original e do leitor da tradução. Em outras palavras, é sempre o leitor que determina a piada ser engraçada ou não, rindo dela. Portanto, a não compreensão da piada traduzida, a perda de sua expressividade, leva à falha na comunicação e, consequentemente, na tradução.

A inclusão do receptor na tradução e a necessidade de considerar também as peculiaridades de caráter extralinguístico levam-nos à possibilidade de estudar a tradução do humor dentro da abordagem funcional-cultural dos Estudos da Tradução, que tem sua origem em meados da década de 1970, na escola alemã Skopostheorie. No caso da tradução do humor, tratase da transferência do cômico não somente para outra língua, mas também para outra cultura, ou seja, de uma transferência cultural, na qual a cultura é concebida, nas palavras de João Azenha, como

um fenômeno abrangente, que abarca todas as manifestações de um povo num ponto específico de um eixo espaço-tempo, estabelece uma relação de condicionantes recíprocas entre linguagem e cultura e inclui os elementos constitutivos da comunicação numa dada situação: emissor, receptor, meio, entre outros. ${ }^{652}$

A abordagem funcionalista nos permite analisar a tradução de um texto partindo da sua função. Segundo a visão funcionalista, expressa no ensaio da linguísta e teórica da tradução alemã Katharina Reiss Type, kind and individuality of text: decision making in translation, um dos objetivos centrais da tradução interlingual é a produção de um texto funcionalmente

\footnotetext{
${ }^{651}$ Apud VANDAELE, Op. cit., p. 151.

${ }^{652}$ AZENHA, João. "Transferência cultural em tradução: contextualização, desdobramentos, desafios". IN:

TradTerm, № 16. São Paulo: Humanitas, 2010, p. 39.
} 
Serguei Dovlátov: texto de cultura na literatura russa contemporânea equivalente ao original. ${ }^{653}$ Portanto, na tradução do humor, em função do texto humorístico, o objetivo central do tradutor seria conservar a comicidade expressa no texto original.

Outro conceito dos Estudos Culturais da Tradução de que nos servimos neste trabalho, é o conceito da marca cultural. O termo será compreendido no sentido mais abrangente: serão denominados de marcas culturais não apenas os fatos referentes à realidade extralinguística própria de uma cultura, mas também "relações que ativam esquemas cognitivos e permitem identificar diferentes ângulos" 654 a partir dos quais o portador de determinada cultura enxerga e descreve o mundo. Portanto, na análise da novela Parque cultural, trataremos como marcas culturais não somente os fenômenos extralinguísticos, próprios da realidade e da cultura russas (como objetos, bebidas, costumes, entre outros), que não têm paralelos em outras culturas, mas todos os tipos de manifestação que reflitam as especificidades da visão de mundo do portador da cultura russa no nível da linguagem.

Com a transferência do humor na tradução estão relacionadas as possíveis estratégias da tradução do texto. Devido à necessidade de adaptação do humor, como demonstrou o cotejo, os tradutores da obra de Dovlátov em várias ocasiões empregaram a estratégia de domesticação. O termo foi introduzido por Lawrence Venuti, teórico e historiador da tradução estado-unidense.

Os termos "domesticação" e "estrangeirização", propostos por Venuti, remontam ao ensaio do filósofo alemão Friedrich Schleiermacher Sobre os diferentes métodos de tradução (título em alemão, Ueber die verschiedenen Methoden des Uebersezens). Nele, o filósofo reflete sobre o antagonismo entre as duas únicas maneiras de traduzir. Segundo Schleiermacher, "Ou o tradutor deixa o escritor o mais tranquilo possível e faz com que o leitor vá ao seu encontro, ou deixa o leitor o mais tranquilo possível e faz com o que o escritor vá ao seu encontro". ${ }^{655} \mathrm{O}$ primeiro método corresponde à estratégia de estrangeirização, ou seja, mantém-se o caráter "estrangeiro" do texto original na tradução, alheio à língua e à cultura de chegada. Diferentemente disso, referindo-se ao outro método, o filósofo assinala que "a tradução quer deixar falar, por exemplo, um autor latino, tal como teria falado e escrito se tivesse sido alemão e se tivesse se dirigido a alemães". ${ }^{656}$ Tal caraterística permite a outro grande teórico da tradução, Antoine Berman, caraterizar o método de domesticação como um método "etnocêntrico".657

Devido à "etnocentria" do humor, ou seja, à sua dependência da contextualização do receptor, como demonstraram o cotejo e a análise das traduções da obra de Dovlátov para o

\footnotetext{
${ }^{653}$ REISS, K. "Type, kind and individuality of text: decision making in translation". IN: Venuti, L. (org.). The translation studies reader. London and New York: Routledge, 2000, p. 160.

${ }^{654}$ AZENHA, J. "Linguística textual e tradução: redefinindo o conceito de marca cultural”. IN: TradTerm, № 12.

São Paulo: Humanitas, 2006, p. 29.

${ }^{655}$ SCHLEIERMACHER, Friedrich. "Sobre los diferentes métodos de traducir", en: Teoría de la traducción. Antología de textos. Cuenca: Ediciones de la Universidad de Castilla-La Mancha, 1996, p. 137.

${ }^{656}$ Ibid.

${ }^{657}$ BERMAN, A. A tradução e a letra, ou, O albergue do longínquo. Rio de Janeiro: 7Letras/PGET, 2007, p. 10.
} 
Serguei Dovlátov: texto de cultura na literatura russa contemporânea inglês, francês e italiano, o recurso mais comum empregado pelos tradutores foi o recurso de domesticação, que permitia "fazer o escritor ir até o leitor", nas palavras de Schleiermacher, ou seja, adaptar a piada para a visão de mundo do leitor e conservar, assim, a expressividade do texto, embora, em muitos casos, seu conteúdo significativo seja diferente do conteúdo no texto original. Do ponto de vista funcionalista, as soluções "domesticadoras", ao acionar o conhecimento do leitor, facilitam a transmissão do efeito cômico presente no texto original.

Uma das peculiaridades do humor de Dovlátov é o seu caráter implícito e culturalmente marcado: em muitos casos, o efeito cômico na obra de Dovlátov se constrói com base em fatos da cultura, pressupondo que o leitor conhece esses fatos. Como analisado, a novela Parque cultural contém várias camadas de informação implícita, referentes à cultura e à literatura russosoviéticas, que o leitor russo reconhece facilmente, mas que, na maioria dos casos, podem não dizer muito para um leitor estrangeiro.

O caráter implícito dessas referências, o uso frequente de insinuações e entretextos, também é uma marca cultural, presente na obra do escritor. Em seus textos, usando esses procedimentos, Dovlátov se dirige em primeiro lugar a pessoas que compartilham a mesma bagagem cultural e opiniões. Svetlana Boym, no seu livro Common places, aponta para tal hábito da intelligentsia russa de "compreender-se um a outro com meia palavra", e que em muitos casos se comunicava por meio de silêncios constitutivos e nuances de entonação, já que "dizer a palavra inteira significava dizer demais; a comunicação ao nível das palavras já era excessiva". Como assinala a pesquisadora, nessa forma de comunicação indireta, de uma maneira curiosa "convergiam a relação quase religiosa com a palavra, procedimentos de poesia romântica, conspirações clandestinas revolucionárias e as táticas da intelligentsia dissidente". ${ }^{658}$

No trabalho com a tradução do texto para o português, fizemos o cotejo com as traduções da novela para o inglês, o francês e o italiano, a fim de analisar os métodos de trabalho com esse material implícito, bem como analisar as soluções achadas pelos tradutores.

Cabe mencionar que das três traduções analisadas, apenas a tradução para o italiano (título em italiano, Il parco di Púškin, tradução de Laura Salmon) possui um posfácio, feito pela tradutora do livro, que contextualiza o leitor: nele, a tradutora, além de fazer uma breve retrospectiva da biografia de Serguei Dovlátov, explica o fenômeno de Aleksándr Púchkin na cultura russa e soviética, o mito referente à sua personalidade e analisa algumas das cenas da

${ }^{658}$ BOYM. Op. cit., p. 1. 
Serguei Dovlátov: texto de cultura na literatura russa contemporânea novela, explicando as intenções e a ironia do autor. ${ }^{659} \mathrm{Na}$ tradução para o francês (título em francês, Le domaine Pouchkine, tradução de Christine Zeytounian-Beloüs), é usado como prefácio o artigo de Piotr Vail Sans Dovlatov (em ruso, Biez Dovlátova, "Sem Dovlátov" ${ }^{660}$ ), escrito a propósito da morte do escritor. A partir desse artigo, o leitor francês pode ter a noção da biografia de Dovlátov e de seu papel na literatura russa da Terceira Onda de emigração, porém, não há nenhuma explicação referente aos temas, fenômenos e imagens descritos na novela. Nenhuma dessas duas traduções possui notas explicativas.

Já a tradução para o inglês (título em inglês, Pushkin Hills), feita pela filha do escritor Katherine Dovlatov, não possui nenhum prefácio ou posfácio explicativo, mas tem várias notas de rodapé, referentes em primeiro lugar a figuras e fatos históricos mencionados no livro, abreviações em russo etc. Ou seja, em geral, apenas a tradução para o italiano contextualiza o leitor quanto a um dos principais temas do texto: o mito puchkiniano.

Um dos leitmotifs da novela é a presença do poeta Aleksándr Púchkin, cuja imagem aparece em várias formas e situações ao longo da narrativa. Nela, as imagens do poeta e alusões a seu aspecto visual sempre aparecem em tom irônico. Como foi visto no Capítulo III, o aspecto físico de Púchkin (e as suíças como o seu traço caraterístico na visão popular) torna-se familiar para qualquer pessoa familiarizada com a cultura russa e não pode passar despercebido para o leitor russo. Porém, se falamos da recepção do texto em outra cultura, só um leitor familiarizado com a cultura e a literatura russa talvez pudesse captar a ironia do autor. Em outros casos, detalhes como as suíças de feltro do garçom no restaurante, não transmitem nenhuma informação adicional (implícita no texto original).

\begin{tabular}{|c|c|c|}
\hline Заповедник & Pushkin Hills & $\begin{array}{l}\text { Le Domaine } \\
\text { Pouchkine }\end{array}$ \\
\hline $\begin{array}{l}\text { Я сел у двери. Через } \\
\text { минуту появился официант } \\
\text { с громадными войлочными } \\
\text { бакенбардами. }\end{array}$ & $\begin{array}{l}\quad \text { I sat by the door. A } \\
\text { waiter with tremendous felted } \\
\text { sideburns materialized a } \\
\text { minute later. }\end{array}$ & $\begin{array}{l}\text { Je m'assieds près de la } \\
\text { porte. Une minute plus tard, le } \\
\text { serveur fait son apparition, le } \\
\text { visage encadré par d'énormes } \\
\text { favoris de feutre. }\end{array}$ \\
\hline
\end{tabular}

\begin{tabular}{|c|l|}
\hline Il parco di Púškin & \multicolumn{3}{c|}{ Parque cultural } \\
\hline Mi sedetti accanto alla & \multicolumn{3}{|c|}{ Sentei-me ao lado da } \\
porta. Dopo un minuto & porta. Em um minuto, \\
comparve il cameriere con & apareceu o garçom com \\
enormi basette di feltro. & enormes suíças de feltro. ${ }^{661}$ \\
\hline
\end{tabular}

${ }^{659}$ DOVLÁTOV, S. Il Parco di Puškin. Palermo: Sellerio, 2004, pp. 171 - 196.

${ }^{660}$ DOVLÁTOV, S. Le domaine Pouchkine. Monaco: Éditions du Rocher, 2004., pp. 7 - 18.

661 Alusão ao aspecto físico do poeta Aleksándr Púchkin (1799-1837), sempre retratado com suíças. 
Serguei Dovlátov: texto de cultura na literatura russa contemporânea

A imagem do garçom com suíças de feltro foi conservada nas três traduções analisadas, porém, nenhuma delas possui algum tipo de comentário ou nota a tal respeito. Para tornar visível a ironia do autor, optamos por usar o recurso de nota de rodapé na tradução para o português.

Esse tipo de alusão, a referência a pequenos "traços" que o leitor russo capta imediatamente, está espalhado ao longo de todo o texto. Além das alusões a Púchkin em geral, na novela abundam várias referências à história e à literatura russas e soviéticas, parodiadas no texto por Dovlátov. Um dos exemplos do humor tipicamente dovlatoviano, que tem como intenção acionar os conhecimentos do leitor, é a conversa da personagem Alikhánov com a guia que trabalha em Mikháilovskoe, chamada Aurora:

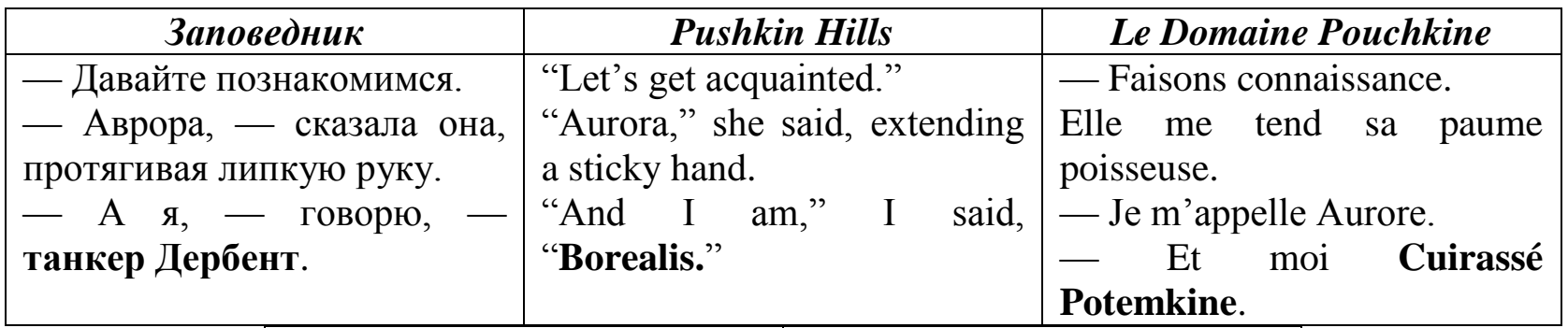

\begin{tabular}{|c|c|}
\hline Il parco di Púškin & Parque cultural \\
\hline - $\quad$ Possiamo & Vamos nos \\
\hline $\begin{array}{l}\text { presentarci? } \\
\quad \quad \text { - Aurora — disse lei }\end{array}$ & $\begin{array}{l}\text { conhecer. } \\
\qquad \text { - Aurora — disse ela, }\end{array}$ \\
\hline $\begin{array}{l}\text { porgendomi la mano } \\
\text { appiccicosa. } \\
\text { - Piacere, signorina } \\
\text { incrociatore, io sono il } \\
\text { cacciatorpediniere Derbent. }\end{array}$ & $\begin{array}{l}\text { estendendo a mão pegajosa. } \\
\qquad \text { - E eu sou o navio- } \\
\text { tanque Derbent. } 662\end{array}$ \\
\hline
\end{tabular}

Se no Brasil Aurora é um nome bastante comum, na União Soviética daquela época a primeira associação que surgia era o cruzador Aurora, um dos símbolos da Revolução de Outubro de 1917. Por isso, o narrador cria a anedota com a associação, que gera o nome da moça, apresentando-se como tánker Derbent ("navio-tanque Derbent") no texto em russo.

Nas traduções em francês e em inglês, as tradutoras usaram a estratégia de domesticação e fizeram adaptações para conservar o efeito cômico. Em francês, "navio-tanque Derbent" foi trocado por "encouraçado Potiómkin" (cuirassé Potemkine), nome de outro navio militar, muito mais conhecido, para fazer assim mais clara a referência à Revolução.

Já em inglês a tradutora decidiu afastar-se do tema da Revolução de Outubro e propôs uma solução construindo a piada com base na expressão aurora borealis, "aurora boreal". A brincadeira produziu o efeito cômico necessário: o nome do protagonista é Boris, portanto, sua

662 Tánker Derbent (1938), novela do escritor soviético Iúri Krýmov (1908-1941), considerada uma das obras clássicas do realismo socialista soviético. Alusão irônica ao navio Aurora, que disparou o primeiro tiro da Revolução de Outubro de 1917. 
Serguei Dovlátov: texto de cultura na literatura russa contemporânea resposta, em inglês, ao mesmo tempo faz alusão ao seu nome e também gera associações com o fenômeno natural, a aurora boreal.

Se por um lado, tal adaptação certamente permitiu conservar a comicidade do fragmento e sua expressividade na tradução, por outro, tal solução não toma em consideração a intenção do escritor no texto original. A esse respeito, vale citar as reflexões de Umberto Eco sobre o que significa uma tradução fiel, expostas no livro Quase a mesma coisa: experiências de tradução (título original, Dire quasi la stessa cosa: Esperienze di traduzione). Segundo o teórico italiano, "o conceito de fidelidade está relacionado com a convicção de que a tradução representa uma das formas de interpretação e, mesmo partindo da cultura e da percepção do leitor, sempre deve aspirar a reproduzir (...) a intenção do texto: aquilo, o que o texto diz ou o que insinua, partindo da língua na qual é expresso, e do contexto cultural, no qual surgiu". ${ }^{663} \mathrm{Ou}$ seja, tal tradução não pode ser considerada fiel, por ter deturpado a intenção do texto original.

Fazendo adaptações para acionar os conhecimentos dos leitores, os tradutores “domesticaram” assim a tradução. Já a tradutora para o italiano optou por deixar na tradução $i l$ cacciatorpediniere Derbent, mas conseguiu fazer visível o trocadilho com o nome da moça e a alusão ao navio militar: no texto em italiano, ao se apresentar, Alikhánov dirige-se a ela como "senhorita cruzador" (signorina incrociatore).

$\mathrm{Na}$ tradução em português, também optamos por manter a tradução "navio-tanque Derbent" e colocar uma nota de rodapé, pois Navio-tanque Derbent (em russo, Tánker Derbent) é nome da novela de Iúri Krýmov, uma das obras clássicas do realismo socialista soviético, à qual Dovlátov faz referência.

Embora Antoine Berman caracterize o método de estrangeirização como o método que "cultiva a língua materna pela incidência de uma outra língua e de um outro mundo", 664 o que, em princípio, dificulta a transferência do humor, nesse caso decidimos conservar a expressão do texto original em detrimento da expressividade humorística justamente pelas conotações literárias que ela traz. Como referido, em Parque cultural o contexto literário é muito importante, sendo um dos leitmotifs da novela, e a alusão ao clássico do realismo socialista (que, aliás, será percebida em russo apenas pelos leitores com um nível de cultura bastante elevado) é importante para o campo semiótico da literatura russa e soviética que o escritor constrói na novela. Embora no caso se perca a expressividade da piada, na tradução será mantido o fundo literário e a alusão ao tema da literatura, tão importante no caso da presente obra.

$\mathrm{Na}$ tradução, usamos amplamente as duas estratégias: a de estrangeirização e a de domesticação, conforme o caráter do fragmento no texto original e a intenção do autor. Vejamos

${ }^{663}$ ECO, Umberto. Skazat potchti to je sámoie. Moscou: AST, 2015, p. 22.

${ }^{664}$ BERMAN. Op. cit., p. 10. 
Serguei Dovlátov: texto de cultura na literatura russa contemporânea outro exemplo de humor culturalmente marcado, que recorre ao estereótipo do alcoolismo na União Soviética, relacionado com a personagem de Mikhal Iványtch. Como vimos, a visão de mundo dessa personagem gira em torno do álcool, o que se reflete em sua linguagem: praticamente nenhuma das falas de Mikhal Iványtch deixa de mencionar uma bebida alcoólica ou alguma situação de embriaguez. A sua visão de mundo, assim como as relações com o álcool, expressam-se plenamente para caracterizar seus inquilinos:

\begin{tabular}{|c|c|c|}
\hline Заповедник & Pushkin Hills & $\begin{array}{r}\text { Le } \\
\text { Pouchkine }\end{array}$ \\
\hline $\begin{array}{l}\text { Прошлый год евреи } \\
\text { жили. Худого не скажу, } \\
\text { люди культурные... Ни тебе } \\
\text { политуры, ни одеколона... } \\
\text { А только белое, красное и } \\
\text { пиво... }\end{array}$ & $\begin{array}{l}\text { Jews had it last year. I } \\
\text { got no complaints, the people } \\
\text { had class... No furniture } \\
\text { polish, no cologne... Just red, } \\
\text { white and beer... }\end{array}$ & $\begin{array}{l}\text { L'an dernier, c'étaient } \\
\text { des Juifs qui l'occupaient. Je } \\
\text { ne peux pas en dire du mal, } \\
\text { des gens bien élevés... Ils ne } \\
\text { bouvaient jamais de vernis à } \\
\text { l'alcool ni d'eau de Cologne... } \\
\text { Seulement du vin blanc, du } \\
\text { vin rouge e de la bière... }\end{array}$ \\
\hline
\end{tabular}

\begin{tabular}{|c|c|}
\hline Il parco di Púškin & Parque cultural \\
\hline $\begin{array}{l}\text { L'anno scorso ci sono } \\
\text { stati degli ebrei. Non posso dir } \\
\text { male, erano gente come si } \\
\text { deve... solo bianco, rosso e } \\
\text { birra... niente lucidante o } \\
\text { dopobarba... }\end{array}$ & $\begin{array}{l}\text { No ano passado uns } \\
\text { judeus moraram aqui. Não } \\
\text { posso dizer nada de mau, } \\
\text { gente culta... Nada de álcool } \\
\text { de limpeza ou de água de } \\
\text { colônia... Só branco, tinto e } \\
\text { cerveja... }\end{array}$ \\
\hline
\end{tabular}

Analisaremos as marcas culturais presentes no fragmento.

Beber perfume ou outros líquidos, que contenham álcool na falta de bebida alcoólica, não é apenas hábito dos bêbados russos, e Mikhal Iványtch, no texto original, bebe politura, um tipo de verniz que contém em torno de $20 \%$ de álcool. Na época, politura era usada na União Soviética como uma substituição barata de bebida alcoólica. Na França, existe um tipo de líquido parecido, vernis à l'alcool; portanto, a tradutora não precisou fazer adaptações para realizar a transferência cultural e procurar um referente paralelo na cultura de chegada.

Já na cultura brasileira, americana e italiana, tal referente não tem um equivalente exato. Para conservar a expressividade do texto original, na tradução para o português optamos por colocar "álcool de limpeza", um paralelo que existe no Brasil, para contextualizar assim o leitor. As tradutoras para o inglês e para o italiano também optaram pela estratégia de domesticação, ao colocar furniture polish e lucidante, respetivamente (ou seja, um tipo de lustra móveis que contém álcool). A tradutora para o italiano também mudou "água de colônia", mencionada no texto original, por dopobarba, "loção pós-barba". Cabe mencionar aqui que, na União Soviética, a loção pós barba também era usada por alcóolatras como alternativa à bebida alcoólica, o que 
Serguei Dovlátov: texto de cultura na literatura russa contemporânea inclusive é mencionado em outros livros de Dovlátov. Assim, no romance $A$ mala, o hábito de beber loção pós-barba serve para caraterizar uma das personagens, o soldado Tchurílin, que trabalha como carcereiro na mesma colônia penal que o protagonista: "O que podia dizer-lhe? O que se pode dizer a um carcereiro que consome a loção pós-barba Higiene apenas para dentro?". 665

Outra marca cultural presente no fragmento é a visão de mundo do alcóolatra soviético, para quem "gente culta” são pessoas que não bebem nenhuma mistura líquida que contenha álcool, mas apenas bebidas alcoólicas propriamente ditas; no caso, vinho e cerveja. No texto em russo, a informação referente ao consumo de bebida alcoólica está implícita, pois Mikhal Iványtch não usa nem o verbo "beber", nem o substantivo para denominar o vinho, apenas suas características: "branco" e "tinto". Tal omissão atribui ao texto uma certa expressividade adicional, demonstrando a familiaridade da personagem com o tema da bebida. Nas traduções para o inglês e para o italiano foi conservada a referida omissão, já o tradutor para o francês acrescentou as palavras boire (“Ils ne bouvaient jamais...”) e vin, empregando, assim, o recurso de explicitação. Em nossa opinião, essa tradução explicativa foi desnecessária, pois tornou explícita a informação, que fora intencionalmente deixada implícita pelo autor. Como aponta Berman, o recurso de explicitação pode levar a duas tendências negativas: à clarificação ("explicitação visa a tornar "claro" o que não é e não quer ser no original" e ao alongamento (embora, segundo Berman, o alongamento seja "uma tendência inerente ao traduzir enquanto tal"). ${ }^{666}$

$\mathrm{Na}$ tradução para o português, optamos por manter a omissão das palavras "beber" e "vinho" para conservar, assim, a evidente familiaridade da personagem com o tema da bebida alcoólica e do alcoolismo.

Como demonstra esse exemplo, no caso de marcas culturais que se referem a objetos que podem não ter paralelo na cultura de chegada, em muitos casos os tradutores conseguem adaptar a tradução e transferir o efeito cômico presente no original. No caso de outros fatos e fenômenos de caráter socio-cultural, ou relacionados com a visão de mundo e mentalidade dos portadores de diferentes culturas, torna-se impossível guardar a expressividade do texto original e transmitir todos os matizes de sentido. Assim, no fragmento seguinte, o autor faz referência a outro fato da cultura soviética (e também russa, já que no país o número de mulheres continua a superar o número de homens ${ }^{667}$ ), que é a "falta de homens" no perfil demográfico dessa sociedade. A

\footnotetext{
${ }^{665}$ DOVLÁTOV. Tchemodán. Op. cit., p. 326.

${ }^{666}$ BERMAN. Op. cit., pp. $51-52$.

${ }^{667}$ Segundo os dados estatísticos do Serviço Estatal de Estatística da Federação Russa de 2010, no país vivam 66.1 milhões de homens e 76,8 milhões de mulheres, ou seja, a população femenina superava a masculina em $16 \%$. Os
} 
Serguei Dovlátov: texto de cultura na literatura russa contemporânea preponderância da população feminina no país sempre foi objeto de piadas, e Dovlátov faz ironia com esse fenômeno tanto nas cenas com as funcionárias do parque cultural, que se interessam por qualquer homem, independentemente de sua aparência ou caráter, assim como no fragmento da conversa telefônica que uma das turistas tem com sua amiga.

\begin{tabular}{|c|c|c|}
\hline Заповедник & Pushkin Hills & $\begin{array}{l}\text { Le Domaine } \\
\text { Pouchkine }\end{array}$ \\
\hline 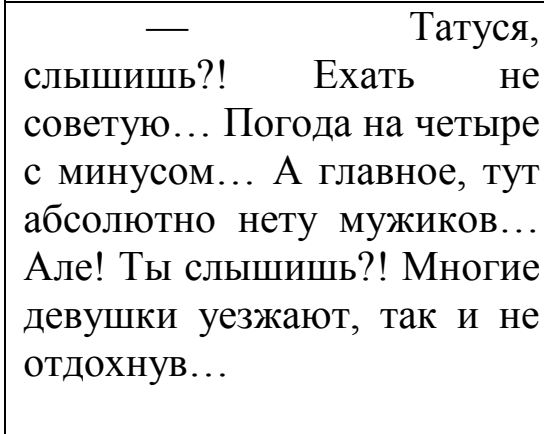 & $\begin{array}{l}\text { "Tata, do you hear? I } \\
\text { wouldn't advise you to come... } \\
\text { The weather here is B- } \\
\text { minus... But most } \\
\text { importantly, there are } \\
\text { absolutely no guys here... } \\
\text { Hello, do you hear me? Lots } \\
\text { of girls leave here without } \\
\text { feeling refreshed..." }\end{array}$ & $\begin{array}{l}- \text { Tatoussia, tu } \\
\text { m'entends? Je te déconseille } \\
\text { de venir. Le temps n'est pas } \\
\text { idéal... Et surtout, il n'y a pas } \\
\text { un seul mec... Allô, tu } \\
\text { m'entends? Beaucoup de filles } \\
\text { sont obligées de rentrer sans } \\
\text { s'être reposées... }\end{array}$ \\
\hline
\end{tabular}

\begin{tabular}{|l|l|}
\hline \multicolumn{1}{|c|}{ Il parco di Púškin } & \multicolumn{3}{|c|}{ Parque cultural } \\
\hline - Tatusja, hai capito & \multicolumn{3}{c|}{ Tatússia, está me } \\
bene?! Ti sconsiglio di & ouvindo?! Não aconselho a \\
venire... Il tempo é da sette & vir... O tempo não está lá \\
meno... E sopratutto non c’è & aquelas coisas... E o mais \\
neppure un maschio... Pronto, & importante: não tem homem \\
mi senti?! Un sacco di ragazze & nenhum... Alô! Está me \\
se ne vanno senza neppure & ouvindo?! Tem muitas \\
essersi divertite... & meninas indo embora sem \\
& nem ter aproveitado... \\
\hline
\end{tabular}

Nos anos 1970, ainda eram sentidas as consequências da Segunda Guerra Mundial, que levou as vidas de mais de 26 milhões de pessoas na União Soviética; outro problema que contribuía para tal disparidade era o alcoolismo, tão comum entre a população masculina do país, de modo que para uma mulher solteira de meia idade era bastante difícil encontrar marido, e uma das possibilidades de conhecer pessoas eram as viagens turísticas. Por isso é tão grande a decepção da personagem que não encontra homens nas Colinas de Púchkin.

A preocupação da personagem que "não pode descansar" (no texto original, o autor emprega o verbo otdokhnut, "descansar") por causa da falta de homens não é tão evidente para nativos de outros países que não enfrentem problema demográfico semelhante. Infelizmente, parece-nos que a piada perdeu uma parte da expressividade que tinha no texto original, por tal diferença entre culturas. Tentamos reforçar o efeito cômico, colocando na frase uma ênfase ("sem nem ter aproveitado"), ausente no texto original e também trocando o verbo "descansar" por "aproveitar".

dados estão disponíveis no site da instituição:

http://www.gks.ru/wps/wcm/connect/rosstat_main/rosstat/ru/statistics/population/demography/\# 
Os exemplos analisados acima demonstram como Dovlátov, na construção do humor, aciona o tempo todo o conhecimento prévio do leitor, fazendo piadas contextuais. É um procedimento muito comum em sua poética que, certamente, gera certas dificuldades para o tradutor, pois quando a comicidade é baseada no subtexto cultural, o tradutor consegue achar um paralelo na outra língua e na outra cultura, que tenha uma expressividade semelhante.

As piadas construidas com base no jogo de palavras também estão bastante presentes na obra do escritor. No caso de Parque cultural, o escritor usa procedimentos linguísticos para gerar efeito cômico, em primeiro lugar, nas falas da personagem Mikhal Iványtch. Em russo, a personagem usa constantemente ocasionalismos e expressões rimadas feitos com base nos palavrões. A expressão seguinte, usada pela personagem, "de tom filosófico", forma uma das frases de Dovlátov, que se tornaram refrões na cultura russa e formam parte do folclore urbano moderno.

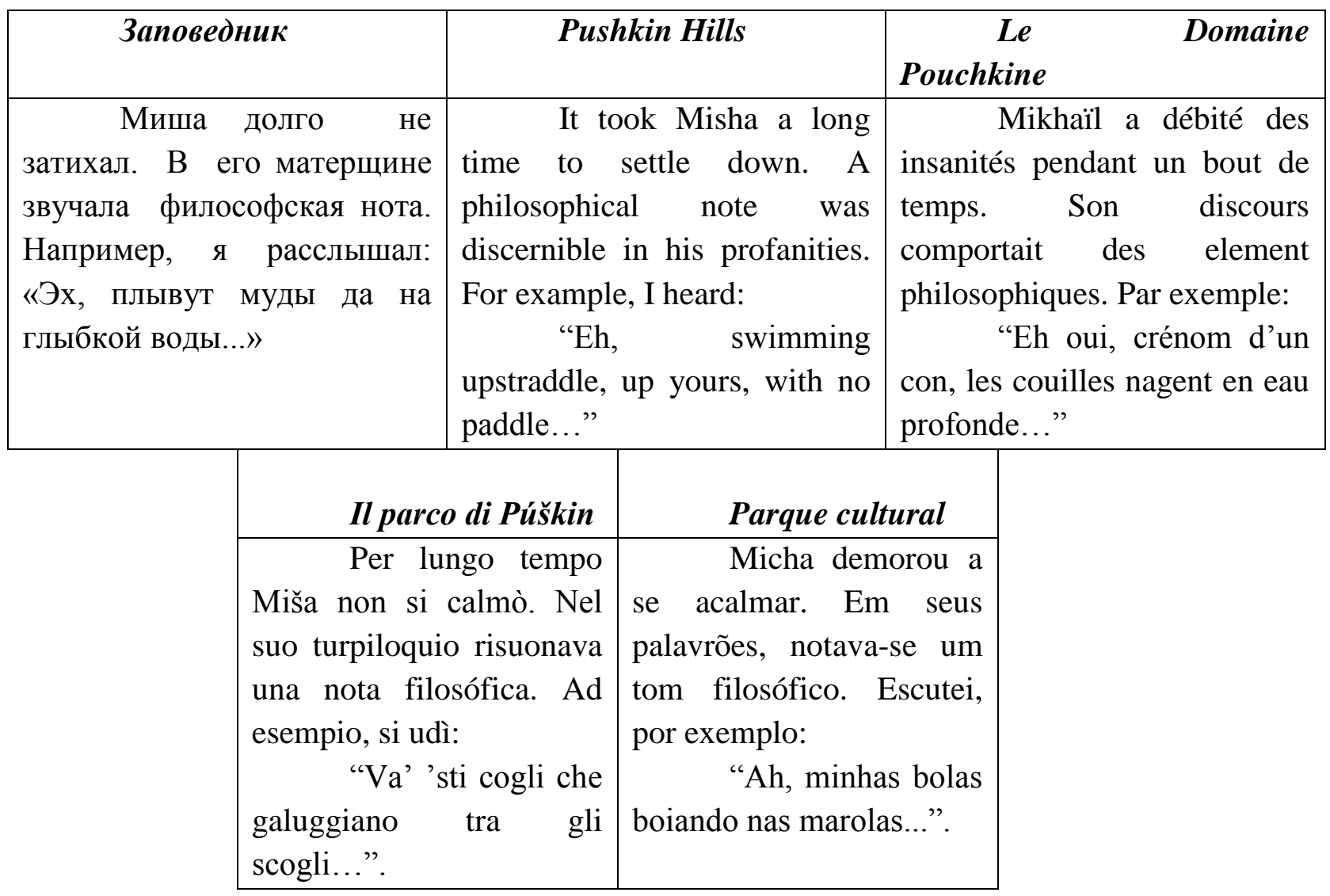

Como demonstrou o cotejo das traduções, na maioria dos casos as tradutoras conseguiram conservar o efeito cômico e a expressividade das frases da personagem em russo, construindo seus paralelos com base nos palavrões e expressões vulgares ou indecorosas na língua de chegada. 
Serguei Dovlátov: texto de cultura na literatura russa contemporânea

Porém, no caso do substrato cultural, pelas diferenças nas visões de mundo, diferentes conhecimentos implícitos e, em alguns casos, ausência de referentes, torna-se mais difícil realizar a transferência do humor, conservando, porém, o mesmo grau de expressividade. Infelizmente, na tradução (e isso provam todas as traduções analisadas aqui), uma parte da expressividade e da comicidade do texto se perde justamente pelas diferenças na visão de mundo entre os portadores de diferentes culturas e pela falta do conhecimento contextual para o leitor estrangeiro. No entanto, os textos analisados mostram que é possível realizar a transferência cultural, ao menos parcialmente, e transmitir o humor para outra língua e também para outra cultura, fazendo as adaptações necessárias. Tal ideia de compromisso, de meio termo entre o texto de partida e texto de chegada, remete à afirmação de Umberto Eco de que a tradução se baseia em negociações, "durante as quais, para ganhar algo, renunciam a outra coisa; e, no final das contas, as partes das negociações devem sair desse processo com uma sensação de satisfação razoável e mútua, lembrando da regra de ouro, segundo a qual é impossível ter tudo". 668

A análise das traduções também demonstrou que, no caso da tradução de um texto muito culturalmente marcado, como são os textos de Dovlátov, pode haver dois extremos: ou o tradutor tentar adaptar a tradução ao máximo à cultura estrangeira e, então, perder a ligação com a cultura original e a intenção do autor, ou manter-se na tradução ao pé da letra, perdendo assim em muitos casos a expressividade e o encantamento da obra. Assim, por exemplo, usando demais o recurso da explicitação, ou seja, oferecendo a informação que está implícita no texto original, ou empregando demais o recurso de nota de rodapé, podemos poluir o texto e não permitir ao leitor a fruição da obra. Com certeza, a diferença entre culturas é o ponto mais complexo do ato de traduzir. O trabalho importante do tradutor, no caso, é não cair em nenhum dos extremos e manter-se no ponto de tensão entre as línguas e as culturas. Parece-nos que a tarefa é possível. Prova disso, é o êxito das traduções da obra de Dovlátov entre o público estrangeiro, não familiar às culturas russa e soviética.

O primeiro desafio na tradução foi o próprio título da novela, já que a palavra zapoviédnik não possui um equivalente em português. Em russo, zapoviéndik pode se referir tanto a uma reserva natural, como a um parque, um lugar que tem valor histórico ou cultural. Como demonstrou o cotejo, nas traduções a outras línguas a maioria dos tradutores optou por uma solução relacionada com o nome de Púchkin ou com o nome do local: em inglês, o título foi traduzido como Pushkin Hills; em francês, Le domaine Pouchkine; em italiano, Il parco di Puškin. Parece-nos que, ao optar por tal tradução, os tradutures guiavam-se também pelas 
Serguei Dovlátov: texto de cultura na literatura russa contemporânea questões comerciais, levando em consideração que o título da novela com o nome do famoso poeta chamaria ainda mais a atenção de leitores que se interessam pela literatura russa (ou seja, o público alvo dessa tradução).

Na tradução para o português, queríamos seguir a intenção do próprio escritor de não limitar o título só ao âmbito do parque museu de Púchkin: nas cartas a seu editor Igor Iefímov, Dovlátov comentava que Zapoviédnik, para ele, era uma metáfora mais ampla da Rússia, da província russa e sua bagagem cultural e histórica, sendo a novela uma espécie de despedida da terra natal. ${ }^{669}$ Foi a resposta do escritor à ideia de Iefímov de por na capa do livro a imagem das Colinas de Púchkin.

A primeira variante da tradução do título foi Patrimônio cultural, porém, durante a discussão no processo de qualificação chegamos à conclusão de que tal tradução não transmitia a ideia de espaço geográfico. Entre as possívei opções, foram sugeridas as variantes Parque cultural e Parque Púchkin. Pensando nas palavras de Dovlátov referentes ao tema do livro, tomamos a decisão de por o título de Parque cultural.

Através dos pequenos detalhes, costumes e hábitos do dia a dia expostos no texto, o leitor pode se inteirar do contexto socio-cultural na União Soviética na época dos anos 1970, de como os acontecimentos históricos e sociais se refletiam na cultura do país. Como aponta Svetlana Boym, o "cotidiano conta a história da modernidade, na qual os cataclismos históricos são substituidos por tarefas do dia a dia" ${ }^{670}$ Da mesma forma, no texto Parque cultural, são feitas referências a vários aspectos da história, ideologia e da cultura do país, que se refletem nas coisas do uso comum, na decoração de moradias, expressões, fraseologismos, etc.

Um dos temas do "cotidiano soviético" que surge várias vezes ao longo da narrativa e se torna objeto de humor é o tema de multiculturalismo na União Soviética: no texto, além dos judeus, mencionam-se várias etnias minoritárias que formavam o país, assim como estereótipos referentes a representantes de diferentes nações soviéticas e relações entre elas.

Um dos exemplos de escárnio de "esteriótipos nacionais" é o relato sobre grupos turísticos de diferentes regiões da URSS, que o protagonista recebe no parque cultural. Em Parque cultural, comparam-se entre si os turistas da região soviética do Báltico (das Repúblicas Socialistas Soviéticas de Letônia, Lituánia e Estônia), e os da região do Cáucaso (as etnias do Cáucaso do Norte, que formavam parte da República Socialista Federativa Soviética da Rússia; e as do Cáucaso Sul, das Repúblicas da Armênia, Geórgia e Azerbaijão). Apesar de se tratarem de

${ }^{669}$ DOVLÁTOV. Epistoliárny román. Op. cit., p. 259.

${ }^{670}$ BOYM. Op. cit., p. 21. 
Serguei Dovlátov: texto de cultura na literatura russa contemporânea etnias que possuem língua própria e traços culturais específicos, na visão do mundo soviética (e russa também) era comum agrupá-los por sua proximidade em primeiro lugar geográfica, e, depois, cultural. Na língua russa, existem termos genéricos para denominar os representantes do Báltico como um conjunto cultural (em russo, pribálty), assim como os caucasianos (kavkáztsy). Evidentemente, em tal generalização de diferentes grupos étnicos se vê um traço da consciência "imperialista" da nação e cultura russa como cultura predominante na região.

No imaginário popular soviético, esses dois grupos formavam como que um par de extremos no seu comportamento, dois polos opostos no mapa do país, e essa imagem é usada pelo autor na novela, que sublinha tais caraterísticas. Se os representantes do Báltico se consideravam os "mais europeus", os mais organizados, indiferentes e pragmáticos, e até eram vistos como estrangeiros por outros povos da União Soviética (e por isso o protagonista de Parque cultural comenta que nunca tinha certeza se os excursionistas do Báltico o entendiam), com os caucasianos se associava o contrário: consideravam-se os mais barulhentos, anárquicos, emocionais e explosivos de todas as nações. De tal forma grotesca, no seguinte fragmento, refletem-se os estereótipos reinantes no país.

Os turistas de Riga são os mais educados. A qualquer coisa que se diga, eles sorriem e acenam com a cabeça. Se fazem perguntas, elas são, como se diz, estatísticas. Quantos servos tinha Púchkin? Que renda dava Mikháilovskoe? Quanto custou a reforma da casa senhorial?

Os caucasianos portam-se de um modo diferente. Eles não escutam em absoluto. Conversam entre si e riem às gargalhadas. No caminho para Trigórskoe, olham com carinho para as ovelhas. Evidentemente, farejam um potencial churrasco. Se fazem perguntas, são totalmente imprevisíveis. Por exemplo: "Por qual motivo Púchkin duelou com Lêrmontov?". 671

Na União Soviética, um dos aspectos importantes da ideologia nacional era o tema da "amizade dos povos", da convivência pacífica de diferentes nações e culturas no país. Porém, a imagem idealizada, difundida pela propaganda, não correspondia por completo à realidade existente no país. Apesar de uma convivência em geral pacífica e amigável, ou seja, sem graves conflitos, existiam certas tensões e antipatias entre diferentes etnias (normalmente relacionadas com disputas históricas de territórios, ou de diferenças de caráter político ou religioso), que se refletiam em primeiro lugar na forma de estereótipos, piadas ou frases feitas (ou seja, de fato, tais antipatias na maioria dos casos não impediam manter amizade entre representantes concretos dessas nacionalidades).

Assim, a existência de uma certa antipatia entre russos e ucranianos se manifesta na frase da personagem Mikhal Iványtch, que "daria uma dúzia de ucranianinhos por um judeu” (em russo, referindo-se a ucranianos, a personagem usa o termo pejorativo de khokhól). Da mesma

${ }^{671}$ DOVLÁTOV. Zapoviédnik. Op. cit., p. 204. 
Serguei Dovlátov: texto de cultura na literatura russa contemporânea forma, reflete-se a relação contraditória entre armênios e georgianos na frase atribuida à mãe do protagonista, representante da diáspora armênia em Tbilissi, capital da Geórgia, que dizia, referindo-se a Stálin, que "nenhum georgiano pode ser um homem decente". ${ }^{672}$ Cabe mencionar que tais "antipatias estereotípicas" continuam a existir também na atualidade.

De modo geral, na novela estão presentes vários marcadores da época: mencionam-se nomes de canções, de escritores, cantores, homens públicos e políticos famosos da época, roupa que estava na moda, etc.

Nesse sentido, é curiosa a personagem Valera Márkov que, chamado pelo protagonista de um "alto-falante quebrado", menciona em sua fala uma infinidade de slogans da época, assim como nomes de programas de televisão, filmes, livros, atores e políticos, letras de canções, etc., e também alusões e referências a acontecimentos políticos e históricos, informando ao leitor o panorama da vida política e dos acontecimentos daquele momento. O próprio Dovlátov considerava certas falas da personagem Valera intraduzíveis para outras línguas, devido a densa intertextualidade e a vinculação com a história e atualidade do país. Cabe mencionar que muitos dos assuntos, aos quais faz referência a personagem, por serem fatos e fenômenos secundários do passado, já não são percebidos por leitores russos de gerações mais novas.

No texto, mencionam-se caraterísticas da época, resultado da economia planificada do país, como, por exemplo, o déficit de alimentos e de artigos de utilidade básica, inclusive os de uso diário, e a necessidade de esperar horas em filas diante de lojas para comprar os produtos mais banais. É conhecido o fato de que, na União Soviética, um dos produtos que por vezes entrava em falta era o papel higiénico; sempre que o producto aparecia nas lojas, formavam-se filas para comprá-lo, e as pessoas tentavam se abastecer com a maior quantidade possível, fenômeno que gerou várias piadas e anedotas na época.

A esses problemas cotidianos se referem as reclamações da personagem Tânia, quando ela explica os motivos do seu desejo de emigrar: "Estou farta de ficar em filas para comprar qualquer porcaria. Farta de andar de meia rasgada. Farta de me alegrar com salsichão...”. 673 Aqui, falando sobre estar farta de usar meia rasgada e se alegrar com salchichão, a personagem faz referência ao déficit de meias de nylon, assim como à escassa variedade de produtos de carne, o que fazia as pessoas se alegrarem com qualquer compra.

Outra curiosa peculiaridade da época que vale a pena comentar e que está relacionada com o déficit de produtos no país, é o fascinio das pessoas soviéticas por coisas importadas. No período, devido à Cortina de Ferro e à necessidade de solicitar o visto para saír do país, inclusive para viajar para os países do "bloco socialista", a maioria dos cidadãos soviéticos não tinha 
Serguei Dovlátov: texto de cultura na literatura russa contemporânea possibilidade de conhecer lugares no exterior, e qualquer brinde ou souvenir trazido do exterior, provocava um vivo interesse, mesmo se se tratasse de objetos comuns como sacolas de plástico de supermercado ou garrafas de refrigerante (as garrafas vazias de Coca-Cola tornaram-se enfeites em casa). Como aponta Svetlana Boym, "nos anos 1970, artefatos do Ocidente tornaram-se fetiche e se converteram em produtos do mercado negro. Mercadorias e prendas de roupa estrangeiras penetram na vida cotidiana soviética. Há um grande fascínio com todo tipo de embalagem estrangeira", 674

Tal caraterística do cotidiano soviético se manifesta no texto de Dovlátov em pequenos detalhes, como a bolsa de pano com a imagem de James Bond da personagem Natella (ou seja, um acessório raro e valioso), ou a descrição do interior do quarto de Tânia na kommunalka, onde o protagonista vê "uma Nefertiti de gesso, um calendário estrangeiro com uma moça de sutiã cor-de-rosa, um cartaz de companhia de aviação transatlântica". ${ }^{675}$

Um detalhe para o qual o leitor estrangeiro pode não dar atenção, a imagem do calendário e do cartaz da companhia de aviação, e a observação da personagem Alikhánov de que Tânia vestia sandálias importadas da marca Rochas, carrega uma camada de informação implícita sobre a personagem. Cartazes, calendários, sacolas de plástico ou garrafas de Coca-Cola, na época, consideravam-se um souvenir valioso que podia ser trazido do exterior.

Em geral, a decoração da casa de Tânia, assim como a de Alikhánov, possuem vários traços de uma casa da intelligentsia soviética: fotos de escritores estrangeiros (ou escritores emigrados russos), como a de Hemingway, livros, máquina de escrever, busto de Nefertiti como decoração, etc. Como assinala Boym, nos anos 1960 - 1970 viagens ao exterior eram quase impossíveis, os cidadãos soviéticos "emprendiam viagens virtuais através do programa popular de televisão Klub kinoputechéstvii (“Clube de cineviagens”), versão nacional de National Geografic, ou através de coleções de selos e imagens de escritores, artistas e intelectuais estrangeiros". A pesquisadora aponta também para a presença nas prateleiras das casas da intelligentsia da "exótica e apolítica Nefertiti". 676

Na obra de Dovlátov, o objeto de decoração com a imagem da rainha egípcia Nefertiti surge em vários textos e se torna um dos símbolos da "casa culta" (que surge também no fragmento citado no Capítulo III, sobre a relação com a bebida, em que "Nefertitis" é mencionada como uma das marcas da "casa culta"). Tal objeto era comum na época. Isso se deve ao fato de que, por um lado, nos anos 1950 - 1960, o Egito era um parceiro importante da União Soviética, ou seja, devido às estreitas relações entre dois países, sabia-se um pouco mais do

\footnotetext{
${ }^{674}$ BOYM. Op. cit., p. 65.

${ }^{675}$ DOVLÁTOV. Zapoviédnik. Op. cit., p. 227.

${ }^{676}$ BOYM. Op. cit., p. 157.
} 
Serguei Dovlátov: texto de cultura na literatura russa contemporânea Egito do que de outros países "do além da Cortina de Ferro". ${ }^{677}$ Além do mais, em 1973, nas cidades soviéticas de Moscou, Leningrado e Kíev teve lugar a mostra "Os tesouros do túmulo de Tutancâmon", que se tornou um acontecimento cultural importante e ressaltou ainda mais o existente interesse pela história e cultura milenar egípcia.

Além das casas dos intelectuais de Leningrado, em Parque cultural também há descrições das moradias na aldeia (a casa de Mikhal Iványtch, assim como as casas dos seus vizinhos Nikítin e a de Valera Márkov) e seus atributos típicos, como reproduções da revista Ogoniok, revista popular soviética que publicava reproduções de famosos quadros e retratos, que as pessoas gostavam de pendurar na parede. Assim, na novela é mencionada a reprodução de $A$ desconhecida, de Kramskói (quadro que era muito difundido na cultura de massa soviética e integra a coleção artística da Galeria Tretiakóv, de Moscou), ${ }^{678}$ ou imagens de Gagárin, Mao, Julius Fucik, entre outras personalidades políticas e históricas da época, provavelmente recortadas da mencionada revista e postas no lugar de ícones, no "canto vermelho" da casa.

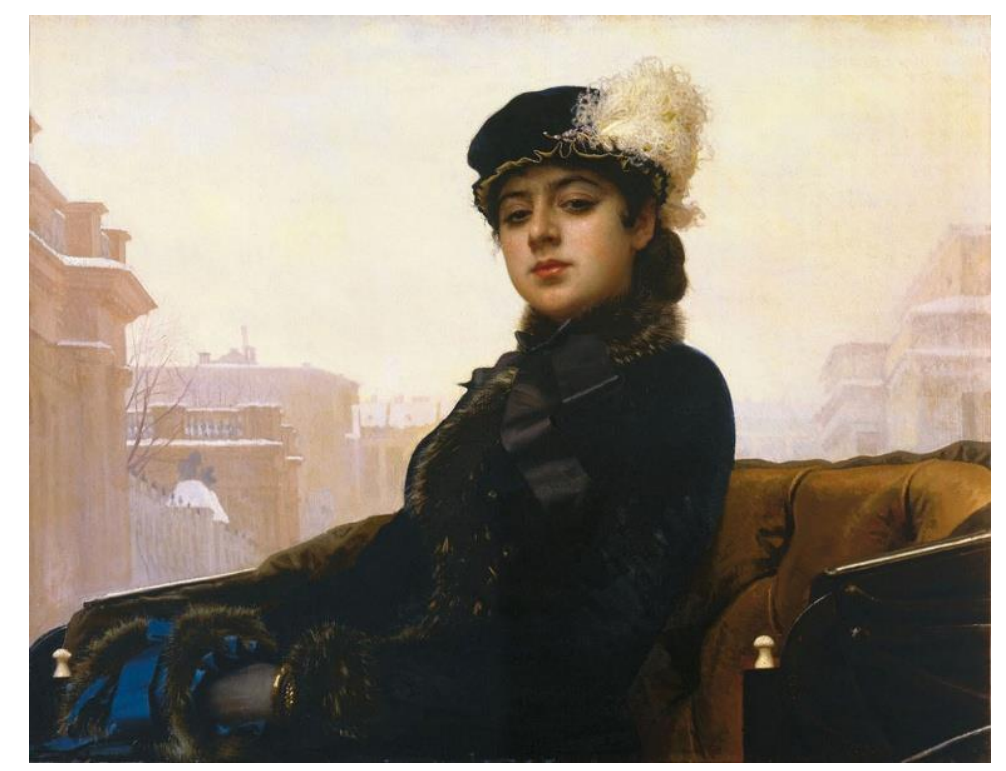

Famoso quadro A desconhecida (em russo, Neizvéstnaia), de Iván Kramskói (1883)

\footnotetext{
${ }^{677}$ Devido às relações comerciais entre dois países havia raros casos de viagens dos cidadãos soviéticos ao Egito. Aqui posso me referir à história da minha própria família: na casa dos meus avôs havia várias imagens de Nefertiti e faraós, junto com outros souvenirs, que a minha avó, sendo funcionária do Ministério de Comércio da URSS, trouxera da viagem de trabalho feita ao Egito.

678 O quadro A desconhecida (em russo, Neizviéstnaia), de Iván Kramskói, um dos ideólogos e líderes do movimento artístico Itinerantes (em russo, Peredvíjniki), provocou o interesse do público já no momento de sua criação, em 1883, além do valor artístico da obra, pela mistificação do nome modelo, que o autor não revelara sequer para os amigos íntimos. E em 1907, o retrato se torna ainda mais notório com a publicação do poema Neznakomka ("A desconhecida”), de Aleksándr Blok, já que a misteriosa personagem feminina do poema passa a se associar com a mulher retratada no quadro de Kramskói. Daqui provém o segundo nome "popular" do quadro, Neznakomka, que coincide com o nome do poema de Blok. Em russo, as duas palavras, neizviéstnaia e neznakomka, são sinônimos (sendo que a primeira palavra, neizviéstnaia, e adjetivo que se pode empregar como sustantivo, e neznakomka é sustantivo). No texto Parque cultural, Dovlátov menciona justamente o nome popular do quadro, Neznakomka. Alguns pesquisadores veem nisso uma alusão ao legado poético de Blok (DOBROZRÁKOVA. Mífy Dovlátova y mífy o Dovlátove. Op.cit., p. 143).
} 
Serguei Dovlátov: texto de cultura na literatura russa contemporânea

Na novela, as personagens Alikhánov e Tânia, a princípio vivem em Leningrado em kommunalka (palavra coloquial para denominar kommunálnaia kvartira, "apartamento comunal"), ou seja, têm quartos num apartamento comunal, um tipo de morada comum na época. ${ }^{679}$ Num apartamento comunal, cada família vivia em um ou mais quartos, e os espaços como cozinha, banheiro e corredores eram considerados espaços de uso comum. Os apartamentos comunais começaram a surgir após a Revolução de 1917, como resultado da política de "condensação": considerava-se que um quarto era suficiente para a vida de uma família (ou dois, no caso de uma família numerosa), e se um apartamento não correspondia a essa norma e havia quartos que "sobravam", esses quartos eram dados a outras famílias. Daí provém o nome do procedimento, uplotniénie: aumentava-se a densidade dos habitantes do apartamento. No próprio conceito de um apatamento comunal ve-se a ideia utópica comunista de vida sem a propriedade privada, assim como sem privacidade: o apartamento comunal era "um experimento sobre o modo de vida, uma tentativa de por em prática ideologias utópicas e de destruir a trivialidade burguesa", nas palavras de Boym. ${ }^{680}$

$\mathrm{Na}$ União Soviética, a kommunalka se tornou um fenômeno de cultura, uma forma de convivência muito específica (em muitos casos os vizinhos de um apartamento comunal pertenciam a diferentes classes sociais): diferentes famílias tinham que conviver num apartamento e inclusive compartilhar os espaços muito privados, como o banheiro e a cozinha. Como assinala Boym, o apartamento comunal "tornou-se a pedra angular da civilização soviética. Era uma forma específica soviética da vida urbana, a memória do desenho utópico comunista, que nunca se implementara na vida, uma forma de controle social e a base para criar informantes da polícia desde os anos 1920 e até os 1980 " ${ }^{681}$ O fenômeno de kommunalka é abordado pela pesquisadora também dentro do conceito geral da privacidade na cultura soviética, da "vida privada, eliminada pelo bolchevismo", junto com a propriedade privada, na expressão de Walter Benjamin. ${ }^{62}$

Em Parque cultural, Dovlátov em geral não explora o tema do apartamento comunal (porém, em outros livros do escritor, como no romance Os nossos, há episódios que relatam a vida do protagonista, na infância, e de seus vizinhos em kommunalka). O escritor apenas menciona que o protagonista e a sua futura mulher viviam em dois apartamentos comunais: "Em

\footnotetext{
679 Cabe mencionar que tais apartamentos comunais existem na Rússia até hoje. Se falamos de Moscou e São Petersburgo, existem kommunalkas em primeiro lugar nos prédios históricos do centro da cidade, onde a propriedade do apartamento pode ser dividida entre diferentes famílias. Se em Moscou os casos de kommunalka já são bastante raros, em São Petersburgo ainda existe em torno de 100000 apartamentos comunais (segundo os dados do jornal Argumiénty $i$ Fákty, do ano 2013; o artigo e disponível na página do jornal: http://www.spb.aif.ru/society/136599).

${ }^{680}$ BOYM. Op. cit., p. 124.

${ }^{681}$ Ibid., p. 123.

${ }^{682}$ BENJAMIN, W. “Moscow”. Op. cit., p. 30.
} 
Serguei Dovlátov: texto de cultura na literatura russa contemporânea nosso casamento, reuniam-se traços de esbanjamento e de miséria. Tínhamos duas casas separadas. A cinco paradas do bonde. Tânia tinha um espaço de vinte e cinco metros quadrados num apartamento comunal. $\mathrm{E}$ eu dois quartinhos apertados, de seis e de oito metros. Falando pomposamente, escritório e dormitório". ${ }^{683}$ Para o leitor russo, é evidente que se trata de quartos em kommunalkas. Para contextualizar o leitor brasileiro, acrescentamos na tradução a explicação de que se tratava de quartos num apartamento comunal (marcado em negrito no fragmento).

Aqui, a ironia do autor expressa de forma grotesca a realidade soviética: apesar do sarcasmo evidente do protagonista, ao chamar dois quartos minúsculos num apartamento comunal de "escritório e dormitório", para uma pessoa que vivia em kommunalka, ter dois quartos de uso privativo para um habitante era compreendido como um verdadeiro luxo. Ao mesmo tempo, o tamanho pequeno dos quartos insinua ao leitor que provavelmente se tratava de um quarto no apartamento comunal, que fora dividido em dois por uma parede improvisada ou por um biombo.

Portanto, quando o protagonista refere que depois de uns anos o casal conseguira trocar os quartos nos apartamentos comunais por um apartamento de dois quartos, ${ }^{684}$ isso singificava uma grande melhora na vida da família. Outra peculiaridade da vida soviética é o fato de que as personagens não compraram, mas trocaram os quartos por um apartamento: como na União Soviética não havia propriedade privada de imóveis, ou seja, todos os bens imóveis pertenciam ao governo, as pessoas não podiam vender ou comprá-los. Devido a isso, as pessoas que não possuiam moradia formavam filas para obter uma do governo. A obtenção de um quarto ou apartamento podia demorar anos, e por isso a personagem Liónia-Dedo-duro expressa as suas esperanças de receber uma moradia em Leningrado com a ajuda da KGB, para a qual trabalha: "Agora, prometeram me dar residência. Pois eu mesmo sou de Kulunda...". 685

Uma das caraterísticas do governo soviético sempre foi o seu caráter policial. Assim, como se sabe, uma das funções "não oficiais" de kommunalka, muitas vezes praticadas por seus habitantes, era a vigia dos vizinhos. Os casos de delações de pessoas por parte dos vizinhos tornaram-se uma prática regular, em primeiro lugar na época de repressões stalinistas: a delação e a posterior detenção de uma família podia significar que o quarto que esta ocupava passava a ser ocupado por seus delatores. O caráter massivo de tais delações por parte dos vizinhos, colegas de trabalho etc., na época dos anos 1930 - 1950, pode ser resumido com a seguinte expressão de Dovlátov, do romance $A$ zona: "Nós amaldiçoamos sem parar o camarada Stálin, e, sem dúvida, com toda razão. Mesmo assim, quero perguntar: quem escreveu quatro milhões de

${ }^{683}$ DOVLÁTOV. Zapoviédnik. Op. cit., p. 233.

${ }^{684}$ Cabe mencionar que na cultura russa não há um espaço como sala, ou seja, na realidade brasileira se trataria de um apartamento de uma sala e um dormitório.

685 Ibid., 270. 
Serguei Dovlátov: texto de cultura na literatura russa contemporânea delações? (Esta cifra aparecia nos documentos internos do partido)". ${ }^{686}$ No romance, o autor discute o caráter ambivalente do ser humano e chega à conclusão de que a existência do sistema penal, com todos seus defeitos, não recai exclusivamente no governo ou no sistema político vigente, mas na sociedade que constrói e apoia este sistema político e, de modo existencial, na natureza humana.

Além das delações feitas por cidadãos comuns por vontade própria, praticamente em todas as instituções públicas do país havia pessoas que exerciam função de espionagem e vigia dos colegas. Tal é o caso da personagem Liónia-Dedo-duro, delator da KGB na universidade. Normalmente o consentimento em desempenhar tais funções e trabalhar para a KGB significava ajuda e vários tipos de apoio por parte das autoridades (como ingresso na universidade, possibilidade de obter uma moradia ou outros privilégios).

Na novela, estão presentes várias marcas de tal caráter policial do governo, que refletem a situação do país na época: a vigia e as perseguições a pessoas de opiniões dissidentes, representantes da literatura e cultura não oficial, eram comuns. Sabe-se que o protagonista está vigiado pela KGB, e, no texto, mais de uma vez se torna objeto de sátira a "onipresência" e "onisciência" desse órgão de governo e seus funcionários, que, pelo visto, conhecem não apenas todos os passos da personagem, mas também as suas intenções e ideias, até as mais incertas. Assim, o "kgbista" na festa na casa dos amigos de Alikhánov sabe que este está prestes a ir às Colinas de Púchkin antes de que o próprio protagonista tomasse essa decisão. Ao mesmo tempo, não se explica o cargo "oficial” da personagem Liónia-Dedo-duro nas Colinas de Púchkin. O encontro das personagens Alikhánov e Liónia na porta do escritório da KGB insinua ao leitor que a sua função consistia justamente em vigiar os funcionários do parque museu e personalidades mal vistas pelas autoridades, como Alikhánov.

Como analisado no Capítulo III, um dos temas importantes da novela é a imagem ideológica soviética de Púchkin, à qual se fazem várias referências e alusões ao longo da narrativa. Além da imagem de "Púchkin soviético" como símbolo da cultura oficial, o escritor ironiza outros símbolos e traços da ideologia comunista oficial e o carater automatizado e quase religioso de sua veneração: a personagem de Mikhal Iványtch tira o chapel ao passar ao lado das imagens dos líderes; ao mesmo tempo, o funcionário do correio não sabe quem é Fernão Magalhães, cuja imagem aparece no selo, e acredita que deve ser algum líder do partido, que mereceu a honra de comparecer no selo de correio por ter morrido ou por ser condecorado com uma ordem:

${ }^{686}$ DOVLÁTOV. Zona. Op. cit., p. 77. 
Serguei Dovlátov: texto de cultura na literatura russa contemporânea

Entrei numa vendinha. Comprei um envelope com um retrato de Fernão de

Magalhães. Sem saber nem para quê, perguntei:

— O senhor não sabe como Magalhães veio parar aqui?

O vendedor respondeu, pensativo:

— Talvez por ter morrido... Ou lhe deram a ordem de herói... ${ }^{67}$

As condecorações soviéticas formavam uma parte importande da ideologia e da cultura oficial. Dovlátov zomba dessa "cultura de ordens" (sabe-se que todos os altos funcionários do partido possuiam grande quantidade de ordens e condecorações que às vezes mal cabiam na farda) na cena na aldeia, quando a personagem Mikhal Iványtch leva o protagonista até a sua moradia e ao caminho encontra uma vizinha, que veste um paletó masculino com a Ordem da Estrela Vermelha na lapela. A Ordem da Estrela Vermelha era outorgada por méritos em prol da defesa do país, na guerra ou na paz, e se pode supor que, na novela, o condecorado com a ordem havia participado na Segunda Guerra Mundial. Normalmente, as ordens eram usadas nos momentos solenes ou oficiais, e, na novela, a discrepância entre o ambiente totalmente informal e a conversação entre as personagens, em que a personagem da mulher veste o paletó masculino, revelam-nos a ironia mordaz do autor. Ao mesmo tempo, nas descrições da aldeia, sente-se um certo tom de amargura, pelo fato de que as pessoas, que heroicamente defenderam o país durante a Guerra, o que lhes resultou tal ordem, vivem num ambiente miserável da aldeia, rodeados de pobreza, decadência e alcoolismo.

Como se vê, tais pequenos detalhes e alusões sutis guardam em si uma grande quantidade de informação implícita, que normalmente é decifrada facilmente pelo leitor nativo, ainda que certas sutilezas do texto também sejam percebidas apenas por um leitor atento.

Na exploração da personalidade de Púchkin, Dovlátov traz ao texto um grande número de informações documentais acerca da biografia e vida do poeta. Na novela, aparecem nomes dos familiares e amigos de Púchkin que posteriormente contribuíram para a formação de seu mito. Assim, menciona-se o seu amigo próximo e vizinho em Mikháilovskoe, Aleksei Vulf (1805 1881), cujos diários Alikhánov lê no ônibus. Outra figura histórica relacionada com Púchkin e presente na novela é a de Aleksándr Turguênev (1784 - 1846), históriador e homem do Estado russo, que participara na vida de Púchkin desde a sua adolescência: foi Aleksándr Turguênev que ajudou o poeta a ingressar no Liceu, e também foi ele que, sob a instrução de Nicolau I, escoltou o corpo de Púchkin até o mosteiro Sviatogórski, em Mikháilovskoe. O autor cita também os nomes dos principais estudiosos puchkinistas soviéticos e seus estudos.

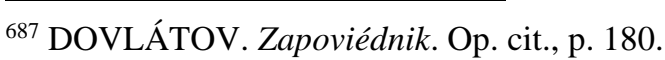


Serguei Dovlátov: texto de cultura na literatura russa contemporânea

No texto, a base factológica da biografia de Púchkin se entrelaça com a ficção da narrativa: tal é o caso do retrato atribuido a Abrám Gannibal, ou a figura da babá Arina Rodiónovna, sobre a qual fala o protagonista aos excurcionistas. Também as personagens Volódia Mitrofánov e Stássik Potótski, na cena do encontro com a mulher de Alikhánov, raciocinam sobre a personalidade de uma das musas mais famosas de Púchkin, Anna Kern, à qual o poeta dedicou vários poemas líricos. De fato, as caraterísticas dadas a Kern pelas personagens correspondem a materiais históricos disponíveis, apesar do mito ideologizado referente às relações entre Púchkin e Anna Kern, existente na cultura russa.

Portanto, apesar de certas modificações da biografia do poeta feitas pelo escritor "em prol da ficção", em primeiro lugar relacionadas com a estadia de Púchkin em Mikháilovskoe, a novela representa uma boa dose de informações, dados históricos e materias documentais para poder centrar o enredo no cronotopo de Mikháilovskoe.

Vale comentar separadamente os ocasionalismos usados pelo autor e as soluções encontradas na tradução. Jogos de palavras são um procedimento comum na poética de Dovlátov para gerar o efeito cômico, que em muitos casos também é usado para caraterizar as personagens. Na tradução, sempre tentamos manter as invenções criativas do autor e criar ocasionalismos em português nos fragmentos respectivos. ${ }^{688}$ Em Parque cultural, em primeiro lugar, vemos exemplos de fraseologismos e jogos de palavras na fala da personagem Mikhal Iványtch.

Em russo, a personagem utiliza construções incoerentes: usam-se formas deturpadas em russo, tampouco se seguem as regras de declinação das palavras e de concordância entre sustantivos e verbos; ao mesmo tempo, nos discursos de Mikhal Iványtch abundam ocasionalismos normalmente feitos com base em palavrões. Outra peculiaridade é o uso de frases rimadas, normalmente de caráter obsceno e com léxico vulgar. A falta de coerência e cohesão faz com que a fala da personagem soe estranha em russo, e em muitos casos o leitor adivinha apenas intuitivamente a intenção do discurso.

Tal caraterística "sugestiva" das falas de Mikhal Iványtch permite ao protagonista compará-las com "a pintura abstrata ou o canto do pintassilgo". ${ }^{69}$ Ao mesmo tempo, a abundância de ocasionalismos feitos com palavrões atrubui-lhes um caráter expressivo e bufo.

\footnotetext{
${ }^{688}$ É preciso comentar aqui que por não ser a autora deste trabalho uma nativa brasileira, todas as soluções de caráter criativo referentes a ocasionalismos e "traduções poéticas" foram encontradas com a ajuda do seu co-tradutor, Prof. Dr. Mário Ramos.

${ }^{689}$ DOVLÁTOV. Zapoviédnik. Op. cit., p 218.
} 
Serguei Dovlátov: texto de cultura na literatura russa contemporânea

Na tradução de aforismos de Mikhal Iványtch, para conservar a expressividade do texto original, tentamos encontrar soluções "paralelas" em português, que transmitiriam o mesmo efeito expressivo e emocional do que em russo. No seguinte fragmento, tentamos manter a incoerência do discurso:

\begin{tabular}{|c|c|}
\hline $\begin{array}{l}\text { Эт сидор-пидор бозна } \\
\text { Пятерку... } \\
\text { гадюшник... Авронс мой тыка што на } \\
\text { дипоненте... Кого же еньть завязывать?.. } \\
\text { Без пользы тыка... И душа не взойде... }\end{array}$ & $\begin{array}{l}\text { Aquele tal veado sei lá de onde... } \\
\text { Pegou cinco paus e partiu prum covil... O } \\
\text { adiantamento tá no depósito... Como que posso } \\
\text { parar de beber?... Não serve um nada... Nem a } \\
\text { alma se levanta... }\end{array}$ \\
\hline
\end{tabular}

Em russo, esse fragmento é dificilmente compreensível mesmo para um nativo, devido à maneira "vulgar" e deturpada de pronunciar as palavras: bozna corresponde a bokh znáiet ("Deus sabe"), khva, uma forma na qual se adivinha o verbo khvatat, "pegar"; bys, býstro ("rápido"); tyka, tolko ("apenas, só”), etc. Ao mesmo tempo, é usado erradamente o pronome kovó ("a quem" ou "de quem"), em vez de kak ("como").

Vê-se que, na tradução, a frase se tornou mais "legível" do que em russo. Porém, tentamos manter as peculiaridades da fala da personagem ao inserir na tradução formas coloquiais e errôneas.

Da mesma forma, mantivemos os ocasionalismos e palavras inusuais em tal contexto, empregados pelo autor. De novo, tentamos achar equivalentes em português que produziriam mais ou menos o mesmo efeito de expressividade do texto em russo:

\begin{tabular}{|c|c|}
\hline $\begin{array}{l}\text { Болтливых женщин он называл } \\
\text { таратайками. Плохих хозяек - росомахами. } \\
\text { Неверных жен - шаландами. Пиво и } \\
\text { водку - балдой, отравой и керосином. } \\
\text { Молодое поколение - описью... }\end{array}$ & $\begin{array}{l}\text { Chamava mulheres tagarelas de } \\
\text { carriolas. Donas de casa ruins de trastes. } \\
\text { Esposas infiéis de galináceas. Cerveja e vodka } \\
\text { de papalvo, veneno e querosene. Jovens de } \\
\text { mijadeiros. }\end{array}$ \\
\hline
\end{tabular}

Da mesma forma, no caso da resposta rude e rimada da personagem ao major da polícia, que continha um palavrão, optamos por encontrar uma expressão em português que contivesse um palavrão e rimasse com a pergunta. Assim como em português, a resposta de Mikhal 
Iványtch não tem em si nenhum sentido adicional, a expressividade gera-se apenas pela rima, imagem obscena à palavra indecorosa usada:

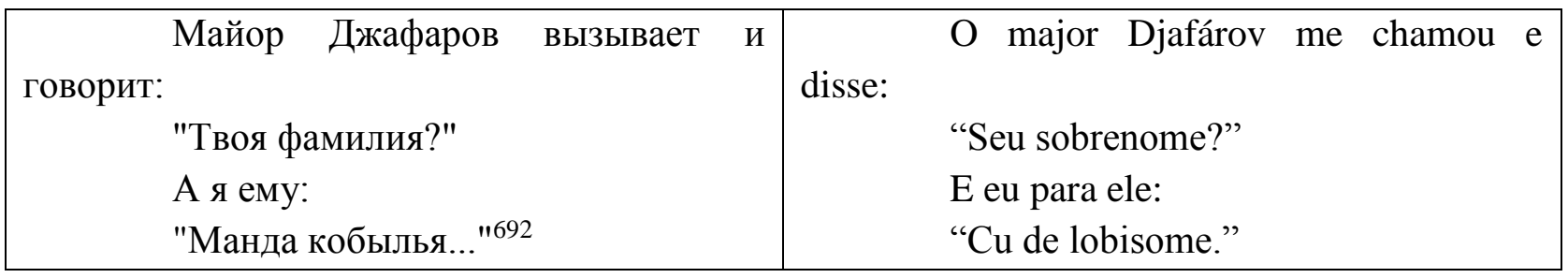

Esses são alguns exemplos das possíveis soluções referentes à criação na tradução. Estamos cientes de que, nesse processo, foram perdidas algumas camadas de significados e intenções do autor, tanto devido à diferença das culturas, como às diferenças nos sistemas morfológicos e sintáticos do russo e do português, bem como às imperfeições da própria tradução. São precisas, nesse sentido, as observações de Umberto Eco de que

traduzir significa compreender o sistema interno de uma determinada língua e a estrutura do texto nessa língua e construir tal sistema textual que em certo sentido possa produzir no leitor um efeito parecido, tanto no plano semântico e sintático como no plano estilístico, métrico, sonoro; assim como o mesmo efeito emocional ao qual tendia o texto original. ${ }^{693}$ 


\section{Considerações nem tanto finais}

Serguei Dovlátov ocupa um lugar especial na contística russa do século XX. Isso se deve tanto ao talento, como à própria biografia do escritor e ao caráter peculiar da sua trajetória literária: se em seu país, a União Soviética, Dovlátov não tinha possibilidades de ser publicado e pertencia à semi-marginalidade da literatura não oficial, na emigração lhe esperavam um sucesso extraordinário para um escritor emigrado, um reconhecimento e uma recepção vibrantes tanto pelo público da colônia de falantes de russo, como pelo público estadounidense.

O sucesso tanto em russo, como na tradução, em inglês, colocou o escritor entre as três principais figuras literárias da Terceira Onda de emigração, que teve lugar nos anos 1970 do século XX. A literatura da Terceira Onda de emigração se insere na vertente da literatura russa de emigração, um ramo específico da literatura russa do século XX que, apesar de sua heterogeneidade interna e as discrepâncias de caráter ideológico, social e cultural com a literatura da metrópole, forma parte do campo maior da literatura russa.

Tal sucesso da obra de Dovlátov entre os leitores e por parte da crítica estão relacionados, em grande medida, com o talento literário e a maestria estilística do escritor, que é destacada pela maioria absoluta de críticos literários. Em sua poética, convergem os traços da modernidade e das buscas criativas do século XX e, ao mesmo tempo, a pertinência ética e estética às tradições da literatura russa do século XIX, bem como o interesse pelo legado de seus maiores representantes, como Aleksándr Púchkin, Anton Tchékhov ou Fiódor Dostoiévski. Em vários textos dovlatovianos se estabelece um diálogo com o legado artístico desses escritores, nos quais o autor vê (em primeiro lugar, referindo-se às figuras de Púchkin e de Tchékhov) grandes pontos de referência, tanto do ponto de vista ético e moral, como no plano estético, no que se refere ao fazer literário.

Uma das caraterísticas da criação de Dovlátov, que contribuiu para a mitificação da figura do escritor ainda em vida, é a relação peculiar entre o autobiografismo e a ficção em sua obra. Tal "processamento literário" (em russo, literatúrnaia obrabotka) da própria vida e dos fatos de sua biografia leva em muitos casos a uma sensação errônea de ter em mãos um texto de memórias, e não ficcional. Todos os principais textos de Dovlátov inserem os acontecimentos mais importantes da sua vida e da sua trajetória pessoal e professional.

É o que sucede em sua novela Parque cultural, na qual o escritor recria a própria experiência de trabalho como guia nas Colinas de Púchkin, a antiga propriedade do poeta 
Serguei Dovlátov: texto de cultura na literatura russa contemporânea

Aleksándr Púchkin, transformada em parque museu. No texto, além do estudo minucioso da biografia e do legado do poeta, Dovlátov descreve e destrona o mito oficial de Púchkin, sobretudo aquele cultuado pela União Soviética. Ao mesmo tempo, na novela são evocados outros fenômenos da história e da cultura russa e soviética, como o fenômeno da literatura não oficial, o movimento dissidente na URSS, as peculiaridades do cotidiano soviético da época de estagnação, o problema da emigração massiva dos anos 1970, entre outros.

Pode-se ver a forte vinculação da obra do escritor com a cultura russa e soviética: em seus textos, estão presentes várias alusões e referências a fatos e costumes do cotidiano, símbolos da cultura e mitos existentes na visão do universo cultural nacional. Tal "expressividade adicional" (expressão de Iúri Lótman ${ }^{694}$ ), inerente à novela Parque cultural, traz em si uma camada de informação implícita (evidente e importante para os portadores da cultura russa), permitiu-nos analisá-la como texto de cultura, com base nos pressupostos teóricos da semiótica da cultura de Iúri Lótman.

Um dos principais símbolos da cultura russa e soviética abordado na novela é a figura do poeta Aleksándr Púchkin, "o sol da poesia russa" e o emblema da literatura nacional. Para compreender melhor o funcionamento do mito puchkiniano, tentamos analisar a sua evolução, desde o surgimento do mito, nos anos 1840, logo após a morte de Púchkin em duelo, até os anos 1970, quando, na União Soviética, a imagem do poeta se tornou um dos elementos de propaganda da ideologia oficial. Ao mesmo tempo, foi analisada a variante do mito, que se desenvolveu no âmbito da emigração russa, bem como o significado que recebeu a figura do poeta para os escritores da literatura não oficial soviética, os quais muitas vezes problematizaram a imagem ideologizada e simplificada dele produzidas. Além de Serguei Dovlátov, dedicaram textos a Púchkin representantes da literatura não oficial, como o escritor Andrei Siniávski e o poeta Joseph Brodsky, entre outros.

Esse estreito vínculo com os fenômenos da cultura russa, ao lado do caráter cômico da prosa de Dovlátov, representam um desafio para o tradutor. A principal peculiaridade na tradução do humor consiste em que a recepção do cômico não depende apenas da forma linguística, mas da contextualização do sujeito receptor (em nosso caso, do leitor brasileiro). Isso requer do tradutor outras estratégias de tradução e de transferência do humor, para que a expressividade e o valor cômico da anedota sejam conservados no texto de chegada. A comicidade da obra de Dovlátov e a presença de grande número de marcas culturais em seus textos implicam a possibilidade de abordar a tradução da novela do ponto de vista funcionalista dos Estudos da Tradução.

${ }^{694}$ LÓTMAN. Ízbrannye statií v triokh tomakh. V. 1. Statií po semiótike i topológuii kultúry. Op. cit., p.165 
Serguei Dovlátov: texto de cultura na literatura russa contemporânea

Nesse trabalho, de certa forma, emprendemos uma tentativa de "abarcar o inabarcável", ao reunir nesta tese vários aspectos, cada um dos quais poderia constituir uma pesquisa independente, como, por exemplo, a relação entre a figura do autor e a sua personagem autobiográfica; o papel do escritor na cultura não oficial soviética, ou no contexto da Terceira Onda de emigração; a análise da obra de Dovlátov como texto de cultura; o surgimento e a evolução do mito puchkiniano na Rússia e na União Soviética e as suas abordagens por diferentes artistas e literatos; as possíveis estratégias da tradução e da transferência cultural dos elementos de humor, entre outros aspectos.

O recorte escolhido teve como objetivo oferecer ao leitor desse trabalho a noção mais volumétrica possível da figura do escritor Serguei Dovlátov, assim como da sua importância no contexto da literatura russa do final do século XX e, particularmente, no contexto da literatura russa de emigração.

O autobiografismo da obra de Dovlátov, e a preocupação jornalística do escritor para com os processos históricos e sociais ao seu redor, fizeram dos seus textos uma espécie de documentos da época, "manuais da vida soviética", em que foram impressos vários fatos, traços da memória coletiva e caraterísticas da história e da cultura do país, no qual vivia e trabalhava o escritor. Em sua obra, revelam-se vários fenômenos culturais, sociais e históricos da vida na União Soviética, que por vezes se tornam o foco especial da atenção do autor e temas principais de suas narrativas, como a especificidade do campo de prisão soviético (no caso do romance $A$ zona), a censura na URSS e o funcionamento da imprensa soviética (A troca), o mito oficial de Púchkin e a literatura não oficial (Parque cultural), a estagnação brejneviana e a massiva emigração dos anos 1970 (Parque cultural, Os nossos, A mala), entre outros. Da mesma forma, em suas novelas tardias, A filial e A estrangeira, dedicadas à vida na emigração, Dovlátov conseguiu documentar o dia a dia e os costumes da colônia russa em Nova Iorque, assim como as peripécias da vida dos ex-cidadãos soviéticos na emigração e da mistura turbulenta de sentimentos, entre amor e ódio, dos "novos americanos" em relação à metrópole e à cultura natal.

Toda essa "bagagem" literária e cultural, a complexidade de camadas de significados presentes nos textos de Dovlátov, expressas pela alta qualidade do próprio estilo, além de seu papel como um dos melhores legado da literatura russa do século XIX e do começo do século $\mathrm{XX}$, situam Dovlátov entre as figuras mais importantes da literatura russa da segunda metade do século XX. Ao mesmo tempo, as peculiaridades da vida do escritor, o seu contexto social, histórico, cultural, e o conjunto de temas abordados em seus livros, oferecem um número inesgotável de reflexões para possíveis e futuras explorações críticas. 


\section{Regras de tradução e transliteração de nomes próprios}

Na tradução, usamos a seguinte tabela de transliteração do idioma russo para o português, elaborada por docentes do Programa de Literatura e Cultura Russa do DLO/FFLCH/USP:

\begin{tabular}{|c|c|c|}
\hline Alfabeto russo & $\begin{array}{l}\text { Transcrição para registro } \\
\text { catalográfico ou lingüístico }\end{array}$ & $\begin{array}{l}\text { Adaptação fonética para } \\
\text { nomes próprios }\end{array}$ \\
\hline A & A & A \\
\hline Б & B & B \\
\hline B & $\mathrm{V}$ & V \\
\hline$\Gamma$ & G & $\mathrm{G}, \mathrm{Gu}$ antes de $e, i$ \\
\hline Д & $\mathrm{D}$ & $\mathrm{D}$ \\
\hline $\mathrm{E}$ & $E$ & E, Ié \\
\hline$\ddot{\mathrm{E}}$ & Io & Io \\
\hline ж & $J$ & $\mathrm{~J}$ \\
\hline 3 & $\mathrm{Z}$ & $\mathrm{Z}$ \\
\hline И & I & I \\
\hline Й & I & I ou - \\
\hline $\mathrm{K}$ & $\mathrm{K}$ & $\mathrm{K}$ \\
\hline Л & $\mathrm{L}$ & $\mathrm{L}$ \\
\hline M & $\mathrm{M}$ & $\mathrm{M}$ \\
\hline $\mathrm{H}$ & $\mathrm{N}$ & $\mathrm{N}$ \\
\hline $\mathrm{O}$ & $\mathrm{O}$ & $\mathrm{O}$ \\
\hline$\Pi$ & $\mathrm{P}$ & $P$ \\
\hline $\mathrm{P}$ & $\mathrm{R}$ & $\mathrm{R}$ \\
\hline $\mathrm{C}$ & S & S, SS (intervocálico) \\
\hline $\mathrm{T}$ & $\mathrm{T}$ & $\mathrm{T}$ \\
\hline $\mathrm{y}$ & $\mathrm{U}$ & $\mathrm{U}$ \\
\hline$\Phi$ & $\mathrm{F}$ & $\mathrm{F}$ \\
\hline $\mathrm{X}$ & $\mathrm{Kh}$ & $\mathrm{Kh}$ \\
\hline Ц & Ts & Ts \\
\hline Ч & Tch & Tch \\
\hline Ш & $\mathrm{Ch}$ & $\mathrm{Ch}$ \\
\hline Щ & Sch (Chtch) & Sch (Chtch) \\
\hline
\end{tabular}


Serguei Dovlátov: texto de cultura na literatura russa contemporânea

\begin{tabular}{|l|l|l|}
\hline b & - & - \\
\hline b & Y & Y \\
\hline b & - & - \\
\hline Э & È & È \\
\hline Ю & Iu & Iu \\
\hline Я & Ia & Ia \\
\hline
\end{tabular}

No que diz respeito aos nomes próprios, como topônimos e nomes comerciais de restaurantes, bebidas, imprensa periódica, etc., optamos por mantê-los em russo, seguindo as normas de transliteração expostas acima. A única exceção foi o nome da Rádio Liberty (no texto, o nome da rádio é usado em russo, Rádio Svoboda), sendo que é uma estação de rádio e organização de comunicação internacional, financiada pelo Congresso dos EUA e conhecida mundialmente por seu nome em inglês (outro nome da organziação é Radio Free Europe). 


\section{Bibliografia}

\section{Bibliografia de S. Dovlátov}

DOVLÁTOV, S. “A mala”. IN: Folha de São Paulo, Ilustríssima. São Paulo, domingo, 06 de novembro de 2011. Tradução de Marina Darmaros.

Disponível em: http://www1.folha.uol.com.br/fsp/ilustrissima/il0611201109.htm

. "Bliesk i nischetá rússkoi literatúry". ("Esplendores e misérias da literatura russa”.) IN: Uróki tchtiénia (Lições de leitura). São Petersburgo: Ázbuka, 2012, p. 226-240.

. "Bliuz dliá Natélly”. (“Um blues para Natella”.) IN: Vstriétilis, pogovoríli

(Encontraram-se, conversaram). São Petersburgo: Ázbuka, 2003, pp. 20 - 24.

. Il Parco di Puškin. Palermo: Sellerio, 2004. Tradução de Laura Salmon.

. Kompromiss. São Petersburgo: Ázbuka, 2003.

. La maleta. Madrid: Metáfora, 2002. Tradução de Justo E. Vasco.

. Le domaine Pouchkine. Monaco: Éditions du Rocher, 2004. Tradução de

Christine Zeytounian-Beloüs.

Los nuestros. La vida de una familia de la Unión Soviética contada con sarcasmo. Barcelona: Áltera, 2008. Tradução de Ricardo San Vicente.

. March odinókikh (A marcha dos solitários). Holyoke, Massachusetts: New

England Publishing Co, 1983.

Disponível em: http://www.sergeidovlatov.com/books/marsh.html

. "Mnoi ovladiélo bespokóistvo". (“Apoderou-se de mim uma preocupação”.)

IN: Chtern, L. Dovlátov - dóbryi moi priátel (Dovlátov, meu bom amigo). São Petersburgo: Ázbuka-Klássika, 2005.

"My natchináli v epókhy zastóia”. (“Começávamos na época da estagnação”.)

IN: Maloizvéstnyi Dovlátov: Sbornik (Dovlátov pouco conhecido: Coletânia). São Petersburgo: AOZT “Jurnal Zvezdá”, 1996, pp. 231 - 235.

. "Na rua e em casa". IN: Nova antologia do conto russo. São Paulo: Editora 34, 2011, pp. 603-610. Tradução de Mário Ramos e Yulia Mikaelyan.

. Náchi (Os nossos). IN: Zapoviédnik (Parque cultural). São Petersburgo:

Ázbuka, 2003, pp. $281-382$. 

. Ours: a Russian family album. Nova Iorque: Weidenfeld \& Nicolson, 1989.

Tradução de Anne Frydman.

. "Perevodnye kartínki". ("Decalcomanias".) IN: Maloizvéstnyi Dovlátov:

Sbornik. São Petersburgo: AOZT “Jurnal Zvezdâ”, 1996, pp. 247 - 264. . "Pissátel v Emigrátsii". ("Escritor na emigração".) IN: Revista "Slovo-

Word”. Nova York, № 9, 1991.

Disponível em: http://www.sergeidovlatov.com/books/slovo.html . Posliédniaia kniga (O último livro). São Petersburgo: Ázbuka, 2012. . Pushkin Hills. London: Alma Classics, 2013. Tradução de Katherine

Dovlatov. . Remesló (O ofício). São Petersburgo: Ázbuka, 2014 . Rietch bez póvoda... ili Kolónki redáktora (Discurso sem pretexto... ou as colunas do redator). Moscou: Izdátelstvo Makhaon i Mejdunaródnyi fond Serguéia Dovlátova, 2006.

. Tchemodán (A mala). IN: Vstriétilis, pogovorili (Encontraram-se, conversaram). São Petersburgo: Ázbuka, 2003, pp. 273 - 386.

. Uróki tchtiénia (Lições de leitura). São Petersburgo: Ázbuka, 2012

. Zapíski tchinóvnika (Notas de um funcionário). IN: Siem dniei (Sete dias).

Nova York, 1984, № 47, pp. 14 - 15.

Disponível em: http://www.sergeidovlatov.com/books/zapiski.html . Zapisnye Kníjki (Cadernos de anotações). São Petersburgo: Ázbuka, 2001. . Zapoviédnik (Parque cultural). São Petersburgo: Ázbuka, 2003. . Zona (A zona). IN: Zapoviédnik. São Petersburgo: Ázbuka, 2003, pp. 9-172.

DOVLÁTOV, S., Iefímov, I. Epistoliárnyi roman (Romance epistolar). Moscou: Zakhárov, 2001 .

VÓLKOVA, M., Dovlátov, S. Ne tolko Brodsky. Rússkaia kultura v portriétakh i anekdótakh. (Não apenas Brodsky. A cultura russa em retratos e anedotas). Moscou: RIK "Kultura", 1992.

\section{Bibliografia sobre S. Dovlátov e sua obra}

ALIÉINIKOV, V. Dovlátov i druguíe (Dovlátov e outros). Moscou: OOO Izdátelski Dom "Sofia", 2006. 
Serguei Dovlátov: texto de cultura na literatura russa contemporânea ALOVIERT, N. "V liubói igrié suschéstvennen itog". ("Em qualquer jogo é importante o final”.) IN: Dovlátov, S. Rietch bez Póvoda... ili Kolónki Redáktora. Moscou: Makhaon, 2006, pp. 20 26.

ÁRIEV, A. "Istória rasskáztchika”. (“A história do contador de histórias”.) IN: Sukhikh, I. Serguei Dovlátov. Vriémia, miesto, sudbá (Serguei Dovlátov. Tempo, lugar, destino). São Petersburgo: Néstor - Istória, 2006, pp. 5 - 9.

(org.). Serguei Dovlátov. Jizn i mniénia. Ízbrannaia perepiska (Serguei Dovlátov. Vida e opiniões. Correspondência seleta). São Petersburgo: OOO Jurnal Zviezdá, 2011.

(org.). Serguei Dovlátov: litsó, sloviéstnost, epokha. Sbórnik statiéi (Serguei Dovlátov: indivíduo, literatura, época. Coletânea de artigos). São Petersburgo: OOO Jurnal Zviezdá, 2012.

(org.). Serguei Dovlátov: tvórtchestvo, lítchosnt, sudbá (Serguei Dovlátov: criação, personalidade, destino). São Petersburgo: Zviezdá, 1999.

BONDARIENKO, V. "Plebiéiskaia proza Serguéia Dovlátova”. (“A prosa plebeia de Serguei Dovlátov".) IN: Rússki perepliot, 1999.

Disponível em: http://www.pereplet.ru/text/bond1.html

BRODSKY, J. "O Serioje Dovlátove". ("Sobre Serioja Dovlátov”.) IN: Dovlátov, S. Posliédniaia kniga. São Petersburgo: Ázbuka, 2012, pp. 294 - 302.

CHTERN, L. Dovlátov - dóbryi moi priátel (Dovlátov, meu bom amigo). São Petersburgo: Ázbuka-Klássika, 2005.

DOBROZRÁKOVA, G. Mífy Dovlátova i mífy o Dovlátove: probliémy morfológuii i stilístiki (Mitos de Dovlátov e mitos sobre Dovlátov: problemas de morfologia e estilística). Samara: Povóljskii Gosudárstviennyj Universtitiet Telekommunikátsii i Informátiki, 2008. . "Tchékhov v proze Serguéia Dovlátova". ("Tchékhov na prosa de Dovlátov".) IN: Izviéstia Samárskovo naútchnovo tsentra Rossíiskoi akadiémii naúk (Boletim do centro de pesquisas da Acadêmia de Ciências da Rússia em Samara). Samara, v. 13, № 2 (2), 2011, pp. $407-412$.

. “Tvórtchestvo S. Dovlátova v kontiekste tradítsii rússkoi literatúry (obzor issliédovanii)". (“A criação de S. Dovlátov no contexto da tradição literária russa”.) IN: Izviéstia Samárskovo naútchnovo tsentra Rossíiskoi akadiémii naúk. Samara, v. 11, № 4 (6), 2009, pp. 1533 - 1541.

DOVlÁTOVA, E. “Nóvyi amerikánets v Novom Sviete”. (“O Novo americano no Novo Mundo”.) IN: Dovlátov, S. Rietch bez Póvoda... ili Kolónki Redáktora. Moscou: Makhaon, 2006, pp. $28-34$. 
Serguei Dovlátov: texto de cultura na literatura russa contemporânea

ERKHÓV, V. (org.) Serguei Dovlátov i ievó guerói (Serguei Dovlátov e o seu herói). Kazan: Otiétchestvo, 2002.

GÉRY, C. "Sergej Dovlatov, le conteur”. IN: Modernités russes 2. Vitesse et modernité. Lyon: Centre d'Études Slaves André Lirondelle, Université Jean Moulin, 2000, pp. 101 - 109.

GUÉNIS, A. Dovlátov i okriéstnosti. Filologuítcheski roman (Dovlátov e o seu entorno. Romance filológico). Moscou: Astriel, CORPUS, 2011. . "Púchkin". IN: Dovlátov, S. Posliédniaia kniga. São Petersburgo: Ázbuka, 2012, pp. $322-339$.

. "Púchkin u Dovlátova". ("Púchkin em Dovlátov".) IN: Serguei Dovlátov: tvórtchestvo, lítchnost, sudbá. Org. A. Áriev. São Petersburgo: Zviezdá, 1999.

Disponível em: http://www.sergeidovlatov.com/books/genis2.html . "Tchessutchá i Rogoja". (“Seda e esteira".) IN: Dovlátov, S. Rietch bez Póvoda... ili Kolónki Redáktora. Moscou: Makhaon, 2006, pp. 13-19.

IEFÍMOV, Igor. "Nepovtorímost liubói tsenói”. ("Unicidade a qualquer preço".) IN: Maloizviéstnyi Dovlátov. São Petersburgo: AOZT Jurnal “Zvezdá”, 1995, pp. 444 - 450.

KARGÁCHIN, I. “Osvobojdiónnoie slovo”. (“A palavra liberada”.) IN: O Dovlátove. Statiĺ, retsénzii, vospominánia. Tvier: Druguie beregá, 2001, pp. $102-124$.

KOVÁlOVA, A., Lurié, L. Dovlátov. São Petersburgo: Amfora, 2009.

KRIVÚLIN, V. "Poésia i anekdot”. (“A poesia e a anedota”.) IN: Dovlátov, S. Posliédniaia kniga. São Petersburgo: Ázbuka, 2012, pp. 375 - 378.

LÓSSEV, L. "Rússki pissátel Serguei Dovlátov”. (“O escritor russo Serguei Dovlátov”.) IN: Dovlátov, S. Posliédniaia kniga. São Petersburgo: Ázbuka, 2012, pp. 379 - 387.

MOTÝGUINA, J. Tvórtcheskaia individuálnost Sergueia Dovlátova (A individualidade criativa de Serguei Dovlátov). Ástrakhan: Izdátelski Dom “Astrakhánski Universitiet”, 2006.

ORLOVA, N., Petrienko, A. Semiotítcheskie e folklórnye modéli smekhovovo mira Serguiéia Dovlátova (Modelos semióticos e folclóricos do mundo cômico de Serguei Dovlátov). Piatigorsk: PGLU, 2011.

PAKHOMOVA, N. Marginal Voices: Sergei Dovlatov and His Characters in the Context of the Leningrad Literature of the 60s and the 70s (thesis). Montreal: Department of Russian and Slavic Studies, McGill University, 2001.

PEKURÓVSKAIA, A. Kogdá slutchílos piet S. D. i mnie. Serguei Dovlátov glazámi piérvoi jenny (Quando S. D. e eu tivemos a ocasião de cantar juntos. Serguei Dovlátov pelos olhos da primeira mulher). São Petersburgo: Simposium, 2001.

POPÓV, V. Dovlátov. Moscou: Molodáia Gvárdia, 2010. 
Serguei Dovlátov: texto de cultura na literatura russa contemporânea . "Krov - edínstvennye tchernila". (“O sangue é a única tinta”.) IN:

Maloizvéstnyi Dovlátov: Sbornik. São Petersburgo: AOZT “Jurnal Zvezdá”, 1996.

REIN, Ie. "Niéskolko slov vdogónku”. (“Algumas palavras no encalço”.) IN: Maloizviéstnyi

Dovlátov: Sbórnik. São Petersburgo: AOZT “Jurnal Zviezdá”, 1996, pp. 397 - 404.

SERMAN, I. “Grajdanin dvukh miróv”. (“O cidadão de dois mundos”.) IN: Zviezdá, 1994, № 4, p. $187-192$.

SOLOVIÓV, V. "Dovlátov na avtootviétchike". ("Dovlátov na secretária eletrónica”.) IN:

Roman s epígrafami. Variánty liubvi. (Romance com epígrafes. Variantes do amor.)São Petersburgo: Aleteia. 2000, pp. 649 - 665.

SOLOVIÓv, V., Klépikova, E. Dovlátov vverkh nogámi: traguédia stchastlívovo tcheloviéka (Dovlátov de cabeça para baixo: a tragédia do homem alegre). Moscou: Kolliéktsia "Soverchenno sekrietno", 2001.

SUKHIKH, I. "Serguei Dovlátov. Proza po kraiám”. (“Serguei Dovlátov. A prosa pelas bordas”.)

IN: Dovlátov, S. Uróki Tchtiénia. São Petersburgo: Ázbuka, 2012, 7-36. . Serguei Dovlátov. Vriémia, miesto, sudbá. (Serguei Dovlátov. Tempo, lugar, destino). São Petersburgo: Néstor - Istória, 2006

VAIL, P. "Bez Dovlátova”. (“Sem Dovlátov”.) IN: Maloizvéstnyi Dovlátov: Sbórnik. São Petersburgo: AOZT “Jurnal Zviezdá”, 1996, pp. 451 - 464.

. "Iz jízni nóvykh amerikántsev". ("Da vida dos novos americanos”.) IN:

Dovlátov, S. Rietch bez Póvoda... ili Kolónki Redáktora. Moscou: Makhaon, 2006, pp. 5 - 12.

VLÁSSOVA, Iú. Issliédovanie tvórtchestva Sergueia Dovlátova (O estudo da criação de Serguei Dovlátov). Moscou: Kompánia Sputnik +, 2001.

YOUNG, Jekaterina. "Narratívnaia Struktura 'Zony"”. (“A estrutura narrativa de A zona".) IN: Serguei Dovlátov: Tvórtchestvo, Lítchnost, Sudbá. São Petersburgo: Zviezdá, 1999.

Disponível em: http://www.sergeidovlatov.com/books/yang.html . Sergei Dovlatov and His Narrative Masks. Northwestern University Press, 2009.

\section{Bibliografia geral}

ANDRADE, M. “Contos e contistas”. IN: O Empalhador de passarinhos. São Paulo: Martins; Brasília: INL, 1972, $3^{\text {a } . ~ e d ., ~ p p . ~ 5-8 . ~}$ 
Serguei Dovlátov: texto de cultura na literatura russa contemporânea AGUENÓSSOV, V. Literatura rússkovo zarubiéjia (A literatura da emigração russa). Moscou: Terra-Sport, 1998.

ALEKSÉIEVA, L. Istória inakomyslia v SSSR: novéichii períod (A história do inconformismo na URSS: novíssimo período). Moscou: Moskóvskaia Khélsinkaia Gruppa, 2012.

ANGELIDES, S. Carta e literatura: correspondência entre Tchékhov e Górki. São Paulo: Editora da Universidade de São Paulo, 2001.

ANÍKIN, A. "Tiema málienkovo tchelovieka v rússkoi klássike”. ("O tema do homem pequeno na clássica russa”.) IN: PETRIENKO, L., Aníkin, A., Gálkin, A. Tiémy rússkoi klássiki. Utchébnoe possóbie. (Temas da clássica russa. Manual de estudos). Moscou: Prometei, 2000, pp. $96-120$.

Disponível em: http://www.portal-slovo.ru/philology/37140.php?ELEMENT_ID=37140\&SHOWALL_2=0

ARANDA, Lucia V. "Forms of creativity in translation”. IN: Cadernos de Tradução, № XXIII. Florianópolis: UFSC, 2009, pp. 23-37.

ARROJO, Rosemary. Oficina de tradução: a teoria na prática. São Paulo: Editora Ática, 2003. AUBERT, Francis Henrik. As (in)fidelidades da tradução: servidões e autonomias do tradutor. Campinas: Editora da UNICAMP, 1993.

AUERBACH, E. Mímessis. Izobrajénie deistvítelnosti v zapadnoevropéiskoi literature (Mimesis a representação da realidade na literatura ocidental). Moscou: Progress, 1976. Tradução de A. Mikháilov.

AZENHA, J. "Linguística textual e tradução: redefinindo o conceito de marca cultural". IN: TradTerm, № 12. São Paulo: Humanitas, 2006, pp. 13-32.

. "Transferência cultural em tradução: contextualização, desdobramentos, desafios”. IN: TradTerm, № 16. São Paulo: Humanitas, 2010, pp. 37-66.

BAKHTIN, M. Problémy poétiki Dostoiévskogo (Problemas da poética de Dostoiévski). Moscou: Soviétskii Pissátel, 1963. . Tvórtchestvo Fransuá Rablé i naródnaia kultura Srednevekóvia i Renessansa (Cultura popular na Idade Média e no Renascimento no contexto de François Rabelais). Moscou: EKSMO, 2014.

. Vopróssy literatúry i estétiki (Questões de literatura e estética). Moscou: Khudójestvennaia literatura, 1975.

BALUKHÁTY, S. "Ránni Tchékhov". (“O Tchékhov do início”.) IN: Vopróssy poétiki (Questões da poética). Leningrado: Izdátelstvo LGU, 1990, pp. 84-160.

BARTHES, R. Ízbrannye. rabóty: Semiótika. Poétika (Obras seletas: Semiótica. Poética). Moscou: Progress, 1989. Tradução de G. Kóssikov. 
Serguei Dovlátov: texto de cultura na literatura russa contemporânea

BEM, A. “Tchudo Púchkina”. (“O milagre de Púchkin”.) IN: Mietch (A espada). Varsóvia, 1937, 14 de fevereiro, № 6.

Disponível em: http://lib-ru.3dn.ru/publ/bem_alfred_ljudvigovich_chudo_pushkina/1-1-0-827

BENJAMIN, W. "Dream Kitsch". IN: Selected Writings. Vol. 2, part 1, 1927 - 1930.

Cambridge, Massachusetts, London, England: The Belknap Press of Harward University Press, 2005. Tradução de Rodney Livingstone e outros, pp. 3 - 5.

. "Introductory Remarks on a Series for L'Humanité". IN: Selected Writings.

Vol. 2, part 1, 1927 - 1930. Cambridge, Massachusetts, London, England: The Belknap Press of Harward University Press, 2005. Tradução de Rodney Livingstone e outros, pp. 20 - 21.

“Moscow”. IN: Selected Writings. Vol. 2, part 1, 1927 - 1930. Cambridge,

Massachusetts, London, England: The Belknap Press of Harward University Press, 2005.

Tradução de Rodney Livingstone e outros, pp. $22-47$.

BERMAN, A. A tradução e a letra, ou, O albergue do longínquo. Rio de Janeiro: 7Letras/PGET, 2007. Tradução de Marie-Helène Catherine Torres, Mauri Furlan, Andreia Guerrini.

BETHEA, D. M. "Emigration and Heritage". IN: The Slavic and East European Journal, Vol. 31, Thirtieth Anniversary Issue, 1987, 141-164.

BÍTOV, A. Púchkinskii tom (O volume puchkiniano). Moscou: AST, 2014.

BOYM, S. Common Places. Mythologies of Everyday Life in Russia. Cambridge: Harvard University Press, 1994.

BRITTO, P. “Tradução e criação”. IN: Cadernos de tradução, № IV. Florianópolis: UFSC, 1999, pp. 239-262.

BRODSKY, J. Sotchiniénia: Stikhotvoriénia. Essé (Obras: Poemas. Ensaios). Ekaterinburgo: UFactória, 2002.

Tchast riétchi. Stikhotvoriénia 1972 - 1976 (Parte do discurso. Poemas de 1972 - 1976). São Petersburgo: Púchkinski Fond, 2000.

BROWN, D. The last years of Soviet Russian literature: prose fiction 1975 - 1991. Cambridge: Cambridge University Press, 1993.

BROWN, E. J. "Russian Literature beyond the Pale". IN: Slavic and East European Journal, Vol. 30, No. 3 (Autumn, 1986), pp. 380-388.

BUARQUE DE HOLANDA, A. F. e Rónai, P. Prefácio a Mar de histórias - antologia do conto mundial. Rio de Janeiro: Nova Fronteira, 1980, vol. I, pp. 11-23.

BÚNIN, I. Míssia rússkoi emigrátsii (A missão da emigração russa). Discurso pronunciado em Paris em 16 de fevereiro de 1924. Disponível em: http://bunin.niv.ru/bunin/bio/missiyaemigracii.htm 
Serguei Dovlátov: texto de cultura na literatura russa contemporânea

CAVAliERE, A. Teatro Russo: percurso para um estudo da Paródia e do Grotesco. São Paulo: Humanitas, 2009

CELLI, M. "A noção de equivalência quando se traduz marcas gramaticais: o caso de mas e suas traduções para o francês e o inglês”. IN: TradTerm, № 16. São Paulo: Humanitas, 2010, pp. 313 341

CHKLÓVSKI, V. "Stroiénie rasskaza i romana". (“A estrutura do conto e do romance".) IN: $O$ teórii prózy (Sobre a teoria da prosa). Moscou: Federátsia, 1992, pp. 68-90.

CORRÊA, M. C. "Tradução e referências culturais". IN: Cadernos de Tradução, № XXIII. Florianópolis: UFSC, 2009, pp. 39-52.

CORTÁZAR, J. "Alguns aspectos do conto". IN: Valise de cronópio. São Paulo: Perspectiva, 2011, $2^{\mathrm{a}}$ ed. Tradução de D. Arrigucci Jr. e J. A. Barbosa, pp. 147-163.

. "Do conto breve e seus arredores". IN: Valise de cronópio. São Paulo:

Perspectiva, 2011, 2ª ed. Tradução de D. Arrigucci Jr. e J. A. Barbosa, pp. 227-237.

DAL, V. Poslóvitsy rússkovo naroda (Provérbios do povo russo). Moscou: Astrel, 2005.

DOSTOIÉVSKI, F. "Púchkinskaia rietch". ("O discurso puchkiniano".) IN: Pólnoe sobránie sotchiniénii (Obras completas), V. 26. Leningrado: Naúka, 1984, pp. 129 - 149.

ECO, U. Skazat potchti to je sámoie (Dizer quase a mesma coisa). Moscou: AST, 2015. Tradução de Andrei Kóval.

Tratado geral de semiótica. $4^{\text {a }}$ edição. São Paulo: Perspectiva, 2009. Tradução de Antônio de Pádua Danesi e Gislon Cesar Cardoso de Souza.

EIKHENBAUM, B. “O Tchékhove". (“Sobre Tchékhov”.) IN: O proze (Sobre a prosa). Leningrado: Khudójestvennaia literatura. Leningrádskoe otdelenie, 1969, pp. 357 - 370.

EPSTEIN, M. N. After the Future: the Paradoxes of Postmodernism and Contemporary Russian Culture. The University of Massachusetts Press, 1995.

"Málenkii tcheloviek v futliáre: sindróm Bachmátchkina-Biélikova". (“O homem pequeno no estojo: síndrome de Bachmátchkin - Biélikov”.) IN: Vopróssy literatúry (Questões da literatura). Moscou, 2005, № 6.

Disponível em: http://magazines.russ.ru/voplit/2005/6/ep7.html

FEDÚLOV, A. Neofitsiálnaia kultura v SSSR vo vtoroi polovine 1960-kh - 1980-e gódy. Dissertátsia na soiskánie utchiónoi stiépeni kandidata istorítcheskikh naúk (A cultura não oficial na URSS na segunda metade de 1960 - 1980. Tese para a obtenção do título de doutor). Elistá: Kalmytski institut gumanitárnykh issliédovani RAN, 2010.

GÓGOL, N. "Niéskolko slov o Púchkine”. (“Algumas palavras sobre Púchkin”.) IN: Pólnoe sobránie sotchiniénii (Obras completas), V. 8. Moscou, Leningrado: Izdátelstvo AN SSSR, 1952 , p. 50-55. 
Serguei Dovlátov: texto de cultura na literatura russa contemporânea GÓRNY, E. “Tchto takoe semiótika?” (“O que é semiótica?”) IN: Ráduga (O arco-íris). Tallin, 1996, pp. $168-175$.

Disponível em: http://www.zhurnal.ru/staff/gorny/texts/what_is_semiotics_r.html

GUL, R. "Progúlki khama s Púchkinym”. ("Passeios de um grosseirão com Púchkin”.) IN: Nóvyi jurnal (A nova revista). Nova Iorque, 1976, № 24.

Disponível em: http://inieberega.ru/node/374

Iá uniós Rossíu. Apológuia rússkoi emigrátsii. V. 3. Rossia v Amiérike (Levei

a Rússia embora. A apologia da emigração russa. V.3. A Rússia na América). Nova Iorque, 1989.

Disponível em: http://www.pseudology.org/Gul/

KARLINSKY, S., Appel Jr., A. (orgs.). The bitter air of exile: Russian writers in the West, 1922 - 1972. Berkley and Los Angeles: University of California Press, 1977.

KATÁIEV, V. “Tchékhov i ievó literatúrnoie okrujénie (80-e gódy XIX vieka)”. (“Tchékhov e o seu entorno literário (os anos 80 do século XIX)”.) IN: Spútniki Tchékhova (Companheiros de Tchékhov). Moscou: Izdátelstvo Moskóvskovo universitiéta, 1982.

Disponível em: http://az.lib.ru/c/chehow_a_p/text_0370.shtml

KAYSER, W. Análise e interpretação da obra literária. Coimbra: Arménio Amado Editor, 1970, Vol. 2.

KISLOV, V. “Oni nazyváli eto - ULIPO”. (“Chamavam isso: OULIPO”.) IN: Mítin Jurnal (A revista de Mítia). Tvier, 1997, № 54, pp. 168 - 219.

KLIÓNOV, A. "Púchkin bez kontsá". ("Púchkin sem final”.) IN: Síntaksis (A sintaxe). Paris, 1982, № 10, pp. 90 - 131.

KONDAKOV, I. “'Púchkin' kak tiekst kultúry XX vieka”. (“'Púchkin’ como texto de cultura do século XX”.) IN: Vmiesto Púchkina. Nezaverchónnyi proekt. Etiúdy o rússkom postmodernisme (Em vez de Púchkin. O projeto inacabado. Estudos sobre o pós-modernismo russo). Moscou: MBA, 2011.

Disponível em: http://www.d-harms.ru/library/pushkin-kak-tekst-russkoy-kultury-Xx-veka.html KOVÁRSKAIA, L. Rússkie pissáteli on Lomonóssova do Tchékhova (Escritores russos de Lomonóssov a Tchékhov). Nova Iorque: Rousen Bros., 1955.

KRÉIDLIN, G., Krongauz, M. Semiótika ili Ázbuka obschénia. Utchébnoe possóbie (A semiótica, ou o Abc da comunicação). Moscou: Flinta - Naúka, 2015.

KRISTEVA, J. "Bakhtin, slovo, dialog i roman". ("Bakhtin, palavra, diálogo e romance”.) IN: Frantsúzskaia semiótica: Ot strukturalizma $k$ poststrukturalízmu (A semiótica francesa: De estruturalismo a pós-estruturalismo). Moscou: IG Progress, 2000, pp. 427 - 457. Tradução de G. Kóssikov. 
Serguei Dovlátov: texto de cultura na literatura russa contemporânea

KURGÁNOV, Ie. Anekdot kak janr v rússkoi sloviésnosti (A anedota como gênero na literatura russa). Moscou: Arsis Books, 2014.

LARANJEIRA, M. Poética da tradução. São Paulo: Edusp, 1993.

LÉRMONTOV, M. "Gerói náchevo vriémeni" (“O herói do nosso tempo".) IN: Sobránie sotchiniénii v tchetyriókh tomakh. V. 4. Proza. Pisma (Obras em quatro volumes. V. 4. Prosa. Cartas). Moscou - Leningrado: Izdátelstvo Akadiémii Naúk SSSR, 1959, pp. 275 - 474.

LEUTA, O. “Iú. M. Lótman o triokh fúnktsiakh tiéksta”. ("Iú. M. Lótman sobre três funções do texto”.) IN: Kántor V (org.). Iúri Mikháilovitch Lótman. Moscou: ROSSPEN, 2009, pp. 294 309.

LINKOV, V. Khudójestvennyi mir prózy Tchékhova (O mundo artístico da prosa de Tchékhov). Moscou: Izdátelstvo Moskóvskovo universitieta, 1982.

LIPOVIÉTSKI, M. Rússki postmodernism (Ótcherki istorítcheskoi poétiki) (O pós-modernismo russo. Ensaios sobre a poética histórica). Ekaterinburgo: Ural. Gos. Ped. Un-t., 1997.

LIVAK, L. How It Was Done in Paris. Russian Émigré Literature and French Modernism. Madison: The University of Wisconsin Press, 2003.

LÓTMAN, Iú. Ízbrannye statií v triokh tomakh. V. 1. Statií po semiótike i topológuii kultúry (Artigos seletos em três volumes. V. 1. Artigos sobre a semiótica e topologia da cultura). Tallin: Aleskandra, 1992

. "Liúdi i znaki". ("Pessoas e signos".) IN: Semiosfera. São Petersburgo: Iskusstvo-SPB, 2010, pp. 5 - 10.

. "Osnovnye etápy razvítia rússkovo realizma”. (“As principais etapas de desenvolvimento do realizmo russo”.) IN: O Rússkoi Literature (Sobre a literatura russa). São Petesburgo: Iskusstvo - SPB, 2005, p. 530-547.

Púchkin. Biográfia Pissátielia. Roman “Ievguéni Oniéguin”. Kommentárii (Púchkin. A biografia do escritor. O romance 'Ievguéni Oniéguin'. Comentários). São Petesburgo: Ázbuka, 2015.

. "Rússkaia literatura poslepietróvskoi epókhi i khristiánskaia tradítsia”. (“A literatura russa da época de após Pedro, o Grande, e a tradição cristã”.) IN: O poétakh i poézii (Sobre poetas e poesia). São Petesburgo: Iskusstvo - SPB, 2011, p. 254-265.

Semiosfera. São Petersburgo: Iskusstvo-SPB, 2010.

. "Símvol v sistieme kultúry". ("O símbolo no sistema da cultura".) IN:

Ízbrannye statií (Obras seletas). V. 1. Tallin, 1992.

Disponível em: http://www.philology.ru/literature1/lotman-92e.htm

"Vnutri mýsliaschikh mirov". ("Dentro dos mundos racionais".) IN: Semiosfera. São Petersburgo: Iskusstvo-SPB, 2010, pp. 149 - 390. 
Serguei Dovlátov: texto de cultura na literatura russa contemporânea MANDELSTAM, N. Vospominánia (Memórias). Moscou: Soglássie, 1999.

Disponível em: http://www.e-reading.club/bookreader.php/37211/Mandel'shtam_-

_Vospominaniya.html

MANN, Iú. "Líchnii tcheloviek”. (“O homem supérfluo”.) IN: Krátkaia literatúrnaia entsiklopédia (A breve enciclopédia literária). V. 4. Moscou: Soviétskaia entsiklopédia, pp. 400 $-402$.

MCMILLIN, A. "Exiled Russian Writers of the Third Wave and the Émigré Press". In: The Modern Language Review. MHRA, Vol. 84, № 2, April, 1989, 406-413.

MELETÍNSKI, E. Ot mifa $k$ literature (Do mito à literatura). Moscou: Rossíiski gossudárstvennyi gumanitárnyi universitet, 2001.

MEREJKÓVSKI, D. "Púchkin”. IN: Viétchnye spútniki. Portriéty iz vsemírnoi literatúry (Os eternos companheiros. Retratos da literatura universal). São Petersburgo: Naúka, 2007, pp. 229 $-297$.

Púchkin s námi (Púchkin conosco), 1937.

Disponível em: http://az.lib.ru/m/merezhkowskij_d_s/text_0140.shtml

MYCHKO-MEGRIN, I. Aproximación pragmática a la traducción de la ironía: problemas traductológicos en la traslación al castellano de los relatos de M. Zóschenko e M. Bulgákov. Tesis para optar al título de doctor por la Universitat de Barcelona. Barcelona: 2011.

NABÓKOV, V. Púchkin, ili Pravda $i$ pravdopodóbie (Púchkin, ou A verdade e a verossimilhança), 1937.

Disponível em: http://lib.ru/NABOKOW/Pushkin.txt

NÓVIKOV, V. Púchkin. Moscou: Molodáia Gvárdia, 2014.

PIGLIA, R. Formas breves. São Paulo: Cia. das Letras, 2004. Tradução de José Marcos M. de Macedo.

PONTIERI, R. Formas históricas do conto. São Paulo, março de 2012.

. "Formas históricas do conto: Poe e Tchekhov". IN: Ficções: leitores e leituras. São Paulo: Ateliê, 2001, pp. 91-111.

PROKÓPOV, T. “Abrám Terts, Roman Gul i... Púchkin”. (“Abrám Terts, Roman Gul e... Púchkin”.) IN: Inye beregá (Outras margens), 2001, № 4 (24).

Disponível em: http://inieberega.ru/node/374

PÚCHKIN, A. “Arap Petrá Velíkovo”. (“O negro do Pedro, o Grande”.) IN: Sotchiniénia v triokh tomakh. V. 3. Proza (Obras em 3 volumes. V. 3. Prosa). Moscou: Khudójestvennaia literatura, 1986, pp. $3-32$.

. "Kámennyi gost". (“O convidado de pedra".) IN: Sotchiniénia v triokh tomakh. V. 2. Poémy. Ievguéni Oniéguin. Dramatítcheskie proizvediénia (Obras em 3 volumes. 
Serguei Dovlátov: texto de cultura na literatura russa contemporânea

V. 3. Poemas. Ievguéni Oniéguin. Dramas). Moscou: Khudójestvennaia literatura, 1986, pp. 450 -478 .

"Kapitánskaia dotchka". (“A filha do capitão".) IN: Sotchiniénia v triokh tomakh. V. 3. Proza. Moscou: Khudójestvennaia literatura, 1986, pp. 229 - 328.

. Poesias escolhidas. Rio de Janeiro: Nova Fronteira, 1992. Tradução de José

Casado.

Sotchiniénia v triokh tomakh. V. 1. Stikhotvoriénia. Skázki. Ruslán i Liudmila

(Obras em 3 volumes. V. 1. Poemas. Contos maravilhosos. Ruslán e Liudmila). Moscou: Khudójestvennaia literatura, 1985.

REISS, K. "Type, kind and individuality of text: decision making in translation". IN: Venuti, L. (org.). The translation studies reader. London and New York: Routledge, 2000: 160-171.

ROMANIENKO, A. (org.) Sólntse Rossíi. Rússkie pissáteli o Púchkine. Viek XIX (O sol da Rússia. Escritores russos sobre Púchkin. Século XIX). Moscou: Drujba naródov, 1999.

Sólntse Rossíi. Rússkie pissáteli o Púchkine. Viek XX (O sol da Rússia. Escritores russos sobre Púchkin. Século XIX). Moscou: Drujba naródov, 1999.

SCHLEIERMACHER, F. "Sobre los diferentes métodos de traducir". IN: Teoría de la traducción. Antología de textos. Cuenca: Ediciones de la Universidad de Castilla-La Mancha, 1996, pp. 129 - 157. Tradução de Hans Christian Hagedorn.

SCHLÖGEL, K. Terror i mietchtá. Moskvá 1937 (Terror e sonho. Moscou 1937). Moscou: ROSSPEN: Fond "Prezidiéntskii tsentr B.N. Iéltsina", 2011. Tradução de B. Brun-Tsekhovói.

SCHNAIDERMAN, B. "Prefácio". IN: A. Tchékhov. "O beijo" e outras histórias. São Paulo: Editora 34, 2010, 3ª ed. Tradução de Boris Schnaiderman, pp. 7-10.

SHRAYER, M. V ojidánii Amiériki (Na espera da América). Moscou: Alpina non-fiction, 2013. Tradução de M. Shrayer.

SKARLÝGUINA, E. Jurnalístika rússkoi emigrátsii: 1960 - 1980-e gódy (O jornalismo da emigração russa: anos 1960 - 1980). Moscou: Fakultiet jurnalístiki Moskovskovo gossudárstvennovo universitieta ímeni M. V. Lomonóssova, 2010.

"V ziérkale triokh emigrátsii". ("No espelho das três emigrações".) IN: $N L O$. Nezavíssimyi filologuítcheskii jurnal (Revista filológica independente), № 93, 2008. Disponível em: http://magazines.russ.ru/nlo/2008/93/sk21.html

SLOBIN, G. N. "The 'Homecoming' of the First Wave Diaspora and Its Cultural Legacy". IN: Slavic Review, Vol. 60, No. 3 (Autumn, 2001), pp. 513-529.

SOLJENÍTSYN, A. "Ugodilo ziórnychko promiéj dvukh jernovóv. Ótcherki izgnánia. Tchast vtoráia (1979 - 1982)”. (“A sementinha caiu entre duas mós. Ensaios do exílio. Segunda parte (1979 - 1982).”) IN: Nóvyi mir (O novo mundo), 2000, № 9. 
Serguei Dovlátov: texto de cultura na literatura russa contemporânea

Disponível em: http://magazines.russ.ru:81/novyi_mi/2000/9/solge.html . “...Koliéblet tvoi trenójnik”. IN: Viéstnik RKHD, 1984, № 142.

Disponível em: http://solzhenicyn.ru/modules/myarticles/article_storyid_316.html

STRUVE, G. Rússkaia literatura v izgnánii (A literatura russa no exílio). Paris - Moscou: YMCA-Press - Rússki Put, 1996.

SUKHIKH, I. Probliémy poétiki A.P. Tchékhova (Problemas da poética de A.P. Tchékhov). Leningrado: Izdátelstvo LGU, 1987.

TCHÉKHOV, A. “A dama do cachorrinho” e outros contos. São Paulo: Editora 34, 2011, 4ª ed. Tradução de Boris Schnaiderman.

Pólnoie sobránie sotchiniénii i píssem: v 30 t. Písma: v 12 t. V. 2. Písma, 1887 - sentiabr 1888. (Obras completas e cartas: em 30 volumes. Cartas: em 12 v. V. 2. Cartas, 1887 - setembro de 1888). Moscou: Naúka, 1975.

. Sem trama e sem final (99 conselhos de escrita). São Paulo: Martins, 2007.

Tradução de Homero F. Andrade.

TERTS, A. Progúlki s Púchkinym (Passeios com Púchkin). Moscou: Globulus, Izd-vo NTS ENAS, 2005.

TIHANOV, G. Narrativas do exílio: Cosmopolitismo além da imaginação liberal. São Carlos: Pedro \& João Editores, 2013. Tradução de Camila Caracelli Scherma e outros. . "Towards a History of Russian Émigré Literary Criticism and Theory between the World Wars". IN: Khronotop i okriéstnosti. Iubiléiny sbórnik v tchiest Nikoláia Pankova (O cronotopo e o seu entorno. Coletânea comemorativa em homenagem a Nikolai Pankóv). Ufá: Vagant, 2011, pp. 321-344.

TOMACHÉVSKI, B. Teória literatúry. Poétika (Teoria da literatura. Poética). Moscou: Aspekt Press, 2003.

TYNIÁNOV, I. Probliema stikhotvórnovo iazyká (O problema da linguagem de verso). Moscou: KomKniga, 2007.

VANDAELE, J. "Humor in translation". IN: Handbook of Translation Studies. Vol 1. Amsterdam \& Philadelphia: John Benjamins, 2010, pp. 147-52.

VENUTI, L. The scandals of translation: towards an ethics of difference. London and New York: Routledge, 1998.

VINOGRÁDOV, V. "Probliema skaza v stilístike". (“O problema do skaz na estilística”.) IN: $O$ iazyké khudójestvennoi prózy (Sobre a linguagem da prosa artística). Moscou: Naúka, 1980, pp $42-54$. 
Serguei Dovlátov: texto de cultura na literatura russa contemporânea . “Osnovnye etápy istórii rússkovo iazyká”. (“As principais etapas da história

da língua russa”.) IN: Ízbrannye trudy. Istória rússkovo literatúrnovo iazyká (Obras seletas. História da língua russa literária). Moscou: Naúka, 1978, pp. 10 - 64.

VÓLKOVA Américo, E. Alguns aspectos da semiótica da cultura de Iúri Lótman. São Paulo, 2012.

ZABALBEASCOA, P. "Humor and translation - an interdiscipline". IN: Humor, № 18 - 2 . Berlin: Walter de Gruyter, 2005, pp. 185-207.

ZAGUIDÚlLINA, M. Púchkinski mif v kontsé XX vieka (O mito puchkiniano no final do século XX). Tcheliábinsk: Izdátelstvo Tcheliábinskovo Gossudárstvennovo Universiteta, 2001.

\section{Obras de referência}

BUARQUE DE HOLANDA, A. F. et al. Nóvo Aurélio Século XXI. Dicionário da língua portuguesa. Rio de Janeiro: Nova Fronteira, 2008.

Houaiss dicionário online da língua portuguesa. Disponível em: http://houaiss.uol.com.br/

DAL, V. Slovar jivóvo velikorússkovo iazyká (Dicionário da língua russa viva). Moscou: Rússki iazyk, 1989.

ÓJEGOV, S., Chvédova, N. Tolkóvyi slovar rússkovo iazyká (Dicionário monolíngue da língua russa). Moscou: Azbukóvnik, 2001.

\section{Filmes sobre S. Dovlátov}

Dovlátov: kompromiss (Dovlátov: a troca, 2010).

Dovlátov: tchemodán (Dovlátov: a mala, 2010).

Intímnyi górod (A cidade íntima, 2007).

Jivaia istória. Dovlátov (A história viva: Dovlátov, 2007).

Jizn nelegká... Vach Serguei Dovlátov (A vida não é fácil... Seu Serguei Dovlátov, 2007).

Koniets prekrásnoi epókhi. Brodsky i Dovlátov (Fim da bela época. Brodsky e Dovlátov, 2007).

Lomovói arkhánguel. Armiéiskie pisma Sergueia Dovlátova (O arcanjo de carga. Cartas do exército de Serguei Dovlátov, 2000).

Moi sossied, Serioja Dovlátov (Meu vizinho, Serioja Dovlátov, 2001).

Napíssano Serguéiem Dovlátovym (Escrito por Serguei Dovlátov, 2011).

Piat uglóv Dovlátova (Cinco esquinas de Serguei Dovlátov, 2015) 
Serguei Dovlátov: texto de cultura na literatura russa contemporânea Serguei Dovlátov. Ekológuia literatúry (Serguei Dovlátov. Ecologia da literatura, 2000). Uchól, tchtóby ostatsa. Serguei Dovlátov (Foi embora para ficar. Serguei Dovlátov, 2011). 